ПРИЧОРНОМОРСЬКИЙ НАУКОВО-ДОСЛІДНИЙ ІНСТИТУТ ЕКОНОМІКИ ТА ІННОВАЦІЙ

\title{
ІННОВАЦІЙНА ПЕДАГОГІКА
}

\author{
Науковий журнал
}

Випуск 31

ToM 1

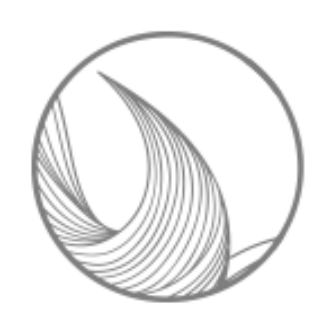


Головний редактор:

Терешкінас Артурас - доктор соціальних наук, професор, профресор кафедри соціології Університету імені Вітовта Великого (Каунас, Литовська Республіка)

Члени редакційної колегії:

Байша кіра Миколаївна - кандидат педагогічних наук, доцент, доцент кафредри іноземних мов Херсонського національного технічного університету

Благун Наталія Михайлівна - доктор педагогічних наук, профресор, профресор касредри педагогіки початкової освіти Прикарпатського національного університету імені Василя Стефраника

Богуш Людмила Андріївна - кандидат педагогічних наук, старший викладач кафедри менеджменту Міжнародного економіко-гуманітарного університету імені академіка Степана Дем'янчука

Бочелюк Віталій Йосипович - доктор педагогічних наук, професор, завідувач кафедри Запорізького національного технічного університету

Кочарян Артур Борисович - кандидат педагогічних наук, доцент, радник Міністра освіти і науки України

Невмержицька Олена Василівна - доктор педагогічних наук, доцент, професор кафедри загальної педагогіки та дошкільної освіти Дрогобицького державного педагогічного університету імені Івана Франка

Пермінова Владислава Анатоліївна - кандидат педагогічних наук, доцент, доцент кафредри іноземних мов профресійного спрямування Чернігівського національного технологічного університету

Пушкарьова Тамара Олексіївна - доктор педагогічних наук, професор, начальник відділу проектного управління ДНУ «Інститут модернізації змісту освіти» МОН України

Шапошникова Ірина Василівна - доктор соціологічних наук, професор, декан соціальнопсихологічного фракультету Херсонського державного університету

Алісаускіене Мілда - доктор соціальних наук, професор, завідувач кафедри соціології Університету імені Вітовта Великого (Каунас, Литовська Республіка)

Гражієне Віталія - доктор педагогічних наук, завідувач відділу якості освіти Вільнюської академії мистецтв (Вільнюс, Литовська Республіка)

Конрад Яновський - PhD, ректор Економіко-гуманітарного університету у Варшаві (Варшава, Республіка Польща)

Електронна сторінка видання - www.innovpedagogy.od.ua

Рекомендовано до друку та поширення через мережу Internet

Вченою радою Причорноморського науково-дослідного інституту

економіки та інновацій (протокол № 1 від 25.01.2021 року)

Журнал включено до Переліку наукових фрахових видань України (категорія “Б») у галузі педагогічних наук (011 - Освітні, педагогічні науки, 012 - Дошкільна освіта, 013 - Початкова освіта, 014 - Середня освіта, 015 - Професійна освіта (за спеціальностями), 016 - Спеціальна освіта) відповідно до Наказу МОН України від 14.05.2020 № 627 (додаток 2)

Журнал включено до міжнародної наукометричної бази Index Copernicus International (Республіка Польща)

Науковий журнал «Інноваційна педагогіка» зареєстровано Міністерством юстиції України (Свідоцтво про державну реєстрацію друкованого засобу масової інформації серія КВ № 22897-12797Р від 02.08.2017 року)

Міжнародний цифрровий ідентисрікатор журналу: https://doi.org/10.32843/2663-6085

Статті у виданні перевірені на наявність плагіату

за допомогою програмного забезпечення StrikePlagiarism.com від польської компанії Plagiat.pl. 
3MICT

\section{РОЗДІЛ 1. ЗАГАЛЬНА ПЕДАГОГІКА ТА ІСТОРІЯ ПЕДАГОГІКИ}

Голуб Т.П., Жигжитова Л.М., Назаренко О.І.

НОВА ОСВІТНЯ ПАРАДИГМА В РЕАЛІЯХ СУЧАСНИХ ГЛОБАЛІЗАЦІЙНИХ ПРОЦЕСІВ.

Зайченко Н.І.

ВИМІРИ МОРАЛЬНОСТІ ЛЮДИНИ В ІСПАНСЬКІЙ ПЕДАГОГІЧНІЙ ДУМЦІ

HA MEЖI XIX - XX CT.

Ільницька Л.в.

ВІТЧИЗНЯНИЙ ДОСВІД СТАНОВЛЕННЯ ПРЕДИКАТІВ

ХУДОЖНЬОЇ ДІЯЛЬНОСТІ В КОНТЕКСТІ ЕСТЕТИЧНОГО ВИХОВАННЯ.

Ісламова О.О.

ОРГАНІЗАЦІЯ ПІДГОТОВКИ ВИКЛАДАЧІВ ЄВРОПЕЙСЬКИХ ПРИКОРДОННИХ

ЗАКЛАДІВ ОСВІТИ ДО ДИСТАНЦІЙНОЇ ФОРМИ НАВЧАННЯ.

Костенко Л.Д.

ІСТОРІОГРАФІЇ ПРОБЛЕМИ РОЗВИТКУ ТЕОРІЇ І ПРАКТИКИ ПОЗАШКІЛЬНОЇ ОСВІТИ

В УКРАЇНІ (ДРУГА ПОЛОВИНА ХХ - ПОЧАТОК ХХІ СТОЛІТТЯ).

Таможська І.В.

МЕТОДОЛОГО-ТЕОРЕТИЧНИЙ ІНСТРУМЕНТАРІЙ ІСТОРИКО-ПЕДАГОГІЧНИХ ДОСЛІДЖЕНЬ.

Федун Д.С.

ІСТОРИЧНІ ЕТАПИ ПРОФЕСІЙНОЇ ПІДГОТОВКИ ЕКОНОМІСТІВ

У СИСТЕМІ ВИЩОЇ ОСВІТИ УКРАЇНИ В ДРУГІЙ ПОЛОВИНІ XX - ПОЧАТКУ XXI СТОЛІТТЯ.

\section{РОЗДІЛ 2. ТЕОРІЯ І МЕТОДИКА ПРОФЕСІЙНОЇ ОСВІТИ}

Адамчук Ю.Д.

КРИТЕРІЇ, ПОКАЗНИКИ ТА РІВНІ СФОРМОВАНОСТІ ГОТОВНОСТІ

МОЛОДШИХ ІНСПЕКТОРІВ ПРИКОРДОННОЇ СЛУЖБИ ДО ПРОФЕСІЙНОЇ ДІЯЛЬНОСТІ

У ПУНКТАХ ПРОПУСКУ ДЛЯ МІЖНАРОДНОГО СПОЛУЧЕННЯ.

Антіпова Ж.І., Барсукова Т.О., Кучеренко Г.В.

ГНУЧКІСТЬ ТА ІІЇ ЗНАЧЕННЯ

В ПІДВИЩЕННІ РІВНЯ ФІЗИЧНОЇ ПІДГОТОВЛЕНОСТІ СТУДЕНТІВ.

Барабаш И.В.

ПРАКТИЧЕСКИЕ АСПЕКТЫ ПРИМЕНЕНИЯ ДИФФЕРЕНЦИРОВАННОГО

ПОДХОДА ПРИ ОБУЧЕНИИ ИНОСТРАННОМУ ЯЗЫКУ

В НЕЯЗЫКОВОМ ВУЗЕ.

Білозерська Г.О., Дабіжа К.Л., Ковальчук В.В., Сізова Н.С.

ПРОБЛЕМА ПІДВИЩЕННЯ

ХУДОЖНЬО-ВИКОНАВСЬКОЇ МАЙСТЕРНОСТІ СТУДЕНТІВ У КЛАСІ ДИРИГУВАННЯ

\section{Бондаренко Є.В.}

САМОСТІЙНА РОБОТА ЯК ЗАСІБ ФОРМУВАННЯ

ПРОФЕСІЙНО-МОВЛЕННЄВОЇ КОМПЕТЕНТНОСТІ МАЙБУТНІХ СУДНОВОДІЇВ

Галіцан О.А., Осипова Т.Ю., Щекотиліна Н.Ф.

ПРОГРАМА РОЗВИТКУ ЗДАТНОСТІ ДО ПЕДАГОГІЧНОЇ ФАСИЛІТАЦІЇ

У МАЙБУТНІХ УЧИТЕЛІВ У ПЕДАГОГІЧНОМУ УНІВЕРСИТЕТІ.

Горянський В.В.

КОНЦЕПТУАЛЬНІ ПІДХОДИ ДО ФОРМУВАННЯ ФАХОВОЇ КОМПЕТЕНТНОСТІ

В УМОВАХ ВИЩОЇ МИСТЕЦЬКОЇ ОСВІТИ, ЗОКРЕМА У ПРОЦЕСІ ПРОФЕСІЙНОЇ ПІДГОТОВКИ

МАЙБУТНІХ БАКАЛАВРІВ ДИЗАЙНУ.

Грицик Н.В., Скорик Т.В.

ТЕХНОЛОГІЗАЦІЯ ЯК НАПРЯМ МОДЕРНІЗАЦІЇ ПРОФЕСІЙНОЇ ПІДГОТОВКИ

МАЙБУТНЬОГО ВЧИТЕЛЯ У ЗАКЛАДІ ВИЩОЇ ОСВІТИ. 
Демченко Л.В.

ВИРОБНИЧА ПРАКТИКА У ФОРМУВАННІ ПРОФЕСІЙНОЇ ГОТОВНОСТІ

МАЙБУТНІХ БАКАЛАВРІВ ФІЗИЧНОЇ ТЕРАПІЇ, ЕРГОТЕРАПІЇ ДО ФІЗИЧНОЇ РЕАБІЛІТАЦІЇ

ДІТЕЙ ДОШКІЛЬНОГО ВІКУ.

Желанова В.В.

ФАСИЛІТАЦІЙНА КОМПЕТЕНТНІСТЬ МАЙБУТНЬОГО ПЕДАГОГА: СУТНІСТЬ І СТРУКТУРА.

Зігунов В.М.

ЗАРУБІЖНИЙ І ВІТЧИЗНЯНИЙ ДОСВІД ПРОФЕСІЙНОЇ ПІДГОТОВКИ

ФАХІВЦІВ СФЕРИ СОЦІАЛЬНОГО ТУРИЗМУ.

Іщенко М.В.

ОЗДОРОВЧІ МЕТОДИКИ У ВПРАВАХ НА ДИХАННЯ ДЛЯ АКАДЕМІЧНИХ ВОКАЛІСТІВ.

Липовецька Є.ю.

КОМПЕТЕНТНОСТІ 3 МИСТЕЦТВА ХУДОЖНЬОГО ТКАЦТВА

ЯК СКЛАДНИК ПРОФЕСІЙНОЇ КОМПЕТЕНТНОСТІ МАЙБУТНЬОГО ФАХІВЦЯ

ДЕКОРАТИВНО-ПРИКЛАДНОГО МИСТЕЦТВА.

Лобачова І.М., Помирча С.В., Луценко Н.О.

ГЕНДЕРНА КУЛЬТУРА МАЙБУТНЬОГО ПЕДАГОГА В МЕЖАХ НЕФОРМАЛЬНОЇ ОСВІТИ ЗВО

Мазуренко О.О.

СТРУКТУРА ГОТОВНОСТІ МАЙБУТНІХ ЛІКАРІВ ДО ПРОФЕСІЙНОЇ ВЗАЄМОДІЇ.

Мазуренко Ю.А.

ПЕДАГОГІЧНІ УМОВИ ПІДГОТОВКИ МАЙБУТНІХ АВІАЦІЙНИХ

ІНЖЕНЕРІВ-МЕХАНІКІВ ДО ПРОФЕСІЙНОÏ КОМУНІКАЦІЇ.

Мамчич О.Б., Михайленко О.В.

ФОРМУВАННЯ ЛІНГВІСТИЧНОЇ КУЛЬТУРИ МАЙБУТНЬОГО ПЕДАГОГА

ПОЧАТКОВОЇ ШКОЛИ.

Мельник Л.В., Малашевська І.В., Лазука М.М.

ВИХОВНИЙ ВПЛИВ МУЗИЧНОГО МИСТЕЦТВА НА ФОРМУВАННЯ ОСОБИСТОСТІ:

РЕТРОСПЕКТИВНИЙ АНАЛІЗ

Мірошніченко В.І., Озимовський В.В.

МЕТОДИЧНІ ОСНОВИ ФОРМУВАННЯ УКРАЇНСЬКОЇ ІДЕНТИЧНОСТІ ПЕРСОНАЛУ

ДЕРЖАВНОЇ ПРИКОРДОННОЇ СЛУЖБИ УКРАЇНИ

Невзоров Р.В.

ПРОБЛЕМНІ ТЕНДЕНЦІЇ ПІДГОТОВКИ МАЙБУТНІХ ВІЙСЬКОВИХ ЛЬОТЧИКІВ

ДО БОЙОВИХ ПОЛЬОТІВ У СВІТЛІ СУЧАСНИХ КОНЦЕПТУАЛЬНИХ

I НОРМАТИВНИХ ВИМОГ ДО НИХ.

Онищенко Н.П.

ВПЛИВ ОСВІТНЬОГО СЕРЕДОВИЩА ВИЩОЇ ШКОЛИ НА ФОРМУВАННЯ ГОТОВНОСТІ

МАЙБУТНІХ УЧИТЕЛІВ ДО ІННОВАЦІЙНОЇ ВИХОВНОЇ ДІЯЛЬНОСТІ.

Охріменко О.В.

РЕЗУЛЬТАТИ ЕКСПЕРИМЕНТАЛЬНОЇ ПІДГОТОВКИ МАЙБУТНІХ БАКАЛАВРІВ

СПЕЦІАЛЬНОЇ ОСВІТИ ДО ВИКОРИСТАННЯ ЦИФРОВИХ ТЕХНОЛОГІЙ

У ПРОФЕСІЙНІЙ ДІЯЛЬНОСТІ В УМОВАХ ІНКЛЮЗИВНОГО ОСВІТНЬОГО ПРОСТОРУ.

Полещук Л.В.

ФОРМУВАННЯ ПРОФЕСІЙНО ЗНАЧУЩИХ ЯКОСТЕЙ МАЙБУТНІХ

МЕНЕДЖЕРІВ ОСВІТИ: КОМПЕТЕНТНІСНИЙ АСПЕКТ.

Роїк Ю.В.

ПЕДАГОГІЧНІ УМОВИ ЗАБЕЗПЕЧЕННЯ ЯКІСНОЇ

ПРОФЕСІЙНОЇ ПІДГОТОВКИ З ЕТНОДИЗАЙНУ КЕРАМІКИ.

Саган Н.Т., Заяць Л.М., Жураківська О.Я., Антимис О.В., Дутчак У.М., Міськів В.А.

ДИСТАНЦІЙНЕ НАВЧАННЯ В МЕДИЧНОМУ ВУЗІ - РЕАЛІЇ СЬОГОДЕННЯ..... 
Саєнко Н.С., Галацин К.О.

ФОРМУВАННЯ ІНФОРМАЦІЙНО-КОМУНІКАТИВНОЇ КОМПЕТЕНТНОСТІ СТУДЕНТІВ

ТЕХНІЧНИХ СПЕЦІАЛЬНОСТЕЙ НА ЗАНЯТТЯХ З АНГЛІЙСЬКОÏ МОВИ.

Снітовська О.Й., Царик Г.М.

ВИКЛАДАННЯ МЕДИЧНОЇ ТЕРМІНОЛОГІЇ ПІД ЧАС ВИВЧЕННЯ АНГЛІЙСЬКОЇ МОВИ

В УМОВАХ ДИСТАНЦІЙНОГО НАВЧАННЯ ЗА ДОПОМОГОЮ ПЛАТФОРМИ

ДЛЯ ПРОВЕДЕННЯ ОНЛАЙН-ЗАНЯТЬ ZООМ..

Tymoschuk N.M.

FORMATION OF ENGLISH COMPETENCE IN DIALOGUE SPEECH

OF FUTURE SPECIALISTS IN HOTELS, RESTAURANTS AND CATERING. 165

Титок I.B.

ЗАПРОВАДЖЕННЯ ІНФОРМАЦІЙНО-КОМУНІКАЦІЙНИХ ТЕХНОЛОГІЙ

У ПРОЦЕС ПРОФЕСІЙНОЇ ПІДГОТОВКИ МОЛОДШИХ СПЕЦІАЛІСТІВ З ПРАВА

ТУЛякова К.Р. ТЕХНОЛОГІЯ МОВНО-КОНФЛІКТНОГО МОДЕЛЮВАННЯ

В ОСВІТНЬОМУ ПРОЦЕСІ.

Хома Т.В., Стеблюк С.В.

ІНТЕГРАЛЬНА КОМПЕТЕНТНІСТЬ ЯК СКЛАДНИК ПРОФЕСІЙНОЇ КОМПЕТЕНТНОСТІ

В ПЕДАГОГІЧНІЙ ОСВІТІ. 


\section{CONTENTS}

\section{SECTION 1. GENERAL PEDAGOGY AND HISTORY OF PEDAGOGY}

Holub T.P., Zhyhzhytova L.M., Nazarenko O.I.

NEW EDUCATIONAL PARADIGM IN THE REALITIES

OF MODERN GLOBALIZATION PROCESSES

Zaichenko N.I.

THE DIMENSIONS OF HUMAN MORALITY IN SPANISH PEDAGOGICAL THOUGHT

AT THE TURN OF THE XIX - XX CENTURIES

Ilnytska L.V.

UKRAINIAN EXPERIENCE OF SETTING PREDICATES OF ARTISTUC ACTIVITY

IN THE CONTEXT OF AESTHETIC EDUCATION.

Islamova 0.0.

ORGANIZATION OF TRAINING OF TEACHERS OF EUROPEAN BORDER GUARD

EDUCATIONAL INSTITUTIONS FOR DISTANCE LEARNING

Kostenko L.D.

HISTORIOGRAPHY OF THE PROBLEM OF THEORY AND PRACTICE DEVELOPMENT

OF OUT - OF SCHOOL EDUCATION IN UKRAINE (THE SECOND HALF OF THE XX -

THE BEGINNING OF THE XXI CENTURY).

Tamozhska I.V.

METHODOLOGICAL AND THEORETICAL TOOLS FOR HISTORICAL

AND PEDAGOGICAL RESEARCHES.

Fedun D.S.

HISTORICAL STAGES OF ECONOMISTS PROFESSIONAL TRAINING

IN THE SYSTEM OF HIGHER EDUCATION OF UKRAINE

IN THE SECOND HALF OF THE 20TH - THE EARLY 21ST CENTURIES

\section{SECTION 2. THEORY AND METHODS OF VOCATIONAL TRAINING}

Adamchuk Yu.D.

CRITERIA, INDICATORS AND LEVELS OF FORMABILITY OF JUNIOR INSPECTORS

OF THE BORDER SERVICE FOR PROFESSIONAL ACTIVITY AT THE MUNICIPALITIES.

Antipova Zh.I., Barsukova T.O., Kucherenko H.V.

FLEXIBILITY AND ITS IMPORTANCE IN INCREASING THE LEVEL

PHYSICAL PREPAREDNESS OF STUDENTS

Barabash Y.V.

PRACTICAL ISSUES OF APPLICATION OF THE DIFFERENTIATED

APPROACH FOR TEACHING FOREIGN LANGUAGES

AT A NON-LINGUISTIC HIGHER EDUCATIONAL INSTITUTION

Bilozerska H.O., Dabizha K.L., Kovalchuk V.V., Sizova N.S.

THE PROBLEM OF IMPROVING STUDENTS' ARTISTIC AND PERFORMING SKILLS

IN THE CONDUCTING CLASS.

Bondarenko Ye.V.

INDIVIDUAL WORK AS A MEANS OF FORMATION OF THE PROFESSIONAL

AND SPEECH COMPETENCE OF FUTURE NAVIGATORS.

Halitsan O.A., Osypova T.Yu., Shchekotylina N.F.

PEDAGOGICAL FACILITATION CAPACITY DEVELOPMENT PROGRAM

FOR FUTURE TEACHERS AT THE PEDAGOGICAL UNIVERSITY.

Horianskyi V.v.

CONCEPTUAL APPROACHES TO THE FORMATION OF PROFESSIONAL COMPETENCE IN THE CONDITIONS OF HIGHER ART EDUCATION, IN PARTICULAR IN THE PROCESS 


\section{Hrytsyk N.V., Skoryk T.V.}

TECHNOLOGIZATION AS DIRECTION OF MODERNIZATION OF PROFESSIONAL TRAINING

OF FUTURE TEACHERS IN HIGHER EDUCATION INSTITUTIONS.

Demchenko L.V.

PRODUCTION PRACTICE IN THE FORMATION OF PROFESSIONAL READINESS

OF FUTURE BACHELORS OF PHYSICAL THERAPY, OCCUPATIONAL THERAPY

FOR PHYSICAL REHABILITATION.

Zhelanova V.V.

FACILITATIVE COMPETENCY OF A FUTURE TEACHER: ESSENCE AND STRUCTURE

87

Zihunov V.M.

FOREIGN AND DOMESTIC EXPERIENCE PROFESSIONAL OF TRAINING SPECIALISTS

IN THE FIELD OF SOCIAL TOURISM..

Ishchenko M.V.

HEALTH TECHNIQUES IN BREATHING EXERCISES FOR ACADEMIC VOCALISTS

95

Lypovetska Ye.Yu.

THE ESSENCE OF THE CONCEPT OF COMPETENCIES IN THE ART

OF ARTISTIC WEAVING OF THE FUTURE SPECIALIST IN ARTS

AND CRAFTS IN ACCORDANCE WITH STATE STANDARDS OF UKRAINE

99

Lobachova I.M., Pomyrcha S.V., Lutsenko N.O.

GENDER CULTURE OF A FUTURE TEACHER WITHIN NON-FORMAL EDUCATION

OF THE HIGHER EDUCATION INSTITUTION

Mazurenko 0.0.

THE STRUCTURE OF READINESS OF FUTURE DOCTORS

FOR PROFESSIONAL INTERACTION

Mazurenko Yu.A.

PEDAGOGICAL CONDITIONS OF AIRCRAFT MAINTENANCE

ENGINEERS' TRAINING FOR PROFESSIONAL COMMUNICATION

Mamchych O.B., Mykhailenko O.V.

FORMATION OF LINGUISTIC CULTURE OF THE FUTURE PRIMARY SCHOOL TEACHER

Melnyk L.V., Malashevska I.V., Lazuka M.M.

EDUCATIONAL INFLUENCE OF MUSICAL ART ON PERSONALITY FORMATION:

RETROSPECTIVE ANALYSIS

Miroshnichenko V.I., Ozymovskyi V.V.

METHODOLOGICAL BASIS OF FORMATION OF UKRAINIAN IDENTITY

OF STATE BORDER GUARD SERVICE OF UKRAINE

Nevzorov R.V.

PROBLEM TENDENCIES OF PREPARATION OF FUTURE SOLDIERY PILOTS

TO BATTLE FLIGHTS IN THE LIGHT OF MODERN CONCEPTUAL

AND NORMATIVE REQUIREMENTS TO THEM.

Onyshchenko N.P.

THE INFLUENCE OF THE EDUCATIONAL ENVIRONMENT OF HIGHER EDUCATION

ON FORMING THE READINESS OF FUTURE TEACHERS FOR INNOVATIVE

EDUCATIONAL ACTIVITIES

Okhrimenko O.V.

RESULTS OF EXPERIMENTAL TRAINING OF FUTURE BACHELORS

OF EDUCATION FOR THE USE OF DIGITAL TECHNOLOGIES

IN PROFESSIONAL ACTIVITY.

Poleshchuk L.V.

FORMATION OF PROFESSIONALLY SIGNIFICANT QUALITIES

OF FUTURE EDUCATIONAL MANAGERS: COMPETENCE ASPECT 
Roik Yu.V.

PEDAGOGICAL CONDITIONS OF PROVIDING QUALITY

PROFESSIONAL TRAINING FROM ETHNODESIGN OF CERAMICS.

Sahan N.T., Zaiats L.M., Zhurakivska O.Ya., Antymys O.V., Dutchak U.M., Miskiv V.A.

DISTANCE LEARNING IN MEDICAL HIGHER EDUCATION INSTITUTIONS -

REALITIES OF TODAY.

Saienko N.S., Halatsyn K.O.

FORMATION OF INFORMATION AND COMMUNICATIVE COMPETENCE

OF STUDENTS OF TECHNICAL SPECIALTIES IN THE ENGLISH

LANGUAGE CLASSES.

Snitovska O.I., Tsaryk H.M.

TEACHING OF MEDICAL TERMINOLOGY DURING THE STUDY

OF ENGLISH IN THE CONDITIONS OF DISTANCE LEARNING USING

A PLATFORM FOR ONLINE CLASSES ZOOM.

Tymoschuk N.M.

FORMATION OF ENGLISH COMPETENCE IN DIALOGUE SPEECH

OF FUTURE SPECIALISTS IN HOTELS, RESTAURANTS AND CATERING.

Tytok I.V.

INTRODUCTION OF INFORMATION AND COMMUNICATION TECHNOLOGIES

IN THE PROCESS OF PROFESSIONAL TRAINING OF JUNIOR LAW SPECIALISTS.

Tuliakova K.R.

LANGUAGE-CONFLICTS MODELING TECHNOLOGY IN ADUCATION.

Khoma T.V., Stebliuk S.V.

INTEGRAL COMPETENCE AS A COMPONENT OF PROFESSIONAL COMPETENCE

IN PEDAGOGICAL EDUCATION. 


\section{НОВА ОСВІТНЯ ПАРАДИГМА В РЕАЛІЯХ СУЧАСНИХ ГЛОБАЛІЗАЦІЙНИХ ПРОЦЕСІВ \\ NEW EDUCATIONAL PARADIGM IN THE REALITIES OF MODERN GLOBALIZATION PROCESSES}

УДК 37.014 .53

DOI https://doi.org/10.32843/2663-

6085/2021/31-1.1

\section{Голуб т.п.,}

канд. пед. наук, доцент,

доцент кафедри англійської мови технічного спрямування № 2

Національного технічного університету України «Київський політехнічний інститут імені Ігоря Сікорського»

\section{Жигжитова Л.М.,}

викладач кафедри англійської мови технічного спрямування № 2

Національного технічного університету України «Київський політехнічний інститут імені Ігоря Сікорського»

\section{Назаренко О.І.,}

викладач кафедри англійської мови технічного спрямування № 2 Національного технічного університету України «Київський політехнічний інститут імені Ігоря Сікорського»
Стаття присвячена дослідженню проблеми формування нової освітньої парадигми в сучасних умовах стрімких соціальних, економічних, екологічних і технологічних змін. Наразі триває переламний момент розвитку освіти, зумовлений світовими тенденціями, національними змінами й глобальними суспільними викликами. Нові умови визначаються чинниками, серед яких глобалізація економіки, технологічні інновації та швидкі соціальні зміни. Ці зміни супроводжуються зростанням мобільності праці й створенням суспільства, яке базується на знаннях і відкриває нові перспективи для освіти й навчання. Особливість нової парадигми освіти полягає в переорієнтації системи освіти на врахування потреб розвитку особистості й надання їй можливості ефрективної участі у сфрері праці. Формування нової освітньої парадигми відбувалося в процесі взаємодії зовнішніх умов світового розвитку з внутрішніми особливостями й логікою розвитку, властивими національним системам освіти. Ключовим фрактором зовнішнього впливу на національні системи освіти є процес глобалізації. Таким чином відбувається конвергенція освітніх систем і виникнення міжнародної моделі освіти. Крім глобалізаиії та поширення інсрормаційнокомунікативнихтехнологій, варто відзначити ще один фрактор, який впливає на системи освіти й є похідним від процесів глобалізаціі та зумовлений посиленням мобільності населення світу - це фрактор зростання мультикультурного характеру національних держав, який має велике значення для Європи в цілому й України зокрема. Розв'язання цих завдань вимагає нової парадигми розвитку освіти, що супроводжується розвитком базових понять і компетенцій, серед яких найважливішим $\epsilon$ вміння вчитися. 3 огляду на зростальний динамізм і взаємозалежність суспільства майбутнього, характер його впливу на освіту, ускладнюється і вплив освіти на хід суспільних процесів, а також маситабність і неординарність завдань, що стоять перед світовою освітою. Можна говорити про те, що пошуки ії нової парадигми вже не $\epsilon$ справою тільки дослідників-педагогів і вимагають широкого впровадження міждисциплінарного підходу. Ключові слова: освітня парадигма, глобалізація, суспільство знань, система освіти, інтернаціоналізація.
The article is devoted to the research of the problem of a new educational paradigm formation in modern conditions of rapid social, economic, ecological and technological changes. A current turning point in education development is driven by global trends, national changes, and global social challenges. The new conditions are determined by the globalization of the economy, technological innovation and rapid social change. These changes are accompanied by increased labour mobility and the creation of a knowledgebased society that opens up new education and training perspectives. The peculiarity of the new educational paradigm is the education system reorientation based on the needs of personal development and the opportunity to participate effectively in the field of labour. The formation of the new educational paradigm takes place in the process of interaction of external conditions of world development with the internal features and logics of national education systems' development. The key factor of external influence on national education systems is the process of globalization. Thus there is a convergence of educational systems and the emergence of an international model of education. In addition to globalization and the spread of information and communication technologies, it is worth noting another factor that affects education systems, is derived from the processes of globalization and is due to increased mobility of the world's population - the multicultural nature of states' growth, which is of great importance for Europe and Ukraine. Solving these problems requires a new paradigm of educational development, accompanied by the development of basic concepts and competencies, among which the most important is the ability to learn. The growing dynamism and interdependence of the society, the nature of its impact on education as well as the scale and originality of the challenges facing world education is constantly becoming more complicated. The search for its new paradigm is no longer a matter for educators and requires the widespread introduction of an interdisciplinary approach.

Key words: educational paradigm, globalization, knowledge society, educational system, internationalization.
Постановка проблеми в загальному вигляді. Освіта як суспільна підсистема знаходиться в прямій залежності від процесів, які відбуваються як у конкретному суспільстві, так і у світі в цілому. Водночас системи освіти національних держав, маючи певні інваріантні характеристики, завжди залишаються культуро-обумовленими конфігураціями.
Наразі освіта переживає переламний момент свого розвитку, який визначається світовими тенденціями, потенціалом внутрішніх змін і глобальними викликами, що постали перед суспільством, зокрема у зв'язку з пандемією COVID-19.

Як зазначається в матеріалах найбільших міжнародних освітніх, економічних і суспільствознавчих 
форумів, XXI століття створює зовсім нове суспільство й економіку, що безперечно чинять свій вплив на освіту. Нові умови визначаються низкою фракторів, серед яких центральне місце посідають глобалізація економіки, технологічні інновації, зокрема в галузі інфрормаційних і комунікаційних технологій, і швидкі соціальні зміни. Ці зміни супроводжуються зростанням мобільності праці й створенням суспільства, яке базується на знаннях, що відкриває нові перспективи для освіти й навчання. В умовах швидких соціальних, економічних, екологічних і технологічних змін переосмислюються і цілі освіти й організація навчання.

Аналіз останніх досліджень і публікацій. Дослідженню змін, які характерні для системи освіти у XXI столітті, присвятили свої наукові праці Ф. Саліцеті [1], Л. Бейкер, С. Врайт, М. Милопулос, М. Куласеґарам, С. Нґ [2], К. О’Браян, П. Говард [3], Ґ.М. Воут [4], С. Каган [5], Дж. Берґманн, А. Семс [6] та інші вчені. Питанням глобалізації та її впливу на систему освіти присвячені роботи Дж. Воґт, Н. Парейя Роблін [7], Ф. Різві, Р. Лінґард [8], Л. Джексон [9], П. Фокс, С. Гандлей [10] та інших науковців.

Виділення не вирішених раніше частин загальної проблеми. Особливість нової парадигми освіти полягає в переорієнтації системи освіти в цілому й вищої освіти зокрема на врахування потреб розвитку особистості й надання їй можливості ефрективної участі у сорері трудової діяльності. Цей підхід базується на визнанні пріоритетності знань і навчання в структурі суспільства й визначає знання головною цінністю як людини, так і соціуму в цілому. Водночас у фрормуванні нової освітньої парадигми важливу роль відіграє врахування умов світового розвитку й національних особливостей систем освіти.

Мета статті - дослідити особливості фрормування нової освітньої парадигми з урахуванням реалій сучасних глобалізаційних процесів.

Виклад основного матеріалу. Провідне місце знань у соціумі характеризує виникнення нового типу суспільства, яке базується на знаннях. Як було заявлено на зустрічі голів держав та урядів країн Європейського Союзу в Лісабоні в травні 2000 року, Європа увійшла в нову епоху, яка отримала назву «Століття знань» [11]. Таке високе значення, яке надається знанням та освіті, засвідчує переосмислення традиційних уявлень про навчання, трудову діяльність і життя в цілому й про вихід на перший план навчання протягом життя як умови забезпечення успішного переходу до економіки й суспільства, що базуються на знаннях.

Формування нової освітньої парадигми відбувалося в процесі взаємодії зовнішніх умов світового розвитку 3 внутрішніми особливостями й логікою розвитку, які притаманні національним системам освіти. Згідно з проєктом Стратегії роз- витку вищої освіти України на 2021-2031 роки, визначено 7 цілей розвитку системи вищої освіти України до 2031 року:

- удосконалення системи управління освітою та забезпечення автономії закладів вищої освіти;

- забезпечення збалансованості ринку праці фрахівців із вищою освітою;

- забезпечення якості й доступності вищої освіти;

- інтеграція науки, освіти й бізнесу для економічного зростання країни;

- розвиток кадрового потенціалу закладів вищої освіти;

- розвиток системи безперервної освіти й навчання протягом життя;

- інтеграція в європейський і світовий освітній простір з урахуванням національних інтересів [12].

Ключовими факторами зовнішнього впливу на системи освіти є процес глобалізації. На відміну від традиційних міжнародних відносин, які базуються на понятті взаємовідносин і взаємодій між націями, глобальні відношення означають, що економічна, політична й культурна діяльність виходять за межі окремої територіальної юрисдикції та, відповідно, за межі національних держав [13]. 3 метою теоретичного осмислення процесу глобалізації проводяться розробки партисипативних стратегій, багаторівневого аналізу, інноваційних фрорм якісних досліджень, інноваційних підходів до оцінки ефективності навчальних закладів, широкомасштабних міжнаціональних досліджень тощо [14].

Як дослідна перспектива процес глобалізації вказує на те, що нова парадигма розвитку потребує одночасного врахування глобальних, національних і локальних факторів. Конвергенція передбачає, що в освітніх системах спостерігається збільшення кількості загальних особливостей, які прослідковуються в системах освіти країн Європейського Союзу, а саме:

- наявність національних освітніх програм, де особлива увага приділяється математиці, природничим наукам та іноземним мовам;

- передавання широких повноважень і прав прийняття рішень навчальними закладами;

- зростальне застосування тестів, які оцінюють діяльність;

- зростальна значущість педагогічної просресії та професіоналізму вчителів;

- розширення доступу до розвитку програм навчання протягом життя тощо [15; 16].

Згідно з моделлю консенсусу, глобальна економіка породжує нові виклики, які чинять майже однаковий вплив на всі системи освіти. Одночасно для підвищення власної конкурентоздатності (у випадку невідповідності внутрішніх моделей освіти задачам економічного розвитку) відбувається запозичення найкращих зарубіжних 
моделей, яке здійснюється за допомогою «відбору» й впровадження найефективніших моделей, що потім поступово витісняють менш ефективні. У такому випадку відбувається конвергенція освітніх систем і виникнення міжнародної моделі освіти. На перший погляд, ця модель, яка тісно пов'язана 3 теорією модернізації, виявляється досить переконливою. Однак вона має досить критиків, які вважають сумнівним саме поняття «найкращі моделі» й вказують на відсутність критеріїв їхнього визначення [17], з одного боку. А з іншого, - будь-яка запозичена модель у випадку прискорення підпадає під «обробку» й трансформації фракторами локального, в результаті чого вона переосмислюється та починає демонструвати якісні відмінності від вихідної моделі, тим самим заперечуючи тезу про конвергенцію систем.

У XXI столітті вимоги до вищої освіти в країнах Європейського Союзу зумовлені метою перетворення Європи на найбільш конкурентоспроможну й динамічну світову економічну систему, яка заснована на знаннях, схильну до стійкого економічного розвитку, що створює нові робочі місця та забезпечує соціальну єдність суспільства [18]. Важливою метою європейської політики в галузі вищої освіти стає сприяння в зближенні рівнів ефективності національних систем вищої освіти в розв'язанні загальних задач.

Крім глобалізації та розповсюдження інформаційно-комунікативних технологій, варто зазначити ще один фрактор, який впливає на системи освіти, похідний від процесів глобалізації та зумовлений посиленням мобільності населення земної кулі. Це фрактор зростання мультикультурного характеру національних держав, який має велике значення для країн Європейського Союзу та Європи в цілому, включаючи й Україну.

Мультикультурний контекст сучасної Європи висуває на перший план задачу вдосконалення навчання іноземним мовам. Як зазначається в документах Лісабонської ради [11], глобалізація економіки й задача фрормування суспільства, яке базується на знаннях, висувають нові вимоги до системи освіти в Європі. У межах цих вимог система професійної освіти повинна розв'язувати потрійну задачу розвитку:

- особистості, здатної повністю реалізувати власний потенціал у професійній та особистій copepi;

- суспільства - шляхом зменшення різниці й нерівності між громадянами й групами громадян;

- економіки - шляхом забезпечення відповідності вмінь на ринку праці потребам промисловості й роботодавців.

Розв'язання цих задач вимагає нової парадигми розвитку освіти, яка супроводжується розвитком базових понять і компетенцій, серед яких найважливішим $€$ вміння вчитися.
Процеси інтернаціоналізації ставлять перед країнами Європейського Союзу майже однакові проблеми, розв'язання яких обов'язково підвищує важливість вивчення позитивного досвіду інших країн. У такому контексті політика Європейського Союзу в галузі вищої освіти спирається на транснаціональне співробітництво, яке визнається найважливішим фактором розвитку інтеграційних процесів. Задачі цього співробітництва сорормульовані в політичних документах Європейського Союзу в галузі вищої освіти, а їхня реалізація здійснюється в межах європейських програм і проєктів, таких як, зокрема, Еразмус +, Темпус, Горизонт 2020 тощо. Спільні транснаціональні програми й проєкти спрямовані на виявлення фрункціональної рівноцінності різноманітних підходів до вищої освіти й моделей її організації.

Інтернаціоналізація освіти супроводжується посиленням міжнародної складової частини розвитку їі окремих елементів, а саме національних і регіональних освітніх систем. У процесі інтернаціоналізації відбувається фрормування нового міжнародного освітнього середовища, де в найефективніших фрормах можуть як реалізовуватися національні інтереси її учасників, так і відбувається спільний пошук розв'язання проблем, які мають життєво важливе значення для людської цивілізації в цілому.

У таких випадках, коли процеси інтернаціоналізації, що розвиваються, накладаються на історичну давню культурну, господарську спільноту групи держав, у світовій освіті фрормуються великі фррагменти, які характеризуються досить подібними напрямами розвитку та якісним станом національних освітніх систем, які входять до них.

Висновки. Ураховуючи зростальний динамізм глобальних процесів, взаємозалежність суспільства майбутнього, характер його впливу на освіту, що неперервно ускладнюється, та освіти на перебіг суспільних процесів, а також масштабність і неординарність задач, що постають перед світовою освітою, можна говорити про те, що пошуки її нової парадигми досі тривають, проте вони вже не $€$ справою лише дослідників-педагогів.

Подальші перспективи досліджень, спрямованих на фрормування нової парадигми освіти, повинні бути зосереджені на вивченні її міжпредметної компоненти й імплементацію цілей і принципів сталого розвитку.

\section{БІБЛІОГРАФІЧНИЙ СПИСОК:}

1. Saliceti F. Educate for Creativity: New Educational Strategies. Procedia - Social and Behavioral Science. 2015. Vol. 197. P. 1174-1178.

2. Baker L., Wright S., Mylopoulos M., Kulasegaram M., Ng S. Aligning and applying the paradigms and practices of education. Academic Medicine. 2020. Vol. 95(1). DOI: 10.1097/ACM.0000000000003050.

3. O'Brien C., Howard P. The Living School: The Emergence of a Transformative Sustainbility 
Education Paradigm. Journal of Education for Sustainable Development. Vol. 10 (1). DOI: https:// doi.org/10.1177/0973408215625549.

4. Voght G.M. New paradigms for U.S. higher education in the twenty-first century. Foreign Language Annals. 2000. Vol. 33. P. 269-277.

5. Kagan S. From Lessons to Structures - A Paradigm Shift for 21st Century Education. San Clemente, CA : Kagan Publishing. Kagan Online Magazine, Spring 2004.

6. Bergmann J., Sams A. Flip your students' learning. Educational leadership. 2013. Vol. 70 (6). P. 16-20.

7. Vogt J., Pareja Roblin N. A comparative analysis of international frameworks for 21st Century competences: Implications for national curriculum policies. Journal of Curriculum Studies. 2012. Vol. 44 (3). P. 299-321.

8. Rizvi F., Lingard R. Globalizing educational policy. London : Routledge, 2010. 240 p.

9. Jackson L. Globalization and Education. 2016. DOI: https://doi.org/10.1093/acrefore/9780190264093.013.52.

10. Fox P., Hundley S. The Importance of Globalization in Higher Education, New Knowledge in a New Era of Globalization. 2011. DOI: 10.5772/17972. URL: https://www.intechopen.com/books/new-knowledge-ina-new-era-of-globalization/the-importance-of-globalization-in-higher-education (дата звернення: 07.01.2021).

11.Lisbon European Council conclusions. 23-24 March 2000. URL: https://www.europarl.europa.eu/summits/lis1_en. htm\#: :text=PRESIDENCY\%20CONCLUSIONS \&text=The\%20European\%20Council\%20held\%20a,of\%20 a\%20knowledge\%2Dbased\%20economy (дата звернення: 07.01.2021).

12. Стратегія розвитку вищої освіти в Україні на 2021-2031 роки. Київ, 2020. 71 с. URL: http://osvita.ua/ doc/files/news/768/76871/STRATEHIYA_ROZVYTKU_ VYSHCHOYI_OSVITY_V_U.pdf (дата- звернення: 07.01.2021).

13. Giddens A. Beyond Right and Left: the future of radical politics. Cambridge : Policy Press, 1995. 270 p.

14. Continuing Vocational Training. Cross Country Analysis. EYF, Luxembourg, 1999. 458 p.

15. Anticipation of Occupations and Qualifications Trends in the European Union / ed. B. Sellin. CEDEFOP, Thessaloniki, May, 2000. 126 p.

16. European Council Presidency Conclusions. Lisbon, 23-24 March, 2000. 59 p.

17. Phillips D. Borrowing Educational Policy. Something Borrowed, Something Learned? The transatlantic Market in Education and Training Reform. The Brookings Institute, Washington DC, 1993. 421 p.

18. Tessaring M. Training for a Changing Society. A Report on Current VET Research in Europe 1998. CEDEFOP Reference Document. Luxembourg, EUR-Op, 1998. 194 p. 


\section{ВИМІРИ МОРАЛЬНОСТІ ЛЮДИНИ В ІСПАНСЬКІЙ ПЕДАГОГІЧНІЙ ДУМЦІ} HA MEЖI XIX - XX CT.

\section{THE DIMENSIONS OF HUMAN MORALITY IN SPANISH PEDAGOGICAL THOUGHT AT THE TURN OF THE XIX - XX CENTURIES}

У статmі здійснюється аналіз проблеми моральності людини в іспанській педагогічній думці на межі XIX - XX cm. Показано, що іспанські педагоги френомен моральності людини досліджували у трьох вимірах - аксіологічному, гносеологічному, праксеологічному. В аксіологічному вимірі моральність людини інтерпретувалася як необхінна умова досягнення «тимчасового» (земного) $і$ «вічного» (небесного) щастя. У гносеологічному вимірі моральність людини - індикатор розвиненої у неї моральної свідомості - здібності розрізняти добро і лихо, доброчесність $і$ порок, святість і гріховність. У праксеологічному вимірі моральність людини - вільне вчинення добрих справ, що включає свідоме виконання людиною моральних обов'язків перед Богом, перед іншими людьми, перед собою.

у трактуванні концепту «моральність людини» іспанські педагоги на межі $X I X-X X c m$. ні на йоту не відступали від християнської етики. Розкриття френомена моральності людини вони вели за такими параметрами: цільове призначення, ціннісні сенси, сутнісні ознаки, змістовні елементи. У працях іспанських педагогів Р. Руїса Амадо, Л. Парраля Крістобаля, П. Креспі, А. Хімено, С. Пуейо Саламеро, П. Відаля Хіменеса, P. Дієса, Л. Морено Бустаманте, К. Йєвеса, Х. Андреу та інших було висвітлено різні аспекти проблеми моральності людини, роз'яснено суб'єктивні позиції стосовно френомена моральності, запропоновано тлумачення понять «добро», «лихо», «доброчесність», «порок», «обов'язок».

Велике значення у формуванні моральност людини іспанські педагоги на межі XIX-XX cm. відводили справі морального виховання. Саме під проводом добре організованого морального виховання (насамперед в освітніх установах) можуть розвинутися моральні здібності людини, дані їй від природи. Розуміння того, яким чином має бути організований чей педагогічний процес, не було можливим поза осмисленням френомена моральності людини у розмаїтті його вимірів. Іспанські педагоги сходилися на тому, що моральне виховання лише допомагає розкритися моральності особистості властивості, притаманній людській істоті від народження. Воно є тим обов'язковим механізмом, який приводить цю властивість у дію, даючи людині змогу осягати «вічний» смисл життя.

Ключові слова: іспанська педагогічна думка, іспанські педагоги, моральність людини, аксіологічний вимір, гносеологічний вимір, праксеологічний вимір, доброчесність, обов'язок, моральне виховання.
The problem of human morality in Spanish pedagogical thought at the turn of the XIX and $X X$ centuries has been analyzed in the article. It is shown that Spanish teachers studied the phenomenon of human morality in three dimensions - axiological, gnoseological and praxeological. In the axiological dimension, human morality was interpreted as a necessary condition for achieving "temporal" (earthly) and "eternal" (divine) happiness. In the gnoseological dimension, human morality was understood as an indicator of a person's developed moral consciousness - ability to distinguish between good and evil, virtue and vice, holiness and sinfulness. In the praxeological dimension, human morality was explained as the free performance of good deeds, including the conscious fulfillment by person of moral responsibilities - to God, to other people, to herself.

In interpreting the concept "human morality" Spanish teachers at the turn of the XIX and XX centuries did not depart from Christian ethics in anything. The disclosure of the human morality phenomenon in Spanish pedagogical thought at the turn of the XIX and XX centuries was carried out according to such parameters as target purpose, value meanings, essential features, significant elements. In the works of Spanish educators R. Ruiz Amado, L. Parral Cristobal, P. Crespi, A. Jimeno Caridad, S. Pueyo Salamero, P. Vidal Jimenez, R. Diez, L. Moreno Bustamante, C. Yeves, J. Andreu Folch and others various aspects of the problem of human morality were covered, subjective positions concerning the morality phenomenon were explained, interpretations of the concepts "good", "evil", "virtue", "vice", "responsibility" were proposed.

Great importance in the formation of human morality was given by Spanish teachers at the turn of the XIX and XX centuries to matter of moral education. It is under the guidance of well-organized moral education (especially in educational institutions) moral abilities of a person, given by nature, can develop. Understanding how this pedagogical process should be organized did not seem possible outside knowing of the human morality phenomenon in the diversity of its dimensions. Spanish educators agreed moral education only helps to reveal the personality morality the property inherent in the human being from birth, but moral education is the obligatory mechanism what drives this prosperity, allowing a person to comprehend the "eternal" meaning of life.

Key words: Spanish pedagogical thought, Spanish teachers, human morality, axiological dimension, gnoseological dimension, praxeological dimension, virtue, responsibility, moral education.
Постановка проблеми в загальному вигляді. Розвинення моральності людини - одне із найважливіших завдань морального (і духовного) виховання, які розв'язувалися в іспанській педагогіці на межі XIX - XX ст. У тогочасній іспанській педагогічній думці поняття «моральність» визначалося по-різному. Зде- більшого обґрунтовувалася ідея про те, що людина народжується із задатками до моральності - моральними здібностями, а для їхнього розвитку необхідний цілеспрямований педагогічний вплив.

Моральність людини іспанські педагоги окреслювали не як статичну характеристику, щось 
одного разу й назавжди задане, а як динамічну, змінювану, процесуальну характеристику. Моральність людини потребує постійного удосконалення, величезної праці самої особистості, її значних духовних зусиль.

Перше питання, яке розглядали іспанські педагоги на межі XIX - XX ст. стосовно моральності людини, навіщо, заради чого її необхідно цілеспрямовано розвивати й удосконалювати. Тим самим задавався пошук ціннісно-смислових значень моральності людини (аксіологічний вимір). Інше питання - чи досить для виявлення моральності людини знання про мораль? В іспанській педагогічній думці на межі XIX - XX ст. це питання при визначенні змісту морального виховання було найбільш дискусійним.

Виховання моральності людини насамперед могло здійснюватися шляхом навчання моральних приписів, постулатів і правил. А от яким чином людина скористається здобутим знанням про мораль? Як їі можна навчити жити доброчесно? Тут починалася та проблемна зона, у площині якої окреслювалися сутнісні ознаки моральності (гносеологічний вимір). Питання про те, як має визначатися моральність людських вчинків, які вкладається у зміст поняття «доброчинна поведінка», відкривали поле для роздумів про діяльнісну сторону моральності (праксеологічний вимір).

Аналіз останніх досліджень і публікацій. Історію іспанської педагогічної думки на межі XIX - XX ст. досліджували науковці Б. Делгадо Кріадо (В. Delgado Criado), А. Капітан Діас (А. Capitan Diaz), В. Гарсія Оз (V. Garcia Hoz), А. Голіно Каррільо (A. Golino Carrillo), X. Pуїс Берріо (J. Ruiz Berrio), X. Геренья (J. Guereña), А. Тіана Феррер (A. Tiana Ferrer), О. Негрін Фахардо (О. Negrin Fajardo), А. Віньяо Фраго (A. Viñao Frago), Р. Вальс Монтес (R. Valls Montes), M. Пуельєс Бенітес (M. Puelles Benitez) та інші.

Окремі аспекти проблеми морального виховання в Іспанії на межі XIX-XX ст. висвітлено у працях сучасних дослідників А. дель Мораль Віко (A. del Moral Vico), Х. Фернандеса Copiї (J. Fernandez Soria), М. Віко Монтеоліви (M. Vico Monteoliva), І. Паласіо Лic (I. Palacio Lis) та інших.

Мета статті - вивчити, яким чином розумівся і тлумачився в іспанській педагогічній думці на межі XIX - XX ст. френомен моральності людини; проаналізувати інтерпретації цього феномена іспанськими педагогами в аксіологічному, гносеологічному, праксеологічному вимірах.

Виклад основного матеріалу. Славетний педагог Р. Руїс Амадо (Ramon Ruiz Amado), представник католицького напряму іспанської педагогічної думки межі XIX-XX ст., стверджував, що «моральність - це якість, властива людським вчинкам; отже, морального вчинку немає там, де людина не діє вільно по совісті» [1, с. 49]. Для того, щоб вчинки людини з точки зору моралі були добрими, не досить зовнішніх умов, має бути внутрішній дух, спрямований на досягнення моральної мети [1, с. 49-50].

Барселонський педагог-богослов С. Пуейо Саламеро (Sebastian Pueyo Salamero) наголошував: «Моральність людських вчинків полягає у відповідності або невідповідності вічному закону Божій волі. Для чинення моральної дії необхідно поєднання розуму і волі, перший - бачитиме мету дії, інша - слугуватиме їі справжньому виконанню» [2, с. 205].

У підручнику для молодших школярів, написаному наприкінці 1890-х років педагогом К. Йєвесом (Carlos Yeves), зазначалося, що людські вчинки за критерієм моральності поділяються на добрі і погані; добрі вчинки - ті, які відповідають закону Божому, погані - ті, які йому не відповідають. Найважливіша моральна проблема для людини - відрізнити добро від лиха. Далі дослівно за текстом: «що розуміється під добром? Добро - це усе, що Бог послав нам. А лихо? Усе, що Бог заборонив нам. Що означає вчиняти добре? Дотримуватися доброчесності» [3, с. 20].

В аксіологічному вимірі моральність людини іспанські педагоги на межі XIX - XX ст. інтерпретували як шлях досягнення «тимчасових» і «трансцендентальних» цілей. Знання моральних норм, приписів і максим, дотримання моральних доброчесностей, виконання моральних обов'язків необхідні умови для здійснення земного життєвого шляху людини. Цей шлях $€$ обмеженим у часі, завершуваним. Ним вимірюється досконала реалізація людського (доленосного) призначення, заради якого Бог привів людину у земний світ. Моральність людини у «тимчасовому» модусі буття - повне провадження власною свободною волею Божого задуму, відповідно до якого людина як найвище Боже творіння постійно прагнутиме до удосконалення, чим заслуговуватиме право на Божу благодать - «небесний рай» або «вічне щастя».

На думку іспанських педагогів межі XIX - XX ст., найголовніша цінність моральності людини - y досягненні щастя «тимчасового» і «вічного». У підручнику П. Відаля Хіменеса (Prudencio Vidal Jimenez), призначеному для навчання моралі учнів початкових шкіл, червоною ниткою проходила думка про необхідність постійного спрямування людини на добрі діяння для «спокою у цьому житті і щастя в іншому». Щастя полягає у тому, щоб робити якомога більше добра і не допускати лиха. Доброчесна поведінка людини сприятиме досягненню щастя не лише у цьому житті, але й в іншому. Особистість має діяти відповідно до того, як вимагає її свідомість, а свідомість виникає тоді, коли мораль впливає на вчинки 
людини. «Щоб досягти повного щастя, необхідно мати живу і чисту віру, а це означає цілковите слідування істинам християнської релігії, точне виконання ії правил, ставлення із великим презирством до порушення традицій і безбожжя", - переконував педагог [4, с. 201].

Про те, що моральність людини - підґрунтя для досягнення трансцендентальних цілей, йшлося у педагогічній праці викладача етики А. Хімено (Antonio Jimeno Caridad). Педагог вказував, що «остання мета - це досягнення вищого щастя людиною» і що «усі зусилля людини у земному житті мають спрямовуватися до останньої мети» $[5$, c. 26].

Видатний іспанський педагог Л. Парраль Крістобаль (Luis Parral Cristobal) вважав моральність людини її основним орієнтиром по життю. Людина завжди має пам'ятати, що є «тимчасові» блага i $€$ «вічні». «Тимчасові» блага можуть бути матеріальними (багатство), розумовими (талант, освіта), моральними (характер, милосердя, набожність). Вони супроводжують земне життя людини, необхідні їй у земному житті, однак вони - лише засоби для досягнення «вічних» благ [6, с. 120].

Ціннісне значення моральності людини обґрунтовував і педагог Р. Руїс Амадо (Ramon Ruiz Amado). На його думку, творення людини як істоти моральної є сенсом виховання. Він писав: «її [дитини] виховання, її моральне виробництво досягається у меті, про яку ми сказали: щоб вона була щасливою, її намагаються зробити доброю; це $є$ основна мета виховання. Для того, щоб вона була щасливішою за своїх батьків, її прагнуть зробити кращою за них; це $є$ творення прогресивного елемента» [1, с. 30]. Моральність людини має і суспільно значущий сенс. «Там, де відсутня моральність у домінуючому ідеалі суспільства і виховання, не можлива гармонія суспільних відносин, а отже громадянське процвітання і індивідуальне міцне щастя», - робив висновок педагог $[1$, c. 35].

У гносеологічному вимірі моральність людини іспанські педагоги на межі XIX - XX ст. розглядали як результат правильно сфрормованої моральної свідомості, що дозволяє особистості не лише розрізняти добре і погане, доброчесне і порочне, святе і гріховне (відповідно до християнської доктрини) та розмірковувати і судити про це, але й слідкувати за власними вчинками, розуміти відповідальність за свої дії; як умова освоєння і зміни світу, адже моральність - це насамперед ставлення людини до навколишнього, і якщо це ставлення буде не доброчесним, людина своїми діями спричинятиме руйнацію довкілля і порушуватиме той порядок, за яким соціум організований.

Педагог Е. Санс Ескартін (Eduardo Sanz у Escartin) висловлював думку про те, що зміцнення духу особистості потребує не лише роз- винення розуму, але й фрормування моральної свідомості. «Не так важливо пізнавати багато, як пізнавати правильно. У навчальних предметах необхідно більше дбати про якість, ніж про кількість. Наука, яка не покращує наших прихильностей, яка не озброює нас для боротьби за життя, яка не направляє нас до добра, є наукою фральшивою і пагубною. Не є, як зазвичай вірять, народи сильніші тим, що багато освічені, але $є$ сильніші тим, що краще освічені. Ця якість освіти визначається не лише правильним спрямуванням пізнання, розуміння, гармонії теорії та практики, але й морального елемента, який уможливлює перетворення знання на дію, особистого інтересу - на обов'язок", - зазначав педагог [7, с. 9].

У педагогічній праці П. Креспі (Pedro Crespi) обґрунтовувалося значення розвинення моральної свідомості у орормуванні особистості. Моральна свідомість людини - це її «внутрішній голос, який постійно наполягає на необхідності виконання моральних обов'язків» [8, с. 58]. Моральна свідомість людини розвинеться поступово під впливом умов навколишнього середовища і дасть їй змогу відділяти добре від поганого, доброчесне від порочного [8, с. 58].

Педагог-богослов С. Пуейо Саламеро (Sebastian Pueyo Salamero) зазначав про те, що моральність людських вчинків визначається відповідно до узгодження їх із вічним законом - Божою волею, який людина має пізнати. Зовнішнім регулятором людських вчинків є закон, внутрішнім совість. Совість - «практичне судження розуму про добро чи лихо вчинку, який необхідно зробити або ж не допустити у певних обставинах, у які потрапив індивід» [2, с. 208].

B іспанській педагогічній думці на межі XIX - XX ст. захищалася ідея про те, що моральність людського вчинку має включати до свого змісту і доброчесність помислу, задуму або наміру вчинити саме такі дії, які спричинять добро. Доброчесність - «звичка душі, яка схиляє людину вчиняти добре» або ж «звичай вчиняти відповідно до порядку, встановленого Богом» [2, с. 220-221].

У праці Е. Рейга (Enrique Reig у Casanova) доброчесність визначалася як «звичка або незмінні воля і намір чинити добро заради Бога» [9, с. 171]. У підручнику П. Відаля Хіменеса (Prudencio Vidal Jimenez) поняття «доброчесність» роз'яснювалося як прагнення робити добро ближнім без особистого інтересу від цього. «Найважливіша, найвеличніша і найвища умова з усіх, які людина може мати на землі, - це умова бути доброчесною, оскільки із доброчесністю ми виконуємо наші обов'язки й таким чином стаємо і причиною справжніх заслуг, і основою нашого щастя. Доброчесність не лише дає нам змогу здобути щастя і безсмертну славу в іншому житті, але й слугує тому, щоб наше життя було сповнене честі 
і користі, спокою і того щастя, яке можливе тут, на землі», - наголошував П. Відаль Хіменес [4, с. 29].

Педагог К. Йєвес (Carlos Yeves) у своєму підручнику наводив такий текст під назвою «Доброчесність і порок»: «Що є доброчесність? Звичка чинити добре. Де бере своє походження доброчесність? Здебільшого - у Божій любові. Як розвинути доброчесність? Пробуджуючи бажання вчиняти добре, докладати зусиль і слідувати тому, до чого схиляє дух; згодом чинити добро стане легко, до прагнення досягати мети додасться звичка. У чому дієвість доброчесності? У духовному спокої, який забезпечує щастя. що є порок? Звичка вчиняти погано. У чому відмінність поганого вчинку від пороку? У тому, що він - один, а порок - це низка поганих вчинків. Як виникає порок? Піддаючись бажанню задовольняти свої пристрасті або спрямовуючи на це свої наміри, людина легко потрапляє у течію власних бажань і набуває звички вчиняти погано. що спричиняє порок? Душевний неспокій, докори совісті, велике нещастя, усілякі страждання в житті й у вічності» [3, с. 22-23].

Спираючись на зміст іспанських підручників із моралі, виданих у 1890-1910-х роках, можна судити про те, що розуміння моралі учнями і студентами передбачало усвідомлення ії як «абсолютної істини» з чітким розмежуванням доброго і лихого, святого і грішного, дозволеного і недозволеного (за законом Божим). Основна ідея засвоєння моралі вихованцями: чинення добра - правильний шлях виконання людського призначення на землі, яке реалізується вільною волею людини за задумом Божим; цей шлях - духовний, він не можливий без спрямованості людського духу (живої субстанції) на світоперетворення.

У праксеологічному вимірі моральність людини окреслювалася в іспанській педагогічній думці на межі XIX - XX ст. насамперед як чинення моральних дій або добрих справ, як виконання моральних обов'язків, як доброчинне поводження людини у соціумі. На думку педагога Р. Дієса (Rodrigo Diez), «будь-який вільно здійснюваний людський вчинок є добрим чи поганим із позиції моралі» [10, с. 303]. Моральний вчинок - це завжди вільне діяння людини, але він має повністю відповідати волі Божій, бути добрим, як його замислив Бог $[10$, с. 304$]$.

Видатний іспанський педагог П. де Алькантара Гарсія (Pedro de Alcantara Garcia) стверджував, що воля - це «найвища моральна здібність», «практична духовна здібність» [11, с. 137]. Людська воля як фрорма діяльності має певні модуси спрямування духу, зокрема, такими модусами виступають свобода діяння та звичка. Свобода у такому випадку розуміється у значенні моральному, як усвідомлення людиною себе та володіння собою. Без такої свободи людина перетворюється на свавільну та капризну істоту [11, с. 138].
Викладач педагогіки і педагог-теоретик П. Креспі (Pedro Crespi) називав волю «єдиною моральною здібністю», «здібністю направляти нас до добра за свідомим розумінням» [8, с. 56].

Уже зі школи початкового навчання дитина мала опановувати, яким $€$ моральний обов'язок і яким чином його необхідно виконувати. Педагоги окреслювали чотири групи моральних обов'язків, про які змалку мали пам'ятати вихованці: обов'язки людини перед Богом; обов'язки перед собою; обов'язки перед іншими людьми; обов'язки, пов'язані зі справою або професією. Основними моральними обов'язками людини перед Богом $€$ «поклоніння, вдячність, страх, довіра, віра, надія і любов» [3, с. 23].

Педагог Л. Морено Бустаманте (Luis Moreno Bustamante) називав моральні обов'язки людини перед Богом «релігійними», оскільки вони ґрунтуються на релігійних доброчесностях любовімилосердя, віри та надії [12, с. 374-375]. Педагог T. Ромеро де Кастилья (Tomas Romero de Castilla) вказував, що «обов'язок - це будь-яка діяльність або бездіяльність, приписана природним законом» $[13$, с. 107].

Стосовно моральних обов'язків перед Богом він окреслював групу «теоретичних» обов'язків, які людина має виконувати «за розумінням». Йдеться як про обов'язки набувати знання про Бога та його властивості; так і про групу «практичних» обов'язків, які проваджуються людиною «за почуттям і волею», наприклад, поклоніння Богові, моління [13, с. 113-114].

Моральні обов'язки людини перед собою - це насамперед уважне ставлення до власної душі, до її здібностей відчувати, думати й воліти. Важливо дотримуватися естетичної та моральної культури у житті. Людина має піклуватися і про власну розумову культуру, не лише удосконалювати здібність спрямовувати свій розум на пізнання істини, але й обходити усе, що може призвести до хиб, несприятливим чином вплинути на неї [12, с. 395].

Педагог Х. Андреу (Jose Andreu у Folch) зауважував, що обов'язки людини перед собою - це «обов'язки стосовно власної душі і тіла». Людина має піклуватися про власну душу, розвивати розум шляхом здобування нових знань, удосконалювати волю. Обов'язки перед ближніми ґрунтуються на трьох заповідях Закону Божого: «люби ближнього як самого себе; вчиняй 3 іншими так, як хочеш, щоб вчиняли 3 тобою; не роби іншому того, чого не хочеш, щоб робили тобі» [14, с. 94-95].

Стосовно інших людина має діяти із милосердям, справедливістю та ввічливістю. Обов'язки перед суспільством становлять велику групу моральних обов'язків і розподіляються на обов'язки перед подружжям, батьками, дітьми, вчителями, учнями, господарями, слугами, управителями, підлеглими. Так, управитель зобов'язаний 
«ставитися до підлеглих із доброзичливістю; здійснювати керівництво справедливо; слідкувати за суспільним порядком; заохочувати розвинення наук і мистецтв; дбати про повагу до законів і про їх дотримання» [14, с. 98]. Підлеглі (громадяни) мають «дотримуватися законів, встановлених цивільною та церковною владою, і виконувати їх положення; сплачувати податки державі зі своїх доходів; власним життям за потреби захищати батьківщину» $[14$, с. 99].

Навчання моралі учнів мало включати і вивчення певних постулатів і прислів"їв. Наприклад: «Той, у кого довгий язик, із часом тяжко кається» [4, с. 19]; «Ледарство живить порок і веде у безодню» [4, с. 37]; «Голос совісті - це голос провидіння» [4, с. 45]; «Хочеш бути вільним - не допускай боргів» [4, с. 51]; «Час - великий скарб, він цінніший за золото» [4, с. 63]; «Заздрість гнітить людину більше, ніж змагальність надихає» [4, с. 69]; «Милосердя - дар неба, джерело, 3 якого випливають усі великі справи» [4, с. 78]; «Жадоба - гріх, який із доброї людини робить погану» [4, с. 83]; «Коли мало тканини, треба шити короткий плащ» [4, с. 124]; «Нині ткач, завтра коваль, а післязавтра - прошак» [4, с. 137]; «Той, хто збирається полювати на двох птахів, жодного не піймає» [4, с. 138]; «Простити кривдника - найкраща помста» [4, с. 194].

Висновки. Проблема моральності людини набула широкого висвітлення в іспанській педагогічній думці на межі XIX - XX ст. Якщо залишити осторонь усі розбіжності педагогів у тлумаченні концепту «моральність людини», можна звести його до такої фрормули: моральність людини - це діяння, здійснювані свободною волею людини за доброчесним помислом, спрямовані на звершення добра. Щонайменше три складники мають бути у наявності для досягнення моральності як стійкої якості особистості: 1) воля людини чинити добрі діяння, оскільки моральність заснована на розумній і вільній природі людини; 2) задум, який передбачає настання таких наслідків діяння, які розцінюються як добро відповідно до закону Божого; 3) саме діяння, результатом якого має стати добро.

Три виміри моральності людини (аксіологічний, гносеологічний, праксеологічний) дозволяють уявити цей феномен не лише у планіметричному, а й у стереометричному огляді. Людина за своєю природою (як її замислив Бог) схильна до чинення моральних дій. У процесі пізнання закону Божого особистість навчається розпізнавати добро і відділяти його від лиха. У своєму прагненні до Божої благодаті і вільному свідомому прийнятті волі Божої вона плекає думки про доброчесні способи життєустрою. Для здобуття «вічного» щастя (заради Бога) вона спрямовується на «тимчасові» (заради спільноти) добрі вчинки.
В іспанській педагогічній думці на межі XIX - XX ст. стосовно френомена моральності людини виявляються такі сенси: ірраціональний - людина усіма своїми добрими справами обов'язково заслужить право на «вічність»; раціональний - індивідуальне життя у людській спільноті вимірюється моральними діяннями людини; гуманістичний - особистість не може здобути щастя (добро, свободу, благодать, смисл) без звершення людських (моральних) вчинків. Саме моральність дозволяє людині у земному світі розкрити людське у собі і повністю втілити його у діяннях із удосконалення навколишнього, тим самим осягаючи «вічний» смисл життя.

\section{БІБЛІОГРАФІЧНИЙ СПИСОК:}

1. Ruiz Amado R. La educacion moral. Barcelona : Libreria Religiosa, 1913. 574 p.

2. Pueyo Salamero S. Lecciones de religion y moral. Barcelona : Imprenta de la Casa Provincial de Caridad, 1911. $340 \mathrm{p}$

3. Yeves C. Mentor de los niños. Coleccion de tratados para la primera enseñanza. Madrid : Libreria de Hernando y C., 1898. 256 p.

4. Vidal Jimenez P. La aurora de la niñez. Libro moral de lectura para niños y niñas. Guadalajara : Establecimiento Tipografico de Antero Concha, 1908. $210 \mathrm{p}$.

5. Jimeno Caridad A. Nociones de Etica. Zamora : Imp. de Enrique Calamita, 1901. 160 p.

6. Parral Cristobal L. Teoria completa de la educacion para los maestros y maestras. Valladolid : Imp. y Libr. Nacional y Extranjera de Andrés Martín, 1900. 158 p.

7. Sanz y Escartin E. La educacion moral. Madrid : Imprenta de E. Raso Lopez, 1910. 60 p.

8. Crespi P. Nociones elementales de Pedagogia o principios de educacion y metodos de enseñanza segun el programa de esta asignatura en la Escuela Normal de Maestros de Baleares. Palma : Establecimiento tipografico de Juan Colomar y Salas, 1891. 206 p.

9. Reig y Casanova E. Elementos de religion y moral. Palma : Tip. de la Viuda e Hijo de Juan Villalonga, 1893. $427 \mathrm{p}$.

10. Diez R. Elementos de religion y de moral para uso de los alumnos de segunda enseñanza y utilidad de toda clase de personas. Salamanca : Imprenta de Calatrava, 1895. 434 p.

11. Alcantara Garcia P. Tratado de Pedagogia. Madrid : Saturnino Calleja, 1896. 440 p.

12. Moreno Bustamante L. Curso de psicologia, logica y filosofia moral. Logroño : Imp. y Lib. de D. Ricardo M. Merino, 1892. 464 p.

13. Romero de Castilla T. Elementos de filosofia moral para uso de los alumos del Instituto de esta provincia. Badajoz : Imprenta y Encuadernacion La Minerva Extremeña, 1893. 232 p.

14. Andreu y Folch J. Historia Sagrada, Religion, Moral y Urbanidad. Nociones de estas asignaturas para los niños que concurren a las escuelas de primera enseñanza. Barcelona : Imprenta y Libreria de Montserrat, 1901. 111 p. 


\section{ВІТЧИЗНЯНИЙ ДОСВІД СТАНОВЛЕННЯ ПРЕДИКАТІВ ХУДОЖНЬОЇ ДІЯЛЬНОСТІ В КОНТЕКСТІ ЕСТЕТИЧНОГО ВИХОВАННЯ}

\section{UKRAINIAN EXPERIENCE OF SETTING PREDICATES OF ARTISTUC ACTIVITY IN THE CONTEXT OF AESTHETIC EDUCATION}

\begin{abstract}
Дослідження присвячується вивченню унікального вітчизняного просресійного досвіду переосмислення термінологічної сутності "художньої діяльності", як наскрізного простору впровадження сучасних основ мистецької освіти при багатоаспектності та спорідненості налаштування естетичного виховання та творчої практики при ораховій підготовиі відповідного профрілю спрямування.

У даному разі предикативна сутність дозволяє спромогтися вийти за межі усталеного міжпредметного коливання з приводу різноманітних трактувань художньої діяльності, адже нагромадження уподібнених, але багатопланових понятійних тверджень поза відсутністю базового змісту лише демонструють важливе значення для обговорення та впровадження запропонованого у статmі наукового механізму об'єднаного погляду на існуючий стан аналізу художньої діяльності. Цей доцільний авторський шлях аргументації вже на основі вагомих вітчизняних наукових здобутків розкриває трьохступеневу форму організаuії естетико-срункціональної універсальності, як головного виміру при формулюванні ціннісних засад художньої діяльнісності в контексті актуальних аспектів естетичного виховання. Разом з тим, у представленому дослідженні додається стисла характеристика тради ції встановлювати відповідний поняттєвий статус художньої діяльності через такий кореневий та близький творчому процесу запозичений зарубіжний поняттєвий аспект, як арт-практика. Окрім того, відзначений специорічний напрям творчої діяльності розкривається через особливий вид сучасної мистецької практики - дизайнерську діяльність, бо дизайн за безпосереднім змістом предикативної своєрідності значень універсального обсягу орункціольності у різноплановості практичного представлення теоретичних засад в найпершу чергу проявлює поєднання художнього та естетичного у створенні неймовірних вимірів мистецького поступу.

Ключові слова: художня діяльність, естетичне виховання, мистеитво, творчість предикати, академічність.
\end{abstract}

This scientific article is devoted to the study of the unique Ukrainian professional experience of rethinking the terminological essence of such a specific concept as artistic activity. In this understanding, it is a crosscutting space for the introduction of modern foundations of education by means of art with a multidimensional homogeneous rootedness of the internal ties of aesthetic education and creative practices with the professional training of specialists of the appropriate level of requirements. Therefore, according to the author, referring to the previous theoretical experience, the predicative essence allows one to try to go beyond the boundaries of the generally accepted intersubject hesitation regarding various interpretations of artistic activity. This presented author's way of understanding the terminological appearance of artistic activity absorbs the experience of previous generations and correlates with the three-step form of organizing aesthetic and functional universality, as the main nodal dimension in the formulation of the main value parameters of artistic activity in the context of the current aspects of aesthetic education.

The general problem field of the presented research is based on formulation of practical bases of art activity in the context of aesthetic education on a scientific and theoretical platform of professional Ukrainian experience. Therefore the theoretical views of well-known Ukrainian scientists from the author's point of view of the predicative component are demonstrated, add inspiration and interest in continuing this line of analysis, involving important points of view of Western European scientists. It should be emphasized that at the level of scientific and pedagogical discourse artistic activity is based on the productivity of software implementation of educational technologies, which provide for the publication of practical experience of terminological correlation of this context to the motivated sense of innovativeness of modular understanding of thematic complexity.

Key words: artistic activity, aesthetic education, creation, predicates.
Постановка проблеми у загальному вигляді та її зв'язок 3 важливими науковими та практичними завданнями. Загальне проблемне поле представленого дослідження базується на формулюванні практичних засад художньої діяльності в контексті естетичного виховання на науковотеоретичній платорормі фрахового вітчизняного досвіду.

Аналіз останніх досліджень та публікацій. 3 даного кола позначеного напрямку існує обмежений перелік наукових розробок. Передбачений розгляд вітчизняного досвіду при встановленні понятійної диспозиції "художньої діяльності" виявляє певну сгрупованість саме тих досліджень, 3 якими корелюється авторська точка зору стосовно застосування "предикативної сутності" до контекстного співвідношення естетичного виховання та художньої діяльності. Насамперед, до цього відібраного кола теоретичних праць слід віднести роботи М. Р. Селівачова [1], Н. В. Барни [2], В. М. Бовсунівського [3].

Виділення невирішених раніше частин загальної проблеми. Наразі зазначена проблемна конфігурація $€$ малодослідженим блоком питань термінологічного, прикладного та методичного напрямків аналізу. Зрештою, не розглянута частина вітчизняного доробку має стати первинною основою для модуляції основи для загальної проблеми. Разом з тим, авторська термінологічна складова "предикативності" стає продуктивним 
ресурсом для виявлення невирішених раніше значень характеристик художньої діяльності.

Мета статті полягає у розширеному термінологічному виявленні естетично-виховної сутності художньої діяльності на основі науково-методичного підґрунтя такого авторського підходу, як "предикативна сутність".

Виклад основного матеріалу. Потужні еквіваленти творчого наповнення гармонійними поштовхами відновленого розуміння справжнього призначення мистецтва спрямовують свій рух до переосмислення практичних наративних предикативних фрорм стосовно діяльнісного способу відображення прекрасного. Нормативні аспекти чіткого встановлення перерозподілу цілісних засадничих вимірів при уважному відокремленні глибинних та поверхневих якостей міждисциплінарного ґатунку відкриває для наукового аналізу складну уніфікацію при пошуку неопосередкованих значень з конкретизації естетично-виховної специфріки у напрямку мистецьких сполучників творчого безмежжя.

Наукові новаторські способи обґрунтування художньої діяльності змістовним чином прояснюють обмеженість джерельної першооснови. Розлогість теоретичних конструкцій демонструє еклектичну природу науково-термінологічного кола близько споріднених кутів огляду. Відтак, слід підкреслити, що потрібно розпочати процес аналітичного відокремлення суперечливого характеру подібностей творчого, творчо-мистецького та художньо-творчого ареалу дотичностей до художньо-діяльнісної сутності естетично-виховного єства. Проте, узагальнена безпосередність предметного поля естетичного виховання, у даному ракурсі, теж ускладнюється термінологічним поєднанням художнього та естетичного, що демонструє полемічність самого підґрунтя спеціалізованого діяльнісного виокремлення 3 мистецької сфрери навчально-виховного профрілю підготовки творчих кадрів. Отже, відсутність системного нагляду за вихідними положеннями принципових параметрів художньо-діяльнісного виміру спонукає до вивчення особливого способу виходу з паралельних понятійних зв'язків.

Потенціал фрахових вітчизняних розробок виявляє полемічність такого виду творчої діяльності, як художня діяльність. Зрештою, умовиводи якісної далекоглядності спрямовують теоретичний поступ у виразну дослідницьку площину маловивченого шляху. Відтак, засадничою науковою працею при вивченні предикативних компонентів художньої діяльності є праця Михайла Романовича Селивачова "Культурологічні проблеми дизайну як виду художньої діяльності" [1]. Навіть мистецтвознавчий контекст роздумів Михайла Романовича вміщує предикативну фрорму навчально-виховного сенсу, де невизначений статус художньої діяльності критично переосмислюється.
На вимогу часу первинність знакового пріоритету широкого аспекту творчої активності має сорормулювати хоча би пріоритети ключового розуміння художньої практики у настановах естетичного виховання, адже безлічь теоретичних ідей, які характеризуєть художній вимір творчості на загальному плані, виблискують вірогідністю. Тому, як при цьому абсолютизувати виховні завдання спеціалізованої фрахової підготовки, якщо митці, арт-критики, історики мистецтва та теоретики естетичної думки світового рівня додають до значного контекстного апробування "художньої діяльності" власні специфічні відтінки, які здебільшого розгортають занурення у творчий стан митця, де пошуки індивідуалізованої художньої мови є домінантними по відношенню до практики повсякденної консолідації художньо-виховного виміру естетичного буття, як закономірного узгодженого методичного процесу.

За поважною думкою Михайла Селивачова, занурення у понятійне середовище художньої діяльності починається з усвідомлення видової специфіки мистецтва, де на прикладі "культурологічних проблем дизайну" відшліфовується в історичних аспектах мистецтва висхідний шлях предметного поля художньої діяльності. Втім, своєчасне започаткування дизайнерської практики на вітчизняних теренах ознаменувалося винятковою абсорбацією двох ресурсних площин: найкращого традиційного етнічного досвіду - художньо-декоративного коріння української народної творчості з багатобарвним відчуттям художньо-технологічного ставлення до модернізації життя на мистецьких теренах Західної Європи. Таким чином, особливий гатунок дизайнерської сорери виявляє потрібні закономірності для теоретичного вдосконалення художньої діяльності, як дотичного та вузлового поняття при упорядкуванні належних чинників підготовки творчих спеціалістів за напрямком "дизайн". Проте, попередньо започатковувалися ознаки певної пріоритетної практики, як зазначає Михайло Романович Селівачов: "у фахових журналах почали дедалі частіше з'являтися статті про "народний дизайн", про реалізацію засад технічної естетики в художній творчості багатьох попередніх епох" [1, с. 351]. Тобто, поступовий обсяг художніх завдань з пріоритетним естетичним ґатунком об'єктивованої стилізації відкрив оновлене ставлення до художньої діяльності. В свою чергу, це спричинило і інший підхід до навчально-дисциплінарного обсягу практичних знань, де певне русло художньо-дизайнерського напряму своєрідним чином доповнило академічні настанови творчої активності у художньодіяльнісний умовивід виховного спрямування. На певному історичному етапі "після 30-річної перерви відновлюється підготовка фрахівців 
3 "художнього конструювання" в навчальних закладах Києва (1962 р.) та Харкова (1963р.)" [1, с. 351]. Прояви конструкторського вміння розкривають технологічний ракурс спеціалізованої дизайнерської підготовки, але навіть у цьому механізмі прикладного навчально-виховного сходження до матеріальності прояв художньості залежить від естетичного розуміння гармонізованого відчуття утилізованого призначення впровадженої технологічної фрорми до глибиннозмістовного рівня накресленого прекрасного, як позачасової домінанти універсальної мотивації.

Поступово, між іншим на думку М. Р. Селівачова, у навчально-виховному середовищі фрормувався також наступний період - художньо-фрункціонального конструювання, який і започаткував майбутні педагогічні реалії дизайнерського сьогодення: "після довгого періоду "прикрашальництва" утверджувалося розуміння краси фрункціональної форми, внутрішніх властивостей матеріалу - його природної структури, текстури, фрактури, тощо" [1, с. 352]. Зрозумілим видається той фракт, що не остаточні засадничі естетично-виховні цілі, саме з часом, викристалізувалися у вагоме художньодіяльнісне осереддя 3 ускладненим витлумаченням якісних практичних джерел історичного самоствердження. Рудименти фрундаментального художнього досвіду відпрацьовували механізми багатошарового комплектування вузького наближення до розкриття художньо-діяльнісного через суспільні запити виконання вагомого комплексного формату масової культури. Навчальні заклади, як ресурсні ареали гартування кадрового потенціалу, започатковували на той момент стихійно-інноваційний підхід образотворчо-прикладного налаштування, художньо-виховну традицію до підготовки майстрів певного, художньо-конструкторсько, утилітарного призначення для фрормування художньотворчого середовища дизайнерського профрілю.

Сучасний етап виводить термінологічну специфріку "художньої діяльності" на спроможність самостійної уніфікації понятійних корелятів, довкола яких і моделюється практичне прагнення до якісної форми навчально-виховного програмного забезпечення. Фактологія, яка детермінує реальну передоснову тлумачення художньо-діяльнісної оболонки за навчальною формою дизайнерської практики, Михайло Селівачовим відшліфовується за вітчизняними надбаннями минулого мистецького та академічного життя, що розвертається і по сьогодні у трансорормативний устрій предикативних узгоджених взаємопов'язаних структур одної естетично-виховної традиції, де взаємопов'язаний чинник $є$ "художня діяльність". Так, на початку XXI століття, а саме "у 2002 р. сталася симптоматична подія. Найстарший в Україні художній навчальній заклад, який веде свій родовід від Харківської рисувальної школи й називався в різний час Хар- ківське художнє училище, Харківський художній інститут, Харківський художньо-промисловий інститут, перейменовано тепер на Харківську державну академію дизайну та мистецтв" [1, с. 352]. Навіть продемонстрована поступова ієрархія перейменувань конкретного Харківського мистецького закладу Вищої освіти позначає, як набутий 3 часом своєрідний художньо-діяльнісний досвід поглиблювався у сенсі уточнюваної з моделюючим у часі наріжним поступом естетичних фрорм трансфрормації прекрасного. Зрештою, первинний образотворчий ґатунок зберігся, як наріжне професійне ядро, а надалі художньо-ремісницький характер превалеював над естетизацію академічних засад навчання. Відтак і художньо-образотворчий рівень втілення естетично-виховних надбань перевтілилось у художньо-промисловий рівень спеціалізованої підготовки і сучасне академічне налаштування на найвищі педагогічні взірці виявило на державному рівні вагомі пріоритети структуризації поетапного досвіду на поєднання художньо-діяльнісного сполучення дизайну та мистецтва, як у авторському розумінні "цілісної сполуки творчоприкладної практики всеохопної естетично-виховної піднесеності та видовищності".

Якщо існує цілісність на творчо-прикладному рівні, як міжпредметної узгодженості, тоді разом з Михайлом Селівачовим варто визначити "труднощі 3 визначенням предмета", які полягають у певному характері, як предикаті організованого та супутнього супровуду цієї художньо-діяльнісної процесуальності творчо-практичного рівня знання. Таких предикативних сутностей характерної якісної реконструкції всього три:

- динамічність;

- естетичність;

- універсальність.

Предикат динамічності в середовищі дизайну, як виду художньої діяльності, розкриває, як творчий напрям завдань "швидко поширюється і змінюється разом 3 промисловим виробництвом". Естетичний предикат "зумовив постання самої проблеми художньої естетики" на момент історичного становлення художньо-образотворчого рівня започаткування 3 паралельним впровадженням художньо-промислового способу встановлення прикладних меж художньо-діяльнісного сенсу мистецької практики. Саме сполучення двох попередніх предикативних сутностей виявляє структурний еквівалент предикату універсальності, як виняткового елементу. За словами М. Селівачова: "при такому підході, природно, наголошувалося... на органічній єдності фрункціонального й естетичного" $[1$, c. 353]. Обидві первинні предикатні сутності динамічної та естетичної фрорми спрямовують різнорівневі ракурси конструктивного виміру аналізу при позначенні корелятивних диспозицій художньої діяльності в оприлюдненні образотворчого 
та утилітарного основ визначення, але при входженні в узагальнене річище предикату універсальності динамічність фрункціональності трансфрормує естетизацію художньості у особливе поле полемічного ґатунку вібраційного коливання естетично-художнього і діяльнісно-фуункціонального ставлення до естетично-виховного контексту.

При виявленні вітчизняного досвіду у авторській транскрипції "предикатної структури художньої діяльності" не слід оминати і той фракт, "що всі сфрери художньої діяльності охоплюються категорією "візуальне мистецтво", яке в нас звикли не зовсім точно називати "образотворчим мистецтвом" [1, с. 354]. Отже, споріднена узгодженість естетичного і функціонального доповнюється відповідним врахуванням видової специсріки мистецької площини при констатації візуальної специфрікації укорінених в образотворчу основу сучасних творчих практик. На думку української дослідниці Н. В. Барни: "візуальні арт-практики - це новітня номінація, якою охоплюється складний симбіоз дизайну, архітектури, моди, мас-медіа, шоу-бізнесу, реклами" [2, с. 152]. Тобто, арт-практика у своєму діяльнісному спрямуванні до художності, як первинного чинника конструктивної змістовності, детермінується статусом номінації у структурі видової специфрікації мистецтва для того, щоб знову ж таки, вийти за усталені межі образотврчого витлумачення художності. Наталія Барна поглиблює думку Михайла Селивачова щодо вітчизняної класисрікації візуальних мистецтв, адже відзначений вище у даному аналізі "естетично-срункціональний ґатунок" в універсальному предикативному контексті виявляє свою естетичновиховну природу на рівні візуальної демонстрації художніх засад видовищності та піднесення.

Врешті-решт, Наталія Віталіївна Барна зазначає, що на рівні художньо-діяльнісного поступу існує "тиск універсалізації праксису мистецтва до загальних категорій" [2, с. 152]. Цей підхід на фрілософрсько-естетичному рівні виявляє категоріальну засадничість античної думки, де ставлення до вмотивованого підходу до продуктивного створення прекрасного у вимірах найвищих почуттів відкриває лейтмотив Арістотелівського прагнення відкрити спалах творчих прагнень через естетичний заклик наближення митців до катарсису. Саме катарсис перетворює звичний хід образотворчої діяльності до набуття художнього звучання у площинах мистецько-візуальних арт-практик. "катарсис - категорія, яку описував ще Арістотель, але тут катарсис стає генеративною емоцією. Це не та емотивна сорера, яка $є$ рухом до результату - афекту,.. а це $€$ вибух почуттів, передбачення і піднесення чуттєвості саме там, де її ніхто не очікував" [2, с. 154]. Спалах неочікуваності розкриває художньо-візуальний ряд такої захоплюючої дизайнерської діяльності, де творчий внесок генерує зображувальні елементи у вимірах теоретично вибудуваної трьох- ступеневої предикативності "естетично-динамічної фрункціональної універсальності".

Зрештою, відокремлення візуальної специфріки 3 мистецького середовища арт-практик у самостійне наповнення художньої діяльності унікальним торетико-практичним сенсом допомагає влучніше охарактеризувати сучасні мистецькі тенденції, що спричиняють вибудовування й інших стилістичних, в тому числі й естетично-виховних наголосів. Мова йде про візуальний інформаційнокомунікаційний зв'язок перерахованих предикатних компонентів художньої діяльності.

Варто підкреслити, що на рівні науково-педагогічного дискурску художня діяльність спирається на продуктивність програмного впровадження виховних технологій, які передбачають оприлюднення практичного досвіду застосування термінологічної кореляції зазначеного контексту на вмотивований сенс інноваційності модульного розуміння тематичного виявлення складності при сполученні художньої діяльності з естетичним вихованням. Таким показником виразного співіснування двох ліній цього дослідження $€$ спроба В. Бовсунівського на предметній основі "художньо-проєктної діяльності" віднайти рівновагу при фрормулюванні "Вступу до дисципліни". Відтак, Валерій Бовсунівський, наприклад, поєднує в одному тематичному блоці "Мистецтво як естетичний феномен" і "Особливості художньої творчості", а в іншому "Художній стиль та естетично-художнє освоєння світу" [3, с. 16]. Отже, багатоплановість теоретико-практичних значень художньої діяльності на вимірі естетичного контексту демонструє на навчально-виховному етапі впровадження строкатість відображеного комбінування трансфрормаційної дискурсивної природи маловивчених термінологічних сенсів.

Висновки та перспективи розвитку цього напрямку. Дослідження спрямоване на якомога глибшу оцінку представленого вітчизняного досвіду щодо встановлення цілісного погляду на сутність художньої діяльності у контекстному відношенні до естетичного виховання. Продемонстровані теоретичні погляди відомих українських вчених під авторським кутом зору предикативної складової, додають наснаги та зацікавлюють продовжити проведення цієї лінії аналізу залучаючи до цього вагомі точки зору західно-європейських вчених.

\section{БІБЛІОГРАФІЧНИЙ СПИСОК:}

1. Селівачов М. Р. Культурологічні проблеми дизайну як виду художньої діяльності. Актуальні проблеми мистецької практики і мистецтвознавчої науки, 2010. Вип. 3. С. 351-355.

2. Барна Н. В. Художня діяльність у контексті розвитку візуальних практик. Мультіверсум. Філософрський альманах, 2014. Вип. 10(138). С. 152-160.

3. Бовсунівський В. М. Особливості підготовки вчителів технологій до проєктно-художньої діяльності у процесі післядипломної освіти. Педагогічні науки, 2013. Вип. 110. С. 11-18. 


\section{ОРГАНІЗАЦІЯ ПІДГОТОВКИ ВИКЛАДАЧІВ ЄВРОПЕЙСЬКИХ ПРИКОРДОННИХ ЗАКЛАДІВ ОСВІТИ ДО ДИСТАНЦИЙНӦ̈ ФОРМИ НАВЧАННЯ \\ ORGANIZATION OF TRAINING OF TEACHERS OF EUROPEAN BORDER GUARD EDUCATIONAL INSTITUTIONS FOR DISTANCE LEARNING}

\begin{abstract}
у статті висвітлено організацію підготовки викладачів європейських прикордонних закладів освіти до дистанційної форми навчання з метою сприяння впровадженню передового європейського досвіду в систему професійної підготовки персоналу Державної прикордонної служби України. Розглянуто питання підготовки викладачів європейських прикордонних закладів освіти в межах спеціального навчального курсу з методики викладання прикордонно-спрямованих дисциплін, який надає викладачам, інструкторам, тьюторам і тренерам європейських прикордонних закладів освіти необхідні знання і навички для проведення занять як уконтактний спосіб, так і онлайн.

Визначено, що необхінним $є$ впровадження передового європейського досвіду з питань підготовки викладачів: використання оцінювальних рубрик для визначення рівня методичної підготовки викладача; впровадження найкращих практик фрасилітації навчання прикордонників за дистаниійною фрормою навчання, надання та отримання зворотного зв'язку, вирішення конфрліктів, організація обговорення в онлайн-групах, застосування веб-квестів, гейміфрікації, розвиток презентаційних навичок, навичок рефлексії, організації роботи в команді. Це гарантує, що після закінчення курсу випускники зможуть більш якісно виконувати фуункиії викладача або тренера, у тому числі й у форматі дистаниійного навчання на базі спільної освітньої веб-платорорми агенції Фронтекс Virtual Aula. Автором визначено, що розробка і проведення навчальних курсів у контексті спільної професійної підготовки фрахівців прикордонних відомств у країнах ЄС відбувається відповідно до спільних освітніх стандартів, основними із яких $є$ унісріковані програми підготовки європейських прикордонників $і$ Галузева рамка кваліфікацій прикордонноі сорери діяльності країн ЄС. Автором було узагальнено досвід організації спільної підготовки прикордонників у країнах ЄС з метою подальшого проведення порівняльних педагогічних досліджень і впровадження передового досвіду в систему підготовки фрахівців Державної прикордонної служби України. Ключові слова: викладачі, прикордонні заклади освіти, професійна підготовка, дис-
\end{abstract}

Союзу.

The article reveals the organization of training of teachers of European border guard educational institutions for distance form of learning in order to facilitate introduction of European best practices in the system of professional training of personnel of the State Border Guard Service of Ukraine. The issue of training teachers of European border guard educational institutions is considered in the framework of the special training course on methodology of teaching border guard related subjects, which provides teachers, instructors, tutors and trainers of European border guard educational institutions with necessary knowledge and skills to conduct classes both in contact with the students and online.

It is determined that it is necessary to introduce the best European experience in teacher training: the use of marking rubrics; facilitatation techniques of training border guards online, providing and receiving effective feedback, resolving conflicts, organizing discussions in online groups, using web-quests, gamification, development of presentation skills, reflection skills, teamwork. This ensures that upon completion of the course, graduates will be able to better perform the functions of a teacher or trainer, including in the form of distance learning on the basis of a joint educational web platform of the Frontex Agency Virtual Aula.

The author determined that the development and implementation of training courses in the context of joint training of border guards in EU countries is conducted in accordance with common educational standards, the main of which are Common Core Curricula for European border guards and the Sectoral qualifications framework for border guarding. The author summarized the experience of organizing joint training of border guards in $E U$ countries in order to further conduct comparative pedagogical research and introduce obtained best practices in the system of training personnel of the State Border Guard Service of Ukraine.

Key words: teachers, border guard educational institutions, professional training, distance learning, countries of the European Union.
Постановка проблеми в загальному вигляді. Нині на європейському освітянському просторі, зокрема завдяки Болонському процесу, широко впроваджується студентоцентрований підхід до навчання. Основною та відправною точкою процесу створення освітньої програми $€$ модель фахівця, який буде затребуваним на ринку праці [4]. Європейська агенція прикордонної і берегової охорони Фронтекс ініціювала створення стандартів викладання, які повинні забезпечувати нову якість прикордонної освіти та підготовки і допоможуть здійснити поступовий перехід від викладацько-орієнтованого до студенто-орієнтованого навчання (шляхом практичного використання компетентністого підходу і результатів навчання) [7].

За умов карантинних обмежень професійна підготовка європейських прикордонників вимагає реформування системи підготовки персоналу у прикордонних відомствах країн-членів ЄС із поступовим впровадженням дис- 
танційної фрорм навчання, що потребує розроблення сучасних освітніх технологій, веб-платорорм, електронних навчальних курсів, у тому числі на основі технологій змішаного і мобільного навчання.

Нині ми спостерігаємо, як закриваються навчальні заклади різних типів через стримування поширення COVID-19. Так, у 191 країні світу це призвело до того, що 1,57 млрд учнів і студентів (90\% світового контингенту) були вимушені навчатися дистанційно [3]. 3 огляду на зростання уваги до підготовки прикордонників у соорматі дистанційного навчання, агенція Фронтекс почала розглядати питання підвищення якості проведення курсів дистанційного навчання професійного спрямування для гармонізації та стандартизації роботи тренерів прикордонних закладів освіти країн $€ C$ відповідно до вимог системи забезпечення якості підготовки персоналу та викладання агенції FRONTEX, положень Болонського і Копенгагенського процесів, Галузевої рамки кваліфікацій (далі - ГРК) ссрери охорони кордону країн $Є$ [11], які сприятимуть результативності підготовки прикордонників та уніфікації підходів до планування і проведення занять [6].

Метою статті $\epsilon$ характеристика підготовки викладачів європейських прикордонних закладів освіти до дистанційної форми навчання з метою подальшого впровадження набутого досвіду в систему професійної підготовки персоналу Державної прикордонної служби України.
Аналіз останніх досліджень і публікацій. Досвід підготовки персоналу прикордонних відомств країн $€ С$ вивчали О. Кірєєв, С. Псьол, Н. Ринденко. Особливості професійної підготовки європейських прикордонників вивчали вітчизняні вчені А. Балендр, О. Діденко, Д. Таушан. Особливості дистанційного навчання прикордонників висвітлив І. Блощинський. Проте нині ґрунтовного аналізу організації підготовки викладачів європейських прикордонних відомств до дистанційної форми навчання практично не існує.

Виклад основного матеріалу. Відповідно до результатів аналізу потреб системи спільної професійної підготовки прикордонників під егідою агенції Фронтекс у межах Мережі прикордонних партнерських академій країн-членів $€ \subset$ було визначено необхідність організації спеціального навчального курсу з методики викладання прикордонно-спрямованих дисциплін, який надає викладачам, інструкторам, тьюторам і тренерам європейських прикордонних закладів освіти необхідні знання i навички для проведення занять як у контактний, так і у безконтактний спосіб (онлайн). Це гарантує, що після закінчення курсу випускники зможуть більш якісно виконувати фрункції викладача або тренера, у тому числі й у фрорматі дистанційного навчання на базі спільної освітньої веб-платформи агенції Фронтекс Virtual Aula (рис. 1) [10].

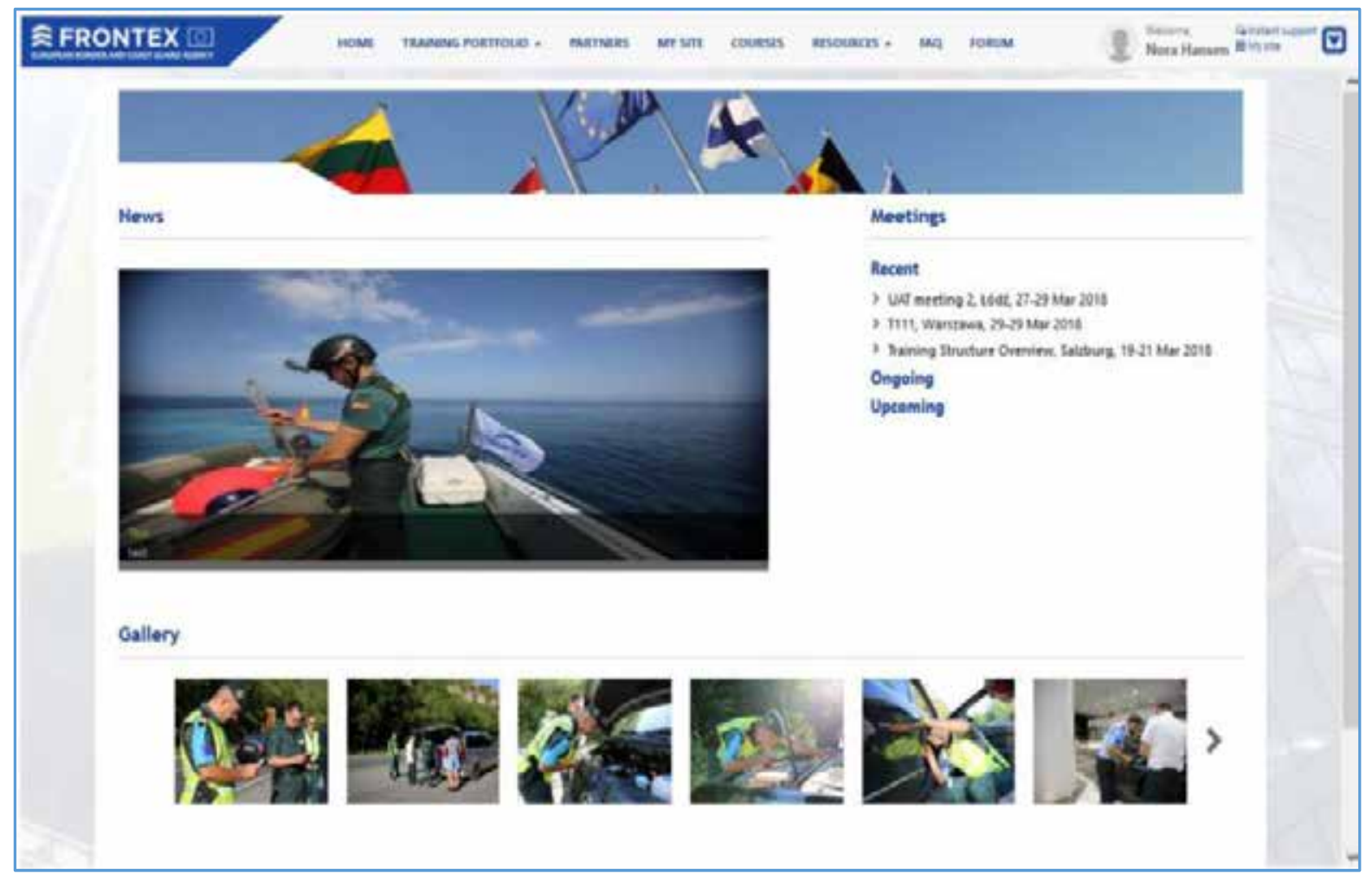

Рис. 1. Платформа електронного навчання європейської агенції прикордонної і берегової охорони Фронтекс 
Навчальний курс спрямований на те, щоб дати змогу учасникам навчитися розробляти та викладати навчальний матеріал прикордонного характеру в умовах дистанційного навчання, а також компетентно оцінювати навчальні досягнення студентів (визначені результати навчання) після закінчення курсу або окремого модуля (рис. 2).

Цей навчальний курс призначений для представників прикордонних відомств країн-членів ЄС, які €:

- експертами 3 навчальних дисциплін прикордонної сорери діяльності, яким все ще потрібно вдосконалювати свої методичні навички щодо ефективної розробки, викладання та оцінювання результатів навчання студентів в умовах дистанційного навчання;

- розробниками навчальних курсів, які потребують додаткового досвіду в застосуванні інтерактивних методів проведення онлайн-тренінгів;

- кваліфікованими тренерами та розробниками курсів національних прикордонних відомств $€ C$, які не знайомі з положеннями, політикою та процедурами організації профресійної підготовки європейської агенції прикордонної і берегової охорони;

- тренерами або експертами з навчальних дисциплін прикордонної ссрери діяльності, які мають обмежені знання сучасних методів викладання, крім орієнтованих на викладача (наприклад, читання зі слайдів PowerPoint презентації), яким необхідно знайомитися зі студентоцентрованими методами викладання;

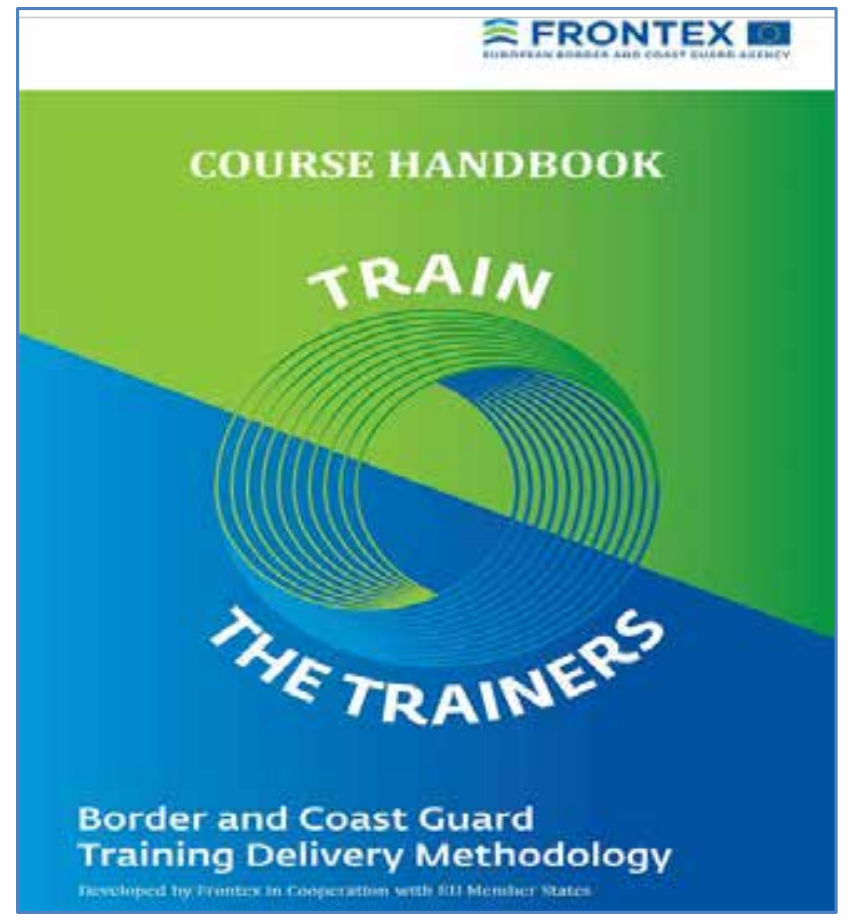

- досвідченими викладачами і тренерами, які розвивали свої навички викладання з точки зору «орієнтації на викладача», а не на студента;

- досвідченими викладачами і тренерами, які кваліфріковано розробляють навчально-матеріальне забезпечення та викладають на прикордонно-спрямованих курсах, але не знайомі 3 особливостями діяльності європейської агенції прикордонної і берегової охорони та відповідного мультикультурного середовища [8].

По завершенні цього навчального курсу студенти досягають специфрічних професійних компетенцій, сорормульованих на основі Галузевої рамки кваліфрікацій сфрери охорони кордону країн $€ C$, яка $€$ системою компетенцій, що описуються з точки зору знань, навичок, відповідальності та автономії та які узгоджено з Європейською рамкою кваліфікацій для навчання протягом життя.

Так, після закінчення цього курсу студенти матимуть знання або розуміння: мандату, політики, стандартів, стратегії та цінностей європейської агенції прикордонної і берегової охорони для розробки та викладання прикордонно-спрямованих дисциплін і навчальних курсів на загальноєвропейському рівні та в межах Мережі європейських прикордонних партнерських академій (Рівень за ГРК сорери охорони кордону - 5).

Будуть уміти: розробляти, оновлювати та адаптувати навчальний матеріал для курсів дистанційного навчання на основі принципів студентоцентризму, дотримуючись освітніх стандартів агенції Фронтекс, використовуючи різні стилі

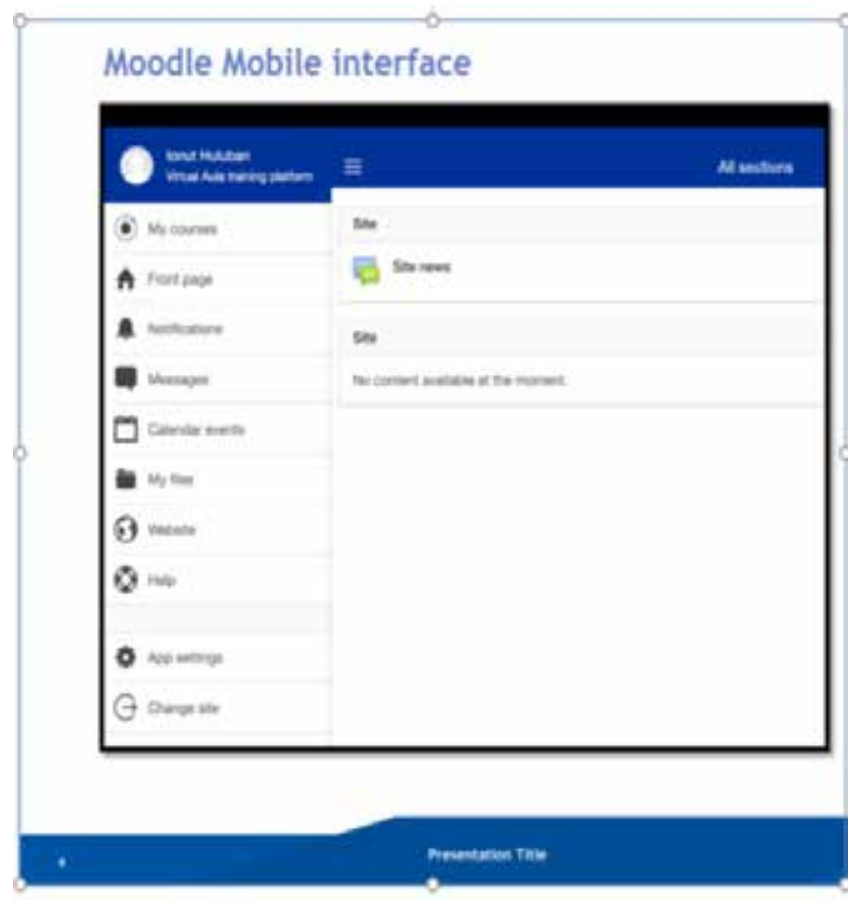

Рис. 2. Головна сторінка електронного навчального курсу з методики викладання прикордонно-спрямованих дисциплін європейської агенції прикордонної і берегової охорони Фронтекс 
викладання, щоб усі студенти могли досягти задекларованих результатів навчання; розробляти та оцінювати досягнення результатів навчання, включаючи експертну перевірку, для забезпечення конструктивного зворотного зв'язку зі студентами онлайн; управляти навчальною діяльністю групи онлайн, включаючи групову роботу, вирішувати проблеми та непередбачувані ситуації; ефективно спілкуватися онлайн, виявляючи повагу до різних студентів для підвищення ефективності навчання (Рівень за ГРК сорери охорони кордону - 5).

Нести відповідальність за: оцінювання якості навчання та вияв ініціативи щодо вдосконалення змісту та забезпечення досягнення стандартів підготовки Фронтекс (Рівень за ГРК сорери охорони кордону - 5).

Організація навчального курсу охоплює 3 модулі:

Модуль 1. Система загальноєвропейської професійної підготовки агенції Фронтекс (3 тижні онлайн в системі управління навчанням Virual Aula, 23 навчальних години).

Модуль 2. Планування навчальних занять у межах навчальних курсів Фронтекс (Фаза самостійного навчання - 3 тижні, в системі управління навчанням Virtual Aula - 22 навчальні години, 24 навчальні години в контактній фразі навчання).

Модуль 3. Принципи викладання (Фаза самостійного навчання - 3 тижні, в системі управління навчанням Virtual Aula - 11 годин, фраза контактного навчання - 4 дні, контактна фраза - 30 навчальних годин, фраза досвідного навчання - 2 тижні, навчання в системі управління навчанням Virtual Aula - 5 навчальних годин [7].

Зміст навчального курсу відображає різні вимоги до навчання цільової аудиторії відомств прикордонної та берегової охорони, а також доповнює та підтримує проведення навчальних курсів за освітніми стандартами агенції Фронтекс (рис. 3).

Так, структура зазначеного навчального курсу на веб-платорормі Virtual Aula представлена такими розділами: «Вступ до навчального курсу», «Посилання на мобільну версію курсу», «Форуми для обговорення за кожним модулем»; «Результати навчання курсу»; «Квізи і веб-квести»; є додаткові онлайн ресурси (Регламент про європейську прикордонну і берегову охорону [8], Кодекс поведінки персоналу, Шенгенське законодавство); відеотека; оцінювання; досвідна фраза навчання; зворотній зв'язок і сертифрікати про закінчення курсу.

У європейських прикордонних організаціях прикордонно-орієнтовані навчальні курси здебільшого проводять практики-експерти підрозділів охорони кордону, ніж викладачі прикордонних закладів освіти [2]. Використання практичного досвіду в підготовці значно підвищує їі якість, але необхідно забезпечити, щоб ці експерти також мали навички передавати свої знання та фрормувати профресійну компетентність інших.

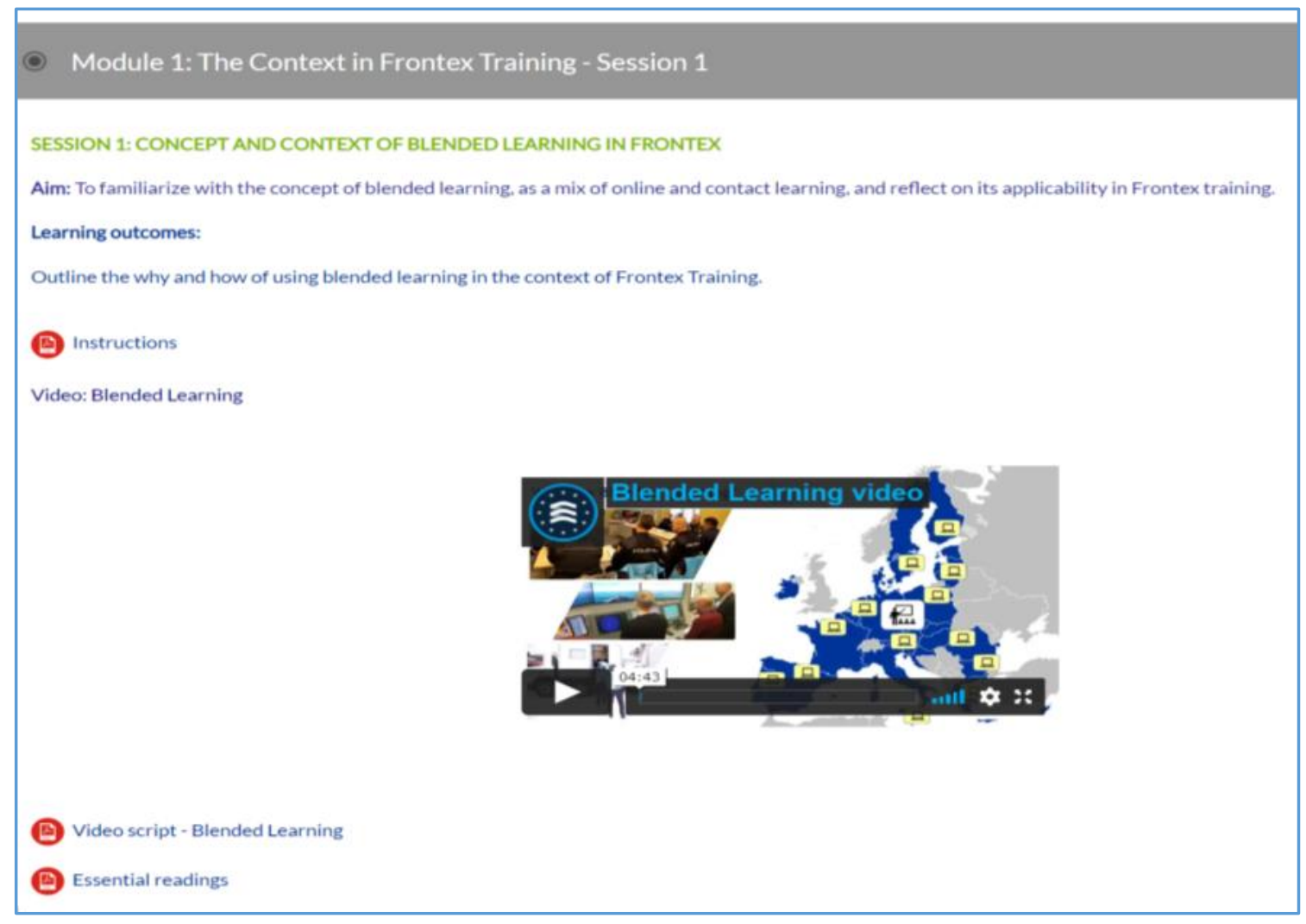

Рис. 3. Зміст навчального курсу з методики викладання прикордонно-спрямованих дисциплін (Модуль 1, заняття 1 «Концепція і контекст змішаного навчання Фронтекс») 
3 огляду на різноманітність представників цільової аудиторії прикордонних відомств країн $\epsilon C$, які володіють низкою компетенцій, і визнаючи, що багато потенційних студентів вже брали участь у несормальній освітній діяльності, застосовується модульний підхід до навчального курсу. Це повинно забезпечити індивідуальну навчальну траєкторію кожного студента, щоб він / вона могли розвивати необхідні знання та вміння, компетентність. Водночас модульна структура забезпечує гнучкий освітній процес, який забезпечує оптимальне використання і підготовку людських ресурсів, а також дозволяє визнавати попереднє навчання відповідно до системи забезпечення якості агенції Фронтекс.

Під час розробки навчального курсу увага звертається на активізацію попередніх знань і досвіду, що дозволяє студентам інтегрувати їх у наступний модуль. Для цього модулі повинні викладатися у зазначеному вище порядку, а студенти повинні засвоювати результати навчання кожного з попередніх модулів, щоб перейти до наступного. Змішаний підхід до навчання пропонує широкий спектр методів розробки та викладання навчального матеріалу. Модуль 1 викладається виключно через віртуальне навчальне середовище. Модулі 2 і 3 містять елементи контактного навчання для розвитку практичних навичок, проте підтримуються фразою самостійного онлайн-навчання для набуття знань за допомогою системи управління навчанням Фронтекс.
Окрім визначення прогресу навчання студентів щодо засвоєння визначених результатів навчання, стратегія оцінювання навчального курсу також підтримує оптимізацію результатів навчання студентів шляхом структурованого фрормативного зворотного зв'язку (Formative feedback). Стратегії оцінювання, які використовуються у всіх модулях, заохочують студентів використовувати власні знання та досвід, отримані під час оперативно-службової діяльності, та сприяють їх загальній підготовці до ролі тренера в мультикультурному середовищі Фронтекс. Кожен модуль має компонент онлайноцінки. Це необхідно для забезпечення чесного та об'єктивного процесу онлайн-оцінювання, а також ознайомлення студентів із платорормою електронного навчання Фронтекс як інструментом для тренерів із інших курсів прикордонного спрямування.

Одним із варіантів формативного оцінювання курсу з методики викладання прикордонно-спрямованих дисциплін $€$ проведення навчальних веб-квестів, які сприяють розвитку пізнавальнопошукових навичок студентів і дозволяють більш глибоко опанувати матеріал навчального курсу (рис. 4).

У модулях із фразами контактного навчання також передбачено практичні оцінки, пов'язані із плануванням та розробкою навчальних занять, використовуються і зворотний зв'язок. Стратегія оцінювання передбачає кожне оцінювання як окремі результати модулю, так і загальний

\title{
FRONTEX
}

* Horre a Dashboard Events $=$ MyCourses \& Thiscourse

$\rightarrow$ Mycourses $\rightarrow$ Introduction to Educational Technology. 1 > Pre-course week $\rightarrow$ Join the educational web quest

\section{Join the educational web quest}

\begin{abstract}
This is a web quest task to identity based on the clues below an influential perwonality in the area of education. The quest is open until Sunday 19 March 2017-23:55. Your answer itext or presentationi will be considered complete if you match all the clues with the percon. and your reasoning is correct. You might want to respond to the quest in a puzzling way, like we proposed, rather than revealing straleht forward the personality name. Participstion is optional.

- When "th four" met. the person etablished "knowledge that"

- He influenced the credtor of $2 P 0$

- Crootivity over repetitiveness

- Scientific pogers were his childhood ganes

- Second in pogularity only to o behoviourist
\end{abstract}


результат навчального курсу, необхідні для фрормування навичок проведення об'єктивного оцінювання, використання узгоджених оцінювальних рубрик і надання конструктивних відгуків. Надання оцінки партнерами (одногрупниками) є ключовим компонентом загальної стратегії оцінки навчального курсу. Стратегія визнає різний досвід і рівні досвіду студентів, досягнутих шляхом несрормального навчання. Кожен метод оцінювання результатів навчання за модулями розроблений таким чином, щоб бути пристосованим до оцінювання попереднього навчання [1].

Усі види оцінювання (як формативне, так і сумативне (з отриманням відповідної оцінки по завершенні модуля або курсу) передбачають повторне оцінювання і проводяться відповідно до політики та процедур забезпечення якості Фронтекс із дотриманням принципів основних прав людини та Кодексу поведінки європейської прикордонної і берегової охорони (далі - Кодекс поведінки). Недотримання зазначеного Кодексу поведінки призводить до незарахування попередніх результатів навчання та відрахування студента із навчального курсу [4].

Під час фрази самостійного (онлайн) навчання розглядаються такі питання:

1. Система управління навчанням Фронтекс.

2. Кодекс поведінки персоналу європейської прикордонної і берегової охорони.

3. Організація та завдання європейської прикордонної і берегової охорони.

4. Оперативно-службова діяльність та організація профресійної підготовки європейської прикордонної і берегової охорони.

5. Забезпечення якості підготовки агенції Фронтекс.

6. Студентоцентрований підхід у навчанні.

7. Принципи створення ефективної презентаціï.

8. Роль тренера в оцінюванні.

9. Основні можливості MOODLE в роботі тренера.

Під час контактного навчання студенти вивчають і вдосконалюють навички із:

1. Навички фрасилітації під час дистанційного навчання.

2. Надання та отримання зворотного зв'язку.

3. Вирішення конфрліктів.

4. Організація обговорення в онлайн-групах.

5. Невербальне спілкування.

6. Презентаційні навички та гейміфікація.

7. Навички рефлексії.

8. Організація роботи в команді.

Учасникам пропонуються практичні завдання для виконання у групах. Кожне практичне завдання презентується у міні-групах 3 метою отримання зворотного зв'язку від учасників і тренерів. 3 метою оцінювання рівня знань кожен учасник проводить відкрите заняття, яке оцінюють як учасники, так і тьютори відповідно до спеціальних оцінювальних рубрик агенції Фронтекс; надає зворотний зв'язок відповідно до оцінювальних рубрик. На завершення навчального курсу в рамках завдання із фрасилітації рефлексії учасників "World Café" («Світове кафе») вони креативно, створюючи у міні-групах постери із візуалізацією результатів навчання, обговорюють позитивні та негативні аспекти в організації та проведенні курсу.

Фаза досвідного навчання триває протягом чотирьох тижнів після закінчення 3 модуля. Мета цієї фрази навчання полягає у тому, щоб дати учасникам можливість застосувати отримані знання на практиці під час самостійної розробки та проведення навчальних занять.

Навчальний курс агенції Фронтекс пройшов процедуру зовнішньої акредитації за європейськими стандартами оранізацією City and Guild (Великобританія). Це дозволяє агенції Фронтекс видавати тренерам із прикордонних питань сертифрікати, які визнаються у майже всіх країнах $€ C$ i світу.

Висновки. Використання європейських підходів гармонізованої підготовки персоналу прикордонних відомств і методики проведення занять дозволить Державній прикордонній службі України вийти на сучасний європейський рівень підготовки прикордонників, а також дасть можливість для подальшого розвитку технології дистанційного навчання та впровадження спільної освітньої вебплаторорми європейських прикордонних відомств для активної участі в мережі прикордонних партнерських академій, акредитації власних навчальних курсів на загальноєвропейському рівні, що сприятиме мобільності студентів, курсантів і викладачів в межах європейських прикордонних програм академічної і професійної мобільності.

Визначено, що нині необхідним є впровадження передового європейського досвіду з питань підготовки викладачів (використання оцінювальних рубрик для визначення рівня методичної підготовки викладача або інструктора; впровадження найкращих практик фрасилітації навчання прикордонників за дистанційною фрормою навчання, надання та отримання зворотного зв'язку, вирішення конфрліктів, організація обговорення в онлайн-групах, застосування веб-квестів, гейміфікації, розвиток презентаційних навичок, навичок рефрлексії, організації роботи в команді).

Підготовка викладачів за загальноєвропейськими стандартами $€$ необхідною для Національної академії Державної прикордонної служби України як партнерської академії агенції Фронтекс. Необхідним $€$ і пожвавлення співпраці з прикордонними відомствами країн-членів ЄС у питаннях впровадження уніфікованих програм підготовки, сучасної методики підготовки персоналу, а також 
участі в європейських грантових програмах прикордонного спрямування. Вивчення особливостей організації підготовки викладачів європейських прикордонних закладів освіти до дистанційної форми навчання уможливлює проведення порівняльних досліджень і подальше впровадження отриманого досвіду в освітній процес закладів освіти українського прикордонного відомства.

Перспективи подальших досліджень полягають у вивченні європейського досвіду дистанційного навчання прикордонників на основі сучасного навчально-методичного забезпечення, технологій мобільного навчання, віртуальної і доповненої реальності.

\section{БІБЛІОГРАФІЧНИЙ СПИСОК:}

1. BalendrA., Biletskyi V., lakymchukA., Sinkevych S., Korolov V., Bloshchynskyi I. (2019). Implementation of European Border Guards' Common Educational Standards in Ukraine: comparative Analysis. Romanian Journal for Multidimensional Education / Revista Romaneasca pentru Educatie Multidimensionala, 11(2).

2. Балендр А. (2017). Характеристика рівнів галузевої рамки кваліфікацій для підготовки прикордонників країн Європейського Союзу в академічній освіті. Педагогічний дискурс, (22), 9-14.

3. Організація освітнього процесу у школах України в умовах карантину : аналітична записка. Київ : Київський університет імені Бориса Грінченка, 2020.
4. Рашкевич Ю. Болонський процес і нова парадигма вищої освіти : монограсрія. Львів : Вид-во Львівської політехніки, 2014. 168 с.

5. Balendr A. Current Status and Prospects for the Quality Assurance in Border Guards Training: european Experience. Comparative Professional Pedagogy. 2018. Vol. 8. №. 4. P. 20-25.

6. Common Core Curriculum for Border Guard Basic training in the European Union (CCC 2017). Produced by Frontex Agency in cooperation with EU Member States and Fundamental rights organisations Warsaw, Rondo ONZ 1, 2017. 343 p.

7. Frontex Training Strategy (2015). Warsaw, Poland: european Agency for the Management of Operational Cooperation at the External Borders of the Member States of the European Union.

8. FRONTEX Virtual Aula. URL: https://aula.frontex. europa.eu (last accessed: 08.04.2020).

9. Regulation (EU) 2016/1624 of the European Parliament and of the Council of 14 September 2016 on the European Border and Coast Guard. URL: https://eur-lex.europa.eu/legal-content/EN/TXT/? uri=CELEX\%3A32016R1624.

10. Training Needs Assessment report (2016). Warsaw, Poland: european Agency for the Management of Operational Cooperation at the External Borders of the Member States of the European Union. URL: http:// sro.sussex.ac.uk/.

11. Sectoral Qualifications Framework for Border Guarding. FRONTEX. Warsaw : Rondo ONZ 1, 2013. Vol. 2. $173 \mathrm{p}$. 
ІСТОРІОГРАФІЇ ПРОБЛЕМИ РОЗВИТКУ ТЕОРІЇ І ПРАКТИКИ ПОЗАШКІЛЬНОЇ ОСВІТИ В УКРАЇНІ (ДРУГА ПОЛОВИНА ХХ - ПОЧАТОК ХХІ СТОЛІТТЯ)

\author{
HISTORIOGRAPHY OF THE PROBLEM OF THEORY AND PRACTICE \\ DEVELOPMENT OF OUT - OF SCHOOL EDUCATION IN UKRAINE \\ (THE SECOND HALF OF THE XX - THE BEGINNING OF THE XXI CENTURY)
}

\begin{abstract}
У публікації на основі історико-педагогічного аналізу розвитку теорії і практики позашкільної освіти в Україні (друга половина $X X$ - початок XXI cm.) розкрито історіографію проблеми та виокремлено два основних iї етапи: 50-80-mi pp. XX cm. - активізація досліджень позашкільної освіти; початок 90-х рр. XX ст.-до сьогодення - етап відновлення вивчення позашкільної освіти. Автор виокремив особливості кожного етапу.

Так, на першому етапі історія позашкільноі освіти України знайшла часткове відображення у працях, присвячених історії освіти України загалом, дитячим і молодіжним організаціям, розвитку дитячого руху, дозвіллю дітей. Видавалися і публікації, присвячені вивченню загальних питань діяльності позашкільних навчальних закладів різного типу. Усі публікації мали ідеологічну орієнтацію відповідно до партійних директив.

На другому етапі дослідники змогли здійснити аналіз розвитку позашкільної освіти без остраху бути звинуваченими у безпартійній $і$ надкласовій оцінці цього важливого суспільно-педагогічного явища. Серед основних проблем позашкільної освіти, які одержали наукове осмислення на другому етапі, автор виокремлює такі: прочеси розвитку особистості у дитячих організаціях; організація дозвілля дітей і підлітків у закладах позашкільної освіти; соціалізація підлітка, його самореалізація у закладах позашкільної освіти; гуманізація, яка забезпечує особистісну орієнтацію діяльності дитячих клубів, гуртків; використання особистісно-діяльнісного підходу до організації позашкільної освіти та формування у дітей досвіду соціальної взаємодії.

Автор доходить висновку, що спеціальних історико-педагогічних праць, присвячених вивченню розвитку теорії і практики позашкільної освіти в Україні (друга половина $X X$ - початок XXI cm.) поки що не створено. Ключові слова: позашкільна освіта, розвиток позашкільної освіти, історіографрія, етап, періодизація.
\end{abstract}

The publication, being based on the historical and pedagogical analysis of theory and practice development of out-of-school education in Ukraine the (second half of the $X X$ - the beginning of the XXI century) reveals the historiography of the problem and distinguishes its two main stages: $50-80$ s of the XX century-intensification of research in out-of-school education; from early 90's of the twentieth century-uptill nowadays the stage of resuming investigations of out-ofschool education. The author distinguishes the features of each stage.

At the first stage, the history of out-of-school education in Ukraine was partially reflected in the works dedicated to the history of education in Ukraine in general, children's and youth organizations, the development of children's movement, children's leisure in particular. Publications devoted to the study of general issues of out-of-school educational institutions of various types were also edited. All publications were ideologically oriented in accordance with party directives.

At the second stage, researchers were able to analyze the development of out-of-school education without fear of being accused of nonpartyandsuper-classassessmentofthisimportant socio-pedagogical phenomenon. Among the main problems of out-of-school education, which received scientific comprehention at the second stage, the author singles out: the processes of personality development in children's organizations; organization of leisure for children and teenagers in out-ofschool educational institutions; socialization of a teenager, his self-realization in out-of-school education institutions; humanization, which provides personal orientation of children's clubs, societies; implementation of personal-activity approach regarding organization of out-of-school education and formation of children's experience of social interaction.

The author comes to the conclusion that special historical and pedagogical works devoted to the study of the development of theory and practice of out-of-school education in Ukraine (the second half of the XX - the beginning of the XXI century) have not been created yet.

Key words: out-of-school education, development of out-of-school education, historiography, stage, periodization.
Постановка проблеми в загальному вигляді. Процес інтегрування України в європейський культурний та економічний простір передбачає кардинальні зміни в суспільно-політичному, соціально-економічному житті, які зумовили рефрормаційні процеси в освітній галузі, спрямовані на досягнення рівня світових стандартів. Саме тому нагальною потребою сьогодення $€$ фрормування повноцінної особистості, розвинутої фрізично, інтелектуально та духовно, здатної стати рушійною силою змін у суспільстві. У зв'язку з цим істотно актуалізуються завдання сучасної освіти.
Серед соціальних інститутів виховання й розвитку підростаючих поколінь особлива роль належить позашкільній освіті. Вона є невід'ємною частиною мікросередовища (соціуму), що сприяє реалізації індивідуальних психофрізичних і соціальних потреб особистості, яка розвивається, розкриттю ії творчого потенціалу, формуванню соціально значущих якостей. Об'єктивний історико-педагогічний аналіз становлення і розвитку позашкільної освіти, теоретичне узагальнення цінного досвіду, що створили педагоги минулого, дають змогу якісно оновити й удосконалити зміст виховної роботи позашкільних закладів України. 
Сутність державної політики України щодо організації позашкільної освіти зафріксовано в Конституції України, Законах України «Про освіту», «Про позашкільну освіту», «Про охорону дитинства», «Про молодіжні та дитячі організації», у Державній національній програмі «Освіта» («Україна XXI ст. ліття»), Національній програмі «Діти України», «Концепції Державної цільової програми розвитку позашкільної освіти на період до 2014 року», реалізація яких сприяє збереженню мережі позашкільних закладів і збагаченню їхнього змісту діяльності, розвитку соціальної активності і творчого потенціалу особистості, створенню умов для повної самореалізації дітей і підлітків.

Осмислення проблеми організації позашкільної освіти дозволяє дійти висновку, що освітній процес, побудований за принципами демократизації, гуманізації, потребує врахування вітчизняних і світових культурно-історичних виховних традицій; педагогічного досвіду організації позашкільної освіти; розширення кадрового забезпечення, підвищення професійної майстерності педагогів, істотних інноваційних змін у системі позашкільної освіти України не лише на мікро-, а й на макрорівнях соціалізації, пошуку оптимальних шляхів її реорганізації з метою всебічного розвитку дітей і підлітків як особистостей у сучасній системі цінностей, здатних до активної соціальної адаптації в суспільстві й самостійного життєвого вибору, до самоосвіти й самовдосконалення. У зв'язку з цим активізувалися наукові пошуки із дослідження проблем позашкільної освіти.

Аналіз останніх досліджень і публікацій. Найбільш вагомий внесок у розробку теоретичної бази позашкільної та позакласної виховної роботи внесли наукові праці Л. Балясної, І. Вінниченко, Б. Кобзаря, Н. Ничкало, Т. Сущенко, Н. Харінко, В. Якубовського. У розробку питань розвитку теорії позашкільної освіти зробили свій внесок українські дослідники А. Алексюк, О. Біляєв, С. Гончаренко, М. Грищенко, К. Демкатний, О. Кондратюк, Г. Костюк, О. Мазуркевич, В. Онищук, В. Паламарчук, О. Савченко, М. Ярмаченко.

Виділення не вирішених раніше частин загальної проблеми. Науковий пошук показав, що, незважаючи на значну кількість наукових публікацій, присвячених вивченню позашкільної освіти, більшість із них мають фррагментарний характер у вивченні теорії і практики позашкільної освіти в Україні (друга половина $X X$ - початок XXI ст.). Мало дослідженою $€$ історіографрія цієї проблеми.

Мета статті - на основі історико-педагогічного аналізу розвитку теорії і практики позашкільної освіти в Україні (друга половина XX - початок XXI ст.) розкрити історіографрію проблеми та виокремити її основні етапи.
Виклад основного матеріалу. Незважаючи на те, що педагогічний інтерес до позашкільної освіти фріксуємо від найдавніших часів, становлення їі як поняття прослідковується лише з початку XX ст. У 20-х рр. XX ст. було визнано, що позашкільна освіта потрібна для культурного поступу країни як найкращий засіб виховання гармонійно розвиненої особистості [4].

Для дослідження проблеми розвитку позашкільної освіти України необхідно проаналізувати їі історіографрію, яка є невід'ємним складником історико-педагогічних досліджень. На основі аналізу наукових публікацій історіографрічне вивчення дає змогу досліднику відстежувати тенденції розвитку історико-педагогічного процесу, дозволяє встановити справжність і об'єктивність відомостей у цій галузі, розширити уявлення про закономірності наукового пізнання, систематизувати знання про те, що відбувалося в історико-культурному процесі.

Історія позашкільної освіти в Україні не раз була предметом дослідження, що знайшло відображення у монографріях, розвідках і статтях. У зв'язку з цим виникла необхідність у проведенні аналізу процесу дослідження і виявлення умов, за яких він $€$ найбільш продуктивним. На нашу думку, вивчення історії позашкільної освіти набуде повноти і довершеності за умов здійснення аналізу історіографрії дослідження.

Історіографія вирішує актуальне завдання підвищення якості узагальнення історії розвитку позашкільної освіти. Такий підхід дає науково обґрунтовану відповідь на низку істотних запитань, наприклад, які проблеми знайшли повне віддзеркалення у дослідженнях, а які вивчені не досить або зовсім не піддавалися науковому аналізу. Дослідження історіографрічного характеру мають важливе значення для планування і координації наукової роботи [2]. У контексті зазначеного постає необхідність періодизації історіографрічних досліджень із проблеми розвитку позашкільної освіти, тобто періодизації досліджуваного явища 3 точки зору історіографії - специфрічної фрорми знання про розвиток певного історико-педагогічного процесу, його своєрідну концепцію [3, с. 207].

В історіографії поділ на етапи і періоди проводиться для того, щоб виявити вирішальний напрям розвитку наукової думки на кожному новому відрізку «історіографрічного часу», виділити нові явища всередині тих історіографрічних пластів, які діють і приходять їм на зміну. Важливо виявити якісні зрушення, досягнуті в розробці основних концепцій історії, розширення проблематики, вдосконалення прийомів дослідження, введення у науковий обіг нових джерел [6].

Аналіз наукової літератури з історії позашкільної освіти за період із другої половини XX ст. і до наших днів показав, що процес накопичення 
знань про її розвиток відбувався у два етапи, зумовлені суспільно-політичними умовами життя держави, які відображають найважливіші педагогічні явища, пов'язані з виконанням завдань виховання дітей і підлітків:

1) середина 50-х-80-ті рр. XX ст. - етап активізації вивчення позашкільної освіти;

2) початок 90-х рр. XX ст.-до сьогодення - етап відновлення вивчення позашкільної освіти.

На першому етапі відбувалася активізація вивчення позашкільної освіти, що насамперед було спричинено соціальним (суспільно-державним) замовленням у педагогічній науці на осмислення та обґрунтування ролі і місця позашкільної освіти в ідейно-моральному всебічному вихованні та розвитку радянських дітей [3, с. 203]. Праці цього етапу здебільшого мали характер простого коментування; історичні явища, фракти в галузі освіти не мали глибокого наукового розкриття.

Звичайно, ми не можемо відмінити прийняті партійні рішення, але зобов'язані їх оцінити об'єктивно, здійснюючи аналітичне і систематичне вивчення таких джерел, показати ті фракти, які були зумовлені політичним життям країни. У сучасних умовах державні та партійні документи науковці мають аналізувати та оцінювати під кутом зору відповідності об'єктивній існуючій реальності, 3 урахуванням часу, мотивів, ситуацій їх прийняття, впливу на освітній процес у закладі освіти, на фрормування особистості молодої людини загалом.

Початок цього етапу пов'язаний із періодом «відлиги», коли помітно змінилися напрями і характер історико-педагогічних досліджень. Проте ідеологізований підхід до аналізу позашкільної освіти, принцип партійності історичної науки, ставили дослідників у жорсткі рамки класового й партійного підходу до її вивчення [1, с. 111]. Водночас у 60-80-х рр. XX ст. як у теорії, так і в практиці відновлюється інтерес до проблем педагогіки середовища, значна увага приділяється організації позакласної та позашкільної виховної роботи [6, с. 24]. У цей час центром виконання такого вивчення стала Академія педагогічних наук СРСР, практичні дії якої свідчили про визнання особливої ролі педагогічної науки у вивченні й узагальненні потенціалу позашкільної освіти та визначенні її шляхів. На цей період припадає створення спеціальних науково-дослідних структур у системі інститутів АПН СРСР, які очолили дослідники позашкільної освіти І. Гордін, Г. Іващенко, Ф. Корольов, В. Ханчин, В. Яковлєв [3, с. 203-204].

Важливим свідченням розвитку вивчення позашкільної освіти на цьому етапі $€$ діяльність науково-дослідних установ як загальносоюзного, так і республіканського рівнів: Науково-дослідних інститутів теорії і історії педагогіки, фрункціонування дослідно-експериментальних шкіл Академії педагогічних наук, проведення науково-практичних кон- фреренцій, педагогічних читань, дискусій з питань позашкільної освіти, поява монографічних праць істориків педагогіки із цієї проблематики.

Історія позашкільної освіти України знайшла часткове відображення у працях, присвячених історії освіти України загалом, дитячим і молодіжним організаціям, розвитку дитячого руху, дозвіллю дітей. Видавалися й публікації, присвячені вивченню загальних питань діяльності позашкільних навчальних закладів різного типу. Усі публікації мали ідеологічну орієнтацію відповідно до партійних директив.

Велике значення для вивчення розвитку системи позашкільної освіти в різних соціальних інституціях мало проведення у країні науковометодичних конференцій різного рівня за участю науковців, спеціалістів, які працюють у галузі позашкільної освіти. Кінець 80-х рр. XX ст. супроводжувався соціальними перетвореннями, що спричинили зміни у науковій сорері. Зокрема, розпалися наукові школи, науково-дослідні установи, відбулася переорієнтація кафедр низки педагогічних університетів, які займалися проблемами позашкільної освіти.

2-й етап - початок 90-х рр. ХХ ст.-до сьогодення - етап відновлення вивчення позашкільної освіти, яке відбувалося в умовах звільнення від партійного диктату в питаннях ідеології, утвердження в галузі науки і мистецтва плюралізму ідей і теорій. Почала набувати виразності нова сучасна концепція позашкільної освіти [5, с. 10-11].

Здобуття Україною незалежності, усунення партійного монополізму на наукові дослідження, дотримання плюралізму думок відкрили шлях до глибокого і всебічного вивчення історії українського суспільства, історії освіти, місця і ролі різних соціальних інститутів. У сучасних умовах зміни пріоритету цінностей дослідники дістали можливість здійснювати аналіз розвитку позашкільної освіти без остраху бути звинуваченими у безпартійній і надкласовій оцінці цього важливого суспільно-педагогічного явища.

Серед основних проблем позашкільної освіти, які одержали наукове осмислення на другому етапі їі вивчення, варто згадати процеси розвитку особистості в дитячих організаціях; організацію дозвілля дітей і підлітків у закладах позашкільної освіти; соціалізацію підлітка, його самореалізацію в закладах позашкільної освіти; гуманізацію, яка забезпечує особистісну орієнтацію діяльності дитячих клубів, гуртків; використання особистісно-діяльнісного підходу до організації позашкільної освіти та фрормування у дітей досвіду соціальної взаємодії.

Висновки. Таким чином, в історіографрії проблеми розвитку позашкільної освіти в Україні у хронологічних межах дослідження виокремлено два етапи: 50-80-ті рр. XX ст. - активізація досліджень позашкільної освіти; початок 90-х рр. XX ст. - до 
сьогодення - етап відновлення вивчення позашкільної освіти.

Підсумовуючи історіографрічний огляд проблеми розвитку позашкільної освіти в Україні (друга половина XX - початок XXI ст.), зазначимо, що, незважаючи на їх значну кількість, більшість досліджень мала суто історичне спрямування, інші ж опосередковано стосувалися досліджуваної теми та мають фррагментарний характер. Спеціальних історикопедагогічних праць, присвячених вивченню розвитку теорії і практики позашкільної освіти в Україні (друга половина $\mathrm{XX}$ - початок XXI ст.) поки що не створено.

\section{БІБЛІОГРАФІЧНИЙ СПИСОК:}

1. Басов Н.Ф. Науковедческие аспекты исследования истории детского движения в России: мето- дология, историография, источниковедение (нач. XX в. - 90-е гг.) : дис. д-ра пед. наук : 13.00.01. Москва, 1997. 348 с.

2. Биковська О.В. Історико-теоретичні основи позашкільної освіти. Педагогіка і психологія фрормування творчої особистості: проблеми і пошуки. 2006. Вип. 42. С. 39-48.

3. Вигина О.М. Детское движение. Москва, 2005. 203 C.

4. Медынский Е.Н. Внешкольное образование. Его значение, организация и техника : монографія. Москва, 1918. 288 с.

5. Найкін О.М. Сторінки літопису піонерської організації Ровенщини. Ровно, 1972. 52 с.

6. Цибулько Л.С. Соціальне виховання у вітчизняній педагогічній теорії та практиці 20-30-х років XX століття : дис. кан. пед. наук: 13.00.01. Слов'янськ, 2005. 185 c. 

МЕТОДОЛОГО-ТЕОРЕТИЧНИЙ ІНСТРУМЕНТАРІЙ
ІСТОРИКО-ПЕДАГОГІЧНИХ ДОСЛІДЖЕНЬ

\section{METHODOLOGICAL AND THEORETICAL TOOLS FOR HISTORICAL} AND PEDAGOGICAL RESEARCHES

\begin{abstract}
У статті висвітлено питання методологотеоретичного інструментарію історикопедагогічного дослідження. Акцентовано увагу на складниках концептуальних моделей теорії історії (наукові знання, орілософрські закони; світоглядні принципи дослідника), на специфрічних ознаках історико-педагогічних досліджень (часовий чинник, територіальна належність, відсутність експерименту, реконструкція форми знань, що набуває ознак історико-педагогічної рефрлексії; характерна розлога система посилань, критичний аналіз фокктів, комплексне використання методологічних підходів), на формі викладу історико-педагогічного дослідження (наративі), що передбачає комплекс взаємопов'язаних історичних методів, знання методології історії, навичок вивчення історичних документів, а також використання джерел, що сприяє сорормованості історико-педагогічного твердження. Наголошено на тому, що теоретичний рівень наукових досліджень залежить від методологічних знань. Зазначені структурні рівні методологічного знання (фрілософрський, загальнонауковий, конкретно науковий, технологічний), ффункції, що виконує нормативне методологічне знання (забезпечує правильність постановки проблеми наукового дослідження, визначає засоби для ії різнобічного аналізу на етапах студіювання, сприяє покращенню організації дослідження); загальнонаукові фрункції методологічного підходу (науково-світоглядна, концептуалізації, технологізаціі), основні методологічні принципи педагогічного дослідження (об'єктивності, доказовості, всебічності, сутнісного аналізу, $є$ єності історичного й логічного, наступності, системності, науковості). Висвітлено систематизацію методологічних принципів та підходів Н. Бордовської. Зосереджено увагу на чинниках підвищення якості та ефективності історико-педагогічних досліджень. Досліджено науковий дискурс понять «методологія», «методологічний підхід».

Ключові слова: історико-педагогічне дослідження, методологія, методологічні знання, методологічний підхід, методологічні принципи.
\end{abstract}

The article outlines the issues of methodological and theoretical tools to conduct historical and pedagogical research. It is focused on the components of conceptual models of history theory (scientific knowledge, philosophical laws; a researcher's worldview), on specific features of historical and pedagogical research (time factor, affiliation, no experiment, knowledge reconstruction, which bears some features of historical and pedagogical reflection. It is characterized by extensive references, critical analysis of facts, integrated application of methodological approaches). Emphasis is put on the form of presenting historical and pedagogical research (narrative), which involves a set of interrelated historical methods, knowledge of historical methodology, skills of studying historical documents as well as appropriate use of sources, which contributes to the reliability of historical and pedagogical statement. It is stressed that the theoretical level of scientific research depends on methodological knowledge. The article describes structural levels of methodological knowledge (philosophical, general scientific, specific scientific, technological), functions performed by normative methodological knowledge (ensures the correctness of the scientific research problem, determines the means for its comprehensive analysis at the stages of studying, improves research organization); general scientific functions of methodological approach (scientific worldview, conceptualization, technologization), main methodological principles of pedagogical research (objectivity, evidence, comprehensiveness, substantive analysis, unity of historical and logical, continuity, system, scientific). The systematization of methodological principles and approaches suggested by N. Bordovska is analyzed. Special attention is paid to the factors contributing to improving the quality and effectiveness of historical and pedagogical research. The scientific discourse of the concepts «methodology», «methodological approach» is researched.

Key words: historical and pedagogical research, methodology, methodological knowledge, methodological approach, methodological principles.
Постановка проблеми в загальному вигляді. Історія педагогіки, як зазначає О. Адаменко, покликана розкривати механізм руху науки, здійснювати раціональну реконструкцію історичного перетворення педагогічного знання, сприяти піднесенню теоретичного рівня сучасної педагогіки, створювати передумови для адекватної оцінки її досягнень [1, с. 1]. Підґрунтя історико-педагогічного дослідження становить методолого-теоретичний інструментарій, що сприяє інтерпретації певних явищ та подій.

Аналіз останніх досліджень і публікацій. Загальнометодологічним засадам наукових досліджень присвячені праці Н. Бордовської,
В. Ворожцова, В. Загвязінського, В. Кохановського, Т. Кристопчук, О. Москаленко, П. Образцова М. Скаткіна, С. Сисоєвої та ін. Концептуальні моделі теорії історії висвітлено в наукових розвідках В. Вороніна, Ю. Маркова, О. Розумовського, Н. Семенова, В. Шмакова. Методологія дослідження історико-педагогічного процесу розглядалася в наукових працях С. Бобришова, л. Ваховського, Е. Панасенко, 3. Равкіна, О. Сухомлинської.

Мета статті - розкрити методологічні основи історико-педагогічних досліджень.

Виклад основного матеріалу. Методологічне значення для історико-педагогічних досліджень 
мають сорормульовані науковцями вимоги до таких наукових праць. Л. Зеленська виокремлює таку низку специфічних ознак дослідження в галузі історії педагогіки, як: 1) часовий чинник (досліджувані явища та процеси стосуються певної епохи, що зумовлює інтеграцію педагогіки та історії); 2) територіальна належність (досліджувані об'єкти вивчаються в межах певного регіону); 3) відсутність експерименту (сучасний контекст наукової проблеми вступає в діалог із педагогічною проблематикою минулого, збагачує й розширює уявлення про приписи, персоналії, інституції, що сприяє вдосконаленню сучасного теоретико-методологічного пошуку; 4) джерельна та джерелознавча база, способи її опрацювання слугують базисом дослідження; 5) фрорма знань у дослідженні реконструюється, набуває характеру історико-педагогічної реслексії; 6) характерна розлога система посилань, критичний аналіз свідчень, наративна форма репрезентації досвіду [12, с. 24].

Розглядаючи концепцію історико-педагогічного дослідження як систематизований конструктивний задум наукової праці, як цілісну систему взаємопов'язаних концептів наукового пошуку, Е. Панасенко називає, крім таких його характерних ознак, як часовий чинник та територіальна належність, неможливість використання емпіричних методів наукового дослідження, комплексне використання методологічних підходів [18, с. 13].

3. Равкіним визначено шляхи підвищення якості та ефрективності історико-педагогічних досліджень: 1) подальше зростання їхнього теоретико-методологічного рівня, посилення світоглядної спрямованості й концептуального характеру; 2) забезпечення вченими-дослідниками інтеграції здобутих знань, системного та цілісного підходу до вивчення педагогічних явищ; 3) здійснення порівняльно-історичних досліджень, заснованих на типологічному аналізі досліджуваних процесів; 4) удосконалення методів обробки та аналізу історичних джерел, введення в науковий обіг нових і маловідомих документів, важливих за своїм значенням фрактів [19, с. 51].

Науковці В. Воронін, Ю. Марков, О. Розумовський, Н. Семенова, В. Шмаков, розглядаючи концептуальні моделі теорії історії, виокремили такі її складники: систему наукових знань, отриманих із фрактичного матеріалу; фрілософрські закони та принципи пояснення; світоглядні принципи історика-дослідника [9, с. 173].

Аналіз розвитку наукового знання, як зазначає В. Степін, є важливим аспектом історико-наукового дослідження, що передбачає виявлення та пояснення фрактів історії науки (емпірична історія науки), реконструкцію шляхів наукової думки, що сприяли формуванню нового знання (теоретичний рівень історико-наукових досліджень) [16, с. 137].
В історичній інтерпретації наукового тексту термін «знання» В. Візгіним тлумачиться як «продукт творчості цілого ряду особистостей, діючих певною мірою когерентно», які започаткували завдяки цьому традицію, наукову школу, науковий напрям. У межах такого підходу «за науковим знанням визнається певне право бути «історичною» реальністю <...>, володіти певною гетерогенністю, що не дозволяє здійснювати однозначний висновок «часткового» й «загального» [16, с. 324].

Г. Воробйов наголошує на тому, що логіка розвитку науки, суспільні потреби практики вимагають від дослідників цілісного та системного вивчення педагогічних процесів. На його думку, «метод дослідження реалізується в такій дослідницької технології, що забезпечує отримання необхідного й достатнього фрактичного матеріалу для побудови об'єктивно діючої закономірності описовими, фрормально-логічними або математичними засобами» [2, с. 69-70].

Теорія направлена, як уважає Е. Юдін, на отримання знань про саму дійсність, а методологія на процес отримання знань; «між теорією і методологією зберігається відношення цілі та засобу» [25, с. 50]. У структурі методологічного знання вчений виділяє такі рівні: 1) фрілософрський (загальні принципи пізнання, категоріальна упорядкованість науки; фрілософські знання виконують методологічні фрункції), 2) загальнонауковий (теоретичні концепції застосовувані до більшості дисциплін); 3) конкретно науковий (методи, принципи дослідження, застосовувані до визначеної дисципліни; методологія науки спрямована не тільки на висвітлення специфічних проблем у певній галузі знань, а й тих питань, що порушуються на більш високому методологічному рівні, наприклад, системного підходу або моделювання в педагогічному дослідженні); 4) технологічний (методика й техніка дослідження забезпечують достовірність отриманого емпіричного матеріалу, первинне опрацювання, що дає можливість увести його в масив наукового знання, яке має нормативний характер). Рівні методологічного знання утворюють складну систему, в межах якої між ними існує певна супідрядність. Водночас фрілософрський рівень $є$ змістовним підґрунтям методологічного знання, адже він визначає світоглядні підходи до процесу пізнання й перетворення дійсності [25].

М. Скаткін відзначає, що методологічні знання сприяють підвищенню теоретичного рівня дослідження, «допомагають рухатися від пізнання явищ до пізнання сутності, розкрити глибше внутрішні зв'язки між ними» [21, с. 132].

На думку В. Ворожцова та О. Москаленка, методологія - це «сплав онтологічних принципів, гносеології, логіки та теоретичного змісту науки та її методів...». Методологія конкретної науки повинна базуватися на теорії досліджуваного об'єкта 
[8, с. 14-15]. В. Кохановський уважає, що методологія - це складна, динамічна, цілісна, субординована система способів, прийомів, принципів різних рівнів, сфрери дії, спрямованості, евристичних можливостей, змістів, структур [13, с. 186].

Учені П. Атутов, 3. Малькова, М. Скаткин акцентують увагу на методологічних орієнтирах, необхідних для розроблення наукової теорії [15, с. 58]. Науковці вибирають такі методичні орієнтири й концептуальні стратегії, керуючись якими, можна описати, пояснити, спрогнозувати тенденції або напрями істотних змін педагогічного об'єкта.

Цінність методологічних орієнтирів, на думку Н. Бордовської, полягає в тому, що вони дають змогу науково обґрунтувати актуальність проблеми педагогічного дослідження та вибір методів і способів їі рішення, а також визначити межі аналізу результатів дослідження, пошуку критеріїв їх об'єктивної науково аргументованої оцінки; мають вплив на структуру, стиль наукового мислення, відбір понятійно-категоріального апарату, виклад наукового тексту, а також слугують підставою для типологізації та систематизації проявів педагогічної реальності; прогнозують конкретні зразки й фрорми наукового пізнання педагогічного об'єкта $[6$, c. 23].

П. Образцов відзначає, що методологія науки характеризує компоненти наукового дослідження (об'єкт, предмет, завдання, методи, засоби, способи), формує уявлення про послідовність дослідницької діяльності в процесі вирішення наукової задачі, набуває нормативної спрямованості, а одним з їі завдань є методологічне забезпечення дослідницької праці [17, с. 9, 13].

Важливою властивістю сучасного наукового мислення, на думку С. Сисоєвої та Т. Кристопчук, є методологічність, адже вона характеризується усвідомленим ставленням до засобів, передумов діяльності щодо фрормування та вдосконалення наукового знання [20, с. 67].

У нормативному методологічному аналізі переважають конструктивні завдання, по'вязані з розробленням «позитивних рекомендацій та правил здійснення наукової діяльності», а в дескриптивному - з ретроспективним описом уже здійснених процесів наукового пізнання [25, с. 40].

В. Загвязінський під нормативністю методологією розуміє не лише вивчення загальних принципів підходу до різних об'єктів дійсності, до різних класів наукових завдань, а й вивчення системи загальних та спеціальних методів, прийомів наукового дослідження. Теоретичний аспект педагогічної методології пов'язаний зі встановленням основних педагогічних закономірностей як вихідних передумов наукового пошуку, що включає світоглядну функцію (оцінка суспільної значимості, соціальної ролі теорії або теоретичного положення). Специфріка методологічного знання полягає в їхній спря- мованості на принципи та методи наукової та науково-практичної діяльності. Науковець відзначає, що в методологічному знанні об'єктом вивчення $€$ педагогічна наука, предметом - проблематика, структура, методи педагогічного дослідження, принципи та способи розвитку педагогічної теорії, а також упровадження її досягнень у практику, тому «важливе значення в структурі методологічного знання набувають принципи й вимоги, в яких виявлені закономірності, спільні дослідницькі підходи втілюються в категоріях діяльності (способи, методи, процедури тощо)» [11, с. 7-8, 32].

Нормативне методологічне знання виконує такі фрункції: 1) забезпечує як змістовно, так і фрормально, правильну постановку проблеми; 2) визначає засоби для вирішення поставлених завдань та проблем («інтелектуальна техніка наукової діяльності»); 3) сприяє покращенню організації дослідження [3, с. 68].

Орієнтація на аналіз сукупності педагогічних явищ та їхній розвиток як частини явищ соціальних становить сутність нового підходу до методологічних досліджень у галузі педагогіки [24, с. 39].

За С. Гончаренко, методологія педагогіки - це система знань про структуру педагогічної теорії, про принципи підходу, способи набуття знань, що відображають педагогічну дійсність, а також це система діяльності з одержання таких знань й обґрунтування програм, логіки, методів та оцінки якості дослідницької роботи. Методологія педагогіки включає такі положення: вчення про структуру й фрункції педагогічного знання; вихідні, ключові, фрундаментальні педагогічні положення (теорії концепції, гіпотези); вчення про логіку й методи педагогічного дослідження; вчення про способи використання одержаних знань для вдосконалення практики [10, с. 499].

Методологія педагогіки П. Образцовим трактується як концептуальний виклад мети, змісту, методів дослідження, що забезпечують отримання максимально об'єктивної, достовірної, систематизованої інформації про педагогічні процеси та явища. Методологія педагогіки виконує такі фрункції: 1) визначає способи отримання наукових знань, що відображають постійно змінювану педагогічну дійсність; 2) спрямовує і зумовлює основний шлях, за допомогою якого досягається конкретна науково-дослідницька мета; 3) забезпечує всебічність отримання інформації щодо досліджуваного процесу або явища; 4) сприяє уточненню, збагаченню, систематизації термінів і понять у педагогічній науці; 5) допомагає введенню нової інформації до теоретичного фронду педагогіки; 6) створює систему інорормації, що спирається на об'єктивні фракти й логіко-аналітичний інструмент наукового пізнання [10, с. 10-11].

Найсучаснішою й ефективнішою методологією історико-педагогічного дослідження Л. Ваховський 
уважає перспективну (нормативну) методологію, яка характеризується конструктивністю, створюваною за допомогою розумового моделювання, що здатна розв'язати низку завдань: забезпечення правильної постановки проблеми щодо її змісту та форми, критичне осмислення існуючих ідей, покращення організації дослідження, коректне інтегрування отриманих результатів [7, с. 8].

О. Сухомлинська акцентує увагу на фрормі викладу історико-педагогічного дослідження (наративі), що «передбачає історичні методи дослідження знань методології історії, навичок вивчення історичних документів та використання джерел, на основі яких фрормується історико-педагогічне твердження», що може мати причинний, еволюційно-генетичний, фрункціонально-генетичний, фуннціональний характер [22, с. 45].

Загальнонаукові методологічні принципи та підходи повинні бути іманентними предмету дисципліни, а також системі понять, що склалася в ній [25, с. 49]. Методологічні принципи «являють собою основні фрілософські світоглядні положення, з позицій яких ведеться наукове дослідження» [14, с. 38]. У методологічних підходах закладена фундаментальна ідея в контексті пізнання або перетворення об'єкта педагогічної реальності [6, с. 22].

Поняття «методологічний підхід» Е. Юдіним трактується як принципова методологічна орієнтація наукового дослідження, з погляду якої розглядається об'єкт дослідження (спосіб визначення об'єкта), поняття або принцип, що спрямовує загальну стратегією дослідження [25, с. 143]. Методологічний підхід уможливлює обґрунтування проєкту педагогічного дослідження; а реалізована методологія дозволяє досліднику отримати нове наукове знання [23, с. 91].

Розглядаючи сутність, зміст, фрункції методологічного підходу в наукових дослідженнях, С. Бобришов дійшов такого висновку: цей підхід не лише задає модель авторського бачення, розуміння та інтерпретації явищ, фрактів, подій в історії педагогіки, а $€$ науково обґрунтованим аксіоматичним каноном цілісного аналізу, репрезентації досліджуваного об'єкта - історико-педагогічного процесу в різних аспектах взаємозв'язку з історією суспільства, держави, культури та науки; визначає погляди на етапи розвитку об'єкта, регламентує відбір та інтерпретацію фрактологічного матеріалу, визначає аксіологічні параметри оцінки досліджуваних історико-педагогічних явищ [5, с. 42].

Науковець виокремлює функції методологічного підходу як регулятора й індикатора наукового дослідження: 1) науково-світоглядна, що сприяє сорормованості дослідних установок ученого щодо цілісного сприйняття об'єкта, комплексного співвіднесення його із соціально-історичною дійсністю; активізує рівні методологічного аналізу, відтворює науковознавчі та світоглядні погляди суб'єкта пізнання; 2) срункція концептуалізації, яка дає змогу сорормуватися концептуальній базі дослідження, досягнути узгодженості із встановленими науковими традиціями; забезпечує фрормування загальної стратегії дослідження відповідно до прийнятих парадигматичних принципів; 3) функція технологізації, що допомагає досягти коректних наукових параметрів та характеристик технологічного аспекту процесу пізнання; забезпечує вибір засобів, методів і прийомів вивчення об'єктів [4, с. 49].

Н. Бордовською систематизовано найбільш використовувані дослідниками методологічні принципи та підходи, а саме: 1) системний, цілісний, антропологічний та комплексний підходи для формування онтологічних, різнобічних уявлень про досліджуваний педагогічний об'єкт; 2) системно-структурний та функціональнодинамічний підходи, принципи безперервності й дискретності, ідеї синергетики та кібернетики, інформаційної теорії та статистичної системної імовірності - для відтворення ґенезису досліджуваного педагогічного об'єкта, визначення динаміки його розвитку та якісної зміни; 3) принцип природо- й культуровідповідності, диференціації, індивідуалізації, гуманізації, технологізації, спільної діяльності - для розкриття властивостей, опису окремих характеристик педагогічного об'єкта; 4) особистісний, діяльнісний та аксіологічний підходи - для визначення значення педагогічного процесу в загальній системі навчання та виховання; 5) процесуальний, функціональний або програмно-цільовий підходи, принципи демократизації, гуманізації, варіативності та диверсиорікації, положення теорії управління, організації, комунікації та соціальних груп - для визначення оптимальних шляхів педагогічного управління та організації педагогічного процесу [6, с. 26-27].

На переконання 3. Равкіна, від ступеня вирішення світоглядних і методологічних проблем даної галузі педагогіки залежить як науковий рівень досліджень, так і його практичне значення, а це «повинно отримати своє конкретне вираження в подоланні описовості, фрактографрічності, емпіризму <..>, в забезпеченні широких історикопедагогічних узагальнень і висновків теоретикометодологічного характеру, концептуальності й цілісності досліджень...» [19, с. 51].

Із-поміж основних методологічних принципів педагогічного дослідження науковцями С. Сисоєвою та Т. Кристопчук виокремлені такі: об'єктивності (врахування фракторів, що зумовлюють явища, умов їхнього розвитку, адекватності дослідницьких підходів, а також засобів, що дають можливість одержати справжні знання про об'єкт, передбачають виключення суб'єктивізму, однобічності й упередженості в доборі, оцінці фрактів); 
доказовості (альтернативність характеру наукового пошуку; вимога виділити й оцінити всі можливі варіанти розв'язування, виявити різні погляди на досліджуване); всебічності (комплексність підходу в дослідженні педагогічних процесів та явищ); сутнісного аналізу (співвіднесення в досліджуваних явищах загального, особливого й одиничного, проникненням в їхню внутрішню структуру, розкриття законів існування й фрункціонування, умов і фракторів їхнього розвитку, можливостей цілеспрямованої зміни); єдності історичного й логічного (поєднання вивчення історії об'єкта (генетичний аспект) і теорії (структури, фрункції, зв'язків об'єкта в його сучасному стані, а також перспектив його розвитку); наступності (урахування досвіду, традицій, наукових досягнень минулого); системності (розгляд об'єкту вивчення як системи) [20, с. 67-70]. Із принципом об'єктивності за змістом схожий принцип науковості, який визначає вимога конкретно-історичного дослідження педагогічних явищ [11, с. 34].

В. Ворожцов та О. Москаленко функціонування методологічних принципів пов'язують із такими особливостями, як забезпечення взаємозв'язку емпіричних даних, концептуального апарату, категорій та законів, ідей, гіпотез, теорій, їх структурування і «субординування» [8, с. 17].

Висновки. Отже, методолого-теоретичний інструментарій історико-педагогічного дослідження дає можливість для створення авторської моделі бачення історичних явищ та подій, їх інтерпретації, розкриває цілісність розгортання означеного питання в логіко-проблемній послідовності, акумулює інсоормацію (змістову, культурологічну, прогностичну) для визначення напрямів творчого, адаптованого до сучасних потреб використання набутого досвіду на сучасному етапі реформування системи вищої освіти України.

\section{БІБЛІОГРАФІЧНИЙ СПИСОК:}

1. Адаменко О.В. Розвиток педагогічної науки в Україні в другій половині XX століття (1950-2000рр.) : автореф. дис. ... д-ра пед. наук : 13.00.01. Луганськ, 2006. 44 C.

2. Атутов П.Р., Скаткин М.Н., Турбовский Я.С. Методологические проблемы развития педагогической науки Москва : Педагогика, 1985. 240 с.

3. Блауберг И.В., Юдин Э.Г. Становление и сущность системного подхода. Москва : Изд-во «Наука», 1973. $270 \mathrm{c}$.

4. Бобрышов С.В. Методология историко-педагогического исследования развития педагогического знания : дисс. ... д-ра пед. наук : 13.00.01. Ставрополь, 2006. 477 с.

5. Бобрышов С.В. Система методологических подходов к изучению историко-педагогического процесса. Вестник Костромского государственного университета имени Н.А. Некрасова: Основной выпуск. Кострома, 2006. № 2. С. 41-46.
6. Бордовская Н.В. Системная методология современных педагогических исследований. Педагогика. Москва, 2005. № 5. С. 21-29.

7. Ваховський Л.Ц. Методологія дослідження історико-педагогічного процесу : постановка проблеми. Шлях освіти. Київ, 2005. № 2 (36). С. 7-11.

8. Ворожцов В.П., Москаленко А.Т. Методологические установки ученого : природа и фрунцции. Новосибирск : Наука, 1986. 234 с.

9. Воронин В.Т., Розумовский О.С., Семенова Н.М. Методологические проблемы оптимизации в науке. Новосибирск : Наука, 1991. 255 с.

10. Енциклопедія освіти / АПН України ; гол. ред. В.Г. Кремень. Київ : Юрінком Інтер, 2008. 1040 с.

11. Загвязинский В.И. Методология и методика дидактического исследования. Москва : Педагогика, 1982. $160 \mathrm{c}$.

12. Зеленська Л.Д. Методи історико-педагогічного дослідження у розрізі парадигми наукового знання. «Психолого-педагогічні проблеми вищої і середньої освіти в умовах сучасних викликів : теорія і практика» : матеріали IV Міжнар. наук.-практ. конф. (м. Харків, 12 грудня 2019 р.). Харків, 2019. С. 23-26.

13. Кохановский В.П. Философрия и методология науки. Ростов н/Д : Феникс, 1999. 576 с.

14. Кыверялг А.А. Методы исследования в профессиональной педагогике. Таллин : «ВАЛГУС», 1980. $334 \mathrm{c}$.

15. Теоретико-методологические проблемы педагогики. Советская педагогика / 3.А. Малькова и др. Москва, 1982. № 3. С. 56-62.

16. Методологические проблемы историконаучных исследований (ответственный редактор И. С. Тиvосреев). Москва : Изд-во «Наука», 1982. 360 с.

17. Образцов П.И. Методы и методология психолого-педагогического исследования. СанктПетербург : Питер, 2004. 268 с.

18. Панасенко Е.А. Концепція історико-педагогічного дослідження : методологічний аналіз. Педагогічна освіта : теорія і практика. Психологія. Педагогіка. Київ, 2016. № 25. С. 11-16.

19. Равкин 3.И. Методологическая функция историко-педагогических исследований. Советская педагогика. Москва, 1984. № 12. С. 50-56.

20. Сисоєва С.О., Кристопчук Т.Є. Методологія науково-педагогічних досліджень. Рівне : Волинські обереги, 2013. 360 с.

21. Скаткин М.Н. Методология и методика педагогических исследований. В помощь начинающему исследователю. Москва : «Педагогика», 1986. 152 с.

22. Сухомлинська О. Історико-педагогічне дослідження та його «околиці». Шлях освіти. Київ, 2005. № 4 (38). C. 43-47.

23. Методологічні засади педагогічного дослідження : монографрія / Є.М. Хриков та ін. Луганськ : Вид-во ДЗ «ЛНУ імені Тараса Шевченка», 2013. 248 с.

24. Шубинский В.С. Общая теория развития педагогических явлений как предмет методологических исследований. Советская педагогика. Москва, 1982. № 3. С. 39-41.

25. Юдин Э.Г. Системный подход и принцип деятельности. Москва : Издательство «Наука», 1978. 391 c. 
ІСТОРИЧНІ ЕТАПИ ПРОФЕСІЙНОЇ ПІДГОТОВКИ ЕКОНОМІСТІВ У СИСТЕМІ ВИЩОЇ ОСВІТИ УКРАЇНИ В ДРУГІЙ ПОЛОВИНІ XX - ПОЧАТКУ XXІ СТОЛІТТЯ

\author{
HISTORICAL STAGES OF ECONOMISTS PROFESSIONAL TRAINING \\ IN THE SYSTEM OF HIGHER EDUCATION OF UKRAINE \\ IN THE SECOND HALF OF THE 20TH - THE EARLY 21ST CENTURIES
}

\begin{abstract}
У статті розглянуто питання необхідності формування систематизованого комплексного підходу до вивчення історичного прогресивного досвіду підготовки економічних кадрів з метою вдосконалення і розвитку сучасної системи економічної освіти у вищих навчальних закладах України. Проаналізовано результати наукових робіт, які торкаються аналізу змісту систем підготовки економістів, з точки зору його історичного розвитку в українських ВНЗ у другій половині XX початку XXI століття. Розкрито поняття економічної системи, визначені фрактори, які впливають на ії розвиток, і наведено класифрікацію економічної системи на основі способу організації господарської діяльності. Дано визначення та охарактеризовано переваги та недоліки відомих типів господарських систем: традиційної, планової, перехідної, ринкової і змішаної. Представлені основні (мета і потенціал) і допоміжні (внутрішні та зовнішні) фрактори, що впливають на якість освітнього процесу. Наведено та охарактеризовано критерії, на грунті яких здійснюється підготовка економістів у системі вищої освіти. 3 метою подальшої комплексної систематизації наукових досліджень дано визначення історичним етапам профресійної підготовки економістів у різних типах економічних систем господарювання в Україні в другій половині XX - початку XXI століття й обгрунтовано хронологічну періодизацію: профресійна підготовка економістів у період із системою планової економіки (початок 60-х середина 80-х років XX cm.); професійна підготовка економістів у перехідний етап (друга половина 80-х - початок 90-х рр.); професійна підготовка економістів у період задекларованого розвитку ринкової економіки (початок 90-х років XX cm. - початок XXI cm. i до нашого часу).

Ключові слова: вища освіта, критеріі навчального процесу, періодизація, професійна підготовка, фрахівець, економічна освіта, економічна система.
\end{abstract}

аспірант кафедри психології,

педагогіки та фрілософії

Кременчуцького національного

університету імені

Михайла Остроградського
The article deals with the need to form a systematic integrated approach to the study of historical progressive experience in economic staff training in order to improve and develop the modern system of economic education in higher educational institutions of Ukraine. The authors have analyzed the results of research papers concerning the content analysis of economists training system from the point of view of its historical development in Ukrainian higher educational institutions in the second half of the 20th - the early 21st centuries. The concept of economic system has been defined, the factors influencing its development have been specified, and the economic systems classification on the basis of economic activity methods has been provided. The authors have defined and characterized the advantages and disadvantages of known types of economic systems: traditional, planned, transitional, market and mixed. The main (purpose and potency) and auxiliary (internal and external) factors influencing the quality of the educational process have been presented. The basis criteria of economists training in the higher education system have been given and characterized. In order to further complex systematization of scientific research, the authors have defined the historical stages of economists professional training in different types of economic systems in Ukraine in the second half of 20th - the early 21st centuries and have grounded the chronological periodization: economists professional training in the planned economy (early 1960s - mid 1980s); economists professional training in the transition stage (second half of the 1980s - early 1990s); economists professional training in the period of the declared development of the market economy (early 90s of the 20th century - early 21st century and to the modern era).

Key words: higher education, criteria of educational process, periodization, professional training, specialist, economic education, economic system.
Постановка проблеми в загальному вигляді. Необхідність визначення історичних етапів професійної підготовки економістів в Україні, а також критеріїв і сракторів, що впливають на їх фрормування, зумовлена безперервним процесом формування національної системи вищої економічної освіти. Використання поетапного структурного аналізу під час вивчення історичного прогресивного досвіду підготовки економічних кадрів у різних економічних моделях господарювання сприятиме подальшому вдосконаленню педагогічних досліджень профресійної підготовки економістів і пошуку потенційно затребуваних сучасною педагогічною системою України трансформаційних тенденцій з метою підготовки сучас- них різнопланових і конкурентних економістів у вітчизняних закладах вищої освіти.

Аналіз останніх досліджень і публікацій. До питання пошуку оптимальних моделей підготовки економічних кадрів у системі вищої освіти України зверталася досить велика кількість науковопедагогічних кадрів. Окремий науковий інтерес до досліджень в області вивчення історичного прогресивного досвіду підготовки економістів проявляли К.Ф. Беркіта, С.Д. Гелей, З.В. Гіптерс, М.М. Голубка, Є.І. Доменнікова, І.В. Жабровець, Р.Ю. Кігель, Л.О. Плахотнікова, Н.О. Красовська, Лантух І.В., О.Н. Місько, Л.М. Потапюк, Л.А. Руденко, А.М. Сінгаївська, В.І. Труба, В.Г. Федоренко, Ю.М. Чекушіна, М.В. Шишкін та ін. Результати аналізу даних робіт 
підтверджують необхідність подальшого вивчення проблеми, а також систематизацію отриманих результатів.

Виділення не вирішених раніше частин загальної проблеми. Проблема вдосконалення підготовки економічних кадрів у системі вищої освіти України з точки зору використання історичного прогресивного досвіду $є$ сьогодні недостатньо вивченою і систематизованою. Особливо явно виділяється відсутність загальної чіткої системності у використанні хронологічної періодизації профресійної підготовки в дослідженнях, застосування якої, з нашої точки зору, особливо вплине на якість, послідовність і спадковість наукових робіт.

Мета статті полягає у визначенні хронологічних етапів професійної підготовки фахівців для економічної галузі в контексті розвитку економічної освіти України в другій половині XX - початку XXI століття, а також у виявленні критеріїв та чинників, що впливають на їх фрормування.

Виклад основного матеріалу. Підготовка економічних кадрів для різних систем господарювання, які в різний час мали місце в економіці України, має досить відмінностей, пов'язаних зі специфрікою економічних взаємин, характерних для конкретних економічних моделей. 3 метою фрормування хронологічних меж періодів підготовки фрахівців у системі вищої економічної освіти України в другій половині XX - початку XXI століття передусім необхідно вивчення понять і визначення характеристик існуючих економічних систем.

Система - це сукупність елементів, що знаходяться у відносинах і зв'язках один з одним, які утворюють певну цілісність, єдність [8].

Економічна система - це особливим чином упорядкована система зв'язків між виробниками і споживачами матеріальних благ і послуг. Функціонування економічної системи націлене на виконання таких найважливіших економічних завдань, як:

- формування та забезпечення працездатності економіки;

- координація всіх видів економічної діяльHOCTі;

- реалізація соціальних цілей.

Економічна система багатофракторна. Серед фракторів, що впливають на іії розвиток, визначальними є такі: існуюча в країні система заходів щодо прийняття господарських рішень, структура власності, механізми забезпечення інформацією і координацією, механізми постановки цілей і спонукання людей до праці. Класифікація економічних систем на основі способу організації господарської діяльності враховує такі ознаки:

- форма власності на фрактори виробництва;

- хто і як приймає основні економічні рішення;

- спосіб координації економічної діяльності;

- мотиви, що стимулюють ведення економічної діяльності [3].
3 огляду на дані фрактори визначаються певні типи економічних систем: традиційна, планова, перехідна, ринкова і змішана.

1. Традиційна економічна система характеризується керівництвом господарської діяльності, звичаями і традиціями суспільства. Є найбільш найстарішою з перерахованих і натепер використовується виключно в одиницях слаборозвинених країн, орієнтованих переважно на сільське господарство. В економіці України в досліджуваний нами період дана система не застосовувалася.

2. Планова економіка - це економіка, за якої матеріальні ресурси становлять в основному державну власність, а спрямування і координація економічної діяльності здійснюються за допомогою централізованого планування, управління і контролю. У плановій економіці основні економічні рішення приймаються централізовано у вигляді планів соціально-економічного розвитку. За допомогою виконання планів досягається збалансованість економічної діяльності [3].

Планова економічна система являє собою складний, свідомо організований і керований процес, пов'язаний з усіма сфрерами суспільної і практичної діяльності людей. Відомі два типи планової економіки: демократична і командна.

Демократична передбачає сукупність суспільної, яка $€$ домінуючою, і приватної власності на економічні ресурси. Планування $€$ обов'язковим виключно для державних підприємств, а для інших носить лише рекомендаційний характер.

Для командної економіки характерна модель побудови економічних відносин, в яких приватна власність категорично виключається. Централізоване державне планування зачіпає всі сорери економічної діяльності суспільства. В умовах командної економіки управління всіма підприємствами здійснюється з єдиного центру. Тому безпосередні виробники обмежені в прийнятті економічних рішень. Вони не мають можливості самостійно вибирати постачальників сировини, устаткування, а також здійснювати збут продукції [3].

Потреба в плановій системі економіки сьогодні значно зросла, оскільки рішення в соціальній, оборонній і технологічній сорерах економіки набувають все більш довгострокового характеру. Крім того, виникли екологічні проблеми, які багатьох аналітиків доводять висновку про необхідність зміни ринку на користь плановості [2].

Період профресійної підготовки фрахівців для економічної галузі в Україні в 60-80-х роках XX століття характеризується етапом розвитку економічної думки в затвердженні суспільної власності на основні засоби виробництва, що створювало умови для планомірного розвитку народного господарства. Досягнута до того моменту ступінь усуспільнення виробництва була визначальною для рівнів, фрорм і методів планування. 
Старт перетворенням у вищій освіті, що мали на меті поліпшення якості підготовки фрахівців для характерної для того періоду планової економіки України, було розпочато в 1958 році. Основоположними в цьому сенсі з'явилися Закон СРСР «Про зміцнення зв'язку школи 3 життям і про подальший розвиток системи народної освіти в СРСР» від 24 грудня 1958 року і пов'язаний з ним Закон УРСР «Про зміцнення зв'язку школи з життям і про подальший розвиток системи народної освіти в Української РСР» від 17 квітня 1959 року.

Для більш глибокого пізнання й оволодіння механізмами використання специфічних законів, необхідних для планомірного розвитку всієї економічної системи держави, вища українська школа забезпечувала в цей період безперервну і послідовну підготовку фахівців для всіх сфер народного господарства, орієнтованого на планову систему управління.

3. Перехідна економіка - це економіка, яка перебуває в процесі переходу від однієї економічної системи до іншої.

Відмінною рисою даного типу економіки є одночасне співіснування двох типів економічних систем: тої, що минає і нової.

Економіку даного типу характеризує багатоукладність. Економіці перехідного періоду властиве загострення соціально-економічних відносин, які зменшується по мірі створення нової економічної системи. Тривалість ринкової трансорормації залежить від рівня соціально-економічного розвитку суспільства [3]

Яскраво вираженим періодом перехідної економічної моделі в Україні ми вважаємо другу половину 80-х - початок 90-х років XX століття. 3 метою проведення глибоких економічних і політичних реорорм був оголошений курс на «перебудову». Початком даних перетворень послужила Постанова ЦК КПРС і Ради Міністрів від 12 липня 1985 року «Про широке поширення нових методів господарювання і посилення їх впливу на прискорення науково-технічного прогресу». Даною Постановою був чітко позначений курс на зміну соціально-економічного вектора в політиці держави. Надалі для продовження реалізації даної програми переходу від методів планової економіки до ринкової були затверджені такі законодавчі акти і постанови: Постанова ЦК КПРС і Ради Міністрів від 17 липня 1986 року «Про вдосконалення планування, економічного стимулювання і управління в державній торгівлі і споживчій кооперації», постанови Ради Міністрів від 22 грудня 1986 року «Положення про госпрозрахункову зовнішньоторговельну організацію (об'єднання) міністерства, відомства» і «Типове положення про госпрозрахункову зовнішньоторговельну фрірму науково-виробничого, виробничого об'єднання, підприємства, організації», Постанова
Ради Міністрів СРСР від 13 січня 1987 року «Про порядок створення на території СРСР і діяльності спільних підприємств, міжнародних об'єднань та організацій СРСР та інших країн - членів РЕВ», Указ Президії Верховної Ради СРСР від 13 січня 1987 року «Про питання, пов'язані зі створенням на території СРСР і діяльністю спільних підприємств за участю радянських організацій і фрірм капіталістичних і країн, що розвиваються», Закон СРСР від 19 листопада 1986 року «Про індивідуальну трудову діяльність» та інші. Основним регламентуючим актом переведення планової економіки на ринкові принципи був Закон «Про державне підприємство (об'єднання)», затверджений Верховною Радою СРСР 30 червня 1987 року.

У перехідному періоді, де відбулися зміни в господарсько-правовій діяльності підприємств, переведення на самоокупність, повний господарський розрахунок і самофінансування, поява самостійних експортно-імпортних операцій, відродження приватного підприємництва, були так само намічені корінні перетворення в процесі підготовки фахівців для економічної галузі.

Плани 3 регулювання і модернізації всієї системи вищої освіти й економічної зокрема, на перехідному етапі від системи з плановою економікою до ринкової, були викладені в Постанові ЦК КПРС і Ради Міністрів СРСР від 13 березня 1987 року «Основні напрями перебудови вищої і середньої спеціальної освіти в країні» і Постанові ЦК КПУ і Ради Міністрів УРСР від 29 квітня 1987 року «Про організацію виконання в Українській РСР постанови ЦК КПРС і Ради Міністрів СРСР від 13.03.1987 року № 326 «Про підвищення ролі науки у вищих навчальних закладах для прискорення науково-технічного прогресу, поліпшення підготовки фрахівців», в яких йшлося про необхідність в умовах економічних перетворень внесення значних змін у систему підготовки фрахівців, які відповідають новим вимогам, до системи вищої економічної освіти з боку держави.

4. Найпоширенішим типом сучасної економічної системи $є$ ринкова економіка, заснована на товарно-грошових відносинах, верховенстві приватної власності, вільної конкуренції виробників і споживачів. Наявність ринкових взаємовідносин суб'єктів ринку має на увазі свободу вибору виду і кількості виробленого продукту, а також свободу в його придбанні. Визначальною умовою придбання продукту кінцевим споживачем $€$ не стільки сам фактор його пропозиції, скільки ціна і якість. Збалансованість економіки досягається за допомогою ринкового механізму. Його основними елементами є попит і пропозиція. 3 урахуванням їх відповідності формується ціна на товари. Рівень ціни є сигналом для збільшення або скорочення їх виробництва [3]. 
Початком періоду, в якому українські ВН3 здійснюють підготовку фрахівців в умовах ринкових відносин, можна умовно вважати 1991 рік. Початок цього етапу охарактеризувався значними законодавчими змінами в реформуванні системи вищої освіти. Із цього моменту Українська державність Постановою Верховної ради Української РСР від 24 серпня 1991 року «Про проголошення незалежності України» здобула незалежність. Урядом було задекларовано курс на фрормування ринкових відносин у всіх економічних галузях і для всіх суб'єктів господарювання.

3 метою підготовки висококласних, конкурентоспроможних, затребуваних на ринку праці фрахівців для економічної галузі на підставі прийнятого в 1991 році «Закону про освіту» з 1993 по 1995 року було запроваджено в дію такі реформаційні укази і постанови, що регламентують підготовку кадрів у системі вищої освіти в умовах розвитку ринкової економіки, як: Постанова Кабінету Міністрів України від 3 листопада 1993 року «Про державну національну програму «Освіта» (Україна XXI століття)»; пакет Наказів Міністерства освіти й науки України (МОН): від 8 квітня 1993 року «Про затвердження Положення про проведення практики студентів вищих навчальних закладів України», від 2 червня 1993 року «Про затвердження Положення про організацію навчального процесу у вищих навчальних закладах», від 2 червня 1995 року «Про затвердження Положення про професійну орієнтацію молоді, яка навчається», Указ Президента України від 12 вересня 1995 року «Про основні напрями ресрормування вищої освіти в Україні» та ін.

Період підготовки економічних кадрів для української держави, яка взяла на початку 90-х років $\mathrm{XX}$ століття курс на розвиток ринкових відносин, триває і сьогодні.

5. Соціально орієнтована змішана економіка - це економіка, що фрункціонує на базі ринкового механізму і державного регулювання господарства. Такі зміни в ролі держави викликані передусім необхідністю розвитку виробничої та соціальної інсрраструктури, науково-технічним прогресом. Змішана економіка - це економічна модель, в якій керуючу роль у питаннях урегулювання соціального порядку, попиту і пропозиції на макрорівні здійснює держава, а питання планування на мікрорівні знаходяться у сфрері діяльності безпосередньо фірм і підприємств [3].

Одиничний і короткочасний період існування такого типу економіки в процесі перехідного періоду від планової економіки до ринкової в кінці 80-х років XX століття в Україні не увінчався успіхом.

Варто так само відзначити, що натепер деякі ознаки змішаного типу демонструють економіки таких країн, як Німеччина, Швеція, Голландія, Япо- нія, США, Великобританія, Франція, Фінляндія та деякі інші.

На підставі аналізу відомих економічних систем виділено три повноцінних соціально-економічних етапи в системі професійної підготовки економістів у вищих навчальних закладах України в період другої половини XX століття - початку XXI століття:

1. Профресійна підготовка економістів у період із системою планової економіки (у складі СРСР, 60-е - середина 80-х років XX ст.);

2. Профресійна підготовка економістів у перехідний етап («перебудова», друга половина 80-х - початок 90-х рр.);

3. Профресійна підготовка економістів у період із задекларованим розвитком ринкової економіки (період незалежності, 90-ті роки XX ст. - початок XXI ст. і до нашого часу).

У періодах з усіма типами економічних систем основними факторами, що впливають на якість професійно-освітнього процесу у ВНЗ, є мета освіти та їі потенціал:

- Мета (відображає тенденцію розвитку освітніх потреб усієї системи вищої освіти, проявляється не тільки в державній політиці, а і в поведінці кожного учасника освітнього процесу);

- Потенціал освіти (можливість досягнення мети з точки зору ресурсів і об'єктивних умов) [6, c. 145].

Допоміжні чинники профресійної освіти умовно можна розділити на групи за внутрішніми й зовнішніми ознаками впливу на освітній процес.

До фракторів зовнішньої групи фрормування якості освіти відносяться: централізоване (державне) управління освітою (Міністерства і відомства), організаційно-правове забезпечення освіти (Закони, Постанови, стандарти тощо), система фрінансування освіти, проява освітніх потреб і суспільне уявлення про якість освіти [6, с. 145].

Внутрішні чинники формування включають: профресорсько-викладацький і студентський склад, прийом абітурієнтів, матеріально-технічне та навчально-методичне забезпечення освітнього процесу, якість технологій освіти і виховну роботу, організацію наукових досліджень, інфрраструктуру $\mathrm{BH} 3$ [6, c. 145].

Ґрунтуючись на даних фракторах, виділимо й охарактеризуємо деякі основні критерії діяльності українських ВН3, які використовуються для підготовки фрахівців у період другої половини XX століття і дотепер у ВНЗ України:

- Навчальний процес - цілеспрямована взаємодія викладача і учнів, у ході чого вирішуються завдання освіти, розвитку і виховання учнів, це організація навчання у взаємозв'язку всіх компонентів;

- Методична робота у ВН3 - це планована діяльність викладачів і співробітників закладу, 
спрямована на освоєння та вдосконалення існуючих, а також розроблення і впровадження нових принципів, фрорм і методів есрективної організації навчального процесу;

- Виробнича практика - вид навчальних занять в освітніх установах, у процесі яких учень, студент самостійно виконує в умовах діючого виробництва реальні виробничі завдання, визначені навчальною програмою. Залежно від професійної спрямованості підготовки виробнича практика буває педагогічною, технологічною, експлуатаційною та іншими. Виробнича практика може поєднуватися за часом з іншими видами навчальних занять, або для її проведення в навчальному плані виділяється окремий період;

- Виховна система - включає навчальний процес, позаурочне життя учнів, їхню діяльність і спілкування за межами навчального закладу, покликана забезпечувати більш повний і всебічний розвиток особистості, фрормування самостійності та відповідальності, громадянського становлення. Виховання у ВНЗ - це робота всього педагогічного колективу вищого навчального закладу над формуванням у студента системи самосвідомості, моральних норм і культурних цінностей, орієнтованих на майбутню спеціальність;

- Науково-дослідницька діяльність студентів - це процес, який формує майбутнього фрахівця шляхом індивідуальної пізнавальної роботи, спрямованої на отримання нового знання, вирішення теоретичних і практичних проблем, самовиховання і самореалізацію дослідницьких здібностей і вмінь [1, с. 22; 1, с. 122; 4; 5, с. 185; 7, с. 42].

Висновки. У процесі вивчення особливостей економічних систем господарювання, що існували в Україні в другій половині XX - на початку XXI століття, і взаємопов'язаних 3 ними педагогічних моделей підготовки економічних кадрів нами були сорормовані три хронологічні періоди: професійна підготовка економістів у період із системою планової економіки (початок 60-х - середина 80-х років XX ст.); професійна підготовка економістів у перехідний етап (друга половина 80-х - початок 90-х рр.); професійна підготовка економістів у період задекларованого розвитку ринкової економіки (початок 90-х років XX ст. - початок XXI ст. і дотепер).

Кожен із цих етапів має своєрідні відмінності ідеологічної і методологічної спрямованості освітнього процесу, які $€$ основоположними для свого періоду під час підготовки фрахівців для економічної галузі України.
Так само ми визначили, що для кожного 3 даних етапів загальними основними фракторами, що впливають на якість освіти, є мета і потенціал. Допоміжні чинники розділені на зовнішні та внутрішні групи за ознаками свого впливу на освітній процес.

Орієнтуючись на наведені фактори, виділені основні критерії профресійної підготовки економістів у ВНЗ України в період другої половини XX - початку XXI століття: навчальний процес, навчально-методична робота, практична підготовка та виробнича практика, самостійна робота студентів, науково-дослідна діяльність, виховний процес.

Виходячи з результатів нашої роботи, з метою систематизації подальших досліджень у сорері вивчення історичного прогресивного досвіду підготовки економістів у системі вищої освіти України ми рекомендуємо використовувати виявлену хронологічну періодизацію, ґрунтуючись на основних чинниках і критеріях діяльності ВНЗ України у профресійній підготовки висококваліфрікованих і конкурентних орахівців.

\section{БІБЛІОГРАФІЧНИЙ СПИСОК:}

1. Коняева Е.А., Павлова Л.Н. Краткий словарь педагогических понятий : учебное издание. Челябинск : Изд-во Челяб. гос. пед. ун-та, 2012. 131 с.

2. Курс экономики и предпринимательства. Москва : Top Russian investment site, 2020. URL: https://adne.info/t/kurs-ekonomiki-i-predprinimatelstva/

3. Маховикова Г.А. Экономическая теория : учебник. Москва : ИНФРА-M, 2011. URL: https:// econ.wikireading.ru/30417

4. Методическая работа в вузе: методические указания / сост. Н.П. Пучков. Тамбов : Изд-во ГОУ ВПО ТГТУ, 2010. 32 с. URL: https://www.tstu.ru/book/ elib/pdf/2010/puchkov.pdf

5. Профессиональная педагогика : учебник для студентов пед. ВУЗов / под ред. С.Я. Батышева, А.М. Новикова. 3-е изд. Москва : ЭГВЕС, 2009. 456 с. URL: https://studmed.ru/view/batyshev-sya-professionalnayapedagogika_d5535ef1363.html?page=19

6. Румянцева О.С. Факторы, обеспечивающие качество высшего профессионального образования. Научный вестник МГТУ ГА. 2013. № 191. С. 145-147.

7. Сычкова Н.В. Организация исследовательской деятельности студентов университета : монография. Магнитогорск : МаГУ, 2002. 342 с.

8. Философрская энциклопедия. Академик, 2000-2020. URL: https://dic.academic.ru/dic.nsf/enc_ philosophy/3310/CИСТЕMA 


\author{
КРИТЕРІЇ, ПОКАЗНИКИ ТА РІВНІ СФОРМОВАНОСТІ ГОТОВНОСТІ \\ МОЛОДШИХ ІНСПЕКТОРІВ ПРИКОРДОННОЇ СЛУЖБИ ДО ПРОФЕСІЙНОЇ \\ ДІЯЛЬНОСТІ У ПУНКТАХ ПРОПУСКУ ДЛЯ МІЖНАРОДНОГО СПОЛУЧЕННЯ \\ CRITERIA, INDICATORS AND LEVELS OF FORMABILITY \\ OF JUNIOR INSPECTORS OF THE BORDER SERVICE \\ FOR PROFESSIONAL ACTIVITY AT THE MUNICIPALITIES
}

Стаття присвячена визначенню критеріїв,
показників і рівнів сформованості готов-
ності молодших інспекторів прикордонної
служби до просесійної діяльності в пунктах
пропуску для міжнародного сполучення.
Критеріями сформованості готовності
молодших інспекторів прикордонної служби
до профресійної діяльності в пунктах про-
пуску для міжнародного сполучення визна-
чено ознаки, на основі яких можна робити
висновок про рівні цієї сорормованості, оці-
нити результати впливу конкретних педа-
гогічних засобів. Автор визначає такі критерії сорормованості готовності молодших інспекторів прикордонної служби до професійної діяльності в пунктах пропуску для міжнародного сполучення: мотиваційний (показники: інте рес до професійної діяльності; ставлення до профресійної діяльності; відповідальність за власні дії; усвідомлення значущості професійної діяльності в пунктах пропуску для міжнародного сполучення), психологічний (показники: ссрормованість психічних якостей; здатність до рефлексії в оцінці власних дій; психологічна готовність до професійної діяльності в пунктах пропуску для міжнародного сполучення; сорормованість умінь приймати рішення), діяльнісний (показники: здатність застосовувати набутий професійний досвід; здатність до дій в умовах, що змінюються; самооцінка своєї професійної діяльності й прийнятих рішень; уміння прогнозувати діяльність у пунктах пропуску для міжнародного сполучення).

На основі вивчення думок науковців, аналізу стану ссрормованості готовності молод ших інспекторів прикордонної служби до професійної діяльності в пунктах пропуску для міжнародного сполучення були науково обгрунтовані три рівні иієї сорормованості: високий, середній, низький.

Ключові слова: молодші інспектори прикордонної служби, критерії, готовність до професійної діяльності в пунктах пропуску для міжнародного сполучення, показники й рівні сорормованості готовності до профресійної діяльності в пунктах пропуску для міжнародного сполучення.
The article is devoted to the definition of criteria, indicators and levels of readiness of junior inspectors of the border service for professional activity at checkpoints for international traffic. The criteria for the formation of the readiness of junior inspectors of the border service for professional activity at checkpoints for international traffic are the features on the basis of which it is possible to draw conclusions about the levels of this formation, to assess the impact of specific pedagogical tools.

The author defines the following criteria for the formation of readiness of junior inspectors of the border service for professional activity at checkpoints for international traffic: motivational (indicators: interest in professional activities; attitude to professional activities; responsibility for their own actions; awareness of the importance of professional activities at checkpoints for international traffic), psychological (indicators: the formation of mental qualities; the ability to reflect in the assessment of their own actions; psychological readiness for professional activities at checkpoints for international traffic; the formation of decision-making skills), activity (indicators: the ability to apply the acquired professional experience; the ability to act in changing conditions; self-assessment of their professional activities and decisions; the ability to predict activities at checkpoints for international traffic).

Based on the study of scientists' opinions, analysis of the state of readiness of junior inspectors of the border service for professional activity at checkpoints for international traffic, three levels of this formation were scientifically substantiated: high, medium, low.

The author provides a description of junior inspectors of the Border Guard Service (according to each of the defined indicators) with high, medium and low levels of readiness for professional activity at checkpoints for international traffic.

Key words: junior inspectors of the border service, criteria, readiness for professional activity at checkpoints for international traffic, indicators and levels of formation of readiness for professional activity at checkpoints for international traffic.
Постановка проблеми в загальному вигляді. Діагностування сорормованості готовності молодших інспекторів прикордонної служби до професійної діяльності в пунктах пропуску для міжнародного сполучення - це визначення та вивчення істотних ознак цієї готовності, форм її вираження в контексті реалізації цілей окресленого процесу.
Критеріями сфрормованості готовності молодших інспекторів прикордонної служби до професійної діяльності в пунктах пропуску для міжнародного сполучення є ознаки, на основі яких можна робити висновок про рівні цієї сорормованості, оцінити результати впливу конкретних педагогічних засобів. Водночас критерії сорормованості готовності 
молодших інспекторів прикордонної служби до професійної діяльності в пунктах пропуску для міжнародного сполучення - це теоретично розроблені показники рівнів сорормованості кожного з них.

Аналіз останніх досліджень і публікацій. Нормативну базу дослідження складають Закони України «Про освіту», «Про національну безпеку України», «Про Державну прикордонну службу України», Стратегія розвитку Державної прикордонної служби України, законодавство з прикордонних питань. Зокрема, зверталась увага, що правове регулювання проходження громадянами України військової служби в Державній прикордонній службі України здійснюється на підставі Закону України «Про військовий обов'язок і військову службу» й Положення про проходження громадянами України військової служби в Державній прикордонній службі України, затвердженого Указом Президента України від 29 грудня 2009 року N 1115/2009.

Формування готовності фрахівців до певного виду діяльності є предметом досліджень у різних галузях. Різноманітні аспекти проблеми фрормування готовності до різних видів профресійної діяльності військовослужбовців містяться в дослідженнях Л. Балагур (готовність до управління основними підрозділами охорони державного кордону), І. Коваля (готовність майбутніх рятувальників до діяльності в екстремальних умовах), Ю. Мойсєєнка (готовність майбутніх офріцерів-прикордонників до співробітництва в сучасній системі охорони державного кордону), О. Татаріна (готовність фрахівців прикордонної служби до застосування заходів фрізичного впливу), Ю. Лісніченка, В. Ягупова (готовність до військово-професійної діяльності) й інших.

Під час розроблення критеріїв та показників сорормованості готовності молодших інспекторів прикордонної служби до професійної діяльності в пунктах пропуску для міжнародного сполучення ми враховували підходи до визначення критеріїв, показників і рівнів, розроблені в працях В. Гащука [1], О. Ставицького й В. Мірошніченко [2], О. Старчука [3], А. Чудика [4] й інших.

Виділення не вирішених раніше частин загальної проблеми. Висновки й положення, зроблені цими й іншими вченими, мають велику наукову цінність для з'ясування критеріїв, показників і рівнів сорормованості готовності прикордонників до професійної діяльності. Але в наукових працях останніх десятиліть у прямій постановці не порушувалась проблема визначення діагностичного апарату сорормованості готовності до профресійної діяльності саме такої категорії, як молодші інспектори прикордонної служби, а також повною мірою не враховувались особливості профресійної діяльності цих фрахівців у пунктах пропуску для міжнародного сполучення.
Метою статті $€$ визначення критеріїв, показників і рівнів ссрормованості готовності молодших інспекторів прикордонної служби до професійної діяльності в пунктах пропуску для міжнародного сполучення.

Виклад основного матеріалу. На основі осмислення специфріки оперативно-службової діяльності молодших інспекторів прикордонної служби в пунктах пропуску для міжнародного сполучення та з урахуванням результатів аналізу наукових праць, опитувань військовослужбовців різних категорій встановлено, що готовність молодших інспекторів прикордонної служби до професійної діяльності в пунктах пропуску для міжнародного сполучення містить такі компоненти: мотиваційний, психологічний, діяльнісний.

щодо поняття «критерій», то в науковій літературі його використовують «для позначення сукупності показників, що дозволяє якісно й кількісно схарактеризувати стан об'єкта вивчення. Критерій (від грецьк. kriterion - засіб судження, мірило) - це мірило для визначення, оцінки предмета, явища; ознака, взята за основу класифрікації. Своєю чергою для позначення ступеня сфрормованості того чи іншого критерію використовують поняття показника, яким позначають якісні або кількісні характеристики сорормованості кожної якості, властивості чи ознак об'єкта» [4, с. 18]. У нашому дослідженні це сорормованість кожної ознаки готовності молодших інспекторів прикордонної служби до професійної діяльності в пунктах пропуску для міжнародного сполучення.

Погоджуємося 3 думкою, що «ступінь виявлення критерію виражається в конкретних показниках. Критерій за своїм обсягом є ширшим поняттям, ніж показник, а останній характеризується низкою ознак. Показник як компонент критерію $€$ типовим і конкретним виявленням суті якостей процесу чи явища, що підлягає вивченню» [5].

Під час дослідження, спираючись на підходи до визначення критеріїв і показників, розроблені в дисертаційних дослідженнях Л. Балагур, П. Дзюби, В. Собка, Ю. Мойсєєнка, О. Татаріна й інших, а також з урахуванням сутнісних характеристик цієї готовності, її компоненти прийнято за критерії, які дозволяють визначити рівень сорормованості готовності молодших інспекторів прикордонної служби до професійної діяльності в пунктах пропуску для міжнародного сполучення. Відповідно, такими критеріями є: мотиваційний, психологічний, діяльнісний.

Услід за О. Татаріним поділяємо думку щодо доцільності ідеї критеріально орієнтованої діагностики [6, с. 132-148.]. Відповідно, адаптувавши цю ідею до контексту процесу фрормування готовності молодших інспекторів прикордонної служби до профресійної діяльності в пунктах пропуску для міжнародного сполучення, отримаємо таке: 
- зосередження уваги на виробленні індивідуального стилю професійної діяльності кожним фрахівцем 3-поміж молодших інспекторів прикордонної служби;

- орієнтування на ситуацію успіху в профресійній діяльності молодших інспекторів прикордонної служби;

- критерії діагностики - це не середньоарифметична характеристика, а те найкраще, що можливе для фрахівця за відповідних умов;

- наповнення змісту методів діагностики прогностичними, моделювальними й управлінськими функціями, спрямованими на фрормування готовності молодших інспекторів прикордонної служби до профресійної діяльності в пунктах пропуску для міжнародного сполучення.

Нами було уточнено показники для кожного критерію (табл. 1).

Як зазначають науковці, виділення будь-яких критеріїв має умовний характер, урахувати їх повною мірою та реалізувати в практичній діяльності досить складно через їхнє взаємопроникнення [1]. Тому в процесі експериментальної роботи увага зверталась на кожний критерій. У своїй сукупності визначені критерії характеризують реально сформованість готовності молодших інспекторів прикордонної служби до професійної діяльності в пунктах пропуску для міжнародного сполучення.

На основі вивчення думок науковців [2-3], аналізу стану сорормованості готовності молодших інспекторів прикордонної служби до профресійної діяльності в пунктах пропуску для міжнародного сполучення нами були науково обґрунтовані три рівні цієї сорормованості: високий, середній, низький.

Для молодших інспекторів прикордонної служби з високим рівнем сорормованості готовності до профресійної діяльності в пунктах пропуску для міжнародного сполучення характерне: виявлення великого інтересу й свідоме ставлення до професійної діяльності; виявлення високої відповідальності за власні дії; глибока усвідомленість значущості професійної діяльності в пунктах пропуску для міжнародного сполучення; опанування добре сфрормованими психічними якостями; систематичне виявлення здатності до рефлексії в оцінці власних дій; вміння приймати рішення, сорормовані добре; виявлення високої психологічної готовності до професійної діяльності в пунктах пропуску для міжнародного сполучення; вміння застосовувати набутий професійний досвід; здатність завжди діяти в умовах, що змінюються; надання об'єктивної самооцінки своєї профресійної діяльності й прийнятих рішень; систематичне здійснення прогнозування професійної діяльності в пунктах пропуску для міжнародного сполучення.

Для молодших інспекторів прикордонної служби з середнім рівнем сформованості готовності до професійної діяльності в пунктах пропуску для міжнародного сполучення характерне: виявлення певного інтересу й досить свідоме ставлення до професійної діяльності; виявлення відповідальності за власні дії час від часу; переважна усвідомленість значущості профресійної діяльності в пунктах пропуску для міжнародного сполучення; часткова сорормованість психічних якостей; періодичне виявлення здатності до рефлексії в оцінці власних дій; часткова сформованість вміння приймати рішення; виявлення достатньої психологічної готовності до професійної діяльності в пунктах пропуску для міжнародного сполучення; переважне вміння застосовувати набутий професійний досвід; в основному здатність діяти в умовах, що змінюються; переважне здійснення об'єктивної самооцінки своєї професійної діяльності й прийнятих рішень; часткове здійснення прогнозування професійної діяльності в пунктах пропуску для міжнародного сполучення.

Для молодших інспекторів прикордонної служби з низьким рівнем сорормованості готовності до професійної діяльності в пунктах пропуску для міжнародного сполучення характерне: виявлення слабкого інтересу й недостатньо свідоме ставлення до профресійної діяльності; майже відсутність відповідальності за власні дії; слабке усвідомлення значущості професійної діяльності в пунктах пропуску для міжнародного сполучення; не достатня сфрормованість психічних якостей; майже відсутність виявлення здатності

Критерії та показники сформованості професійної надійності майбутніх

Таблиця 1 офіцерів-прикордонників у процесі фрахової підготовки

\begin{tabular}{|l|l|}
\hline \multicolumn{1}{|c|}{ Критерії } & \multicolumn{1}{|c|}{ Показники } \\
\hline мотиваційний & $\begin{array}{l}\text { інтерес до просресійної діяльності; ставлення до просресійної діяльності; відповідальність за } \\
\text { власні дії; усвідомлення значущості профресійної діяльності в пунктах пропуску для міжнарод- } \\
\text { ного сполучення }\end{array}$ \\
\hline психологічний & $\begin{array}{l}\text { сорормованість психічних якостей; здатність до ресрлексії в оцінці власних дій; ссрормованість } \\
\text { умінь приймати рішення; психологічна готовність до профресійної діяльності в пунктах про- } \\
\text { пуску для міжнародного сполучення }\end{array}$ \\
\hline діяльнісний & $\begin{array}{l}\text { уміння застосовувати набутий професійний досвід; здатність до дій в умовах, що змінюються; } \\
\text { самооцінка своєї професійної діяльності й прийнятих рішень; уміння прогнозувати діяльність } \\
\text { у пунктах пропуску для міжнародного сполучення }\end{array}$ \\
\hline
\end{tabular}


до рефрлексії в оцінці власних дій; виявлення вміння приймати рішення лише в окремих випадках; не завжди виявлення психологічної готовності до професійної діяльності в пунктах пропуску для міжнародного сполучення; переважна відсутність вміння застосовувати набутий професійний досвід; не завжди здатність діяти в умовах, що змінюються; виникнення труднощів у здійсненні самооцінки своєї профессійної діяльності й прийнятих рішень; виявлення слабких умінь здійснювати прогнозування професійної діяльності в пунктах пропуску для міжнародного сполучення.

Висновки. Отже, критеріями сорормованості готовності молодших інспекторів прикордонної служби до профресійної діяльності в пунктах пропуску для міжнародного сполучення визначені: мотиваційний (показники: інтерес до професійної діяльності; ставлення до професійної діяльності; відповідальність за власні дії; усвідомлення значущості профресійної діяльності в пунктах пропуску для міжнародного сполучення), психологічний (показники: сорормованість психічних якостей; здатність до рефлексії в оцінці власних дій; психологічна готовність до професійної діяльності в пунктах пропуску для міжнародного сполучення; сорормованість комунікативних умінь), діяльнісний (показники: здатність застосовувати набутий професійний досвід; здатність до дій в умовах, що змінюються; самооцінка своєї професійної діяльності й прийнятих рішень; уміння прогнозувати діяльність у пунктах пропуску для міжнародного сполучення). Відповідно до критеріїв і показників визначено три рівні сорормованості готовності молодших інспекторів прикордонної служби до профресійної діяльності в пунктах пропуску для міжнародного сполучення: високий, середній, низький.

Перспективним $€$ дослідження педагогічних умов фрормування готовності молодших інспекторів прикордонної служби до профресійної діяльності в пунктах пропуску для міжнародного сполучення, а також розроблення організаційнопедагогічної моделі цього процесу.

\section{БІБЛІОГРАФІЧНИЙ СПИСОК:}

1. Гащук В.А. Визначення критеріїв та показників деонтологічної підготовленості майбутніх офріцерівприкордонників. Наукові записки Вінницького державного педагогічного університету імені Михайла Коцюбинського. Серія : Педагогіка і психологія. Вінниця : ТОВ «Нілан ЛТД», 2014. Вип. 42. Ч. 1. C. 131-135.

2. Мірошніченко В.І., Ставицький О.М. Педагогічні умови фрормування готовності майбутніх офріцерів до використання stem-технологій в освітньому процесі. Освітній простір України. 2019. № 17. Ч. 2. C. 310-317.

3. Старчук О.О. Методика формування фрізичної готовності майбутніх офріцерів до військово-професійної діяльності : дис. ... канд. пед. наук : 13.00.02. Хмельницький, 2011. 199 с.

4. Чудик А.В. Методичні рекомендації з підготовки до застосування спеціальних засобів та заходів фрізичного впливу. Хмельницький, 2015. 113 с.

5. Фіцула М.М. Педагогіка вищої школи : навчальний посібник. Київ : Академвидав, 2006. 352 с.

6. Ярулов А.А. Критериально-ориентированная диагностика и культура интегративного управления. Школьные технологи. 2005. № 3. С. 132-148. 


\section{ГНУЧКІСТЬ ТА ІІЇ ЗНАЧЕННЯ В ПІДВИЩЕННІ РІВНЯ ФІЗИЧНОЇ ПІДГОТОВЛЕНОСТІ СТУДЕНТІВ}

\section{FLEXIBILITY AND ITS IMPORTANCE IN INCREASING THE LEVEL PHYSICAL PREPAREDNESS OF STUDENTS}

Стаття присвячена одній з актуальних проблем фрізичного виховання студентів у закладах вищої освіти - розвитку фрізичних якостей у процесі навчальних занять. Зокрема, розкривається сутність таких понять, як фрізична культура, фрізична підготовленість, фрізичні якості, гнучкість. Основна увага зосереджена на розкритті питання про важливість розвитку гнучкості в житті студента й необхідності фрізичного виховання як навчального предмета в закладах вищої освіти. На підставі дослідження структури орізичної підготовленості студентів і засобів ї розвитку вивчалося питання раціонального й ефрективного застосування вправ на розвиток гнучкості. Показана важливість вивчення якості гнучкості, їі можливості в міру рухливості в суглобах та окремих частинах тулуба з максимальною амплітудою, відбивається взаємозв'язок гнучкості й розумової діяльності, аналізується необхідність застосування гнучкості в різних видах спорту. На основі аналізу потокових публікацій обгрунтовується застосування методики експерименту, досліджується вплив гнучкості на підвищенні рівня фрізичної підготовленості студентів. Комплекси орізичних вправ апробовані й надані методичні рекомендації щодо їx застосування. Показана значущість фрізичного гарту для підтримки необхідної в процесі навчання працездатності. Відзначається, що достатнє фрізичне загартування цілюще впливає не тільки на працездатність студентів, а й на стимуляцію розумової діяльності, яка сприяє розвитку необхідних психічних фрункцій (пам'яті, уваги, мислення, вольових якостей, адаптаціі до середовища). Глибокі всебічні дослідження об'єднують теоретичні відомості, практичний матеріал і методичні рекомендації цього напряму. Підкреслюється, що сучасність підносить нам у студентське життя і гіподинамію (малу рухливість), і одноманітність рухів, і зниження рівня здоров'я, $і$ зменшення рухової активності. Тому позначається актуальність нашої теми й гостра потреба в зміцненні здоров'я студентів, їх гармонійному розвитку, об'єднуючи розумовий, духовний і фрізичний.

Ключові слова: фрізичне виховання, фрізична підготовленість, гнучкість, здоров'я, студенти, заклади вищої освіти.
The article is devoted to one of the urgentproblems of physical education of students in institutions of higher education - the development of physical qualities in the process of training. In particular the essence of such concepts as physical culture, physical fitness, physical qualities, flexibility is revealed. The main attention is focused on disclosing the issue of the importance of developing flexibility in a student's life and the need for physical education as a subject in higher education institutions. On the basis of the study of the structure of physical fitness of students and the means of its development the question of rational and effective use of exercises for the development of flexibility was studied. The importance of studying the quality of flexibility, its capabilities in terms of the degree of mobility in the joints and individual parts of the body with maximum amplitude is shown, the relationship between flexibility and mental activity is reflected, the need to use flexibility in various sports is analyzed. On the basis of the analysis of streaming publications, the applied experimental technique is substantiated, the influence of flexibility on increasing the level of physical fitness of students is investigated. The complexes of physical exercises have been tested and methodical recommendations for their use are given. The importance of physical hardening for maintaining the working capacity necessary in the learning process is shown. It is noted that sufficient physical conditioning has a beneficial effect not only on the performance of students, but also on the stimulation of mental activity, which contributes to the development of the necessary mental functions (memory, attention, thinking, volitional qualities, adaptation to the environment). Deep in-depth research combines theoretical information, practical material and methodological recommendations in this direction. It is emphasized that modernity presents us in student life with hypo dynamic (low mobility), and monotony of movements, and a decrease in the level of health, and a decrease in physical activity. Therefore, the relevance of our topic and the urgent need for strengthening the health of students, their harmonious development, uniting the mental, spiritual and physical are indicated

Key words: physical education, physical fitness, flexibility, students, institutions of higher education.
Постановка проблеми в загальному вигляді. Проблема зміцнення здоров'я молоді $€$ однією 3 найактуальніших завдань сучасності. У зв'язку із цим формування позитивного ставлення до здорового способу життя є одним із найбільш пріоритетних у сучасній педагогіці, тому не викликає сумнівів, що розвиток гнучкості (рухливості) в студентської молоді є актуальним і значущим питанням, яке пов'язано з розв'язанням найважливіших завдань державної політики в галузі вищої освіти: формування індивідуальності кожного студента, виховання його здорової та всебічно розвиненої особистості [1, с. 24].

У розвитку й формуванні особистості студента має вплив фрізичне виховання, а в теорії та методиці фрізичної культури гнучкість (рухливість) розглядається як багатофункціональна властивість опорно-рухового апарату молодої особи, що визначає межі рухів ланок тіла. У студентів у процесі завершення росту тіла в довжину триває морфрофункціональний розвиток організму: спостерігається збільшення маси тіла, окружності грудної 
клітки, життєвої місткості легень, м'язової сили, фрізичної працездатності [2, с. 168]. У цей період біологічного розвитку молодого організму зберігається досить висока пластичність опорно-рухового апарату. Тому в період «студентського» віку необхідно більше уваги приділяти профрілактиці захворювань опорно-рухового апарату (хребта й суглобів).

Під час організації та проведення занять викладачу необхідно враховувати вікові морфофрунціональні й психологічні особливості студенів, які безпосередньо пов'язані з їхніми фрізичними властивостями. Усі фрізичні якості людини є вродженими, тобто присутні у вигляді природних задатків, які необхідно розвивати, вдосконалювати, а рухи, що здійснюються, визначаються будовою та властивостями тіла [3, с. 27]. У молодої людини, яка не володіє достатньою гнучкістю, знижена здатність м'язів до розтягування, підвищений м'язовий тонус, що не дає можливості виконувати різноманітні множинні рухи, завдяки яким людина розвиває певні фрізичні якості Студентський вік можна назвати прикінцевим етапом вікового фрізичного розвитку. Сила, швидкість, спритність, гнучкість і витривалість - параметри рухових фрункцій організму, поліпшення яких сприяє комплексному розвитку фрізичного стану мускулатури молодої людини, тому завданням кожного заняття з фрізичної культури є збереження позитивних результатів із тестування загальної фрізичної підготовленості, а надалі - поліпшення цих показників. Більшість придбаних фрізичних якостей дають можливість студенту безболісно адаптуватися до всіляких негативних, життєвих і побутових умов, майбутньої трудової діяльності. Ці якості виховують характер і забезпечують стабільну працездатність і в повсякденному житті студента й у спорті.

Гнучкість - невіддільна якість для багатьох видів спорту Спортивна гімнастика, художня гімнастика, кікбоксинг, карате, східні єдиноборства, плавання, акробатика, стрибки на лижах із трампліна, фрігурне катання, синхронне плавання, стрибки у воду з трампліна. I це далеко не весь список, де використовують гнучкість. У кікбоксингу гнучкість важлива для нанесення високо поставлених ударів, спритності й хорошої координації в поєдинку. Подібна роль гнучкості існує і в інших видах спорту, які пов'язані з боротьбою. Фігурне катання, синхронне плавання показує нам всю грацію та красу, придбані завдяки розвитку гнучкості спортсменів. Перед змаганнями фрутболісти, легкоатлети виконують нахили; випади вперед, в сторони; розтягують м'язи, зв'язки, сухожилля ніг. Лижникам для швидкого проходження спусків, підйомів, поворотів необхідна розтяжка, гнучкість зв'язок, сухожиль гомілковостопних і колінних суглобів. Для тенісистів, волейболістів, баскетболістів, бадмінтоністів важлива гнучкість плечових суглобів. Будь-який спорт не обійдеться без вправ на гнучкість [4, с. 46]. Розвиток гнучкості набуває під час занять спортом особливої актуальності тому, що вона полегшує зусилля, береже м'язи від надмірного напруження, розтягнень, пошкоджень і серйозних травм м'язів і зв'язок.

Гнучкість - фрізична якість, за розвитку якої з'являється здатність виконувати вправи з великою амплітудою, це абсолютний діапазон рухів у ряді суглобів, який досягається в миттєвому зусиллі. Розвинена гнучкість забезпечує студентам швидкість, свободу, допомагає ефективно докладати зусилля під час проведення фрізичних вправ, виконання самостійних завдань і активної участі в навчальному процесі. Високий рівень розвитку гнучкості дозволяє уникнути падіння в разі втрати рівноваги, ускладнити координацію рухів, яка обмежує переміщення окремих частин тіла. Важливість вивчення якості гнучкості також викликана необхідністю визначити можливості студентів виконувати рухи з максимальної амплітуди, тому що гнучкість - це якість, що характеризується здатністю виконувати суглобові рухи з великою амплітудою. Глибоке вивчення такої проблеми дозволить не лише оновити програму з фрізичного виховання для студентів, а й підвищити зацікавленість студентів у відвідуванні навчальних занять, фрормуючи мотиваційне ставлення до оздоровчих занять і спорту, ведення здорового способу життя.

Аналіз останніх досліджень і публікацій. Проблеми вдосконалення такої фрізичної якості постійно знаходяться в полі зору вчених і фахівців. Так, Т.С. Лисицька, Л.П. Матвєєв, В.І. Лях провели дослідження 3 використання різноманітних засобів фрізичної культури, які розширюють можливості розвивати гнучкість (рухливість суглобів) під час занять ритмічною гімнастикою. 3 цією метою необхідно урізноманітнити навчальний процес, використовуючи інноваційні технології та досвід роботи в навчальних закладах. Вони вважають, що за високого рівня рухливості виникають передумови для економічного руху в суглобі, бо коли виявляється більшою вихідна довжина м'язів, це дозволяє виявити більшу силу, зчленування стають податливішими, а отже, для здійснення руху в суглобі потрібно менша сила. А от Д.Т. Тагіров, Н.В. Дробинина, Н.К Камалов відзначають, що гнучкість повинна бути в оптимальному співвідношенні 3 м'язовою силою, оскільки недостатній розвиток м'язів, що оточують суглоби, може призвести до їх надмірної рухливості й відповідних порушень рухів тіла в цілому. В.Ю. Зіамбетов переконаний, що особливого значення гнучкість набуває під час занять спортом. С.К. Якубович, В.А. Ярмолюк у своїй роботі довели, що кращі показники рухливості в плечовому суглобі мають студенти, що спеціалізуються в бігу на короткі дистанції, 
а для дівчат найкраща рухливість плечового суглоба в баскетболісток.

Виділення не вирішених раніше частин загальної проблеми. Нині розглянуто багато варіантів і методик із розвитку гнучкості в студентів [5, с. 47]. Однак ця тема ще не досить вивчена й потребує дослідження та творчого підходу під час їхньої реалізації. Вивчивши досвід педагогів і вчених, ми припустили, що застосування в програмі з фрізичного виховання додаткового комплексу на розвиток гнучкості не тільки буде сприяти фрізичної підготовленості й зміцненню здоров'я, але й підвищить мотивацію студентів до занять.

Мета статті. Головною метою нашого дослідження було обґрунтування значення гнучкості в підвищенні рівня фрізичної підготовленості студентів, зображення взаємозв'язку гнучкості й розумової діяльності.

Виклад основного матеріалу. Нами були проведені дослідження з теми з метою підвищити ефективність роботи, припустивши, що систематичне використання вправ, спрямованих на фрормування гнучкості, в парах у процесі фрізкультурної освіти студентів буде найефективніше. Для досягнення поставленої мети треба розв'язати такі завдання: 1) Систематичне застосування різних фрізичних вправ із розвитку пасивної гнучкості в парах; 2) Визначення та розробка найоб'єктивніших контрольних вправ для показників гнучкості. У роботі використовувалися такі педагогічні методи досліджень, як спостереження, опитування, тестування, пояснення.

Для підтвердження ефективності дослідницької роботи й демонстрації її результатів біли створені чотири групи студентів на базі Національного університету «Одеська юридична академія»: дві контрольні групи (далі - КГ) і дві експериментальні групи (далі - ЕГ). КГ-1 та ЕГ-1 були створені зі студентів першого курсу Судово-адміністративного фракультету, а КГ-2 та ЕГ-2 були створені зі студентів фракультету Прокуратури й слідства. Усього було залучено до досліджень 80 осіб.

Протягом першого семестру 2018-2019 року заняття в контрольних групах (КГ-1 і КГ-2) проводилися за розробленою навчальною програмою фрізичного виховання з розділу «Спортивні ігри». Уся робота здійснювалася в рамках навчальних занять за розкладом (2 рази на тиждень). Студенти експериментальних груп (ЕГ-1 та ЕГ-2) додатково регулярно виконували комплекси вправ для розвитку пасивної гнучкості в парах: у розминці й основній частині занять виконувалися вправи, які містили пасивні способи впливу на гнучкість. Пасивні вправи містили вправи 3 партнером: нахили із застосуванням ваги й сили партнера, потягування під час стійки «міст», вправи на спину (нахили й повороти в парах), згинання, розгинання, розведення, зведення за допомогою партнера.
Була введена система домашніх завдань для виховання гнучкості самостійно, що забезпечувало б систематичність та ефективність дій, але це виявилося не досить надійним способом: важко знайти партнера (як висловилися студенти), важко перевірити й контролювати самостійну роботу в домашніх умовах (як висловилися викладачі).

На заняттях пропонувалися вправи, демонструвався наочний варіант виконання (запрошувалися гімнасти), а також використовувалися спілкування 3 іншими спортсменами, які розповідали про спеціальну гнучкість та їі значення. Зі студентами вивчалися комплекси фрізичних вправ (на гнучкість) із високою амплітудою руху з основ оздоровчої гімнастики й фрізкультурно-спортивної діяльності із застосуванням різних видів спорту. Ці практичні навички розвитку гнучкості можуть бути використані студентами для самостійних занять. Теоретичні знання, практичні навички й комплекси в майбутньому також зможуть мати прикладне значення. Робота з виховання гнучкості позитивно позначалася і на інших показниках, такий комплексний підхід був одним із головних підходів у дослідженні.

Результати дослідження та їх обговорення. Для того, щоб оцінити результати й простежити динаміку розвитку у 2-х контрольних і 2-х експериментальних групах були обрані контрольні вправи: нахил вперед зі стійки ноги нарізно на гімнастичній лавці, упор стоячи, ноги максимально нарізно, гімнастичний міст. Ступінь гнучкості в суглобах вимірювалася в сантиметрах від точки опори до верхньої вимірювальної точки. Потім сума показників цих трьох контрольних нормативів складалася із цими ж показниками студентів усієї групи й загальні показники груп порівнювалися. Контроль показників гнучкості в цих групах проводився в жовтні й грудні, дані представлені в таблиці 1.

Після закінчення занять ми порівняли показники у всіх групах. Усі показники змінилися в кращу сторону, але в контрольних групах за першим нормативом КГ-1 - на 16 см, що становить 21,9\%, КГ-2 - на 15 см, що становить 23,8 \%. В експериментальних групах: ЕГ-1 збільшився на 26 см, що становить $38,2 \%$, в ЕГ-2 - на 37 см, що становить $56 \%$.

За другим нормативом: в КГ-1 показник покращився на 198 см, що становить 17,8\%, в КГ-2 на 207 см, що становить 18,6\%. В ЕГ-1 показник покращився на 560 см, що становить 43,2\%, а в ЕГ-2 - на 532 см, що становить 46,6\%.

За третім нормативом: в КГ-1 покращився показник на 40 см, що становить 3,2\%, в КГ-2 - на 26 см, що становить 2\%. В ЕГ-1 показник покращився на 111 см, що складає 9,3\%, а в ЕГ-2 - на 148 см, що становить 13,1\%.

Підсумкові результати показують, що комплекс вправ у парах для розвитку гнучкості зробив 
Показники контрольної та експериментальної групи

\begin{tabular}{|c|c|c|c|c|c|c|c|c|c|}
\hline \multirow{3}{*}{$\begin{array}{l}\text { № } \\
3 / \Pi\end{array}$} & \multirow{3}{*}{ Контрольні вправи } & \multicolumn{4}{|c|}{ Жовтень } & \multicolumn{4}{|c|}{ Грудень } \\
\hline & & \multicolumn{2}{|c|}{ КГ } & \multicolumn{2}{|c|}{$E \Gamma$} & \multicolumn{2}{|c|}{ КГ } & \multicolumn{2}{|c|}{$E \Gamma$} \\
\hline & & КГ-1 & КГ-2 & $E \Gamma-1$ & $E \Gamma-2$ & КГ-1 & КГ-2 & $E \Gamma-1$ & $E \Gamma-2$ \\
\hline 1 & $\begin{array}{l}\text { Нахил вперед } \\
\text { зі стійки ноги } \\
\text { нарізно на гімнас- } \\
\text { тичній лаві (см) } \\
\end{array}$ & 73 & 63 & 68 & 66 & 91 & 78 & 94 & 103 \\
\hline 2 & $\begin{array}{l}\text { Упор стоячи, ноги } \\
\text { максимально } \\
\text { нарізно (см) }\end{array}$ & 1108 & 1112 & 1187 & 1140 & 910 & 905 & 627 & 608 \\
\hline 3 & $\begin{array}{l}\text { Гімнастичний міст } \\
\text { (см) }\end{array}$ & 1246 & 1286 & 1186 & 1125 & 1266 & 1294 & 1297 & 1273 \\
\hline & Разом: & 2427 & 2461 & 2441 & 2337 & 2267 & 2277 & 2018 & 1984 \\
\hline
\end{tabular}

величезний позитивний вплив на розвиток рухливості в суглобах і загальну фрізичну підготовленість студентів. Теоретична робота з формування знань про значення гнучкості для студента, для здоров'я та естетики позитивно сприяла на розвиток розумової діяльності, мотиваційне ставлення студентів до занять фрізичним вихованням у цілому. А соціальні, гігієнічні й фрізіологічні аспекти такого питання сприяли фрормуванню мотиваційного ставлення до занять, що врештірешт сприяє підвищенню рівня його працездатності. Розвиток рухливості, розумової діяльності, підвищення рівня працездатності позитивно відбився на весь організм студента:

- На здоров'я судин. 3 розвитком гнучкості тренується та збільшується еластичний компонент судин, а також покращується координація, підвищується уважність, знімається напруга після занять. Від гнучкості безпосередньо залежить здорових судин;

- На можливості перероблювання навчальної інформації. Гнучкість покращує роботу систем кровообігу й дихання, а головне для студентів - це підвищення сприйняття та перероблювання інсрормації;

- На роботу всіх систем організму. Від вправ на розтяжку тіло посилає множину сигналів у центральну нервову систему. Звідти відбувається рефлекторна відповідь на органи людини, стимулюючи їх і покращуючи якість роботи всіх систем організму;

- На опорно-руховий апарат та імунну систему. Вправи на розтяжку покращують роботу: імунної, кардіореспіраторної, сечостатевої систем, опорно-рухового апарату;

- На зовнішній вигляд. Важливість гнучкості полягає в придбанні граціозності, прямої, витонченої постави й легкої ходи, перетворення тіла в красивіші форми, що надає впевненості в собі;

- На адаптацію до навколишнього світу. Швидка адаптація на новому робочому місці, швидка реакція на різноманітні ситуації, добре самопочуття та здоровий імунітет.
Висновки. Різниця завершального результату в контрольних нормативах в експериментальній і контрольній групах наочно показує ефективний вплив на успішно результативний розвиток гнучкості в студентів. Контрольні вправи констатують об'єктивний розвиток рухливості в різних суглобах і зв'язковому апараті. Ці нормативи можуть використовуватися в практиці фрізичного виховання як контрольні нормативи під час визначення та оцінюванні об'єктивної гнучкості студентів.

Таким чином, ми дійшли висновку, що гнучкість для студента має величезне насамперед оздоровче й розвивальне значення. Розвивати й підтримувати їі на належному рівні необхідно регулярно з урахуванням індивідуальних можливостей і здібностей студента. Поліпшення показників гнучкості значно підвищують рівень фрізичної підготовленості, усвідомлену мотивацію та емоційний настрій студентів. Результат успішного складання контрольних нормативів - це сходинка до головної мети студента збереження здоров'я під час опанування необхідними навичками майбутньої професії.

Досвід роботи може успішно використовуватися в освітніх установах будь-якого рівня з урахуванням вікових особливостей тих, хто займається. Робота не претендує на те, щоб бути завершеною, і з успіхом може бути продовжена іншими викладачами (вченими) у сорері фрізичного виховання, спираючись на результати, отримані в нашому дослідженні.

\section{БІБЛІОГРАФІЧНИЙ СПИСОК:}

1. Копылов Ю.А. Концепция структуры и содержания оздоровительных занятий для студентов высших учебных заведений. Физическое воспитание студентов. 2015. № 5. C. 23-31. URL: http://nbuv.gov.ua/ UJRN/PhVSTS 201556.

2. Захаров Е.Н., Караев А.Н., Сафонов А.А. Энциклопедия фризической подготовки (Методические основы развития фризических качеств) / под общей ред. А.В. Карасева. Москва : Лептос, 1994. 368 c.

3. Кудашова Л.Т., Венгерова Н.Н., Люйк Л.В. Современные подходы к развитию гибкости студен- 
тов : учебное пособие. Санкт-Петербург : Изд-во СПбГЭУ, 2016. 127 с.

4. Алтер М.Дж. Наука о гибкости : учебное пособие. Киев : Олимпийская литература, 2001. 430 с.

5. Кудрявцев М.Д., Мартиросова Т.А., Яцковская Л.Н. Методика развития гибкости у студентов вузов : учебно-практическое пособие. Красноярск : КГТЭИ, 2010. С. 46-48.

6. Антипова Ж.І., Фідірко М.А. Фізична активність студентів - фрактор зміцнення здоров'я і підвищення працездатності. Internacional Cientifica $y$ Practica: ЛОГОС. Vol. 4. 24 квітня 2020 р. Barcelona. C. 122-124. DOI: 10/36074/24.04.2020.v4.

7. Антіпова Ж.І., Гоголєва О.М. Аспекти впливу рухової активності на організм студента. The VIII Internationale sentific and practical "Dynamics of the defelopment of world science", PerfektPublishing, Vankouver, Canada. 17 квітня 2020 р. C. 243-245.

8. Balitskaya E.P. Students' motivation to fitness classes at technical university. Pedagogics, psychol- ogy, medical-biological problems of physical training and sports. 2013. Vol. 6. P. 3-6. URL: http:// dx.doi.org/10.6084/m9.figshare.714933.

9. Belykh S.I. Dynamics of knowledge, skills and abilities in the process of personal physical education based university students. Pedagogics, psychology, medical-biological problems of physical training and sports. 2013. Vol. 8. P. 3-11. URL: http:// dx.doi.org/10.6084/m9.figshare.745776.

10. Gordienko Y.V. Theoretical training in physical education of higher educational establishments' girl students. Physical Education of Students. 2015. No. 4. P. 3-9. URL: http://dx.doi.org/10.15561/20755279. 2015.0401.

11. Pichurin V.V. Coping strategies and psychological readiness of students for professional work. Pedagogics, psychology, medical-biological problems of physical training and sports. 2015. Vol. 2. P. 53-59. URL: http://dx.doi.org/10.15561/18189172.2015.0209. 


\title{
ПРАКТИЧЕСКИЕ АСПЕКТЫ ПРИМЕНЕНИЯ ДИФФЕРЕНЦИРОВАННОГО ПОДХОДА ПРИ ОБУЧЕНИИ ИНОСТРАННОМУ ЯЗЫКУ В НЕЯЗЫКОВОМ ВУЗЕ
}

\author{
ПРАКТИЧНІ АСПЕКТИ ЗАСТОСУВАННЯ ДИФЕРЕНЦІЙНОГО ПІДХОДУ \\ ПІД ЧАС ВИКЛАДАННЯ ІНОЗЕМНОЇ МОВИ В НЕМОВНОМУ ВНЗ \\ PRACTICAL ISSUES OF APPLICATION OF THE DIFFERENTIATED \\ APPROACH FOR TEACHING FOREIGN LANGUAGES \\ AT A NON-LINGUISTIC HIGHER EDUCATIONAL INSTITUTION
}

В статье представлен анализ практического опыта реализации дисрференцированного подхода при обучении иностранному языку в неязыковом вузе. Дано описание модели дифрференциации контингента учащихся на основе первоначально исходного и в дальнейшем актуального уровня иноязычной компетенции студентов, которая была успешно апробирована коллективом кафредры иностранных языков в ходе работь проекта по углубленному изучению английского языка студентами первого курса фракультета информационных технологий Приазовского государственного технического университета.

В статье обосновывается необходимость создания иерархии учебных групп с относительной стабильностью состава и возможностью перехода студентов вверх или вниз по иерархии в зависимости от реального роста их иноязычной коммуникативной компетенции. Созданные в результате дияфреренциации условия обучения в группе, с одной стороны, максимально учитывали индивидуальные способности студентов, воспринимались ими как комфортные и безопасные, способствовали раскрытию их потенциала; u, с другой стороны, облегчали для преподавателей задачу поиска адекватных форм и видов учебной деятельности при работе с группой.

Для успешной реализации представленного вида диррференциации постулируются такие положения: необходимость постоянного мониторинга уровня развития речевых навыков и умений студентов способами диагностического контроля, самоконтроля, анкетирования студентов; освоение педагогическим коллективом командных методов работы с равной долей ответственности преподавателей за ход и результаты учебно-педагогической работы; принятие преподавателями демократического, паритетного, не авторитарного стиля взаимодействия со студенческой аудиторией; широкое использование интерактивных методов обучения иностранному языку, создающих активную творческую обучающую среду разнообразными средствами группового взаимодействия. Таким образом, диффреренциация как фоорма организации учебного прочесса представляет собой эфрфективный способ реализации личностно-ориентированного подхода, свойственного гуманистической концепцией современного образования.

Ключевые слова: личностно-ориентированный подход, интерактивный метод, обучающая среда, дирореренциация, коммуникативная компетенция.
У статті представлений аналіз практичного досвіду реалізації дифреренційованого підходу під час викладання іноземної мови в немовному виші. Дано опис моделі дифреренчіації контингенту учнів на основі спочатку вхідного й надалі актуального рівня іншомовної компетенції студентів, яка була успішно апробована колективом кафредри іноземних мов у процесі роботи проєкту з поглибленого вивчення англійської мови студентами першого курсу фракультету інформаційних технологій Приазовського державного технічного університету.

у статті обгрунтовується необхідність створення ієрархії навчальних груп із відносною стабільністю складу й можливістю переходу студентів вгору або вниз за ієрархією залежно від реального зростання їхньо іншомовної комунікативної компетенції. Створені в результаті дифреренціації умови навчання в групі, з одного боку, максимально враховували індивідуальні здібності студентів, сприймалися ними як комсрортні й безпечні, сприяли розкриттю їхнього потенціалу; й, з іншого боку, полегшували для викладачів завдання пошуку адекватних форм і видів навчальної діяльності під час роботи з групою.

Для успішної реалізації представленого виду дияреренціації постулюється таке: необхідність постійного моніторингу рівня розвитку мовних навичок та умінь студентів способами діагностичного контролю, самоконтролю, анкетування студентів; освоєння педагогічним колективом командних методів роботи з рівною часткою відповідальності викладачів за хід і результати навчально-педагогічної роботи; прийняття викладачами демократичного, паритетного, не авторитарного стилю взаємодії зі студентською аудиторією; широке використання інтерактивних методів навчання іноземної мови, що створюють активне творче навчальне середовище різноманітними засобами групової взаємодії.

Таким чином, дифреренціація як фрорма організації навчального процесу $\epsilon$ ефрективним способом реалізації особистісно орієнтованого підходу, властивого гуманістичній концепції сучасної освіти.

Ключові слова: особистісно орієнтований підхід, інтерактивний метод, навчальне середовище, диреренціація, комунікативна компетенція.

The article presents the analysis of practical realization of the differentiated approach used for teaching a foreign language at a non-linguistic higher educational establishment. It provides description of a students' differentiation pattern based, firstly, on students' initial and further their 
actual level of foreign language competence. The pattern was successfully tested by the department of foreign languages in the course of implementation of the project in intensive English teaching of first-year students of IT faculty at Pryazovskyi State Technical University.

The article stipulates the necessity for building hierarchy of learners' groups that show relative stability of their members as well as let students go up or down the group hierarchy on the basis of actual growth of their foreign language communicative competence. The learning conditions built in the student group by means of the given differentiation, on one hand, highly corresponded to students' individual abilities and were perceived by students as comfortable and secure, thus letting all their potential reveal itself. On the other hand, they facilitated teachers' making choice of adequate teaching forms and means in their communication with the student group. For successful realization of the described differentiation pattern the following issues are postulated: necessity for constant monitoring students' speech skills development through means of diagnosis control, self-evaluation and questionnaires; implementation of teamwork by the teaching staff when all teachers share equal responsibility for the course and results of their teaching and pedagogical activities; accepting democratic, non-authoritarian, parity style by teachers in communication with students; an extensive application of interactive methods of teaching foreign languages which are able to build up an active and creative learning environment by means of various forms of group interaction. Thus, differentiation as an organizational form of study process is an effective tool for realization of learner-centered approach peculiar of the humanistic concept of the contemporary education.

Key words: learner-centered approach, interactive method, learning environment, differentiation, communicative competence.
Постановка проблемы в общем виде. Возрастающая роль иностранного языка как одной из базовых общеобразовательных дисциплин в системе профессиональной подготовки специалистов в высшей технической школе выдвигает широкий спектр задач, связанных с практической реализацией современных подходов к обучению иностранному языку, таких как личностно-ориентированный, проблемно-ориентированный, ситуативный коммуникативный, интерактивный, дифференцированный и другие. Такие подходы согласуются с гуманистической концепцией, лежащей в основе современного инновационного обучения, ставящей во главу угла личность обучаемого, учет ее индивидуально-психологических особенностей и, соответственно, создание условий для наиболее полной реализации личностных потенциалов.

Одним из эфрфективных способов индивидуализации процесса обучения в условиях высшей школы, на наш взгляд, является применение технологий дифреренцированного обучения, которое, с одной стороны, помогает преодолеть трудности, часто возникающие из-за различий в исходном уровне языковой компетенции студентов на начальном этапе обучения, и, с другой стороны, способствует устойчивому формированию и совершенствованию индивидуальных коммуникативных навыков и умений студентов при групповом фрормате обучения.

Анализ последних исследование и публикаций. Дифференциация как принцип организации учебного процесса исторически зародилась в массовой школе еще в XIX веке. C тех пор, естественно, принципы и фрормы организации дифрференцированного обучения неоднократно менялись в соответствии с существующей на том или ином этапе развития общества концепцией образования.

Современная концепция образования исходит из того, что готовность к будущей деятельности является внутренней индивидуальной потребностью личности и не может полностью определяться извне. Следовательно, главной задачей вуза является оказание услуг в области удовлетворения образовательных потребностей личности [5].

Достижение этой цели предполагает создание определенных условий образовательной среды, при которых возможно максимальное раскрытие потенциала студента. В этом контексте диффреренцированное обучение рассматривается отечественными и зарубежными учеными как эфффективное средство создания такой продуктивной образовательной среды, учитывающей индивидуально-психологические особенности личности [3]. Методология современного понятия диффреренцированного подхода опирается, прежде всего, на работы в области психологии личности С.Л. Рубенштейн, К.К. Платонова, Б.Г. Ананьева, А.Н. Леонтьева, П.Я. Гальперина и другие, системной дифференциации и индивидуализации учебно-педагогического процесса Н.И. Уинт, Х.И. Лийметс, К. Уошбарн, А.А. Кирсанова, Ю.К. Бабанского, роли учебной мотивации Л.И. Божович, Т.И. Шамовой, Г.И. Щукина и другие, а также на положениях теории о «зоне ближайшего развития» Л.С. Выготского. Большое значение для формирования концепции дифроеренцированного обучения как средства фрормирования профессиональной иноязычной компетенции студентов имели исследования о развивающем потенциале иностранного языка таких ученых: И.Л. Бим, Н.И. Гез, И.А. Зимняя, Г.А. Китайгородская, Е.И. Пассов и другие.

Выделение не решенных ранее частей общей проблемы. Тем не менее многие аспекты практической реализации принципов дифореренцированного обучения в условиях высшей технической школы, в частности применительно к обучению иностранному языку, остаются, на наш 
взгляд, недостаточно освещенными, как, например: взаимодействие педагогического коллектива в условиях дифрференцированного обучения, организация работы в относительно стабильных группах, допускающих возможность перехода студента в созданной иерархии групп в зависимости от его действительного уровня иноязычной компетенции, приоритетные методы обучения в условиях уровневой дифроеренциации и другие.

Цель статьи. Обобщить имеющийся опыт использования технологий диффреренцированного обучения на занятиях по иностранному языку в рамках проекта по углубленному изучению английского языка в группах первого курса студентов IT специальностей, рассмотреть актуальные проблемы, возникающие в процессе дифрореренциации, и способы их решения.

Изложение основного материала. Дифроеренцированное обучение понимается, с одной стороны, как создание разнообразных условий с целью учета особенностей контингента учащихся и, с другой, как комплекс методических, психолого-педагогических и организационных мероприятий, обеспечивающих обучение в гомогенных группах [6].

Принято различать «внутреннюю» и «внешнюю» диффреренциацию. Внутренняя дифференциация подразумевает такую организацию учебного процесса, при которой учитываются индивидуальные особенности обучаемого в разнородной (гетерогенной) / смешанной группе. Распространенной фрормой внутренней дифореренциации является «уровневая дифреренциация», позволяющая студенту овладевать учебным материалом, навыками и умениями в пределах одного из определенных программой уровней (не ниже базового) в соответствии со своими способностями и индивидуальными потребностями. При внешней дифореренциации фрормируются группы учащихся с относительно однородным (гомогенным) составом с той же целью: достижения максимальной индивидуализации процесса обучения в группе. Иными словами, задача диффреренциации - обеспечить обучение каждого студента в группе на уровне его возможностей. Опираясь на актуальный уровень развития навыков и умений, знаний по предмету студента / группы, преподаватель определяет их зону ближайшего развития и, используя разнообразный спектр методических приемов и фрорм, выводит их к более высокому уровню.

Важно понимать, что дифроеренциация заключается не только в разделении контингента студентов сообразно их исходным способностям и уровню знаний, но и естественным образом предполагает дифференциацию содержания обучения и фрорм, видов аудиторной и самостоятельной работы.
Рассмотрим выше представленные теоретические положения на конкретном примере реализации проекта по углубленному изучению английского языка в группах бакалавров первого курса фракультета информационных технологий. Проект успешно реализовывался в течение 8 лет на базе кафредры иностранных языков Приазовского государственного технического университета. Цель проекта - фрормирование высокого уровня иноязычной языковой компетенции студентов, который позволил бы им активно включаться в международные проекты, слушать курсы лекций по профильным предметам на английском языке, заниматься научной работой и тому подобное. Соответственно, ставилась задача достижения уровня владения основными видами речевой деятельности не ниже В1+ / В2 по Общеевропейским стандартам. Кафредрой был разработан учебно-методический комплекс на основе учебных пособий издательства Oxford University Press; приоритетным методом обучения был выбран интерактивный метод как метод, который создает наиболее активную обучающую среду, моделирующую в той или иной мере фрормы реального общения, в которой студент как сторона учебного процесса приобретает максимальную субъектность, раскрывает свой творческий потенциал [4].

Необходимо отметить, что выбор студентов первого курса в качестве целевой аудитории определялся двумя фракторами. Во-первых, первый курс - это период адаптации студентов к новым условиям академической среды, когда они максимально восприимчивы к целенаправленному психолого-педагогическому воздействию и демонстрируют оптимум развития своих сенсорно-перцептивных, мнемических, психомоторных и особенно речемыслительных ффункций [1]. Во-вторых, неоднородность исходного уровня подготовки по иностранному языку, свойственная студентам первого курса в неязыковых вузах, является актуальной проблемой, решить которую предполагалось средствами дифреренцированного обучения.

Результаты входного контроля по английскому языку, проводимого перед началом курса среди вновь поступивших студентов технических специальностей, показывают в последние годы устойчивую тенденцию градации их иноязычных компетенций по трем уровням (согласно Общеевропейской системе уровней владения иностранным языком): Elementary (A 1-2), Pre-Intermediate (A 2, В 1) и Intermediate (B 1+). Соответственно, учебные группы фрормировались согласно трем уровням. В процентном соотношении распределение студентов по уровням на начальном этапе составляло: Elementary - 20 \%, Pre-Intermediate $70 \%$, Intermediate - $10 \%$. Принципиальным моментом в дифрференциации учебных подгрупп по уровням стала дальнейшая градация подгрупп 
в пределах уровня как «более сильная / менее сильная». Основным принципом группообразования, обеспечивающим гибкость и адаптивность такой иерархии к динамике иноязычной компетенции каждого студента, стала возможность перехода студента из группы в группу внутри своего уровня или в группу другого уровня по академическим показателям в течение семестра (по промежуточным итогам). Такая фрорма комплектования группы, «со скольжением» (Л.М. Фридман), с одной стороны, мотивирует студента на активное развитие, стимулирует его стремление перейти в группу более высокого уровня, с другой стороны, позволяет преподавателю подбирать темп, формы и виды учебной работы, максимально отвечающие потребностям конкретной группы.

Решению о переводе / переходе студента в группу уровнем ниже или выше в системе подгрупп всегда предшествовал глубокий анализ его текущих показателей успеваемости, студенческих отчетов по самооценке динамики формирования основных видов речевой деятельности, учебной мотивации, психологической совместимости в группе и тому подобное.

Традиционное анкетирование среди студентов по окончании курса обучения показало, что 88 \% (средний показатель за весь период существования проекта) поддержали уровневый принцип фрормирования групп с возможностью «скольжения». Аналогично, такая система дифореренциации на относительно гомогенные по составу группы была положительно оценена преподавателями кафедры, поскольку облегчала процесс подготовки к занятиям, ускоряла процесс освоения материала в группе, создавала психологический климат успешности для студентов. Вместе с тем возможность быть переведенным как «вниз», так и «вверх» препятствовала проявлению ряда негативных сторон уровневой диороеренциации, которые широко дискутируются в методической литературе [7] (например, снобизм у сильных студентов или чувство неполноценности у слабых), так как побуждала каждого студента учиться с максимальной отдачей.

Основополагающим условием успешной реализации предложенной многоуровневой дифференциации при обучении иностранному языку, на наш взгляд, является освоение качественно нового стиля работы коллектива преподавателей - слаженной командной работы, когда каждый работает в условиях повышенной личной ответственности за результаты общего дела, творческой инициативы, поддержки и взаимопомощи, где ответственные решения принимаются коллегиально, взвешенно и открыто. На кафедре с самого начала проекта была сорормирована инициативная группа преподавателей, курирующая вопросы учебно-методической, технической и организационной поддержки; реализовывался принцип сменяемости координаторов проекта. Командная организация работы педагогического коллектива также позволяла четко выдерживать критерии оценивания, не допуская завышения / занижения оценок и не размывая тем самым уровневую структуру.

Употребляя определение «гомогенность» или «однородность» применительно к учебной группе, следует подчеркнуть относительность этого понятия, так как на практике редко встречаются учащиеся с одинаковыми показателями развития всех видов речевой деятельности, личностными характеристиками, мотивационными установками и тому подобное. Поэтому комфортность работы для преподавателя в таких условиях следует расценивать, как возможность максимально адекватно использовать все разнообразие фрорм и видов учебной деятельности, возможность экспериментировать.

Для кафедры проект по углубленному изучению английского языка стал экспериментальным не только в плане нового подхода к формированию учебных групп, а также позволил широко апробировать в аудитории интерактивные виды работы. Можно сказать, что дифреренциация создала благоприятные условия для эффрективной реализации интерактивного подхода в учебном процессе. Поскольку интерактивное обучение в своей основе опирается на коллективное взаимодействие учащихся при выполнении задач, моделирующих разнообразные фрормы реального общения, и направлено на раскрытие творческого потенциала каждого участника в процессе самоактуализации и самореализации [4], подбор студентов в академической группе играет большую роль.

Проектом были охвачены студенты всех выпускающих кафедр фракультета информационных технологий, поэтому в результате дифференциации в учебной группе могли оказаться студенты разных специальностей, что привело, по мнению участников проекта, к сплочению курса, который на протяжении всего обучения существовал как единый организм. В свою очередь такая смешанность групп потребовала поточной фрормы составления расписания и дополнительной разработки сводных таблиц успеваемости для журналов академических групп.

При организации межличностного взаимодействия в группе первостепенной задачей для преподавателей стало создание позитивной атмосферы в аудитории, установление неформальных и равноправных, эмоционально насыщенных и положительных отношений, которые с самого начала строятся на основе взаимопомощи и доброжелательности, взаимной поддержки и одобрения, взаимного участия и интереса [2]. Авторитарный стиль взаимодействия преподавателя со студенческой аудиторией уступил место паритетному, 
демократическому, что было положительно воспринято как студентами, так и преподавателями.

В заключении следует отметить, что дифроеренциация контингента студентов по актуальному уровню иноязычной компетенции не исключает использование дифференцированных фрорм и видов учебной работы в аудиторной и внеаудиторной / самостоятельной работе внутри относительно гомогенных групп, так как основная цель - максимальный учет индивидуальных особенностей учащихся, среди которых уровень иноязычной компетенции хоть и важный, но не единственный компонент.

Выводы. Анализ апробированного в проекте вида учебной дифрференциации показал, что эфрфективность такого подхода зависит от таких базовых условий, как: использование диагностического входного контроля, форм самоконтроля студентов, анкетирования их на всех этапах обучения; формирование групп с возможностью перехода («скольжения») по результатам текущей успеваемости; командный стиль взаимодействия членов педагогического коллектива; создание психологически благоприятной учебной атмосферы и активной творческой учебной среды с применением интерактивных методов обучения иностранному языку. При соблюдении этих условий дифроеренцированное обучение как форма организации учебной деятельности становится эффрективным средством реализации личностно-ориентированного подхода при обучении студентов в техническом вузе.
БИБЛИОГРАФИЧЕСКИЙ СПИСОК:

1. Ананьев Б.Г. Психофизиология студенческого возраста и усвоения знаний. Вестник высшей школы. 1972. № 7. 46 с.

2. Китайгородская Г.А. Методика интенсивного обучения иностранным языкам : учебное пособие. Изд. 2-е, испр. и доп. Москва : Высшая шк., 1986. $103 \mathrm{c}$.

3. Лазаренко Л.Н, Барабаш И.В Влияние интерактивных методов на изучение иностранных языков. Язык и культура : научное издание. Киев : Издательский дом Дмитрия Бураго, 2016. Вип. 19. T. III (183). C. 388-394.

4. Лазаренко Л.М. Педагогічні умови використання активних методів навчання у процесі фрормування професійної іншомовної компетентності бакалаврів. Молодь і ринок : Щомісячний науковопедагогічний журнал. 2018. № 3 (158). C. 63-68. DOI: https://doi.org/10.24919/2308-4634.2018.128970.

5. Николаев Е.И. Дифрференциация как педагогическая технология повышения интереса к знаниям: на примере обучения иностранному языку в неязыковом вузе : автореф. дисс. ... канд. пед. наук : 13.00.01. Якутск, 2005. 15 с.

6. Селевко Г.К. Современные образовательные технологии : учебное пособие. Москва : Народное образование, 2008. 200 с.

7. Тусулбекова М.Ж. Проблемы организации индивидуально-дифференцированного подхода обучения английскому языку студентов неязыковых специальностей в теории и практике. Молодой ученый : сборник научных статей. 2009. № 3 (3). С. 195-201. URL: https://moluch.ru/archive/3/216/ (дата обращения: 03.01.2021). 


\section{ПРОБЛЕМА ПІДВИЩЕННЯ ХУДОЖНЬО-ВИКОНАВСЬКОЇ МАЙСТЕРНОСТІ СТУДЕНТІВ У КЛАСІ ДИРИГУВАННЯ}

\section{THE PROBLEM OF IMPROVING STUDENTS' ARTISTIC AND PERFORMING SKILLS IN THE CONDUCTING CLASS}

УДК 378.011.3-52:71.071.2]:005.963 DOI https://doi.org/10.32843/26636085/2021/31-1.11

\section{Білозерська Г.О.,}

канд. пед. наук,

старший викладач кафедри

вокально-хорової підготовки,

теорії та методики музичної освіти

Вінницького державного

педагогічного університету

імені Михайла Коцюбинського

\section{Дабіжа К.Л.,}

заслужений артист України, доцент кафредри вокально-хорової підготовки, теорії та методики музичної освіти

Вінницького державного педагогічного університету імені Михайла Коцюбинського

\section{Ковальчук В.В.,}

заслужений працівник культури України, викладач-методист

Комунального закладу вищої освіти «Вінницький гуманітарно-педагогічний коледж»

\section{Сізова Н.C.,}

кандидат мистецтвознавства, старший викладач кафредри вокально-хорової підготовки, теорії та методики музичної освіти Вінницького державного педагогічного університету імені Михайла Коцюбинського
Сучасний освітній простір вимагає пошуку нових методів підготовки конкурентоспроможних спеціалістів, які б володіли профоесійно-виконавськими вміннями в нерозривному зв'язку з всебічним, універсальним розвитком особистості. У такому аспекті актуальним $є$ значне акцентування вищих навчальних закладів на проблемі підвищення художньо-виконавської майстерності студентів у класі диригування.

На основі вивчення теоретико-практичних і методичних аспектів художньої майстерності майбутніх фрахівців музичного мистецтва в статті обгрунтовано впровадження специсрічних методів у розвитку творчо індивідуальності студента, його артистичності у сфрері диригентського мистецтва. Акцентовано на фрормуванні профресійних якостей, що відіграють ключову роль у розкритті творчого потенціалу в індивідуальній діяльності майбутнього фрахівця.

Обгрунтована важливість застосування активних і творчих методів навчання. Запропоновані методи в контексті зазначеної проблеми, класифріковані за різними основами в класі диригування (за джерелом знань, за видами діяльності, за логікою навчального процесу), зокрема пояснювально-ілюстративний, інструктивно-репродуктивний, проблемний, метод творчого діалогу, створення виконавської моделі й інші.

Акцентується на важливості впровадження художньо-виконавської роботи в класі диригування, що буде дієвою разом з опануванням диригентським артистизмом, а особливо мануально-пластичним мистецтвом.

Обгрунтовується доцільність використання спеціальних диригентських жестів для успішної роботи над художньо-виконавською майстерністю в класі диригування, які виокремлюють репетиційний і концертний жести. Звернено увагу на те, що для продуктивного формування художньо-виконавських умінь майбутнього спеціаліста доцільно активно впроваджувати комп'ютерні технологіі навчання, зокрема створювати відеозаписи виконуваних творів студентом із майбутнім аналізуванням досягнень і помилок.

У розв'язанні проблеми художньо-виконавської майстерності студентів у класі диригування необхідне насамперед опанування технічними прийомами, й зокрема диригентською технікою.

Ключові слова: хорове диригування, художньо-виконавська майстерність, творча інди- відуальність, активні творчі методи, диригентський артистизм.

The modern educational space requires the search for new methods of training competitive professionals who would have professional and executive skills in inseparable connection with the comprehensive, universal development of the individual. In this aspect, it is important to significantly focus the attention of higher education institutions on the problem of improving students' artistic and performing skills in the conducting class.

The article scrutinizes the introduction of specific methods in the development of student's creative personality and his artistry in the field of conducting art, based on the study of theoretical, practical and methodological aspects of artistic skills of prospective specialists in music.

The formation of professional qualities that play a key role in the disclosure of creative potential in the individual activities of the prospective specialist is specified.

In the context of the problem under study the methods, classified on different bases in the class of conducting (by the source of knowledge, the type of activity, the logic of the educational process), in particular, explanatory-illustrative, instructive-reproductive, problematic, method of creative dialogue, creation of executive model and others, are presented.

The article highlights the importance of introducing artistic and performing work in the conducting class, which will be effective together with the mastery of conducting artistry and especially manual and plastic art.

The expediency of using special conducting gestures, distinguished between rehearsal and concert gestures, for successful work on artistic and performing skills in the conducting class, is substantiated.

Attention is drawn to the fact that for the productive artistic and performing skills formation it is advisable for the prospective specialist to actively implement computer-based learning technologies, in particular, to create the videos of students performing works, in order to analyze their achievements and mistakes.

Solving the problems of students' artistic and performing skills in the conducting class, first of all it is necessary to acquire techniques, in particular, conducting technique.

Key words: choral conducting, artistic and performing skills, creative personality, active creative methods, conducting artistry.
Постановка проблеми в загальному вигляді. Впровадження багатоступеневої системи освіти й необхідність інтенсифрікації освітнього процесу в закладах вищої освіти вимагає пошуку нових методів підготовки конкурентоспроможних спеціалістів, які б володіли професійновиконавськими вміннями в нерозривному зв'язку 3 всебічним, універсальним розвитком особистості, розширенням її художнього й загально- культурного кругозору, активізацією творчо-пізнавальних здібностей.

У такому аспекті актуальне значне акцентування вищих навчальних закладів на проблемі підвищення художньо-виконавської майстерності студентів у класі диригування, спрямоване на практичне застосування здобутих знань, умінь і навичок у майбутній професійній діяльності. 
Аналіз останніх досліджень і публікацій. Теоретичне осмислення проблеми підвищення художньо-виконавської майстерності студентів у класі диригування стало об'єктом наукових досліджень С. Казачкова, В. Кузнєцова, К. Ольхова. Практичний досвід видатних диригентів-педагогів викладений у працях I. Мусіна, М. Колесси, Л. Гінзбурга. Вагомий внесок у дослідження диригентського мистецтва зроблено представниками науководослідного напряму з історії та естетики (Л. Сідєльніков), із психології та педагогіки (Г. Ержемський, В. Ражніков, І. Букреєв), із семіотики (О. Поляков), із мистецтвознавства (Л. Сівіз'янов).

Значну роль відіграють дослідження науковців-сучасників у сорері диригентського мистецтва як художнього й соціокультурного френомену (Б. Смірнов, 2004 р.), розвитку артистичності диригента (Ю. Іванова, 2018 р.), обґрунтування методів виконавської інтерпретації хорового твору (Є. Карпенко, 2013 р.; Л. Шумська, 2017 р.). Проте малодослідженим залишається використання необхідного комплексу активно-творчих методів у розв'язанні проблеми художньо-виконавської майстерності студентів у класі диригування.

Метою дослідження $\epsilon$ вивчення специфрічних методів і прийомів викладання хорового диригування у вищій школі для розв'язання проблеми підвищення художньо-виконавської майстерності студентів у класі диригування.

Виклад основного матеріалу. У фоомуванні професійних якостей майбутнього спеціаліста (диригента, хормейстера) дисципліна «Хорове диригування» відіграє ключову роль, адже дає практичні навички управління хоровим колективом, виховує художній смак, розвиває ініціативу й організаційні якості, самостійне й творче мислення. Завдяки індивідуальному характеру навчання майбутній диригент розвивається як цілісна особистість на емоційному, мисленнєвому, когнітивному рівнях, має музичні інтереси, смаки, потреби, індивідуальні творчі здібності, музичнотворчу активність, що припускає схильність і можливість розкриття творчого потенціалу в індивідуальній діяльності.

Робота над підвищенням художньо-виконавської майстерності студентів у класі хорового диригування не можлива без використання активних і творчих методів навчання, адже творчий підхід до розвитку індивідуальності є одним із пріоритетних завдань музичної педагогіки (О. Олексюк). У такому аспекті важливе все: індивідуальний підбір репертуару, методи й прийоми, засоби й форми навчання, самостійна робота студента.

Заняття 3 хорового диригування передбачають застосування специсрічних диригентсько-хорових методів навчання, що класифрікують за різними основами (за джерелом знань, за видами діяльності, за логікою навчального процесу), серед яких:
1. Пояснювально-ілюстративний (розповідь, показ, прослуховування партитури у звукозаписі або виконанні на фортепіано).

2. Інструктивно-репродуктивний (вправи, розбір партитури, вивчення окремих диригентських прийомів).

3. Проблемний (художня інтерпретація, створення виконавської концепції, пошук виконавських засобів виразності, адекватних художньому образу, вивчення необхідної теоретичної та музичної літератури, аудіозаписів).

4. Порівняльне втілення художнього образу (одночасне вивчення кількох контрастних хорових партитур для усвідомлення студентом диригентського жесту як художнього засобу) [2, с. 185-196].

5. Творчий діалог (співбесіди викладача й студента 3 метою добору художньо-доцільних мануальних алгоритмічних моделей для семантичномовного втілення хорового твору) [5, с. 16].

6. Освоєння партитури за допомогою музичнотеоретичного, вокально-хорового й виконавського аналізу.

7. Створення виконавської моделі хорового звучання.

8. Розвиток мануальної техніки й пластичності диригентського апарату.

9. Розробка плану роботи з хором.

10. Прогнозування хорового звучання та аналіз отриманих на репетиціях результатів [3, c. 147-161].

11. Контроль та оцінка знань.

Удосконалення технічних навичок і вмінь у класі диригування повинна розглядатися як художньовиконавська робота.

Для розв'язання проблеми підвищення художньо-виконавської майстерності студентів у класі диригування доцільно приділити увагу диригентському артистизму, а особливо мануально-пластичному мистецтву диригента.

Опанування артистизмом на художньому рівні характерне в підготовці диригента, адже на вмінні передавати емоційну інсрормацію за допомогою рухів, постави, міміки зосереджена індивідуальна робота викладача. На такому етапі важливе застосування творчого підходу до виконавського аналізу хорового твору, але «<..> не шаблонний аналіз засобів виконавської виразності, а система мислення хоровими образами, яка передбачає знання хору, його засобів виразності й засобів реалізації їх у хоровому виконавстві» [1, с. 131].

У такому аспекті науковцем Ю. Івановою рекомендується використовувати інтонаційний метод, що дозволяє віднайти в музиці виразне, емоційне начало, а інтонаційний аналіз стане фундаментом в артистичному втіленні художнього образу Tвору [1].

Перед викладачем постає завдання пояснювати студенту художню мету кожного технічного 
завдання та вимагати такого втілення твору, яке максимально відповідає його художньому образу.

Для передачі виконавського наміру важливе опанування мануально-пластичним мистецтвом диригента, метою якого $є$ створення музичного образу за допомогою художніх засобів (окрім технічних).

У такому аспекті диригування як творчий процес $є$ таким явищем, що межує між керуванням і пластичним мистецтвом, тобто керування через мистецтво [4, с. 9].

Опанування студентом у класі диригування художньою технікою виконання (пластичним мистецтвом) апріорі спрямоване на художню інтерпретацію музики й впливає на змістовність і духовний сенс хорового виконання.

Художня техніка $є$ носієм мануально-пластичного образу, що проявляється у виразних рухах і тілесній пластиці диригента, джерелами яких $€$ музика, яку відчуває керівник хору та яка здатна надихнути колектив задля втілення задуму композитора.

Для успішної роботи в класі диригування над художньо-виконавською майстерністю обґрунтовується доцільність використання системи парної класифрікації диригентських жестів (Є. Карпенко): репетиційний-концертний; вказівка-нагадування; навчальний-практичний. Автором зазначається, що в застосуванні репетиційного жесту можуть бути перебільшені певні художньо-виконавські елементи, тоді як у концертному - варто зосередитися на гнучкості фрраз, відчутті цілісного розвитку музичного матеріалу. У використанні професійної пари «вказівка-нагадування» слід розмежовувати імпровізацію диригента з обов'язковою вказівкою та своєчасне нагадування ритму навіть у підготовлених місцях. У навчально-практичній системі парної класифікації жестів слід усвідомлювати, що в класі диригування важливою є міцна ритмічна основа, тоді як у практичній діяльності професійні диригенти вільніші у виборі рухів, зумовлених конкретними виконавськими потребами [2, с. 185-196].

Вимоги до диригентського жесту - яскравість і виразність, стриманість і лаконічність, чіткість і конкретність, наявність вольового й емоційного начал, свобода й природність, звукова насиченість, спрямованість на коректування виконання.

У процесі роботи на художнім виконанням хорового твору в класі диригування доцільно використовувати комп'ютерні технології задля відео- записів виконуваних хорових творів із майбутнім аналізом. Таким чином, продуктивність фрормування художньо-виконавських умінь буде аргументуватись демонстрацією досягнень і помилок студента. Також корисний перегляд відеозаписів 3 участю відомих диригентів, обговорення яких спонукатиме майбутнього фрахівця на виправлення помічених недоліків.

Висновки. Практична робота в класі диригування здатна забезпечити фрормування організаційних якостей майбутнього фрахівця, його творчої індивідуальності й самостійності за умов використання комплексу активних методів навчання.

Проте в розв'язанні проблеми художньо-виконавської майстерності студентів у класі диригування необхідне насамперед опанування технічними прийомами, й зокрема диригентською технікою.

Виокремлені специфрічні диригентсько-хорові методи повинні застосовуватись через призму художньо-виконавської роботи зі зверненням особливої уваги на артистизм диригента, опануванні мануально-пластичним мистецтвом. Значна увага в такому процесі відводиться систематичному аналізу відеозаписів власних творчих здобутків.

Подальші перспективи дослідження проблеми вбачаємо у вивченні зарубіжного досвіду роботи над художньо-виконавською майстерністю студентів у класі диригування.

\section{БІБЛІОГРАФІЧНИЙ СПИСОК:}

1. Іванова Ю.М. Артистизм у контексті фрахової підготовки студента-хормейстера. Культура України. 2018. Вип. 61. С. 128-137. URL: http://nbuv.gov.ua/ UJRN/Kum_2018_61_15.

2. Карпенко Є.В. Удосконалення методики викладання хорового диригування на старших курсах факультетів мистецтв. Актуальні питання мистецької освіти та виховання. Випуск 1 (1). Суми, 2013. C. 185-196.

3. Комурджи Р.3. Содержание и специфика работы дирижера. Проблеми сучасної педагогічної освіти. 2013. Вип. 39 (1). С. 147-161. URL: http:// nbuv.gov.ua/UJRN/pspo 2013 39\%281\%29 26.

4. Смирнов Б.Ф. Дирижерское искусство как художественный и социокультурный феномен : автореф. дисс. ... докт. искусств. : 17.00.02. СанктПетербург, 2004. 32 с.

5. Шумська Л.Ю. Хорове диригування : навчальний посібник. 2-ге видання. Ніжин : НДУ ім. М. Гоголя, 2017. 105 c. 


\section{САМОСТІЙНА РОБОТА ЯК ЗАСІБ ФОРМУВАННЯ ПРОФЕСІЙНО-} МОВЛЕННЄВОЇ КОМПЕТЕНТНОСТІ МАЙБУТНІХ СУДНОВОДІЇВ

\section{INDIVIDUAL WORK AS A MEANS OF FORMATION OF THE PROFESSIONAL AND SPEECH COMPETENCE OF FUTURE NAVIGATORS}

Нині майбутній фрахівець морського профрілю має відповідати міжнародним стандартам ринку праці, а саме згідно з документами Міжнародної морської організації, Міжнародної конвениії про підготовку й дипломування моряків і несення вахти з Манільськими поправками (2010р.), Міжнародної конвенції з охорони людського життя на морі (1947р.) та освітньо-професійною програмою підготовки майбутніх судноводіїв передбачається становлення висококваліфрікованих, конкурентоспроможних, відповідальних і компетентних фахівців. Вищі навчальні заклади висовують вимоги до майбутніх фрахівців не тільки щодо фоххової підготовки, але й до рівня особистісного розвитку. У зв'язку із цим набуває важливості самостійна робота курсантів. Саме чей вид навчально-пізнавальної пращ студентів набуває значущості в професійній підготовці майбутніх судноводіїв. Нині підготовка майбутніх судноводіїв у вищих навчальних закладах не лише $є$ видом діяльності, котра забезпечує формування системних фунндаментальних і спеціальних теоретичних і практичних знань студентів, мотивів професійної діяльності, компетентностей, якостей, досвіду, а й сприяє їх саморозвитку. У статті розглядаються прийоми самостійної роботи у формуванні профресійно-мовленнєвої компетентності майбутніх судноводіїв. Самостійна робота студентів є засобом формування теоретичних і прикладних знань курсантів, інтеріоризації практичних умінь, активізації їхньої пізнавальної мотиваціі, виховання самостійності, відповідальності, цілеспрямованості, ініціативності.

Аналітичні самостійні завдання передбачали ознайомлення з теоретичною інорормацією, ї аналіз, систематизацію, узагальнення та представлення у вигляді есе аналітичного характеру, доповідей, доповідей-презентацій, а також пресконсререниій як інтерактивного виду організації повідомлень. Ці завдання слугували розширенню системи теоретичних знань, які вже сорормовані, їньому динамічному засвоєнню.

Репродуктивні завдання із самостійної роботи орієнтували курсантів на виявлення творчого підходу до розв'язання певних проблем. Вони насамперед були спрямовані на орормування вмінь обговорення проблеми, мобільного аналізу ситуації, ії оцінювання 3 різних аспектів, проведення дискусій щодо розв'язання певних проблем, продукування ідей і захист їхньої доцільності, розробку рекомендацій.

Ключові слова: самостійна робота, прийоми, професійно-мовленнєва компетент- ність, майбутні судноводії, професійна підготовка.

Today a future marine specialist should comply with international labor market standards, namely to such documents as International Marine Organization (IMO), International Convention on Standards of Training Certification and Watchkeeping for Seafarers with Manila Amendments (STCW) 2010, Safety of Life at Sea (SOLAS) 1947 and educational training programs for future navigators which expect highly qualified, competitive, responsible and competent professionals. Now, higher educational establishment make demands as to the future specialists not only in professional training but also for the level of the personal development. In this regard the individual work of cadets becomes more important. It is this type of educational and cognitive work of students requires significance in the training of future navigators. Currently, the professional training of future navigators in higher education is a kind of activity that provides the formation of systemetic fundamental and special theoretical and practical knowledge of students, motives of professional activity, competencies, qualities and experience but also promotes their self-development. The article considers the methods of individual work in the formation of professional speech competence of future navigators. Individual work of students is a mean of the formation theoretical and applicative knowledge of the cadets, internalization of practical skills, and activation of their cognitive motivation, education of independent behavior, responsibility, purposefulness and initiative.

Analytical individual tasks included acquaintance with theoretical information, its analysis, systematization, generalization and presentation in the form of analytical essay, reports and also press conference as an interactive type of organization report. These tasks served to extend the system of theoretical knowledge which has been already formed to its dynamic assimilation. Reproductive tasks of the individual work oriented cadets to identify a creative approach to solve certain problems. They were primarily focused on developing skills to discuss problems, mobile analysis of the situation, its assessment from various aspects, conducting different discussions on solving certain problems, production of ideas and defense of their feasibility and development of recommendations.

Key words: individual work, means, professional speech competence, future navigator, professional training.
Національного університету

«Одеська морська академія»
Постановка проблеми в загальному вигляді. Важливою проблемою сьогодення $є$ підвищення ефективності профресійної підготовки майбутніх фрахівців, зокрема судноводіїв, оскільки ії розв'язання суттєво впливає на розвиток економічного потенціалу України, забезпечення ії рівноправної участі в різноманітних міжнародних проєктах. У цьому аспекті пріоритетним стає сормування професійно-мовленнєвої компетентності майбутніх судноводіїв, що пов'язане 3 необхідністю їхньої участі в комунікації із членами багатонаціональних екіпажів, представниками 
міжнародних організацій, підготовки документів англійською мовою тощо. Неабияке значення у формуванні окресленої компетентності в процесі професійної підготовки майбутніх судноводіїв має самостійна робота курсантів, що пояснюється ії творчим характером, спрямованістю на досягнення особистісно важливих результатів, реалізації прагнень до саморозвитку й самовдосконалення.

Аналіз останніх досліджень і публікацій. Проблема викладалася 3 таких наукових позицій: підготовка майбутніх судноводіїв з боку компетентнісного підходу (О. Безбах, Н. Степаненко, М. Шерман, В. Чернікова), теоретичні засади впровадження самостійної роботи майбутніх фрахівців (Л. Головко, С. Гончаренко, Л. Журавська, М. Князян, С. Кустовський, Г. Романова), види автономії студентів у процесі організації роботи (І. Задорожна), використання комунікаційних технологій протягом самостійного навчання (О. Писарчик).

Виділення не вирішених раніше частин загальної проблеми. Аналіз наукових праць дозволяє констатувати, що проблема впровадження в навчальний процес самостійної роботи курсантів як засобу фрормування їхньої професійно-мовленнєвої компетентності вимагає детальнішого викладення.

Метою статті $€$ на основі аналізу наукових джерел розкрити сутність самостійної роботи студентів, схарактеризувати самостійні завдання (аналітичні й репродуктивні) як засіб фрормування профресійно-мовленнєвої компетентності майбутніх судноводіїв.

Виклад основного матеріалу. Насамперед наголосимо, що професійно-мовленнєва компетентність майбутніх судноводіїв віддзеркалює переконання у важливості опанування мовами (українською та англійською) за професійним спрямуванням, знання про норми мови, вміння в аудіюванні, говорінні, читанні, письмі з огляду на особливості профресійної діяльності судноводіїв, здатність до співпраці, комунікації в багатокультурному екіпажі, рефрлексії та корекції курсантами свого мовлення. Структурними компонентами цієї компетентності нами були визначені мотиваційноаксіологічний, когнітивно-знаннєвий, діяльніснопроцесуальний.

Наголосимо, що під сутністю самостійної навчальної роботи доцільно розуміти різноманітні види індивідуальної та колективної навчальної діяльності, яка здійснюється на заняттях або вдома, під керівництвом учителя, але без його безпосередньої участі. С. Гончаренко, зокрема, серед найпоширеніших видів самостійної роботи зазначає такі з них: написання рефрератів, творів, проведення самостійних спостережень, дослідницької діяльності, моделювання, конструювання тощо [2].
У такій площині привертає увагу наукова позиція Є. Рапацевич, що в процесі самостійної роботи студент виступає як активна особистість, яка створює власну культуру, ерудицію, готовність до майбутньої діяльності. Ця активність проявляється і в постановці цілей роботи, її плануванні, визначенні оптимальних засобів, самоконтролі. Серед переваг самостійної роботи науковець цілком слушно називає такі як актуалізація мислення, інтенсивне виконання пізнавальних завдань, запам'ятовування наукової інформації. Основним чинником ефективності такої роботи науковець доцільно зазначає усвідомлення ії цілей, засобів, власного організаційного потенціалу [8].

У довідкових педагогічних джерелах наголошується на вияві самостійності учня на рівні всіх компонентів самостійної роботи (від постановки мети до самоконтролю та самокорекції) [6]. Водночас самостійність викладається психологами як така властивість особистості, котра проявляється в критичності, ініціативності, відповідальності за результати своєї діяльності, адекватній самооцінці. Важливим у професійній підготовці майбутніх судноводіїв $€$, на наш погляд, положення про двобічний зв'язок самостійності особистості й мисленнєвої та емоційно-вольової діяльності: як підкреслює В. Шапар, розвиток мислення, почуттів і волі $€$ необхідною передумовою самостійних суджень; судження та дії, які розвиваються в процесі самостійної роботи, фрормують здатність домагатися успішного виконання намічених рішень всупереч труднощам, котрі виникають у діяльності [11]

С. Кустовський слушно підкреслює, що самостійна робота передбачає чітке усвідомлення студентами мети тих завдань, які їм пропонуються у фрорматі цієї роботи, її планування, пошук і вибір необхідного наукового матеріалу, його опрацювання, використання методів наукового дослідження, фрормулювання власної позиції, проведення самоаналізу, самоконтролю, саморегуляції [7].

3 позиції Л. Журавської та інших провідними фрункціями самостійної роботи студентів є виховання самостійності як особистісної риси, пізнавальних потреб, опанування технікою самостійної роботи, вміннями формулювати завдання, приймати рішення, визначати методи розв'язання проблем, розширювати як загальноосвітні, так і профресійні знання [3].

Варто зазначити, що сутність самостійної роботи розкривається і з позиції управління нею. Наприклад, Г. Романова, викладаючи чинники підвищення ефективності такої роботи, наголошує на важливості самоуправління студентів, яке розгортається поряд з опосередкованим управлінням з боку викладачів. Водночас як цілі самостійної роботи науковець висовує такі: розвиток у майбутніх фрахівців навичок самоуправління, 
вміння вчитися, розширення системи професійно важливих знань, фрормування здатності до творчості. Викликає інтерес для нашого дослідження класифікація етапів розгортання самостійної роботи студентів: підготовчий, метою якого $є$ реалізація цілеутворювальної, діагностувальної, мотиваційної та планувальної фрункцій такої роботи; реалізаційний - організаційної, інфрормаційної та контрольної функцій; завершальний етап - аналітичної, коректувальної функцій [10].

Як особливу форму пізнавальної діяльності, результативність котрої визначається витраченим часом, обсягом опрацьованого матеріалу, чіткістю рекомендацій викладача, активністю студента, матеріально-технічними можливостями вищого закладу освіти, розкриває сутність самостійної роботи студентів Л. Головко. Науковець викладає структуру такого феномена, як досвід самостійної роботи, котру доцільно представляти афрективним (емоційне ставлення до самостійної роботи), когнітивним (фрахові теоретичні знання), аксіологічним (мотиви й ціннісні орієнтації особистості), праксеологічним (вміння самостійно працювати) компонентами [1].

М. Князян слушно стверджує, що в сучасній педагогічній думці склалася тенденція відносити до сутнісних характеристик самостійної роботи знаннєво-змістову (вільне володіння знаннями як засобом генерації власних ідей і гіпотез), конвіктивно-мотиваційну (переконання та потреби особистості в самоактуалізації в процесі пізнавальної діяльності), процесуально-діяльнісну (дослідження об'єктів навколишнього світу 3 використанням новітніх інформаційних засобів), комунікативно-інтерактивну (творча співпраця в групі задля досягнення спільних цілей). Це дозволило науковцю дійти слушного висновку, що самостійна робота $є$ засобом не лише інтеріоризації знань і вмінь, а й фрормування професійно важливих якостей компетентної особистості [5].

О. Писарчик наголошує на тому, що успішність навчання залежить насамперед від правильної організації та контролю самостійної роботи студентів. Важливого значення водночас набуває використання комунікаційних технологій, котрі, на думку науковця, сприяють налагодженню взаємодії між викладачами й студентами, активізують індивідуальні здібності майбутніх фрахівців (пізнавальні, креативні, здатність керувати своїми емоціями, соціальні навички, прагнення до самопідготовки). Самостійна робота передбачає передачу відповідальності за результативність професійної підготовки від викладача до студента, що в проєкції, наприклад, на підготовку майбутніх судноводіїв актуалізує пріоритетність фрормування умінь планування, самоконтролю, самокорек- ції, швидкість виконання яких визначає ефективність такої підготовки [9].

Цю ідею висловлює й І. Задорожна, яка трактує самостійну роботу студентів як таку фрорму навчальної діяльності, котру організовує і контролює студент на базі опосередкованого управління нею з боку викладача. Метою самостійної роботи $€$ фрормування певних компетенцій та автономії. Відповідно до характеру взаємодії викладача й студента науковець виокремлює види автономії, як-от: часткова автономія (передбачається жорстке управління такою роботою викладачем), напівавтономія студентів (за умови відносно жорсткого управління), частково-залежна автономія (мається на увазі відносно гнучке управління з боку викладача), умовно повна автономія (за умов гнучкого типу управління). І. Задорожна цілком слушно наполягає на тому, що рівень автономії залежить від готовності студентів до самостійної роботи (а саме від мотиваційної готовності, здатності до саморегуляції та сорормованості навчально-стратегічної компетенції) [4]. Дослідниця доречно акцентує на необхідності впровадження засобів проблемного, проєктного навчання, портфоліо, інформаційно-комунікаційних технологій [4].

Отже, самостійна робота студентів є засобом фрормування теоретичних і прикладних знань курсантів, інтеріоризації практичних умінь, активізації їхньої пізнавальної мотивації, виховання самостійності, відповідальності, цілеспрямованості, ініціативності.

Слід наголосити, що професійна підготовка майбутніх судноводіїв має деякі принципові особливості, наприклад, як підкреслюють О. Безбах, Н. Степаненко, М. Шерман, В. Чернікова, провідною з них $є$ нерівномірність навчального процесу (котра зумовлена тривалістю морської практики), професійною зорієнтованістю змісту, а тому й зростає роль самостійної роботи [12-14].

Для того, щоб професійна підготовка майбутніх судноводіїв набула ознак вищої ефективності, доцільно систематизувати самостійні завдання відповідно до рівня підготовки (сорормованості знань і вмінь) курсантів: аналітичні й репродуктивні.

Аналітичні самостійні завдання передбачали ознайомлення 3 теоретичною інфрормацією, ї̈ аналіз, систематизацію, узагальнення та представлення у вигляді есе аналітичного характеру, доповідей, доповідей-презентацій, а також пресконференцій як інтерактивного виду організації повідомлень. Ці завдання слугували розширенню системи теоретичних знань, які вже сорормовані, їхньому динамічному засвоєнню.

Репродуктивні завдання із самостійної роботи орієнтували курсантів на виявлення творчого підходу до розв'язання певних проблем. 
Вони насамперед були спрямовані на фрормування вмінь обговорення проблеми, мобільного аналізу ситуації, її оцінювання 3 різних аспектів, проведення дискусій щодо розв'язання певних проблем, продукування ідей і захист їхньої доцільності, розробку рекомендацій.

Експериментальна робота організовувалася нами протягом спецсемінару «Професійно-мовленнєва компетентність у діяльності судноводія», практичних занять із навчальних дисциплін «Ділова українська мова», «Англійська мова за профресійним спрямуванням», «Історія та культура України».

Метою окресленого спецсемінару було ознайомлення курсантів зі значенням профресійномовленнєвої компетентності в діяльності судноводія, її сутністю, структурою. Спецсемінар був організований на двох заняттях: «Сутність і структурно-компонентний склад професійномовленнєвої компетентності» й «Володіння професійно-мовленнєвою компетентністю як передумова досягнення успіху діяльності судноводія».

Задля забезпечення ефективності підготовки курсантів до першого заняття спецсемінару їм були запропоновані самостійні аналітичні завдання 3 пошуку й опрацювання інформації про сутність і структуру понять «компетенція», «компетентність», «профресійно-мовленнєва компетентність судноводія». Викладач уточнював відповіді, пояснював зміст компонентів, розкривав ті провідні засоби, які слугують для фрормування та оцінювання кожного 3 компонентів. Як узагальнення знань курсантів їм було запропоновано написати невелике есе аналітичного характеру «Профресійно-мовленнєва компетентність у моєму професійному зростанні». Окрім цього, було впроваджене самостійне репродуктивне завдання з організації дискусії про методи й прийоми самонавчання задля розширення когнітивно-знаннєвого компонента такої компетентності.

Підготовка курсантів до другого заняття передбачала виконання ними самостійних аналітичних завдань із підготовки доповіді-презентації про значущість опанування судноводієм профресійномовленнєвою компетентністю як чинника ефективності виконання ним професійних обов'язків. Наприкінці заняття було організовано також пресконореренцію «Профресійно-мовленнєва компетентність у площині вимог до підготовки бакалавра судноводіння», задля чого були утворені дві групи, одна з яких - «журналісти» - готувала питання за темою, а інша - «експерти» - мала дати повні, аргументовані відповіді на них. Виконання цього самостійного завдання передбачало аналіз вимог освітньо-професійної програми підготовки бакалавра судноводіння. Це дозволило систематизувати й узагальнити уявлення майбут- ніх фрахівців про специфріку профресійно-мовленнєвої компетентності саме судноводіїв. Викладач аналізував думки курсантів, пояснював пріоритетність зазначеної компетентності не лише в праці судноводія, а й в його життєдіяльності в цілому, наводив приклади.

Впровадження спецсемінару дозволило закласти певні базові знання про сутність професійно-мовленнєвої компетентності (ії когнітивнознаннєвий компонент), створити пізнавальну мотивацію, а саме інтерес до вивчення української, англійської мов, переконання у важливості опанування такою компетентністю.

Самостійні завдання впроваджувалися й у процесі вивчення навчальної дисципліни «Ділова українська мова», наприклад, за темою практичного заняття «Лексика української літературної мови» курсанти мали виконати таке самостійне аналітичне завдання, як підготувати доповідь «Українська лексикографія. Типи словників», в якій представити критичний аналіз різних типів словників і зробити рекомендації щодо використання найкорисніших із них у профресійній діяльності судноводія.

За темою «Фразеологізми в українському діловому мовленні» курсанти готували есе аналітичного характеру про потенціал використання фрразеологічних зворотів в усному мовленні судноводія; вони наводили приклади, аналізували різні моделі діалогічного мовлення, класифікували фрразеологізми, які найчастіше вживаються в такому виді мовленнєвої діяльності.

Варто підкреслити, що значний інтерес у курсантів першого року навчання викликало самостійне завдання, котре виконувалося в процесі самопідготовки до практичного заняття «Основи української пунктуації». Так, курсанти мали підготувати доповідь за темою «Особливості пунктуації в офріційно-ділових текстах», зокрема представити систему правил, що віддзеркалюють особливості пунктуації в офріційних документах, та офрормити доповідь у вигляді презентації.

Схарактеризовані вище завдання слугували фрормуванню лінгвістичних знань курсантів когнітивно-знаннєвого компонента професійно-мовленнєвої компетентності.

3 метою розширення соціолінгвістичних знань майбутніх судноводіїв, а саме знань про історію України, в процесі вивчення відповідної дисципліни - «Історія та культура України» - за темою «Українські землі наприкінці 18 - у першій половині 19 століття» курсанти зробили самостійне аналітичне завдання, а саме доповідь-презентацію про створення Одеського морського порту.

За розділом «Україна в Першій світовій війні» було організовано своєрідну пресконференцію за темою «Бойові подвиги Чорноморського фрлоту в Першій світовій війні». Частина групи виступила 
в ролі доповідачів про події, інші, як і протягом проведення спецсемінарів, - у ролі «журналістів». Три курсанти виконували функції своєрідних «експертів» та оцінювали коректність, логічність запитань і повноту, правильність відповідей на них.

До самостійних аналітичних завдань, що слугували фрормуванню соціолінгвістичних знань, належать і ті, котрі передбачали підготовку повідомлень про історію Одеси у 20 столітті, наприклад: про Одесу в Другій світовій війні («Героїчна оборона Одеси», «Партизанський рух в Одесі», «Визволення Одеси: 10 квітня 1944 року»), культурне життя Одеси («Літературна Одеса: минуле й сучасне», «Одеські письменники-моряки», «Образ моря в літературній і художній творчості Одеси»), міжнародні культурні зв'язки («Містапобратими Одеси»). Оскільки тематика цих повідомлень пов'язана з життям рідного для багатьох курсантів міста, це позитивно вплинуло на фрормування інтересу до соціокультурних знань профресійно-мовленнєвої компетентності.

Підготовка всіх окреслених вище завдань із тих дисциплін, що за освітньо-профресійною програмою викладаються в першому семестрі першого курсу, передбачала оцінювання як точності, логічності, граматичної, орфроепічної правильності, лексичної та стилістичної виразності мови доповідей, повідомлень, есе, так і повноти, системності тієї інформації, що викладалася відповідно до тем самостійних завдань.

Так, на заняттях із навчальної дисципліни «Ділова українська мова» впроваджувалися і самостійні репродуктивні завдання, наприклад, на практичному занятті «Графріка й орфографрія» було організовано колективне обговорення в академічній групі проблеми правопису слів іншомовного походження. Після цього курсанти провели генерацію ідей щодо систематизації правил, варіантів їх офрормлення у вигляді компактної таблиці для того, щоб вони могли використовувати її в професійній діяльності за необхідністю під час підготовки, наприклад, офріційних документів.

У процесі викладання навчальної дисципліни «Історія та культура України» за темою «Культура України 19 - початку 20 століття» було організоване колективне обговорення проблеми «Роль Одеси в розвитку літературного, театрального, музичного, кінематографічного мистецтва України». Усі курсанти були розділені на чотири групи відповідно до виду мистецтва; кожна з груп на основі вивчення джерел доповідала основні фракти, представники інших груп ставили запитання. Особливий інтерес викликали запитання про вплив діячів - вихідців з Одеси на розвиток культури не лише в Україні, а й в інших країнах світу.

Висновки. Самостійна робота студентів $€$ засобом фрормування теоретичних і прикладних знань курсантів, інтеріоризації практичних умінь, активізації їхньої пізнавальної мотивації, виховання самостійності, відповідальності, цілеспрямованості, ініціативності.

Розроблені й впроваджені нами самостійні аналітичні й репродуктивні завдання передбачали ознайомлення 3 теоретичною інорормацією, іï аналіз, систематизацію, узагальнення та представлення у вигляді доповідей, есе аналітичного характеру, повідомлень, пресконореренцій, колективних обговорень. генерації ідей, розробки рекомендацій. Ці завдання слугували створенню інтересу до професійної діяльності як ціннісної орієнтації; переконань у важливості опанування культурою україномовного й англомовного спілкування; розширенню системи теоретичних знань; інтеріоризації вмінь у письмі, читанні, діалогічному мовленні.

Перспективи дослідження полягають у розробці системи самостійної роботи 3 формування професійно-мовленнєвої компетентності для другого (магістерського) рівня підготовки майбутніх судноводіїв.

\section{БІБЛІОГРАФІЧНИЙ СПИСОК:}

1. Головко Л.Л. Формування досвіду самостійної діяльності студентів вищої сільськогосподарської школи : автореф. дис. ... канд. пед. наук : 13.00.04. Київ, 2000. 20 с.

2. Гончаренко С.У. Український педагогічний словник. Либідь, 1997. 376 с.

3. Журавська Л.М. Викладач як керівник процесу самостійної діяльності студентів. Теоретично-методичні проблеми навчання і виховання. Збірник наукових праць : педагогічні науки. Київ : Фенікс, 2000. С. 38-45.

4. Задорожна І.П. Теоретико-методичні засади організації самостійної роботи майбутніх учителів 3 оволодіння англомовною комунікативною компетенцією : автореф. дис. ... д-ра пед. наук : 13.00.02. Київ, 2012. 44 c.

5. Князян М.О. Система фрормування самостійнодослідницької діяльності майбутніх учителів іноземних мов у процесі ступеневої підготовки : дис. ... д-ра пед. наук : 13.00.04. Ізмаїл, 2007. 445 с.

6. Коджаспирова Г.М., Коджаспиров А.Ю. Словарь по педагогике. Москва : МарТ ; Ростов-на-Дону : МapT, 2005. 448 c.

7. Кустовський С.М. Дидактичні умови організації самостійної навчально-пізнавальної діяльності майбутніх економістів у вищих навчальних закладах : автореф. дис. ... канд. пед. наук : 13.00.04. Вінниця, 2005. 20 c.

8. Рапацевич Е.С. Педагогика: Большая современная энциклопедия. Минск : Современное слово, 2005. 720 c

9. Писарчик О.Л. Організація самостійної роботи студентів. Новітні освітні технології : науково-практична конференція. URL: http://confesp.fl.kpi.ua/ node/1258.

10. Романова Г.М. Індивідуально-типологічні та дидактичні чинники результативності самостійної роботи студентів економічних університе- 
тів : автореф. дис. ... канд. пед. наук : 13.00.09. Київ, 2003. 20 c.

11. Шапар В.Б. Сучасний тлумачний психологічний словник. Харків : Прапор, 2005. 640 с.

12. Шерман М.І. Визначення структури інорормаційної культури майбутніх судноводіїв. Мультидисциплінарні академічні дослідження і глобальні інновації: гуманітарні та соціальні науки (MARGIHSS 2015) : матеріали I Міжнародної науково-практичної е-конференції, м. Київ, 10-11 вересня 2015 р. / Київський національний лінгвістичний університет. Київ : КНЛУ, 2015. С. 44-47.
13. Шерман М.І. Структура профресійної підготовки майбутніх судноводіїв у вищих морських навчальних закладах у контексті проблем фрормування інфрормаційної культури. URL: https:// www.cuspu.edu.ua/en/prohramy-vstupnykh-vyprobuvan/ 280-naukovi-konferentsii.

14. Шерман М.І. Формування іншомовної профресійної компетентності майбутніх судноводіїв засобами інфрормаційно-комунікаційних технологій. Актуальні проблеми державного управління, педагогіки та психології. 2013. Вип. 2. С. 481-486. 
ПРОГРАМА РОЗВИТКУ ЗДАТНОСТІ ДО ПЕДАГОГІЧНОЇ ФАСИЛІТАЦІЇ PEDAGOGICAL FACILITATION CAPACITY DEVELOPMENT PROGRAM
FOR FUTURE TEACHERS AT THE PEDAGOGICAL UNIVERSITY

Стаття викладає методичний контекст підготовки майбутніх учителів сучасної української школи як фрасилітаторів освітнього середовища. Спираючись на результати аналізу науково-методичного фоонду (теоретичні розвідки вчених, розробки методистів та учителів-практиків), схарактеризовано специфріку професійної діяльност сучасного вчителя, яка має віддзеркалювати конструктивні зміни в парадигмі «учителювання» - зміщення акцентів у бік гуманізаці та «олюднення» освітнього процесу школи. Доведено, що чі процеси відбивають феномен здатності до педагогічної фрасилітації як механізму педагогічної підтримки вчителем особистісного зростання учня як особистості й педагогічного супроводу його навчальних досягнень в освітньому процесі. Розроблено експериментальну програму формування здатності до педагогічної фрасилітації майбутніх учителів у педагогічному університеті, яка передбачала набуття студентами спеціальних знань щодо феномену фрасилітації та механізмів ії реалізації в просессійній діяльності в школі (знання щодо рольових позичій сучасного вчителя-срасилітатора, едвайзера, тьютора); набуття студентами досвіду впровадження механіз мів здатності до педагогічної фрасилітаціі (педагогічної підтримки й педагогічного супроводу особистісного зростання учнів та їхніх навчальних досягнень). У межах роботи студентської проблемної групи було реалізовано експериментальну програму (у формі спецкурсу) для студентів «Формування здатності до педагогічної фрасилітаціі майбутніх учителів». Запропонований студентам спецкурс передбачав 16 лекційних годин, 36 семінарсько-практичних годин, а 8 годин відводилось на самостійну роботу студентів. Зміст елективного спецкурсу структуровано в таких модулях, як «Теоретичні засади орормування здатності до педагогічної фрасилітації майбутніх учителів» $i$ «Практикум із формування здатності до педагогічної фрасилітації майбутніх учителів». Ефективність реалізації експери ментальної програми формування здатності до педагогічної фрасилітації перевірена шляхом порівняння одержаних даних до й після проведення роботи зі студентами. На початковому етапі роботи зі студентами експериментальної (впроваджувалась експериментальна програма; далі) й контрольної (навчання відбувалось традиційним способом) групи зафріксовано такі результати: в експериментальній групі на високому рівні $2,69 \%$, на достатньому рівні - 10,44\%, на низькому рівні - 86,87\% опитаних студентів; у контрольній групі на високому рівні 3,88 \%, на достатньому рівні - 10,34 \%, на низькому рівні - 85,78 \% усіх опитаних студентів. Після проведення експериментальної роботи було одержано такі дані: в експери ментальній групі на високому рівні - 22,56 \%, на достатньому рівні - 56,20\%, на низькому рівні -21,24 \% опитаних студентів; у контрольній групі на високому рівні - 5,62\%, на достатньому рівні - 14,01\%, на низькому рівні - 80,37 \% усіх опитаних студентів.

Ключові слова: фрасилітація, педагогічна фасилітація, здатність до педагогічноі фасилітації, майбутні вчителі, розвиток, педагогічний університет, експериментальна програма.

The article highlights the methodological context of training future teachers of the modern Ukrainian school as facilitators of the educational environment. Based on the results of the analysis of scientific and methodological fund (theoretical research of scientists, development of methodologists and teachers-practitioners) the specifics of professional activity of modern teachers are characterized, which should reflect constructive changes in the paradigm of "teaching" - shifting accents towards humanization and "humanization". It is proved that these processes reflect the phenomenon of ability to pedagogical facilitation, as a mechanism of pedagogical support by the teacher of personal growth of the student, as the personality and pedagogical support of his educational achievements in the educational process. An experimental program for the formation of the ability to pedagogical facilitation of future teachers at the pedagogical university has been developed, which provided for the acquisition by students of special knowledge about the phenomenon of facilitation and mechanisms of its implementation in professional activities at school (knowledge of the role positions of a modern teacher - facilitator, advisor, tutor): acquisition by students of experience of introduction of mechanisms of ability to pedagogical facilitation (pedagogical support of personal growth of students and their academic achievements). An experimental program was implemented within the work of the student problem group (in the form of a special course) for students "Formation of the ability to pedagogical facilitation of future teachers". The special course offered to students included 16 lecture hours, 36 seminar-practical hours, and 8 hours were allocated for independent work of students. The content of the elective special course is structured in such modules as: "Theoretical principles of forming the ability to pedagogical facilitation of future teachers" and "Workshop on the formation of the ability to pedagogical facilitation of future teachers". The effectiveness of the experimental program for the formation of the ability to pedagogical facilitation was tested by comparing the data obtained before and after working with students. At the initial stage of work with students of experimental (experimental program was implemented) and control (learning took place in the traditional way) the following results were recorded: in EG at a high level $2.69 \%$, at an average level - $10.44 \%$, at the low level $-86.87 \%$ of the surveyed students; in CG at a high level $-3.88 \%$, at an average level - $10.34 \%$, at a low level - $85.78 \%$ of all surveyed students. After the experimental work, the following data were obtained: in EG at a high level - $22.56 \%$, at an average level - $56.20 \%$, at a low level $-21.24 \%$ of surveyed students; in CG at a high level - $5.62 \%$, at a medium level $14.01 \%$, at a low level $-80.37 \%$ of all surveyed students.

Key words: facilitation, pedagogical facilitation, ability to pedagogical facilitation, future teachers, development, pedagogical university, experimental program. 
Постановка проблеми в загальному вигляді. Актуальність дослідження пов'язана з тим, що особистісно зорієнтована діяльність учителя сучасної української школи ґрунтується на гуманістичних основах, які віддзеркалюють пріоритет індивідуальності, самобутності, самоцінності особистості, невідступне врахування вихователем того фракту, що кожен учень $є$ носієм унікального суб'єктивного досвіду, носієм лише йому притаманних певних можливостей, здатностей, інтенцій. У попередніх дослідженнях із проблеми [10; 11] доведено, що педагогічна фрасилітація в системі професійної діяльності сучасного вчителя має виконувати провідну роль, адже саме фрасилітація педагога забезпечує педагогічну підтримку особистісного розвитку учня та педагогічний супровід його навчальних досягнень.

Зв'язок із важливим науковим та практичним завданням. В умовах трансформаційних процесів в освіті важливу роль відіграє коректне визначення теоретичних засад переорієнтації роботи вчителя 3 «транслятора знань» на «генератора освітніх цінностей». Отже, вимагає ретельного розгляду специфіка профресійної діяльності вчителя як фрасилітатора, що невіддільно пов'язана зі сорормованістю в нього емпатійності, фасилятивності, рефлексивності як якостей його особистості, які за наявністю спрямованості на педагогічну діяльність перетворюються в якості професійно-значущі. Крім того, слід розглянути детальніше той аспект, що використання вчителем потенціалу педагогічної фрасилітації передбачає наявність усталених настанов на цей вид діяльності, які забезпечують безумовне позитивне прийняття того, хто навчається, емпатійне, щире й відкрите ставлення до нього. Потребує доведення той фракт, що ефективність здатності до педагогічної фрасилітації вчителя забезпечується усвідомленням специфіки й складності педагогічного спілкування, сорормованістю комунікативних, діалогічних, гуманістичних, рефрлексивних умінь, що дозволяють створювати атмоссреру, що стимулює потяг учня до нових знань, сприяє його творчому розвитку й особистісному зростанню.

Аналіз останніх досліджень і публікацій. У дослідженнях І. Авдєєвої [1], Г. Балла [4], О. Галіцан [10], Н. Носової [5], К. Роджерса [11] визначено фундаментальні й прикладні аспекти підготовки майбутніх учителів як фрасилітаторів освітнього процесу сучасних закладів освіти. Зокрема, Н. Носовою визначено потенціал урахування педагогом інтенцій, схильностей, здатностей, нахилів і талантів дитини для подальшого становлення їі індивідуальності, потреби в самореалізації та утвердженні власного «Я» [5, с. 287]. Розмірковуючи над специфікою сучасних змін у стратегічних підходах до учителювання та розробки освітнього середовища, дослідники фріксують, що «втілення гуманістичної ідеї в педагогічному процесі несумісне $з$ авторитарністю, з будь-якими проявами насильства над свідомістю та волею дитини, 3 маніпулюванням її поведінкою» [5, с. 289]. Як бачимо, науковцями доведено, що саме педагогічна фрасилітація як спосіб учителювання на позиціях тріади «педагогічна емпатія / педагогічна конгруентність / педагогічний оптимізм» (відповідно до позиції К. Роджерса [11, с. 137]) увиразнює гуманістичний підхід в оновленні системи фрункціювання закладів освіти нашої країни. Проте деталізація підготовки майбутніх учителів як фрасилітаторів для нової української школи, зокрема методичний аспект підготовки майбутніх учителів як фрасилітаторів, ще й досі залишається невирішеною частиною загальної науково-методичної проблеми.

Мета дослідження - розробити програму розвитку здатності до педагогічної фасилітації в майбутніх учителів у педагогічному університеті й експериментально перевірити її ефективність.

Завдання дослідження: 1) схарактеризувати особливості педагогічної фрасилітації як професійно-педагогічної діяльності сучасного вчителя; визначити показники її сорормованості в студентів педагогічного університету; 2) розробити експериментальну програму розвитку здатності до педагогічної фрасилітації студентів - майбутніх учителів у педагогічному університеті; 3) перевірити ефективність експериментальної програми розвитку здатності до педагогічної фрасилітації шляхом її впровадження в освітній процес педагогічного університету.

Методи дослідження. Для перевірки результатів упровадження експериментальної програми фрормування здатності до педагогічної фрасилітації студентів було використано теоретичні методи: вивчення та аналіз програм підготовки майбутніх учителів фрізико-математичних дисциплін і майбутніх учителів початкової школи (фізико-математичний фракультет (респонденти експериментальної групи (далі - ЕГ), 122 студенти) й фракультет початкового навчання (респонденти контрольної групи (далі - КГ), 130 студентів) Південноукраїнського національного педагогічного університету імені К.Д. Ушинського (м. Одеса); освітній рівень «бакалавр»); емпіричні методи: констатувальний експеримент для визначення вихідного рівня сорормованості здатності до педагогічної фрасилітації майбутніх учителів; формувальний експеримент із метою впровадження експериментальної програми фрормування здатності до педагогічної фрасилітації студентів; кількісний та якісний аналіз результатів дослідження для підтвердження дієвості впровадження розробленої експериментальної програми.

У дослідженні використано арсенал діагностувальних (тести, анкети, питальники) методик: методика визначення рівня емпатійності студента 
[7, с. 56]; методика діагностування показника доброзичливості [8, с. 117]; методика діагностування рівня «прийняття іншого» [2, с. 211]; діагностування особистісної настанови «альтруїзм егоїзм» [3, с. 314]; методика для діагностування «емоційного інтелекту» [8, с. 591]; орієнтована анкета для визначення мотивації на професійно-педагогічну діяльність [7, с. 167]; методика визначення рівня сорормованості педагогічного мислення [9, с. 278]; орієнтована анкета для визначення рівня сформованості знань специфіки педагогічного спілкування [9, с. 289]; методика діагностування рівня комунікабельності [8, с. 153]; методика діагностування здатності до самоконтролю в спілкуванні [6, с. 461]; методика діагностування рівня перцептивно-інтерактивної компетентності [9, с. 120]; методика діагностування рівня перцептивно-невербальної компетентності [9, с. 105]; орієнтована анкета «Чи вмієте Ви слухати» [3, с. 599]; методика діагностування рівня сорормованості рефлексивних педагогічних умінь [7, с. 245]; експрес-діагностика рівня самооцінки [6, с. 218]; методика діагностування імпульсивності особистості [2, с. 346]; методика діагностування рівня відповідальності особи [2, с. 160].

Виклад основного матеріалу. У процесі розробки експериментальної програми було враховано, що педагогічне спілкування створює умови для реалізації потенційних сутнісних сил суб'єктів педагогічного процесу. Щоб осмислити процеси педагогічного спілкування, майбутнім учителям необхідно визначити їхні ціннісні орієнтири, усвідомити, що вища цінність педагогічного спілкування - індивідуальність педагога й учня [1, с. 90] Специфіка педагогічного спілкування полягає в його першочерговій значущості - ефективне навчання, виховання та розвиток нової особистості. Через спілкування йде трансляція досвіду поколінь новому поколінню [1, с. 115]. Особливого значення ця проблема набуває в аспекті фрормування здатності до педагогічної фрасилітації майбутніх учителів, оскільки це така педагогічна діяльність, що має фрункціональним «інструментом» спілкування $з$ учнями, крім того, специфріка такої діяльності передбачає не лише мінімально необхідну сорормованість умінь спілкування, а й майстерне опанування не тільки всіма доступними видами профресійно-педагогічної комунікації, а ще й специфічними елементами педагогічної техніки, а саме навичками активного, пасивного, емпатійного й рефлексивного слухання тощо. Тому ми вважали необхідним сприяти розвитку умінь спілкування студентів, що позитивно впливає на розвиток комунікативної компетентності майбутніх учителів та $є$ складовою частиною здатності до педагогічної фрасилітації.

Домінувальними формами й засобами роботи зі студентами було обрано інтерактивні фрорми навчання, що передбачали використання різного типу вправ, рольових і моделювальних ігор, виконання психофрізичних вправ тощо; насичення навчального матеріалу наявних нормативних курсів інфрормацією про діалог, особливості використання діалогічного мовлення в професійній діяльності вчителя, діалог як засіб гуманізації спілкування між вчителем та учнями.

У межах роботи студентської проблемної групи було реалізовано експериментальну програму (у фрормі спецкурсу) для студентів «Формування здатності до педагогічної фрасилітації майбутніх учителів». За своїм обсягом спецкурс мав 60 навчальні години й проводився протягом року. Запропонований студентам спецкурс передбачав 16 лекційних годин, 36 семінарсько-практичних годин, а 8 годин відводилось на самостійну роботу студентів. Зміст було структуровано в таких модулях, як «Теоретичні засади фрормування здатності до педагогічної фрасилітації майбутніх учителів» і «Практикум із фрормування здатності до педагогічної фрасилітації майбутніх учителів».

Перший змістовий модуль спецкурсу передбачав проведення п'яти лекцій (10 годин), двох семінарсько-практичних занять (4 години), а також 8 годин навчального навантаження було відведено для самостійної роботи студентів. У межах змістового модуля «Теоретичні засади фрормування здатності до педагогічної фрасилітації майбутніх учителів» лекційний матеріал було присвячено таким темам, як «Педагогічна фрасилітація вчителя як психолого-педагогічний френомен», «Властивості та якості особистості вчителя-орасилітатора», «Профресійно-педагогічна компетентність вчителя-фрасилітатора», «Специфріка профресійної діяльності вчителя-орасилітатора».

На лекційних заняттях із теми «Педагогічна фасилітація вчителя як соціально-педагогічний феномен» студенти проаналізували літературні джерела, розглянули історичне підґрунтя становлення френомену фрасилітації як об'єкту наукових досліджень, зрозуміли, що гуманістична педагогічна думка $є$ історичною першоосновою для усвідомлення сутності здатності до педагогічної фрасилітації. Крім того, студентам було запропоновано розглянути різні інтерпретації терміну «фрасилітація» та «педагогічна орасилітація», вони ознайомились зі специфічними рольовими позиціями педагога-фрасилітатора, едвайзера, тьютора, ментора. Для самостійного опрацювання студентам було запропоновано дібрати й проаналізувати літературні джерела, скласти наукові доповіді з таких проблемних питань, як-от: фрасилітація як френомен вивчення різних наук; діяльність вчителяфасилітатора в педагогічних поглядах вітчизняних учених; педагогічні погляди й практична діяльність українських педагогів у контексті здатності до педагогічної фрасилітації. 
У контексті вивчення теми «Властивості та якості особистості вчителя-фрасилітатора» студентами було розглянуто напрями підготовки вчителя-фрасилітатора в системі національної освіти, розглянуто фрасилятивність та емпатійність як необхідні якості вчителя-фрасилітатора. Крім того, було приділено увагу розгляду профресійно-педагогічної спрямованості, гуманістичної спрямованості, педагогічній рефрлексії та профресійно-педагогічній усталеності вчителя-фрасилітатора. Для самостійного опрацювання в межах теми студентам було запропоновано торкнутися таких запитань, як: професійно-значущі якості й властивості особистості майбутнього вчителя-фрасилітатора; місце й роль здатності до педагогічної фрасилітації в системі профресійної підготовки майбутніх учителів; педагогічна фрасилітація як основа гуманізації освітнього процесу сучасної школи.

Під час розгляду теми «Професійна компетентність вчителя-фрасилітатора» студентами було з'ясовано сутність понять «компетентність», «професійна компетентність» і «профресійнопедагогічна компетентність», крім того, в контексті компетентнісного підходу в освіті ними було розглянуто важливий аспект професійної діяльності вчителя-фрасилітатора, а саме набуття ним комунікативної компетентності як комплексу певних знань, умінь і навичок професійно-педагогічного спілкування. Також студентам було надано новий теоретичний матеріал щодо аутопсихологічної компетентності вчителя-фасилітатора, діалогічних і гуманістичних умінь, необхідних для успішного виконання ним своєї професійної діяльності. Для самостійного опрацювання та аналізу для студентів було обрано такі аспекти: професійно-педагогічна компетентність сучасного вчителя-фрасилітатора; гуманізація та діалогізація взаємостосунків у діяльності вчителяфрасилітатора; гуманістичні вміння як запорука успішної діяльності вчителя-фрасилітатора.

У процесі засвоєння студентами матеріалу теми «Специфіка профресійної діяльності вчителя-фрасилітатора» майбутні вчителі розглянули педагогічну фрасилітацію в системі професійної підготовки фрахівців у ЗВО, проаналізували головні настанови в професійній діяльності вчителяфасилітатора за К. Роджерсом, а саме безумовне позитивне прийняття, емпатійне розуміння, відкритість і щирість, педагогічно їх інтерпретували. Крім того, було розглянуто профресійно-педагогічні рольові позиції в професійній діяльності вчителяфрасилітатора. Особливу увагу було приділено суб'єкт-суб'єктній і діалогічній позиції вчителяфасилітатора. Для самостійного розгляду студентам було обрано такі мінітеми: педагогічна емпатія в системі професійної діяльності вчителя-фрасилітатора; особливості профресійно-педагогічного спілкування вчителя-фрасилітатора; вербальні й невербальні засоби комунікації в профресійній діяльності вчителя-срасилітатора.

Другий змістовий модуль спецкурсу передбачав проведення двох лекцій (4 години), п'ятнадцяти семінарсько-практичних занять (30 годин), а 2 години було відведено для самостійної роботи студентів. Другий змістовий модуль спецкурсу «Практикум із формування здатності до педагогічної фрасилітації майбутніх учителів» містив такі теми лекцій, як «Розвиток професійно-значущих властивостей та якостей особистості майбутніх учителів» та «Актуалізація ціннісного ставлення до майбутньої професійної діяльності й усвідомлення специфіки професійної діяльності вчителяфрасилітатора».

На цих лекційних заняттях студенти усвідомлювали й обговорювали, аналізували специфічні фрункції та роль вчителя-срасилітатора в сучасній школі; розглядали педагогічну фрасилітацію як механізм гуманізації навчально-виховного процесу сучасної школи.

У ході практичних занять обов'язковим було залучення студентів до групових фоорм роботи, а саме: виконання завдання в групі під час семінарських і практичних занять; виконання домашнього завдання, що потребувало роботи в групі, підготовка сумісних рефрератів, доповідей тощо.

3 метою моніторингу динаміки сорормованості здатності до педагогічної фрасилітації в студентів було здійснено серію діагностувальних зрізів. За результатами діагностувальних зрізів на початку експериментальної роботи було одержано такі дані за показниками (емпатійність, рефлексивні педагогічні вміння, фрасилятивність, емоційний інтелект, перцептивно-інтерактивна компетентність, мотивація на професійно-педагогічну діяльність, педагогічне мислення; невербальна компетентність, обізнаність зі специорікою педагогічного спілкування, потреба в спілкуванні, здатність до самоуправління в спілкуванні, позиція в спілкуванні, самооцінка, професійна самосвідомість) в ЕГ: на високому рівні - 2,69\%, на достатньому рівні - 10,44 \%, на низькому рівні - 86,87 \% опитаних студентів; у КГ: на високому рівні - 3,88 \%, на достатньому рівні - 10,34 \%, на низькому рівні 85,78 \% всіх опитаних студентів. Сорормованість здатності до педагогічної фрасилітації студентів майбутніх учителів на прикінцевому етапі експерименту в ЕГ: на високому рівні - 22,56 \%, на достатньому рівні - 56,20 \%, на низькому рівні - 21,24 \% опитаних студентів; у КГ: на високому рівні $5,62 \%$, на достатньому рівні - 14,01 \%, на низькому рівні - 80,37 \% усіх опитаних студентів.

Висновки. Специфріка професійної діяльності сучасного вчителя має віддзеркалювати конструктивні зміни в парадигмі учителювання - зміщення акцентів у бік гуманізації та «олюднення» освітнього процесу школи. Названі процеси відбивають 
френомен здатності до педагогічної фрасилітації як способу педагогічної підтримки вчителем особистісного зростання учня як особистості й педагогічного супроводу його навчальних досягнень.

Розроблено експериментальну програму фрормування здатності до педагогічної фрасилітації майбутніх учителів у педагогічному університеті, яка передбачала набуття студентами спеціальних знань щодо френомену фрасилітації та механізмів ії реалізації в професійній діяльності в школі (знання щодо рольових позицій сучасного вчителя-срасилітатора, едвайзера, тьютора); набуття студентами досвіду впровадження механізмів здатності до педагогічної фрасилітації (педагогічної підтримки й педагогічного супроводу особистісного зростання учнів та їхніх навчальних досягнень).

Ефективність реалізації експериментальної програми формування здатності до педагогічної фрасилітації перевірена шляхом порівняння одержаних даних до й після проведення спеціальної експериментальної роботи (реалізація експериментальної програми у фрормі елективного курсу) зі студентами.

Перспективи подальших наукових розвідок у напрямі полягають у розробці спеціальної технології фрормування здатності до педагогічної фрасилітації в майбутніх учителів різного профрілю.

\section{БІБЛІОГРАФІЧНИЙ СПИСОК:}

1. Авдєєва І.М., Мельникова І.М. Інноваційні комунікативні технології в роботі куратора академгрупи : навчальний посібник. Київ : Профресіонал, 2002. 320 c.
2. Альманах психологических тестов / Составитель Р.С. Немов. Москва : КСП, 1995. 400 с.

3. Анастази А. Психологическое тестирование : Мастера психологии. Санкт-Петербург : «ПИТЕР», 2002. $688 \mathrm{c}$.

4. Балл Г.О. Психологічні аспекти гуманізації освіти : книга для вчителя. Київ : Рівне, 1996. 128 с.

5. Носова Н.В. Фасилітативна діяльність педагогів як складова гуманізації навчально-виховного процесу. Проблеми сучасної педагогічної освіти. Сер.: Педагогіка і психологія. Вип. 10. Ч. 1. Ялта : РВВ РВНЗ КГУ, 2006. С. 285-293.

6. Практикум по общей, экспериментальной и прикладной психологии: психологический практикум / В.Д. Балин и др. Санкт-Петербург : «ПИТЕР», 2003. 560 C.

7. Психологические тесты / под ред. А.А. Карелина. Москва : Гуманит. изд. центр ВЛАДОС, 2003. T. 1.312 c.

8. Райгородский Д.Я. Практическая психодиагностика : учебное пособие. Самара : Издательский дом «БАХРАХ», 1998. 672c.

9. Фетискин Н.П. Социально-психологическая диагностика развития личности и малых групп. Москва : Изд-во Института Психотерапии, 2002. $490 \mathrm{C}$.

10. Halitsan O. Innovative pedagogical technologies in a modern high school: facilitation and vitagene pedagogical technologies of teaching and upbringing students. Modern tendecies in pedagogical education and science of Ukraine and Israel : the way to integration. Ariel, 2017. № 8. P. 130-136.

11. Rogers C.R. The interpersonal relationship in the facilitation of learning. Educational Forum. 1976. Vol. XI. № 4. P. 136-154. 
КОНЦЕПТУАЛЬНІ ПІДХОДИ ДО ФОРМУВАННЯ ФАХОВОЇ КОМПЕТЕНТНОСТІ В УМОВАХ ВИЩОЇ МИСТЕЦЬКОЇ ОСВІТИ, ЗОКРЕМА У ПРОЦЕСІ ПРОФЕСІЙНОЇ ПІДГОТОВКИ МАЙБУТНІХ БАКАЛАВРІВ ДИЗАЙНУ

\author{
CONCEPTUAL APPROACHES TO THE FORMATION OF PROFESSIONAL \\ COMPETENCE IN THE CONDITIONS OF HIGHER ART EDUCATION, \\ IN PARTICULAR IN THE PROCESS OF PROFESSIONAL TRAINING \\ OF FUTURE BACHELORS OF DESIGN
}

Сучасне суспільство диктує нові вимоги до майбутнього бакалавру дизайну. Необхідно володіти певним рівнем фрахової компетентності для успішного впровадження інновацій у практику дизайнерської діяльності й реалізації ї у нових економічних і політичних умовах. Художньо-графрічні дисципліни, побудовані на основі компетентнісного підходу, мають широкі можливості для поглиблення загальноосвітньої підготовки, формування духовної культури й всебічного розвитку студентів. Нагальною потребою сучасної системи освіти є створення інноваційного художньопедагогічного освітнього середовища, яке забезпечить самореалізацію особистості майбутнього бакалавра дизайну в умовах вищої мистецької освіти. Необхідними компонентами такого середовища $є$ розробка й застосування в навчальному процесі інтенсивних, інтерактивних та інформаційнокомунікаційних орорм і методів задоволення професійних, освітніх $i$ художньо-творчих потреб студентів. Для забезпечення впровадження всіх вищезгаданих компонентів у навчальний процес в умовах вищої мистецької освіти в Україні необхідна обірунтована система проєктування освітнього середовища профресійної підготовки майбутніх дизайнерів, яка б реалізувала себе всередині освіт нього середовища профессійної підготовки таких фрахівців. У статті окреслено концептуальні підходи до розв'язання проблем формування фрахової компетентності майбутніх бакалаврів дизайну в умовах вищої мистецької освіти в Україні. Здійснено ірунтовний аналіз сучасних досліджень і публікацій щодо формування фрахової компетентності майбутніх бакалаврів дизайну. Обгрунтовано сутність поняття «компетентність» через призму державних освітніх стандартів вищої профресійної освіти щодо фрормування базових професійних компетентностей у майбутніх фрахівців дизайну. Розглянуто дизайн як невіддільну частину предметного й цифрового середовища і його роль у формуванні світогляду й естетики сучасної людини. Переглянуто методику формування фрахової компетентності майбутніх бакалаврів дизайну в процесі вивчення художньо-графічних дисциплін.

Ключові слова: фрахова компетентність, художньо-грасрічні дисципліни, вища мистецька освіта, дизайн, бакалавр дизайну.
Modern society dictates new requirements for the future Bachelor of Design. It is necessary to have a certain level of professional competence for the successful implementation of innovations in the practice of design activities and their implementation in the new economic and political conditions. Art and graphic disciplines, built on the basis of a competencybased approach, have ample opportunities for deepening general education, the formation of spiritual culture and comprehensive development of students. An urgent need of the modern education system is the creation of an innovative artistic and pedagogical educational environment, which will ensure the self-realization of the future bachelor of design in higher art education. Necessary components of such an environment are the development and application in the educational process of intensive, interactive and informationcommunication forms and methods of meeting the professional, educational and artistic needs of students. To ensure the implementation of all the above components in the educational process in the field of higher art education in Ukraine, a sound system of designing the educational environment of professional training of future designers, which would realize itself within the educational environment of professional training of these specialists. The article outlines the conceptual approaches to solving the problems of formation of professional competence of future bachelors of design in the conditions of higher art education in Ukraine. A thorough analysis of current research and publications on the formation of professional competence of future bachelors of design. The essence of the concept of "competence" through the prism of state educational standards of higher professional education for the formation of basic professional competencies in future design professionals is substantiated. Design is considered as an integral part of the subject and digital environment, and its role in shaping the worldview and aesthetics of modern man. The method of formation of professional competence of future bachelors of design in the process of studying graphic and graphic disciplines is revised.

Key words: professional competence, graphic arts disciplines, higher art education, design, bachelor of design.
Постановка проблеми в загальному вигляді. Профресійна діяльність фрахівця успішна тоді, коли ще під час навчання у вищому навчальному закладі він набуває досвіду практичної діяльності. Основу успішної професійної діяльності майбутніх бакалаврів дизайну становлять: сукупність фрахо- вих компетенцій, які передбачають опанування знаннями, вміннями й навичками в дизайнерській діяльності, уміння застосовувати набуті знання та вміння для розв'язання профеесійних завдань із дизайну, готовність до аналізу проблемних ситуацій і пошуку шляхів їх розв'язання, здатність 
майбутнього бакалавру дизайну працювати самостійно й у групі. Сорормовані компетентності використовуються як у практичній діяльності за орахом, так і залежно від умов, обставин і видів виконуваної дизайн-діяльності. Отже, професійна компетентність майбутнього бакалавру 3 дизайну виявляється в готовності здійснювати певну діяльність у конкретних ситуаціях [3].

Для забезпечення впровадження всіх вищезгаданих компонентів у навчальний процес в умовах вищої мистецької освіти в Україні необхідна обґрунтована система проєктування освітнього середовища профресійної підготовки майбутніх дизайнерів, яка б реалізувала себе всередині освітнього середовища професійної підготовки таких фрахівців.

Аналіз спеціальної та науково-педагогічної літератури свідчить, що проблеми фрормування компетентності студентів в умовах вищої мистецької освіти у своїх роботах розкривають багато дослідників: В. Даниленко, І. Герасименко, Є. Лазарєв (дизайн як система технології та естетики); О. Трошкін (розвиток ініціативності майбутніх дизайнерів у процесі навчально-творчої діяльності); О. Фурса (дизайн-освіта в мистецьких коледжах); В. Прусак (підготовка дизайнерів у вищих навчальних закладах). Теоретичні засади впливу творчої діяльності на розвиток особистості розглянуті в працях К. АльбухановоїСлавської, Ю. Бабанського, А. Брушлинського, В. Загвязінського, С. Рубінштейна, С. Сисоєвої та інших психологів і педагогів. Проблему творчої активності особистості вивчали Л. Виготський, А. Пономарьов, творчу індивідуальність розглядали А. Гільманов, В. Сластьонін. Окрім того, досліджувалися такі питання: творча діяльність особистості (В. Андреєв, Н. Нікандров), творчі здібності особистості (Д. Богоявленська, В. Юркевич, В. Розумовський), творчий потенціал особистості (А. Щетинська).

Виділення не вирішених раніше частин загальної проблеми. Проблема фрормування в майбутніх бакалаврів дизайну фрахової компетентності в зазначених та інших роботах не розглядається, що й зумовило актуальність теми статті.

Постановка завдання. Мета статті - схарактеризувати й викласти основні концептуальні підходи до формування фрахових компетентностей у майбутніх бакалаврів дизайну в умовах вищої мистецької освіти.

Разом із цим постає питання про обґрунтування сутності фрахової компетентності майбутніх бакалаврів дизайну й опис оптимальних методичних рішень для досягнення вищеназваних цілей.

Поставлені завдання розв'язуються такими методами дослідження: теоретичним - аналіз і вивчення психолого-педагогічної, фрілософрської, спеціалізованої та художньої літератури для визначення та обґрунтування фрормування фрахової компетентності майбутніх бакалаврів дизайну в умовах вищої мистецької освіти України; уточнення поняття «компетентність» і «фрахова компетентність»; праксиметричним - для визначення ефективності поетапного впровадження методики розвитку фрахової компетентності майбутніх бакалаврів дизайну під час подальших досліджень.

Виклад основного матеріалу. Розвиток мотивів студентів у навчальній діяльності, зокрема таких важливих, як інтерес до обраної профресійної діяльності, стимулює прагнення досягти в ній певних результатів, пов'язане 3 дотриманням принципу творчості й співтворчості в навчанні. В основу цього принципу покладено ідеї В. Андреєва, В. Кан-Каліка, А. Мудрика, О. Яковлевої про «творчу самодіяльність», «розвиток самого себе через творчу діяльність», унаслідок чого навчання перетворюється на особистісно зорієнтований процес, що дає змогу розширити можливості розвитку індивідуальності студента, поглиблює його креативність, веде до формування його профресійної компетентності. У творчості, зокрема дизайнерській, студент реалізується як цілісна особистість, котра розвивається [1].

У сучасному його розумінні дизайн вже не ідентифрікується з художнім конструюванням, промисловою естетикою тощо. Якщо раніше його роль вбачалася в основному в облагороджуванні зовнішнього вигляду продуктів промислового виробництва (з метою поліпшення їх збуту), то нині дизайн, крім власне художнього конструювання, передбачає практично весь комплекс проблем, пов'язаних зі створенням предметного й цифрового середовища сучасної людини й займає одну з головних ролей у формуванні світогляду й естетики тих, хто користується результатами дизайн-діяльності. [8]. Невірна чи неповна ідентифрікація дизайну в системі сучасної дизайносвіти - причина її застарілості. Одним зі шляхів оновлення змісту мистецької освіти й узгодження його із сучасними потребами, інтеграцією до європейського й світового освітніх просторів є орієнтація навчальних програм на набуття ключових компетентностей і створення ефективних механізмів їх запровадження.

У сучасній педагогіці й психології постійно досліджується професійно-педагогічна підготовка майбутнього педагога як компетентного, здатного до саморозвитку в умовах нової структури й змісту початкової освіти (Н. Бібік, О. Савченко); загальні принципи організації педагогічного процесу й основні напрями конструювання змісту психолого-педагогічної підготовки, що забезпечують формування вчителя-новатора, який перебуває в постійному пошуку ефективних і раціональних методів навчання та виховання (Л. Хомич); фрормування творчої особистості (Н. Кічук, С. Сисоєва); 
організація професійного самовиховання майбутніх педагогів (О. Кучерявий); формування етичної компетентності майбутніх вчителів (Л. Хоружа) [2].

Готовність педагога до профресійної діяльності трактується вченими як особистісне утворення, що забезпечує внутрішні мотиви діяльності, педагогічну самосвідомість, педагогічні здібності, знання, вміння та навички, здатність до інтегрування знань, просресійно значущі якості особистості. Воно містить особистісну (педагогічну самосвідомість, інтерес до діяльності, потреба в ній, мотиви діяльності) й процесуальну (педагогічні здібності, знання про предмет і способи діяльності, навички й уміння, професійно значущі якості) частини, мобілізує особистість на включення в професійну діяльність [7].

Вимоги суспільства до суттєвого зростання предметної, методичної та наукової компетентності випускників ВН3, підготовки дизайнера як високопрофесійного фрахівця, спроможного до есрективної профресійної діяльності, спричиняють появу необхідності розробки нових підходів, форм і методів для здійснення процесу мистецької підготовки майбутніх бакалаврів дизайну. Профресійнопедагогічна підготовка розглядається вченими (О. Хижна) як підготовка майбутнього дизайнера до неперервного профресійного розвитку, процес опанування знаннями, уміннями, навичками, способами дій у системі професійної освіти, необхідних для здійснення того або іншого виду профресійної діяльності. Бувши за своєю суттю культуротворчою, художньо-педагогічна діяльність у різні періоди розвитку суспільства відбивала й відбиває певний рівень культури. Художньо-педагогічна підготовка розглядається в такому контексті як важливий механізм культурної спадкоємності, форма збереження та розвитку культурного надбання нації та всього людства, фрактор життєздатності молодого покоління, яке завтра визначатиме долю України, як важливий ресурс духовного відродження та стратегічний напрям державної політики й зумовлює їі визначення як процес і результат педагогічно організованого становлення особистості студента як суб'єкта культури й освіти шляхом освоєння системи художньо-педагогічних знань, цінностей, принципів комунікації та досвіду художньо-педагогічних практик, що є невіддільною частиною художньо-графрічної компетентності.

У чому ж полягає компетентнісний підхід в освіті? Насамперед у підвищенні ролі інтелектуального, комунікативного, морального, когнітивного й інорормаційного освітнього компонентів. Крім того, важливим завданням сучасної освіти $€$ визначення складових частин компетентності, що забезпечують якість освіти. Саме тому, на думку вчених (Н. Бібік, О. Овчарук, О. Пометун, О. Савченко, А. Хуторськой), необхідно переорієнтувати навчальні програми й педагогічні технології на компетентнісний підхід, а це вимагає перегляду специфріки побудови освітнього середовища профресійної підготовки. Адже саме компетентнісний підхід забезпечує фрормування фахової компетентності як інтегрованого багаторівневого утворення в цілісній професійній структурі особистості майбутнього бакалавра дизайну, спрямовується на досягнення поставленої мети, є показником сформованості професійно необхідних знань, умінь, навичок, якостей, цінностей і практичного досвіду самостійної та пошуково-дослідної роботи [2].

Вітчизняні дослідники В. Олійник, Я. Болюбаш, Л. Даниленко, І. Єрмаков, С. Клепко вважають, що профресійна компетентність дизайнера $є$ інтегральною якістю особистості, що має свою структуру, яка дає змогу фрахівцеві найефективнішим способом здійснювати свою діяльність, а також сприяє його саморозвитку й самовдосконаленню як у системі підвищення кваліфікації, так і в процесі самоосвітньої роботи. А в «Національному освітньому глосарії вищої освіти» фрахова компетентність визначається як динамічна комбінація знань, вмінь і практичних навичок, способів мислення, професійних, світоглядних і громадянських якостей, морально-етичних цінностей, яка визначає здатність особи успішно здійснювати професійну й подальшу навчальну діяльність і $є$ результатом навчання на певному рівні вищої освіти [6, с. 25].

Створення інноваційного художньо-педагогічного освітнього середовища, спрямованого на забезпечення самореалізації особистості майбутнього бакалавра дизайну в умовах вищої мистецької освіти, засноване на розробці й застосуванні в навчальному процесі інтенсивних, інтерактивних та інформаційно-комунікаційних фрорм і методів задоволення його професійно-освітніх і художньотворчих потреб. Проєктоване нами інноваційне художньо-педагогічне освітнє середовище характеризується такими ознаками: наявність настанов і позитивної мотивації на художньо-педагогічну діяльність майбутнього бакалавра дизайну; здійснення цілеспрямованої, систематичної підготовки студентів до опанування знаннями 3 психологопедагогічних і профресійно орієнтованих дисциплін художньо-педагогічного спрямування та фрормування індивідуально-творчого стилю професійно педагогічної діяльності; наявність емоційно-сприятливого клімату й взаємостосунків співпраці й співтворчості, діалогового спілкування між викладачами й студентами в процесі професійної підготовки; створення атмоссрери культурно-освітнього середовища, наповненого художньо мистецьким змістом.

Художньо-грасрічні дисципліни, побудовані на основі компетентнісного підходу, мають широкі можливості для поглиблення загальноосвітньої підготовки, формування духовної культури й всебічного розвитку студентів. Водночас зберігаються 
передбачені наявними програмами власне технологічні знання та вміння. Однак тут вони виконують роль засобу, а не мети навчання. Разом із тим не $€$ метою цього предмету фрормування в майбутніх бакалаврах дизайну системи спеціальних знань із галузі дизайну. Усе це лише становить необхідну основу (яка $є$ у будь-якого навчального предмета), що дозволяє організувати вивчення навколишнього світу з певних позицій, які не використовуються в інших галузях знань і доповнюють його загальну картину. Мета компетентнісного підходу в технологічній освіті майбутніх бакалаврів дизайну - допомогти їм розглянути зміст і призначення предмета по-іншому й організувати процес дизайн-діяльності не тільки як послідовність технологічних процесів та операцій, а як проєктну діяльність. Формування фрахової компетентності в технологічному навчанні змінює й методику організації діяльності студентів.

Висновки. Отже, фрормування профресійної компетентності майбутнього бакалавра дизайну в умовах вищої мистецької освіти являє собою цілісний безперервний процес, який реалізується в умовах освітнього середовища професійної підготовки таких фрахівців. Технологія проєктування освітнього середовища професійної підготовки передбачає єдність, взаємозумовленість, наступність усіх фрункцій і структурних компонентів, що ії формують. Іїі неперервність $€$ необхідною умовою розширення та поглиблення професійної підготовки, забезпечення можливості постійного переходу фрахівця на новий, вищий рівень фахової компетентності.

На вимогу сучасного суспільства майбутньому бакалавру дизайну для успішного впровадження в практику інновацій і реалізації їх у нових економічних і політичних умовах необхідно володіти певним рівнем фрахової компетентності. Основу професійної компетентності майбутнього бакалавру дизайну становлять виховання сприйняття проєктної культури й розвиток дизайнерського мислення. Її фрормування є важливою передумовою та показником готовності майбутнього бакалавру дизайну до професійної діяльності. Така готовність досягається під час морально-психологічної, професійної та художньої підготовки і $є$ результатом всебічного розвитку його особистості. Зміст профресійної компетентності майбутнього бакалавра дизайну визначається квалісрікаційною характеристикою, що представлена нормативною моделлю компетентності фрахівця та відбиває науково обґрунтований склад професійних знань, умінь і навичок [4, с. 303]. Художньографрічні дисципліни, побудовані на основі компетентнісного підходу, мають широкі можливості для поглиблення загальноосвітньої підготовки, фрормування духовної культури й всебічного розвитку студентів.

\section{БІБЛІОГРАФІЧНИЙ СПИСОК:}

1. Бібік Н.В. Компетентнісний підхід: рефлексивний аналіз. Компетентнісний підхід у сучасній освіті: світовий досвід та українські перспективи: Бібліотека з освітньої політики / за ред. О.В. Овчарук. Київ : «К.І.С.», 2004. С. 45-50.

2. Зимняя И.А. Ключевые компетентности - новая парадигма результата образования. Высшее образование сегодня. 2003. № 5. С. 34-42.

3. Коваль Л.В. Просресійна підготовка майбутніх учителів початкової школи: технологічна складова : монографрія. Донецьк : Юго-Восток, 2009. 375 с.

4. Марущак О.В. Зміст профресійної компетентності майбутнього вчителя технологій з дизайну одягу. Збірник наукових праць Кам'янець-Подільського національного університету ім. Івана Огієнка. Сер. Педагогічна. 2013. Вип. 19. С. 302-304.

5. Нагорна Н.В. Формування у студентів понять компетентності й компетенції. Виховання і культура. 2007. № 1-2. C. 266-268.

6. Національний освітній глосарій : вища освіта. 2-е вид., перероб. і доп. / В.М. Захарченко та ін. ; за ред. В.Г. Кременя. Київ, 2014. 100 с.

7. Пометун. О.І. Компетентнісний підхід у сучасній освіті: світовий досвід та українські перспективи. Бібліотека з освітньої політики / за ред. О.В. Овчарук. Київ : К.І.С., 2004. С. 64-70.

8. Фалько В.П. Формирование художественнопроектной компетенции педагога профессионального обучения в области дизайна : дис. ... канд. пед. наук : 13.00 .08 ; Рос. гос. профр.-пед. ун-т. Екатеринбург, 2009. 188 с. 


\section{ТЕХНОЛОГІЗАЦІЯ ЯК НАПРЯМ МОДЕРНІЗАЦІЇ ПРОФЕСІЙНОЇ ПІДГОТОВКИ} МАЙБУТНЬОГО ВЧИТЕЛЯ У ЗАКЛАДІ ВИЩОЇ ОСВІТИ

\section{TECHNOLOGIZATION AS DIRECTION OF MODERNIZATION OF PROFESSIONAL TRAINING OF FUTURE TEACHERS IN HIGHER EDUCATION INSTITUTIONS}

\begin{abstract}
у статті досліджуються питання технологізації як напряму модернізації просресійної підготовки майбутнього вчителя в закладі вищої освіти. Дослідження базується на розкрuтmi сутності й змісту таких дефрiнiuiŭ, як «технологізація», «технологічний підхід» та аналізу їх взаємозв'язків у контексті професійної підготовки майбутнього вчителя в закладі вищої освіти. Незважаючи на явну схожість інтерпретації понять «технологічний підхід» $i$ «технологізація», в нашому дослідженні пріоритет віддається другому терміну, тому що для опису тенденції, напряму модернізації профресійної підготовки майбутнього вчителя ия дефрініція ширша. Технологічний підхід - це практичний підхід, який застосовується для управління освітнього прочесу й гарантує досягнення навчальних завдань.
\end{abstract}

На основі системного вивчення вище вказаних понять зроблено висновок про те, що технологізація - це сучасна тенденція, основа модернізації професійної підготовки майбутнього вчителя в закладі вищої освіти, що передбачає ефективне перетворення освітнього процесу в закладі вищої освіти, спрямованого на його оптимізацію та раціоналізацію, а також сприяє формуванню технологічної культури майбутнього педагога, активне проєктування та реалізацію технологій у профресійній діяльності майбутнього вчителя. У статmі представлена хронологія впровадження технологізації як напряму реформування та модернізації профресійної освіти й описані основні їі етапи (20-mi - 50-mi pp. XX cm.; 50-mi - 60-mi pp. XX cm.; 70-mi pp. $X X$ cm.; 80-mi pp.; 90-mi pp. XX cm. 2000-mi pp.). Виокремлено основні принципи модернізації профресійної підготовки майбутнього вчителя в умовах технологізації вищої освіти України, а саме: орієнтованості на розвиток особистості майбутнього вчителя; відповідності змісту професійної підготовки майбутнього вчителя сучасним і прогнозованим тенденціям розвитку науки й суспільства; оптимального поєднання традиційних, групових та індивідуальних орорм організації освітнього процесу закладу вищої освіти; раціонального застосування сучасних методів і засобів навчання; відповідності навчальних результатів підготовки майбут нього вчителя вимогам сфрери його профресійної діяльності; сприяння забезпечення конкурентоспроможності майбутнього вчителя. Ключові слова: технологізація, технологізація освіти, технологічний підхід, технологізація профресійної підготовки майбутнього вчителя, принципи модернізації профресійної підготовки майбутнього вчителя.

The article examines the issues oftechnologization as a direction of modernization of professional training of future teachers in higher education $(\mathrm{HEI})$. The research is based on the disclosure of the essence and content of such definitions as "technologization", "technological approach" and analysis of their relationships in the context of professional training of future teachers in freelance education. Despite the obvious similarity in the interpretation of the concepts of "technological approach" and "technologicalization", in our study, priority is given to the second term, as to describe the trend, the direction of modernization of professional training of future teachers, this definition is broader. The technological approach is a practical approach that is used to manage the educational process and ensures the achievement of educational objectives. Based on a systematic study of the above concepts, it is concluded that technologization is a modern trend, the basis for modernization of professional training of future teachers in free economic education, which provides effective transformation of the educational process into free economic education, aimed at its optimization and rationalization. culture of the future teacher, active design and implementation of technologies in the professional activities of the future teacher. The article presents the chronology of the introduction of technologicalization as a direction of reforming and modernization of vocational education and describes its main stages The basic principles of modernization of professional training of the future teacher in the conditions of technologicalization of higher education of Ukraine are allocated, namely: orientation on development of the personality of the future teacher; compliance of the content of professional training of the future teacher with modern and forecasted tendencies of development of science and society; optimal combination of traditional, group and individual forms of organization of the educational process of HEl; rational application of modern teaching methods and tools; compliance of the educational results of the future teacher's training with the requirements of the sphere of his professional activity; promoting the competitiveness of future teachers.

Key words: technologicalization, technologicalization of education, technological approach, technologicalization of professional training of future teachers, principles of modernization of professional training of future teachers. Національного університету «Чернігівський колегіум» імені Т.Г. Шевченка

Неписьменними у XXI столітmі будуть не ті, хто не вміє читати й писати, а mi, хто не може вчитися та переучуватися.

Е. Тосрорлер

Постановка проблеми в загальному вигляді. Проблема модернізації професійної підготовки педагога актуальна в усьому світі. Сучасна підготовка вчителя до трудової та професійної діяльності вима- гає переосмислення самого змісту освіти, структури й фрорм організації.

Не випадково ці питання відбиті в нормативних освітніх документах, спрямованих 
на забезпечення якісної підготовки майбутніх учителів: Національній стратегії розвитку освіти в Україні на 2012-2021 роки (2012 р.), Галузевій концепції розвитку неперервної педагогічної освіти, проєкті «Шкільний вчитель нового покоління» (2013р.), Законі України «Про вищу освіту» (2014 р.), Концепції «Нова українська школа» (2016 р.), Концепції розвитку профресійної освіти і навчання в Україні (2010-2027 рр.) [6; 7], «Про Концепції розвитку педагогічної освіти» (2018р.).

Питання оновлення стандартів професійної підготовки вчителів відбито в низці міжнародних документів, а саме: рекомендації ЮНЕСКО та МОП (Міжнародної організації праці) «Про становище і статус учителів» (1996р.), «Європейська Хартія регіональних мов або мов меншин Маніфест Ради Європи» (1996 р.), «На шляху до Європи знань» (1997 р.), «Неперервна освіта у XXI ст.: зміна ролей педагогічного персоналу» (2000р.) і «Загальноєвропейські рекомендації з мовної освіти: вивчення, викладання, оцінювання» (Страсбург, 2002 р.).

«Поява державних стандартів загальної, середньої та вишівської освіти, - зазначає І. Зязюн, фрормує ситуацію суміщення дослідницької домінанти у вивчені системи неперервної педагогічної підготовки в напрямі способів збільшення міри суб'єктності майбутніх спеціалістів у процесі свого саморозвитку, а також вивчення процесів саморегуляції в системі професійного становлення та пошуку інноваційних технологій підготовки» [5].

Перед сучасним закладом вищої педагогічної освіти (3ВО) стоїть завдання впровадження новітніх підходів до навчання, що забезпечують поряд із його фундаментальністю та дотриманням вимог Державних освітніх стандартів розвиток комунікативних, творчих і професійних компетентностей, потреб у самоосвіті на основі потенційної багатоваріантності змісту й організації освітнього процесу. Очікується, що саме технологізація профресійної підготовки майбутнього педагога сприятиме розв'язанню цих задач.

Аналіз останніх досліджень і публікацій. Питання вдосконалення процесу просресійної підготовки спеціалістів в умовах вищої школи підіймаються в багатьох сучасних наукових дослідженнях. У роботах учених-педагогів увага приділяється розвитку загальної методології профресійної освіти (І. Зязюн, В. Євтух, О. Дубасенюк, Р. Гуревич, В. Курило, А. Міненок, Н. Ничкало, О. Пєхота, С. Сисоєва й інші).

Особливий інтерес у питанні модернізації фрахової підготовки майбутнього вчителя становить технологізація. Передумови й особливості технологізації навчання схарактеризовані в роботах зарубіжних вчених Б. Блум, Дж. Керрол, Д. Брунер, Г. Гейс, В. Коскареллі й інших.

Технологізація як механізм впровадження педагогічних технологій у систему діяльності загальноосвітнього закладу й вищої школи досліджували науковці Ю. Бабанський, В. Беспалько, В. Бондар, М. Кларін, О. Пєхота, С. Прийма, Т. Селевко й І. Середа, Н. Тализіна, О. Янкович та інші.

Постановка мети та завдань. Мета статті розкрити сутність ідей технологізації та їх вплив на модернізацію професійної підготовки майбутнього вчителя в закладі вищої освіти. Задля досягнення мети були визначені такі завдання дослідження:

- проаналізувати сутність поняття «технологізація»;

- визначити етапи технологізації як напряму модернізації професійної підготовки майбутнього вчителя;

- виокремити основні принципи вдосконалення професійної підготовки майбутнього вчителя в умовах технологізації вищої освіти України

Методи дослідження. Дослідження проведене із застосуванням таких теоретичних методів: системний аналіз і синтез, індукція та дедукція, порівняння, класифікація, узагальнення та систематизація, ідеалізація та абстрагування.

Виклад основного матеріалу. Розбудова інфрормаційно-технологічного суспільства, глобалізація та рефрорми вищої та середньої школи потребують підготовки вчителя нової генерації [6]. У Концепції Нової української школи зазначається, що «суттєвих змін зазнає процес і зміст підготовки вчителя, оскільки педагог виконуватиме роль не тільки наставника і джерела знань, а коуча, фасилітатора, тьютора, модератора в індивідуальній освітній траєкторії дитини» [7]. Для досягнення цих завдань необхідно створювати й впроваджувати новітні освітні технології, які б задовольняли повноцінне освоєння змісту майбутньої педагогічної діяльності.

Різні автори трактують поняття «профресійна освіта» по-різному: як особистісні характеристики готовності до професійної діяльності (Р. Гуревич, О. Пєхота, С. Сисоєва), як компетентність (Г. Волновицький, В. Гайворонський, Г. Сєрікова), як майстерність (І. Зязюн, В. Сластьонін), як освіченість (О. Кульчицька, О. Романовський), як профресіоналізм (Н. Ничкало, О. Отич).

Впровадження технологізації як напряму рефрормування та модернізації професійної освіти можна умовно розділити на кілька етапів:

- 20-ті - 50-ті рр. XX ст. - технологізація освіти за допомогою технічних засобів навчання ( «Технізація освіти»);

- 50-ті - 60-ті рр. XX ст. - програмно орієнтоване навчання з паралельним розвитком технічних засобів навчання; сплеск інтересу до електроннообчислювальних машин; початок використання дефрініції "educational technology" на Заході;

- 70-ті рр. XX ст. - активне використання в зарубіжній науці терміна "educational technology"; популяризація поняття «технологія» в науковопедагогічній літературі; 
- 80-ті рр. - 90-ті рр. XX ст. - активне використання поняття «технологія» у вітчизняній педагогіці; бум інформаційних технологій в освіті;

- 3 90-х рр. XX ст. починають з'являтись дослідження вітчизняних науковців про використання технологій у підготовці вчителя; пошук та опис нових освітніх технологій; переосмислення можливостей реалізації технологізації освіти на основі зміни способів та основ навчання;

- $з$ 2000-х років у ЗВО з'являються навчальні курси, які містять елементи сучасних педагогічних технологій. Такі курси характеризуються професійною та практичною спрямованістю.

Ступінь вивченості переваг технологізації та використання педагогічних технологій висока в контексті модернізації професійної підготовки сучасного вчителя.

У монографрії О. Янкович «Освітні технології вищої школи України: проблеми та перспективи» подано ретроспективний аналіз розвитку освітніх технологій та інтеграції вищої освіти України для підготовки педагогів до реалізації технологічного підходу, вказано на доцільність національнопарксеологічної моделі освітньо-виховної концепції держави (суспільної метатехнології), детально проаналізовано експериментально розроблену технологію «організації успішної діяльності» [15].

Деякі вчені вважають, що технологізація допоможе в досягненні прогресивно-якісного й нового результату в освіті й науці. Основними принципами покращення технологічності освітнього процесу, за М. Фіцулою [13], є: ефективність; керованість; концептуальність; системність; відтворюваність.

Аналіз публікацій науковців засвідчив, що технологічні рішення модернізації професійної підготовки сучасного вчителя прискорюють і полег- шують процес засвоєння знань, умінь і способів діяльності, забезпечують гарантований результат.

Технологізація як узагальнювальне поняття модернізації та вдосконалення освітньої сфери вимагає поняттєвого аналізу й уточнення.

Наведемо спочатку приклади нечисленних визначень технологізації як сучасної тенденції (напряму) вдосконалення професійної підготовки майбутнього вчителя у ЗВО (таблиця 1).

Розгорнуте визначення технологізації пропонує І. Зязюн, який вважає, що технологізація - історично неперервний в освіті процес. Ми переконані, що завдяки технологізації в системі освіти здійснюється спадковість нових технологій, виникає готовність до їхньої адаптації через призму реолексії. Ми погоджуємося також із твердженням автора, що, хоча технологізація освіти є об'єктивним процесом, який постійно розвивається, її вектор визначається в основному науково-технічним прогресом і технологізацією суспільства, яка охоплює всі сорери його буття [5].

У сучасній педагогічній науці визначено об'єкти й продукти технологізації освітнього процесу. До складу об'єктів технологізації в освітній діяльності належать: цілі, зміст, організаційні форми сприйняття, перероблення та представлення інфрормації, взаємодії суб'єктів освітньої діяльності, процедури їхньої особистісно-профресійної поведінки, самоуправління та творчого розвитку. До продуктів технологізації освітнього процесу (з боку того, хто навчається) належать: особистісні соціально й професійно важливі алгоритми й стереотипи поведінки, мірою доцільності й ефективності яких $€$ успішність і конкурентоспроможність випускників освітніх установ [10].

У близькому за контекстом до «технологізації» в науково-педагогічній літературі використовують

\section{Визначення технологізації, надані різними вченими}

Таблиця 1

\begin{tabular}{|c|c|}
\hline О. Янкович [15] & $\begin{array}{l}\text { «<..> технологізацією української педагогічної освіти є проєктування та впровадження тех- } \\
\text { нологій професійної підготовки майбутнього фрахівця та технологій фрормування компетент- } \\
\text { ностей, необхідних у діяльності вчителя». }\end{array}$ \\
\hline І. Смагін [12] & $\begin{array}{l}\text { “<...> технологізація як відповідна індустріальному суспільству модернізація освіти вступає } \\
\text { в суперечність з особистісно орієнтованою освітою, зміст якої потрібно пророщувати в особі } \\
\text { кожного учня. Алгоритмізація педагогічних дій конфрліктує з необхідністю пошуку й творчості». }\end{array}$ \\
\hline с. Сисоєва [10] & $\begin{array}{l}\text { «Головна ідея технологізації освітнього процесу полягає в перетворенні педагогічного про- } \\
\text { цесу в освітній установі на цілеспрямований процес діяльності всіх його суб'єктів». }\end{array}$ \\
\hline $\begin{array}{l}\text { М. Вовк } \\
\text { і С. Ходаківська [2] }\end{array}$ & $\begin{array}{l}\text { «Тенденція технологізації навчання слугує підтвердженням конструктивних змін в європей- } \\
\text { ському освітньому середовищі, що зумовлено інтенсифрікацією набуття життєих і професій- } \\
\text { них навичок різних категорій дорослих, необхідністю оптимізації термінів і змісту навчання } \\
\text { у зв'язку зі зміною фраху, пошуку нових видів діяльності особистістю, що прагне змінити } \\
\text { індивідуальну траєкторію життя». }\end{array}$ \\
\hline В. Желанова [4] & $\begin{array}{l}\text { «технологізація освіти в сучасному ВНЗ є есрективною щодо фрормування в студентів нави- } \\
\text { чок XXI століття, якими є емоційний інтелект, критичне мислення, навички комунікації та } \\
\text { співробітництва, медіаграмотність, креативність і новаторство особистості, її адаптаційні } \\
\text { можливості». }\end{array}$ \\
\hline В. Вишківська [1] & $\begin{array}{l}\text { “<...> саме технологізація навчання шляхом цілеспрямованого педагогічного управління } \\
\text { процесом суб'єктного перетворення студентів може забезпечити розвиток співробітництва, } \\
\text { саморозвиток і самоуправління суб'єктів навчального процесу». }\end{array}$ \\
\hline
\end{tabular}


поняття «технологічний підхід», який широко використовується під час вивчення проблеми підготовки кадрів і застосовують із метою фрормування професійно значущих компетентностей майбутнього вчителя. На думку В. Курило й Г. Щуки, технологічний підхід визначається як метод пізнавальної та управлінської діяльності, що дозволяє за допомогою об'єкта-замінника системи адекватно й цілісно зобразити її сутність, найважливіші якості й засоби. [8]. Г. Селевко вважає, що значущість технологічного підходу до організації педагогічного процесу полягає в тому, що це дає змогу: з більшою визначеністю передбачати результати й керувати педагогічними процесами; аналізувати й систематизувати на науковій основі наявний практичний досвід і його використання; комплексно розв'язувати освітні й соціально-виховні проблеми; забезпечувати сприятливі умови для розвитку особистості; зменшувати ефект впливу несприятливих обставин на людину; оптимально використовувати наявні в розпорядженні ресурси; вибирати найефективніші й розробляти нові технології та моделі для розв'язання утворюваних соціальнопедагогічних проблем [11]. О. Дубасенюк, кажучи про технологічний підхід стосовно професійнопедагогічної підготовки майбутніх учителів, у такий спосіб характеризує його: «<...> педагогічна діяльність складна й багатогранна й містить безліч непередбачених педагогічних ситуацій. Тому творчий характер педагогічної професії не потребує повної деталізації та конкретизації усього навчального процесу, <...> вимоги повного засвоєння навчального матеріалу слід застосовувати до виділених базових педагогічних знань та умінь. Бажано спеціально передбачати навчальну діяльність із додаткового й розвивального матеріалу» [3, с. 11]. Узагальнюючи думки вище зазначених дослідників, можемо стверджувати, що технологічний підхід - це практичний підхід, який застосовується для управління освітнім процесом і гарантує досягнення навчальних завдань.

Незважаючи на явну схожість інтерпретації понять «технологічний підхід» і «технологізація», в нашому дослідженні пріоритет віддається другому терміну, тому що для опису тенденції, напряму модернізації профресійної підготовки майбутнього вчителя ця деорініція ширша.

У монографії О. Пєхоти й І. Середи «Формування технологічної культури майбутнього викладача» наголошується на необхідності опанування технологічними вміннями й навичками, що виявляється в набутті досвіду застосування сучасних технологій у професійній діяльності під час стажування майбутнього викладача й самостійному обґрунтованому виборі напрямів розвитку технологічної культури [14, с.91-95]. У дисертації С. Прийми показано, що функцією технологічної культури $€$ здійснення профресійно-педагогічної діяльності в умовах технологізації освіти, а системоутворювальним фрактором є сама професійнопедагогічна діяльність [9]. Повністю погоджуємось із позицією авторів із боку їхнього розуміння технологізації та вважаємо, що для технологізації професійної підготовки майбутнього вчителя в закладі вищої освіти потрібна не лише розробка технології його підготовки, а й формування вміння застосовувати в професійній діяльності дидактичні інструментарії для реалізації технологій навчання на його основі.

Визначення сутності, змісту й структури десрініції «технологізація» ще не знайшло свого остаточного тлумачення. Більшість дослідників розглядають технологізацію як процес теоретичного обґрунтування та реалізації технологій із метою рівня сорормованості в майбутніх фрахівців визначених компетентностей і гарантують досягнення навчальних завдань. Тобто під технологізацією можна розуміти сучасну тенденцію, основу модернізації професійної підготовки майбутнього вчителя в закладі вищої освіти, що передбачає ефективне перетворення освітнього процесу у ЗВО, спрямованого на його оптимізацію та раціоналізацію, а також що передбачає сорормованість рівня технологічної культури майбутнього педагога, активне проєктування та реалізацію технологій у професійній діяльності майбутнього педагога.

Висновки та перспективи подальших досліджень. Відомо, що освітній процес у ЗВО потребує постійної модернізації, як і підготовка майбутнього фрахівця. Нині можемо говорити про те, що технологізація сприяє вдосконаленню та модернізації профресійної підготовки майбутнього вчителя в закладі вищої освіти. Спираючись на нові методи, теоретичні й методичні засади в освітньому просторі, можемо вдосконалювати систему якості освіти й зміцнити їі конкурентоспроможність у ринковому середовищі держави. 3 огляду на зазначене, варто виокремити основні принципи модернізації професійної підготовки майбутнього вчителя в умовах технологізації вищої освіти України:

1) орієнтованості на розвиток особистості майбутнього вчителя;

2) відповідності змісту професійної підготовки майбутнього вчителя сучасним і прогнозованим тенденціям розвитку науки й суспільства;

3) оптимального поєднання традиційних, групових та індивідуальних форм організації освітнього процесу 3ВО;

4) раціонального застосування сучасних методів і засобів навчання;

5) відповідності навчальних результатів підготовки майбутнього вчителя вимогам сорери його профресійної діяльності;

6) сприяння забезпечення конкурентоспроможності майбутнього вчителя. 
Межі нашого наукового пошуку дозволили нам розв'язати не всі аспекти модернізації професійної підготовки майбутнього вчителя в закладі вищої освіти. На нашу думку, подальші наукові дослідження з питання полягають у тому, щоб удосконалити поєднання означених принципів в умовах технологізації 3ВО. Потребують подальшого дослідження педагогічні умови, що найкраще сприятимуть формуванню та вдосконаленню особистості майбутнього педагога.

\section{БІБЛІОГРАФІЧНИЙ СПИСОК:}

1. Вишківська В.Б. Формування у майбутніх учителів здатності до конструювання навчальнопізнавальної діяльності школярів : дис. ... канд. пед. наук : 13.00.04 «Теорія і методика професійної освіти». Національний педагогічний ун-т ім. М.П. Драгоманова. Київ, 2006. 219 с.

2. Вовк М.П., Ходаківська С.В. Технології навчання дорослих в умовах формальної і несормальної освіти. Освіта дорослих: теорія, досвід, перспективи. 2019. Вип. 2 (16). С. 39-48.

3. Дубасенюк. О.А. Технології професійно-педагогічної підготовки майбутніх учителів : навчальний посібник / Житомир. держ. пед. ун-тет. Житомир, 2001. 384 c.

4. Желанова В.В. Розвиток рефрлексивної компетентності та суб'єктності як ознак обдарованої особистості майбутнього педагога у ВНЗ. Вісник Житомирського державного університету імені Івана Франка. Педагогічні науки. 2017. Вип. 2. С. $118-122$.

5. Зязюн І.А. Технологізація освіти як історична неперервність. Неперервна професійна освіта : теорія і практика. 2001. Вип. 1. С. 73-85.
6. Концептуальні засади розвитку педагогічної освіти України та її інтеграції в європейський відкритий простір. URL: http:osvita/legisbation/Visha/ osvita/3145.

7. Концепція Нової української школи. URL: https:// www.kmu.gov.ua /.../ukrainska-shkola-compressed.pd.

8. Курило В.С., Щука Г.П. Можливості оптимізації науково-дослідної роботи студентів. Освіта та педагогічна наука. 2016. № 1 (164). С. 5-12.

9. Прийма С.М. Формування технологічної культури майбутніх учителів інсрорматики у процесі професійно-педагогічної підготовки : дис. ... канд. пед. наук : 13.00 .04 «Теорія і методика просресійної освіти» ; Харківський національний педагогічний ун-т ім. Г.С. Сковороди. Харків, 2006. 256 с.

10. Сисоєва С.О. Педагогічні технології: коротка характеристика сутнісних ознак. Педагогічний процес: теорія та практика. 2006. Вип. 2. С. 127-131.

11. Селевко Г.К. Сучасні освітні технології : навчальний посібник. Миколаїв : Народна освіта, 1998. 256 c.

12. Смагін I.I. Педагогічна технологія і методична система в шкільному навчанні. Вісник Житомирського державного університету імені Івана Франка. 2013. Вип. 1. С. 40-43.

13. Фіцула М.М. Педагогіка : навчальний посібник для студентів вищих педагогічних закладів освіти. Київ : Академія, 2002. 528 с.

14. Формування технологічної культури майбутнього викладача : монограсрія. / за ред. О.М. Пєхота, І.В. Середа, Н.О. Прасол та ін. Миколаїв : Іліон, 2016. 314 c.

15. Янкович О.І. Освітні технології вищої школи України: проблеми та перспективи : монографрія /Тернопільський національний педагогічний університет імені В. Гнатюка, Ін-т педагогіки і психології. Тернопіль : Підручники і посібники, 2010. 208 с. 


\section{ВИРОБНИЧА ПРАКТИКА У ФОРМУВАННІ ПРОФЕСІЙНОЇ ГОТОВНОСТІ МАЙБУТНІХ БАКАЛАВРІВ ФІЗИЧНОЇ ТЕРАПІї, ЕРГОТЕРАПІї ДО ФІЗИЧНОЇ РЕАБІЛІТАЦІї ДІТЕЙ ДОШКІЛЬНОГО ВІКУ

\author{
PRODUCTION PRACTICE IN THE FORMATION OF PROFESSIONAL \\ READINESS OF FUTURE BACHELORS OF PHYSICAL THERAPY, \\ OCCUPATIONAL THERAPY FOR PHYSICAL REHABILITATION
}

У статті розглянуто проблему покращення фахової підготовки майбутніх бакалаврів із фрізичної терапії та ерготерапії через особливу організацію їхньої виробничої практики. Встановлено й схарактеризовано напрями поліпшення умов організації практично підготовки майбутніх фрахівців із фрізичної терапії та ерготерапії в умовах потениійної майбутньої професійної діяльності. Основна думка спрямована на розкриття прочесу підготовки майбутніх срахівців із фрізично терапії та ерготерапії як складної прогресивної системи, яка здійснює підготовку квалісрікованого фрахівия нового покоління для реалізації вмінь і навичок у сфрері оздоровчореабілітаційних і відновлювальних послуг, а отже важливою складовою є організація практичної роботи студентів.

Стаття характеризує

- низку фуункиій виробничої практики: адаптаційну, навчальну, виховну, розвивальну й діагностичну;

- дотримання специфрічних принципів: динамічності й комплексності, інтеграції закладу освіти й бази практики, варіативності змісту, формм і методів навчання, колективного аналізу діяльності студентів та інше;

- специфрічні завдання виробничої практики: спостереження за роботою реабілітологів; складання плану індивідуальних програм реабілітації окремих пацієнтів; співпрацю (допомогу) з персоналом реабілітаційної установи; виконання індивідуального завдання в галузі фрізичної реабілітації дітей дошкільного віку; накопичення емпіричного матеріалу для виконання кваліфрікаційного дослідження.

Аналіз стану виробничої п рактики майбутнього спеціаліста з фрізичної терапії та ерготерапії як засобу підготовки фрахівців цієі галузі для фьізичної реабілітації дітей дошкільного віку виявив ряд суттєвих недоліків: перебільшення обсягу теоретичної підготовки в освітніх програмах і недостатній обсяа педагогічної практики; переважна спрямованість підготовки майбутніх фрахівиів на теоретичне осмислення профресійної діяльності без урахування важливості знань, умінь і навичок майбутнього спеціаліста у фрізичній реабілітації дітей дошкільного віку; тенденція до збільшення часу на самостійну й індивідуальну роботу студентів і зменшення кількост годин на теоретичні лекції та практичну підготовку майбутніх срахівців із фрізичної терапіі та ерготерапії; порівняно короткий період стажування, що недоцільно для формування професійних навичок і вмінь фрізичної реабілітації дітей дошкільного віку.

Ключові слова: виробнича практика, професійна готовність, майбутні орахівці 3 фрізичної терапії та ерготерапії, срізична реабілітація, діти дошкільного віку.
The article analyzes the problem of optimizing the practical training of future specialists in physical therapy and occupational therapy. The article reveals the peculiarities of the organization of production practice of future specialists in physical therapy and occupational therapy; identified areas for improving the practice of future specialists in physical therapy and occupational therapy. The leading idea of the study is based on understanding the process of training future specialists in physical therapy and occupational therapy as a complex dynamic system that provides the formation of a competent specialist of the new generation, prepared for professional activity and competitive in the market of health and rehabilitation services.

The article describes:

- a number of functions of production practice: adaptive, educational, pedagogical, developmental and diagnostic

- observance of specific principles: dynamism and complexity, integration of educational institution and base of practice, variability of the maintenance, forms and methods of training, the collective analysis of activity of students and others,

- specific tasks of production practice observation of the work of rehabilitation specialists; drawing up a plan of individual rehabilitation programs for individual patients cooperation (assistance) with the staff of the rehabilitation institution; performance of an individual task in the field of physical rehabilitation of preschool children; accumulation of empirical material for qualification research.

Analysis of the state of production practice of the future specialist in physical therapy and occupational therapy as a means of training specialists in physical therapy and occupational therapy for physical rehabilitation of preschool children has identified a number of significant shortcomings: exaggeration of the volume of theoretical training in educational programs and insufficient volume of pedagogical practice; the predominant orientation of the training of future professionals on the theoretical understanding of professional activity, without taking into account the importance of knowledge, skills and abilities of the future specialist in the physical rehabilitation of preschool children; the tendency to increase the time for independent and individual work of students and reduce the number of hours for theoretical lectures and practical training of future specialists in physical therapy and occupational therapy; a relatively short period of internship, which is impractical for the formation of professional skills and abilities of physical rehabilitation of preschool children. Key words: production practice, professional readiness, future specialists in physical therapy and occupational therapy, physical rehabilitation, preschool age. 
Постановка проблеми в загальному вигляді. Проблема фрормування професійної готовності майбутніх фрахівців фрізичної терапії та ерготерапії актуальна, оскільки студенти, які здійснюють навчання на таких спеціальностях, повинні бути готовими до майбутньої професійної діяльності в особливих умовах. Необхідність осмислення проблем профресійної готовності майбутніх фрахівців із фрізичної терапії та ерготерапії до фрізичної реабілітації дітей дошкільного віку в сучасних умовах зумовлена насамперед розвитком високотехнологічного освітнього процесу в дошкільних установах і гострою потребою у кваліфрікованих фрахівцях, здатних здійснювати творчий підхід у розв'язанні пріоритетних завдань профресійної діяльності. Слід готувати майбутніх фрахівців із фрізичної терапії та ерготерапії до певної специфіки їхньої практики, яка потребує високого рівня підготовленості, в тому числі й фрізичної, що передбачає сорормований і водночас активний характер рухових дій, психічної, що забезпечує сприйняття особливих соціальних і психологічних умов професійної діяльності, підготовленості до саморозвитку, зокрема розвитку в собі здатностей адаптуватися та самонавчатися.

У межах професійної підготовки фрахівця педагогічна практика $є$ одним із дієвих засобів фрормування професійної готовності. Освітні програми їхньої підготовки 3 необхідністю передбачають вивчення фахових дисциплін, яке завершується виробничою практикою, що гарантує студентам результативність у формуванні уявлень про майбутню професійну діяльність та особливості їі реалізації в реальних умовах.

Аналіз останніх досліджень і публікацій. Організація практики студентів регулюється низкою нормативних актів і положень: Закони України «Про освіту» (2017р.), «Про вищу освіту» (2014 р.), чинні натепер Накази Міністерства освіти і науки України (далі - МОНУ) «Про затвердження Положення про проведення практики студентів вищих навчальних закладів України» (1993р.), внутрішні університетські положення про організацію практик студентів закладів вищої освіти тощо. Удосконалення практичної підготовки студентів увиразнено в таких нормативних документах: лист МОНУ «Про практичну підготовку студентів» (2009 р.), Положення «Про практичну підготовку студентів вищих навчальних закладів» (2011р.), розпорядження Кабінету Міністрів України «Про затвердження плану першочергових заходів із виконання Державної програми розвитку внутрішнього виробництва» (2012 р.), наказ Міністерства освіти і науки, молоді та спорту України «Щодо плану першочергових заходів з виконання Державної програми розвитку внутрішнього виробництва» (2012р.), рекомендації про проведення практики студентів вищих навчальних закладів, які розроблені Інститутом інноваційних технологій і змісту освіти.

Закон України «Про вищу освіту» (2017р.) визначає практичну підготовку студентів у ЗВО як один із важливих компонентів освітнього процесу. Разом з іншими видами занять, фрорм навчання та засобів фрахової підготовки практична підготовка «здійснюється шляхом проходження практики на підприємствах, в установах та організаціях згідно 3 укладеними вищими навчальними закладами договорами або в його структурних підрозділах, що забезпечують практичну підготовку» [3].

Проблему професійної підготовки майбутніх фрахівців із фрізичної реабілітації та ерготерапії у ЗВО розглядають Ю. Лянной (2015 р.), Н. Бєлікова (2012 р.), Л. Сущенко (2015 р.) та інші. У своїх дослідженнях автори більшою мірою приділяють увагу моделюванню та характеристиці основних компонентів профресійної компетентності, розглядають становлення особистості фрахівця в контексті цілей і завдань фрізичної культури $[1 ; 4 ; 7]$.

Проте узагальнення результатів наукових розвідок свідчить, що в теорії професійної освіти проблема формування професійної готовності майбутніх бакалаврів фрізичної терапії, ерготерапії до фрізичної реабілітації дітей дошкільного віку засобами виробничої практики не знайшла свого системного розв'язання.

Виділення невирішених раніше частин загальної проблеми. Залишається відкритим питання вдосконалення практичних вмінь і навичок майбутніх фрахівців із фрізичної терапії, ерготерапії в процесі роботи з дітьми дошкільного віку шляхом реорганізації виробничої практики.

Мета статті - обґрунтувати важливість і доцільність фрормування професійної готовності майбутніх бакалаврів фрізичної терапії, ерготерапії до фрізичної реабілітації дітей дошкільного віку засобами виробничої практики.

Досягнення мети дослідження потребувало використання низки теоретичних методів наукового пізнання: аналіз наукових джерел і нормативних актів із метою обґрунтування актуальності проблеми дослідження; систематизація та узагальнення результатів наукових розвідок щодо визначення провідних ідей дослідження; термінологічний аналіз для уточнення ключових десініцій дослідження; структурнологічний аналіз для виявлення важливих складових частин практичної підготовки фрахівців із фрізичної терапії, ерготерапії; а також емпіричних методів: опитування для виявлення негараздів в організації виробничої практики майбутніх фрахівців із фрізичної терапії, ерготерапії.

Виклад основного матеріалу. Кожна освітня програма передбачає необхідною складовою частиною виробничу практику, в процесі якої відбувається інтенсивне засвоєння теоретичних знань, набутих під час навчання, розвивається 
усвідомлене ставлення до профресійних умінь, розвиваються навички, які спонукають до професійного розвитку й саморозвитку, поглиблюється інтерес до профресії. Як зазначає О. Сергійчук, виробнича практика $€$ важливим етапом фрахової підготовки й інструментом практичного опанування профресією [6, с. 189]. Саме в процесі виробничої практики закладаються основи фрахової діяльності, фрормуються професійні якості особистості й розвивається інтерес до майбутньої професії. Отже, виробничу практику необхідно сприймати провідною ланкою в процесі фрормування професійної готовності майбутніх фрахівців із фрізичної терапії та ерготерапії (далі - ФТіЕ) до фрізичної реабілітації дітей дошкільного віку.

Зміст практики фрахівців із ФТіЕ з фрізичної реабілітації дітей дошкільного віку охоплює всі фрункції та види їхньої професійної діяльності. Під час виконання завдань програми практики передбачено практичний досвід щодо фрормування окремих умінь: умінь планувати, організовувати, здійснювати специсрічні види професійної діяльності в умовах дошкільних і реабілітаційних закладів. Виконання обов'язків реабілітолога в процесі виробничої практики сприяє фрормуванню навичок профресійної рефрлексії та саморозвитку, усвідомленню важливих психологічних якостей фрахівця ФТіЕ, становленню та успішній професійній адаптації в майбутньому.

Як зазначають науковці О. Браславська, І. Макаревич, Г. Черкас, виробнича практика, в тому числі й майбутніх фрахівців ФТіЕ, виконує низку фрункцій: адаптаційну, навчальну, виховну, розвивальну й діагностичну (рис. 1) [2; 8].

Також слід зважати на результати досліджень Н. Недосєкової [5, с. 69-75], яка в організації виробничої практики виокремлює чотири етапи, які будуть доцільними для організації виробничої практики майбутніх ФТіЕ (рис. 2).

Узагальнення результатів наукових розвідок щодо організації виробничої практики майбутніх фрахівців засвідчує, що практика організовується не лише 3 урахуванням загальнодидактичних принципів навчання, серед яких зв'язок навчання з життям, безперервність, послідовність, зв'язок теорії та практики, системність, наочність, індивідуалізація та диференціація та інше, а й специорічних принципів, серед яких відзначимо принципи

адаптаційна функція практики виявляеться в тому, що майбутні фахівці 3 фізпчної терапії та ерготерапії знайомляться 3 різними типами реабілітаційних закладів, організацією роботи в них, адаптуються до умов праці, ритму, починає реально уявляти труднощі й можливі досягнення професійної діяльності

навчальна функція практики полягає в практичній перевірці знань, набутих у процесі теоретичної підготовки, відбувається процес формування професійних цінностей, рефлексія, що дозволяє моделювати і вшконувати власну професійну ділльність

виховна функція практики виявляється в тому, що студент може виробити в собі терпіння, відповідальність, почуття обов'язку, витримку, сформувати потребу в самоосвіті й самовихованні

розвивальна функція забезпечує розвиток практичних вмінь та навичок професійної діяльності студента, який навчається думати і діяти в реальних професійних ситуаціях

діагностична функція виявлясться у забезпеченні студентові можливості оцінити недоліки в теоретичній підготовці, свій емоційнпй стан, усвідомпгт напрямп подальшого професійного самоудосконалення 
динамічності й комплексності, інтеграції закладу освіти й бази практики, варіативності змісту, форм і методів навчання, колективного аналізу діяльності студентів та інші (їхній розширений перелік подано на рис. 3).

Виробнича практика майбутніх фрахівців ФТіЕ проводиться після опанування студентами теоретичного матеріалу загальноосвітніх дисциплін (цикл загальної підготовки) й професійно орієнтованих дисциплін (цикл професійної підготовки).
У процесі виробничої практики теоретичні знання студентів і квазіпрофесійні уміння мають інтегрувати між собою та поглибитися, конкретизуватися, розвинутися та удосконалитися. Саме в процесі виробничої практики майбутніх фрахівців ФТіЕ в них фрормуються індивідуальні способи дій, напрацьовується індивідуальний стиль, відбувається опанування професійних фрункцій.

Основними завданнями (навчальними й практичними) майбутніх фрахівців ФТіЕ в процесі
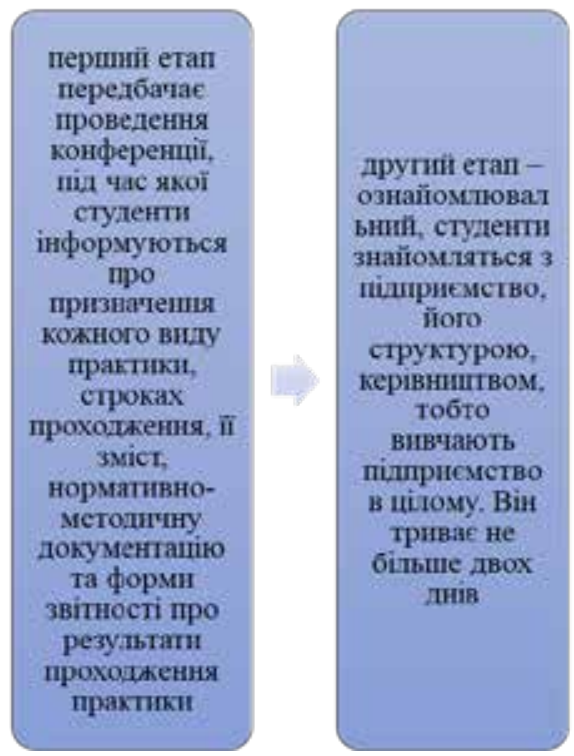

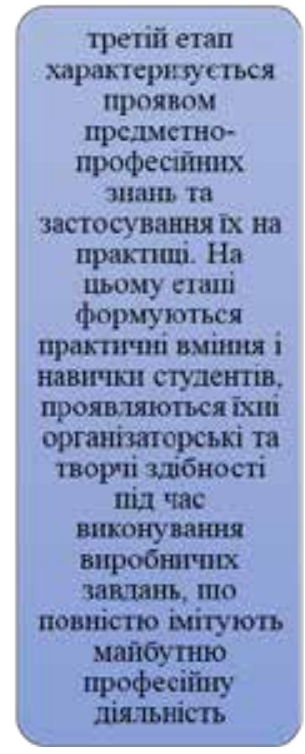

Рис. 2. Етапи організації виробничої практики

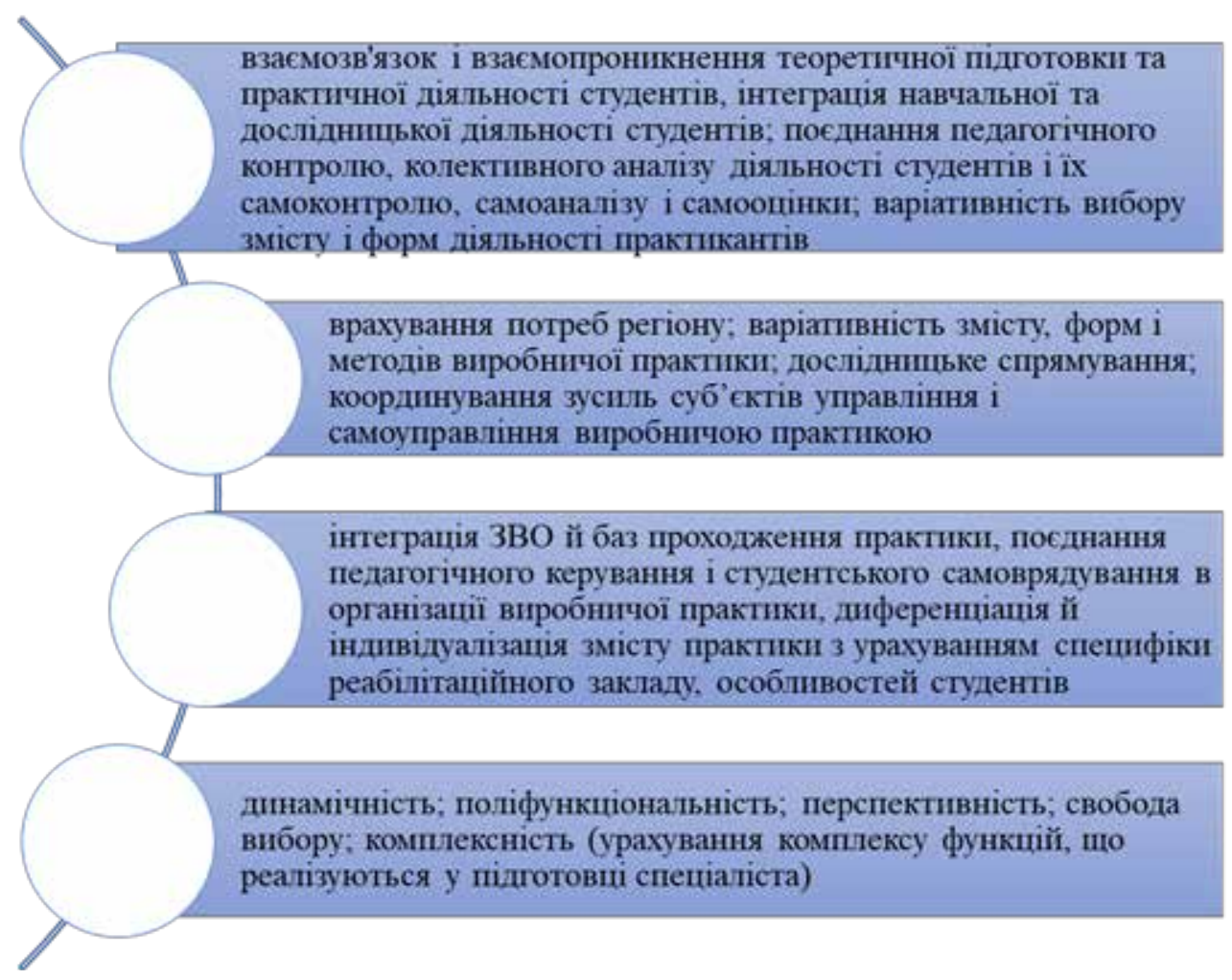

Рис. 3. Принципи організації виробничої практики 
виробничої практики в дошкільних закладах є: спостереження за роботою реабілітологів; складання плану індивідуальних програм реабілітації окремих пацієнтів; співпраця (допомога) з персоналом реа- білітаційної установи; виконання індивідуального завдання в галузі ФТіЕ (це може бути реферат або презентація або доповідь); накопичення матеріалу для кваліфрікаційної роботи (рис. 4).

спостерігати за роботою реабілітологів, фізичних терапевтів, ерготерапевтів, які працюють у дошкільному закладі

•проводити оцінку стану фізичної реабілітації дітей дошкільного віку: збирати анамнез, проводити обстеження, обираючи адекватні методи обстеження (тести), які прийняті у фізичній терапії та ерготерапії, відповідно до стану дитини, враховуючи патологічні розлади органів та систем дитини з обмеженням життєдіяльності; проводити педагогічні спостереження, застосовуючи різноманітні вимірювання та оцінювальні шкали

планувати індивідуальну програму реабілітаційних заходів: аналізувати інформацію зібрану з
медичних записів; виявляти основні проблеми та складати реабілітаційний прогноз; визначати
короткотермінові та довготермінові цілі; вибирати відповідні методи реабілітації, включаючи ї
послідовність, частоту та тривалість

•проводити реабілітаційні втручання (заходи), використовуючи різні форми лікувальної фізичної культури, методи масажу, механотерапію, фізіотерапію, ерготерапевтичні маніпуляції при фізичній реабілітації дітей дошкільного віку

співпрацювати в процесі проходження практики з персоналом закладу, дотримуючись деонтологічних принципів спілкування: зберігати конфіденційність інформації, уникаючи обговорення іiі зі сторонніми особами

•в процесі реабілітації забезпечувати поточний та етапний контроль за станом дитини з оцінкою ефективності проведення фізичної терапії та ерготерапії й аналізом отриманих результатів: спостерігати за симптомами та реакцією дитини на реабілітаційне втручання; вносити корекцію у програму, враховуючи результати спостереження та повторні обстеження дітей; надавати чіткі та стислі вказівки дитині для заохочення та досягнення оптимального результату; надавати практичні рекомендації членам сім'ї щодо подальшого відновлення функцій, правильного поводження; надавати долікарську допомогу при невідкладних станах

виконати індивідуальне завдання: підготувати реферат або презентацію на задану тематику, використовуючи тематичну науково-методичну літературу, Інтернет-ресурс

використати практичний досвід, набутий під час проходження практики (лабораторноінструментальні результати оцінки ефективності застосовуваних реабілітаційних процедур при функціональних порушеннях органів і систем, зумовлених різними нозологічними формами захворювань чи травмами) для виконання кваліфікаційної роботи

\section{Рис. 4. Завдання майбутніх фахівців із фрізичної терапії та ерготерапії під час проходження практики}

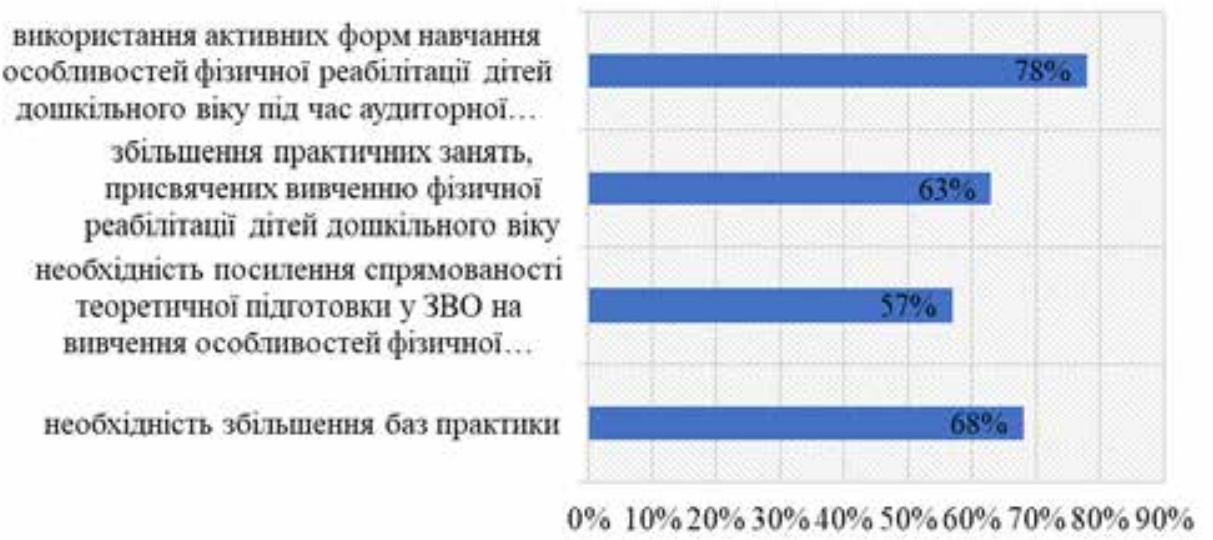

Рис. 5. Розподіл відповідей за результатами опитування 
Нами було проведено опитування, до якого залучено 54 студенти й 12 викладачів, яке мало на меті визначити недоліки в організації виробничої практики майбутніх фрахівців ФТіЕ для успішного фрормування в них готовності до фрізичної реабілітації дітей дошкільного віку.

Опишемо отримані результати (рис. 5).

Розподіл відповідей на запитання анкети «Чи вважаєте Ви, що під час проходження виробничої практики набули здатностей до фрізичної реабілітації дітей дошкільного віку?» як суб'єктивну оцінку результатів практики подано на рис. 6 .

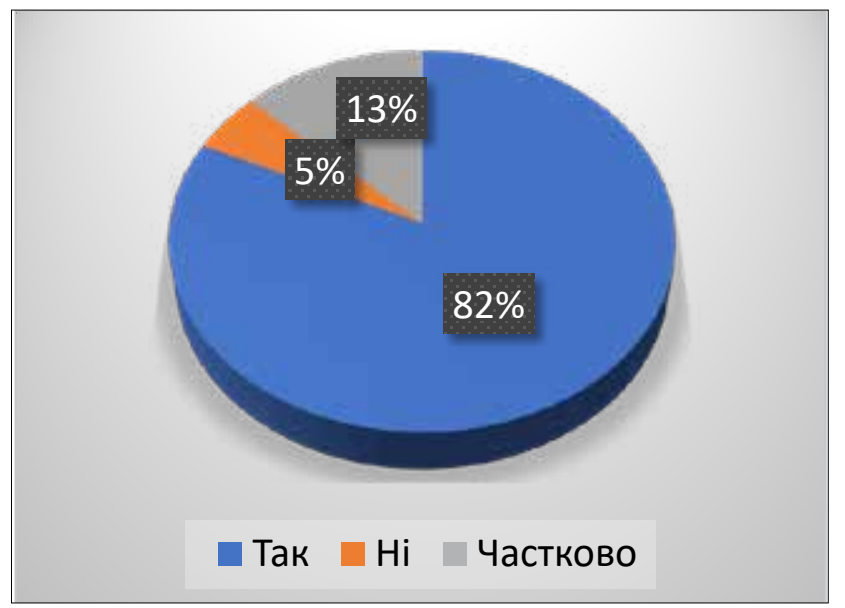

\section{Рис. 6. Суб'єктивна оцінка результатів практики щодо набуття здатностей до фізичної реабілітації дітей дошкільного віку}

Аналіз практичного стану розробленості проблеми організації виробничої практики майбутніх фрахівців із ФТіЕ як невіддільного компонента їхньої професійної підготовки в контексті фрормування готовності до фрізичної реабілітації дітей дошкільного віку дозволив виокремити низку проблем:

- замалі щодо загальної теоретичної підготовки фрахівців обсяги кредитів, що відведені на виробничі практики (6-9 кредитів до 240 загальних, з яких близько половини відводиться на теоретичну підготовку майбутніх орахівців ФТіЕ);

- орієнтування освітніх програм професійної підготовки майбутніх фрахівців ФТіЕ більшою мірою на загальне теоретичне усвідомлення професійної діяльності, натомість незначними є акценти на теоретичну й практичну підготовку фрахівців за спеціалізацією, зокрема до реабілітації дітей дошкільного віку;

- негативний вплив трендів збільшення самостійної роботи у вивченні кожної з дисциплін, що нівелює можливість якісної комунікації з фрахівцями галузі, набуття практичних вмінь у навчальній аудиторії як квазіпрофесійному просторі;

- карантинні обмеження зумовили зменшення контактних годин із фахівцями й пацієнтами в і так відносно короткий термін виробничої практики, що знизило можливість фрормування професійної готовності майбутніх фрахівців ФТіЕ до фрізичної реабілітації дітей дошкільного віку.

\section{Висновки.}

1. Однією з важливих складових частин фрормування профресійної готовності майбутніх фрахівців ФTіЕ до фрізичної реабілітації дітей дошкільного віку є виробнича практика, яка включена до освітньо-профресійних програм їхньої підготовки й має на меті набуття навичок організації фрахової діяльності, інтеграцію теоретичних знань і професійних умінь і навичок для розроблення індивідуальних програм фрізичної реабілітації дітей дошкільного віку.

2. Виробнича практика майбутніх фрахівців ФТіЕ з фрізичної реабілітації дітей дошкільного віку виконує низку фрункцій: адаптаційну, навчальну, виховну, розвивальну й діагностичну й передбачає дотримання специорічних принципів: динамічності й комплексності, інтеграції закладу освіти й бази практики, варіативності змісту, фрорм і методів навчання, колективного аналізу діяльності студентів та інші.

3. У фрормуванні готовності майбутніх фрахівців ФTіЕ до фрізичної реабілітації дітей дошкільного віку важливим $€$ виконання в процесі виробничої практики низки специфічних завдань: спостереження за роботою реабілітологів; складання плану індивідуальних програм реабілітації окремих пацієнтів; співпраця (допомога) з персоналом реабілітаційної установи; виконання індивідуального завдання в галузі фрізичної реабілітації дітей дошкільного віку; накопичення емпіричного матеріалу для виконання кваліфікаційного дослідження.

4. Аналіз практичного стану розробленості проблеми організації виробничої практики майбутніх фрахівців із ФТіЕ в контексті фрормування в них готовності до фрізичної реабілітації дітей дошкільного віку дозволив виокремити низку проблем, які слід послідовно розв'язувати розробникам освітніх програм, аби поліпшити якість професійної підготовки й забезпечити успішне фрормування готовності майбутніх фрахівців ФТіЕ до фрізичної реабілітації дітей дошкільного віку.

\section{БІБЛІОГРІФІЧНИЙ СПИСОК:}

1. Бєлікова Н.О. Підготовка майбутніх фрахівців 3 фрізичної реабілітації до здоров'язбережувальної діяльності : теорія та методика : монографрія. Київ : TOВ «Козарі», 2012. 584 с.

2. Браславська О.В., Макаревич І.М. Сучасні підходи до створення організаційно-педагогічних умов педагогічної практики студентів ВНЗ. Збірник наукових праць Уманського державного педагогічного університету. 2014. Ч. 1. С. 52-58.

3. Про освіту : Закон України від 5 вересня 2017 р. № 2145-VIII / Верховна Рада України. URL: https:// zakon.rada.gov.ua/laws/show/2145-19. 
4. Лянной Ю.О. Профресійна підготовка магістрів 3 фрізичної реабілітації у вищих навчальних закладах України. Science and Education a New Dimension. Pedagogy and psychology. 2015. III (29): 57. C. 39-42.

5. Недосєкова Н.С. Критерії та рівні ссрормованості готовності до професійної діяльності майбутніх інженерів-педагогів харчового профілю в процесі виробничої практики. Вісник Черкаського університету. Серія: Педагогічні науки. 2013. № 26 (279). C. 69-75.

6. Сергійчук О.М. Профресійна компетентність у вищій педагогічній освіті - від теорії до практики.
Теоретична і дидактична фрілологія. 2017. № 24. C. 183-193.

7. Сущенко Л.П. Розвиток здібностей майбутніх фахівців з фрізичної реабілітації в процесі фрахової підготовки. Фізичне виховання, спорт і культура здоров'я у сучасному суспільстві. 2015. № 3 (31). C. 52-55.

8. Черкас Г.В. Педагогічна практика у системі підготовки вчителів. Педагогіка, психологія та медикобіологічні проблеми фрізичного виховання і спорту. 2008. № 8. С. 155-158. 
ФАСИЛІТАЦІЙНА КОМПЕТЕНТНІСТЬ МАЙБУТНЬОГО ПЕДАГОГА: СУТНІСТЬ I СТРУКТУРА

\section{FACILITATIVE COMPETENCY OF A FUTURE TEACHER: ESSENCE AND STRUCTURE}

\begin{abstract}
Актуальність цієї статті зумовлена соціально-економічними, інноваційно-освітніми трансорормаціями в житті України, а також глобалізаційними процесами, орієнтованими на інтеграцію нашої держави зі світовою спільнотою, які об'єктивно зумовлюють зміни векторів розвитку усіх ланок освіти в напрямі людиноцентризму, розгляду особистості здобувача освіти як вищої цінності. y cmammi розглянуто френомен фрасилітації у межах реалізації компетентнісного підходу. На основі аналізу семантичних складників, якими є «фрасилітація» та «компетентність», обгрунтовано поняття «фрасилітаційної компетентності». Представлено авторську дефрініцію фрасилітаційної компетентності майбутнього педагога як його інтегровану характеристику, що синтезує його провідні профресійно-особистісні якості, які забезпечують готовність до фрасилітації суб'єктів освітнього процесу. Визначено структуру фасилітаційної компетентності майбутнього педагога, яка містить мотиваційно-аксіологічний, когнітивний, праксіологічний компоненти, що мають аспект перцепції, інтеракції, комунікації.

З'ясовано, що мотиваційно-аксіологічний компонент пов'язаний із фасилітаційною позичією, яка передбачає людиночентровану установку, ставлення до здобувачів освіти як до найвищої цінності, відкритість, доброзичливість, толерантність, тактовність, емпатійність; когнітивний компонент містить знання про сутність фрасилітаційної взаємодії та спілкування, вікові й індивідуальні особливості суб'єктів освіти; праксіологічний компонент представлений перцептивними, проектувально-конструктивними, комунікативними, рефрлексивно-аналітичними вміннями. Визначено, що подальшого студіювання потребує аспект етапності формування фрасилітаційної компетентності майбутнього педагога в процесі професійної підготовки у $3 В О$.

Ключові слова: компетентнісний підхід, компетенція, компетентність, фрасилітаційна компетентність, структура фрасилітаційної компетентності майбутнього педагога.
\end{abstract}

The relevance of this article is conditioned by socio-economic, innovative and educational transformations in Ukraine's life, as well as by globalization processes focused on the integration of our state with the world community which objectively determine changes in the vectors of development of education at all levels in the direction of human-centrism, the view of the personality of an applicant for education as the highest value.

The article deals with the phenomenon of facilitation within the framework of the competence-based approach. On the basis of the analysis of semantic components which are 'facilitation" and "competency', the concept of facilitative competency has been substantiated. The author's definition of facilitative competency of a future teacher as an integrated characteristic of a future teacher has been presented, which synthesizes his leading professional and personal qualities ensuring the readiness to facilitate the subjects of the educational process. The structure of the facilitative competency of a future teacher has been determined which contains motivational-axiological, cognitive and praxeological components, which in turn have the aspect of perception, interaction and communication.

It has been found out that the motivationalaxiological component is associated with a facilitative position, which provides for a humancentered mindset, attitude towards applicants for education as to the highest value, openness, benevolence, tolerance, tactfulness, empathy; the cognitive component contains knowledge about the essence of facilitative interaction and communication, age and individual characteristics of subjects of education; the praxeological component is represented by perceptual, design-constructive, communicativeempathic and reflexive-analytical skills. It has been determined that further study requires the aspect of the phased formation of the facilitative competency of a future teacher in the process of professional training at a higher educational establishment.

Key words: competence-based approach, competence, competency, facilitative competency, structure of facilitative competency of a future teacher.
Постановка проблеми в загальному вигляді. Глобалізаційні та євроінтеграційні виміри сучасного суспільства, стратегічні позиції педагогіки партнерства, задекларовані в концепції Нової української школи (2017 рік), пов'язані з ідеями рівності, діалогу, співпраці. Вони детермінують потребу у фахівцях, здатних комунікувати, взаємодіяти з іншими людьми, спільно вирішувати певні проблеми, працювати в команді, тобто бути готовими до фрасилітативної підтримки суб'єктів різних ланок освіти в Україні.

3 огляду на людиноцентровані й компетентнісні орієнтири сучасної освіти, постає необхідність у фрормуванні такої суттєвої профресійно-особистісної якості майбутнього педагога як фрасилітаційна компетентність, яка передбачає реалізацію його супровідної, підтримувальної, допоміжної, партнерської функції в освітньому процесі. Зазначені об'єктивні обставини загострюють актуальність проблеми визначення сутності й структури фрасилітаційної компетентності майбутнього педагога як цільових орієнтирів професійної підготовки майбутнього педагога у закладі вищої освіти (далі - 3ВО).

Актуальність обраної проблеми посилюється наявними в сучасній системі освіти суперечностями 
між її оновленими цілями, зорієнтованими на гуманізацію освітнього процесу та визнання особистості найвищою цінністю і здебільшого низьким рівнем готовності певної кількості педагогів до фасилітаційної взаємодії зі здобувачами освіти.

Аналіз останніх досліджень і публікацій. Концептуалізація френомену фасилітації відбулася у студіях М. Бердяєва, М. Бахтіна, Г. Ващенко, Г. Сковороди. Однак наукового статусу фрасилітація набула у працях відомого гуманістичного психолога К. Роджерса.

Поняттєве поле френомену фрасилітації представлено такими варіативами: соціальна фрасилітація (Л. Тимоніна, В. Фрейнберг); педагогічна фрасилітація (І. Авідєєва, О. Галіціан, О. Димова, Р. Димухаметов, І. Жижина); фрасилітуюча позиція (О. Фісун); фрасилятивність особистості (М. Казанджи); фрасилітаційне спілкування (О. Врубльовська, В. Суміна); фрасилітація як важливий чинник ефрективного спілкування у контексті самоактуалізації особистості (А. Адлер, Г. Балл, Е. Бернс, М. Еріксон, А. Маслоу, К. Ясперс); фрасилітаційна взаємодія (І. Прокопенко, Р. Шаповал).

Низка досліджень присвячена розгляду пізнавальної, комунікативної, діагностико-прогностичної фрункції фрасилітації (Т. Лозова); дидактичнопрофесійній, нормативній (О. Жерновникова); захисній фрункції (Л. Перминова). Процес фрасилітативного розвитку особистості висвітлено у дослідженнях Н. Завацької, І. Ісаєва, 3. Ковальчук, В. Слободчикова.

Сучасний науковий дискурс щодо феномену компетентності представлений дослідженнями фундаментальних засад компетентнісного підходу (О. Субетто, І. Байденко, І. Зимня, Ю. Татур), питань впровадження компетентнісного підходу у систему освіти (Н. Бібік, С. Вітвицька, О. Дубасенюк, О. Локшина, О. Овчарук, О. Пометун, О. Савченко). Феномен фрасилітаційної компетентності майбутніх вчителів гуманітарних спеціальностей порушено у дисертації О. Фокши. Фасилітаційна компетентність керівника закладу освіти стала предметом дослідження Т. Сорочан.

Виділення не вирішених раніше частин загальної проблеми. Стратегічні орієнтири сучасної вітчизняної освіти, пов'язані з її людиноцентрованими, суб'єктно-діяльнісними вимірами, реалізацією принципів педагогіки партнерства, ідей компетентнісної парадигми освіти, зумовлюють зміну статусу педагога в напрямі гуманізації стосунків зі здобувачами освіти, оволодіння стилем міжособистісних відносин, заснованих на взаєморозумінні, співробітництві й емпатії, що акумулюються у фасилітаційній компетентності. За досить широкої дослідженості проблеми фрасилітації аспект сутності та структури фрасилітаційної компетентності майбутнього педагога залишився поза увагою науковців, тому він потребує наукової розвідки.
Мета статті - визначити сутність і структуру фрасилітаційної компетентності майбутнього педагога.

Виклад основного матеріалу. Розглянемо базове поняття дослідження «фрасилітаційна компетентність майбутнього педагога» на основі аналізу його семантичних складників, якими $є$ «фрасилітація» та «компетентність».

Етимологія поняття «фрасилітація» пов'язана 3 англійським "facilitate" (у перекладі «допомога, полегшення, сприяння»). У педагогічну теорію термін «фрасилітація» ввів К. Роджерс. Відомий психотерапевт і педагог виділив три основні установки вчителя-фрасилітатора:

1) «істинність» та «відкритість»;

2) «прийняття» і «довіра»;

3) «емпатичне розуміння» [9].

К. Роджерс пов'язував фрасилітацію 3 відкритістю власним думкам і переживанням, здатністю чесно, щиро, відкрито транслювати їх своїм вихованцям; 3 особистісною впевненістю педагога в можливостях і здібностях учнів; із баченням вчителем внутрішнього світу та поведінки кожного учня 3 його внутрішньої сторони.

Педагогічний контекст фрасилітації (О. Димова, І. Жижина) передбачає організацію певного типу міжособистісних відносин, які забезпечують створення ефективних умов для саморозвитку й самореалізації особистості, спонукають її до реалізації зусиль для розкриття власних внутрішніх потенцій. Суттєвими ознаками таких взаємовідносин є взаємопізнання, взаєморозуміння, узгодженість спільних дій і взаємовплив між всіма учасниками [2; 3].

$€$ доцільним трактування френомену фрасилітації (О. Фокша), пов'язане з такими його аспектами:

- взаємовплив людей, зумовлений соціальними контактами, що підвищує їхню активність, сприяє активізації психічних процесів, поліпшенню самопочуття;

- специфічний вид спілкування, який передбачає полегшення взаємодії усіх суб'єктів освітнього процесу;

- спосіб допомоги групі в пошуку шляхів виявлення й розв'язання проблем [8, с. 8].

Беручи до уваги окреслені наукові позиції, будемо тлумачити педагогічну фрасилітацію як процес взаємодії, спілкування між суб'єктами освітнього процесу на засадах людиноцентризму, міжсуб'єктності, толерантності й емпатії, що сприяє особистісному саморозвитку та їх конструктивній взаємодії.

Феномен фрасилітації ми досліджуємо в межах реалізації компетентнісного підходу, який є спрямованістю освіти на розвиток особистості в результаті фрормування в неї таких особистісних якостей як компетентність засобами розв'язання профресійних і соціальних завдань в освіті (І. Зимня) [4]; 
на фрормування й розвиток ключових (базових, основних) і предметних компетентностей особистості (О. Пометун) [6].

Ґрунтовними поняттями компетентнісного підходу $€$ категорії «компетенція» та «компетентність», які ми трактуємо так:

- компетенція - це задана вимога, норма освітньої підготовки; це об'єктивна сукупність певних знань у будь-якій галузі; це змістовна потенційна характеристика; коло повноважень певної організації, установи або особистості;

- компетентність є суб'єктивною, актуальною, особистісною характеристикою; це реально сорормовані особистісні якості та досвід діяльності особистості.

Поняття «фрасилітативна компетентність» у працях Т. Сорочан використано у форматі складника управлінської компетентності керівників закладів освіти, який авторка визначає як здатність керівника бути провідником змін в освіті, мотивувати учасників освітнього процесу до особистісного розвитку, забезпечувати для цього необхідні умови [7].

О. Фокша обґрунтовує конструкт «фрасилітативна компетентність майбутнього вчителя гуманітарних спеціальностей», який трактує як «інтегративний динамічний комплекс індивідуально-особистісних і професійно-діяльнісних якостей педагога, який характеризуються здатністю вибудовувати фрасилітаційну взаємодію 3 усіма суб'єктами освітнього процесу з урахуванням розвивального потенціалу гуманітарних дисциплін» [8, c. 8].

На нашу думку, фрасилітативна компетентність - це інтегрована характеристика майбутнього педагога, яка синтезує його провідні професійно-особистісні якості, що забезпечують готовність до фрасилітації суб'єктів освітнього процесу.

Представимо структуру фрасилітативної компетентності. Відомий підхід О. Фокши, яка виокремлює гносеологічний, праксеологічний, аксіологічний компоненти фрасилітаційної компетентності [8]. Наше трактування структури фрасилітативної компетентності базується на двох позиціях. Перша пов'язана зі структурно-діяльнісною ознакою, яка ґрунтується на психологічній структурі діяльності, визначеній О. Леонтьєвим як єдність і взаємодія категорій потреби, мети, мотивів, дій (операцій) [5], а також на підході О. Бодальова [1], відповідно до якого у структурі фрасилітативної компетентності доцільно виокремити дві групи особистісних утворень: ті, що постають як спонукачі діяльності та поведінки, ті, що складають їх виконавчий компонент. У цьому контексті структура фрасилітаційної компетентності майбутнього педагога представлена мотиваційно-аксіологічним, когнітивним, праксіологічним компонентами. Тобто спонукаль- ним складником фрасилітаційної компетентності є їі мотиваційно-аксіологічний компонент; виконавчим - когнітивний і праксіологічний компоненти.

Основою другої позиції $є$ тлумачення фрасилітації як сукупності фрасилітаційної позиції, фрасилітаційної взаємодії, фрасилітаційного спілкування. Відповідно до цього підходу структура фрасилітаційної компетентності містить аспекти перцепції, інтеракції, комунікації.

Отже, обґрунтована у дослідженні структура фасилітаційної компетентності є синтезом окреслених наукових позицій. Підтвердженням цього $€$ фракт зв'язку мотиваційно-аксіологічного, когнітивного, праксіологічного компонентів фрасилітаційної компетентності з механізмами перцепції, комунікації та інтеракції.

Зупинимося детальніше на розгляді певних структурних складників рефлексивної компетентності майбутнього вчителя початкової школи.

Мотиваційно-аксіологічний компонент досліджуваного нами френомену пов'язаний із фрасилітаційною позицією майбутнього педагога, яка відбиває професійні мотиви й потреби, установки педагога на взаємодію, співпрацю й спілкування на засадах партнерства й міжсуб'єктності зі здобувачами освіти, ціннісне ставлення до них на засадах відкритості, доброзичливості, толерантності, тактовності, емпатійності.

Когнітивний компонент - система знань, які є теоретичною базою для фасилітаційної компетентності. Ми їх визначаємо як систему понять і уявлень просутністьімеханізмифрасилітації, віковійіндивідуальні особливості здобувачів освіти, про принципи й методи організації фрасилітаційного спілкування і взаємодії.

Праксіологічний компонент. Цей складник фрасилітаційної компетентності представлений системою умінь, серед яких виокремлюються перцептивні вміння (вміння адекватно сприймати й розуміти партнерів по спілкуванню); проектувально-конструктивні (вміння організувати командну роботу, надавати педагогічну підтримку й допомогу); комунікативні вміння (вміння організувати партнерські стосунки із суб'єктами освіти, встановлювати 3 ними зворотній зв'язок); рефлексивно-аналітичні вміння (вміння, пов'язані із самопізнанням і розумінням іншого, самоінтерпретацією та інтерпретацією іншого, вміння бачити себе «очима партнера»).

Висновки. На підставі викладеного зазначимо, що фрасилітація як процес взаємодії, спілкування між суб'єктами освітнього процесу на засадах людиноцентризму, міжсуб'єктності, толерантності й емпатії є суттєвим складником профресійної діяльності, а фрасилітаційна компетентність як інтегрована характеристика майбутнього педагога, що синтезує його провідні професійноособистісні якості, які забезпечують готовність до 
фрасилітації суб'єктів освітнього процесу, є важливою професійно-особистісною характеристикою сучасного педагога.

Структура фрасилітаційної компетентності майбутнього педагога містить мотиваційно-аксіологічний, когнітивний, праксіологічний компоненти, які мають аспект перцепції, інтеракції, комунікації. При цьому мотиваційно-аксіологічний компонент пов'язаний із фрасилітаційною позицією, яка передбачає людиноцентровану установку, ставлення до здобувачів освіти як до найвищої цінності, відкритість, доброзичливість, толерантність, тактовність, емпатійність; когнітивний компонент містить знання про сутність фрасилітативної взаємодії та спілкування, вікові й індивідуальні особливості суб'єктів освіти; праксіологічний компонент представлений перцептивними, проектувально-конструктивними, комунікативними, рефлексивно-аналітичними вміннями.

Подальшого студіювання потребує аспект етапності фрормування фрасилітаційної компетентності майбутнього педагога в процесі професійної підготовки у 3 ВО.

\section{БІБЛІОГРАФІЧНИЙ СПИСОК:}

1. Бодалев А.А. Психология личности. М. : МГУ, 1988. 188 с.
2. Димова О.И. Педагогические условия развития способности к фрасилитирующему воздействию у будущих учителей : дис. канд. пед. наук. Хабаровск : Комсомольский-на-Амуре государственный педагогический университет, 2002. 199 с.

3. Жижина И.В. Психологические особенности развития фрасилитации педагога : дис. канд. псих. наук. Екатеринбург, 2000. 186 с.

4. Зимняя Н.А. Ключевые компетентности как результативно-целевая основа компетентностного подхода в образовании. М. : ИЦ ПКПС, 2004. 220 с.

5. Леонтьев А.Н. Деятельность. Сознание. Личность. М. : Политиздат, 1977. 304 с.

6. Пометун О. Запровадження компетентнісного підходу - перспективний напрям розвитку сучасної освіти. URL: http://visnyk.iatp.org.ua.

7. Сорочан Т.М. Розвиток професіоналізму управлінської діяльності керівників загальноосвітніх навчальних закладів у системі післядипломної педагогічної освіти [Текст] : дис. д-ра пед. наук: 13.00.04. Луганський національний педагогічний ун-т ім. Тараса Шевченка. Луганськ, 2005. 478 с.

8. Фокша О.М. Педагогічні умови формування фрасилітаційної компетентності майбутніх вчителів гуманітарних спеціальностей у професійній підготовці [Текст] : автореф. дис. канд. пед. наук: 13.00.04. Держ. закл. «Південноукр. нац. пед. ун-т ім. К.Д. Ушинського». Одеса, 2019. 21 с.

9. Rogers C. Freedom to learn for the 80's. Columbus - Toronto - London - Sydney : Ch. E. Merrill Publ. Company, A Bell \& Howell Company, 1983. 312 p. 


\section{ЗАРУБІЖНИЙ І ВІТЧИЗНЯНИЙ ДОСВІД ПРОФЕСІЙНОї ПІДГОТОВКИ ФАХІВЦІВ СФЕРИ СОЦІАЛЬНОГО ТУРИЗМУ}

\section{FOREIGN AND DOMESTIC EXPERIENCE PROFESSIONAL OF TRAINING SPECIALISTS IN THE FIELD OF SOCIAL TOURISM}

\begin{abstract}
Статтю присвячено проблематиці профресійної підготовки орахівців ссрери туризму загалом $і$ соціального туризму зокрема. Сутність статmі зосереджено на особливостях професійної підготовки майбутніх фрахівців сорери туризму у закладах освіти Канади, США та країн Європи (Іспанія, Італія, Німеччина, Чехія, Швейцарія). Проаналізовано останні дослідження та публікації науковців щодо проблематики професійної підготовки фахівців сорери туризму. Зазначено, що досвід США, Канади та країн Європи дає можливість адаптувати процес професійної підготовки фахівців сорери туризму в Україні.

Визначено сучасні тенденції розвитку туризму загалом і соціального зокрема як у світі, так і в Україні. Виокремлено проблематику профресійної підготовки майбутніх фрахівців сфрери туризму до професійної діяльності в Україні. Розкрито проблематику розвитку соціального туризму у світі та в Україні, а саме застарілу нормативноправову базу, недостатнє орінансування. Наголошено на перспективах розвитку соціального туризму, що зумовлюють важливість рівня профресійної компетентності фрахівців, які працюють із незахищеними верствами населення, тобто із соціальними туристами.

У статті зазначено про актуальність професійної підготовки фрахівців сфрери соціального туризму. 3 огляду на досвід вітчизняних учених, визначено три основні аспекти профресійної підготовки майбутніх фрахівців сорери туризму. Вказано на важливість професійної підготовки фрахівців сфери соціального туризму. Зроблено висновки про вдосконалення стану соціального туризму, а також щодо вдосконалення процесу професійної підготовки орахівців ссрери туризму загалом і соціального туризму зокрема Ключові слова: зарубіжний досвід, професійна підготовка, сорера туризму, соціальний туризм, система освіти, професійна діяльність.
\end{abstract} 6085/2021/31-1.18

\section{Зігунов B.M.}

канд. пед. наук

доцент кафедри туризму

і готельно-ресторанного сервісу

Сумського державного педагогічного

університету імені А.С. Макаренка
The article is devoted to the issue of professional training of specialists in the field of tourism and in particular, social tourism. The essence of the article is focused on the features of professional training of future specialists in the field of tourism in educational institutions of Canada, the USA and European countries (Spain, Italy, Germany, the Czech Republic, Switzerland). The latest research and publications of scientists on the issues of professional training of specialists in the field of tourism are analyzed. It is noted that the experience of the USA, Canada and European countries provides an opportunity to adapt the process of professional training of tourism professionals in Ukraine.

The current trends in the development of tourism in general and in particular, social, both in the world and in Ukraine. The problems of professional training of future specialists in the field of tourism for professional activity in Ukraine are highlighted. The problems of social tourism development in the world and in Ukraine are revealed, namely outdated legal framework, insufficient funding, etc. Emphasis is also placed on the prospects for the development of social tourism, which determine the importance of the level of professional competence of professionals who work with vulnerable groups, i.e. with social tourists.

The urgency of professional training of specialists in the field of social tourism is also noted. Based on the experience of domestic scientists, three main aspects of professional training of future specialists in the field of tourism have been identified. The importance of professional training of specialists in the field of social tourism is indicated. Conclusions were made on improving the state of social tourism, as well as on improving the process of professional training of specialists in the field of tourism and, in particular, social tourism.

Key words: foreign experience, vocational training, tourism, social tourism, education system, professional activity
Постановка проблеми в загальному вигляді. Нині тенденції розвитку українського суспільства співпадають зі світовими тенденціями, спрямованими на інтеграцію зі світовими ринками. Тому суспільству потрібні висококваліфіковані фрахівці, які володіють знаннями у своїй професійній сфрері і можуть застосовувати їх у різних життєвих ситуаціях. Після закінчення навчального закладу фрахівці повинні вміти адаптовуватися у різних професійних середовищах. Традиційний підхід до освіти не задовольняє запити з боку динамічного сучасного суспільства, яке постійно розвивається, тому що традиційний підхід до освіти спрямований на засвоєння якомога більшого обсягу теоретичних знань.

Одним 3 інструментів соціально-економічного розвитку країни є туризм. Спираючись на тенден- ції розвитку соціальної ссрери, можна сказати, що актуальним $є$ розвиток саме соціального туризму. Однак необхідно зазначити, що нині цей сегмент туристичної діяльності ще не досяг рівня розвитку, адекватного його потенційним можливостям. Перспективи розвитку сорери соціального туризму зумовлюють важливість рівня професійної компетентності фрахівців, які працюють із незахищеними верствами населення.

Отже, соціальний туризм $є$ актуальною сорерою розвитку туризму, тому підготовка фрахівців сорери соціального туризму також $€$ нагальною. Для цього необхідно дотримуватися певних критеріїв, а саме практичних теоретичних і комунікативних вмінь і навичок із організації туристичної діяльності. 
Аналіз останніх досліджень і публікацій. Аналіз останніх джерел і публікацій може засвідчити, що інтерес науковців до проблем профресійної підготовки фрахівців сорери туризму нині значний. Так, теоретичні засади професійної підготовки майбутніх фрахівців туристичної сфери закладено у таких напрямах наукових досліджень: теоретичні і методологічні засади професійної підготовки (Р. Вайнола, А. Капська, О. Карпенко, Л. Міщик, В. Поліщук); технологічні та методичні основи професійної підготовки до певних видів профресійної діяльності (І. Ковальчук, О. Пожидаєва); основи практичної підготовки майбутніх фахівців туристичної сфери (О. Бартків, Н. Ларіонова, 3. Фалінська); особливості підготовки фрахівців в сучасних умовах висвітлювали О. Біла, С. Грищенко, Т. Мальцева, П. Скляр, Р. Чубук.

Об'єктом вивчення практичної підготовки фахівців туристських спеціальностей за кордоном займалися українські науковці А. Кузнецов (Італія), л. Гілева (Швейцарія), І. Сандовенко (Канада), Л. Кнодель (Іспанія), Л. Чорна (США), О. Звєрєва (Німеччина), В. Захарченко (Чехія), а також Л. Сакун, М. Скрипник, Г. Цехмістрова, В. Федорченко, Н. Фоменко та інші [2].

Виділення не вирішених раніше частин загальної проблеми. Система туристичної освіти в Україні знаходиться лише в стадії свого розвитку, тому ще необхідно вирішити багато важливих завдань для досягнення високого рівня профресійної підготовки кадрів. У цьому може допомогти досвід інших більш розвинених країн світу (США, Канада, країни Європи) [1]. Найкращим рішенням для вирішення цих завдань буде використання досвіду інших країн світу, які більш розвинені у туристичній галузі та туристичній освіті, а саме США, Канади та країн Європи.

Мета статті - проаналізувати зарубіжний і вітчизняний досвід професіійної підготовки майбутніх срахівців сорери туризму.

Виклад основного матеріалу. Ринок праці в Україні та країнах світу, а також динамічний розвиток туристичної галузі останніми роками вимагають достатнього рівня профресійної підготовки фахівця із туризму. Необхідно зазначити, що актуальною є проблема дослідження, організації та розвитку саме соціального туризму відповідно до вимог сучасності. Питання соціального туризму $є$ важливим напрямом стратегій розвитку туризму як у міжнародній, так і в національній системах, що доводять деякі міжнародні організації, які опікуються питаннями розвитку туризму загалом і соціального зокрема.

В Україні розв'язання проблемних питань щодо розвитку соціального туризму гальмується через застарілу нормативно-правову базу. До того ж такі проблеми виникають через несорормованість державницького мислення у багатьох керівників орга- нів державної влади та управління, через недооцінку ролі системи професійної освіти в умовах ринкової економіки та незадовільне фрінансування.

Американське суспільство висуває певні вимоги до процесу підготовки майбутніх фрахівців із туризму, тому державна політика США у туристичній галузі спрямована не лише на забезпечення умов для розвитку туристичної галузі країни та зростання обсягів туристичних потоків, але й на розв'язання проблем із підготовки спеціалістів і проведення науково-дослідної роботи у цій галузі. Окрім професійних якостей, галузеві структури США розглядають позитивні особистісні якості майбутнього фрахівця (відповідальність, добросовісність, загальнокультурну грамотність) як запоруку його соціальної придатності. Підтвердженням цього фракту $є$ «Етичний кодекс» Американського товариства туристичних агенцій, яке має у своєму складі Автоматизовану коаліцію освіти [3].

Стосовно Канади можна зазначити, що іï університети надають можливість користуватися різними туристичними академічними програмами. Йдеться про більш ніж 50 різних профресійних програм - сертифікаційні програми післядипломної освіти або дипломні програми середньо-спеціальної освіти. Також йдеться про програми вищої освіти (отримання академічного ступеня бакалавра або наукового ступеня магістра). Досвід країн Європи дає можливість адаптувати процес професійної підготовки фрахівців сфери туризму в Україні, тому велику цінність становить багаторічний досвід туристичної освіти та туристичної сорери європейських країн.

Якщо здійснити порівняльний аналіз завдань, спрямованих на підвищення якості підготовки фрахівців туристичної сорери у Польщі та в Україні, то побачимо, що їх актуальність і розв'язання збігаються. Що ж стосується фрорм їх реалізації в умовах Європейського Союзу, то вони мають значно ширші можливості (і нормативно-правові, і фрінансові, і кадрові, і науково-методичні) для модернізації підготовки фрахівців туризму в контексті інтеграційних процесів [4].

Німецька система освіти спрямована на трирічну базу навичок, які надаються молодим спеціалістам. Потім молодий фрахівець протягом 2 років працює на підприємстві 3 метою ознайомлення з іншими методами роботи. Після цього він протягом 2 років відвідує школу готельного чи туристичного бізнесу для удосконалення професійних вмінь і опанування такими дисциплінами як «Бухгалтерський облік», «Контроль», «Робота із кадрами». Така система освіти дозволяє сорормувати компетентних практиків із чіткою практичною орієнтацією [5].

Бакалаврська програма відділення туризму напряму підготовки «Туризм і регіональний розвиток» Празького економічного університету дає 
змогу студентам отримати теоретичні знання відповідно до необхідного набору знань у туризмі, практичні знання в області туристської діяльності та управління туристичною організацією на регіональному рівні, здійснити аналіз регіонів із точки зору існування культурних, історичних та економічних передумов розвитку туризму. Важливу роль відіграють і комунікативні, соціальні та культурні знання для пристосовування та просування на підприємстві, формування мовних навичок спілкування за допомогою вивчення кількох (2-3) іноземних мов. Приділяється увага й фрормуванню адекватного психологічного сприйняття обов'язків керівництва підприємствами туризму та регіонального управління [6].

Характерною особливістю сучасної системи професійної підготовки майбутніх фрахівців сорери туризму у Швейцарії є практичне спрямування освіти та її тісний зв'язок із виробництвом. Навчальний процес у закладах вищої освіти Швейцарії на університетському рівні ґрунтується на поєднанні загальноосвітніх предметів управління разом із набором добре продуманих туристичних предметів, які вирішують найважливіші питання, що стоять перед фрахівцями сорери туризму XXI ст.

Програми дають студентам можливість брати участь у реальних проектах, спрямованих на розвиток професійних, комунікативних та аналітичних навичок. Так, програма «Магістр наук у галузі ділового адміністрування», спеціалізація «Туризм» пропонує поєднання теоретичних основ і практичного досвіду з метою підготовки кваліфікованого фрахівця сорери туризму, здатного конкурувати у динамічному бізнес-середовищі. Основними характеристиками програм є поглиблені знання особливостей загального менеджменту і туризму, аналітичні навички розв'язання проблем, інноваційні вміння із управління та організації, вміння працювати у полікультурному середовищі, багатонаціональний студентський і викладацький склад, поєднання практичних і методичних знань, фрормування лідерських якостей, науково-дослідна діяльність [7].

Профресійна підготовка фрахівців у сорері туризму в Італії спрямована на проведення закордонної практики, позитивним наслідком якої $\epsilon$ удосконалення професійних компетенцій, накопичення досвіду спілкування, розвиток організаторських і соціокультурних здібностей. За міжнародними стандартами персональна характеристика, яку отримує студент від керівника практики приймаючої сторони, складається із таких позицій: знання роботи департаменту, знання англійської мови, мови країни перебування або іншої іноземної мови, здатність до навчання та покращення профресійних навичок, надійність, почуття відповідальності, комунікабельність, співробітництво, взаємини із керівником підприємства та колегами, толерантність, використання ініціативи. Найвища оцінка професійних навичок і здібностей здебільшого застосовується до стажерів, яким видають міжнародний сертифрікат, ідентичний листу-рекомендації від роботодавця. Він високо цінується на міжнародному ринку праці у сорері туризму та готельного менеджменту [5].

Окремі країни Європи використовують уже сорормований досвід відомих навчальних закладів у підготовці кадрів для туристичної сфрери. Наприклад, в Іспанії заклади вищої освіти, в яких відбувається підготовка спеціалістів для туризму, вона проводиться за американською системою або за системою швейцарської школи Les Roches. Остання має цікавий досвід післядипломної освіти у галузі готельного менеджменту - «постдиплом». Унікальність цієї програми полягає у тому, що в ній чергується теоретичний семестр із практичним, так званим семестром стажування. Завдяки досить інтенсивному навчанню за рік студенти активно розвивають свої професійні навички, працюючи у ресторанах, готелях та багатьох інших компаніях як в Іспанії, так й в інших країнах світу [8].

Варто зауважити, що існує безліч всесвітньо відомих закладів, які спеціалізуються лише на туризмі і готельному господарстві. Наприклад, Школа готельного господарства у Гаазі, Інститут міжнародного готельного менеджменту у Швейцарії, Інститут туризму економічного університету Відня в Австрії, Інститут гостинності й туризму "Le Monde" у Греції, Університет Джеймса Кука в Австралії, Університет Джорджа Вашингтона у США, Корнельський університет у США та багато інших. Ця особливість дає змогу налагодити зв'язок із туристичними організаціями та підприємствами, а також готелями для проходження практик із подальшим працевлаштуванням. Це свідчить про те, що навчальний заклад докладає максимум зусиль для розробки нових технологій викладання та для вдосконалення навчального процесу.

Однією з головних проблем туристичної освіти в Україні $є$ відсутність їі системності та єдності, що зумовлює не конкурентоспроможність української освіти в туристичній галузі та в сорері обслуговування на світовому ринку праці.

Провідні вітчизняні вчені присвятили цим проблемам свої наукові праці. Л. Сакун стверджує, що існує три аспекти підготовки фрахівців, які $€$ важливими для будь-якої сорери туризму: фрундаментальне навчання (знання), яке відповідає за отримання знань згідно навчального плану спеціальності; технічне навчання (знання, як робити), яке відточує майстерність і розробляє навички, необхідні для певної спеціалізації; особисті здібності (знати, як бути і як себе поводити), що відображають особисті якості фрахівця [4]. 
Деякі країни світу, залучені до праці в туристичній галузі, розробляють свої системи туристичної освіти, які б підходили до всіх вимог сучасності та об'єднували у собі усі три вказані вище аспекти. В усьому світі приділяється велика увага підготовці фахівців сфери туризму за рахунок збільшення кількості навчальних закладів, які займаються підготовкою таких фахівців. Особлива увага присвячується практичній підготовці майбутніх фрахівців. Важливо зазначити, що практична підготовка майбутніх фрахівців із туризму є досить великою проблемою в Україні, оскільки немало дисциплін вивчається лише із теоретичної сторони. У зарубіжних же навчальних закладах практичній підготовці присвячується не менше 50\% від загальної, що є гарантією успіху в підготовці фрахівців із туризму.

Висновки. Аналізуючи зарубіжний і вітчизняний досвід, можна зробити висновок, що закріпити свої позиції соціальний туризм може лише за наявності продуманої соціальної політики в галузі туризму на національному, регіональному і міжнародному рівнях. Саме за рахунок впровадження у систему освіти зарубіжного досвіду можна вдосконалити процес професійної підготовки фрахівців сорери туризму загалом і соціального туризму зокрема.

\section{БІБЛІОГРАФІЧНИЙ СПИСОК:}

1. Федорченко В.К. Історія екскурсійної діяльності в Україні : навч. посіб. Київ : Кондор, 2010. 166 с.

2. Степанець Н.П. Досвід розвинутих країн у підготовці фрахівців для сфери туризму: компетентісний підхід. Географрія та туризм. 2012. № 20. С. 19-25.

3. Чорна Л.В. Система підготовки майбутніх фрахівців із туризму в університетах США. Викладач і студент: суб'єкт і суб'єктні відносини. 2008. C. 89-91.

4. Польова Л.В. Особливості підготовки менеджерів із туризму у Польщі. Туристична освіта в Україні: проблеми і перспективи : зб. наук. праць. Київ : Тонар, 2007. 356 c.

5. Уварова Г.Ш. Шляхи поглиблення міжнародного співробітництва у підготовці кадрів для ссрери туризму. Географрія і туризм. 2011. № 16. С. 18-25.

6. Захарченко В.Ю. Підготовка фрахівців ссрери туризму у вищих навчальних закладах Чехії (на прикладі Празького економічного університету). Вісник Луганського національного університету ім. Т. Шевченка. 2012. № 4. С. 176-180.

7. Закордонець Н.І. Психолого-педагогічні аспекти підготовки магістрів для ссрери туризму у вищих навчальних закладах Швейцарії. Педагогіка і психологія професійної освіти. 2014. № 2. 240 с.

8. Кнодель Л.В. Система образования в ссрере туризма в Испании. Вісник Луганського національного університету ім. Т. Шевченка. 2012. № 4. C. $180-184$ 


\section{ОЗДОРОВЧІ МЕТОДИКИ У ВПРАВАХ НА ДИХАННЯ ДЛЯ АКАДЕМІЧНИХ ВОКАЛІСТІВ}

\section{HEALTH TECHNIQUES IN BREATHING EXERCISES FOR ACADEMIC VOCALISTS}

Стаття присвячена одній із актуальних проблем підготовки до профресій, у компетенцію яких входить управління диханням. До таких професій належать співаки-вокалісти, артисти хору, студенти музичних навчальних закладів. У всіх різновидах вокалу безперечним $\epsilon$ підхід до оволодіння диханням, яким забезпечується довге профресійне життя співака.

Підхід до роботи над диханням організують із оздоровчих позицій. Відомі системи, які використовують у лікувальній практиці $i$ які не мають у своїй структурі протиріч із методиками академічного співочого виховання. У роботі з розвитку професійного дихання застосовувалися засоби немедикаментозних безапаратних оздоровчих методів. Активуюче, або мобілізуюче дихання здебільшого застосовують у підготовчій частині занять, перед виконанням співочих вправ і творів.

Дихальні вправи ефективні при позитивному психоемоційному налаштуванні: кожен вдих супроводжується відчуттям оздоровлюючої життєвої сили, енергії, найсильнішим почуттям радості $і$ отриманням задоволення. Затримка дихання - засвоєння цієї сили; затримка в спеціальних вправах із напругою і максимальним часом - відчуття повного поглинання енергії. Видих - вивільнення непотрібного, неактивного і зайвого для організму. Кожен цикл (вдих-затримкавидих) - сприйняття найтонших особливостей свого тіла, сходження на сходинку до здоров'я $i$ прекрасного співу. Свідоме регулювання ритму дихання і обсягу вентиляції легень може нормалізувати фрізіологічні процеси і помітно поліпшити не лише професійні співочі досягнення, а й психологічний стан. Використання методик роботи над правильним диханням дозволяє досягати професійної мети у роботі співаків, музикантів різних спеціальностей. Не менш важливим завданням, яке розв'язують у професійній роботі оволодінням співом, виявляється зміцнення здоров'я різних систем організму Ключові слова: управління диханням, ліквідація глибокого дихання, професійне оздо- ровче дихання, довге професійне життя співака, дихальні вправи.

The article is devoted to one of the urgent problems of preparation for professions, the competence of which includes the management of respiration. Such professions include singersvocalists, choir artists, students of music schools. In all types of vocals, the approach to mastering the breath is indisputable which ensures a long professional life of the singer.

The approach to work on breathing is organized from health-improving positions. There are systems of work on breathing, which are used in medical practice and which do not have in their structure contradictions with the methods of academic singing education. Activating or mobilizing breathing is usually used in the preparatory part of classes, before performing singing exercises and works. Soothing breathing - after classes.

Breathing exercises are effective with a certain psycho-emotional setting: each breath is accompanied by a feeling of healing vitality, energy, the strongest feeling of joy and pleasure. Respiratory arrest - the assimilation of this force; delay in special exercises with tension and maximum time - a feeling of complete absorption of energy. Exhalation - the release of unnecessary, inactive and unnecessary for the body. Each cycle (inhale-delay-exhale) - the perception of the subtle features of your body, climbing the step to health and beautiful singing. Conscious regulation of respiratory rhythm and lung ventilation can normalize physiological processes and significantly improve not only professional singing achievements, but also the psychological state. The use of methods of working on proper breathing allows you to achieve the professional goal of singers, musicians of various specialties. No less important task, which is solved in professional work by mastering singing, is to strengthen the health of various body systems.

Key words: breath control, elimination of deep breathing, professional health breathing, long professional life of the singer, breathing exercises. педагогічного університету імені К.Д. Ушинського

Постановка проблеми в загальному вигляді. Дослідження багатьох авторів доводять, що професії, до компетенцій яких входить управління диханням, вимагають спрямованої роботи з володінням комплексами дихальних вправ. До таких професій належать співаки-вокалісти, артисти хору, студенти музичних навчальних закладів.

У сучасній музичній культурі існує поділ виховання співочого голосу на академічний і естрадний вокал. Такий поділ є досить умовним, про що свідчить успіх багатьох академічних співаків у виконанні популярних творів, які відносять до естрадного напряму. У системі музичної освіти, в педагогічних навчальних закладах, у тому числі і тих, у яких ведеться підготовка естрадних музикантів, у навчальних планах $€$ дисципліна «Вокал». Співоча підготовка у кожному з напрямів повинна включати класичну і академічну основи співу. Насамперед це відноситься до оволодіння диханням. При всіх відмінностях академічного та естрадного вокалу безперечним $€$ підхід, яким забезпечується довге професійне життя співака. Тому очевидно, що підхід до роботи над диханням повинен бути організований насамперед із оздоровчих позицій.

Аналіз останніх досліджень і публікацій. $€$ безліч вітчизняної та зарубіжної літератури, присвяченої розвитку навичок співочого дихання із 
застосуванням різного виду дихальної гімнастики («звучної» $\mathrm{i}$ «беззвучної»). Існують системи роботи над диханням, які використовують у лікувальній практиці і які не мають у своїй структурі протиріч із методиками академічного співочого виховання. У роботі Н. Івасик [1] наведено огляд поширених методик безапаратного тренування дихання, спрямованих на лікування. Проблема дихання значне місце займає в методиках оздоровлення у фрізичних заняттях [2].

Ю.А. Ковнер (1976 рік, [3]) розробив систему вправ для вироблення чіткої дикції, для розвитку дихальних м'язів, м'язів артикуляційного апарату, для вміння розслаблятися, знімати зайву напругу. Для допомоги в оволодінні співочим звукоутворення Ю.А. Ковнер з успіхом застосовував систему спеціальних вправ. Суть методики розвитку голосу Ю.А. Ковнера полягає у точних прийомах тренування дихальних м'язів і всього вокальномовного апарату. Ці тренувальні вправи допомагають виробити правильне налаштування голосу, збагатити його за рахунок резонування у грудному і головному резонаторах. Збереження грудної і головної резонації протягом усього діапазону призводить до однорідного звучання голосу без перелому регістрів. Для того, щоб передбачувана система тренувальних вправ дала бажані результати, необхідно виконувати певні правила.

Ю.А. Ковнер радить, що тренування дихання необхідно починати із активного видиху, потім зробити невелику паузу, поки з'явиться необхідність вдиху. Вдих слід робити безшумно, повільно, помірно, заповнюючи легені, але не до відмови (тренування такого повноцінного дихання корисне для організму людини взагалі: і в житті, і в роботі, i для фрізичних вправ), оскільки правильне дихання оздоровлює організм. До цього необхідно додати загартовування організму водними процедурами.

Відомий український педагог П.В. Голубєв [4] вважав, що більшість висловлювань із рекомендацією щодо певного способу «правильного» дихання характеризується досить істотними недоліками, насамперед відсутністю необхідного обліку індивідуальних властивостей кожного співочого організму.

Виділення не вирішених раніше частин загальної проблеми. Свідоме регулювання ритму дихання і обсягу вентиляції легень може нормалізувати фрізіологічні процеси і помітно поліпшити не лише професійні співочі досягнення, а й психологічний стан. Оскільки спів $є$ найскладнішою функцією органів дихання, то вправи, які розвивають співочий голос, на шляху до оптимального розвитку насамперед спираються на природне дихання. У співі ритм дихання продиктований музичним текстом і узгоджується з ним. У цьому сенсі дихання $€$ динамічним процесом, який зумовлює вибір системи дихальних вправ.
Розвиток вчительських мовних, співочих навичок, оптимальна його методика не є однаковими із завданнями підготовки артистів опери, співаків в естрадних жанрах. Але $є$ спільне - забезпечення здорового функціонування мовного апарату людей, для яких є професійною необхідністю велика тривалість роботи голосового апарату.

Метою статті $€$ аналіз і вибір оптимальної системи дихальних вправ як основи розвитку системи дихання для різних професій із високими професійними навантаженнями голосу.

Виклад основного матеріалу. Із методичних робіт з описом спостережень за диханням відомо, що укорочений видих і подовжений вдих надають активуючу дію на нервову систему, а подовжений видих з укороченим вдихом - заспокоюють і розслаблюють їі.

Активуюче, або мобілізуюче дихання здебільшого застосовують у підготовчій частині занять. Доцільно застосовувати активізуюче дихання перед виконанням співочих вправ і творів. При виконанні активуючого дихання роботу розділяють на кілька елементів за збільшуваною складністю: від двох секунд - вдих, далі - затримка, чотири секунди - видих, до збільшення до 16-8-4 поступово за 3-4 тижні занять.

Заспокійливе дихання застосовують після занять. Ознакою ефективності занять є легка втома голосового апарату. Заспокійливе дихання характеризується поступовим подовженням видиху і збільшенням часу пауз після видиху за схемою: одна секунда - вдих, дві секунди - видих, дві секунди - пауза. До чотирьох секунд - вдих десять секунд - видих, шість секунд - пауза. Удари серця можна вважати засобом рахування часу.

Активуюче дихання сприяє мобілізації сил організму, а заспокійливе - прискорює відновлення, знижує нервово-м'язову і емоційну збудливість. Для зняття втоми, нервової напруги, розвитку голосу, просрілактики захворювань дихальної системи іноді застосовують методику трифразного дихання.

Дихальні вправи у першій половині XX ст. здебільшого використовували у лікуванні респіраторних захворюваннях, а також у профресійній підготовці співаків, дикторів, вчителів і спортсменів [5]. Відомими були системи триоразного дихання Л. Кофрлера, О. Лобанової і Е. Лук'янової. Відмінністю цієї методики є фріксація уваги на паузі, яка настає після видиху. Пауза використовується для того, щоб вдих здійснювався мимовільно, як природна потреба. Послідовність трифразного дихання: видих-пауза-вдих. Між вдихом і видихом паузи немає.

Один із найстаріших засобів лікувальної дихальної гімнастики - дихальна гімнастика А.Н. Стрельникової [6] - це немедикаментозний оздоровчий метод, створений на межі 30-40-х років XX ст. як 
засіб для відновлення співочого голосу. Дихальна гімнастика А.Н. Стрельникової включає безліч вправ, проте базовими 3 них є три: «Долоньки», «Погончики» і «Насос». Ці вправи присутні у всіх спеціалізованих комплексах, спрямованих на лікування тих чи інших захворювань, вони є основою для використання цієї методики в академічній роботі з голосом.

Вважаємо доцільною таку модисрікацію методики у роботі з постановки і розвитку дихання 3 академічною спрямованістю. Вправа «Долоньки». Початкове положення - стоячи або сидячи прямо, руки зігнуті в ліктях, долоні - від себе. Стискають долоні в кулаки, одночасно роблять різкі і гучні вдихи. Після завершення серії із 8 вдихів недовгий відпочинок і повторення вправи, усього 20 серій по 8 вдихів. Вправа «Погончики». Початкове положення - стоячи або сидячи прямо, ноги трохи ширше ширини плечей, руки на рівні поясу, долоні стиснуті в кулаки. На вдиху різко опускають руки, розтискають кулаки і розчіплюють пальці, із максимальною силою напружуючи кисті і плечі. Усього виконують 8 серій по 8 разів. Вправа «Насос». Початкове положення - стоячи або сидячи прямо, ноги трохи ширше ширини плечей. Голосно вдихнути і повільно нахилитися, здійснити один нахил у секунду. Зробити вдих і випрямитися, видихнути через рот. Наступні секунди знову нахилитися, і так до восьми видихів, а потім так само повільно повернутися у вихідне положення. Виконувати 8 серій по 8 разів.

Одним із засобів лікувальної дихальної гімнастики, який застосовується і нині, є метод вольової ліквідації глибокого дихання, створений на основі методики К.П. Бутейко [7], яка може слугувати гіпоксичним тренуванням в оздоровчих заняттях і у спорті. Суть методики К.П. Бутейко - це довільна гіповентиляція легень. Гіповентиляція призводить до гіпоксемії та гіпоксії тканин, паралельно розвивається гіперкапнія, що призводить до розширення бронхів і підвищення артеріального тиску. Застосовують гіповентиляцію і затримки дихання на вдиху і на видиху при різних фрізичних вправах, що добре тренує стійкість до гіпоксії і розширює адаптивні можливості організму.

В останнє десятиліття XX ст. метод подолання глибокого дихання вдосконалив В.Ф. Фролов (1997). Цей метод набув широкого розповсюдження [8]. Учений сорормулював і теоретично обґрунтував доцільність діафррагмального типу дихання як основного моменту для досягнення високого впливу на багато процесів в організмі. Методика В.Ф. Фролова спрямована на фрормування типу дихання, яке по суті $є$ основним типом співочого дихання.

Співоче дихання - черевне, або діафрагмове, воно $€$ головним фрактором, який визначає якісні характеристики одержуваного звуку. Тому поста- новка дихання при співі є одним із найважливіших завдань для того, щоб навчитися красиво співати. Черевний подих освоюють із диханням у системах йогів - це свідомо контрольоване і регульоване дихання. Контроль ритму здійснюється за ударами пульсу (скороченнями серця). Одне скорочення серця - це одиниця виміру тривалості вдиху, затримки дихання і видиху.

Дихання здійснюється через ніс, якщо спеціально нічого іншого не вказано, а видих - через рот. Займатися дихальною гімнастикою краще вранці натщесерце або через 2 години після прийому їжі. Вправи можна виконувати лежачи, стоячи, сидячи на стільці або на підлозі (сидять по-турецьки, в позі лотоса або в позі полулотоса). Хребетний стовп обов'язково випрямлений, голова, шия і тулуб становлять пряму лінію, м'язи обличчя і рук розслаблені, руки лежать на колінах.

При диханні йогів вдих особливий, його потрібно відчути і зрозуміти. Ніздрі при вдиху і видиху зовсім пасивні. Вдих робиться не носом, а ротом, струмінь повітря вдаряє в задню стінку носоглотки і горла. При вдиху повітря ніби ковтається, а при видиху - ковзає уздовж горла (вдих звук «Са!!!», видих - «Ху!!!»).

Основна вправа дихальної гімнастики йогів це повне дихання, яке включає три елементи: черевне (нижнє, діафрагмальне), грудне (середнє, реберне) і ключичне (верхнє). Спочатку освоюється кожен елемент окремо. Черевне дихання освоюють лежачи або стоячи (сидячи його освоїти важче). Необхідно зробити видих, при цьому живіт підтягується (діафррагма піднімається вгору). Потім слід вільно вдихнути, повільно, через ніс, живіт випинається (діафррагма опускається), грудна клітка нерухома. Нижня частина легень наповнюється повітрям (живіт випинається). При видиху живіт підтягується, діафрагма піднімається, повітря виштовхується із нижніх часток легень. У черевному диханні бере участь лише діафррагма (ребра і міжреберні м'язи нерухомі). Черевний подих сприяє венозному поверненню крові до серця, знижує артеріальний тиск, масажує органи черевної порожнини.

Реберне (середнє) дихання виконують стоячи, лежачи або сидячи. Після видиху через ніс (ребра при цьому опускаються) необхідно зробити повний тривалий вдих, розширюючи грудну клітку, живіт при цьому не випинати. Видих роблять через ніс, ребра стискаються, а повітря витісняється із середньої частини легень. Середнє дихання покращує кровообіг у печінці, шлунку, нирках, селезінці, підшлунковій залозі.

Верхнє дихання виконується стоячи, сидячи або лежачи. Після видиху необхідно зробити повільний вдих через ніс, піднімаючи ключиці і плечі, заповнюючи повітрям верхні відділи легень (ніби нюхаємо квіти). Діафрагма знаходиться 
в піднятому положенні, легені не можуть розширюватися вниз. Анатомічно верхня частина легень - найменша, тому обсяг повітря невеликий. При видиху плечі повільно опускають униз, живіт і середня частина грудної клітини залишаються нерухомими. При верхньому диханні покращується фрункція прикореневих лімфатичних вузлів легень, підвищується захисна функція, краще вентилюються верхні відділи легень.

Повне дихання йогів - основна вправа із контрольованого дихання, в якому об'єднуються усі три типи дихання. Вихідне положення - стоячи або сидячи, голова, шия і хребет знаходяться на одній лінії. Починають із енергійного видиху (втягнути стінку живота). Потім починають вдихати через ніс зевом, рухом діафрагми необхідно випнути живіт і заповнити повітрям нижню частину легень, потім розширити нижню і середню частину грудної клітки і наповнити їх повітрям, підняти плечі і заповнити верхню частину легень, у цей час живіт підтягується. У процесі вдиху повітря надходить безперервним струменем і чується характерний шум у носоглотці (ніби шум насоса: «Са!!!»). Видих виконують через ніс, при цьому чується звук «Фу!!!», який здійснюють теж носоглоткою, втягуючи живіт. Повітря видаляється із нижньої частини легень, потім необхідно стиснути ребра, опустити плечі і вкінці видиху втягнути живіт, виштовхнувши залишки повітря.

Ритмічне дихання - це повне дихання, синхронізоване з ударами серця або пульсом, або за відчуттям серцебиття. Удари серця добре відчуваються при повному диханні. Вдих здійснюється на два удари пульсу, а видих - на 4. Видих завжди повинен бути удвічі довшим, аніж вдих. Наступний ритм дихання - це вдих на два удари пульсу, затримка на два і видих на чотири. Далі - вдих на чотири удари пульсу, затримка - на два, видих на вісім. Так підходимо до ритму: вдих - на чотири удари, затримка - на чотири удари, видих - на вісім ударів пульсу. Потім можна тренувати затримку дихання до 16 ударів пульсу, послідовно збільшувати видих теж до 16 ударів пульсу. Отримуємо такий ритм: вдих - на вісім ударів пульсу, затримка - 16 ударів, видих - 16 ударів. 3 метою оздоровлення збільшувати затримку дихання не рекомендується. Краще ритмічно подихати 4:4:8, зробивши від трьох до восьми подихів. Рекомендується почати із трьох вправ, додаючи щотижня по одній. Не рекомендується робити більше 10 подихів в одному занятті. Дихання позитивно позначається на фрункціях серцево-судинної, дихальної, травної та нервової систем.

Очисне дихання. Вихідне положення - стоячи, видихнути і зробити повний вдих на чотири рахунки, затримати подих на чотири рахунки, скласти губи як для свисту і зробити видих через рот, виштовхуючи повітря порціями за рахунок скорочення м'язів живота, діафррагми і міжреберних м'язів. У разі епідемії, вірусних захворювань цю вправу виконують 4-5 разів на день по 2-3 рази. Очисний подих можна виконувати після закінчення різних вправ.

Висновки. Таким чином, використання методик роботи над правильним диханням дозволяє досягти професіональної мети співаків, музикантів різних спеціальностей. Не менш важливим завданням, яке розв'язується у професійній роботі 3 оволодіння співом, є зміцнення здоров'я різних систем організму.

Дихальні вправи ефективні при позитивному психоемоційному налаштуванні: кожен вдих супроводжується відчуттям оздоровлюючої життєвої сили, енергії, найсильнішим почуттям радості і отриманням задоволення. Затримка дихання дає відчуття засвоєння цієї сили; затримка у спеціальних вправах із напругою і максимальним часом відчуття повного поглинання енергії. Видих - це вивільнення непотрібного, неактивного і зайвого для організму. Кожен цикл (вдих-затримкавидих) - це сприйняття найтонших особливостей свого тіла, сходження до здоров'я і прекрасного співу.

\section{БІБЛІОГРАФІЧНИЙ СПИСОК:}

1. Івасик Наталія. Безапаратні методики дихальної гімнастики. / Фізична культура, спорт та здоров'я нації : збірник наукових праць. Випуск 17. Вінницький державний педагогічний університет імені Михайла Коцюбинського. Вінниця : ТОВ «Планер», 2014. С. 670-677.

2. Іщенко М.В. Методики оздоровлення у фрізичному вихованні студенток : навчальний посібник. Одеса : ПНПУ ім. К.Д. Ушинського, 2015. 154 с.

3. Ковнер Ю.А. Тренировочные упражнения в развитии певческого голоса / Ю.А. Ковнер // Выпуск 5: Вопросы вокальной педагогики : сборник статей / Редакция Л. Дмитриев. Москва : Музыка, 1976. $39 \mathrm{c}$

4. Голубєв П.В. Поради молодим педагогам-вокалістам. К. : Муз. Україна, 1983. 62 с.

5. Кофлер Л. Искусство дыхания как основа звукоизвлечения : учебное пособие. Издательство «Лань», «Планета музыки», 2019. 320 с.

6. щетинин М.Н. Дыхательная гимнастика А.Н. Стрельниковой. Москва : Метасрора, 2010. 376 с.

7. Бутейко В.К, Бутейко М.М. Теория Бутейко о роли дыхания в здоровье человека: научное введение в метод Бутейко для специалистов (рус., англ.). Воронеж : ООО «Общество Бутейко», 2005. 100 с.

8. Фролов В.Ф. Способ тренировки дыхательной системы, европейский патент № 2123865, приоритет от 1995 года. Патент США № 5755640, приоритет от 26 мая 1998 года. 
КОМПЕТЕНТНОСТІ 3 МИСТЕЦТВА ХУДОЖНЬОГО ТКАЦТВА ЯК СКЛАДНИК ПРОФЕСІЙНОЇ КОМПЕТЕНТНОСТІ МАЙБУТНЬОГО ФАХІВЦЯ ДЕКОРАТИВНО-ПРИКЛАДНОГО МИСТЕЦТВА

\section{THE ESSENCE OF THE CONCEPT OF COMPETENCIES IN THE ART OF ARTISTIC WEAVING OF THE FUTURE SPECIALIST IN ARTS AND CRAFTS IN ACCORDANCE WITH STATE STANDARDS OF UKRAINE}

УДК 378.147:745/749

DOI https://doi.org/10.32843/26636085/2021/31-1.20

\section{Липовецька Є.ю.}

аспірант кафедри теорії та методики просресійної освіти

Ніжинського державного університету імені Миколи Гоголя,

викладач кафредри мистецтв

Ніжинського коледжу культури і

мистецтв імені Марії Заньковецької
В освітньому просторі спостерігається помітне зростання педагогічного інтересу до відродження традиційних художніх народних промислів із художнього ткацтва, килимарства, вишивки, мереживоплетіння. Існують і педагогічно процвітають численні центри вивчення традиційних народних ремесел (клуби, студії, гуртки, школи, коледжі, інститути), у яких вивчаються і реалізуються традиції народних мистецтв.

Учені, художники текстильних промислів, педагоги не перестають звертатися до традицій, продовжують дослідження побуту народів світу, розглядаючи особливості ткацьких технологій і знарядь праці, вивчення і розширровку тканого орнаменту, його значення і ролі в системі національноі культури. Для підвищення візуальної бібліотеки і розвитку почуття декоративності часто проводяться майстер-класи, конкурси, семінари, на яких майстри діляться своїм унікальним досвідом. Особливе місце у розкритті художніх сторін у традиційному декоративному мистецтві займають фестивалі та виставки, оскільки побудова експозицій забезпечує можливість учням побачити дивовижні вироби, виконані в техніці художнього ткацтва, килимарства, а також вишивки.

Декоративна діяльність, а саме вивчення художнього текстилю, розглянута у дослідженні, дає широкі можливості для розкриття індивідуальності. Заснована на багатовіковому народному досвіді, вона розвиває творчі здібності, духовно збагачує особистість, несе в собі знання і вміння багатьох поколінь. У прочесі художнього ткацтва формується інтелектуальний потенціал, розвивається психіка, творча активність, ініціатива, виховуються посидючість, працьовитість. Проте нині ссрормовано протиріччя між вивченістю питань формування професійних компетентностей студентів у педагогічній теорії і практиці та їх недостатньою розробленістю 3 підготовки фрахівців декоративно-прикладного мистецтва.

У статті розглянуто компетентності 3 мистецтва художнього ткацтва як складник просресійної компетентності майбутнього фрахівия декоративно-прикладного мистецтва.

Ключові слова: художнє ткацтво, декоративно-прикладне мистецтво, срахова компетентність, компетентності з мистецтва художнього ткацтва, педагогіка, художня освіта, професійна освіта.

In the educational space there is a marked increase in pedagogical interest in the revival of traditional folk crafts in artistic weaving, carpet weaving, embroidery, lace weaving. There are and pedagogically prosperous numerous centers for the study of traditional folk crafts, such as clubs, studios and clubs, schools, colleges and institutes, which study and implement the traditions of folk arts.

Scientists, artists of textile crafts, teachers do not stop turning to traditions, continue to study the life of the peoples of the world, considering the features of weaving technologies and tools, continue to study and decipher the woven ornament, its meaning and role in national culture. To improve the visual library and develop a sense of decorativeness, master classes, competitions, seminars are often held, at which masters share their unique experience. Festivals and exhibitions occupy a special place in the disclosure of artistic aspects in traditional decorative art, as the construction of exhibitions provides an opportunity for students to see amazing products made in the technique of artistic weaving, carpet weaving and embroidery. Decorative activity, namely the study of artistic textiles, considered in the study, provides ample opportunities for the disclosure of individuality. Based on centuries of folk experience, it develops creative abilities, spiritually enriches the personality, carries the knowledge and skills of many generations. In the process of artistic weaving the psyche develops, intellectual potential is formed, creative activity, initiative develop, perseverance, diligence and much more are brought up. However, currently there is a contradiction between the study of the formation of professional competencies of students in pedagogical theory and practice and their lack of development in the training of arts and crafts.

The article considers the competencies in the art of artistic weaving as a component of the professional competence of the future specialist in a decorative arts, semantic, artistic, technological aspects of hand weaving are considered.

Key words: artistic weaving, decorative and applied art, professional competence, competence in the art of artistic weaving, pedagogy, art education, professional education.
Постановка проблеми в загальному вигляді. В сучасних умовах системи мистецької освіти поширене збереження і розвиток народних традицій в області художнього ткацтва. Нині основна відмінність методичних основ навчання художньої обробки текстильних матеріалів (на прикладі художнього ткацтва) полягає у тому, що, на відміну від системи навчання, яка панувала ще якихось 20 років тому, в художній практиці студентів використовується проектування, застосовуються комп'ютерні технології, подача візуалізованих матеріалів здійснюється 3 інтернет-ресурсів [3; 5]. При всій схожості навчання на рівні оволодіння техніко-технологічними основами в області 
художнього ткацтва має місце відмінність в організації проектного виконання робіт і переведення їх у матеріал. Закономірності навчання за типом творчості в декоративно-прикладному мистецтві (повтор, варіація, імпровізація) зберігаються в рамках народної культури, творчості, самобутності, а також у зверненнях до позицій арт-індустрії.

Для вдосконалення художньої майстерності у студентів необхідно використовувати традиційні навчальні матеріали, починаючи від створення орнаментальної композиції до створення проекту в матеріалі. Загалом така методика навчання спрямована на включення студентів у простір стилізації як прийому художньої організації орнаментики на поверхні текстильного об'єкта.

У системі профресійної мистецької освіти навчання відбувається шляхом вивчення технологічних прийомів 3 використанням технічних замальовок, що здебільшого співвідноситься з етапами роботи народних майстрів і є необхідним для розвитку насамперед ручної вмілості у студентів.

Методичні основи навчання художньої обробки текстильних матеріалів у рамках художнього проектування в техніці художнього ткацтва спрямовані на гармонійну взаємодію традицій і сучасної освіти. Навчання необхідно проводити на об'єктах, в умовах вивчення і використання матеріалів народних художніх текстильних промислів. Методика полягає не лише у збереженні технікотехнологічних аспектів народного мистецтва, а й у підготовці студентів до дотримання технологічних і образних основ декоративного мистецтва. Необхідно мати на увазі, що нині прикладний характер мистецтва здебільшого перегукується 3 ідеями наростання естетики і ослаблення фрункціональних закономірностей, що є загальним художнім процесом, який впливає на естетичну затребуваність творів цього виду мистецтва.

Нині сорормувалося протиріччя між вимогами сучасного суспільства до рівня майстерності майбутніх фрахівців декоративно-прикладного мистецтва і відсутністю науково-обґрунтованої системи поетапного формування компетентностей із художнього ткацтва різних рівнів [1, с. 283].

Аналіз останніх досліджень і публікацій. Загальна френоменологія професійної компетентності вчителя знайшла відображення у дослідженнях Г. Балла, О. Бондаревської, Н. Гузій, І. Зимньої, Н. Кузьміної, А. Маркової, В. Маслова, О. Пометуна, О. Савченко, О. Хуторського. Дослідження у сорері педагогіки мистецтва здійснювали О. Гайдамака, О. Кабкова, Л. Масол, Н. Миропольська, М. Михаськова, О. Олексюк, Г. Падалка, О. Рудницька, М. Семко, О. Щолокова.

Вивченням методики фрормування певних компонентів фрахової компетентності вчителя мистецьких дисциплін займалися І. Зязюн, М. Лещенко, Л. Масол, Г. Падалка, О. Ростовський, О. Руд- ницька, О. Щолокова. Мистецьку компетентність як необхідну умову професійного виконання фахових обов'язків вчителя образотворчого мистецтва розглядали О. Кайдановська, С. Коновець, І. Мужикова, О. Плотницька [2, с. 71-79].

Виділення не вирішених раніше частин загальної проблеми. У дослідженнях переважає аналіз окремих компонентів професійного становлення студентів, однак питання освоєння компетентностей із художнього ткацтва як чітко сорормованої системи, яка утворює комплекс навчально-творчих завдань зростаючої складності, не отримали належного висвітлення.

Мета статті - розкрити сутність поняття «компетентностей із мистецтва художнього ткацтва» як складника професійної компетентності майбутнього фрахівця декоративно-прикладного мистецтва.

Виклад основного матеріалу. Виявлена актуальність проблеми формування професійних компетентностей майбутніх фрахівців декоративноприкладного мистецтва засобами народного декоративно-прикладного мистецтва дає підставу до виділення таких протиріч:

1) між об'єктивною необхідністю збереження і розвитку декоративно-прикладного мистецтва як невід'ємною частиною самобутньої народної культури і орієнтацією у професійній підготовці майбутніх фрахівців декоративно-прикладного мистецтва здебільшого на інтернаціональні тенденції і західноєвропейську культуру;

2) між вивченістю питань формування професійних компетентностей студентів у педагогічній теорії і практиці та їх недостатньою розробленістю 3 підготовки фрахівців декоративно-прикладного мистецтва;

3) між можливостями народного декоративноприкладного мистецтва як засобом формування професійних компетентностей майбутніх фрахівців декоративно-прикладного мистецтва і відсутністю методичного забезпечення процесу їх реалізації [6, с. 165-174].

Якісної підготовки майбутніх фрахівців декоративно-прикладного мистецтва не може бути без створення методики навчання художнього ткацтва майбутніх фрахівців декоративно-прикладного мистецтва в закладах вищої освіти. Разом із тим постає питання щодо висвітлення сутності та структури поняття «компетентностей із мистецтва художнього ткацтва майбутніх фрахівців декоративно-прикладного мистецтва».

Основна проблема визначається створенням оптимально продуктивної методики навчання художньому ткацтву майбутніх фрахівців декоративно-прикладного мистецтва, що забезпечує високий рівень формування компетентностей із художнього ткацтва як складника профресійної компетентності майбутнього фрахівця декоративно-прикладного мистецтва. Загалом методика 
навчання художнього ткацтва передбачає фрормування сукупності компетентностей із художнього ткацтва у майбутніх фрахівців декоративно-прикладного мистецтва. Тому поняття «методика навчання художнього ткацтва» і «фрормування компетентностей із художнього ткацтва» ми розглядаємо як суміжні. Без сукупності фрахових компетентностей не можна досягнути професійної досконалості в оволодінні методикою.

У сучасному освітньому і соціокультурному просторі спостерігається величезний інтерес до відродження традицій художнього ткацтва. На сучасному етапі в просторі інтернет-технологій $€$ багато матеріалів із художнього ткацтва, які фррагментарно використовуються в освітньому просторі. Наявність навчальної літератури, різноманіття авторських програм по ручному ткацтву, вільний доступ в інтернеті до етнографрічних матеріалів дає додаткову можливість для створення унікальних сучасних проектів із застосуванням технологій [8].

Сучасні художники займаються пошуком нових оригінальних форм із застосуванням технологічно складних прийомів художнього переплетення ниток, фрактури і текстури художніх природних і штучних текстильних матеріалів. У цьому їм допомагає найдавніше ремесло, яке часом виявляє себе із несподіваного боку у вирішенні образу і формоутворення.

Створення педагогічних умов щодо збереження традицій декоративно-прикладного мистецтва і народних художніх промислів необхідне для того, щоб художній творчий досвід розкрився для студентів як джерело традиційної художньої спадщини.

Для вирішення питань забезпечення наочності у навчанні текстильному проектуванню необхідно створювати систематизовані матеріали у вигляді альбомів, навчальних посібників, методичних розробок за такою тематикою: «Композиційна побудова текстильного геометричного орнаменту», «Плетіння і ткацтво поясів», «Ручне ткацтво на рамі», «Ручне ткацтво », що розкриває можливості для найкращої реалізації ідей, закладених у компетенціях.

Вивчення студентами різних прийомів художнього ткацтва, практичне застосування вивчених технік у сучасному різноманітті текстильного проектування необхідні для підвищення виразності. Це стає можливим завдяки виділенню чітких основ художнього проектування, в якому застосовуються закономірності побудови геометричного орнаменту за допомогою комп'ютерних програм. Знання та навички, набуті на практичних заняттях із текстильним проектуванням, застосовуються в художньо-творчій, прикладній діяльності, у побуті, в дизайні костюма, дизайні інтер'єру.

3 огляду на різний інтерес студентів, рівень їхніх умінь, можна їх комплектувати по групах для розробки індивідуальних і колективних проектів.
Виконані навчальні практичні роботи обов'язково необхідно супроводжувати коментарями, організовувати поточні перегляди, а також відбирати найбільш вдалі проектні розробки для виставок [13].

Успіх творчої роботи залежить від захопленості студентів, хорошої організації занять із ними, забезпечення практичних занять необхідними інструментами, матеріалом для роботи. При плануванні навчальної роботи необхідно враховувати кількість студентів, годин, тематику завдань для кожного курсу залежно від напряму і форм навчання, їхню складність, методику проведення занять і організацію перегляду підсумкових робіт [4].

Досвід викладання показує, що на початковому етапі потрібно проводити знайомство студентів 3 матеріалами і теорією техніко-технологічних основ у переплетенні ниток. Далі необхідно вивчити закономірності побудови текстильного орнаменту за дидактичним принципом від простого до складного. Застосування технік у композиції різних видів виробів для інтер'єру та дизайну костюма має відбуватися поетапно, з огляду на прийнятий у декоративно-прикладному мистецтві поділ на різні види виробів, що стає важливою практикою, а й необхідне студентам для підвищення їхньої професійної підготовки.

У навчанні слід звертатися до традиційних виробів, які складають об'єкти предметно-матеріальної культури: одяг: пояси, сумки, декоративні елементи одягу, поясні вироби, головні убори, спідниці, сукні, блузи, пальто; площинні вироби: рушники, серветки, скатертини; покривала, накидки на крісло; декоративні настінні панно, портьєри, технології та дизайн авторської ляльки (при реконструкції народних костюмів) [7, с. 244-250].

Висновки. Основною проблемою профресійної підготовки студентів на художньо-графічних фракультетах $€$ ефрективне фрормування компетентностей студента у процесі навчання декоративноприкладному мистецтву. У більш вузькому контексті проблемою $є$ відсутність загальної методики навчання художньому ткацтву майбутніх фрахівців декоративно-прикладного мистецтва, яка забезпечить повноцінне формування компетентностей із мистецтва художнього ткацтва у майбутніх фрахівців із декоративно-прикладного мистецтва.

Загалом методика навчання художнього ткацтва передбачає формування сукупності компетентностей із художнього ткацтва у майбутніх фрахівців декоративно-прикладного мистецтва. Тому поняття «методика навчання художнього ткацтва» і «формування компетентностей із художнього ткацтва» ми розглядаємо як суміжні. Без сукупності фрахових компетентностей не можна досягнути професійної досконалості в оволодінні методикою [12, с. 43-46].

Надалі плануються теоретичні дослідження, які передуватимуть створенню методики навчання художнього ткацтва майбутніх фрахівців декоративноприкладного мистецтва в закладах вищої освіти. 


\section{БІБЛІОГРАФІЧНИЙ СПИСОК:}

1. Андрущенко В.П., Зязюн І.А., Кремень В.Г. Максименко С.Д., Ничкало Н.Г., Сисоєва С.О., Цехмістер Я.В., Чалий О.В. Неперервна професійна освіта: фрілософрія, педагогічні парадигми, прогноз : монографрія / за заг. наук. ред. В.Г. Кременя. Київ : Наукова думка, 2003. 853 с.

2. Балик Н.Р., Шмигер Н.П. Формування інфрормаційних та соціальних компетентностей студентів 3 метою їх професійної підготовки у педагогічному університеті. Науковий огляд : міжнародний науковий журнал. 2016, № 4. С. 71-79.

3. Бриткевич М.С. Инновационный педагогический опыт как фрактор профессионального совершенствования учителя в условиях системы повышения квалификации : автореф. дис. канд. пед. наук : 13.00.01. Белгород, 2018. 20 с.

4. Бучківська Г.В. Система професійної підготовки майбутніх вчителів початкових класів на засадах народного декоративно-ужиткового мистецтва : авторефр. дис. д-ра педагогічних наук: 13.00.04 / Тернопільський національний педагогічний університет імені Володимира Гнатюка. Тернопіль, 2019. 39 с.

5. Ващенко Л.С. Уміння вчитися - ключова компетентність студентської молоді сучасного інформаційного суспільства. Інформаційні технології і засоби навчання. 2014. № 5. С. 1-14.

6. Король А. Художньо-графрічна компетентність студентів загальноосвітніх навчальних закладів як педагогічна проблема. Збірник наукових праць. Вип. 2. Київ, 2016. С. 165-174.

7. Корнеева Е.Н., Кузнецов М.С. Создание интерактивного учебного пособия по текстиль- ному дизайну (в рамках программы этнодизайна). Перспективы науки-2015 : сб. докл. I Междунар. заоч. конкурса науч.-исследовательских работ, 12-26 окт. 2015 г. Т. 1 (Социально-гуманитарные науки). Казань : Рокета-Союз, 2015. С. 244-250.

8. Руденченко А.А. Теоретичні і методичні засади навчання етнодизайну студентів у вищих мистецьких навчальних закладах : автореф. дис. докт. пед. наук : 13.00.02. Київ, 2017. 42 с.

9. Оршанський Л.В. Концептуальні засади та модель художньо-трудової підготовки майбутніх вчителів трудового навчання. Сучасні інформаційні технології та інноваційні методики навчання у підготовці фрахівців: методологія, теорія, досвід, проблеми : зб. наук. праць. 2008. № 16. С. 421-426.

10. Оршанський Л.В. Художньо-трудова підготовка майбутніх вчителів трудового навчання : [монографрія]. Дрогобич : ШвидкоДрук, 2008. 278 с.

11. Свінцицька Н.М. Формування готовності майбутніх вчителів трудового навчання до роботи в гуртках декоративно-прикладної творчості: змістовий компонент підготовки. Педагогіка формування творчої особистості у вищій і загальноосвітній школах. 2016. № 50(103). C. 239-249.

12. Соколов М.В. Профрессиональная подготовка художника декоративного искусства на основе активизации проектной деятельности. Педагогическое образование в России. 2015. № 11. С. 43-46.

13. Сотська Г.І. Теоретичні і методичні засади формування естетичної культури майбутніх вчителів образотворчого мистецтва в педагогічних університетах : монографрія / за наук. ред. О.М. Отич. Київ : Ін-т обдарованої дитини, 2014. 382 с. 


\section{ГЕНДЕРНА КУЛЬТУРА МАЙБУТНЬОГО ПЕДАГОГА В МЕЖАХ НЕФОРМАЛЬНОÏ ОСВІТИ ЗВО}

\section{GENDER CULTURE OF A FUTURE TEACHER WITHIN NON-FORMAL EDUCATION OF THE HIGHER EDUCATION INSTITUTION}

\begin{abstract}
Статтю присвячено дослідженню проблеми срормування гендерної культури майбутнього педагога в межах неформальної освіти ЗВО. Зазначено, що питання впровадження гендерного компонента в українських вишах можна віднести до найменш розроблених, оскільки система освіти залишається досить консервативною і не досить готовою до залучення гендерних нововведень. Важливою стає імплементація гендерного підходу у процес підготовки майбутніх педагогів, які працюватимуть у системі «людина - людина» і у своїй професійній діяльності мають враховувати гендерний чинник.
\end{abstract}

у статті наголошено, що доцільно акцентувати увагу на гендерній культурі як дієвому фоакторі та базовому компоненті впливу у вихованні національно свідомої особистості. Визначено, що гендерна культура $€$ системою иінностей, гендерних знань, статево-рольових норм поведінки, які сприяють реалізації срахових здібностей спечіалістів різної статі як рівних соціальних істот. Ідеали гендерної культури маркують соціальну сторону взаємин між статями, основу якої повинні складати моральні норми і иінності. Метою формування гендерної культури у позанавчальний час має стати не лише формування правильного розуміння сутності моральних норм та установок у ссрері взаємин між статями, але й потреби керуватися ними в усіх сфрерах діяльності. З'ясовано, що гендерне виховання молоді в Україні вимагає певних дій: введення спеціальних предметів і спецкурсів із гендерного питання; розроблення відповідних навчальних програм, методичних посібників, майстер-класів, семінарів, проведення гендерних тренінгів. Визначено, що використання гендерного тренінгу під час організації нефрормальної освіти сприяє повноцінному розвитку усіх компонентів підготовки майбутніх педагогів до основ гендерної освіти як профресійно важливої якості фрахівця. Запровадження ідей гендерного тренінгу в системі неформальної освіти майбутнього педагога сприяє підвищенню його самосвідомості, можливості самореалізації шляхом усвідомлення абсолютної цінності прав чоловіків і жінок; надає можливість відчувати власну гідність, гуманізм, толерантність, здатність до компромісу.

Ключові слова: гендерна культура, гендерний світогляд, гендерний стереотип, гендерний тренінг, неформальна освіта, статево-рольовий підхід.

Updating the content of Ukrainian higher education actualizes the task of developing the student's personality, in particular as a representative of a certain sex and modern requirements for university education prioritize both the professional qualities of the future professional and his / her competence as a subject of interaction with people of different sexes. It is especially important to implementing a gender approach in the process of training future teachers who will work in the system "person person" and to choosing an effective strategy for interaction with other people the gender factor must be taken into account.

It is determined that the gender culture is a system of values, gender knowledge, gender role norms of behavior that contribute to the realization of professional abilities of teachers of different sexes as equal social beings. The main stages of activity during the development of gender culture are singled out (the stage of forming the system of gender knowledge; the stage of forming skills of the analysis of phenomena and situations of gender inequality; the stage of improving skills of gender-competent behavior). The study and implementation of the gender culture in the informal sphere will make it possible to overcome the situation of gender disorientation, which is invaluable for the development of Ukraine as a European state.

The aim of forming the gender culture in extracurricular time should be both to realize a correct understanding of the essence of moral norms and attitudes in the field of relations between the sexes and the need to be guided by them in all spheres of activity. It is found out that the use of gender training in the organization of non-formal education performs the full development of all components of future teachers training to the basics of gender education as a professionally important quality of the future teacher. It is determined that the implementation of ideas of gender training in the system of non-formal education of the future teacher helps to increase his / her self-consciousness, possibilities of self-realization through realizing the full value of the rights of men and women; provides an opportunity to feel one's own dignity, humanism, tolerance, ability to compromise, etc. Key words: gender culture, gender worldview, gender stereotype, gender training, non-formal education, gender role approach.
Постановка проблеми в загальному вигляді. Комплексне вирішення проблем розвитку суспільства не можливе без створення рівних можливостей для самореалізації особистості в будь-якій сорері життєдіяльності незалежно від її статі. Оновлення змісту української вищої освіти актуалізує завдання розвитку особистості студента, зокрема і якпредставника певної статі, а сучасні вимоги до університетської освіти визначають пріоритетом не лише профресійні якості майбутнього фрахівця, але і його компетентність як суб'єкта взаємодії 3 людьми різної статі.

Особливо важливим $€$ впровадження гендерного підходу у процес підготовки майбутніх педагогів, які працюватимуть у системі «людина людина» і для обрання ефективної стратегії взаємодії 3 іншими людьми мають враховувати гендерний чинник. Тому доцільно акцентувати 
увагу на гендерній культурі як дієвому фракторі та базовому компоненті впливу у вихованні національно свідомої особистості.

Аналіз останніх досліджень і публікацій. Вивчення і впровадження гендерної культури саме в неформальній сорері дасть змогу подолати ситуацію гендерної дезорієнтації, що дуже важливо для розвитку України як європейської держави. Нині проблема інтеграції гендерного підходу в систему вищої освіти відображена у працях вітчизняних науковців, які розвивають погляди на засоби розвитку гендерної культури студентів (Л. Булатова, Т. Дороніна, І. Жеребкіна, О. Кікінежді, О. Луценко, М. Пірен). Філософські, соціальні, педагогічні, психологічні аспекти, які розглядаються в руслі гендерної культури, простежується у роботах В. Агеєвої, Р. Айвазової, Р. Айслер, О. Андрієнко, М. Гімбутас, Т. Говорун, Н. Грицяк, Г. Зіммеля, О. Кізь, І. Клименкової та інших науковців.

Виділення не вирішених раніше частин загальної проблеми. У науковому колі дослідження проблеми формування готовності здобувачів вищої освіти до втілення гендерної культури становить чималий доробок, однак потребують уточнення зміст, структура та умови ефективності реалізації цього процесу в освітній діяльності вишу.

Гендерний світогляд фрормується на основі гендерних знань. Засвоюючи основи наук, сповнених гендерним підходом до висвітлення усіх сорер життя людини, студенти самостійно і за участю педагогічних наставників фрормують систему поглядів. Тому важливо долучати молодь до вивчення гендерних аспектів у неформальній діяльності, щоб уникнути в майбутньому дискримінації як щодо жінок, так і щодо чоловіків. Насамперед необхідно стимулювати критичне осмислення з урахуванням гендерного аспекту в усіх галузях суспільного життя.

Мета статті. Метою статті є визначити зміст поняття «гендерна культура» як ключової категорії гендерно-культурних досліджень та обґрунтувати теоретичні основи використання засобів нефрормальної освіти (гендерного тренінгу) під час фрормування гендерної культури.

Виклад основного матеріалу. Новим явищем у розвитку загальної та професійної культури в XXI ст. стає гендерна культура, покликана фрормувати цілісне сприйняття людьми гендерних взаємин на основі їх інтелектуального, духовного і практичного усвідомлення.

У сучасних наукових джерелах поняття «гендерна культура» витлумачене як «сукупність статево-рольових цінностей у суспільних відносинах і відповідних до них нормативів поведінки, потреб, інтересів і форм діяльності, зумовлена суспільним устроєм, національними шлюбно-сімейними звичаями і традиціями, релігійними віруваннями»
[2, с. 36]; як «сукупність суспільних цінностей, які склалися в певному суспільстві, відшліфровувалися під час його історії, їм повинен підпорядковуватися кожний індивід, дотримуючись норм і стосовно чоловіка, і щодо жінки» [1, с. 7-11]. Гендерна культура - це система діючих у певному суспільстві поглядів, установок, принципів, матриць поведінки, які формують соціокультурні аспекти статі.

Гендерна культура фрормується в результаті критичного осмислення загальноприйнятих стереотипів і упереджень щодо мужності та жіночності, вона виявляється в дотриманні цих принципів у повсякденному житті. Молоде покоління стикається 3 великим обсягом досить суперечливої інфрормації про гендер, що спричиняє синтезування взаємовиключних позицій у його світогляді. Суперечливі уявлення про гендерні характеристики, моделі поведінки, зумовлені гендерною належністю, не лише є стійкими, але і відіграють роль соціальних приписів для молоді, які реалізуються в ситуаціях соціальної взаємодії. Поява гендерних стереотипів зумовлена тим, що модель гендерних відносин історично вибудовувалася у такий спосіб, що статеві відмінності переважали над індивідуальними, якісними відмінностями особистості чоловіка і жінки.

Функціонально гендерні стереотипи діють на психологічному і соціальному рівнях. На психологічному рівні їх наявність дозволяє людині економити зусилля в ситуаціях соціальної взаємодії, систематизуючи знання, одержані нею 3 навколишнього середовища, передбачати поведінку людини або групи; дозволяє ідентисрікувати себе 3 групою, підтримувати власну цінність і цінність групи. На соціальному рівні гендерні стереотипи забезпечують підтримку соціального порядку, що не лише підтверджує їх стійкість, але і пояснює їх внесок у процес орормування гендерної ідентичності в соціокультурному ракурсі.

Відповідно до фрункції соціального контролю гендерні стереотипи пояснюють наявні в суспільстві відносини статевої ієрархії, а також набувають нормативного статусу, підтримуючи соціально прийнятні зразки поведінки. Гендерні стереотипи забезпечують інтеграцію соціальної спільності, оскільки суспільні уявлення про чоловічі та жіночі якості сприяють створенню загального інфрормаційного простору, дозволяють відчувати належність до соціуму та підтримують стабільність, стійкість соціальної системи [5, с. 45].

Виконуючи роль нормативів, гендерні стереотипи як зразки справжньої мужності або жіночності, наявні в суспільній свідомості, здебільшого не відповідають моделям маскулінної і фремінної поведінки, що репрезентується їхніми носіями. Така ситуація розглядається як криза гендерної ідентичності, яка виявляється у соціокультурній площині як криза образів і норм маскулінності і 
фремінності, пов'язана із «розмиванням» або із зайвою стереотипізацією норм у комунікаційних каналах соціуму. У зв'язку з цим можна говорити про наявність проблем, пов'язаних з утриманням гендерних стереотипів як регуляторів статеворольового розвитку і поведінки; про ускладнення процесу статевої соціалізації молодого покоління, оскільки усі суспільні осередки пропускають крізь себе масові гендерні стереотипи.

Соціальний стан і характер діяльності чоловіків і жінок змінюються, що передбачає тривалу зміну їхніх базових установок і цінностей. Такий процес $€$ проблемою не окремої особистості, а станом психологічної нестабільності, характерним для значної частини чоловіків і жінок як представників гендерних груп.

Проблема формування гендерної культури повинна розглядатися на рівні суспільства і держави. Політика держави повинна бути орієнтована на забезпечення гендерної рівності як одного 3 компонентів гендерної культури. У ст. 24 Конституції України йдеться, що «рівність прав жінки і чоловіка забезпечується наданням жінкам рівних із чоловіками можливостей у громадсько-політичній і культурній діяльності, у здобутті освіти і професійній підготовці, у праці та винагороді за неї» [4].

Метою Закону України «Про забезпечення рівних прав та можливостей жінок і чоловіків» $€$ досягнення паритетного становища жінок і чоловіків у всіх сорерах життєдіяльності суспільства шляхом правового забезпечення рівних прав та можливостей жінок і чоловіків, ліквідації дискримінації за ознакою статі та застосування спеціальних тимчасових заходів, спрямованих на усунення дисбалансу між можливостями жінок і чоловіків реалізовувати рівні права, надані їм Конституцією і законами України.

В Україні гендерна рівність забезпечується на рівні Основного Закону країни, їі можна розглядати в контексті гендерного аспекту в політиці держави. Формування гендерної культури особистості $€$ одним із пріоритетних напрямів державної політики і в галузі сучасної освіти, яка має сприяти фрормуванню особистості майбутніх жінок і чоловіків із достатнім розумінням специфічних соціальних фрункцій, зумовлених саме статевою належністю.

У цьому аспекті важливим стає статево-рольовий підхід в освіті як традиційна система поглядів на призначення чоловіка і жінки в суспільстві відповідно до їхніх біологічних характеристик і фрізіологічних відмінностей між ними. У межах цього підходу заохочується виховання дівчат поступливими, слухняними, жіночними, а хлопчиків - мужніми, сміливими. Таким чином заклад освіти готує молодь виконувати у суспільстві відведені їм ролі. Статево-рольовий підхід впливає на вибір змісту освіти на основі закріплених у суспільній свідомості стереотипів [5, с. 421].
Загальна ідея фрормування гендерної культури полягає в утвердженні соціального статусу чоловіка і жінки, усвідомленні особистістю себе суб'єктом гендерної самоосвіти, прийнятті відповідальності за власне гендерне самоконструювання, гендерну поведінку, яка є запорукою успішної гармонії між статями в сучасному суспільстві. Формування гендерної культури не можливе без широкого гендерного просвітництва, здебільшого воно може здійснюватися в контексті неформальної освіти.

У ст. 8 Закону України «Про освіту» зазначено, що «неформальна освіта - це освіта, яка здобувається, як правило, за освітніми програмами та не передбачає присудження визнаних державою освітніх квалісрікацій за рівнями освіти, але може завершуватися присвоєнням професійних та/або присудженням часткових освітніх кваліфрікацій» [3].

Формування гендерної культури може здійснюватися через такі види неформальної освіти: профресійні тренінги (курси, семінари), які забезпечують підвищення кваліфікації та/або здобуття нових навичок; громадську освіту, яка готує індивіда виконувати роль громадянина; профресійне стажування для практичного оволодіння фрахом; онлайн-курси MOOC як інтерактивний додаток до традиційних видів навчання через мережу Інтернет.

Неформальна освіта користується великою свободою щодо змісту, методів і форм навчання та характеризується такими ознаками: орієнтація на конкретні освітні запити різних соціальних, професійних, демограсрічних груп населення; відсутність примусового характеру, власна мотивація; високий особистісний смисл навчання; внутрішня відповідальність особи за результат освітньої діяльності; гнучкість в організації та методах навчання; високий рівень активності студентів; самооцінка слухачами отриманих результатів на основі значущих для них критеріїв; побудова навчальної діяльності на взаємній повазі, демократичній культурі, культурі участі [6].

Гендерне виховання молоді в Україні передбачає не лише вивчення різних аспектів стосунків жінок і чоловіків у суспільстві, а й вимагає певних дій: введення спеціальних предметів і спецкурсів із гендерного питання; розроблення відповідних навчальних програм, методичних посібників, майстер-класів, семінарів, проведення гендерних тренінгів.

Зазначимо, що запровадження ідей гендерного тренінгу в системі неформальної освіти майбутнього педагога сприятиме підвищенню не лише його самосвідомості, а й можливості самореалізації шляхом усвідомлення абсолютної цінності прав чоловіків і жінок; дасть можливість відчувати власну гідність, гуманізм, толерантність, здатність до компромісу; бажання обирати активну позицію, щоб брати участь у вирішенні гендерних питань. 
Інтерактивна методика гендерної тренінгової програми ґрунтується на твердженні, що люди навчаються із більшим бажанням, коли відчувають цінність власних знань і досвіду та мають можливість поділитися ними в середовищі, яке для них є безпечним і позитивним.

Програму тренінгу рекомендовано побудувати так, щоб надану інформацію можна було закріпити через практичні вправи (рольові ігри, роботу в парах, застосування театральних дійств). Під час таких тренінгів змінюється не лише поведінка людини, а й методи виконання вправ учасниками, які набуватимуть практичних навичок, виявляючи відповідні знання та вміння щодо окресленої теми; збільшується сприйняття шляхом розширення розуміння теоретичних питань; змінюється ставлення до стереотипного сприйняття стосунків між чоловіками та жінками; мовний дискурс; виникає бажання внести зміни до своєї роботи, які базуються на гендерній чуйності. Проведення гендерних тренінгів у позанавчальній діяльності студентів сприяє фрормуванню в них навичок бути вільними від гендерних стереотипів і реалізує відповідальність за власну поведінку і міжособистісні взаємини.

Висновки. Гендерна культура майбутнього педагога $є$ системою цінностей, гендерних знань, статево-рольових норм поведінки, що сприяють розвитку здібностей фрахівців різної статі як рівних соціальних істот, які фрормують гендерні якості особистості шляхом реалізації певних педагогічних умов. У результаті засвоєння гендерних стереотипів, гендерних ролей, гендерних установок та інших елементів гендерної культури суспільства відбувається процес статево-рольової соціалізації індивідів, який детермінує ставлення людей до певних соціальних груп. Використання гендерного тренінгу під час організації неформальної освіти дозволяє здійснювати повноцінний розвиток усіх компонентів підготовки майбутніх педагогів до основ гендерної освіти як професійно важливої якості фрахівця.

У подальших розвідках заплановано дослідити стан сорормованості гендерної культури майбутніх педагогів шляхом проведення низки майстер-класів у межах неформальної освіти.

\section{БІБЛІОГРАФІЧНИЙ СПИСОК:}

1. Гендерні аспекти державної служби : монографрія: М. Пірен, Н. Грицяк, Т. Василевська, О. Іваницька; за заг. ред. Б. Кравченка. К. : Вид-во Соломії Павличко «Основи», 2002. С. 7-11.

2. Гендерна політика в Україні. Методичний посібник для державних службовців, представників органів місцевого самоврядування та ЗМІ. Харків : Райдер, 2007. 44 c.

3. Закон України «Про освіту». URL: https:// zakon.rada.gov.ua/laws/show/2145-19\#Text (дата звернення: 10.01.2021).

4. Конституція України. URL: https://www. president.gov.ua/ua/documents/constitution/konstituciyaukrayini-rozdil-ii (дата звернення: 10.01.2021).

5. Основи теорії гендера : навчальний посібник. K. : «K.I.C.», 2004. 536 C.

6. Перспективи впровадження несрормальної освіти в рамках процесу євроінтеграції. URL: http:// inmad.vntu.edu.ua/portal/static/3A799584-E5E44289-908C-9D4606BAE443.pdf (дата звернення: 11.01.2021) 


\section{СТРУКТУРА ГОТОВНОСТІ МАЙБУТНІХ ЛІКАРІВ ДО ПРОФЕСІЙНОЇ ВЗАЄМОДІї}

\section{THE STRUCTURE OF READINESS OF FUTURE DOCTORS FOR PROFESSIONAL INTERACTION}

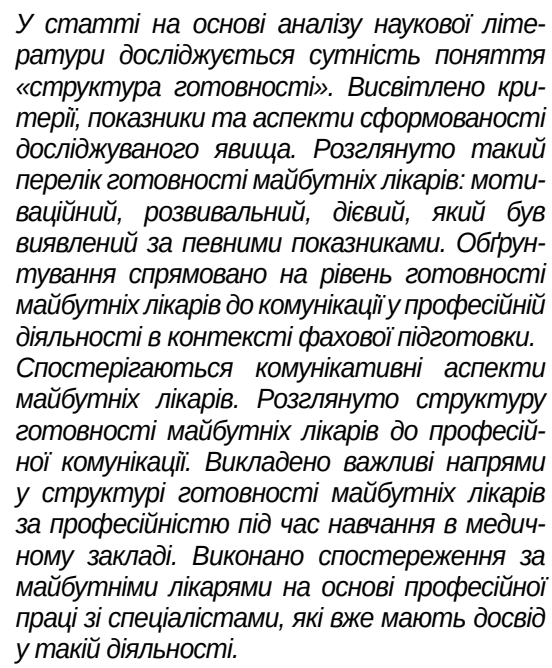

Розкрито психологічні проблеми майбутніх фрахівців у медичній ссрері, розвиток студента-медика за попередні роки навчання. Наведено інфрормацію про сформованість особистих показників готовності до праці після здобуття диплому і проходження першого етапу психологічного тиску. Передано ставлення майбутнього фахівия до поставлених цілей $і$ задач. Визначено позитивні якості медичного працівника, що є фундаментом готовності до процесу основної бази профресіоналізму.

Виявлено, що структура готовності майбутніх лікарів залежить від педагогічних умов рівня навчально-пізнавальної діяльності у медичних закладах. Структуре готовності виявлено на основі комунікації та робочого процесу під час практичних занять медичного закладу. Розкрито комунікаційні аспекти лікаря та студентамедика як початок формування психологічних уявлень; зв'язок досвідченого фрахівия із майбутнім медиком на останніх курсах практичних робіт для здобуття психологічних і фрізичних навиків. Виявлено різні компоненти на основі досліджень вченихмедиків у галузі фрахової підготовки. Розкрито аналізи та структури щодо майбутніх фрахівців як важливі критерії професійної діяльності майбутнього лікаря. Описано прочес залучення майбутнього фрахівця в перші робочі моменти.

Ключові слова: структура готовності, комунікації, компоненти, критерії, фоомування готовності, показники.

The article describes in detail the analysis of scientific and pedagogical literature and considers the essence of the concept of "readiness structure". This paper discusses all issues and aspects of this topic. It should be noted that the structure of readiness of future doctors directly depends on the pedagogical conditions of their educational and cognitive activities in higher medical education, so it is important that the organization of the educational process is consistent with the dynamics of personal and professional development of each student.

The methodology is designed to develop health readiness, which has proven to be effective and can be used by teachers to train future professionals in the qualification of "doctor", as well as for the formation and development of activities in other categories of the population.

Thus, an important factor in ensuring the professional readiness of future doctors at the present stage of reforming the system of higher medical education is the application to the organization of the educational process, which significantly affects the personal development of students and their professional identification. Students, getting more opportunities to choose the content, pac e, method and place of study, become active participants in the organization of the educational process.

This significantly affects the growth of their internal motivation to improve personal and professional qualities, which, in turn, becomes the basis for the implementation of the content of professional training of future doctors, the formation of their personal values, professionally important qualities. The need for professional training for future employment and the social function of professional awareness are a fundamental factor in ensuring the effectiveness of educational and cognitive activities of future health professionals.

Key words: specialists, structure, provision, development, formation Кіровоградського медичного фахового коледжу імені $€ . \breve{. ~ М у х і н а ~}$

Постановка проблеми в загальному вигляді. Психологічний тиск майбутніх лікарів, «здорове» сприйняття ситуації майбутнім лікарем, ставлення до людини як до цінності не можливі без високого рівня особистої зрілості лікаря, доброчесності, гармонії його профресійної свідомості.

Аналіз останніх досліджень і публікацій. У працях М. Дьоміної розкрита структура цілісного ставлення до професіоналізму; формування професійної спрямованості учнів на медичну професію - у роботах Р.В. Іваненко, Ю.Є. Кьюшиної, І.С. Вітенка, О.В. Денисової, Б.І. Ороховського. Профресійна готовність розглядається в контексті аналізу особистісно-профресійного становлення лікаря у працях Яська [3]. Аналіз теоретико-методичних основ формування професійної готовності майбутніх лікарів досліджував В.М. Галузяк. Науковці досліджують результат підготовки студентів до професійної та комунікативної діяльності тощо.

У структурі готовності майбутніх лікарів дуже важливі два напрями. Готовність майбутнього фрахівця як особистісна якість $€$ необхідною умовою діяльності людини під час виконання своїх обов'язків. Аналізуючи сутність цього поняття, вчені наводять різні його визначення, розглядаючи його як: 1) наявність в особистості певних 
здібностей (Б. Ананьєв, Н. Левітов, С. Рубінштейн); 2) якісну характеристику особистості (К. Платонов); 3) психологічний стан, суттєву ознаку установи (І. Блажава, Д. Узнадзе); 4) психологічну умову досягнення позитивного результату діяльності (І. Ладанов); 5) комплексну інтегральну характеристику особистості, яка визначається переконаннями, морально-вольовими якостями, стилем поведінки, сорормованістю знань про професію і профресійно необхідними практичними вміннями та навичками (Р. Романенко, В. Сєріков).

Мета статті - дослідити структуру готовності майбутніх лікарів до професійної взаємодії у навчальних закладах (комунікація, правильний виклад потрібного матеріалу).

Виклад основного матеріалу. Підготовка майбутнього лікаря до профресійної комунікації украй необхідна, оскільки у молодого фрахівця немає практики у профресійно-спрямованому мовленні, він допускає суттєві помилки [9]. Студентів у ВМНЗ під час навчального процесу мають навчити певним комунікативним уміннями: висвітлити тему та проблему комунікації, продемонструвати свої знання у лікувальній сорері, реагувати на сказане співрозмовником, вживаючи правильну інтонацію, правильно висловлювати свої думки [9, с. 68].Тому готовність до професійної комунікації як важливий аспект профресійної діяльності майбутнього лікаря є невід'ємною частиною роботи студентів за фрахом. Готовність майбутніх лікарів до професійної комунікації $€$ результатом послідовних дій, які потрібно реалізувати під час навчання у ВМНЗ.

Нині у психолого-педагогічних дослідженнях активно вивчаються проблеми в галузі профресійної підготовки фрахівців, насамперед педагогічної. У монографії Тихолаз «Розвиток профресійної спрямованості студентів вищих медичних навчальних закладів» на основі аналізу психолого-педагогічної літератури і педагогічної практики виявлено сутність і структуру спрямованості студентів вищих медичних навчальних закладів, розроблено критерії, показники та рівні її складання. Досліджено умови педагогіки, наведено приклад розвитку професійної спрямованості, що сприяє фрормуванню адекватного та натхненного ставлення студентів до медичної профресії. У статті запропоновано методичні рекомендації щодо розвитку професійної спрямованості майбутніх лікарів у процесі їх підготовки в медичних вузах [3].

У дослідницькому аналізі професійної діяльності лікаря важливо враховувати результати досліджень доктора психології, одного із основоположників новітньої психологічної галузі «Психології професій» $\quad €$. Зеєра. Дослідник зазначає про два етапи готовності майбутніх фрахівців. Для першого з них характерне прагнення особистості оволодіти певною професією, спеціальністю, для другого - підготовленість до певного виду професійної діяльності.

Дослідник виявив основні моменти цих рівнів:

1. Мотиваційний момент, який включає потребу у праці, зацікавленість професією та уявлення про соціальний статус.

2. Пізнавальний - розуміння соціальності, суспільної необхідності обраної профресії, визначеність методів досягнення мети.

3. Емоційний - моральна підготовленість майбутнього фрахівця до праці.

4. Вольовий - це компонент, який відповідає за вміння самоорганізації, досягнення та створення власної мети.

На другому рівні структура $€$ більш наближеною до професійної діяльності та розглядається як сфрормованість особистісних і професійних якостей, необхідних для успішної реалізації фахових завдань [4]. Існують специфрічні вимоги та умови для профресії майбутніх лікарів. Фахівці приділяють особливу увагу специфічним умовам і вимогам до особистісних якостей і ціннісних пріоритетів медика. Належить до професій суб'єктно-суб'єктного типу і лікувальна справа, діяльність лікаря в умовах підвищеної соціальнопсихологічної напруженості. Складність професійних завдань лікаря і його обов'язки зумовлюють вимоги до його профресійної готовності, тому студент-медик має бути впевнений у питанні обрання майбутньої профресії.

Лікарі часто працюють в умовах великого емоційного перенавантаження (операції, дитячі рідкісні хвороби, невиліковні пацієнти). Періодично виникають стресові ситуації, які потребують прийняття оперативних рішень без досить чіткої інфрормації. У Міністерстві охорони здоров'я сказано, що кожен лікар має бути кваліфікований і працювати офріційно. Майбутній лікар, готовий працювати, повинен розуміти, як працювати із сучасним обладнанням, правильно застосувати диореренційну діагностику, проводити лікування, реабілітацію та диспансеризацію хворих у межах своєї спеціальності.

Існує багато критеріїв, за якими лікар, працюючи у лікарні, може надавати швидку та невідкладну медичну допомогу; проводити нагляди за діями лікарських засобів, щоб уникнути фратальності; очікувати результатів на користь хворого при правильному лікуванні за певного діагнозу; вести документацію, правильно заповнювати картку хворого; дотримуватися принципів медичної деонтології; бути в змозі брати керування над медичним персоналом; постійно працювати над своїми знаннями [3].

На думку Л. Супрун, рівень якостей будь-якого медика має складати психологічну готовність до майбутньої профресії. Дослідниця зазначає такі якості: стресостійкість, комунікабельність, терпимість, 
чесність, відвертість, відповідальність, активність. У дослідженні І. Вітенко було виявлено проблеми стосовно профресійної готовності майбутніх лікарів.

Висновки. Соціальна функція професійної обізнаності $€$ головним аспектом ефективності навчально-пізнавальної діяльності майбутніх фрахівців у галузі охорони здоров'я. Методика розроблена для фрормування готовності працювати у сорері охорони здоров'я. Вона виявилася ефективною і може бути використана педагогами для підготовки майбутніх фрахівців за кваліфрікацією «лікар», а також для фрормування та розвитку діяльності інших категорій населення.

Необхідно зауважити, що структура готовності майбутніх лікарів залежить лише від педагогічних умов їх навчальної та пізнавальної діяльності у вищих навчальних закладах, тому важливо, щоб така організація узгоджувалася із динамікою особистісного та професійного розвитку кожного студента. Профресійна готовність якості педагогічних умов розвитку майбутніх лікарів визначає багато компонентів, які дуже необхідні як майбутньому фрахівцю, так і досвідченому лікарю [6].

\section{БІБЛІОГРАФІЧНИЙ СПИСОК:}

1. Бабин І. Зміна парадигми підходу до навчання в університеті - із орієнтованого на викладача до студентоцентрованого як основна вимога ЄПВО. І. Бабин [Електронний ресурс].

2. Вітенко І.С. Психологічні основи підготовки медичних кадрів / І.С. Вітенко. Х. : Основа, 1995.158 с.

3. Галузяк В.М. Розвиток професійної спрямованості студентів вищих медичних навчальних закладів. В.М. Галузяк, С.І. Тихолаз. Вінниця, 2016. 228 с.

4. Зеер Э. Компетентносный подход к модернизации профессионального образования. Э. Зеер, Э. Сыманюк. Высшее образование в России. 2005. № 4. C. 23-30.

5. Лещенко О. Політика ЮНЕСКО в освітній сорері. О. Лещенко. [Електронний ресурс].

6. Любіна Л.А. Гендерні особливості фрормування професійної компетентності майбутніх лікарів. Л.А. Любіна; Ін-т психології ім. Г.С. Костюка НАПН України. К., 2015. 18 с.

7. Національний освітній глосарій: вища освіта. 2-ге вид., перероб. і доп. / [авт.-уклад.: В.М. Захарченко, С.А. Калашнікова, В.І. Луговий, А.В. Ставицький, Ю.М. Рашкевич, Ж.В. Таланова]; за ред. В.Г. Кременя. К. : ТОВ «Видавничий дім «Плеяди», 2014. 100 c.

8. Скоробагата О.М. Готовність до діяльності як психолого-педагогічна проблема. О.М. Скоробагата [Електронний ресурс].

9. Супрун Л.М. Психологічний аналіз готовності майбутніх медсестер до професійної діяльності. Л.М. Супрун; Ін-т психології АПН України. К., 1994. 17 с. 


\section{ПЕДАГОГІЧНІ УМОВИ ПІДГОТОВКИ МАЙБУТНІХ АВІАЦІЙНИХ ІНЖЕНЕРІВ-МЕХАНІКІВ ДО ПРОФЕСІЙНОЇ КОМУНІКАЦЇ̈ \\ PEDAGOGICAL CONDITIONS OF AIRCRAFT MAINTENANCE ENGINEERS' TRAINING FOR PROFESSIONAL COMMUNICATION}

У статті визначено та обгрунтовано педагогічні умови підготовки майбутніх авіаційних інженерів-механіків до професійної комунікації: розвиток мотивації до спілкування шляхом активної взаємодії та створення ситуацій успіху на заняттях; моделювання профресійно-комунікативних ситуацій для забезпечення практичної спрямованості навчання; використання технологічних інновацій для самоаналізу та самоосвіти.

у контексті дослідження визначено педагогічні умови як сукупність пов'язаних між собою і взаємозумовлених обставин, як впливають на організацію педагогічного процесу та сприяють забезпеченню бажаної ефективності навчання для фрормування усіх складників підготовки майбутніх авіачійних інженерів-механіків до професійно комунікації. Педагогічні умови було визначено через вплив на основні компоненти готовності майбутніх авіаційних інженерівмеханіків до професійної комунікації: перша педагогічна умова впливає на мотиваційночіннісний компонент; друга - на когнітивнопраксеологічний; третя - на рефлексивнокорегувальний. Проте виокремлені умови знаходяться у тісному зв'язку й впливають i на інші компоненти.

Визначено, що мотивація відіграє значну роль у формуванні комунікативної компетентності, їй сприяє створення позитивної обстановки у прочесі срахової освіти та атмосфрери інтерактивної взаємодії. Зауважено, що зменшення мотивів неуспіху та мотивування на досягнення забезпечить успішність навчання професійній комунікаціі майбутніх авіаційних інженерів-механіків.

Застосування діяльнісного та контекстного підходів, роль професійно орієнтованого та профрільного змісту навчання робить акцент на моделювання профресійно-комунікативних ситуацій для забезпечення практичної спрямованості навчання. Впровадження зазначеної педагогічної умови у підготовку майбутніх авіаційних інженерів-механіків дозволить покращити процес оволодіння знаннями та вміннями зі сфрери профресійної комунікації.

УДК 378.14

DOI https://doi.org/10.32843/2663-

6085/2021/31-1.23

Мазуренко Ю.А.,

аспірант кафедри

професійної педагогіки

та соціально-гуманітарних наук

Льотної академії

Національного авіаційного університету діяльність, майбутні інженери-механіки, авіаційні фрахівиі.

The article defines and substantiates the pedagogical conditions for training future aircraft maintenance engineers for professional communication, namely: the development of motivation to communicate through active interaction and the creation of situations of success in the classroom; modeling of professional-communicative situations to ensure the practical orientation of training; use of technological innovations for self-analysis and self-education.

In the context of the study, pedagogical conditions are defined as a set of interrelated and interdependent circumstances that affect the pedagogical process and contribute to the desired effectiveness of the formation of all components of aircraft maintenance engineers' training for professional communication. The pedagogical conditions were determined through the impact on the main components of the future aircraft maintenance engineers' readiness for professional communication: the first pedagogical condition affects the motivational and value component; the second influnces cognitive-praxeological component; and the third - reflexive-corrective one. However, it has been noted that the selected conditions are closely related and affect other components.

It has been stated that motivation plays a significant role in the formation of communicative competence, it is facilitated by the creation of a positive environment in the process of professional education and the creation of the atmosphere of interactive interaction. Reducing the motives of failure and increasing motives of success will ensure effective training in professional communication of future aircraft maintenance engineers.

The use of activity and contextual approaches, the role of professionally oriented and profile content of education determine the pedagogical condition of modeling professional and communicative situations to ensure the practical orientation of learning. The introduction of this pedagogical condition in the future aircraft maintenance engineers' training will improve the process of acquiring knowledge and skills of professional communication.

The use of technological innovations for selfanalysis and self-education has been determined due to the process of informatization in the society and the role of self-study in professional training. It has been suggested that the introduction of technological innovations for self-education, which are carefully selected to neutralize the disadvantages of their application, will improve knowledge, skills and develop communication skills of future aircraft maintenance engineers. Key words: pedagogical conditions, readiness for professional communication, professional activity, future aviation maintenance engineers, aviation specialists. 
Постановка проблеми в загальному вигляді. Метою вищої освіти є підготовка висококваліфрікованого компетентного фрахівця, здатного до розв'язання складних задач професійної діяльності. Освітня галузь знаходиться у стадії постійного реформування для забезпечення цієї мети, пошуку нових шляхів і засобів покращення підготовки. Авіаційні фрахівці не є виключенням. До них висуваються підвищені міжнародні вимоги, запити від роботодавців акцентують увагу на необхідності модернізації підготовки. Існує потреба у визначенні фракторів і можливостей змісту освіти, що є дієвим інструментом для моделювання процесу фахової підготовки. Обґрунтування та реалізація ефрективних педагогічних умов дозволить підвищити рівень сорормованості готовності майбутніх інженерів-механіків до професійного спілкування.

Аналіз останніх досліджень і публікацій. Окремі аспекти профресійної підготовки майбутніх інженерів в авіації були предметом дослідження Л. Барановської, Н. Глушаниці, О. Гнатюк, А. Кокарєвої, Е. Лузік, Л. Конопляник, О. Панченко та інших. Готовність до професійної комунікації та використання іноземної мови майбутніх авіаційних та інженерних кадрів була предметом дослідження О. Каверіної, Л. Конопляник, О. Москаленко.

Виділення не вирішених раніше частин загальної проблеми. Питання визначення та обґрунтування педагогічних умов підготовки майбутніх авіаційних інженерів-механіків до профресійної комунікації ще не було предметом наукового пошуку.

Мета статті - виокремити та обґрунтувати педагогічні умови підготовки майбутніх авіаційних інженерів-механіків до профресійної комунікації.

Виклад основного матеріалу. У нашому дослідженні ми розуміємо педагогічні умови як сукупність пов'язаних і взаємозумовлених обставин, які впливають на організацію педагогічного процесу та сприяють забезпеченню бажаноі ефрективності навчання для фрормування усіх складників підготовки майбутніх інженерів-механіків до профресійної комунікації.

Аналіз теоретичних засад проблеми підготовки майбутніх інженерів-механіків до професійної комунікації, бесіди та опитування діючих фрахівців авіаційної галузі, викладачів льотних ЗВО дозволили визначити такі педагогічні умови, вплив яких найефективніше діє на процес фрормування готовності до професійної комунікації:

1) розвиток мотивації до спілкування шляхом активної взаємодії та створення ситуацій успіху на заняттях;

2) моделювання профресійно-комунікативних ситуацій для забезпечення практичної спрямованості навчання;

3) використання технологічних інновацій для самоаналізу та самоосвіти.
У попередніх дослідженнях було виокремлено компоненти готовності майбутніх авіаційних інженерів-механіків до профресійної комунікації. У процесі теоретичного аналізу було виокремлено умови, які, на нашу думку, будуть найеорективніше впливати на кожен компонент (мотиваційно-ціннісний, когнітивно-праксеологічний, рефрлексивнокорегувальний).

Щодо першої педагогічної умови - розвитку мотивації до спілкування шляхом інтерактивної взаємодії та створення ситуацій успіху на заняттях необхідно зазначити про значний вплив мотивації до спілкування на фрормування комунікативної компетентності. Роль мотивації у навчанні іншомовного спілкування була предметом дослідження низки вчених (І. Зимня, А. Щукін). І. Зимня зазначає, що мотивація є сукупністю різних збудників (потреби, мотиви, почуття, інтереси); це те, що визначає, стимулює, спонукає людину до виконання якоїсь дії, включеної до визначеної цією мотивацією діяльності [5, с. 100].

Позитивна обстановка у процесі вивчення мови визначена серед чинників, які впливають на формування мотивації до навчання. А. Щукін підкреслював, що додатковими чинниками, які впливають на мотивацію до вивчення мови, є привабливість матеріалу, характер методичних прийомів, психологічна обстановка та вміння викладача знайти індивідуальний підхід, суб'єктивні особливості студентів, сорормованість вміння та готовність вчитися, особистісні риси викладача [12, с. 24].

Л. Подоляк і В. Юрченко [7] зазначають, що фрормування мотивів навчання можливе лише в діяльності, організованій викладачем. На їхню думку, для забезпечення стійкої мотиваційної сорери необхідно збагачувати зміст навчального матеріалу, розкривати суспільне значення майбутньої професійної діяльності, фрормувати уявлення про майбутнє професійне життя, допомагати усвідомити ближні й кінцеві цілі навчання, важливість самостійного навчання, роботи з літературою, підтримувати пізнавальний психологічний клімат у навчальній групі, виховувати відповідальне ставлення до навчання [7, с. 164].

Питання про інтерактивну взаємодію та ії̈ суть розглядають Б. Бадмаєв, М. Кларін, О. Комар, А. Панфрілова, Л. Пироженко, О. Пєхота, О. Пометун, Т. Розумна, С. Стеблюк та інші. Т. Розумна визначає інтерактивну взаємодію як «суб'єктсуб'єктну взаємодію на основі діалогу вчителя 3 учнями та учнів між собою, побудовану на засадах співпраці, та припускає унікальність суб'єктів та їхню принципову рівність, варіативність позицій кожного суб'єкта на сприйняття, розуміння й активну інтерпретацію точок зору іншими суб'єктами» [9, с. 5].

Учена доводить, що забезпечити вказану вище взаємодію можна за наявності позитивних 
стосунків між викладачем і студентами, співпраці, опертя на особистісний досвід студентів, включення у навчальний процес яскравих прикладів, фрактів; за наявності різних фрорм діяльності студентів та їх регулярної зміни; за включення внутрішньої та зовнішньої мотивації діяльності, а також взаємомотивації студентів [9, с. 8].

Інтерактивна взаємодія на занятті виникає завдяки мотивації викладача, оскільки насамперед він налаштовує на позитивні та дружні стосунки зі студентами та студентів між собою. У процесі роботи на занятті викладач підтримує мотивацію до спілкування шляхом застосування цікавого матеріалу, співпрацю та використання досвіду, що стимулює до взаємомотивації зі сторони студентів.

О. Пометун [8, с. 15] зазначає, що «без можливості обговорювати, ставити питання, опрацьовувати й навіть навчати іншого реальне засвоєння не відбувається». У такому навчанні викладач $€$ фасилітатором, а міжособистісні зв'язки та співпраця допомагають досягти оптимальних результатів у навчання. Інтерактивна взаємодія сприяє підготовці студентів до профресійної комунікації, у процесі спільного вирішення проблем і дискусії відбувається професійне становлення фрахівця.

Створення ситуацій успіху важливе для мотивації майбутніх інженерів-механіків, оскільки воно спрямоване на залучення «мотиву досягнення». На думку С. Занюка [4], успіхи від діяльності залежать не лише від здатності, знань, умінь і навичок, але й від мотивації досягнення. Людина за високим рівнем мотивації на досягнення буде працювати більше, намагатися отримати високі результати, цілеспрямовано досягати поставлених цілей. Те, наскільки людина мотивована на досягнення, вимірюється впливом таких чинників: значимість досягнення успіху, надія на успіх, суб'єктивно оцінена вірогідність досягнення успіху, суб'єктивні еталони досягнення.

Серед основних чинників, які перешкоджають вільному спілкуванню у процесі оволодіння комунікативною компетентністю і спрямовуються на неуспіх, необхідно назвати побоювання отримати низьку оцінку та засудження одногрупниками. Зменшення мотивів неуспіху та мотивування на досягнення забезпечить успішність навчання професійній комунікації майбутніх авіаційних інженерів-механіків.

Друга педагогічна умова підготовки майбутніх авіаційних інженерів-механіків до професійної комунікації - моделювання професійно-комунікативних ситуацій для забезпечення практичної спрямованості навчання. Насамперед вона пов'язана із застосуванням діяльнісного та контекстного підходів у навчанні. Суть діяльнісного підходу (Л. Виготський, Б. Ломов, А. Леонтьєв, С. Рубінштейн) полягає у засадничій ролі діяль- ності в житті людини: особистість у діяльності не лише виявляє себе, але й формується. Контекстний підхід передбачає «занурення» в профресійну діяльність у процесі навчання.

Дослідник А. Вербицький визначає контекстне навчання як таке, «у якому моделюється предметний і соціальний зміст майбутньої професійної діяльності спеціаліста, а засвоєння ним абстрактних знань як знакових систем накладено на канву цієї діяльності» [3, с. 33]. В основу контекстного навчання покладено проблемну ситуацію, що зумовлює концентрацію знань для вирішення поставленого завдання. Через активні методи навчання відбувається предметне й соціальне моделювання майбутньої професійної діяльності.

На ролі профресійно-орієнтованого та профрільного змісту навчання іноземних мов у ЗВО наголошували дослідники О. Бернадська, О. Пометун, О. Тарнопольский, Л. Якубовська. О. Тарнопольський підкреслює, що в навчанні видів іншомовної мовленнєвої діяльності повинен бути пріоритет і домінування комунікативного підходу, «створюючи умови, які $є$ максимально наближеними до реальних умов іншомовної мовленнєвої комунікації та моделюють їх» [10, с. 243].

Дослідниця О. Бернадська [2] зазначає про переваги моделювання професійно-комунікативних ситуацій у формуванні навичок іншомовного професійного спілкування: наявність елементів новизни, творчості; засіб для позбавлення одноманітності; створення атмосфери спілкування у процесі заняття; підвищення якості навчання іноземної мови. Учена пропонує такі етапи педагогічного моделювання професійних ситуацій: постановка проблеми, побудова моделі певної педагогічної ситуації, вибір способу її застосування, реалізація плану застосування моделі у навчальному процесі, аналіз одержаних результатів.

Важливим науковим доробком дослідження О. Бернадської є така класифікація видів профресійно-комунікативних ситуацій: ситуація-вправа, ситуація-ілюстрація, ситуація-оцінка, ситуаціязапит інформації, ситуація-виклад, ситуація-проблема. Експериментальне дослідження використання системи ситуацій професійної діяльності передбачає активізацію процесу навчання і сприяння фрормуванню комунікативних умінь.

Л. Якубовська експериментально довела, що використання навчально-рольових ігор професійної спрямованості у процесі вивчення іноземної мови допомагає ефективно розв'язати комплекс важливих завдань: активізація процесу навчання, надання йому творчого характеру; набуття курсантами досвіду іншомовного спілкування в контексті майбутньої професії; розвиток не лише пізнавальних, а й професійних мотивів; формування цілісного уявлення про майбутню профресійну діяльність, її специфіку та фрункції; вдосконалення 
комунікативних умінь і навичок соціальної взаємодії, індивідуального і колективного прийняття рішень; підвищення навчальної успішності курсантів $[13$, с. $12-13]$.

Отже, впровадження педагогічної умови моделювання професійно-комунікативних ситуацій для забезпечення практичної спрямованості навчання у підготовку майбутніх авіаційних інженерів-механіків дозволить покращити процес оволодіння знаннями та вміннями професійної комунікації, підвищить мотивацію до спілкування та професійної діяльності, дозволить розвинути якості та навички профресійної взаємодії.

щодо третьої педагогічної умови підготовки майбутніх авіаційних інженерів-механіків до професійної комунікації - використання технологічних інновацій для самоаналізу та самоосвіти зазначаємо, що роль інформаційно-комунікаційних технологій (далі - IKT) в освіті нині важко переоцінити. А. Андрєєв [1] зауважує, що інформатизація суспільства $€$ важливою відмінною рисою сучасного етапу розвитку. Останніми роками процес інформатизації суспільства набув дійсно глобального характеру та охопив не лише усі розвинені країни, але й держави, які розвиваються.

Для сучасного процесу підготовки до профресійної комунікації з використанням ІКТ характерні тенденції до постійного збільшення обсягу інорормації, наявність широкого спектру технологічних інновацій, швидка зміна технологій та їх застаріння. Чимало провідних учених вказували на зростаючу роль самоосвіти у рамках розвитку інорормаційного суспільства (А. Андрєєв, В. Корвяков, В. Надеїн, Є. Полат, Г. Сєріков, М. Солдатенко, О. Шукліна та інші), а також використання IKT як засобу самоосвіти (Є. Ганін, Ю. Калугін, О. Кисельова, С. Яшанов). У контексті застосування ІКТ для підготовки майбутніх авіаційних фахівців важливими є дослідження Л. Герасименко, О. Діденко, О. Москаленко, Т. Плачинди та інших.

О. Тищенко наголошує на ролі самоосвіти у процесі фрахової підготовки і зазначає, що «самоосвіта $€$ результатом освіти й обов'язковою умовою ефективності останньої» [11, с. 161]. Дослідниця визначила зв'язок процесів освіти й самоосвіти, що зумовлено кількома фракторами: самоосвіта сприяє накопиченню знань, фрормуванню інтелекту, розвитку розумових сил і здібностей; самоосвіта $€$ інформативним процесом, складником розумового самовиховання, завдяки якому виробляються якості, необхідні для успішного оволодіння знаннями; самоосвіту не можна ототожнювати із самостійною роботою, тому що самоосвіта є цілеспрямованим добровільним удосконаленням особистості у сфері науки, культури за допомогою самостійної та науково-дослідницької діяльності.
О. Кисельова виокремила особливості самоосвіти в умовах сучасного інформаційно-навчального середовища, які $є$ й перевагами застосування ïx у підготовці майбутніх авіаційних інженерів [6, с. 7]: відкритість і динамічність інорормаційного простору самоосвіти; розширення форм самоосвіти; відсутність часових і територіальних обмежень щодо її здійснення; варіативність самоосвітніх електронних навчально-інсрормаційних ресурсів; опосередкованість доступу до інтернетджерел; наявність додаткових можливостей для самоконтролю.

Навчальні плани підготовки майбутніх авіаційних механіків передбачають значну кількість годин на опрацювання навчального матеріалу самостійно. Вища освіта ще знаходиться у пошуку шляхів організації самостійної підготовки таким чином, щоб це відбувалося максимально ефективно. Дослідники підготовки авіаційних фрахівців засобами IKT (Т. Плачинда, Л. Герасименко, К. Крижевська, Г. Пухальська [14]) зазначали, що на самостійну роботу у підготовці авіаційних фахівців виділено до 60\% часу. 3 огляду на теоретичні дослідження з ІКТ для самостійної підготовки та той фракт, що студенти активно користуються ґаджетами у повсякденному житті, вони запропонували використання системи MOODLE для організації самостійної підготовки та експериментально довели ії ефективність.

Дослідники [14] вказали на переваги та недоліки використання цієї платформи. Серед переваг застосування платформи був зазначений опір на ІТ-звички студентів; доступ до інформації 24/7; зручне структурування матеріалу; зручність в оцінюванні; простота оновлення матеріалу та його редагування; легкість у плануванні завдань; використання аудіо- та відеоматеріалів; автоматизована система рейтингу студентів; самоперевірка; психологічний і фрізіологічний коморорт; об'єктивна оцінка (без помилок людини).

Негативними сторонами реалізації платорорми MOODLE були визначені такі аспекти: трудомістка технологія розміщення навчальних матеріалів; неможливість ідентифрікувати особу, яка виконує завдання (можливість виконувати завдання для друга); відсутність у студентів самодисципліни; тимчасова відсутність доступу до ресурсу через технічні проблеми; втрата зв'язку; не соціалізація та відсутність навичок публічного виступу; складність підготовки викладачів для використання веборієнтованої платформи MOODLE.

Ми вважаємо, що запровадження комплексу технологічних інновацій для самоосвіти, які $€$ ретельно підібраними, щоб максимально нейтралізувати недоліки застосування, сприятиме покращенню знань, умінь і навичок та розвитку здатностей до профресійної комунікації майбутніх авіаційних інженерів-механіків. 
Висновки. Отже, ми виокремили такі педагогічні умови формування готовності майбутніх авіаційних інженерів-механіків до професійної комунікації: розвиток мотивації до спілкування шляхом активної взаємодії та створення ситуацій успіху на заняттях; моделювання професійно-комунікативних ситуацій для забезпечення практичної спрямованості навчання; використання технологічних інновацій для самоаналізу та самоосвіти.

Перша педагогічна умова впливає на мотиваційно-ціннісний компонент; друга - на розвиток когнітивно-праксеологічного компоненту; третя - на використання технологічних інновацій для самоаналізу та самоосвіти і здійснює значний вплив на ресрлексивно-корегувальний компонент. Проте виокремлені умови знаходяться у тісному зв'язку й впливають і на інші компоненти.

Подальші дослідження вбачаємо в розробці структурно-фуункціональної моделі підготовки майбутніх авіаційних інженерів-механіків до професійної комунікації та експериментальній перевірці запропонованих умов.

\section{БІБЛІОГРАФІЧНИЙ СПИСОК:}

1. Андреев А.А. Педагогика высшей школы. Новый курс М. : Московский международный институт эконометрики, информатики, фринансов и права, 2002. $264 \mathrm{c}$.

2. Бернадська О.В. Моделювання ситуацій професійної діяльності у навчанні іноземної мови у вищому навчальному закладі військового профілю : автореф. дис. канд. пед. наук: 13.00.04 / Київський національний університет імені Тараса Шевченка. Київ, 2004. 21 с.

3. Вербицкий А.А. Активное обучение в высшей школе: контекстный поход : методическое пособие. М. : Высш. шк., 1991. 207 с.
4. Занюк С.С. Психологія мотивації : навч. посібник. К. : Либідь, 2002. 304 с.

5. ЗимняяИ.А. Психология обучения иностранным языкам в школе. М. : Просвещение, 1991. 222 с.

6. Кисельова О.Б. Формування компетентності самоосвіти у майбутніх педагогів в умовах інформаційно-навчального середовища : автореф. дис. на здобуття наук. ступеня канд. пед. наук : 13.00.09 / ХНПУ імені Г.С. Сковороди. Харків, 2011. 20 с.

7. Подоляк Л.Г., Юрченко В.І. Психологія вищої школи : підручник. 2-ге вид. Київ : Каравела, 2008. 352 с.

8. Пометун О. Енциклопедія інтерактивного навчання. Київ, 2007. $141 \mathrm{c.}$

9. Розумна Т.С. Підготовка майбутніх вчителів гуманітарних спеціальностей до організації інтерактивної взаємодії з учнями : автореф. дис. канд. пед. наук : 13.00.04 / Бердянський державний педагогічний університет. Бердянськ, 2012. 23 с.

10. Тарнопольський О.Б. Методика навчання іншомовної мовленнєвої діяльності у вищому мовному закладі освіти : навч. посіб. К. : Фірма «ІНКОС», 2006. 248 c.

11. Тищенко O.І. Самоосвітня діяльність вчителя як педагогічна проблема. Педагогіка фрормування творчої особистості у вищій і загальноосвітній школах. 2016. Вип. 47. С. 159-163.

12. Щукин А.Н. Обучение иностранным язывам: теория и практика : учебное пособие для преподавателей и студентов. М. : Филоматис, 2004.406 с.

13. Якубовська Л.П. Використання навчальнорольових ігор професійної спрямованості у процесі навчання іноземної мови майбутніх офріцерів-прикордонників : авторефр. дис. канд. психол. наук : 20.02.02 / Нац. акад. прикорд. військ України ім. Б. Хмельницького. Хмельницький, 2002. 18 с.

14. Plachynda T., Herasymenko L., Pukhalska G., Kryzhevska K. Using Information Communication Technologies in Professional Training of Future Civil Aviation Pilots. Revista Romaneasca pentru Educatie Multidimensionala, 2019. № 11(2), P. 270-281. 
ФОРМУВАННЯ ЛІНГВІСТИЧНОЇ КУЛЬТУРИ МАЙБУТНЬОГО ПЕДАГОГА ПОЧАТКОВОЇ ШКОЛИ

\section{FORMATION OF LINGUISTIC CULTURE OF THE FUTURE PRIMARY SCHOOL TEACHER}

Статтю присвячено актуальній проблемі створення педагогічних умов для самореалізації педагогічної особистості, міжособистісних відносин у профресійній діяльності. Метою дослідження є визначення, наукове обгрунтування та експериментальна перевірка освітньої технології формування на основі аналізу авторського тексту просресійної лінгвістичної культури особистості майбутнього педагога початкової щколи у закладах вищої освіти на засадах кращих національних духовних традицій в умовах Нової української школи. Духовна культура, частиною якої $\epsilon$ лінгвістична культура, мовна і мовленнєва, створює особливий світ цінностей, формує та задовольняє інтелектуальні, емоційні потреби особистості. «Класичною тріадою духовної культури $\epsilon$ істина, добро, краса», а складники духовної культури - знання, інформація, значення, норми, звичаї.

Науковою новизною дослідження $є$ розроблення і впровадження в освітній процес вищої школи інтегративної системи інди відуально орієнтованої технології вивчення, аналізу й закріплення навчального матеріалу на основі авторського тексту, що сприяе ефективності процесу підвищення рівня лінгвістичної культури педагогічної особистості майбутнього вчителя початкової школи.

У статті обгрунтовано теоретичні засади процесу фрормування лінгвістичної культури особистості педагога початкової школи, експериментально перевірено модель їі реалізації у професійному розвитку майбутнього фрахівця. Здобуті результати підтвердили правомірність вихідних положень дослідження, а реалізація мети $і$ завдань стали підставою для відповідних висновків. Сорормований рівень лінгвістичної культури студентів, майбутніх учителів початкової школи, у процесі виконання ними мовних завдань на основі аналізу авторського тексту $\epsilon$ підтвердженням рівня лінгвістичної компетентності та результатом складного процесу набуття ії в умовах інноваційних технологій, спрямованих на розвиток мислення, пізнання, мови, мовлення, а отже інтелектуальної культури майбутніх фрахівців в умовах нової української школи.

Ключові слова: лінгвістична культура, рідна мова, Нова українська школа, педагогічна особистість, майбутній учитель початкової школи, лінгвістична компетент- ність, духовна культура, інтелектуальна культура.

The article is devoted to the actual problem of creating pedagogical conditions for selfrealization of a teacher personality, interpersonal relations in the professional activity. Article's purpose is definition, scientific substantiation and experimental verification of the educational technology of forming a professional linguistic culture of the teacher personality of the primary school based on the analysis of the author's text in higher educational establishments in accordance with the best national spiritual traditions in the conditions of the New Ukrainian School. Spiritual culture, a part of which is the culture of language and speech, creates special world of values, forms and satisfies individual's intellectual and emotional needs. "The classical triad of spiritual culture is the truth, kindness, beauty". The components of spiritual culture are knowledge, meaning, norms, and customs

The scientific novelty of the research is creating and realization of an individually oriented technology of studying, analysis and consolidation of educational material on the basis of the author's text in the higher educational process of the higher school, which contributes to the efficiency of the process of raising the level of linguistic culture of the future teacher of the primary school.

The theoretical foundations of the process of forming the linguistic culture of the personality of a primary school teacher were substantiated; the model of its implementation in the professional development of the future specialist was experimentally tested in the research. The obtained results confirmed the validity of the initial provisions of the research, and the realization of the purpose and the objectives became the basis for the relevant conclusions and recommendations.

The formed level of students' linguistic culture while performing their language tasks based on the analysis of the author's text is confirmation of a linguistic competence level and is the result of a complex process of obtaining it in the conditions of innovative technologies aimed at the development of thinking, cognition, language, speech, and therefore the intellectual culture of students.

Key words: linguistic culture, native language, New Ukrainian School, pedagogical personality, future teacher of the primary school, linguistic competence, spiritual culture, intellectual culture.
Постановка проблеми у загальному вигляді. Сучасна система освіти в контексті вимог програми Нової української школи передбачає створення умов для самореалізації особистості.

Лінгвістична культура створює особливий світ цінностей, фрормує та задовольняє інтелектуальні, емоційні потреби особистості. До складників духовної культури ми відносимо знання, інфрормацію, значення, норми, звичаї. Особистість - це сукупність суспільних відносин, але вона є такою настільки, наскільки реалізується у діяльності. За думкою О. Леонтьева [8], поняття особистості так само, як і поняття індивіда, виражає цілісність суб'єкта життя, це особливе цілісне утворення, нею не народжуються, а стають. Доведено, що виховати особистість здатна тільки особистість, яка завжди визначається духовністю, інтелігентністю, рівнем інтелекту, повагою до себе і до інших, 
почуттям власної гідності i, безперечно, вмінням відчувати Слово і вдало ним користуватися. Саме такий учитель може задовольнити потреби сучасного суспільства. На думку Ш. Амонашвілі, «слово «вчитель» після слова БОГ очолює усі слова в усіх мовах» [2]. Отже, навчити розуміти слово необхідно і можливо, варто тільки намагатися фрормувати особистість майбутнього педагога початкової школи таким чином, щоб лінгвістична культура переважала в усьому, а особливо - у знаннях. Основна мета освіти - допомогти дітям в інтелектуальному, духовному, емоційному, фрізичному та соціальному розвитку, створити їм відповідні умови для навчання. Саме тому поняття «мовна особистість» (В. Виноградов) [5] є зараз особливо актуальним, консолідуючи підходи таких наук, як педагогіка, психологія, комунікативна лінгвістика, педагогічна риторика, лінгводидактика.

Аналіз останніх досліджень і публікацій доводить, що теоретичною основою дослідження $\epsilon$ теоретико-методичні та культурологічні аспекти фрілософії фрормування нового покоління фрахівців (В. Андрущенко, І. Зязюн, В. Кремень, В. Луговий, В. Роменець); педагогічні надбання педагогів-класиків (Г. Ващенко, С. Русова, В. Сухомлинський, К. Ушинський); психологічна теорія зв'язку мови та мислення, мови та пізнання, мови та мовлення (Ш. Амонашвілі, Л. Виготський, О. Леонтьєв, І. Огієнко, О. Потебня, С. Рубінштейн); наукові праці 3 проблем лінгвістичного аналізу тексту (М. Бахтін, Л. Булаховський, В. Виноградов, Д. ОвсяникоКуликівський); роботи мовознавців, лінгводидактів, методистів ыз питань фрормування лінгвістичної компетентності і культури особистості педагога в процесі використання сучасних освітніх технологій (А. Білецький, Г. Онкович, О. Пономарів, О. Савченко).

Виділення не вирішених раніше частин загальної проблеми. Мовна освіта й мовленнєвий розвиток особистості - одна 3 центральних проблем сучасності, але сьогодні проблема оволодіння мовою - це проблема не стільки лінгвістична, скільки соціально-психолого-педагогічна. Аналізуючи ії, неможливо не врахувати, що рівень підготовки вчителя початкової школи є відповідним рівнем професійної майстерності високоосвіченої мовної особистості, адже освіченим є той, хто володіє високим рівнем лінгвістичної культури, що $€$ частиною невирішених проблем загальної проблеми. На жаль, і дотепер бракує нових інтегрованих авторських методик фрормування лінгвістичної культури фрахівця, адже рівень мовного інтелекту залежить від ступеня розвитку суспільства, від умов навчання мови окремого індивідуума, від виховання в особистості мовної інтуїції, відчуття енергії Слова, розвитку внутрішнього мислення та мовлення.

Метою статті є визначення, наукове обґрунтування та експериментальна перевірка освітньої технології фрормування на основі аналізу авторського тексту професійної лінгвістичної культури особистості майбутнього педагога.

Концептуальною ідеєю статті $€$ положення про те, що формування лінгвістичної культури педагогічної особистості майбутнього вчителя початкової школи є соціальною вимогою, базується на психолого-педагогічній теорії і практиці, спрямовано на реалізацію міжособистісних відносин у профресійній діяльності і створення умов для вдосконалення мовної та мовленнєвої культури студентів на засадах кращих національних традицій.

Вивчення рідної мови є шляхом набуття знань задля того, щоб згодом, поступово накопичуючи їх, послідовно передати нащадкам найважливіше, найцікавіше. Відомо, що мова бере участь у творенні людини, оскільки мова сама в собі має свого роду енциклопедію знань (А. Білецький) [4]. І дійсно, енциклопедичний рівень мовних знань може мати будь-яка людина. Важливо, якщо ці знання має фрахівець, педагогічна особистість, яка вільно володіє граматично правильно спрямованим головним знаряддям їхньої передачі - словом. Тільки тоді можна сподіватися, що слово педагога позитивно впливатиме на результат навчання та виховання його учнів, особливо в умовах Нової української школи. Мова $€$ не тільки предметом навчання, а й засобом духовного плекання особистості. Отже, і мовна особистість, якою має бути вчитель початкової школи, теж не виникає сама по собі, сприяє цьому саме освіта - основа інтелектуального, культурного, духовного, соціального, економічного розвитку суспільства і держави, оскільки метою освіти є всебічний розвиток людини як особистості та найвищої цінності суспільства. Вона складається не тільки з особистісних характеристик людини взагалі, а є результатом об'єднання зусиль співпраці викладача та студента.

Виклад основного матеріалу. Критеріями фрормування лінгвістичної культури компетентної педагогічної особистості майбутнього вчителя початкової школи є: теоретичні знання рідної мови, літературного читання, дитячої літератури, інших мов, практичні вміння (гностичні, проектувальні, конструктивні, організаторські, комунікативні) та навички застосування набутих знань і умінь як важливих складників загальної культури мовної особистості сучасного фрахівця.

За твердженням О. Лазурського [7], кожна особистість здійснює відповідний шлях розвитку, досягаючи, зрештою, того чи іншого рівня, отже, розвивати особистість означає розвивати їі у постійному контакті із суспільством. Адже мова, «як дзеркало, відображає обидва світи: поза людиною, тобто той, що її оточує, і в людині, тобто той, що $є$ створеним нею самою». Таке дзеркало може бути «кривим», якщо система особистісних орієнтацій не дає змоги носієві мови правильно 
оцінювати своє місце у суспільстві. Якщо рівень мовної та мовленнєвої культури особистості $€$ обмеженим, це свідчить про інтелектуальне та духовне жебрацтво мовної особистості як носія певної мови. Мовна ж особистість майбутнього педагога початкової школи потребує постійної уваги та підтримки для створення педагогічних умов та напрямів правильного ії̈ розвитку, і процес цей $є$ наскрізним. Виховати у студента інтерес до вивчення рідної мови, однієї зі складних навчальних дисциплін, $€$ основним завданням системи освіти, адже інтерес до навчання $€$ важливим особистісним утворенням, навчати мови без виховання інтересу до неї, її історії, духовних засад - справа марна. Саме інтерес до предмета, пізнання його глибинного змісту, його духовного складника забезпечує свідоме вивчення, розвиває почуття, асоціативне мислення, надає нового імпульсу розвиткові процесу самосвідомості. Майбутній учитель початкової школи має виховати інтерес до слова у своїх учнів, якщо сам він є зацікавленим пізнати це унікальне явище - мова - і володіє нею бездоганно.

Основою нашого дослідження є припущення, що рівень сфрормованості лінгвістичної культури особистості майбутнього педагога початкової школи підвищиться за умов змодельованого добору текстового мовного матеріалу з урахуванням орієнтації на досягнення комунікативної мети вивчення мови, а також засвоєння студентами освітньої технології вивчення авторського тексту, що передбачає використання системи індивідуальних інтегративних знань проблемного характеру.

Основними завданнями дослідження $€$ розроблення та експериментальна перевірка комплексу логічних і послідовно пов'язаних між собою індивідуально орієнтованих моделей вивчення авторського тексту, що утворюють принципово нову раціональну інтегративну систему структурного набуття теоретичних знань, практичних умінь і навичок як основної умови формування лінгвістичної культури майбутнього вчителя початкової школи в контексті НУш.

Технологія аналізу тексту є інструментом ґрунтовного розвитку творчих здібностей майбутніх педагогів. Здійснюючи, згідно з авторською методикою, порівняння лінгвостилістичних особливостей авторських творів, вдалося навчити студентів спостерігати ознаки індивідуального почерку творчої особистості письменників, що дало змогу більш глибоко пізнати світогляд автора, його творче обличчя, образ мислення, сприяло фрормуванню трирівневої організації навчально-пізнавальної діяльності студентів: перший рівень - структурносистемне угрупування навчального матеріалу; другий - самостійна аналітична робота зі структурно-складовими частинами; третій - створення індивідуальної структурної моделі знань.
Така технологія ефективно впливає на процес засвоєння знань, практичних умінь і навичок, сприяє поглибленню інтелектуальних можливостей педагога, розвиткові мови і мовлення, реалізації комунікативної мети вивчення мови і мовлення, що неодмінно позначається на процесі фрормування лінгвістичної культури педагогічної особистості вчителя початкової школи в контексті НУШ.

Сучасний когнітивний підхід до вивчення мови «дозволяє зв'язати воєдино процеси людської свідомості, мислення та мови $з$ процесами дійсності, що в них відображується». Отже, «якщо зіставити мову та мовлення, то мова виступає саме тим початком, що має закони, які є здатними керувати мовленням. Думка стає доступною, якщо вона $€$ втіленою в мові», і дійсно, за переконанням англійського вченого X. Алдера [1], важко уявити собі свідоме мислення без зв'язку 3 мовою, бо мова $€$ єдиним розумним засобом підтримки соціальних контактів.

Можливості мислення мовної особистості мають постійно розвиватися, адже мислення педагога $€$ особливим складом мислення, воно наповнюється новим змістом, власними спостереженнями мовної особистості педагога за навчанням та поведінкою своїх учнів. Більш високий рівень організації мислення визначається не тільки вродженими фракторами, а й вихованням духовності, освітою, стилем життя, оскільки людина взагалі «створюється» тією мовою, носієм якої вона $є$, культурою цієї мови, духовністю та ментальністю. Отже, всі ми є творцями нашої мови, і тільки від носіїв мови залежить, чи відображатиме мова діалектику життя, що змінюється та міцніє, чи залишатиметься нікому не потрібним «мертвим морем» слів.

Уміння користуватися словом $€$ основною умовою формування мовної культури майбутнього вчителя початкової школи, що складається з культури мислення, культури мовлення, комунікативної культури. Комунікативна культура, що ії̈ має педагог, завжди свідчить про рівень мовної впевненості, вільного спілкування, потребу в якому має відчувати справжній фахівець, який є носієм відповідного рівня ментальності, національної ідентичності. Профресійна компетентність фрахівця педагогічної профресії завжди ототожнюється учнями (студентами) з можливостями вдалого використання ним мовних фрорм викладу думок, адже можливості мови є настільки значними, що грамотне послуговування ними свідчить про рівень розвитку інтелектуальної бази особистості.

Зразкове, вишукане, шляхетне мовлення, на жаль, зараз майже не зустрічається, воно лишається прерогативою спеціалістів. Той «мовний матеріал», який в особі абітурієнта отримує вища школа від школи середньої, досить часто не відповідає рівню навіть школи початкової. 
Це і абсолютна відсутність чуття тексту, нерозуміння його будови, семантичної наповненості, звідси - і невміння продемонструвати відповідні знання пунктуації. Граматичний обрис слова часто залишається невідомим для учня саме 3 причини незнання ним його семантики, різнобарвності лексичного значення. Роздуми про семантичну картину світу тоді «розбиваються» об загальну непоінформованість та низький рівень інтелекту учнів, а іноді (як не прикро це констатувати) й окремих педагогів. Негаразди, що відбуваються у суспільстві, призводять до падіння інтелектуальної та духовної культури особистості, адже мова є потребою людини виразити, отже, об'єктизувати себе.

Джерелом формування лінгвістичної культури педагогічної особистості майбутнього вчителя початкової школи $€$ процес аналізу авторського тексту, адже авторський текст є багатющим мовним і мовленнєвим джерелом ілюстративного матеріалу для вивчення ситуацій спілкування, навчає комунікативної взаємодії. Саме за допомогою авторського тексту виробляються навички продуктивної мовної поведінки майбутнього педагога, отже, фрормується культура його мовлення та загальний рівень інтелектуальної культури. Професійно навчити студента відчувати магічність тексту, аналізуючи його лінгвостилістичні особливості, означає створити мовне середовище для розвитку мовленнєвої діяльності майбутнього фахівця. Пізнаючи мову письменника, майбутній педагог не тільки вивчає особливості творчої своєрідності автора, а й намагається пізнати особливості «емоційного мислення» його творця, виробити своє, індивідуальне, розуміння мовного світогляду творів митця, що сприяє розвиткові креативності його мислення та розширення міжособистісного простору. Текст, безсумнівно, розвиває художнє мислення, художнє мовлення, емоційність, творчу франтазію, є животворним джерелом естетичного виховання. Використання вмінь і навичок аналізу тексту синтезує теоретичні знання, сприяє розвиткові наукового мислення і пізнання педагогічної особистості майбутнього вчителя початкової школи, що сприяє фрормуванню відповідного рівня його лінгвістичної культури.

Надзвичайно важливо, на нашу думку, розвиваючи лінгвістичну культуру майбутнього вчителя початкової школи, враховуючи соціальні фрункції мови, керувати цим процесом, адже рівень лінгвістичної культури педагога має надзвичайно велике значення для набуття ним професійного досвіду з метою компетентного осмислення усіх понять, якими він має оперувати постійно. Сфрормована мовна, мовленнєва компетентності $€$ основою рівня соціокультурної компетентності, яка дозволяє сучасному педагогу вільно орієнтуватися у суспільстві, не відчуваючи вербального дефіциту, що $є$ сьогодні нагальною проблемою у зв'язку зі зниженням позитивної мотивації молоді до процесу читання. Мова опосередковує багатогранну розумову діяльність особистості, зокрема, її сприймання, уяву, мислення, ось чому рівень лінгвістичної та комунікативної компетентностей завжди свідчить про рівень культури фрахівця, і не тільки педагога. Але профресія педагога $€$ креативною, її приховані резерви, дістатися глибин яких вдається далеко не кожному, хто навчається і навіть уже працює педагогом, неодмінно свідчить про те, чи здатна педагогічна особистість бути нею по-справжньому, пізнавати особливості її творчої специоріки, реалізовувати себе в ній постійно, враховуючи вимоги часу та якість нової генерації.

Безумовно, мова є дещо більшим, аніж інстинкт особистісного інтелекту, вона є органом народного духу, тобто мова є не тільки інструментом пізнання та комунікації, а й культурним кодом нації, носієм і хранителем етичних та естетичних понять, архетипів поведінки, які формують відмінний від інших націй погляд на зовнішній та духовний світ, що, зрештою, створює менталітет нації. Тому надзвичайно важливо, задовольняючи потреби суспільства, враховуючи соціальні фрункції мови, керувати процесом формування професійної лінгвістичної культури педагогічної особистості майбутнього вчителя початкової школи, особливо в контексті НУШ. Сучасна лінгвоосвіта орієнтована на соціалізацію особистості, на гуманістичний підхід до кожного студента, мовне середовище, що формується мовним колективом через окремі мовні особистості, конструює мовний стан, адже мова входить у життя людини через конкретні висловлювання так само, як і життя входить у мову. Навколишній світ СЛОВА створює для особистості відповідне мовне поле, що потребує системного енергетичного зарядження, яким для педагога $€$ постійне намагання підвищити рівень своєї лінгвістичної культури, зробити його якомога позитивнішим для оточення 3 метою презентації особистих досягнень, спрямованих на процес плекання мовної особистості учня, згодом студента. Саме 3 початкової школи цей процес набуває свідомого напряму підвищення мовної культури, оскільки мова та мовлення особистості безпосередньо впливають на створення індивідуальної моделі їі знань, що свідчить про творчу нестандартність, особистісний зміст досягнення мети навчання і $€$ ознакою майстерності педагога.

Досягти високого рівня мовної обізнаності майбутнього фрахівця $€$ надзвичайно важливим за умови використання сучасних інноваційних освітніх технологій для реалізації ситуацій проблемного навчання, проектного навчання, ТРВЗ, модульного навчання, технології критичного мислення, моделюючи такі активні методи і фрорми їхнього втілення, що сприяють фрормуванню та всебічному розвиткові культури та духовності мовної 
особистості. У процесі навчання мови необхідно враховувати особистісно-діяльнісний підхід, міжпредметну координацію, контекстні умови, когнітивність, адже означені складники є основою лінгвопедагогічного підходу у процесі професійної підготовки фрахівця. Вже 3 початкової школи цей процес набуває свідомого освітнього спрямування, тому винятково важливо, щоб він коригувався компетентними мовними педагогічними особистостями. Від ступеня сорормованості лінгвістичної культури педагога початкової школи залежать мовна активність, рівень вербальної адаптивності, лінгвістична відповідальність, комунікативна орієнтованість та реалізація позитивного внутрішнього та зовнішнього образу майбутнього вчителя, отже, цілісний розвиток його як мовної особистості. Якість особистісного та професійного іміджу майбутнього фрахівця неодмінно свідчить про есрективність освітнього процесу у вищій школі, що $є$ пов'язаним також із рівнем викладання дисциплін лінгвістичного циклу.

Найкращим місцем сприйняття структурносемантичного поля слова $€$ текст, який розглядається нами як реалізація функціонування мови у процесах комунікації (М. Шевченко) [16]. Саме в аналізі авторського тексту закладено величезні можливості для процесу розвитку мови і мовлення майбутнього вчителя. Для того щоб цей процес мав позитивне забарвлення, маємо в процесі навчання та виховання розвивати духовну культуру мови та мовлення студентів. Мова і культура $€$ взаємопов'язаними: культура впливає на мову та мовлення, а рівень мови та мовлення є ознакою індивідуальної культури особистості, культурою мовлення надзвичайно важливо володіти всім, хто за родом своєї діяльності є пов'язаним із людиною, організовує та спрямовує їі діяльність, навчає та виховує. Рівень мовної культури свідчить про смак людини, він є частиною нашої загальної поведінки в житті, визначає ступінь психологічної врівноваженості, і навіть ступінь можливої закомплексованості людини, адже ми знаходимося «в обіймах» своєї мови, вона визначає відповідний мовний імідж особистості. Саме рідна мова створює певне коло, в якому людина фрормується 3 дитинства, відображає рівень свого духовного виховання в родині і суспільстві, адекватність своєї поведінки, демонструє набуті мовні вміння та навички, що $є$ виробленими в результаті спілкування з довкіллям. Це означає, що основи плекання мовної особистості необхідно закладати від самого народження дитини й розвивати їх постійно, вже з раннього віку цей процес має набути свідомого навчального та виховного напряму, що є націленим на регуляцію та підсилення позитивних моментів життя і намагання уникнути негативних.

Три галузі людської культури - наука, мистецтво і життя - поєднуються тільки в особистості, яка залучає їх до своєї діяльності, бути особистістю означає бути суб'єктом діяльності, спілкування, самосвідомості, культура мови та мовлення особистості безпосередньо впливають на створення перцептивної карти реальності - унікальної моделі сприйняття кожною людиною навколишнього світу [1]. Те, як педагог, мовна особистість, сприймає закони мовленнєвого оточення, свідчить про якість його власного самостійного розуму, реалізацію духовних потреб, правильного оцінювання свого особистісного професійного престижу. Коригуючи слово, керуючись ним, висловлюючи свої думки, намагаючись досягти ефективного результату може тільки та особистість, яка є здатною чітко усвідомлювати своє духовне та педагогічне призначення і пам'ятати про те, яку відповідальність вона має перед суспільством, а особливо - перед самою собою. Отже, мовна особистість педагога $€$ комунікативним партнером, який, завдяки вільній мовленнєвій орієнтованості, є здатним продемонструвати свої здібності, рівень мислення та культури. Ще С. Рубінштейн [13] ототожнював процес розвитку здібностей людини з процесом розвитку самої людини. Оскільки «особистість педагога як складна система завжди перебуває у певному локальному просторі», викладач має постійно сприяти «індивідуації» (К. Юнг) [17] процесу освіти та розвитку індивідуальних психологічних властивостей, якостей, що роблять людину неповторною духовною особистістю.

Творча діяльність, що є спрямованою на формування таких якостей особистості, як динамічність розуму, сміливість та незалежність суджень, умінь аналізувати та синтезувати явища, процеси тощо, переконує в тому, що від ступеня сфрормованості мовної та мовленнєвої культури залежить профресіоналізм педагогічної особистості вчителя початкової школи, її лінгвістична активність, рівень вербальної адаптивності, лінгвістична відповідність, комунікативна орієнтація.

Оскільки «слово як уявлення є тільки точкою опори або місцем прикріплення різноманітних ознак», а «життя слова 3 психологічного, внутрішнього боку полягає у застосуванні його до нових ознак, і кожне таке застосування збільшує його зміст» [15], основним завданням викладання дисциплін циклу лінгвістичного циклу у системі наскрізної освіти в контексті НУШ має бути таке знання рідної мови, що дає змогу через слово відчути свою причетність не тільки до сучасної семантики, а й до древніх коренів мови, її духовних засад, її самобутності й неповторності. Необхідно абсолютно по-іншому подивитися на процес набуття мовних знань майбутніми вчителями початкової школи та втілювати інноваційну інтегровану модель мовної та мовленнєвої підготовки педагогічної особистості за допомогою авторських освітніх технологій, що є спрямованими на 
підвищення рівня лінгвістичної культури майбутнього фрахівця.

Висновки. Педагогічна особистість вчителя початкової школи розглядається нами як специфічна мовна особистість, від рівня лінгвістичної культури якої залежить рівень її особистісного статусу досвідченого, компетентного фрахівця. Мовну стратегію визначено одним із державних освітніх пріоритетів, найважливішим фрактором впливу на фрормування лінгвістичної культури інтелектуальної педагогічної особистості в контексті Нової української школи.

Теоретичні знання є основою свідомого фрормування та вдосконалення умінь і навичок, інструментом посилення практичного напрямку навчання рідної мови, засобом синергетичного розвитку духовної та інтелектуальної культури педагогічної особистості. Так реалізується не тільки інорормативна, а й комунікативна мета вивчення мови, саме тому рівень мовної та мовленнєвої культури майбутнього вчителя початкової школи перевіряється синтаксичною вивіреністю, досконалістю мови особистості та презентує рівень їі зв'язного мовлення.

Майбутній педагог поступово накопичує різний за своїм потенціалом педагогічний, лінгвістичний та комунікативний досвід, адже рівень розвитку особистості $€$ різним. Отже, фрормується педагогічна, лінгвістична, комунікативна особистісна модель, яка виявляється у відповідній структурі духовних якостей особистості, і саме формування такої моделі вважаємо інноваційною перспективою наших подальших досліджень. Її параметри свідчать про самовизначення особистості, окреслюють шляхи її духовного самовдосконалення та рівні самосвідомості, адже самореалізація, самопізнання і саморозвиток особистості є єдиним процесом.

Отже, рівень сорормованості лінгвістичної культури педагогічної особистості майбутнього педагога початкової школи підвищиться за умов змодельованого добору текстового матеріалу 3 урахуванням орієнтації майбутніх вчителів на досягнення комунікативної мети вивчення мови, а також процесу засвоєння майбутніми педагогами методики вивчення аналізу авторського тексту 3 використанням системи індивідуальних інтегративних знань проблемного характеру.

Нами науково обґрунтовано та експериментально підтверджено впровадження освітньої технології формування лінгвістичної культури майбутнього вчителя початкової школи, вироблено відповідні прийоми процесу набуття теоретичних знань, практичних умінь і навичок, що сприяють ефективному фрормуванню лінгвістичної культури педагогічної особистості, що дало змогу створити інтегративну систему структурного фрормування теоретичних знань, практичних умінь і навичок як основної умови фрормування лінгвістичної культури педагогічної особистості вчителя в умовах Нової української школи.

\section{БІБЛІОГРАФІЧНИЙ СПИСОК:}

1. Алдер Х. НЛП : Современные психотехнологии. СПб : Питер, 2000. 160 с.

2. Амонашвили Ш. Личностно-гуманитарная основа педагогического процесса. Минск : Университетское, 1990. 560 с.

3. Бахтин М. Литературно-критические статьи / сост. С. Бочаров и В. Кожинов. Москва : Художественная лититература, 1986. 543 с.

4. Білецький А. Про мову і мовознавство : навч. посібник для студентів фрілологічних спеціальностей вищих навчальних закладів. Київ : АртЕК, 1997. 224 C.

5. Виноградов В. О теории художественной речи : учеб. пособие для студентов фил. спец. ун-тов и пед. ин-тов. Москва : Высшая школа, 1971. 239 с.

6. Індивідуальні особливості мислення : вебсайт. URL: http://www.studbase.com (дата звернення: 12.04.2020).

7. Лазурский А. Избранные труды по психологии. Москва : Наука, 1997. 446 с.

8. Леонтьев А. Индивид и личность. Психология индивидуальных различий : Тексты. Москва : Издательство Московского университета, 1982. С. 15-20.

9. Мамчич О. Актуальні питання лінгвопідготовки магістрів початкової школи (Авторська модель програми). Початкова школа. 2008. № 5. С. 9-12.

10. Мамчич О. Актуальні питання сучасної української літературної мови. Авторська програма для фрахівців педагогічних ВН3 IV рівня акредитації ступінь освітньої підготовки - магістр. Чернігів : ЧДПУ, 2004. 23 c.

11. Мамчич О. Синтаксичний аналіз тексту у вищій педагогічній школі : метод. посіб. для студентів сракультету початкового навчання. Чернігів : ЧНПУ, 2004. 46c.

12. Мамчич О. Формування лінгвістичної компетентності майбутніх учителів початкових класів (на матеріалі вивчення синтаксису). Вісник Чернігівського державного педагогічного університету ім. Т.Г. Шевченка. Сер. Педагогічні науки. 2003. Вип.18. C. 98-101.

13. Основы общей психологи. В 2 т. Т. 1 / С. Л. Рубинштейн. Москва : Педагогика, 1989. 488 с.

14. Пономарів О.Д. Культура слова : Мовностилістичні поради : навч. посіб. Вид. 2-ге, стереотип. Київ : Либідь, 2001. 240 с.

15. Потебня А.А. Слово и миф. Москва : Правда, 1989. $622 \mathrm{c}$.

16. Шевченко М. Сприйняття образу в поетичному тексті. Текст як одиниця словесно-художньої комунікації. Українська мова та література. 2001. 4 січня. С. 11-12.

17. Юнг К.Г. Отношения между «Я» и бессознательным. Очерки по аналитической психологии. Минск, 2003. С. 200. 


\title{
ВИХОВНИЙ ВПЛИВ МУЗИЧНОГО МИСТЕЦТВА НА ФОРМУВАННЯ ОСОБИСТОСТІ: РЕТРОСПЕКТИВНИЙ АНАЛІЗ
}

\author{
EDUCATIONAL INFLUENCE OF MUSICAL ART ON PERSONALITY \\ FORMATION: RETROSPECTIVE ANALYSIS
}

Стаття присвячена одній з актуальних проблем - фрормуванню особистості молодого покоління засобами музичного мистецтва на основі аналізу літературних джерел, в історичному, мистецько-педагогічному та культурному ракурсах. Наголошено, що ключову роль у зазначеній проблемі відводиться процесу розвитку духовного світу та музичної культури молоді у процесі спілкування $з$ музикою, адже саме вона володіє величезним виховним потенціалом. Звернено увагу до проблеми та проаналізовано сучасний стан музичних творів у наукових прачях описано їі значущість для актуалізації індивідуальних, суспільних і національно-патріотичних інтересів у контексті формування педагогічної культури. Досліджено виховний потенціал музики в історичному, мистецькопедагогічному та культурному ракурсах. З'ясовано, що трансорормація музики в дієвий засіб естетичного та духовного розвитку особистості повною мірою залежить від аналізу музичних творів, що сприяє свідомому та емоційному сприйманню. Доведено, що, звертаючись до емоційної сторони особистості, музика орормує у дітей відчуття і співпереживання, активно розвиває моральні та духовні якості особистості. Наголошено на тому, що ключовою основою розвитку музичної культури молодого покоління є знайомство з кращими зразками української класичної спадщини, народної музики та фольклору. Зазначено, що музика $\epsilon$ благодатним ґрунтом для патріотичного виховання, що нині набуває ще більшої актуальності. Звернено увагу, що ключова роль у освітньому моменті належить педагогаммузикантам, адже саме вони розвивають здібності розуміти музичну мову, вчать духовно відчути їі виразність та фоормують культурний та емоційно-духовний світ особистості, про що зазначали у своїх працях видатні композитори, педагоги-музиканти, мистецтвознавці, психологи. Музика вміщує в собі величезний виховний арсенал засобів, сприяючи фрормуванню духовного світу сучасної молоді. Вплив музичного мистецтва на виховання та формування багатосторонньої та гармонійно розвиненої особистості перебуває у колі зору багатьох дослідників, проте $\epsilon$ актуальним і неостаточно вирішеним питанням.

Ключові слова: музичне мистецтво, музичне виховання, музика, креативність, творчість, гуманістичне, моральне, естетичне, національне виховання, самоактуалізація, дослідження.

The article is devoted to one of the urgent problems of forming the personality of the young generation by means of musical art on the basis of the analysis of literary sources, in historical, art-pedagogical and cultural foreshortenings. It is noted that the key role in this problem is assigned to the process of development of the spiritual world and musical culture of young people in the process of communication with music, because it has a huge educational potential. Attention is paid to the problem and the current state of musical works in scientific works is analyzed, its significance for actualization of individual, public and national-patriotic interests in the context of formation of pedagogical culture is described. The educational potential of music in historical, artistic, pedagogical and cultural perspectives is studied. It is established that the transformation of music into an effective means of aesthetic and spiritual development of the individual depends entirely on the analysis of musical works, promotes conscious and emotional perception. It is proved that accumulating in the emotional side of the personality, music forms feelings and empathy in children, actively develops the moral and spiritual qualities of the personality. It is noted that the key basis for the development of musical culture of the young generation is the acquaintance with the best examples of Ukrainian classical heritage, folk music and folklore. It is noted that music is a fertile ground for patriotic education, now it is becoming even more relevant. Attention is drawn to the fact that the key role in the educational moment belongs to music teachers, because they develop the ability to understand musical language, teach to feel its expressiveness spiritually and form the cultural and emotional-spiritual world of a person, art critics, psychologists. Music contains a huge educational arsenal of tools, contributing to the formation of the spiritual world of modern youth. The influence of musical art on the upbringing and formation of a multifaceted and harmoniously developed personality is in the field of view of many researchers, but it is a topical and not completely resolved issue.

Key words: musical art, musical education, music, creativity, creativity, humanistic, moral, aesthetic, national education, self-actualization, research.

Комунального закладу вищої освіти

«Луцький педагогічний коледж»

Постановка проблеми у загальному вигляді. Музика як один із провідних видів мистецтва $€$ рушійною силою пізнання навколишнього світу і формування духовного та культурного світу особистості. Під час занять музичним мистецтвом у молоді розвивається світогляд, відбувається виховання моралі, пізнання навколишньої дійсності, тому необхідно залучати молоде покоління до музичної діяльності, адже без музики неможливе формування гармонійної та всебічно розвиненої особистості.
Аналіз останніх досліджень і публікацій. Проблемі історії становлення української музичної освіти присвячені теоретичні та практичні дослідження В. Аскоченського, С. Голуба, О. Коши, В. Цукермана, П. Козицького, В. Петрушевського, 3. Хижої та інших. Про важливість взаємодії виховання і музики зазначають фахівці різних галузей наукових знань, зокрема: В. Матоніс, О. Семашко, А. Сохор, М. Бахтін, В. Біблер, М. Каган, Ю. ФохтБабушкін, І. Огієнко, В. Суханцева, В. Шинкарук 
та інші. У різні роки над проблемою виховання особистості молоді засобами музичних дисциплін працювали такі дослідники, як: О. Костюк, О. Лосоя, В. Блудова, А. Гостдинер, В. Максимов, €. Назайкинський, В. Медушевський, І. Пясковський, С. Раппопорт, О. Рудницька, Г. Тарасов, М. Старчеус, Л. Столович, Н. Яранцева.

Виділення не вирішених раніше частин загальної проблеми. Залишаються недостатньо дослідженими питання впливу музичного мистецтва на фрормування особистості з позиції культурологічного та мистецтвознавчого підходу.

Мета статті. Дослідження виховного потенціалу музики на основі аналізу педагогічної, психологічної, культурологічної, соціологічної, фрілософської та іншої спеціальної літератури.

Виклад основного матеріалу. Рефрормування системи освіти неможливе без виховання і розвитку високодуховної та творчої особистості, чинне місце займає музичне мистецтво, яке тісно пов'язане 3 фрормуванням духовної культури. Через музику людина пізнає й оцінює сучасний світ, фрормує та поширює фрілософсько-етичні та культурологічні ідеї. Музичне мистецтво сприяє передачі глибоких почуттів, емоцій та фрормуванню світоглядних позицій людини.

Аналіз літературних джерел показав, що питання впливу музики на фрормування гармонійно розвиненої особистості привертало увагу багатьох дослідників, однак залишається не до кінця опрацьованим та потребує подальшого дослідження [7].

Проблему впливу музичного мистецтва на духовний розвиток особистості досліджували А. Алексюк, Б. Тєплов. О. Апраксіна, Л. Виготський, А. Готедінер, Л. Артемова, В. Бехтєрєв. У своїх працях вони зазначали, що музичним вихованням потрібно займатися з раннього дитинства, забезпечуючи в майбутньому формування всебічно гармонійної особистості [1].

Відомий педагог В. Сухомлинський, котрий приділяв величезну увагу формуванню гармонійної особистості дитини, наголошував на актуальності й необхідності музичних занять, тому що вони безпосередньо впливають на загальний розвиток, формуючи емоційну сореру, пробуджуючи уяву, волю, франтазію. Він зазначає, що без музичного виховання неможливий повноцінний інтелектуальний розвиток особистості. Педагог доводив, що саме в мелодії та словах української пісні криється потужний виховний потенціал, який розкривають перед особистістю дитини народні ідеали. Відомі українські композитори М. Лисенко, К. Стеценко та К. Квітка зазначали, що чинне місце у фрормуванні особистості, розвитку їі духовного світу належить музиці, адже вона сприяє розвитку високих ідеалів людяності та патріотизму. Вони наголошували на тому, що кожний народ зобов'язаний починати музичний розвиток із народної музики, з вагомих та цінних автентичних музичних творів, з метою фрормування індивідуального музичного смаку особистості, також позитивно впливає на розвиток естетичного смаку та талантів [2; 4].

Відомі дослідники Л. Мазель, Л. Виготський та С. Смірнов, котрі досліджували музичні здібності, описували музичне мистецтво в тісній взаємодії з людською психікою, що сприяє фрормуванню моральних, ідейних, естетичних поглядів [7, с. 4-5]. Ці погляди розділив відомий фрранцузький письменник В. Гюго, котрий наголошував на трьох константах успішного громадянина суспільства, таких як мова, цифра й нота, де мова необхідна для спілкування, цифра - для розвитку мислення, а нота й музика - для духовного світу [5].

Потрібно також зазначити про важливе значення музичного мистецтва у процесі національно-патріотичного виховання молодого покоління, що нині рахується найбільш актуальним 3 усіх напрямів виховання. Відомі педагоги Г. Ващенко, С. Русова, К. Ушинський зазначають, що дошкільне виховання неможливе без національного та патріотичного духу, вміщуючи в собі величезний потенціал української народної культури. А. Богуш переконує у тому, що фольклор та народна творчість є найбільш дієвим засобом морально-етичного виховання, де художнє відображення хвилюючих суспільних проблем проявляється у словесно-музичних фрормах, оспівуючи життя й побут українців [3].

Відомі видатні діячі культури М. Колесса, О. Кощиця, М. Лисенко, Г. Нудьга, 3. Яропуд, І. Нечуй-Левицький, І. Франко, С. Русова, В. Сухомлинський наполягали на ключовій ролі використання української народної музики з метою виховання патріотизму та інтересу до національних цінностей. Вони наголошували на глибинній природі народної музики, в котрій захований надзвичайно сильний генетичний код українців. 3 національно-виховною метою О. Ольжович рекомендує використовувати твори українського фрольклору: пісні, думи, колядки, щедрівки, гаївки, коломийки, обрядові пісні [3]. Таким чином, українська народна музика та пісня, що віддзеркалюють українську національну культуру, $€$ рушійною силою виховання молодого покоління. Порівнюючи дослідження вчених, ми можемо зробити висновок про те, що музичне виховання пробуджує творчу активність, фрормує художньо-естетичні здібності та задатки, істотно впливає на глибинні процеси фрормування особистості молодого покоління, розвитку патріотизму і підвищення цікавості до українських національних цінностей та ідеалів [4].

Формування національної культури засобами музичного виховання $€$ першоосновою всебічного гармонійного розвитку особистості. М. Басова та Н. Ветлугіна зазначали, що музика $є$ наймогутнішим засобом естетичного та культурного фрормування 
особистості. Вони наголошували на доцільності використання української народної музики та фролькльору в процесі національно-культурного виховання, що сприяє знайомству молоді 3 культурноісторичними та національними традиціями України. Цих тверджень дотримувались О. Кисельова, Г. Волкова, котрі зазначали, що музика має невичерпний арсенал виховних засобів для впливу на внутрішній світ молодого покоління, фрормування її моральноетичних ідеалів [9].

Композитор Д. Кабалевський, досліджуючи ключову роль музичного виховання, зазначав, що музика допомагає дошкільнятам пізнавати навколишній світ та виховує їх, адже під час занять музикою вивільнюються численні можливості для формування основ морально-естетичних якостей та для гармонійного розвитку особистості. Він переконує в тому, що гуманістичні цінності, засвоєні через заняття музикою, фрормують емоційний стан, створюють сприятливе русло для усвідомлення прекрасного і некрасивого, добра i зла, кохання і ненависті, сприяють покращенню власної самооцінки, власній соціалізації [6]. Музика трансформує загальнолюдські цінності в індивідуальні, які займають чинне місце у житті суспільства, стають важливим моментом, який уособлює значення занять музикою у гуманістичному та патріотичному вихованні молодого покоління [8].

Під час розгляду питання щодо музичного виховання важливо враховувати погляди А. Шевчук, Т. Науменко, Т. Сороки, Н. Рубальської, котрі в своїх працях детально проаналізували концепції художньо-естетичного впливу засобів музики та музичного мистецтва загалом і фрормування гармонійної особистості. Зазначеній проблемі також присвячені дослідження А. Артоболєвської, Л. Баренбойма, Б. Кобзар, О. Кононко та Б. Яворського, у яких наголошувалось на ключовій ролі музики в розумовому та творчому розвиткові й вихованні дітей різного віку. Вони зазначали, що спілкування з музичним мистецтвом формує в дитини гарний музичний смак, творче естетичне й художнє сприйняття, виховує почуття та повагу до світових та українських національних музичних культурних цінностей і надбань. У своїх працях В. Мазепа та Г. Шевченко наголошували, що абсолютно всі фрорми художнього виховання втілюють у собі важливі константи комплексного гармонійного виховання дитини, що забезпечує різносторонній розвиток особистості [3].

Дослідник В. Букіна зазначає, що завдяки музичному мистецтву в людини розвиваються естетичні здібності і таланти, художня свідомість, накопичується та передається досвід художньоестетичного розвитку суспільства, котрий трансформується в музичний образ, виникають та реалізуються художньо-естетичні здібності, інтереси, почуття [8].
Питанню виховання дітей-дошкільнят засобами музики приділяли увагу Н. Ветлугина та М. Стельмах. У своїх працях вони переконували, що художньо-естетичне виховання повинно бути націлене на розвиток творчих здібностей, сприймання, відчуттів, розуміння краси навколо себе, сприяти творчій самореалізації в мистецтві. Дослідниці зазначали, що художньо-естетичне виховання дітей засобами музичного мистецтва буде плідно здійснюватися завдяки фрормуванню в них загальної музичності, діти зможуть відчувати настрій та характер музичного твору, навчаться співпереживати почутому, розуміти музичний образ, розрізняти музичні явища. Ось чому з формуванням загальної музичності дітей проявляється емоційне ставлення до музичного мистецтва, формується та розвивається музично-слухова культура, активізується творче ставлення до музичного твору, що пробуджує уявлення про красу не лише у самому собі, а й в навколишньому світі [5].

Як зауважують Л. Мазель і В. Цуккерман, у музикознавстві питання про естетичне виховання молоді засобами музики, потенціал засобів виховання функціонують разом 3 іншими фрормами та напрямами виховання. Вони є фундаментом, де фрормується психолого-чуттєве підґрунтя, що сприяє розвитку емоційно-пізнавальних, креативно-інтелектуальних, комунікаційних здібностей та талантів. При цьому необхідно враховувати, що результат музично-естетичного виховання залежить від сприймання мистецтва як важливої фрорми національно-суспільної свідомості, поєднуючи в собі величезну кількість засобів художньо-естетичного впливу, які розвивають творчість та патріотизм. Без музичного мистецтва неможливо фрормувати морально-етичні цінності (співчуття, переживання, повагу, шанування), які проявляються у ставленні до навколишнього світу, до суспільства. Музичне мистецтво, підсвідомо впливаючи на почуття особистості, фрормує їі мораль, сприяє фрормуванню її національної культури [6].

Розглядаючи проблематику музичних творів, В. Асмус, В. Городинський, Ю. Кремльов та М. Рижкін зазначають, що музичне мистецтво сприяє «прозрінню» людей до краси в усьому. Вони вважають, що культура виховання гармонійної особистості в основному визначається кількістю музики в житті людини, адже, якщо порівнювати ії зі спортом, який розвиває тіло, музика - душу особистості [9]. Автори наголошують на тому, що музичне мистецтво сприяє фрормуванню моральних цінностей молоді, закладає фрундамент загальної культури майбутнього громадянина суспільства [5].

Видатний діяч Б. Асафєв стверджував, що саме музична творчість сприяє покращенню процесу виховання засобами музичного мистецтва та передбачає дотримання педагогами таких принципів, як: 
- поєднання навчання і виховання;

- свідомість і науковість під час занять;

- взаємозв'язок навчання із суспільним життям;

- доступність та індивідуальний підхід до кожного [7].

В. Бехтерєв та В. Медушевський наголошують на тому, що від детального опрацювання питання музичного виховання дошкільнят повною мірою залежить художньо-естетичний та культурно-моральний розвиток особистості і суспільства загалом. Відомі композитори Г. Гендель та Л. Бетховен зазначали про вплив музичного мистецтва на моральний розвиток, переконуючи, що від музики необхідно ставати кращими, а не лише просто отримувати задоволення, слухаючи іiі. Дослідник Д. Кабалевський зауважував, що музика покликана впливати на весь духовний світ молодого покоління, виховуючи його [9].

У музичній педагогіці художньо-естетичному вихованню дітей засобами музичного мистецтва приділяли увагу Г. Волкова, М. Каган та Л. Столович. Вони переконували, що музика сприяє фрормуванню духовного світу молоді, пробуджує та виховує почуття патріотизму, розширює світогляд [1].

Висновки. Таким чином, провівши дослідження та проаналізувавши літературні джерела, ми можемо зробити висновок про те, що музичне мистецтво, активно впливаючи на духовний світ людини на емоційному рівні, виступає рушійною силою та потужним засобом виховання молодого покоління. Видатними діячами культури, мистецтвознавцями, музикознавцями, письменниками, психологами та педагогами доведено, що саме музика втілює в собі величезний арсенал виховних засобів, використання якого сприяє гармонійному розвитку особистості. Без сумніву, під час занять музичною творчістю молодь дізнається про різноманітні музичні твори, отримує певний багаж знань, умінь та навичок, виховується любов та повага до музичного мистецтва, фрормуються музичні здібності, гідне ставлення до українських та світових музичних творів.

\section{БІБЛІОГРАФІЧНИЙ СПИСОК:}

1. Волкова Г.А. Логопедическая ритмика.учеб. для студ. высш. учеб. заведений. Москва. Гуманит. издат. центр «ВЛАДОС», 2002. 272 с.

2. Газіна І.О. Методика музичного виховання дітей дошкільного віку. Навчально-методичний посібник для студентів напряму підготовки «Дошкільна освіта. Кам'янець-Подільський. Аксіома, 2013. 196 с.

3. Кисельова O.I. Морально-етичне виховання дітей старшого дошкільного віку засобами. Педагогіка і психологія професійної освіти. Одеса, 2009. 22 c

4. Лисенко М.В. Характеристика музичних особливостей українських дум і пісень у виконанні кобзаря Вересая. Київ. Музична Україна, 1978. 95 с.

5. Медушевский В.В. О закономерностях и средствах художественного воздействия музыки Москва. Музыка, 1976. С. 6, 29.

6. Медушевский В.В. К проблеме семантического синтаксиса. Москва. Советская музыка. 1973. № 8. C. 21.

7. Смирнов С. Эмоциональный мир музыки : исследование. Москва. Музыка, 1990. 320 с.

8. Фоломєєва Н.А. Педагогічні технології естетичного виховання дітей віком 5-10 років засобами музичного мистецтва: автореф. дис. канд. пед. наук. спец.13.00.07. «Теорія і методика виховання». АПН України. Ін-т пробл. виховання. К., 2001. 22 с.

9. Яхнина Е.3. Методика музыкально-ритмических занятий с детьми, имеющими нарушения слуха : учеб. пособие для студ. высш. учеб. заведений Москва. Гуманит. издат. центр «ВЛАДОС», 2003. 272 c.

10. Цуккерман В.А. Музыкально-теоретические очерки и этюды. Москва. Советский композитор. 1970. C. 410. 


\section{МЕТОДИЧНІ ОСНОВИ ФОРМУВАННЯ УКРАЇНСЬКОЇ ІДЕНТИЧНОСТІ ПЕРСОНАЛУ ДЕРЖАВНОЇ ПРИКОРДОННОЇ СЛУЖБИ УКРАЇНИ \\ METHODOLOGICAL BASIS OF FORMATION OF UKRAINIAN IDENTITY OF STATE BORDER GUARD SERVICE OF UKRAINE}

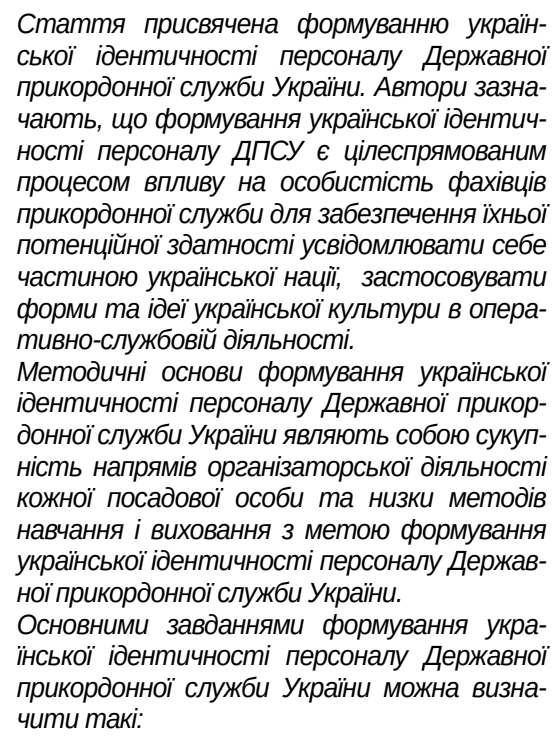
- розуміння кожним прикордонником об'єктивних закономірностей історичного процесу становлення Української держави, необхідності свідомого виконання усіх вимог законодавства України, що стосуються захисту держави та ї̈ державного кордону; - інсрормування і роз'яснення персоналу сутності поняття «української ідентичності» та сутності суспільно-політичних процесів, що відбуваються в Україні;

- згуртування персоналу навколо ідеї фрормування української ідентичності персоналу та усвідомлення кожним прикордонником особистої відповідальності за забезпечення втілення українських цінностей у ссреру профресійної діяльності;

- створення у підрозділах сприятливої психологічної обстановки і забезпечення формування української ідентичності персоналу;

- формування і підтримання просресійно спрямованої мотивації персоналу Державної прикордонної служби України до виконання завдань з охорони державного кордону;

- формування і розвиток у прикордонників професійних та особистих якостей, необхідних для виконання завдань оперативнослужбової діяльності;

- забезпечення високого престижу служби в прикордонному відомстві, високого автоpuтету ДПСу в суспільстві загалом і у жителів прикордоння зокрема.

Ключові слова: українська ідентичність, персонал Державної прикордонної служби
України, профессійна (оперативно-службова) діяльність, профресійна підготовка.

The article is devoted to the formation of the Ukrainian identity of the staff of the State Border Guard Service of Ukraine. The authors note that the formation of the Ukrainian identity of the State Border Guard Service of Ukraine staff is a purposeful process of influencing the identity of border guards to ensure their potential ability to realize themselves as part of the Ukrainian nation, to apply forms and ideas of Ukrainian culture in operational activities.

Methodical bases of formation of the Ukrainian identity of the personnel of the State Border Guard Service of Ukraine represent set of directions of organizational activity of each official and a number of methods of training and education for the purpose of formation of the Ukrainian identity of the personnel of the State Border Guard Service of Ukraine.

The main tasks of forming the Ukrainian identity of the staff of the State Border Guard Service of Ukraine can be identified as follows:

- understanding by each border guard of objective laws of the historical process of formation of the Ukrainian state, the need for conscious fulfillment of all requirements of the egislation of Ukraine relating to the protection of the state and its state border;

- informing and explaining to the staff the essence of the concept of "Ukrainian identity" in particular and the essence of socio-political processes taking place in Ukraine

- uniting staff around the idea of forming the Ukrainian identity of staff and awareness of each border guard of personal responsibility for ensuring the implementation of Ukrainian values in the field of professional activity;

- creating a favorable psychological environment in the units and ensuring the formation of the Ukrainian identity of the staff,

- formation and maintenance of professionally oriented motivation of the staff of the State Border Guard Service of Ukraine to perform tasks on protection of the state border;

- formation and development of border guards professional and personal qualities necessary to perform the tasks of operational and service activities;

- ensuring the high prestige of the service in the border department, the high authority of the SBGS in society in general, the border residents in particular.

Key words: Ukrainian identity, personnel of the State Border Guard Service of Ukraine, professional (operational and service) activity, professional training.
Постановка проблеми. У нормативно-правових документах, що регламентують діяльність Державної прикордонної служби України (далі - ДПСУ) та визначають основні завдання щодо змісту та якості підготовки персоналу, вказується, що для успішного вирішення завдань оперативно-службової діяльності персонал ДПсУ повинен бути ком- петентним щодо охорони державного кордону. Це зумовлено тією воєнною та політичною ситуацією, яка склалася на сході країни, появою нових загроз прикордонній безпеці. Утвердження особистості кожного прикордонника як суб'єкта суспільних відносин потребує нового осмислення сутності процесу профресійної підготовки прикордонника як 
особистості, як національно свідомого громадянина зі сфрормованою українською ідентичністю.

Від сорормованості української ідентичності прикордонників залежить значною мірою успіх їхньої професійної (оперативно-службової) діяльності загалом.

Аналіз останніх досліджень. Нормативну базу дослідження становлять Закони України «Про вищу освіту», «Про національну безпеку України», «Про Державну прикордонну службу України», Стратегія розвитку Державної прикордонної служби України, законодавство з прикордонних питань.

Теоретичну основу нашого дослідження становлять праці С. Арутюнова, Ю. Бромлея, І. Беха, І. Вільчинської, В. Кременя, Р. Павелківа та інших. Питання української ідентичності різних категорій вихованців в останні роки є в центрі уваги науковців щодо психологічного аспекту фрормування української ідентичності фрахівців (Т. Стефраненко, О. Шевченко), фрормування української ідентичності в контексті громадянського виховання особистості (М. Боришевський, Г. Філіпчук), формування української ідентичності у контексті професійної підготовки фрахівців (О. Безкоровайна, Т. Потапчук), у тому числі професійного становлення прикордонників (С. Білявець, О. Ставицький) тощо. Але у дослідженнях, які проводилися, у прямій постановці не вивчалася проблема формування української ідентичності персоналу Державної прикордонної служби України.

Виділення не вирішених раніше частин загальної проблеми. Наукові положення, висновки та рекомендації, які містяться у зазначених вище та інших наукових дослідженнях, мають велику цінність для вирішення проблеми фрормування української ідентичності персоналу Державної прикордонної служби України. Однак у більшості цих праць не бралися до уваги особливості професійної (оперативно-службової) діяльності прикордонників, зокрема необхідності опановувати цінності з метою урахування їх безпосередньо під час виконання професійних завдань, а також оцінювати сорормованість української ідентичності - власної та підпорядкованого персоналу.

Як свідчать результати дослідження, категорія «українська ідентичність» $€$ предметом наукових пошуків представників різних галузей: фрілософрії, юриспруденції, соціології, політології, педагогіки, психології, військових наук тощо. У контексті нашого дослідження найбільший інтерес становлять підходи до тлумачення української ідентичності як категорії військової психолого-педагогічної науки та практики.

Постановка завдання. Метою статті є обґрунтування методичних основ фрормування української ідентичності персоналу Державної прикордонної служби України.
Виклад основного матеріалу дослідження. У сучасному науковому просторі націона́льна ідентичність трактується, з одного боку, як «персональна ідентичність або відчуття приналежності до певної держави чи нації» [1]. 3 іншого боку, як «сенс нації як цілісного цілого, представленого самобутніми традиціями, культурою та мовою» [2]. Нами було враховано, що «національна ідентичність може означати суб'єктивне відчуття, яке людина поділяє з групою людей про націю, незалежно від законного статусу громадянства [3, c. 129].

Більшість дослідників вважають, що національна ідентичність $є$ явищем соціальним, не $€$ вродженою рисою, а набувається у процесі життя, в тому числі професійного. Важливою для нашого дослідження $є$ думка про те, що «люди включають національну ідентичність у свою особисту ідентичність, приймаючи переконання, цінності, припущення та очікування, які відповідають національній ідентичності» [4]. Люди з ідентиорікацією їхньої нації розглядають національні переконання і цінності особистісно значущими і транслюють ці переконання і цінності у повсякденній практиці [1]. У нашому разі національні переконання і цінності транслюються у переконання і цінності в оперативно-службовій діяльності персоналу дПСУ.

У зв'язку із цим доцільно звернути увагу на поняття етнічної ідентичності як відчуття належності до певної етнічної спільноти, однаковості 3 іншими її членами внаслідок спільності історичної пам'яті, емоціональних зв'язків із батьківщиною. Тому у змісті заходів професійної підготовки завжди враховуються особливості підготовки персоналу ДПСУ, яка зорієнтована на запити суспільства. Варто згадати про таку систему військового виховання, яка історично склалася і максимально враховує неповторність українців, як українська козацька педагогіка. Вона надихала цілі покоління діячів на вірне служіння рідному народу. Козацтво втілювало в собі фрізичне і духовне здоров'я нації, інтелектуальну силу, життєздатність, оптимізм і енергію. Це була об'єднана, згуртована, ідейно і духовно зцементована, суворо дисциплінована національна сила, яка очолювала боротьбу проти чужоземних ворогів. Українські козаки започаткували славні бойові традиції, гідними продовжувачами яких є українські прикордонники [5, с. 293].

Особливе значення в контексті фрормування української ідентичності персоналу дПСУ приділяється вихованню персоналу на прикладах життя і служби ветеранів-прикордонників, учасників АТО (OOC). Тому і започатковано систематичне проведення зустрічей ветеранів-прикордонників, учасників АTO (OOC) з персоналом, який щойно прийняв присягу та вступив на службу, з метою виховання персоналу на героїчному минулому нашої держави та героїчних прикладах сучасників - 
захисників цілісності та незалежності України; на прикладах мужності та сумлінного ставлення до несення служби прикордонниками.

Автори навчального посібника з українознавства справедливо розглядають українську ідентичність як історично сорормовану адаптивно-еволюційну систему ознак і властивостей, які вирізняють українську людину, українську спільноту й українську культуру 3-поміж інших аналогічних об'єктів (феноменів). У сучасному українознавстві та суміжних науках (зокрема, історії України) йдеться про широке синтетичне розуміння українства, українська ідентичність визначається наявністю хоча б однієї з таких чотирьох ознак, як: етнічне походження та самоідентифікація; усвідомлення спільної 3 іншими представниками українського етносу історичної долі та часової перспективи; залученість в український культурно-інорормаційний простір; свідома діяльність із поширення української культури [6, с. 18]. Якщо спроєктувати такий підхід у площину оперативно-службової діяльності персоналу ДПСУ, то маємо зосередити увагу на тих ознаках і властивостях, які вирізняють українських прикордонників як носіїв саме української ідентичності.

3'ясовано, що формування української ідентичності персоналу ДПСУ є цілеспрямованим процесом впливу на особистість фрахівців прикордонної служби для забезпечення їхньої потенційної здатності усвідомлювати себе частиною української нації, застосовувати фрорми та ідеї української культури в оперативно-службовій діяльності.

3 метою виявлення стану сфрормованості української ідентичності персоналу дПсУ проведено констатувальний етап експерименту, на якому було зібрано інформацію про стан досліджуваного явища. Використовувалися такі методи, як анкетування та інтерв'ювання, спостереження, опитування, самооцінка; вивчалися можливості окремих тем із професійної підготовки різних категорій персоналу. Експериментальним дослідженням було охоплено 158 осіб різних категорій персоналу ДПСУ, які проходять службу в Східному регіональному управлінні ДПСУ, а також проведено анкетування 78 військовослужбовців, які впродовж 1-2 років проходили службу в Луганському, Сумському, Харківському прикордонних загонах ДПСУ. В анкетах містилися питання щодо того, як персонал ДПСУ усвідомлює значущість сформованості української ідентичності в оперативно-службовій діяльності, чи виявляють інтерес до фрормування української ідентичності, чи прагнуть набувати профресійний досвід тощо.

Методичні основи фрормування української ідентичності персоналу Державної прикордонної служби України являють собою сукупність напрямів організаторської діяльності кожної посадової особи (загальне керівництво, планування, орга- нізація, проведення заходів) та низки методів навчання і виховання з метою формування української ідентичності персоналу Державної прикордонної служби України.

Актуальною для нашого дослідження $€$ думка С. Павлюка щодо «складності розв'язання проблеми самоідентифрікації українців у сучасних умовах з огляду на ії закорінення у лінгвокультурне комунікативне середовище, у якому реально живе культура. Реальне лінгвокомунікативне середовище, де здійснюється колообіг культури, особливо в містах, серйозно зруйноване. Відсутність такого середовища, пише вчений, не може дати «на виході» відносно цілісної ідентичності. Тому і проблема реанімації глибоко кризової української ідентичності $є$ насамперед проблемою подолання глибокої кризи лінгвокультурного стану, зокрема у містах. Для цього потрібно: поглибити у міському середовищі українську культуру, підкріпивши анемічні, безсилі українські інфрормаційні потоки; надати соціопрестижного статусу українському інорормаційному продукту; здійснювати державну політику протекціонізму для вирівняння разючої структурної і фрункціональної асиметрії в українському інфрормаційному просторі російськомовного і україномовного матеріалу; забезпечити державне сприяння у формуванні модернізованої інфраструктури для представлення української культури у світовій цивілізації; розробити стратегію націокультурної політики» [7, с. 10-11].

Оскільки лінгвокомунікативне середовище військових структур, у тому числі прикордонного відомства, значною мірою поруйноване під впливом різних оракторів, подолання кризи лінгвокультурного стану персоналу відомства $€$ однією 3 визначальних організаційно-педагогічних умов формування української ідентичності персоналу Державної прикордонної служби України. Тому значущості набувають внутрішні комунікації як комплекс цільових організаційних і практичних заходів контрпропагандистської, ідеологічної, інфрормаційно-роз'яснювальної, національно-історичної, військово-соціальної роботи з метою підтримання зворотного зв'язку вищого керівництва Адміністрації Державної прикордонної служби України з особовим складом органів та підрозділів Державної прикордонної служби України.

Аналіз наукової літератури та досвід практичної діяльності засвідчують, що фрормування української ідентичності персоналу Державної прикордонної служби України відбувається в системі соціально-гуманітарного та морально-психологічного забезпечення, яке $€$ «складовою частиною діяльності органів управління і посадових осіб усіх рівнів і $є$ одним із видів забезпечення оперативно-службової діяльності з охорони державного кордону. Соціально-гуманітарне та моральнопсихологічне забезпечення містить систему 
правових, організаційних, педагогічних, психологічних, інфрормаційних, культурно-просвітницьких та соціальних заходів, спрямованих на забезпечення морально-психологічної готовності персоналу Державної прикордонної служби України до виконання професійних (оперативно-службових) завдань» [8].

Складниками соціально-гуманітарного та морально-психологічного забезпечення є: морально-психологічне забезпечення, національно-патріотичне виховання, військово-соціальна робота.

Основними завданнями у системі соціальногуманітарного та морально-психологічного забезпечення щодо фрормування української ідентичності персоналу Державної прикордонної служби України можна визначити такі:

- розуміння кожним прикордонником об'єктивних закономірностей історичного процесу становлення Української держави, необхідності свідомого виконання усіх вимог законодавства України, що стосуються захисту держави та її державного кордону;

- інорормування і роз'яснення персоналу сутності поняття «української ідентичності» зокрема та сутності суспільно-політичних процесів, що відбуваються в Україні, воєнної та безпекової політики держави;

- згуртування персоналу навколо ідеї фрормування української ідентичності персоналу та усвідомлення кожним прикордонником особистої відповідальності за забезпечення втілення українських цінностей у сфреру діяльності ДПСу;

- створення в підрозділах сприятливої психологічної обстановки і забезпечення фрормування української ідентичності персоналу;

- формування і підтримання професійно спрямованої мотивації персоналу Державної прикордонної служби України до виконання завдань 3 охорони державного кордону;

- фрормування і розвиток у прикордонників професійних та особистих якостей, необхідних для виконання завдань оперативно-службової діяльності;

- забезпечення високого престижу служби в прикордонному відомстві, високого авторитету ДПСУ в суспільстві загалом, у жителів прикордоння зокрема.

Висновки. Отже, на підставі вивчення психолого-педагогічної літератури, проведеного опитування та з урахуванням специфріки оперативно-службової діяльності персоналу Державної прикордонної служби України ми доходимо висновку, що методичні основи орормування української ідентичності прикордонників доцільно розглядати як складник їх профресійної підготовки. Перспективу подальших досліджень окресленої проблеми становлять такі питання, як: регіональні та історичні особливості фрормування української ідентичності персоналу ДПСУ; чинники формування української ідентичності персоналу дПСУ; вплив екстремальних умов оперативно-службової діяльності на процес фрормування української ідентичності персоналу ДПСУ; розроблення критеріїв та показників для визначення рівнів сорормованості української ідентичності персоналу ДПСУ.

\section{БІБЛІОГРАФІЧНИЙ СПИСОК:}

1. Ashmore Richard D. Social identity, intergroup conflict, and conflict reduction. Oxford [England] : Oxford University Press. 2001. ISBN 978-0-19-513743-9. OCLC 60314432.

2. Dollinger Stefan. National Dictionaries and Cultural Identity. Oxford Handbooks Online. 2015. doi:10.1093/oxfordhb/9780199691630.013.42. Процитовано 2020-12-07.

3. Guibernau Montserrat. Anthony D. Smith on nations and national identity: a critical assessment. Nations and Nationalism. № 10 (1-2). 2004. C. 125-141. ISSN 1354-5078. doi:10.1111/j.1354-5078.2004.00159.x. Процитовано 2020-12-07.

4. Bar-Tal Daniel, Staub Ervin. Patriotism in the lives of individuals and nations. Chicago: NelsonHall Publishers. 1997. ISBN 0-8304-1410-X. OCLC 34281235 .

5. Мірошніченко В.І. Система патріотичного виховання майбутніх офріцерів-прикордонників : монографрія. Хмельницький : Вид-во НАДПСУ, 2012. 376 с.

6. Українознавство: Навч. посіб. для студ. вищ. навч. закл.; за ред. М. І. Обушного. Київ, ВПЦ «Київський університет», 2008. 218 с.

7. Павлюк С. Драматичність процесу самоідентифрікації українців у сучасних умовах: влада і суспільство. Україна - проблема ідентичності: людина, економіка, суспільство : матеріали конфреренції українських випускників програм наукового стажування у США. (Львів, 18-21 вересня 2003 р.). Київ, Projec. 306 c.

8. Про організацію соціально-гуманітарного та морально-психологічного забезпечення у Державній прикордонній службі України: наказ Адміністрації ДПСУ від 19 жовтня 2018 року № 95. 


\section{ПРОБЛЕМНІ ТЕНДЕНЦІЇ ПІДГОТОВКИ МАЙБУТНІХ ВІЙСЬКОВИХ ЛЬОТЧИКІВ ДО БОЙОВИХ ПОЛЬОТІВ У СВІТЛІ СУЧАСНИХ КОНЦЕПТУАЛЬНИХ I НОРМАТИВНИХ ВИМОГ ДО НИХ \\ PROBLEM TENDENCIES OF PREPARATION OF FUTURE SOLDIERY PILOTS TO BATTLE FLIGHTS IN THE LIGHT OF MODERN CONCEPTUAL AND NORMATIVE REQUIREMENTS TO THEM}

УДК 378.147

DOI https://doi.org/10.32843/2663-

6085/2021/31-1.27

\section{Невзоров Р.В.}

канд. пед. наук,

начальник кафедри тактики авіації

Харківського національного

університету повітряних сил

імені Івана Кожедуба
Стаття присвячена досі не дослідженій у вітчизняній військовій педагогіці тематииі виокремлення проблемних тенденцій підготовки військових пілотів до бойових польотів. Актуальність піднятої проблеми пов'язана 3 підвищеними оборонними запитами держави останніх шести років, поступовим переходом Збройних Сил Украӥни на стандарти НАТО, суттєвим науково-технічним прогресом у військовій авіації, що об'єктивно вимагають оновлення системи фрахової підготовки курсантів - військових льотчиків. Підготовка останніх до бойових польотів розглядається як чентральна підсистема системи їх фрахової підготовки у вищому військовому закладі освіти. Автор здійснив пошук $і$ виділення вказаних тенденцій шляхом екстраполяцій наявних концептуальних вимог до військових пілотів (на основі аналізу доктринальних документів у галузі оборони і національної безпеки України) на реальний стан у системі вітчизняної військової авіаційної підготовки. Остання, як свідчить практика, залишається доволі консервативним елементом в освітньому процесі вищого військового закладу освіти України через закономірну орієнтацію на наявний авіачійний парк Повітряних Сил Збройних Сил України, що в середньому експлуатується вже 25-30 років і потребує глибокої модернізації. Розалянуті й охарактеризовані ключові соціальні, економічні, політичні, військові та організаційно-правові чинники, що впливають на формування тенденцій підготовки майбутніх військових льотчиків до бойових польотів. Проаналізовані доктринальні документи, дотичні до неї, дають підстави говорити про закладені в них концептуальні вимоги, що протирічать реальному стану речей у сфрері бойової підготовки курсантів - військових льотчиків. Однією з головних причин цього $є$, на думку автора, наявні проблемні тенденціі технічного відставання вітчизняного авіа парку і недосконалість військового менеджменту.

Ключові слова: військовий пілот, система фрахової підготовки, підготовка до бойових польотів, концептуальні вимоги, вищий військовий заклад освіти.
The article is sanctified to the until now not investigational in home military pedagogics subjects of selection of problem tendencies of preparation of soldiery pilots to battle flights. Actuality of heaved up a problem is related to increase defensive queries of the state of the last six years, gradual passing of the Armed Forces of Ukraine to the standards of NATO, by substantial scientific and technical progress in air force, that objectively require updating of the system of professional preparation of students soldiery pilots. Preparation of the last to battle flights is examined as a central subsystem of the system them professional preparation in higher military establishment of education. An author man-hunted and selection of the indicated tendencies by extrapolation of existent conceptual requirements to the soldiery pilots (on the basis of analysis of doctrine documents in industry of defensive and national safety of Ukraine) on the real state in the system of home military aviation preparation. The last, as practice testifies, remains sufficiently a conservative element in the educational process of higher military establishment of formation of Ukraine in force of appropriate orientation on the existent aviation park of Aircrafts of the Armed Forces of Ukraine that on the average is exploited already 25-30 and needs deep modernisation. Key social, economic, political, soldiery and organizationally legal factors that influence on forming of tendencies of preparation of future soldiery pilots to battle flights are considered and described. The analysed doctrine documents, tangents to her, ground to talk about the conceptual requirements that have contradiction to the real state of affairs in the sphere of the combat training of students soldiery pilots stopped up in them. One of main reasons of it are there, in opinion of author, existent problem tendencies of technical lag of home aviation park and imperfection of military management.

Key words: military pilot, system of professional preparation, preparation to battle flights, conceptual requirements, higher military establishment of education.
Постановка проблеми в загальному вигляді. Якісна фрахова підготовка професійних військових кадрів для потреб Збройних Сил України (далі ЗС України) в умовах конфрліктної геополітичної ситуації навколо України, зазіхання на ії територіальну цілісність і державний суверенітет останніх шести років закономірно стала однією 3 домінант реформи сектору оборони і національної безпеки. Прийнятий державою на конституційному рівні євроатлантичний курс нашої держави та пов'язані з ним конвергенція й адаптація військових стан- дартів НАТО об'єктивно диктують потребу модернізації системи підготовки військових фрахівців загалом і військових пілотів зокрема.

При цьому однією 3 найбільш консервативних і важко змінних складових частин цієї системи залишається педагогічна модель вказаної підготовки (організаційна схема, освітні технології, освітньо-інсрормаційне середовище, засоби інтеграції навчання і виховання 3 науковими дослідженнями і практичною діяльністю тощо), що дісталася у спадок від радянської військово-освітньої 
системи. Оцінити її реальну ефективність у сучасних умовах можна по-різному.

Одним 3 інструментів такого оцінювання $є$ виокремлення й аналіз тенденцій фрункціонування системи, що в науковій практиці НАТО, а в останні роки і в 3С України, розглядається як складова частина основного методу оборонного планування на основі спроможностей [1, с. 7]. Виділення серед тенденцій проблемних особливо важливе і цінне для розуміння реального стану системи (моделі) 3 метою її подальшого вдосконалення. При цьому ефективність такого підходу підвищується в разі його екстраполювання на наявні концептуальні і нормативні вимоги до основного суб'єкта системи курсанта вищого військового закладу освіти (ВВ3О), в нашому разі - майбутнього військового льотчика.

Аналіз останніх досліджень і публікацій засвідчив, що тенденції підготовки майбутніх льотчиків до бойових польотів в ВВЗО України як самостійна військово-педагогічна проблема досі ще не досліджувалися. Науково-теоретичною базою, дотичною до нашого дослідження, слід вважати праці в галузі авіаційної психології і педагогіки таких авторів, як Д. Гандер, Н. Завалова, Б. Ломов, В. Маріщук, К. Платонов, Б. Покровський, В. Пономаренко та інших.

Виділення не вирішених раніше частин загальної проблеми. Низка важливих тенденцій системи підготовки майбутніх військових льотчиків розглянута нині з військових, економічних і соціально-політичних позицій. Однак поза увагою науковців залишилися проблеми тенденції вказаної підготовки у світлі сучасних концептуальних і нормативних вимог до військових пілотів саме під педагогічним (військово-педагогічним) кутом.

Мета статті. Метою статті $€$ виділення проблемних тенденцій шляхом аналізу наявних в Україні концептуальних і нормативних вимог до військових льотчиків.

Виклад основного матеріалу. Поняття «тенденція» (від лат. tendo - направляти, спрямовувати і пізньолат. tendentia - спрямованість, напрям) у широкому фрілософському сенсі означає напрям розвитку певного об'єкта, явища, процесу (напр., ссрер суспільного життя - культури, політики, релігії тощо); відповідно до системи, як правило, вживається на означення наявних у неї стійких властивостей, відносин та ознак, що можна вважати, 3 певною часткою умовності, проявом локального закону. Останнім часом як синонім до цього поняття широко використовується термін «тренд».

Тенденції складаються під впливом загальносуспільних запитів і очікувань, соціальних, економічних процесів, розвитку систем вищого рівня (наприклад, підсистема фрахової підготовки військових льотчиків у ВВЗО України не може не змінюватися під впливом змін і модернізації у загальній вітчизняній системі вищої військової освіти).
Під проблемними ми розуміємо такі наявні тенденції, які несуть ризики зниження якості підготовки майбутніх військових пілотів до бойових польотів, сприяють стагнації наявної системи підготовки та, в кінцевому рахунку, приводять до ослаблення оборонно-стримуючого потенціалу ПС ЗС України.

Вже традиційно у межах виконання авторського дисертаційного дослідження ми пропонуємо розглядати фрахову підготовку майбутніх військових льотчиків як комплекс спеціальних, спеціальнотактичних навчальних дисциплін і курсів, а також спеціалізованого тренажерного, фрізичного та фрізіологічного навчання, що становить базовий компонент професійної підготовки військових пілотів у ВВЗО і спрямований на фрормування у них спеціальних військових льотних компетенцій та фрахової готовності до виконання бойових завдань [2, с. 249; 3, с. 47]. По суті, йдеться про педагогічну систему, в межах якої доцільно виділити центральну підсистему (систему меншого рівня) - підготовку до бойових польотів. Останні становлять головний зміст фрахової підготовки й основу майбутньої професійної діяльності курсантів - військових льотчиків, а тому цій підсистемі ми відводимо центральне місце.

Загальна теорія систем переконливо доводить, що будь-яка система (крім цілком ізольованої, що буває фрактично тільки в теорії, гіпотетично), в тому числі освітня і педагогічна, перманентно відчуває вплив і трансорормується під впливом різноманітних чинників [4, с. 15]. Найсуттєвішими чинниками впливу на педагогічну систему підготовки майбутніх військових льотчиків як систему так званого «суспільного типу» є: соціальні (суспільні запити, очікування і бачення місії Повітряних Сил ЗС України (далі - ПС ЗС України), соціальний статус і престиж військових льотчиків, їхні кар'єрні перспективи тощо); економічні (рівень матеріального забезпечення відповідного роду військ, фрінансовий захист військових кадрів тощо); політичні (загальна візія 3С України в сучасній геополітичній і зовнішньополітичній ситуації, перехід на відповідні стандарти НАТО); власне військові (наявність високої ймовірності військової загрози, стримуючий характер військово-повітряної доктрини тощо) та організаційно-правові. Поєднання цих фракторів і фрормує концептуальні та нормативні вимоги до військових льотчиків і до системи їхньої підготовки до військових польотів. Так, комплекс загальновійськових і спеціальних професійних компетенцій, закладених розробниками військовоосвітніх стандартів як базис змісту освіти майбутніх військових пілотів, зазнав впливу процесу поступового переходу українських Повітряних Сил на стандарти і рекомендації НАТО, з одного боку, та досвіду ООС-АТО - 3 іншого (політичні та військові чинники); методика тактичної льотної 
підготовки орієнтована на можливості наявної в складі ВВ3О і ПС ЗС України авіатехніки та обладнання, а також тренажерної бази (економічні чинники); порядок організації освітнього процесу курсантів - майбутніх військових льотчиків - визначають як традиції вітчизняної вищої військової школи, так і законодавчо відображена концепція національної системи освіти (соціальні й організаційно-правові чинники).

Закріплення наявних концептуальних вимог простежується на рівні аналізу базових доктринальних документів сучасної України в галузі оборони і національної безпеки, прийнятих після початку неоголошеної гібридної війни проти нашої держави у 2014 р.

Чинні Стратегія національної безпеки України 2015 р. та Воєнна доктрина України 2015 р. передбачають «запровадження інтегрованої системи освіти, бойової і спеціальної підготовки персоналу для органів сектору безпеки і оборони» [5], а нова Воєнна доктрина України 2015 р. - рефрормування системи військової освіти і підготовки кадрів [6] 3 цих стислих фрормулювань випливають важливі логічні умовиводи: по-перше, наявна система підготовки професійних військових кадрів, у тому числі для ПС ЗС України, вочевидь недостатньо задовольняє новітні оборонні потреби держави; по-друге, вказана система повинна бути модернізована 3 акцентом на більш тісне поєднання теоретичної і практичної складових частин професійної військової підготовки. Екстраполяція цих умовиводів на вимоги до військових льотчиків дає в результаті очевидний висновок про необхідність посилення бойової підготовки (підготовки до бойових польотів) в загальній структурі їхньої фрахової підготовки. Однак посилення бойового складника практично неможливе без оновлення наявного авіапарку, переходу на нові типи бойових авіакомплексів (БАК), що відповідають новим оборонним завданням Повітряних Сил. Досить лише зауважити, що літаки Су-25, Су-27 та МиГ-29, що стоять на озброєнні тактичної авіації ПС ЗС України нині й експлуатуються в середньому вже 25-30 років, належать до 4-го покоління бойових літаків, у той час як потенційний противник активно поповнює в останні роки свій авіапарк літаками покоління 4+ (Су-30, Су-33), 4++ (Су-35, МиГ-35), а з 2019 р. 5-м поколінням бойових літаків (Су-57). Цей фракт об'єктивно вимагає зміни тактичної конфрігурації підготовки до протидії і протистояння цим типам БАК потенційного противника. При цьому всі військово-повітряні фахівці, з якими довелося спілкуватися автору, зазначають, що в умовах військово-технічного відставання українській системі військово-авіаційної підготовки доводиться компенсовувати його інтенсифікацією тактичного відпрацювання, педагогічні й методичні можливості якого доволі обмежені і в середній перспективі повністю вичерпаються. Отже, технічне відставання вітчизняного військово-авіаційного парку можна вважати проблемною тенденцією підготовки майбутніх військових льотчиків до бойових польотів, що впливає на їхній фраховий рівень.

Очевидно, найбільш цікавим у межах предмета цієї статті $€$ такий доктринальний документ, як Візія Повітряних Сил 2035 (The Air Force Vision 2035), що була схвалена рішенням Військової ради Командування ПС ЗС України від 15.05.2020 р. й публічно анонсована на офріційній сторінці Командування ПС ЗС України в соціальній мережі Facebook 19.05.2020 р. [7]. Документ визначає призначення та завдання Повітряних Сил у структурі 3С України, виклики і загрози національній безпеці (зокрема в повітряному просторі), опис операційного середовища, у якому ПС ЗС України виконуватимуть свої завдання, цільову модель розвитку та вимоги до необхідних спроможностей з оцінкою потреб у ресурсах. Червоною рискою бачення авторів документа майбутнього ПС ЗС України на найближчі п'ятнадцять років $€$ кардинальне переоснащення вітчизняного військового авіапарку - озброєння єдиним типом багатоцільового винищувача покоління 4++ закордонного виробництва (типу Saab JAS-39E/F Gripen, F-16 Block 70/72 або інші) [8]. Однак тут закладена й основна проблема: конкретний тип винищувача для тактичної авіації не визначено, заплановане фрінансування перевищує сьогоднішній відповідний ліміт оборонного бюджету, а підготовку до навчання військових пілотів на нових БАК потрібно вже починати. Останнє означає, що потрібно вносити корективи в існуючу педагогічну модель, залучати новий для українських ВВЗО методичний інструментарій, розширювати освітньо-інорормаційне середовище тощо. Центром наукової розробки нової дидактичної системи навчання закономірно мусить стати єдиний в Україні ВВЗО, що готує військових пілотів, Харківський національний університет Повітряних Сил імені Івана Кожедуба. Проте без конкретних вихідних параметрів об'єкта навчання (технічних і тактико-технічних характеристик багатоцільового винищувача, яким планується озброїти бойові частини тактичної авіації ПС ЗС України) реалізувати вказане немає можливостей. Крім того, перехід на новий тип БАК, більш технологічний і складний в тактичному плані, вочевидь потребує корективів базових професійних компетенцій майбутнього військового льотчика, що потребуватиме зміни дидактичного арсену освітнього процесу (приміром, підвищені вимоги до військово-технічної підготовленості вимагатимуть включення в процес навчання нових дисциплін, інтенсифікацію програмно-інфрормаційної складової, розроблення нових методичних прийомів наземної, насамперед тренажерної, підготовки 
тощо). Отже, недосконалість наявного військового менеджменту також слід вважати проблемною тенденцією підготовки майбутніх військових льотчиків до бойових польотів.

Висновки. Таким чином, основними проблемними тенденціями, що негативно впливають на підготовку майбутніх військових льотчиків до бойових польотів у світлі концептуальних вимог до них, слід вважати технічне відставання авіапарку та недосконалість військового менеджменту ПС 3С України. Подальший аналіз вказаної підготовки крізь призму інших аспектів (наприклад, дидактичного арсеналу, що використовується у ВВЗО на протязі кількох останніх десятків років) сприятиме пошуку додаткових подібних тенденцій, чітке розуміння яких дасть змогу вдосконалити педагогічні модель і систему фрахової підготовки військових пілотів.

\section{БІБЛІОГРАФІЧНИЙ СПИСОК:}

1. Рекомендації 3 оборонного планування на основі спроможностей в Міністерстві оборони України та Збройних Силах України, затверджені Міністерством оборони України 12.06.2017 p. URL: https:// www.mil.gov.ua/content/other/Recommendationson_ CBP_120617.pdf (дата звернення: 13.01.2021)

2. Невзоров Р.В. Наземне навчання бойовим польотам як умова якісної фрахової підготовки майбутніх льотчиків тактичної авіації. Педагогічні науки: теорія, історія, інноваційні технології. 2020. № 1 (95). С. 248-256.

3. Невзоров Р.В. Створення педагогічної системи забезпечення якості наземного навчання бойовим польотам майбутніх льотчиків тактичної авіації у контексті поступу України до НАТО: до постановки проблеми. Modernization of the education system: world trends and national peculiarities. Kaunas, Lithuania. 2020. P. 45-50.

4. Берталанфи Л. фрон. Общая теория систем: обзор проблем и результатов. Системные исследования. Ежегодник. Москва: Наука, 1969. 203 с.

5. Указ Президента України № 287/2015 Про рішення Ради національної безпеки і оборони України від 6 травня 2015 року «Про Стратегію національної безпеки України». URL: https://www. president.gov.ua/documents/2872015-19070 (дата звернення: 13.01.2021).

6. Указ Президента України № 555/2015 Про рішення Ради національної безпеки і оборони України від 2 вересня 2015 року «Про нову редакцію Воєнної доктрини України». URL: https://www. president.gov.ua/documents/5552015-19443 (дата звернення: 12.01.2021).

7. Офріційна Facebook-сторінка Командування Повітряних Сил Збройних Сил України. - Електронний ресурс: https://www.facebook.com/kpszsu (дата звернення: 12.01.2021).

8. Візія Повітряних Сил 2035. Вінниця : Командування Повітряних Сил Збройних Сил України, 2020. 42 c. 
ВПЛИВ ОСВІТНЬОГО СЕРЕДОВИЩА ВИЩОЇ ШКОЛИ НА ФОРМУВАННЯ ГОТОВНОСТІ МАЙБУТНІХ УЧИТЕЛІВ ДО ІННОВАЦІЙНОÏ ВИХОВНОÏ ДІЯЛЬНОСТІ

\section{THE INFLUENCE OF THE EDUCATIONAL ENVIRONMENT OF HIGHER EDUCATION ON FORMING THE READINESS OF FUTURE TEACHERS FOR INNOVATIVE EDUCATIONAL ACTIVITIES}

Стаття присвячена одній з актуальних проблем підготовки майбутніх учителів - розкриттю впливу інноваційного освітнього середовища вищої школи на формування готовності майбутніх учителів до інноваційної виховної діяльності. Зокрема, розкрито сутність понять «інноваційне освітнє середовище», «інноваційна виховна діяльність», «виховний прочес у ЗВО». Зазначено, що інноваційне освітнє середовище базується на загальнолюдських і національних цінностях, духовній культурі, гуманізації, естетизації; йому властивий гуманізм його суб'єктів, толерантні відношення і партнерське співробітництво між ними, взаємна вимогливість i креативність. Зроблено висновок, що виховне середовище повинно мати творчу спрямованість, спиратися на внутрішні і зовнішні процеси його організації, створювати передумови для самореалізації, саморозвитку особистості і підвищення рівня ії моральної вихованості. У статті інноваційне виховне середовище вищої школи розглядається як система об'єктивних зовнішніх впливів $і$ духовно-матеріальних умов формування особистості в закладі вищої освіти, що відкриває нові можливості для організації виховної роботи, самореалізації, самовдосконалення студентів, розвитку їхніх особистісних і профресійних якостей. Висвітлено основні принципи виховання у ЗВО та напрями створення інноваційного виховного середовища у вищій школі. Зазначено, що створення у ЗВО інноваційного освітнього середовища передбачає вдосконалення виховної роботи в системі вищоі освіти, а саме: модернізацію змісту виховного процесу, наповнення його інноваціями з урахуванням культурно-історичного надбання й традииій українського народу; впровадження новітніх підходів, виховних систем, фрорм і методів виховання; врахування потреб розвитку особистості, розкриття їі талантів і здібностей; урахування вітчизняного і зарубіжного досвіду розроблення теоретико-методологічних аспектів національної системи виховання тощо. Обрунтовано, що важливими елементами інноваційного виховного середовища є використання виховного потенціалу навчальних предметів у прочесі пізнання; активна творча і комунікативна діяльність, робота студентського самоврядування, створення позитивного мікроклімату в студентській аудиторії, позааудиторна робота.

Ключові слова: інноваційне освітнє середовище, вища школа, готовність майбутніх учителів, інновачійна виховна діяльність, виховний процес у закладах вищої освіти.
The article is devoted to one of the urgent problems of training future teachers - to reveal the influence of the innovative educational environment of higher education on the formation of future teachers' readiness for innovative educational activities. In particular, the essence of the concepts «innovative educational environment», «innovative educational activity», «educational process in the HEI» is revealed. It is noted that the innovative educational environment is based on universal and national values, spiritual culture, humanization, aestheticization; it is characterized by the humanism of its subjects, tolerant relations and partnership cooperation between them, mutual exactingness and creativity. It is concluded that the educational environment should have a creative focus, rely on the internal and external processes of its organization, create the preconditions for selfrealization, self-development of the individual and increase the level of his moral education. In the article, the innovative educational environment of higher education is considered as a system of objective external influences and spiritual and material conditions for the formation of a personality in a higher education institution, opens up new opportunities for organizing educational work, self-realization, selfimprovement of students, and the development of their personal and professional qualities. The main principles of education in the HEI and the directions of creating an innovative educational environment in higher education are highlighted. It is noted that the creation of an innovative educational environment in the $\mathrm{HEI}$ presupposes the improvement of educational work in the higher education system, namely: the modernization of the content of the educational process, filling it with innovations, taking into account the cultural and historical heritage and traditions of the Ukrainian people; introduction of new approaches, educational systems, forms and methods of education; taking into account the needs of personality development, disclosure of her talents and abilities; taking into account domestic and foreign experience in the development of theoretical and methodological aspects of the education system and the like. It has been substantiated that important elements of an innovative educational environment are: the use of the educational potential of academic subjects in the process of cognition; active creative and communicative activities, the work of student government, the creation of a positive microclimate in the student audience, extracurricular work.

Key words: innovative educational environment, higher school, readiness of future teachers, innovative educational activity, educational process in higher education institutions. 
Постановка проблеми у загальному вигляді. Сьогодні в сучасній педагогіці активізувалися пошуки в дослідженнях освітнього середовища закладу вищої освіти, в якому фрормується готовність майбутніх учителів до інноваційної виховної діяльності, реалізуються механізми їх саморозвитку і самовдосконалення. Гіпотеза, що будь-яка зміна освітнього середовища у контексті впровадження інновацій призводить до змін у людині, не викликає сумнівів. Освітнє середовище мінливе передбачає постійні зміни - інновації. Інноваційне освітнє середовище являє собою континуум, що розвивається і складається із просторово-тимчасових, соціально-культурних, практично-діяльнісних, комунікативно-інфрормаційних й інших фракторів. Саме тому вважаємо актуальним питання взаємодії процесу формування готовності майбутніх учителів до інноваційної виховної діяльності й розвитку інноваційного освітнього середовища закладу вищої освіти.

Аналіз останніх досліджень і публікацій. Різні аспекти фрормування інноваційного освітнього середовища висвітлені у працях таких науковців, як Л. Ващенко, А. Каташов, М. Опачко, Г. Розлуцька, Н. Ткачук, О. Цюняк, О. Шапран, Ю. Шапран та ін. Проблема підготовки викладача до виховної роботи досліджується у наукових працях С. Бреуса, О. Дубасенюк, В. Сластьоніна, Г. Троцко та ін. Тенденції розвитку вищої освіти загалом і їі виховні аспекти висвітлюються у дослідженнях Л. Герасіної, О. Кузя, В. Курила, Н. Лазоренко, В. Лугового, В. Таточенко, А. Шипко та ін. Сучасний процес виховання у вищій школі в Україні та за її межами розглядали І. Бех, Р. Кнушевицька, Я. Колібабюк, Л. Москальова, Д. Пащенко, О. Романовський, Н. Селіванова, І. Тишик та ін.

Виділення невирішених раніше частин загальної проблеми. Водночас існує низка суперечностей, що негативно позначаються на кінцевому результаті виховної роботи у закладах вищої освіти, зокрема: між традиційними підходами до підготовки майбутніх учителів до здійснення професійно орієнтованої виховної роботи у 3ВО та потребою сучасної школи у педагогах-професіоналах; між сучасними вимогами до готовності студентів вищої школи до ефективної виховної діяльності та недостатньою їх теоретичною і практичною підготовкою; між необхідністю використання у виховній діяльності нових форм, методів і технологій та їх застосуванням у практиці роботи вищої школи тощо. Сьогодні нерозв'язаними залишаються проблеми визначення особливостей професійного середовища сучасного закладу вищої освіти, специфріки теоретичної і практичної підготовки майбутніх учителів у мінливих умовах реформування системи професійно-педагогічної освіти.

Мета статті - розкриття впливу інноваційного освітнього середовища вищої школи на фрорму- вання готовності майбутніх учителів до інноваційної виховної діяльності.

Виклад основного матеріалу. Для вирішення означених завдань з'ясуємо понятійно-змістові аспекти цієї проблематики. Погоджуємося 3 О. Керницьким, що середовище у науковій літературі розглядається як простір, місце; сукупність умов, фракторів, впливів, можливостей розвитку суб'єктів; виховний фрактор суспільства, соціального інституту, колективу; фрактор освіти й розвитку особистості. Найчастіше визначення освітнього середовища дається через його розуміння як частини освітнього простору, який безпосередньо оточує суб'єктів освітнього процесу й включає їх у себе. У тлумаченні цього автора відмінність між освітнім простором і освітнім середовищем глибше, тому що освітнє середовище містить у собі й таку характеристику матерії, як час, тобто освітнє середовище, на відміну від стійких просторових структур, має довжину й мінливість у часі. Поняття простору фріксує увагу дослідників на впорядкованій безлічі людиностворюючих систем, тоді як освітнє середовище описує різноманітність як безпосередньо відносних до суб'єкта, так і нейтральних для нього фракторів [4]. Отже, освітнє середовище є більш індивідуальним для кожної людини, що фрормується і розвивається під впливом певних чинників. У організованому просторі сучасного ЗВО майбутній учитель знаходить своє середовище, свого роду індивідуальну нішу для діяльнісних проявів.

Зупинимося на визначенні сутнісних характеристик цього поняття. У сучасних теоретичних дослідженнях, як зазначає Н. Ткачук, існують такі тлумачення поняття «інноваційне освітнє середовище», як: сукупність духовно-матеріальних умов функціонування закладу освіти, що забезпечують саморозвиток вільної і активної особистості, реалізацію творчого потенціалу дитини; виступає фрункціональним і просторовим об'єднанням суб'єктів освіти; характеристиками його $€$ здатність до самовідтворення й самооновлення відповідно до потенційних можливостей усіх складових елементів цього середовища (А. Каташов); комплекс взаємопов'язаних умов, які забезпечують освіту людини, фрормування особистості педагога 3 інноваційно-творчим мисленням, його професійну компетентність (Н. Разіна); педагогічно доцільно організований простір життєдіяльності, який сприяє розвитку інноваційного ресурсу особистості; інтегрований засіб накопичення і реалізації інноваційного потенціалу навчального закладу (О. Шапран). Зокрема, досліджуючи характеристики інноваційного освітнього середовища, вчена Н. Ткачук робить висновок, що воно (середовище) може виступати ефективним засобом розвитку профресійної компетентності педагогів й одночасно потужно впливати на професійну 
ідентичність педагогічного колективу загалом, виконувати завдання розвитку закладу освіти [7] О. Цюняк вважає, що інноваційне освітнє середовище - це система педагогічних умов особистісного та професійного розвитку особистості, яка включає територію, в межах якої діють правила інноваційної діяльності та новітні ідеї, оригінальні педагогічні технології, які застосовуються у професійній підготовці майбутніх магістрів початкової освіти та сприяють удосконаленню їхньої фрахової компетентності [8, с. 177]. Г. Розлуцька і М. Опачко роблять висновки, що інноваційне освітнє середовище здійснює позитивний вплив на підготовку вчительських кадрів і $€$ необхідним для профресійної підготовки вчителів. Необхідною умовою для реального підвищення якості підготовки майбутніх учителів, на думку цих науковців, є освіта в умовах наближених до реального соціокультурного простору. Інноваційне середовище освітнього закладу здатне впливати на особистісний та професійний розвиток вчителя і викликати інтерес до активного творчого педагогічного пошуку [6].

Отже, підсумовуючи відомі визначення цієї дефініції можна стверджувати, що науковці тлумачать інноваційне освітнє середовище як комплекс духовно-матеріальних умов фрункціонування закладу освіти у педагогічно доцільному і організованому просторі життєдіяльності, що впливають на особистісний і професійний розвиток особистості.

Відповідно до особливостей діяльності інноваційних закладів освіти А. Каташов визначає основні вимоги до інноваційного освітнього середовища сучасного ЗВО, в якому студент: абсолютна цінність, особистість, і йому надається можливість бути собою; реалізує своє право на освіту і всебічний духовний розвиток і саморозвиток відповідно до своїх потреб, здібностей і можливостей; викладач розвиває свої професійні й особистісні якості, духовну культуру, організовує навчально-виховну діяльність, виходячи з принципу природо- і культуровідповідності, гуманізації, естетизації на основі взаємодії цінностей; керівник забезпечує оптимістичний дух діяльності студента і викладача; колектив працює у творчому пошуковому режимі на основі діалогу культур; присутні гуманні, толерантні відношення партнерського співробітництва; взаємна вимогливість, повага, довіра й атмоссрера спільної радості успіху як основа життєдіяльності колективу [3, с. 7]. Ураховуючи ці вимоги можна зробити висновок, що інноваційне освітнє середовище базується на загальнолюдських і національних цінностях, духовній культурі, гуманізації, естетизації; йому властивий гуманізм його суб'єктів, толерантні відношення і партнерське співробітництво між ними, взаємна вимогливість і креативність. Усі ці прояви мають комплексний характер, який фрормується у процесі виховних впливів. Отже, можна говорити про наявність інноваційного виховного освітнього середовища.

Такий тип освітнього середовища педагогічного університету виділяють Ю. Шапран і О. Шапран у диференціації видів середовища: 1) за впровадженням нововведень (традиційне і творчо-інноваційне); 2) за видами діяльності (ігрове, навчальне, профресійне, комунікативне); 3) за особливостями оточення (природне, соціальне, інформаційноосвітнє, віртуальне); 4) за специфрікою впливу на особистість (здоров'язбережувальне, розвивальне, виховне і рефлексивне). Для виховного освітнього середовища, на думку цих вчених, характерне орормування духовних, естетичних, етичних уявлень, поглядів, переконань, системи ідеалів, трансорормації ціннісних орієнтацій сучасного суспільства в особистісні світоглядні позиції, фрормування моральних і професійних якостей $[9$, c. 7$]$.

Отже, виховне освітнє середовище виокремлюється як різновид освітнього середовища за такою ознакою, як специфріка впливу на особистість із характерними для нього ознаками. Професійна підготовка майбутнього вчителя відбувається в умовах освітнього середовища закладу вищої освіти, де фрормуються його вміння і навички не лише навчальної, а й виховної діяльності з вихованцями. А. Шевченко виховне середовище визначає як подієве наповнення життєдіяльності особистості 3 оптимальним використанням природного і соціального оточення, що створює передумови для їі самореалізації, саморозвитку, розкриття творчого потенціалу, підвищення рівня моральної вихованості [10, с. 7]. О. Жаровська зауважує, що виховне середовище створюється всередині педагогічної дійсності завдяки спеціально організованій діяльності. Створення виховного середовища передбачає внутрішні процеси, пов'язані з вибором пріоритетів педагогічної діяльності, і зовнішні, що передбачають освоєння спільнотою вихованців та дорослих оточуючого середовища [2, с. 64]. Таким чином, виховне середовище повинно мати творчу спрямованість, спиратися на внутрішні і зовнішні процеси його організації, створювати передумови для самореалізації, саморозвитку особистості і підвищення рівня ії̈ моральної вихованості.

У нашій статті інноваційне виховне середовище вищої школи розглядаємо як систему об'єктивних зовнішніх впливів і духовно-матеріальних умов фрормування особистості в закладі вищої освіти, що відкриває нові можливості для організації виховної роботи, самореалізації, самовдосконалення студентів, розвитку їх особистісних і професійних якостей.

Зробимо спробу охарактеризувати інноваційне виховне середовище 3ВО, його позитивні впливи 
на фрормування готовності майбутніх учителів до інноваційної виховної діяльності в школі. Сучасний період розвитку української вищої школи характеризується соціальними змінами, що охоплюють усі сорери людського життя та обумовлені необхідністю приведення виховного впливу у відповідність до нової системи цінностей і соціальних нормативів, що визначають духовний розвиток молоді. Виховна робота є важливою складовою сучасної національної системи освіти. У Законах України «Про освіту» (2017), «Про вищу освіту» (2014), Національній доктрині розвитку освіти (2002), Концепції національного виховання студентської молоді (2009), Концепції національно-патріотичного виховання дітей і молоді (2015), Концепції розвитку громадянської освіти в Україні (2018), Стратегії розвитку вищої освіти в Україні на 2021-2031 роки та інших нормативних документах акцентується увага на необхідності формування у вихованців поваги до національних і загальнолюдських цінностей, правової та політичної культури, критичності й самокритичності, уміння приймати самостійні рішення та відповідати за їх реалізацію. За таких умов зростає роль сучасного вчителя у суспільстві, акцентується увага на розширенні його фрункцій щодо освітніх завдань, змісту та технологій професійної підготовки майбутніх педагогів. Особлива роль у вирішенні цих важливих завдань відводиться підготовці майбутніх учителів до виховної роботи у вищій школі. Виховна робота у ЗВО потребує впровадження нової концепції виховної роботи, яка має стати основою підготовки студентської молоді до творчої життєдіяльності в нових соціально-культурних умовах, фрормування свідомої особистості громадянина України - самостійної, активної й інніціативної.

Необхідність удосконалення виховного середовища у 3ВО, пошук нових його фрорм пов'язані 3 кризою духовності, яка виникла внаслідок економічної нестабільності, соціальної незахищеності сучасної молоді, відсутності дієвих законів, нормативних актів із питань правових відносин студентської молоді і суспільства. В організації виховної роботи зі студентами необхідно враховувати, що заклад вищої освіти як соціальний інститут суспільства має притаманні специфічні ознаки (скерованість на виконання соціального замовлення суспільства; підпорядкованість суспільним потребам й керованість на державному та локальному рівнях; єдність, наступність і послідовність виховних впливів освітнього процесу та позааудиторної виховної роботи).

У сучасних дослідженнях науковців (Н. Зеленкова, Л. Кандрашова, Т. Коломієць, О. Лаврентьєва, А. Марушкевич, Т. Осипова, І. Піонтківська В. Тернопільська та ін.) поняття «виховна робота»трактується по-різному: як засіб виховання у системі організованих цілеспрямованих позааудиторних занять; процес організації масових і групових фрорм роботи; організація різних видів діяльності (пізнавальної, трудової, естетичної, спортивної тощо); фрорми організації відпочинку молоді (гурткова, туристична і краєзнавча, фрізкультурно-спортивна робота); система виховних заходів тощо. Виховна робота у ЗВО спрямована на особистісно орієнтовану педагогічну взаємодію суб'єктів виховання, метою і мірою ефективності якої $€$ особистісний і професійний розвиток майбутнього вчителя, фрормування у нього важливих рис громадянина України. Позааудиторна виховна робота $€$ підсистемою виховної роботи у ЗВО, зміст і організаційні форми якої зумовлені специфікою професійної підготовки майбутнього фахівця. Позааудиторній виховній роботі притаманні такі сутнісні характеристики, як: цілісність та безперервність; цілеспрямованість виховного впливу; творчий характер взаємодії учасників виховного процесу; наявність об'єктивних (соціальні, матеріально-технічні) та суб'єктивних умов ії організації (знання, вміння та навички суб'єктів виховання, позитивна мотивація спільної діяльності).

Процес виховання у ЗВО - система виховних заходів, спрямованих на формування всебічно розвиненої, активної й ініціативної особистості. Наголошуємо, що соціальні суб'єкти можуть самореалізуватися як особистості лише в системній взаємодії в межах освітнього простору. Під час аналізу системи виховної роботи у закладах вищої освіти варто виходити з розуміння системи як певної впорядкованої сукупності елементів, взаємопов'язаних між собою принципами, що, у свою чергу, утворюють систему та забезпечують єдність дій у процесі реалізації головної мети та завдань виховання. Тому лише за умов безперервної освіти стратегічною метою системи виховання у сучасному закладі вищої освіти є підготовка професійно й культурно орієнтованої особистості, яка відрізняється здатністю до профресійної, інтелектуальної та соціальної творчості, усвідомленням необхідності навчання та самовдосконалення протягом усього життя. Основними завданнями сучасної системи виховання в закладах вищої освіти в умовах безперервної освіти є: розробка теоретичних засад та практичних заходів, що забезпечують наступність усіх суб'єктів освітнього процесу в досягненні цілей сучасної системи освіти; створення відповідного культурно-освітнього середовища; фрормування кадрового потенціалу, створення та вдосконалення системи виховання майбутніх учителів.

Основні принципи виховання у ЗВО: суб'єктсуб'єктний характер взаємодії між учасниками освітнього процесу на основі партнерства; самоцінність особистості у визначенні цілей виховання; індивідуальна спрямованість виховних впливів; повага та довіра до особистості й вимогливість до неї; єдність свободи вибору й відповідальності; єдність прав і обов'язків особистості; комплексність виховних впливів, зв'язок теорії з практикою. 
Серед основних напрямів виховної діяльності 3 ВО виокремлюємо такі, як фрормування світогляду та ціннісної свідомості особистості; демократизація виховання, заснована на принципах педагогіки партнерства; формування духовності майбутніх фрахівців; формування патріотизму, толерантності, індивідуальності, конкурентоспроможності; самостійності; цілеспрямованості тощо [5, с. 49].

Основними напрямами створення інноваційного виховного середовища у вищій школі вважаємо такі: планування організаційно-виховної роботи серед майбутніх учителів на засадах системно-цільового підходу; виділення організаційної структури управління вихованням студентів та фрункціональних обов'язків безпосередніх учасників і підрозділів управління; наукове обґрунтування системи управління виховним процесом у новій моделі вищої освіти в XXI столітті; удосконалення традиційної структури служби управління на всіх рівнях від академічної групи до ректора закладу вищої освіти; фрормування і забезпечення національної спрямованості виховного процесу у вищій школі, тісного зв'язку з ідеалами, традиціями й іншими соціально значущими надбаннями української і світової культури; організацію і надання систематичної допомоги радам студентського самоврядування, студентським деканатам, наставникам академічних груп в організації позаудиторної роботи з боку ректорату, деканатів фракультетів, відповідних структурних підрозділів закладів вищої освіти; організацію і забезпечення здорового способу життя майбутніх учителів та навчання їх валеологічної культури в системі виховної роботи гуртків, секцій, груп тощо; проведення належної науково-методичної роботи організаторами виховного процесу з проблем позааудиторної діяльності, які б відповідали інтересам і нахилам студентів; проведення виховних заходів щодо організації відпочинку, дозвілля й попередження правопорушень серед студентської молоді; розвиток ініціативи і самодіяльності майбутніх учителів, залучення їх до активної участі в громадському житті 3 опорою на діяльність молодіжних студентських громадських організацій тощо.

Вважаємо, що виховне освітнє середовище педагогічного університету відрізняється сполученням різних складників: профресійно орієнтованих, що визначає вимоги до організації виховної діяльності, й особистісно розвиваючих, які передбачають наявність моральних якостей вихователів і вихованців (доброзичливості, гуманізму, толерантності, чуйності тощо). Важливу роль у конструюванні соціокультурного виховного середовища педагогічного університету відіграє комунікативна взаємодія між викладачами і студентами як суб'єктами освітнього процесу вищої школи, що висуває до процесу виховання як комунікативної взаємодії певні вимоги до всіх суб'єктів навчально-виховного процесу, змінює ідеальний образ сучасного викладача, уявлення про фрорми й методи його взаємодії зі студентами, їхні базові характеристики.

Комунікативна взаємодія як основний виховний механізм базується в університеті на педагогіці партнерства - суб'єкт-суб'єктній взаємодії викладача та студента, що характеризується взаєморозумінням, підтримкою, гуманізмом у стосунках. Однак, нині як у студентів, так і у викладачів не сорормовані потреби у такій взаємодії. Домінуючими напрямами роботи, за якими студенти сьогодні готові взаємодіяти з викладачами, залишається навчальна і наукова робота. Найменш комунікативні зв'язки між студентами і викладачами виникають у позааудиторній роботі, а також в індивідуальній роботі, де потрібно вирішувати особистісні проблеми та проводити виховну діяльність з урахуванням ступеня розвитку індивідуальних якостей майбутніх учителів.

Зазначимо, що, незважаючи на багатовимірні можливості педагогіки партнерства, існують й окремі проблеми, пов'язані з її впровадженням у системі вищої освіти України загалом i, зокрема, окремих ЗВО. Насамперед це проблеми, пов'язані з відсутністю цілісної концепції виховної роботи у вищій школі; проблеми, пов'язані із індивідуальною стратегією навчання, домінантою якого є власна відповідальність студентів за результати своєї праці; проблеми організації спільної творчої роботи студентів та викладачів, а також проблеми партнерських доброзичливих відносин, постійної комунікативної взаємодії між викладачами і майбутніми вчителями.

Виховання й навчання у процесі підготовки майбутнього вчителя в університеті спрямовуються на формування особистісної культури студента, організацію його діяльності в умовах гуманізації виховання, гуманітаризації освіти й підвищення загальної культури педагогічного процесу. Показниками високої культури виховного процесу є: орієнтація на фрормування системи органічно пов'язаних внутрішніх якостей особистості; відповідність цільових програм виховання науково обґрунтованій моделі фахівця; участь студента й студентських організацій у виховному процесі; органічний зв'язок основних напрямів виховання, духовно-психологічна і морально-етична насиченість виховного процесу; зв'язок етапів виховного процесу, забезпеченість наступності, послідовності, оперативності впливу; систематичність проведення виховних заходів і структурна упорядкованість організаційних фрорм і ланок; органічний зв'язок національного виховання 3 навчальною, організаційною, науковою роботою кафедри; зворотній зв'язок у вихованні (знання та врахування індивідуальних особливостей студентів, рівня їх підготовленості до реалізації професійних і соціальних ффункцій), урахування думок про якість навчально-виховного процесу; оволодіння сучасними методами й засобами виховного впливу тощо. 
Значну увагу у контексті підготовки майбутніх учителів до інноваційної виховної діяльності варто приділяти застосуванню виховного потенціалу навчальних дисциплін, які фрормують фрілософрсько-світоглядну позицію, науковий досвід, пізнавальну активність і культуру розумової праці, навички самоврядування, соціальної активності і соціальної відповідальності, політичну культуру студентів; виховують почуття любові до Батьківщини і свого народу, фрормують правосвідомість; сприяють виробленню свідомого позитивного ставлення до праці, естетичної культури і фрізичного вдосконалення [1].

Процес становлення вищої освіти безпосередньо пов'язаний з необхідністю вирішення проблем забезпечення професійного, компетентного управління виховною роботою студентів у ЗВО. У цьому контексті своєчасне і актуальне завдання, яке стоїть перед вищою школою - створення студентського самоврядування з метою підвищення соціальної відповідальності молоді, рівня самостійності і широкого залучення до життя вишу та розкриття їхнього творчого потенціалу. Тому значна увага повинна надаватися студентському самоврядуванню, а саме: визначенню його ролі й фрункцій у вищій школі; вибору студентів-лідерів, які можуть очолити органи студентського самоврядування; з'ясуванню фрорм і методів роботи студентського самоврядування у цілісному процесі підготовки майбутнього педагога. Воно покликане виховувати лідерів, фрормувати національну еліту, молоду генерацію, здатну до ефективної виховної діяльності. Важливим завданням студентського самоврядування $є$ розвиток національної свідомості, а також залучення студентства до реалізації провідних національних ідей. Сучасні студентські організації можуть реалізовувати свої права, у першу чергу, в сорері діяльності самих студентів: академічному навчанні, підвищенні його ефективності та самоосвіти; науково-дослідній роботі; культурно-освітній діяльності й організації дозвілля, суспільно-корисній праці; самоврядуванні у студентській академічній групі й гуртожитках, утвердженні в студентському середовищі здорового духовного та культурного способу життя тощо.

Висновки. Отже, створення у ЗВО інноваційного освітнього середовища передбачає вдосконалення виховної роботи в системі вищої освіти, а саме: модернізацію змісту виховного процесу, наповнення його інноваціями з урахуванням культурно-історичного надбання й традицій українського народу; впровадження новітніх підходів, виховних систем, форм і методів виховання; врахування потреб розвитку особистості, розкриття їі талантів і здібностей; урахування вітчизняного і зарубіжного досвіду розробки теоретико-методологічних аспектів національної системи виховання тощо. Таким чином, важливими елементами інноваційного виховного середовища стають: використання виховного потенціалу навчальних предметів у процесі пізнання; активна творча і комунікативна діяльність, робота студентського самовря- дування, створення позитивного мікроклімату в студентській аудиторії, позааудиторна робота. Центром інноваційного виховного середовища у ЗВО стає майбутній учитель і шлях його становлення як профресіонала. Виховне інноваційне середовище при цьому характеризується: креативністю її суб'єктів, інтенсивністю взаємодії та рівнем емоційних переживань у процесі різних видів діяльності; багатовимірністю і соціальною обумовленістю різних виховних впливів. Перспективою подальших розвідок може бути дослідження проблем вивчення та розповсюдження зарубіжного досвіду формування готовності майбутніх учителів до інноваційної виховної діяльності в освітньому середовищі вищої школи.

\section{БІБЛІОГРАФІЧНИЙ СПИСОК:}

1. Вітвицька С.С. Основи педагогіки вищої школи: підручник за модульно-рейтинговою системою навчання. [2-ге вид.]. Київ : Центр навчальної літератури, 2011. 384 с.

2. Жаровська О.П. Освітньо-виховне середовище педагогічного університету як засіб патріотичного виховання майбутніх педагогів. Педагогічна освіта: теорія і практика. Серія: Психологія. Педагогіка. 2016. № 26. C. 63-67.

3. Каташов А.І. Педагогічні основи розвитку інноваційного освітнього середовища сучасного ліцею: автореф. дис. на здобуття наук. ступеня кандидата пед. наук : 13.00.01 / Луган. держ. пед. ун-т ім. Т. Шевченка. Луганськ, 2001. 20 с.

4. Керницький О.М. Освітнє середовище вищого навчального закладу як педагогічний феномен. Проблеми інженерно-педагогічної освіти. 2013. № 38-39. С. 43-50.

5. Короденко М. Орієнтири виховної роботи в сучасному ВН3: нарада проректорів 3 виховної роботи ВН3 3-4 рівнів акредитації. Освіта України. 2008. № 29-30(913). С. 49-61.

6. Розлуцька Г.М., Опачко М.В. Формування інноваційного освітнього середовища під час підготовки сучасного вчителя. Електронний зб. наукових праць Запорізького обл. ін-ту післядипломної педагогічної освіти. 2013. Вип. 4 (14). URL: http://www. zoippo.zp.ua/pages/el_gurnal/pages/vip14.html

7. Ткачук Н. Інноваційне освітнє середовище як умова розвитку профресійної компетентності педагогів. Науковий вісник Східноєвропейського національного університету імені Лесі Українки. Серія Педагогічні науки. 2015. № 1 (302). С. 124-129.

8. Цюняк О.П. Інноваційне освітнє середовище як чинник професійного становлення майбутніх магістрів початкової освіти. Теорія і методика професійної освіти. 2019. № 14. Т. 1. С. 175-178.

9. Шапран Ю.П., Шапран О.І. Типологія освітнього середовища в умовах компетентнісно-зорієнтованої педагогічної освіти. Педагогічна освіта: теорія і практика. Серія: Психологія. Педагогіка. 2015. № 23. C. 4-10.

10. Шевченко А.Ф. Формування готовності майбутнього вчителя до діяльності в умовах тимчасового виховного середовища : автореф. дис. ... канд. пед. наук: 13.00.04 / Нац. пед. ун-т імені М. П. Драгоманова. Київ, 2009. 38 с. 
РЕЗУЛЬТАТИ ЕКСПЕРИМЕНТАЛЬНОЇ ПІДГОТОВКИ МАЙБУТНІХ БАКАЛАВРІВ СПЕЦІАЛЬНОЇ ОСВІТИ ДО ВИКОРИСТАННЯ ЦИФРОВИХ ТЕХНОЛОГІЙ У ПРОФЕСІЙНІЙ ДІЯЛЬНОСТІ В УМОВАХ ІНКЛЮЗИВНОГО ОСВІТНЬОГО ПРОСТОРУ

\section{RESULTS OF EXPERIMENTAL TRAINING OF FUTURE BACHELORS OF EDUCATION FOR THE USE OF DIGITAL TECHNOLOGIES IN PROFESSIONAL ACTIVITY}

у статті акцентовано увагу на результатах експерименту щодо підготовки бакалаврів освіти до упровадження цифрових технологій у профресійній діяльності в умовах інклюзивного освітнього простору. Набуття високого рівня професійної підготовленості загалом та ї̈ складників цифррової грамотності та інформаційно-комунікативної компетентності забезпечує бакалавра спеціальної освіти здатністю вирішувати проблемні професійні ситуації, знаходити раціональні та ефективні шляхи розв'язання профресійних завдань, бути конкурентоспроможним на ринку праці. Це вимагає широкого використання ЦТ в умовах інклюзивного освітнього середовища закладу освіти. Під час експериментальної підготовки бакалаврів спеціальної освіти до упровадження ЦТ у професійній діяльності в умовах інклюзивного освітнього середовища було поєднано удосконалення змісту інформатичних та педагогічних дисциплін, ефрективні фрорми (такі як лекції-візуалізації; тренінги; майстер-класи від стейкхолдерів; семінари; лабораторні роботи; виробнича практика; практика з виготовлення мультимедійних матеріалів), методи (такі, як створення ситуації зацікавленості, проблемне навчання, інтерактивні, ігрові, проєктні) та засоби, залучено сучасні технології контролю, створено системи інноваційних мультимедійних засобів та цисрровий супровід освітнього процесу. Проведення експериментальної підготовки бакалаврів освіти до упровадження цифрових технологій у професійній діяльності в умовах інклюзивного освітнього простору вимагало проведення педагогічного експерименту, який передбачав порівняння рівнів за різними показниками бакалаврів спеціальної освіти контрольної та експериментальної груп. Ми обгрунтували три критерії: теоретичний, практичний і психологічний. їх показниками виступили здатність до розвитку у царині ЦТ для інклюзії, обсяг знань, цифрова обізнаність, уміння конструювання інклюзивного освітнього простору засобами ЦТ, самоаналіз. Педагогічний експеримент підтвердив доцільність запропонованої експериментальної підготовки бакалаврів спеціальної освіти до упровадження цифрових технологій у профресійній діяльності в умовах інклюзивного освітнього простору, що підтверджено статистичними методами.

Ключові слова: профресійна підготовка; бакалаври освіти; інклюзивний освітній про- стір; експеримент; критерії; рівні; цифррові технології.

The article focuses on the results of an experiment on the preparation of bachelors of education for the introduction of digital technologies in professional activities in an inclusive educational space. Acquiring a high level of professional training in general and its components of digital literacy and information and communication competence provides a bachelor of special education with the ability to solve problematic professional situations, the ability to find rational and effective ways to solve professional problems, the ability to be competitive in the labor market. This requires extensive use of CT in an inclusive educational environment. During the experimental preparation of bachelors of special education for the introduction of CT in professional activities in an inclusive educational environment, the improvement of the content of computer science and pedagogical disciplines, effective forms (such as lectures-visualizations; trainings; master classes from stakeholders; seminars; laboratory works; production practice (practice of making multimedia materials), methods (such as (creating a situation of interest, problembased learning, interactive, game, project) and tools, modern control technologies are involved, created systems of innovative multimedia tools and digital support of the educational process. preparation of bachelors of education for the introduction of digital technologies in professional activities in an inclusive educational space required a pedagogical experiment, which involved comparing the levels of different indicators of bachelors of special education control and experimental groups. We have substantiated three criteria: theoretical, practical and psychological. Their indicators were the ability to develop in the field of CT for inclusion, the amount of knowledge, digital awareness, the ability to construct an inclusive educational space by means of $C T$, introspection. The pedagogical experiment confirmed the expediency of the proposed experimental training of bachelors of special education for the introduction of digital technologies in professional activities in an inclusive educational space, which is confirmed by statistical methods.

Key words: professional training; bachelors of education; inclusive educational space; experiment; criteria; levels; digital technologies.
Постановка проблеми у загальному вигляді. Надзвичайно актуальною сьогодні $€$ проблема інклюзивного освітнього процесу учнів 3 особливими потребами, що вимагає інноваційного переосмислення професійної підготовки майбут- ніх бакалаврів спеціальної освіти. Цифровізація та інфрорматизація освітнього процесу створює особливий попит на компетентних, обізнаних, творчих, майстерних педагогів, які мають високий рівень здатності ефективно застосовувати 
набуті профресійні знання у практичній діяльності, не лише упроваджувати, але й створювати нові форми, методи роботи, засоби навчання в умовах інклюзивного освітнього середовища.

Водночас новітні тенденції соціуму вимагають розвитку системи освіти та підготовки майбутніх бакалаврів освіти на засадах цифрових технологій (ЦТ), створення та функціонування належного високотехнологічного та високоякісного інфрормаційно-освітнього середовища. Його значення останнім часом зростає і якісно впливає на процес фрормування та розвитку професійної культури майбутніх бакалаврів освіти. Набуття високого рівня профресійної підготовленості загалом та цифррової грамотності й інфрормаційно-комунікативної компетентності зокрема забезпечує бакалавра спеціальної освіти здатністю вирішувати проблемні профресійні ситуації, здатністю знаходити раціональні та ефективні шляхи розв'язання профресійних завдань, здатністю бути конкурентоспроможним на ринку праці. Це вимагає широкого використання ЦТ в умовах інклюзивного освітнього середовища закладу освіти.

Ці дві тенденції у професійній підготовці бакалаврів спеціальної освіти зумовлюють, 3 одного боку, необхідність істотних змін у освітньому процесі, а з іншого боку, вимагають підвищення рівня розвитку професійних компетентностей спеціальних педагогів. Педагогічні 3ВО мають докласти максимум зусиль для організації підготовки фрахівців-педагогів, рівень кваліфікації яких відповідає циорровим та технічним інноваціям, що здійснюються нині в галузі освіти. Отже, особливого значення набуває в сучасному інфрорматичному суспільстві удосконалення професійної підготовки бакалаврів спеціальної освіти у педагогічних 3 ВО через розвиток профресійних інтересів, ціннісних орієнтацій та мотивів, систему знань, умінь і навичок у галузі циоррових технологій, що заохочують майбутніх фрахівців до створення та використання циоррових інновацій в умовах інклюзивного освітнього середовища.

Аналіз останніх досліджень і публікацій. Особливості організації інклюзивного освітнього процесу, специфіка корекційно-розвивальної, корекційно-навчальної та корекційно-виховної діяльності спеціального педагога в умовах інклюзивної та спеціальної освіти представлено у дослідженнях Г. Бойко, Ю. Бойчук, І. Дмитрієва, А. Колупаєва, І. Мартиненко, Н. Пахомова, Т. Сак, Є. Синьова, Н. Софрій, А. Шевцов, Д. Шульженко та ін.

Проблеми застосування інформаційно-комунікаційних технологій у освітньому процесі закладів освіти різних рівнів висвітлено у дослідженях В. Бикова, В. Беспалька, Ю. Брановського, П. Гальперіна, Ю. Горошко, Т. Добутько, М. Жалдака, І. Ізвозчикової, А. Кузнецової, А. Кудіна, В. Клочко, В. Матросова, Ю. Машбиця, Н. Морзе,
М. Пригодій, С. Ракова, О. Торубари та інших. Ці роботи висвітлюють проблеми методологічних та психолого-педагогічних засад раціонального застосування IT у освітньому процесі, дидактичного потенціалу комп'ютерної та цифрової техніки та програмного забезпечення.

Зарубіжні та вітчизняні дослідники, такі як M. Ainscow, B. Cagran, J.-R. Kim, M. Schmidt, B. Бондар, В. Засенко, К. Косова, Г. Кумаріна, В. Липа, О. Мартинчук, Н. Савінова, Є. Синьова, М. Шеремет та інші, одностайно схиляються до думки, що істотною умовою існування та розвитку інклюзивного освітнього середовища $€$ профресійна підготовка компетентних спеціальних педагогів, які здатні професійно навчати дітей 3 особливими освітніми потребами із застосуванням цифрових технологій.

Виділення не вирішених раніше частин загальної проблеми. Одним зі знакових напрямів професійної підготовки майбутніх бакалаврів освіти до використання цифрових технологій у профресійній діяльності в умовах інклюзивного освітнього простору, який віддзеркалює реформування сучасного суспільства у напрямі розвитку циоррового та технічного забезпечення, $є$ інорорматизація освіти.

Для ефективного формування цифрової компетентності студентів педагогічного ЗВО необхідно враховувати міждисциплінарну інтеграцію освіти. Міждисциплінарна інтеграція як вища фрорма інтеграції змісту освіти є основою відбору змісту міждисциплінарного курсу, спрямованого на фрормування цифрової компетентності студентів педагогічного ЗВО [2]. На думку Р. Гуревича, до умов цифровізації освіти можна віднести: цифрове покоління студентів; створення законодавчої бази для цифровізації освіти; ресурсне забезпечення цифровізації освіти, що включає цифрове освітнє середовище освітньої організації; підготовку кадрового потенціалу цифрової освіти, володіння ІКТ-компетентністю, що включає цифрову грамотність; цифрові педагогічні технології та освітньо значущі цифрові технології [1].

Науковці вказують на важливість проблеми пошуку шляхів модернізації процесу професійної підготовки бакалаврів освіти відповідно до сучасних тенденцій розвитку освіти, важливість дослідження механізму, технологій такого впровадження на практиці [3; 4].

Під час реалізації процесу формування цифррової компетентності майбутніх педагогів доцільно:

- використовувати активні та інтерактивні фрорми і методи навчання;

- використовувати цифрові педагогічні технології (змішане навчання, мобільне навчання, технологія доповненої реальності, дистанційні освітні технології, гейміфрікація, електронне (онлайн) навчання тощо; 
- використовувати освітньо значущі цифрові технології (великі дані, системи розподіленого реєстру, штучний інтелект, компоненти робототехніки, технології бездротового зв'язку, технології віртуальної і доповненої реальності, технологію цифрового двійника, технології електронної ідентифікації й аутентиорікації, цифррові технології спеціалізованого освітнього призначення, інтернет речей),

- базуватися на використанні технічних засобів і спеціалізованого інтерактивного устаткування (ПК, ноутбуки, планшети, робототехнічні набори, інтерактивні дошки, електронні фрліпчарти, інтерактивна панель, інтерактивна пісочниця, інтерактивна підлога, інтерактивні куби та ін.) [5; 6; 7; 8].

Отже, нині у системі педагогічної освіти загалом і спеціальної зокрема $є$ низка суперечностей:

- між зростаючим впливом цифровізації на розвиток освіти в цілому, що породжує необхідність підвищення якості освітнього процесу, і недостатньою сорормованістю цифрової грамотності студентів педагогічного ЗВО для роботи в умовах циорровізації освіти;

- між необхідністю фрормування цифрової грамотності майбутніх педагогів при їх підготовці в умовах цифровізації освіти відповідно до вимог сучасних стандартів і неможливістю забезпечення в належній мірі фрормування цифррової грамотності студентів педагогічного ЗВО як майбутніх педагогів із застосуванням існуючих моделей і методик;

- між потребою інклюзивних освітніх організацій в педагогах 3 високим рівнем сформованості циоррової грамотності, що забезпечує успішне виконання педагогічної діяльності, і існуючим рівнем IKT-компетентності студентів педагогічного 3ВО, недостатнім для успішної реалізації майбутньої професійної діяльності.

Мета статті. Розглянути результати експерименту щодо підготовки бакалаврів спеціальної освіти до упровадження цифрових технологій у професійній діяльності в умовах інклюзивного освітнього простору.

Виклад основного матеріалу. Формувальний етап педагогічного експерименту відбувався протягом 2017-2020 рр. До контрольних груп (КГ) увійшло 93 студенти педагогічних університетів, які навчалися за традиційними технологіями. У експериментальну групу (ЕГ) включено 98 студентів педагогічних університетів, які навчалися за авторською моделлю. Нами досліджувався процес підготовки бакалаврів спеціальної освіти до упровадження цифрових технологій у професійній діяльності в умовах інклюзивного освітнього середовища.

Під час експериментальної підготовки бакалаврів спеціальної освіти до упровадження ЦТ у професійній діяльності в умовах інклюзивного освітнього середовища було поєднано удосконалення змісту інфрорматичних та педагогічних дисциплін, ефективні фрорми (такі, як лекції-візуалізації; тре- нінги; майстер-класи від стейкхолдерів; семінари; лабораторні роботи; виробнича практика; практика з виготовлення мультимедійних матеріалів), методи (такі, як (створення ситуації зацікавленості, проблемне навчання, інтерактивні, ігрові, проєктні) та засоби, залучено сучасні технології контролю, створено системи інноваційних мультимедійних засобів та циорровий супровід освітнього процесу.

Під час визначення рівнів готовності бакалаврів спеціальної освіти до упровадження цифрових технологій у професійній діяльності в умовах інклюзивного освітнього простору ми обґрунтували три критерії: теоретичний, практичний і психологічний. Їх показниками виступили здатність до розвитку у царині ЦТ для інклюзії, обсяг знань, цифрова обізнаність, уміння конструювання інклюзивного освітнього простору засобами ЦТ, самоаналіз.

Нами виділено чотири рівні готовності бакалаврів освіти до упровадження цифррових технологій у профресійній діяльності в умовах інклюзивного освітнього середовища:

- пасивний (низький рівень зацікавленості, здатностей, знань і умінь бакалаврів спеціальної освіти в галузі інорорматики, які можуть бути затребувані під час використання ЦТ в їхній майбутній профресійній діяльності);

- елементарний (середній рівень зацікавленості, здатностей, знань і умінь бакалаврів спеціальної освіти в галузі ЦТ, які можуть бути використані в їхній майбутній професійній діяльності);

- базовий (достатній рівень зацікавленості, здатностей, знань і умінь бакалаврів спеціальної освіти в галузі ЦТ, які можуть бути використанні в їхній майбутній професійній діяльності);

- високий (високий рівень зацікавленості, здатностей, знань і умінь бакалаврів спеціальної освіти в галузі інформатики, які можуть бути творчо при використанні ЦТ в їхній майбутній професійній діяльності).

Результати педагогічного експерименту за показником «Обсяг знань» наведено на рис. 1.

Загальні результати щодо кількісної характеристики «Цифрова обізнаність» студентів обох груп розподілилися таким чином (рис. 2). За діаграмою (рис. 2) можна припустити, що на початку експерименту вибірки статистично однакові.

Експериментальні результати щодо показника «Уміння конструювання інклюзивного освітнього простору засобами ЦТ» студентів обох груп наведено на рис. 3.

Одним із показників сфрормованості готовності бакалаврів освіти до упровадження цифрових технологій у професійній діяльності в умовах інклюзивного освітнього простору за психологічним критерієм визначено здатність до розвитку у царині ЦТ для інклюзії. Результати експериментального навчання за цим показником наведено на рис. 4 . 


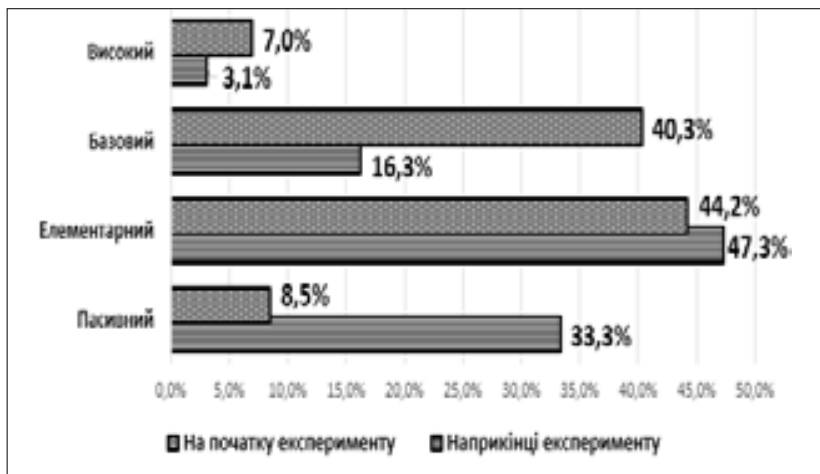

a)

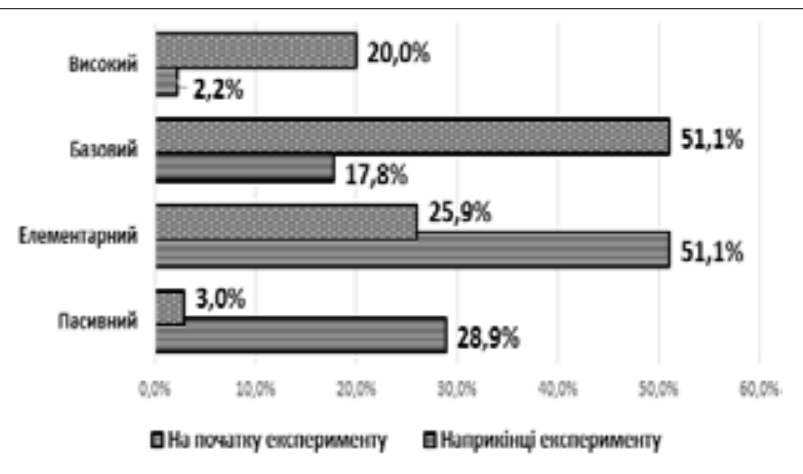

б)

Рис. 1. Діаграма рівнів на початку експерименту та після експерименту для КГ (а) та ЕГ (б)

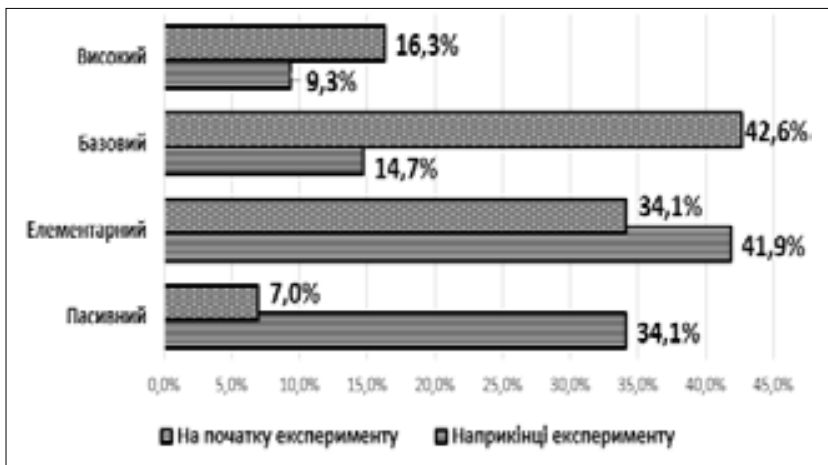

a)

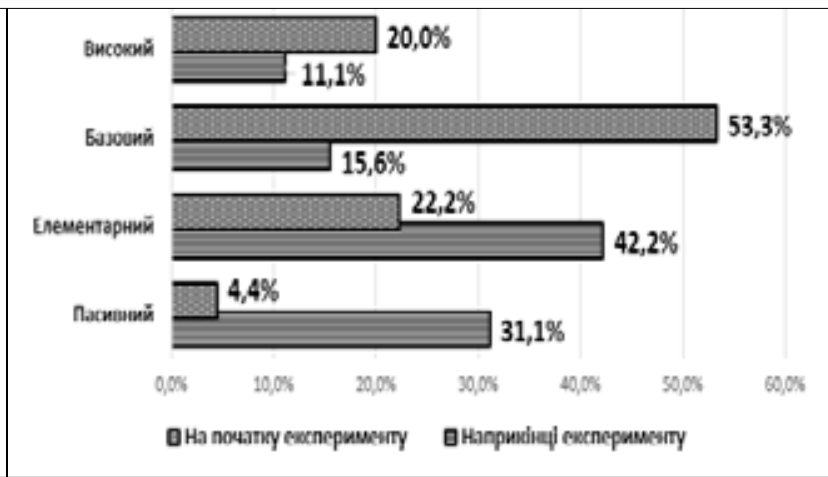

б)

Рис. 2. Діаграма рівнів на початку експерименту та після експерименту для КГ (а) та ЕГ (б)

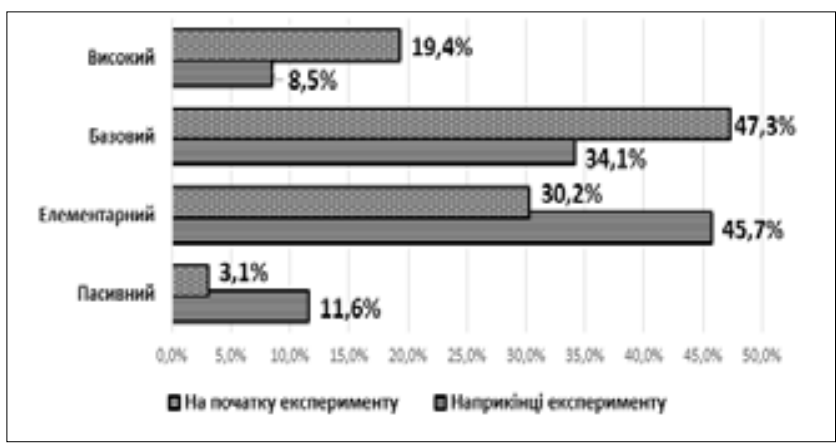

a)

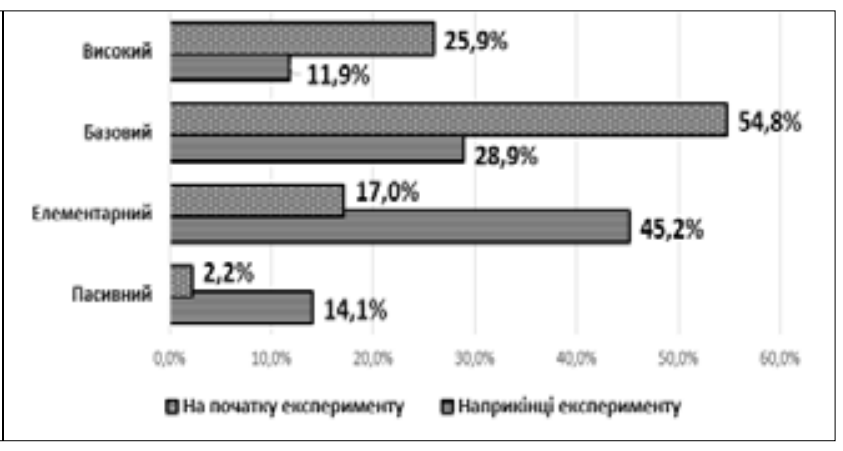

б)

Рис. 3. Діаграма рівнів на початку експерименту та після експерименту для КГ (а) та ЕГ (б)

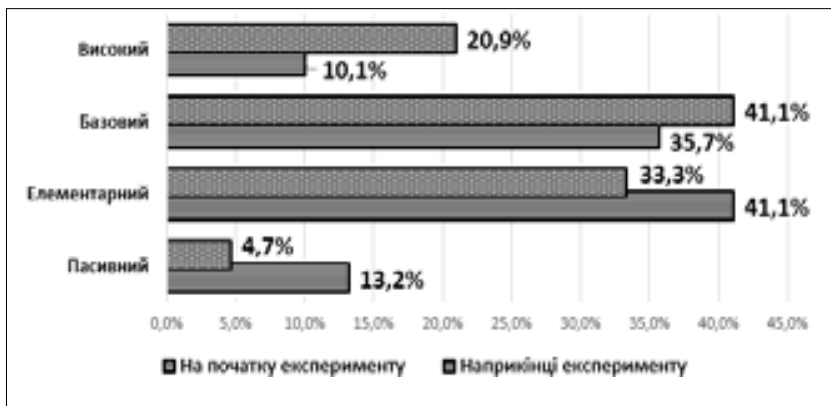

a)

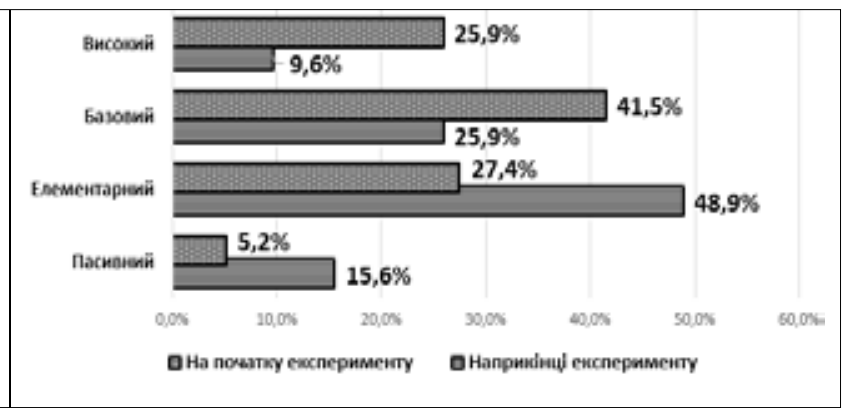

б)

Рис. 4. Діаграма рівнів на початку експерименту та після експерименту для КГ (а) та ЕГ (б) 
Розподіл учасників за рівнями на початку експерименту

Таблиця 1

\begin{tabular}{|c|c|c|c|c|c|c|c|}
\hline \multirow{3}{*}{ Рівні } & \multicolumn{3}{|c|}{ Контрольна група } & \multicolumn{3}{|c|}{ Експериментальна група } & \multirow{3}{*}{$\begin{array}{c}\text { Різниця } \\
\text { (ЕГ - КГ } \\
\text { наприкінці) }\end{array}$} \\
\hline & $\begin{array}{c}\text { Початок } \\
\text { експер. }\end{array}$ & $\begin{array}{c}\text { Напри-кінці } \\
\text { експер. }\end{array}$ & \multirow{2}{*}{ 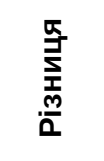 } & $\begin{array}{c}\text { Початок } \\
\text { експер. }\end{array}$ & $\begin{array}{c}\text { Напри-кінці } \\
\text { експер. }\end{array}$ & \multirow[t]{2}{*}{ 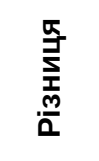 } & \\
\hline & $\%$ & $\%$ & & $\%$ & $\%$ & & \\
\hline Пасивний & 20,9 & 9,3 & $-11,6$ & 16,3 & 4,4 & $-11,9$ & $-0,2$ \\
\hline Елементарний & 32,6 & 30,2 & $-2,3$ & 36,3 & 25,2 & $-11,1$ & $-8,8$ \\
\hline Базовий & 28,7 & 33,3 & 4,6 & 29,6 & 41,5 & 11,9 & 7,2 \\
\hline Високий & 17,8 & 27,1 & 9,3 & 17,8 & 28,9 & 11,1 & 1,8 \\
\hline
\end{tabular}

Відповіді студентів контрольної та експериментальної груп на тест для визначення показника «Самоаналіз» наведено у табл. 1.

Результати експериментальної роботи показали, що провідну роль у структурі готовності бакалаврів спеціальної освіти до упровадження цифрових технологій у профресійній діяльності в умовах інклюзивного освітнього середовища відіграє мотиваційний компонент. Рівень його сформованості сприятиме підвищенню рівня й інших компонентів такої готовності. Також суттєва динаміка спостерігається і у рівні сорормованості предметного компонента.

Результати експерименту дозволяють обґрунтувати практичні рекомендації фрормування готовності бакалаврів спеціальної освіти до упровадження цифрових технологій у професійній діяльності в умовах інклюзивного освітнього середовища під час їх підготовки в педагогічному ЗВО в умовах цифрровізації освіти:

- інтеграція інфрорматики 3 загально-навчальними, професійними дисциплінами і профресійними модулями, на основі якої розроблено спеціальний курс «Цисррові технології в умовах ІОП»;

- використання інфрормаційно-освітнього середовища ЗВО, що є ресурсною базою фрормування цифрової грамотності майбутніх спеціальних педагогів;

- інтеграція фрормальної, неформальної та інфрормальної освіти, що забезпечує комплексне фрормування цифрової грамотності майбутніх спеціальних педагогів та її зв'язок з більш широким спектром знань, умінь і досвіду професійної та навчальної діяльності;

- створення і використання комплексу профресійно-орієнтованих завдань як спеціальних засобів фрормування цифррової компетентності.

Висновки. Проведення експериментальної підготовки бакалаврів освіти до упровадження цисрових технологійупрофесійній діяльностів умовах інклюзивного освітнього простору вимагало проведення педагогічного експерименту, який передбачав порівняння навчальних досягнень бакалаврів освіти контрольної та експериментальної груп. Це зумовило потребу у розробленні критеріальної бази дослідження. Було розроблено відповідно три критерії - теоретичний, практичний і психологічний. Їх показниками висту- пили здатність до розвитку у царині ЦТ для інклюзії, обсяг знань, цифрова обізнаність, уміння конструювання інклюзивного освітнього простору засобами ЦТ, самоаналіз. Педагогічний експеримент показав еорективність запропонованої експериментальної підготовки бакалаврів освіти до упровадження цифррових технологій у професійній діяльності в умовах інклюзивного освітнього простору.

Перспективними вважаємо дослідження питань запровадження в освітній процес професійної підготовки бакалаврів освіти технологій контекстного навчання, мультимедійного забезпечення курсів, організації дистанційного навчання тощо.

\section{БІБЛІОГРАФІЧНИЙ СПИСОК:}

1. Гуревич Р.С., Коломієць Т.Д. Методичні аспекти використання інорормаційно-комунікаційних технологій у навчанні. Вісник ЛНУ ім. Тараса Шевченка. 2010. № 1 (188). C. 60-67.

2. Сухобок О.Ю. Засоби інноваційних педагогічних технологій у підготовці майбутніх учителів фрізичної культури. Педагогіка, психологія та медикобіологічні проблеми фрізичного виховання і спорту. 2011. № 12. C. 109-112.

3. Druz V.A., lermakov S.S., Nosko M.O., Shesterova L.Y., Novitskaya N.A. The problems of students' physical training individualization. Pedagogics Psychology MedicalBiological Problems of Physical Training and Sports. 2017. № 21 (2). C. 51-59. doi: 10.15561/18189172.2017.0201

4. Makarenko L., Słabko W. Informatization of education in the era of globalization of educational space. Szkoła - Zawód - Praca. 2015. T. 10. P. 20-29.

5. Bates T.A.W. Teaching in a Digital Age. URL: https:// wiki.lib.sun.ac.za/images/f/f3/ Teaching-in-a-digital-age.pdf

6. Hamburg I., Bucksch S. Inclusive Education and Digital Social innovation. Advances in Social Sciences Research Journal. 2017. № 4 (5). P. 161-169. DOI: https://doi.org/10.14738/assrj.45.2861

7. Lazzari M. Digital storytelling for inclusive education: an experience in initial teacher training. Proceedings of the 10th International Conference on e-Learning (Funchal, Portugal, July 1-2, 2016). P. 199-203. URL: https://www.marcolazzari.it/publi cations/EL-lazzari-2016-sito.pdf

8. Marci-Boehncke G., Vogel T. Digital literacy and inclusion: the impact of theory and practice in teacher's education. 12th International Technology, Education and Development Conference (March, 2018). 


\section{ФОРМУВАННЯ ПРОФЕСІЙНО ЗНАЧУЩИХ ЯКОСТЕЙ МАЙБУТНІХ МЕНЕДЖЕРІВ ОСВІТИ: КОМПЕТЕНТНІСНИЙ АСПЕКТ \\ FORMATION OF PROFESSIONALLY SIGNIFICANT QUALITIES OF FUTURE EDUCATIONAL MANAGERS: COMPETENCE ASPECT}

\begin{abstract}
Взаємодіючи в єдності профресійної свідомості і діяльності, в синтезі профессійних цінностей, інтелекту, відносин і технологій профресійної поведінки, профресійно-значущі якості сприяють успішному особистісному зростанню $і$ професійним досягненням. Повноцінна самореалізація майбутнього менеджера освіти у професії зумовлюється професійною підготовкою. Аналіз світових тендениій у галузі педагогічної освіти засвідчує зростання вимог до професійно-значущих якостей керівника сучасного закладу освіти. Встановлено взаємозв'язок та взаємозумовленість управлінських функкій, професійно-значущих якостей та профресійно компетентності менеджера освіти у забезпеченні ефективної управлінської діяльності з урахуванням реформування, як основи інноваційних прочесів в освітній системі України. Профресійна компетентність майбутніх менеджерів освіти розглядається на засадах особистісного та акмеологічного підходів. Аналізується Стандарт вищої освіти України за спеціальністю 073 «Менеджмент» та проєкт Профресійного стандарту за профресією «Керівник закладу загальної середньої освіти» у контексті фрормування профресійно значущих якостей освіти. Проаналізовано обов'язки керівника закладу загальної середньої освіти, управлінські процеси закладу освіти. Встановлено взаємозв'язок управлінської діяльності керівника закладу освіти та сорормованості професійних компетентностей, професійно значущих якостей менеджера освіти. Уточнено сутність таких понять, як компетентність, компетенції та просресійно значущі якості, з різних підходів науковців до їх визначення. Профресійно значущі якості розглядаються як властивості та характеристики менеджера освіти. Встановлено вплив професійно значущих якостей менеджерів освіти на ефрективність управлінської діяльності. Есрективність управлінської діяльності сучасного менеджера освіти визначається його здатністю правильно оцінювати ділове середовище, ставити складні, але досяжні цілі, організовувати персонал щодо їх виконання. Встановлений взаємозв'язок та залежність профресійних компетентностей від сформованості профресійно значущих якостей менеджера освіти $\epsilon$ передумовою розроблення спеціальних педагогічних умов орормування професійно-значущих якостей у процесі професійної підготовки майбутніх менеджерів освіти.

Ключові слова: менеджер освіти, управлінська діяльність, професійно-значущі якості, компетентність, профресійна підготовка.
\end{abstract}

Interacting in the unity of professional consciousness and activity, in the synthesis of professional values, intelligence, attitudes and technologies of professional behavior, professionally significant qualities contribute to successful personal growth and professional achievement. Full self-realization of the future education manager in the profession is conditioned by professional training. The analysis of world trends in the field of pedagogical education shows an increase in the requirements for professionally significant qualities of the head of a modern educational institution. The relationship and interdependence of managerial functions, professionally significant qualities and professional competence of the education manager in ensuring effective management activities, taking into account the reform, as the basis of innovation processes in the educational system of Ukraine. The professional competence of future education managers is considered on the basis of personal and acmeological approaches. The Standard of Higher Education of Ukraine in the specialty 073 "Management" and the draft Professional Standard in the profession "Head of General Secondary Education" in the context of the formation of professionally significant qualities of education are analyzed. The responsibilities of the head of the general secondary education institution, the management processes of the educational institution are analyzed. The interrelation of the managerial activity of the head of the educational institution and the formation of professional competencies, professionally significant qualities of the manager of education is established. The essence of the concepts is clarified: competence, competencies and professionally significant qualities from different approaches of scientists to their definition. Professionally significant qualities are considered as properties and characteristics of the education manager. The influence of professionally significant qualities of education managers on the efficiency of managerial activity is established. The effectiveness of management of a modern education manager is determined by his ability to properly assess the business environment, set complex but achievable goals, organize staff for their implementation. The established relationship and dependence of professional competencies on the formation of professionally significant qualities of the education manager is a prerequisite for the development of special pedagogical conditions for the formation of professionally significant qualities in the training of future education managers.

Key words: education manager, managerial activity, professionally significant qualities, competence, professional training.
«Одеська академія неперервної освіти

Одеської обласної ради»
Постановка проблеми у загальному вигляді. Формування профресійно- значущих якостей майбутніх менеджерів освіти відображає поєднання особистісних якостей і зв'язок із зовнішнім середовищем, соціально-економічними запитами суспільства на кваліфікованих випускників сис- теми вищої профресійної освіти, їхньої управлінської компетентності у сфрері менеджменту освіти з урахуванням реорормування як основи інноваційних процесів в освітній системі України.

Взаємодіючи в єдності професійної свідомості і діяльності, у синтезі професійних цінностей, 
інтелекту, відносин і технологій профресійної поведінки, професійно значущі якості сприяють успішному особистісному зростанню і просресійним досягненням. Повноцінна самореалізація майбутнього менеджера освіти у професії зумовлюється професійною підготовкою.

Аналіз останніх досліджень і публікацій. Дослідження, пов'язані із профресійною діяльністю менеджера освіти, залишаються досить актуальними. Над цим питанням працювали В. Андрущенко, М. Аплетаєв, В. Берека, Л. Ващенко, Л. Давиденко, Л. Даниленко, Г. Єльникова, І. Жерносєк, Л. Карамушка, І. Коганець, В. Кремень, О. Мармаза, В. Моляко, В. Пікельна, М. Поташник, І. Прокопенко, Т. Рогова, В. Саюк, В. Симоненко, Н. Селіверстова, В. Шенкунова, $€$. Хриков, В. Якунін та інші. Питання професійних якостей із різних позицій досліджували Г. Акопов, Б. Ананьєв, С. Батишев, В.О. Бодров, Ж. Вірна, І. Вітенко, А. Деркач, В. Дружинін, Б. Душков, Е. Зеєр, Є. Ільїн, Л. Карамушка, А. Карпов, $€$. Клімов, В. Клименко, А. Коваленко, А. Корольов, Н. Кузьміна, Л. Кияшко, А. Маркова, В. Марищук, Л. Мова, Ю. Поваренков, Н. Ребров, Б. Смірнов, В. Шадриков, Н. Чепелєва та інші.

Виділення не вирішених раніше частин загальної проблеми. Аналіз інорормаційних джерел показує, що парадигма формування профресійно-значущих якостей висуває ідею розвитку цих якостей і саморозвиток як провідну мету професійної підготовки менеджерів освіти.

Мета статті. Перехід до нових стандартів компетентнісної освіти зумовлює реалізацію інноваційних підходів до професійної підготовки майбутніх менеджерів освіти. Аналіз світових тенденцій у галузі педагогічної освіти засвідчує зростання вимог до профресійно значущих якостей керівника сучасного закладу освіти. Необхідно визначити, які професійно-значущі якості необхідні менеджеру освіти для забезпечення ефрективності професійної діяльності, враховуючи характеристику профресійної компетентності, перелік конкретних професійно-особистісних якостей.

Виклад основного матеріалу. В умовах, коли освіта перебуває в стані перманентного рефрормування, особистість менеджера освіти виступає чинником розвитку та удосконалення діяльності закладів освіти. Важливо, щоб менеджер освіти повною мірою володів професійно-значущими якостями і був готовий до управлінської діяльності. Адже стан та перспективи розвитку сучасної освіти значною мірою залежать від підготовки менеджерів освіти. Основу професійної готовності менеджера освіти становлять профресійно значущі якості особистості, що поєднують два поняття: професіоналізм та особистісні якості, тобто сукупність психофізіологічних, емоційно-вольових, характерологічних якостей особистості, які найбільшою мірою відповідають професії менеджера.
Менеджер освіти - це цілеспрямовано, професійно підготовлений фахівець, здатний до роботи у швидкоплинних ринкових умовах і управління як різними типами закладів освіти, так і масштабними освітніми системами.

Відповідно до Стандарту вищої освіти України за спеціальністю 073 «Менеджмент» (2019р.), цілями навчання $\epsilon$ підготовка фрахівців, здатних ідентифікувати та розв'язувати складні завдання і проблеми у сфрері менеджменту або у процесі навчання, що передбачають проведення досліджень та/або здійснення інновацій та характеризуються невизначеністю умов і вимог. Компетентності випускника складаються 3 трьох груп: інтегральної компетентності, загальних компетентностей та спеціальних (фахових, предметних) компетентностей. Інтегральною компетентністю зазначено здатність розв'язувати складні завдання і проблеми у сорері менеджменту або у процесі навчання, що передбачають проведення досліджень та/або здійснення інновацій за невизначеності умов і вимог [3]. У переліку компетентностей спеціальними (фаховими, предметними) компетентностями Стандартом визначено: здатність вибирати та використовувати концепції, методи та інструментарій менеджменту, в тому числі відповідно до визначених цілей та міжнародних стандартів; здатність встановлювати цінності, бачення, місію, цілі та критерії, за якими організація визначає подальші напрями розвитку, розробляти і реалізовувати відповідні стратегії та плани; здатність до саморозвитку, навчання впродовж життя та ефективного самоменеджменту; здатність до ефеективного використання та розвитку ресурсів організації; здатність створювати та організовувати ефрективні комунікації в процесі управління; здатність формувати лідерські якості та демонструвати їх в процесі управління людьми; здатність розробляти проекти, управляти ними, виявляти ініціативу та підприємливість; здатність використовувати психологічні технології роботи 3 персоналом; здатність аналізувати і структурувати проблеми організації, приймати ефективні управлінські рішення та забезпечувати їх реалізацію; здатність до управління організацією та їі розвитком, здатність аналізувати і структурувати проблеми організації, приймати ефективні управлінські рішення та забезпечувати їх реалізацію; здатність до управління організацією та ії̈ розвитком.

Згідно $з$ проєктом Професійного стандарту за професією «Керівник закладу загальної середньої освіти» (2020р.) в розділі Навчання та профресійний розвиток, первинна професійна підготовка має відбуватися на другому (магістерському) рівні вищої освіти. У Проєкті визначено групи трудових функцій, а саме: стратегічний розвиток закладу загальної середньої освіти; керівництво та моніторинг освітнього процесу; лідерство і партнерська 
взаємодія; організація здорового, безпечного, розвивального, інклюзивного освітнього середовища; безперервний просресійний розвиток керівника. Відповідно до визначених фрункцій подано перелік профресійних компетентностей за трудовою дією або групою трудових дій, що входять до них, зокрема це: компетентність стратегічного управління закладом загальної середньої освіти, компетентність стратегічного управління персоналом, компетентність забезпечення освітнього процесу, компетентність моніторингу діяльності закладу загальної середньої освіти, компетентність забезпечення внутрішньої системи якості освіти, лідерська компетентність, емоційно-етична компетентність, компетентність педагогічного і соціального партнерства, здоров'язбережувальна компетентність, інклюзивна компетентність, проєктувальна компетентність, інноваційна компетентність, здатність до навчання впродовж життя, рефлексивна компетентність [4].

Відповідно до статті 38 Закону України «Про повну загальну середню освіту» керівник закладу загальної середньої освіти зобов'язаний: планувати та організовувати діяльність закладу загальної середньої освіти; організовувати фрінансово-господарську діяльність закладу загальної середньої освіти в межах затвердженого кошторису; забезпечувати розроблення та виконання стратегії розвитку закладу загальної середньої освіти; організовувати освітній процес та видачу документів про освіту; створювати умови для реалізації прав та обов'язків усіх учасників освітнього процесу, в тому числі реалізації академічних свобод педагогічних працівників, індивідуальної освітньої траєкторії та/або індивідуальної програми розвитку учнів, фрормування у разі потреби індивідуального навчального плану; забезпечувати розроблення, затвердження, виконання та моніторинг виконання індивідуальної програми розвитку учня; контролювати виконання педагогічними працівниками та учнями (учнем) освітньої програми, індивідуальної програми розвитку, індивідуального навчального плану; забезпечувати здійснення контролю за досягненням учнями результатів навчання, визначених державними стандартами повної загальної середньої освіти, індивідуальною програмою розвитку, індивідуальним навчальним планом; створювати необхідні умови для здобуття освіти особами з особливими освітніми потребами; створювати умови для здійснення дієвого та відкритого громадського нагляду (контролю) за діяльністю закладу загальної середньої освіти; створювати умови для діяльності органів громадського самоврядування в закладі загальної середньої освіти; формувати засади, створювати умови, сприяти формуванню культури здорового способу життя учнів та працівників закладу загальної середньої освіти; створювати в закладі загальної середньої освіти безпечне освітнє середовище; організовувати харчування та сприяти медичному обслуговуванню учнів відповідно до законодавства; забезпечувати відкритість і прозорість діяльності закладу загальної середньої освіти та інші [1].

У Порядку проведення інституційного аудиту закладів загальної середньої освіти, затвердженого Наказом МОН від 09.01.2019 № 17, висвітлені основні управлінські процеси закладу освіти: наявність стратегії та системи планування діяльності закладу, моніторинг виконання поставлених цілей і завдань; фрормування відносин довіри, прозорості, дотримання етичних норм; ефективність кадрової політики та забезпечення можливостей для професійного розвитку педагогічних працівників; організація освітнього процесу на засадах людиноцентризму, прийняття управлінських рішень на основі конструктивної співпраці учасників освітнього процесу, взаємодії закладу освіти 3 місцевою громадою; фрормування та забезпечення реалізації політики академічної доброчесності [2].

В усіх розглянутих нормативних документах простежується взаємозв'язок управлінської діяльності та рівня сформованості професійних компетентностей, особистісних якостей керівника закладу - менеджера освіти. Зазначені управлінські фрункції здатен виконувати фрахівець зі сорормованими відповідними компетентностями та розвинутими професійно-значущими якостями.

Логіка започаткованого дослідження потребує розглянути поняття «профресійна компетентність» із різних підходів. Дослідники, що тлумачать професійну компетентність з погляду особистісного підходу, визначають їі як сукупність особистісних якостей, особистісну характеристику, властивість особистості, особистісне новоутворення, інтегровану якість особистості, готовність до здійснення професійної діяльності тощо. Представники акмеологічного підходу акцентують увагу на тому, що професійна компетентність передбачає володіння на досить високому рівні власне професійною діяльністю в певній галузі, здатність нести професійну відповідальність за результати своєї праці, уміння професійно спілкуватися й проєктувати свій подальший професійний розвиток [5].

Я. Єпутаев, один 3 авторів «Словника компетенцій», вважає, що необхідно розрізняти терміни «компетенція», «компетентність», «профресійно значущі якості». Дослідник вважає, що «компетенції» - це властивості (якості) особистості, необхідні для успішного виконання роботи, їх можна оцінити за допомогою ключових поведінкових індикаторів; під «компетентністю» розуміє здатність виконувати роботу відповідно до прийнятих стандартів, тобто не тільки володіти певним набором знань, умінь і навичок, а й здатність їх застосувати; «профресійно значущі якості» - це будь-які властивості людини, 
значущі для успішної діяльності в певній профресії, а також фрізичні якості, що відповідають вимогам до людини будь-якої певної професіії і сприяють успішному оволодінню цією профресією [6].

Словник сучасної англійської мови тлумачить: competens - «компетенція» - 1) здібність й уміння здійснювати необхідну діяльність; 2) володіння спеціальною сферою знань; 3) спеціальні вміння для виконання певних професійних обов'язків. Компетентність (від лат. competens - належний, відповідний) становить сукупність необхідних щодо ефрективної професійної діяльності (вишу, студента, викладача), систематичних функціональних знань і вмінь (науково-виробничих, суспільно-політичних, психолого-педагогічних, економічних, предметних і відповідних особистісних якостей) [7].

На думку Б. Ананьєва, вивчення людини як суб'єкта праці не може обмежитися характеристиками підготовленості, досвідченості, майстерності, продуктивності та якості виконуваної в цей момент роботи. Важливо визначити можливості подальшого розвитку трудової діяльності людини, внутрішні сили особистості, значущі для підвищення продуктивності праці в умовах вдосконалення самого виробництва. Причому під час визначення профресійно значущих якостей необхідно враховувати не тільки сукупність тих чи інших якостей, a і певну структуру, фрункціональний склад і різне поєднання, в якому можливий нерівномірний розвиток окремих компонентів та їх прояв в конкретній професійній діяльності [8].

Визначення поняття «професійно значущі якості» 3 різних підходів науковців узагальнено наведені у таблиці 1.
Проведений аналіз профресійно-значущих якостей дає підстави стверджувати, що це не лише властивості та характеристики особистості, але й один із чинників успішної професійної діяльності, що можуть розвиватися у процесі професійної підготовки.

Стан і перспективи розвитку сучасної освіти значною мірою залежать від якості профресійної підготовки менеджерів освіти, у зв'язку з чим суспільство висуває нові вимоги до менеджменту. Сучасний менеджер освіти - це професійний управлінець, компетентний в питаннях юриспруденції, економіки, педагогіки та психології. Це людина, яка власною репутацією впливає на імідж закладу освіти. На перші позиції виходять лідерські якості керівника сучасного закладу освіти, професійна мобільність, уміння аналізувати та вирішувати консрлікти, стресостійкість, володіння основами управління, прийняття рішень у складних і непередбачуваних умовах, відповідальність за стратегічний розвиток закладу освіти. Зазначимо, що запорукою ефеективної управлінської діяльності менеджера освіти стають партнерські відносини з колективом, узгодженість цілей та дій. Сьогодні заклади освіти прозоро та відкрито здійснюють профресійну діяльність, що потребує від менеджера освіти будувати публічний діалог із громадськістю. Залежність профеесійних компетентностей від сорормованості професійно-значущих особистісних якостей менеджера освіти очевидна, що доводить потребу їх формування у процесі професійної підготовки.

Висновки. На основі аналізу нормативної бази та наукових публікацій з проблем професійної підготовки менеджерів освіти, виділено основні професійні

\section{Підходи науковців до визначення поняття професійно значущі якості}

Таблиця 1

\begin{tabular}{|c|c|}
\hline А. Маркова & $\begin{array}{l}\text { е якості людини, що впливають на ефрективність здійснення її праці за основними характерис- } \\
\text { иками. Вони є передумовою професійної діяльності, будучи її новоутворенням [9]. }\end{array}$ \\
\hline О. Коржук & $\begin{array}{l}\text { це стійкі загальні та специфрічні риси, що забезпечують повноцінне виконання ним своїх про- } \\
\text { фесійних фуунцій та обов'язків. Це інтегроване комплексне утворення, яке фрормується шляхом } \\
\text { синтезу професійних і особистісних якостей. Воно виникає внаслідок професіоналізації особис- } \\
\text { тісних якостей і трансфрормації їх в особистісно цінні [10]. }\end{array}$ \\
\hline В. Шадріков & $\begin{array}{l}\text { це якості суб'єкта діяльності, які впливають на есрективність цієї діяльності й успішність її вико- } \\
\text { нання [11]. }\end{array}$ \\
\hline Р. Гейзерська & $\begin{array}{l}\text { це комплекс логічно й діалектично пов'язаних між собою взаємовпливових індивідуально-осо- } \\
\text { бистісних рис та здібностей, що зумовлюють одна одну, актуалізуються на рівні просресійних } \\
\text { завдань, на поведінковому рівні й у процесі соціалізації особистості та сприяють успішності про- } \\
\text { фресійної діяльності в науковій і викладацькій ссрері та на виробництві [12]. }\end{array}$ \\
\hline О. Шушеріна & $\begin{array}{l}\text { це ті якості, які пред'являються сучасним суспільством до фрахівців цієї професії, впливають на } \\
\text { успішність навчальної діяльності студента, дають йому можливість найбільш ефективно реалізу- } \\
\text { вати себе і розвиток яких забезпечує у подальшому високу якість його професійної діяльності [13]. }\end{array}$ \\
\hline В. Сластьонін & $\begin{array}{l}\text { сукупність найбільш суттєвих, відносно стійких властивостей та характеристик, що зумовлюють } \\
\text { готовність до виконання певних соціальних та професійних функцій [14]. }\end{array}$ \\
\hline $\begin{array}{l}\text { Ю. Поварен- } \\
\text { ков }\end{array}$ & $\begin{array}{l}\text { професійні інтереси, установки, риси характеру і низка інших. Визначають відношення людини } \\
\text { до профресійних фрункцій та до профресіоналізації загалом, ступінь їх прийняття [15]. }\end{array}$ \\
\hline $\begin{array}{l}\text { Б. Душков, } \\
\text { А. Корольов, } \\
\text { Б. Смирнов }\end{array}$ & $\begin{array}{l}\text { один із найважливіших чинників професійної придатності, вони не тільки побічно характеризують } \\
\text { певні здібності, але й органічно входять в їх структуру, розвиваючись у процесі навчання } \\
\text { і діяльності [16]. }\end{array}$ \\
\hline
\end{tabular}


фрункції, профресійні компетентності та просресійнозначущі якості менеджера освіти, що є передумовою розроблення спеціальних педагогічних умов фрормування професійно значущих якостей у процесі профресійної підготовки майбутніх менеджерів освіти.

\section{БІБЛІОГРАФІЧНИЙ СПИСОК:}

1. Про повну загальну середню освіту : Закон України від 16.01.2020 № 463-IX Дата оновлення: 01.08.2020. URL: https://zakon.rada.gov.ua/laws/ show/463-20/ed20200801\#Text

2. Наказ Про затвердження Порядку проведення інституційного аудиту закладів загальної середньої освіти : наказ Міністерства освіти і науки від 09.01.2019 p. № 17. URL: https://zakon.rada.gov.ua/ laws/show/z0250-19\#Text

3. Стандарту вищої освіти України за спеціальністю 073 «Менеджмент» [Чинний від 2019-07-10]

4. Профресійний стандарт за професією «Керівник закладу загальної середньої освіти» : Проєкт Міністерства освіти і науки. URL: https://mon.gov.ua/ua/news/ ministerstvo-osviti-i-nauki-ukrayini-proponuye-dogromadskogo-obgovorennya-proyekt-profesijnogostandartu-za-profesiyeyu-kerivnik-zakladu-zagalnoyi-serednoyi-osviti

5. Керекеша-Попова О.В. Формування управлінської компетентності майбутніх інженерів-педагогів у процесі професійно-педагогічної підготовки. Кваліфрікаційна наукова праця на правах рукопису : дис. ... канд. пед. наук 13.00.04 / Бердянський державний педагогічний університет, Бердянськ, 2020. 317 с.

6. Словарь компетенций. URL: https://hr-portal.ru/ page/slovar-kompetenciy

7. Кубенко І.М. Що таке компетентність і як її розуміють в освіті URL: http://tme.umo.edu.ua/docs/ Dod/1_2010/kubenko.pdf
8. Ананьев Б.Г. Избранные психологические труды : в 2 т. / Б.Г. Ананьев. М. : Педагогика, 1980. T. 1.230 с. T. $2 .-288$ c.

9. Маркова А.К. Психология профессионализма. М. : Знание, 1996. 312 с.

10. Коржук О. Емпатія як професійно значуща якість особистості вихователя дітей дошкільного віку. Вісник інституту розвитку дитини. Серія : Філософрія. Педагогіка. Психологія : Збірник наукових праць Нац. пед. ун-та ім. М. П. Драгоманова. Київ: Вид-во НПУ ім. М. П. Драгоманова. 2012. Вип. 23. С. 84-90.

11. Шадриков В.Д. Деятельность и способности. Москва : Логос. 1994. 210 с.

12. Гейзерська Р.А. Формування професійно-значущих якостей майбутніх магістрів економічного просрілю у процесі фрахової підготовки : автореф. дис. ... канд. пед. наук : 13.00.04. Луганськ, 2008. 20с.

13. Шушерина О.А. Ответственность профессионально значимое качество будущего специалиста (педагогическийаспект) : монография. Красноярск : СибГТУ. 2002. 186 с.

14. Сластенин В.А. Профессиональная готовность учителя в воспитательной работе : содержание, структура, фрункционирование : учеб. пособие для студ. высш. пед. учеб. Заведений. Москва. Изд-во Моск. пед. ин-та им. В.И. Ленина, 1982.

15. Поваренков Ю.П. Системогенетическая концепция профессионального становления человека. Идея системности в современной психологии / под ред. В.А. Барабанщикова. М. : Изд-во «Институт психологии РАН». 2005. С. 360-384.

16. Душков Б.А., Королев А.В., Смирнов Б.А. Психология труда, профессиональной, инорормационной и организационной деятельности : словарь. Москва. 2003. 848 с. 


\section{ПЕДАГОГІЧНІ УМОВИ ЗАБЕЗПЕЧЕННЯ ЯКІСНОЇ ПРОФЕСІЙНОӦ ПІДГОТОВКИ З ЕТНОДИЗАЙНУ КЕРАМІКИ \\ PEDAGOGICAL CONDITIONS OF PROVIDING QUALITY PROFESSIONAL TRAINING FROM ETHNODESIGN OF CERAMICS}

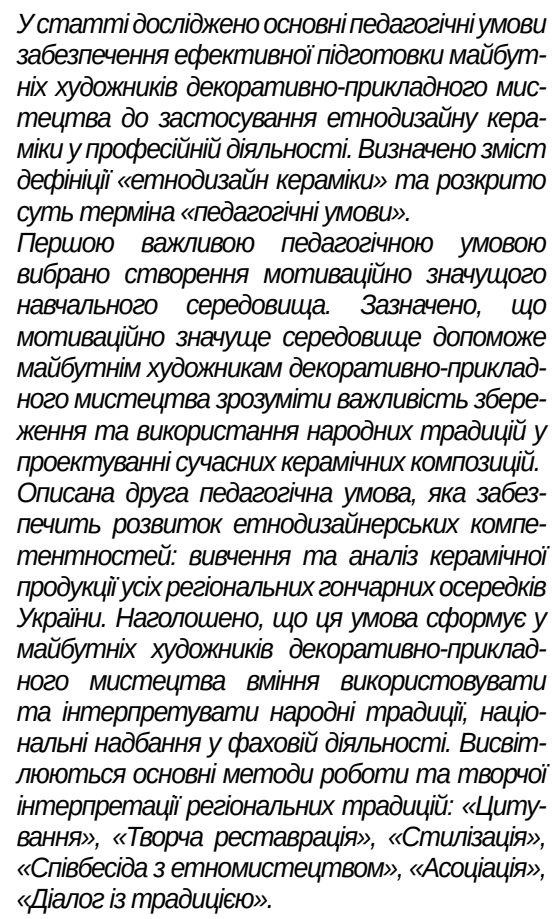
Охарактеризовано третю педагогічну умову: забезпечити вільне володіння сучасними технологіями, комп'ютерними програмами, новітніми матеріалами, інструментами. Не менш важливою та заключною педагогічною умовою просресійної підготовки художників-керамістів до застосування етнодизайну у професійній діяльності стає виділення сильних сторін майбутнього художника декоративно-прикладного мистецтва, створення основи для розвитку авторського бренду, фрормування власного стилю, підсилення підприємницьких навичок. у статmі наголошується на важливості розвитку творчих та інтелектуальних здібностей студента за допомогою вільного використання національних надбань, а також усіх можливостей сучасного світу. Ключові слова: педагогічні умови, етнодизайн кераміки, майбутні художники деко- ративно-прикладного мистецтва, етнічні регіони.

The article describes the main pedagogical conditions for ensuring effective professional training of future artists of decorative and applied arts to the application of ethnic design of ceramics. The meaning of the definition "ethnodesign of ceramics" is defined and the essence of the term "pedagogical conditions" is revealed.

The first important pedagogical condition is the creation of a motivational and meaningful learning environment. It is noted that the motivationalsignificant environment will help future artists of decorative and applied to understand the importance of preserving and using folk traditions, the achievements of pottery centers in the design of modern ceramic compositions. The second pedagogical condition that will ensure the development of ethnodesign competencies is the study and analysis of techniques of creation, methods of decorating ceramics of all regional pottery centers of Ukraine. This condition will form in future artists of decorative and applied arts the ability to use and interpret folk traditions, national heritage in professional activities. The main methods of creative interpretation of regional traditions in the design of ceramics are mentioned: "Citation", "Creative restoration", "Stylization", "Interview with ethno-art", "Association", "Dialogue with tradition".

The third pedagogical condition is characterized: free possession of modern technologies, computer programs, the latest materials, tools. Highlighting their strengths, creating a basis for brand development, the formation of the author's style becomes the final and no less important component of the professional training of artists - ceramists for the use of ethnic design in professional activities.

The article emphasizes the importance of developing creative and intellectual abilities of students through the free use of national heritage and all the possibilities of the modern world.

Key words: pedagogical conditions, ethnodesign of ceramics, future artists of decorative and applied art, ethnic regions.
Постановка проблеми у загальному вигляді. Профресійна підготовка майбутніх художників декоративно-прикладного мистецтва у закладах вищої мистецької освіти потребує новітніх ефективних шляхів, наукових підходів, педагогічних умов для форомування нової генерації художників-керамістів, здатних створити свій особистий бренд, застосовуючи етнодизайн. Тобто, не відриваючись від традиції, національного коду, створювати нові твори декоративно-прикладного мистецтва, зразки етнодизайну кераміки.

Отже, у процесі професійної підготовки майбутніх художників декоративно-прикладного мис- тецтва до застосування етнодизайну кераміки педагогічні умови є необхідними обставинами, які забезпечать ефективний розвиток етнодизайнерських компетентностей.

Аналіз останніх досліджень та публікацій. Етнодизайн як важлива складова частина профресійної підготовки майбутніх художників декоративно-прикладного мистецтва став головним предметом наукових досліджень Б. Тимкова, В. Тименка, М. Близнюка, Л. Оршанського. Також різні аспекти етнодизайну висвітлено у працях В. Бутенка, А. Бровченка, В. Жлудько, Л. Корницької, А. Крижанівського, Е. Муртазаєвої, А. Руденченко. 
Безперечно, результат професійної підготовки залежить від педагогічних умов. Термін «педагогічні умови» був предметом дослідження К. Дубич, Н. Житнік, Ю. Костюшко та інших. Дослідження найесективніших педагогічних умов організації навчального процесу висвітлено у працях В. Стасюк, Ю. Бабанського, С. Савельєвої, А. Литвина. Однак варто зауважити, що проблема дієвих педагогічних умов для формування у майбутніх художників-керамістів етнодизайнерських компетентностей ще не була досліджена. Вказана причина стала основною під час написання статті.

Метою статті $€$ форомування комплексу відповідних педагогічних умов, які підвищать результативність професійної підготовки майбутніх художників декоративно-прикладного мистецтва до застосування етнодизайну кераміки у професійній діяльності; пошук шляхів реалізації сфрормованого комплексу педагогічних умов.

Виклад основного матеріалу дослідження. Сьогодні глобалізаційні процеси, потреби ринку, стан суспільства вимагають докорінної перебудови освітнього процесу, а ідея модернізації та націоналізації сучасної мистецької освіти спричиняє науковий інтерес до професійної підготовки художників декоративно-прикладного мистецтва. Новаторська ідея розвитку сучасної української мистецької освіти полягає у поєднанні національних традицій з новітніми технологіями, теоретичних знань із практичною діяльністю. Тому, аналізуючи науково-педагогічну літературу та сучасні тренди, можна відзначити, що нині особливого значення набуває пошук найбільш дієвих педагогічних умов, необхідних для формування у майбутніх художників декоративно-прикладного мистецтва компетентностей з етнодизайну. На нашу думку, важливо виявити такі педагогічні умови професійної підготовки до застосування етнодизайну кераміки, за яких усі зазначені вище компоненти би взаємодіяли.

Насамперед роз'яснимо, що таке етнодизайн кераміки. Етнодизайн кераміки - це система організаційно-педагогічних заходів, зорієнтованих на особистісний розвиток художника декоративноприкладного мистецтва на національних традиціях та сучасних технологіях, метою і кінцевим результатом якого має стати готовність до виконання професійної діяльності [7]. Головна мета та завдання етнодизайну кераміки - це свідома інтерпретація художниками-керамістами національних традицій - потужного джерела натхнення, та пошук авторського стилю, опираючись на досвід поколінь, код нації.

Для реалізації ідей професійної підготовки художників декоративно-прикладного мистецтва до застосування етнодизайну кераміки необхідно створити певні педагогічні умови у закладах вищої мистецької освіти. Зазначимо, що педагогічні умови - це цілеспрямовано організоване викладачем педагогічне середовище, система педагогічних засобів, комплекс педагогічних взаємодій. К. Дубич визначає «педагогічні умови» як сукупність взаємозалежних і взаємозумовлених заходів педагогічного процесу, які забезпечують досягнення конкретної мети [1, с. 79]. На думку В. Стасюк, педагогічні умови професійної підготовки це обставини, від яких залежить та відбувається цілісний продуктивний педагогічний процес підготовки фрахівців, що опосередковується активністю особистості, групи людей [8]. Проаналізувавши знайдені нами визначення терміна «педагогічна умова» різних дослідників, ми розуміємо дефрініцію «педагогічні умови» у контексті нашої статті як сукупність обставин, засобів і заходів, підходів, психологічних компонентів, які сприяють якісній підготовці майбутніх художників декоративно-прикладного мистецтва до застосування етнодизайну кераміки у профресійній діяльності.

Дослідивши зміст етнодизайну кераміки, ми виокремили педагогічні умови, які, на нашу думку, створять найбільш позитивний вплив на студентів та забезпечать успішний розвиток етнодизайнерських компетентностей у майбутніх художниківкерамістів.

Ми виділили такі організаційно-педагогічні умови, як:

1) створення мотиваційно-ціннісного середовища для підвищення мотивації до етнодизайнерської діяльності майбутнього художника декоративно-прикладного мистецтва;

2) активізація та розвиток етнодизайнерських компетентностей за рахунок вивчення особливостей регіональних гончарних осередків України, співпраці 3 народними майстрами та освоєнням основних методів художньої інтерпретації національних надбань;

3) активізація навчально-пізнавальної діяльності майбутніх фрахівців із етнодизайну кераміки за рахунок використання новітніх технологій (IT), матеріалів та комп'ютерних програм;

4) розвиток власного бренду, який виділить студентів із потоку конкурентів; розвиток підприємницького складника - від самопрезентації до формування особистої стратегії розвитку художника-кераміста.

Розглянемо їх детальніше. Першою важливою педагогічною умовою $є$ створення мотиваційнозначущого навчального середовища. Мотиваційно-значуще середовище допоможе майбутнім художникам декоративно-прикладного мистецтва зрозуміти важливість збереження та використання народних традицій, національних надбань у сучасних творах мистецтва, відчути позитивне ставлення до народних ремесел та новітніх технологій, зміцнити задоволення особистими досягненнями, ссрормувати мету навчання та освоєння фраху. 
Як відомо, мотивація $є$ рушійною силою та важливим поштовхом до всіх починань. За словами І. Зимньої, мотивація - «механізм запуску» будь-якої діяльності (праці, спілкування, пізнання). Якщо немає успіху, то мотивація згасає, що негативно впливає на виконання певної діяльності. І. Зимня вважає, що, окрім мети, мотивів, потреб, інтереси, бажання і наміри також спонукають та активують людську діяльність [2, с. 32].

Ми вважаємо, що для підсилення мотивації у майбутніх художників-керамістів під час профресійної підготовки до застосування етнодизайну кераміки варто застосовувати «Метод моделювання cumуацій профресійної спрямованості». Такий метод пропонує використання завдань, які дають студентам можливість активізувати творчі, підприємницькі, етнодизайнерські вміння для досягнення поставленої мети та виконання потрібного завдання, а саме розроблення конкретного замовлення від дизайнера інтер'єрного чи екстер'єрного середовищ. Окреслений метод доцільно використовувати під час роботи з проектами, підключаючи до професійної підготовки майбутніх художниківкерамістів реальних замовників. Наприклад, студенти отримують завдання виготовити у власному стилі керамічні предмети (тарелі, вази, лампи, чаші тощо), декоративні композиції з етнічними елементами для певного сучасного інтер'єру. Застосування цього методу підвищує професійний інтерес студентів, активізує наявні знання, закріплює навички аналізу й узагальнення, розвиває творчі здібності та підприємницьку, соціальну сторону особистості. За допомогою цього методу готується фрахівець, який готовий до реальних умов та обов'язково буде затребуваним спеціалістом після закінчення навчання.

Вивчення техніки створення та декорування глиняних виробів регіональних гончарних осередків України, на нашу думку, також $є$ важливою педагогічною умовою, яка забезпечить розвиток етнодизайнерських компетентностей та сформує у майбутніх художників декоративно-прикладного мистецтва вміння використовувати та інтерпретувати народні традиції, національні надбання у фаховій діяльності.

До найважливіших етнографрічних гончарних регіонів України ми віднесли: Наддніпрянщину, Слобожанщину, Полтавщину, Поділля, Полісся, Буковину, Волинь, Прикарпаття, Закарпаття, Сокальщину, Гуцульщину та Покуття. Але знання представленої керамічної продукції регіонів $€$ критично недостатнім для виведення мистецтва кераміки на новий рівень. Тому сучасні художникикерамісти повинні навчитися не просто копіювати народну кераміку, а й вміло використовувати методи опрацювання фрольклорного матеріалу. Погоджуючись з О. Петровою, ми виділили найефективніші методи роботи з народними орна- ментами, фрормою, композицією, кольором: «Сmuлізація», «Співбесіда з етномистецтвом» та «Діалог з традицією» [3]. Також проведений нами аналіз дослідницьких матеріалів дає можливість виділити основні методи проектування керамічних виробів на основі традицій: «Цитування», «Копіювання», «Інтерпретація», «Стилізація» й «Асоціація». Розглянемо їх детальніше.

методи «/нтерпретація» та «Стилізація» покликані розвивати тонке світосприйняття та креативність, адже змушують побачені способи декорування (ритування, димлення, молочіння, фрляндрівка та інші), стилістичні особливості, орнаменти перефразувати, подати у новому амплуа. За переконаннями В. Радкевич, від майбутнього фахівця необхідно вимагати не тільки високої технічної майстерності, а й свідомого творчого ставлення до своєї художньої діяльності та її результатів, глибокого проникнення в художню культуру народного промислу, в якому він працює, знання тенденцій розвитку сучасного декоративно-вжиткового мистецтва українського народу [5 с. 420]. Тому найбільш широкі можливості надає метод «Асоціація».

«Асоціація» - це творчий метод, який дає змогу, переосмисливши всю отриману інсрормацію, створювати сучасні твори художньої кераміки, наділені емоцією, енергетикою, відчуттям першоджерела.

Нам імпонує вислів М. Некрасова: «Чим глибше засвоює художник місцеві традиції, тим яскравіше виявляється його творча індивідуальність» [4, с. 20]. Все вищесказане підтверджує нашу думку, що єднання професійного мистецтва з регіональними етнічними традиціями є найперспективнішим способом розвитку мистецтва художньої кераміки.

Третя педагогічна умова передбачає орієнтацію професійної підготовки майбутніх художників декоративно-прикладного мистецтва на IT (інорормаційні технології). Відзначимо, що поєднання ідей інтеграції традиційного з сучасним дає можливість розглянути питання підготовки майбутніх художників до застосування етнодизайну кераміки на якісно новому рівні.

На нашу думку, сучасні художники-керамісти для створення авторських керамічних композицій можуть користуватися графрічними, живописними та скульптурними Digital-програмами. Для створення графрічних та кольорових ескізів майбутні художники декоративно-прикладного мистецтва сміливо можуть використовувати Adobe Illustrator, Adobe Photoshop, Adobe Fresco та інші. Підбір колірної гамми буде значно простішим 3 такими ресурсами, як Adobe Kuler, Colrd, Colorcheme та ін. Після розроблення ескізу, підбору колірної гами можна переходити до 3D-скульптингу. Найпопулярнішими програмами для 3-скульпингу $є$ Blender, Zbrus, Мауа та інші. 
Впровадження інформаційних та цифрових технологій значно оптимізує освітній процес майбутніх художників декоративно-прикладного мистецтва. Серед найесективніших напрямів організації освітньої діяльності з етнодизайну кераміки $€$ використання ЗД-моделювання творчих проектів 3 їх подальшою презентацією в інтер'єрному чи екстер'єрному середовищі. Уведення IT-технологій у професійне навчання має для сучасного художника-кераміста багато переваг, таких як творча візуалізація (розвиток конструктивного мислення), оперативність (швидка зміна ідеї, розвиток композиційного мислення), мобільність та потужна мотивація (відчуття потрібності та розуміння в сучасних виробництвах) [6, с. 40].

Завершальною педагогічною умовою нашого комплексу ефективної професійної підготовки майбутніх художників декоративно-прикладного мистецтва до застосування етнодизайну кераміки $€$ впровадження блоку з розвитку підприємницької діяльності, створюючи національний сувенірний автентичний продукт, самопрезентацію та створення авторського бренду. Навчання підприємницькій діяльності повинно обов'язково включати моделювання особистої craft-стратегії. Наприкінці навчання сучасний художник-кераміст має володіти художніми, технологічними, етнодизайнерськими знаннями та вміннями, вміло оперувати отриманою основою для розвитку власного бренду та підкорення нових вершин в профресії.

Варто зазначити, що сутність згаданих педагогічних умов полягає у зміні негативного або байдужого ставлення майбутнього художника декоративно-прикладного мистецтва до народних мотивів, національних надбань, сучасних технологій та нововведень на усвідомлене, успішне навчання.

Висновки. На основі аналізу й узагальнення науково-педагогічної літератури у статті нами охарактеризовано комплекс найефективніших педагогічних умов щодо формування компетентностей 3 етнодизайну кераміки у майбутніх художників декоративно-прикладного мистецтва, серед яких: створення мотиваційно-ціннісного середовища; вивчення особливостей регіональних гончарних осередків України, освоєння основних методів художньої інтерпретації національних надбань; використання новітніх технологій (IT), матеріалів та комп'ютерних програм; розвиток підприємницької складової. Отже, на шляху становлення етнодизайну кераміки як важливої складової частини сучасного навчання майбутніх художників декоративно-прикладного мистецтва $€$ помітні педагогічні здобутки, але й залишається чимало питань, які потрібно ще вирішувати та досліджувати. У перспективі плануємо включити комплекс педагогічних умов у повноцінну модель підготовки майбутніх художників декоративно-прикладного мистецтва до застосування етнодизайну кераміки у професійній діяльності.

\section{БІБЛІОГРАФІЧНИЙ СПИСОК:}

1. Дубич К. . Особистісно орієнтоване виховання студентів в умовах соціокультурного середовища вищого навчального закладу : дис. ... канд. пед. наук : 13.00 .07 / Рівне. 2007. 267 с.

2. Зимняя И.А. Социальная работа как профессиональная деятельность. Социальная работа. 1992. Вып. 2. С. 32-37.

3. Петрова О.Н. Заметки о категориях «прекрасного» и «безобразного» в художественной практике Украины. Санкт Петербургское философрское общество. 2001. № 4. С. 401-423.

4. Некрасова М.А. К вопросу о понятии «народный мастер». О природе его творчества. Народные мастера. Традиции, школы. 1985. Вып. 1. С. 20.

5. Радкевич В.О. Теоретичні і методичні засади профресійного навчання у закладах профтехосвіти художнього профрілю : монографрія. Київ : УкрIHTEI, 2010. 420 c.

6. Роїк Ю.В. Використання інсрормаційних технологій у етнодизайну кераміки. Інфоормаційні технології в соціокультурній сорері, освіті та економіці : 3б. матеріалів учасн. IV Міжнар. наук.-практ. конфр. студ. і молод. учен. Київ : Видавничий центр КНУКіМ, 2020. 216 c

7. Роїк Ю.В. Етнодизайн кераміки: сутність поняття. Сучасний рух науки : тези доп. III між нар. наук.-практ. інтер.-конф., 1-2 жовтня 2018 р. Дніпро, 2018. C. 545-550.

8. Семенова А. Словник-довідник з просресійної педагогіки. Одеса: Пальміра, 2006. 272 с. 
ДИСТАНЦІЙНЕ НАВЧАННЯ В МЕДИЧНОМУ ВУЗІ - РЕАЛІЇ СЬОГОДЕННЯ

\section{DISTANCE LEARNING IN MEDICAL HIGHER EDUCATION INSTITUTIONS - REALITIES OF TODAY}

УДК 378.147.157

DOI https://doi.org/10.32843/2663-

$6085 / 2021 / 31-1.32$

\section{Саган H.T.,}

канд. мед. наук,

асистент кафедри патофрізіології

Івано-Франківського національного

медичного університету

\section{Заяць Л.М.,}

\section{докт. мед. наук,}

завідувач кафедри патофрізіології

Івано-Франківського національного

медичного університету

\section{Жураківська О.Я.,}

докт. мед. наук,

профресор кафедри анатомії

Івано-Франківського національного

медичного університету

Антимис О.В.,

канд. мед. наук,

доцент кафедри анатомії

Івано-Франківського національного

медичного університету

\section{Дутчак У.М.,}

канд. мед. наук,

доцент кафедри анатомії

Івано-Франківського національного

медичного університету

Міськів В.А.,

канд. мед. наук,

доцент кафедри анатомії

Івано-Франківського національного

медичного університету
Сьогодні цілий світ став заручником пандемії COVID-19, яка вже забрала більше мільйона життів і заразила понад 30 мільйонів людей у 190 країнах. Вищі навчальні заклади зіткнулись із таким викликом, як організація дистанційного навчання в умовах карантинних заходів. Дистанційне навчання в сучасному розумінні - че інтегровані очне, вечірнє $і$ заочне навчання з використанням новітніх комп'ютерних технологій на основі використання всесвітніх і локальних комп'ютерних мереж (Internet). Основою дистанційного навчання (Distance Learning, Distance Education) є самостійна робота. Студент працює з викладачем дистанційно, відповідно до програми, за допомогою засобів телекомунікації. Самостійна робота - це форма організації навчального прочесу, коли студент індивідуально вивчає навчальний матеріал. Мета самостійноі роботи - допомагати студентові формувати особистісну самостійність як професійну якість, з умінням планувати, систематизувати, а також регулювати своє навчання без контролю викладача. Позитивними рисами дистанційного навчання у медичному виші є: можливість працювати зі значно більшою аудиторією; можливість ширше використовувати інтерактивні методи навчання; можливість займатися у зручній для себе обстановці; рівні можливості отримання освіти незалежно від стану здоров'я та матеріальної забезпеченості студента; стимулювання студентамедика до самоорганізації, самодисципліни, самостійного оволодіння матеріалом та самостійного прийняття відповідальних рішень, збільшуючи при цьому його інтелектуальний потенціал; стимулювання студента-медика вдосконалювати володінням комп'ютерною технікою; оновлення ролі викладача, який повинен підвищувати педагогічну активність і кваліфрікацію відповідно до інновацій та нововведень. Незважаючи на деякі негативні моменти, впровадження в медичному виші дистанційних технологій навчання себе виправдало $i$, можливо буде розвиватися як одна із форм освітнього прочесу в поєднанні з очним навчанням (змішаний навчальний процес). Ключові слова: дистанційне навчання, медичний ВНЗ, інноваційні технології.

Today, the whole world has become hostage to the Covid-19 pandemic, which has already claimed more than a million lives and infected more than 30 million people in 190 countries. Higher education institutions have faced the challenge of organizing distance learning in quarantine. Distance learning in the modern sense is an integrated full-time, part-time and distance learning using the latest computer technology based on the use of global and local computer networks (Internet). The basis of distance learning (Distance Learning, Distance Education) is independent work. The student works with the teacher remotely, according to the program by means of telecommunications. Independent work is a form of organization of the educational process in which the student individually studies the educational material. The purpose of independent work is to help the student to form personal independence as a professional quality, with the ability to plan, systematize and regulate their learning without the control of the teacher. The positive features of distance learning in medicalschool are: the ability to work with a much larger audience; opportunity to use interactive teaching methods more widely; opportunity to practice in a comfortable environment; equal opportunities for education - regardless of the state of health and financial security of the student; stimulating the medical student to self-organization, self-discipline, independent mastery of the material and independent decisionmaking, while increasing his intellectual potential; encouraging medical students to improve their computer skills; updating the role of the teacher, who should increase pedagogical activity and qualification in accordance with innovations and innovations. Despite some negative aspects, the introduction of distance learning technologies in medical schools has paid off and may develop as a form of educational process in combination with full-time education (mixed learning process).

Key words: distance learning, medical university, innovative technologies.
Постановка проблеми в загальному вигляді. Сьогодні цілий світ став заручником пандемії COVID-19. Минуло менше року після того, як ми вперше почули про пандемію, однак вона вже забрала більше мільйона життів і заразила більше 30 мільйонів людей у 190 країнах. Генеральний директор організації ЮНЕСКО заявила, що через цю пандемію, яка вимагає карантинних заходів, 1,5 мільярда молодих людей у 165 країнах світу не можуть відвідувати заняття [1, с. 131]. Тому виник запит на організацію дистанційного навчання.

Аналіз останніх досліджень і публікацій. В Україні цей вид навчання відомий як «заочний», на Заході - як «кореспондентський» (The Distance Education and Training Council - існує з 1926 року).
Деякі вчені вважають, що ідея навчання на відстані була ще в XVII столітті, коли Святий Павло відправляв усні посилання християнам [2, с. 119].

Розвиток технологій дистанційного навчання тісно пов'язаний з так званими «інфрормаційними революціями», тобто змінами інструментальної основи, способів передачі та збереження інформації. Вважається, що було 5 «інфрормаційних революцій» [3, с. 37]. Першою «інфрормаційною революцією» вважають розвиток мови як джерела спілкування. Другою - письменність та книгодрукування. Третя зробила інфрормацію публічною. Четверта «інфрормаційна революція» пов'язана із застосуванням електронної апаратури, що дало можливість швидкого поширення інфрормації. 
П'ятий етап характеризується створенням швидкісних комп'ютерів, наповненням автоматизованих баз даних, створенням і швидким розвитком комунікативних сіток.

Виділення не вирішених раніше частин загальної проблеми. Нині дистанційне навчання у медичних вишах тільки набирає свого розвитку і потребує нововведень і корекцій. Багато питань ще залишається поза увагою педагогів.

Формулювання цілей статті (постановка завдання). Мета нашого дослідження - проаналізувати методи дистанційного навчання та обґрунтувати доцільність його впровадження у педагогічний процес медичних вишів.

Виклад основного матеріалу дослідження. Дистанційне навчання в сучасному розумінні це інтегровані очне, вечірнє і заочне навчання 3 використанням новітніх комп'ютерних технологій на основі використання всесвітніх і локальних комп'ютерних мереж (Internet). Дистанційний спосіб навчання став доволі неочікуваним та випробовувальним для всіх учасників освітнього процесу. Однак у вищій школі за останні роки, відповідно до втілення в життя Болонської системи, почали широко використовуватись інтерактивні технології, які і стали рятівним колом під час упровадження дистанційного навчання [4, с. 117]. На кафредрі анатомії людини Івано-Франківського національного медичного університету (ІФНМУ) комп'ютерні технології за останній час широко впроваджені у навчальний процес. Навчальна програма передбачає перевірку знань за допомогою тестових завдань на кожному практичному занятті. Для цього на нашій кафедрі розроблені комп'ютерні контролюючі програми, які охоплюють матеріал із кожної теми, розділу, всього курсу дисципліни, що дає змогу об'єктивно оцінювати студента під час вивчення всього курсу. Звичайно, на кожному практичному занятті виділено час для тестування на початку (10 хв.) і в кінці (10 хв.) заняття. На початку заняття ми визначаємо початковий (вхідний) рівень знань студентів, тобто з якими знаннями вони прийшли на практичне заняття. Для цього ми використовуємо графрічні тести - це переважно тести з тестовими завданнями закритої форми на вибір однієї правильної відповіді. За їх допомогою перевіряють розуміння студентами суті основних положень практичного заняття. За результатами виконаного тесту відбувається умовний перерозподіл студентів на такі дві групи, як: студенти, які готові до сприйняття матеріалу, і студенти, які потребують додаткових індивідуальних консультацій викладача. Після закінчення цього тестування зазвичай проводиться «робота над помилками», впродовж якої студенти мають змогу проконсультуватися 3 викладачем стосовно допущених огріхів. Тести вхідного рівня знань $є$ своєрідним «сигналом» про початок заняття, дають можливість студентам налаштуватися на подальше сприйняття інорормації, а викладачу - зрозуміти слабкі сторони студентів для можливості в подальшому приділяти їм більше уваги, що дасть змогу значно покращити рівень знань академічної групи. Згідно з результатами тестування, повинна відбуватися корекція навчального процесу, але при цьому потрібно враховувати також можливості студента як у розумовому, так і у психологічному плані. У кінці кожного аудиторного заняття використовуються тести для визначення кінцевого рівня знань студентів, що складаються із ситуаційних завдань за темою заняття, взятих із бази тестів «Крок 1». Тести цього виду контролю передбачають перевірку, оцінку вміння обґрунтувати, проводити аналіз, шукати вирішення нестандартних завдань. У кінці кожного змістовного модуля навчальною програмою визначено складання підсумкового модульного контролю, основною частиною якого $€$ тестування. Для підсумкового тестування знову ж таки використовується база тестів «Крок 1» для студентів за темою цього змістовного модуля.

Основою дистанційного навчання (Distance Learning, Distance Education) $є$ самостійна робота [5, с. 31]. Студент працює 3 викладачем дистанційно, відповідно до програми за допомогою засобів телекомунікації. Самостійна робота - це фрорма організації навчального процесу, за якої студент індивідуально вивчає навчальний матеріал. Мета самостійної роботи - допомагати студентові формувати особистісну самостійність як профресійну якість з умінням планувати, систематизувати, а також регулювати своє навчання без контролю викладача. Слово «студент» (studens той, хто вчиться) означає необхідність наполегливої напруженої мозкової діяльності для оволодіння глибокими знаннями. Німецький педагог А. Дістервег визначив суть навчального процесу: «Розвиток і освіта ні одній людині не можуть бути дані або повідомлені. Усяк, хто бажає до них прилучитися, повинен досягнути цього власною діяльністю, власними силами, власним напруженням».

В Івано-Франківському національному медичному університеті самостійній роботі студентів відводиться пріорітетне місце. Самостійна робота студентів складається 3 кількох етапів: позааудиторна, аудиторна та творча робота. Студенти самостійно готуються до практичного заняття. На практичному занятті викладач ставить завдання студентам, які ті повинні самостійно вирішити. Для цього вони активно спілкуються між собою та отримують консультації викладача. Творча робота - це індивідуальна робота студентів, яка оцінюється під час вивчення кожного змістовного модуля, участі у конференціях та олімпіадах. Творча робота спрямована на розвиток у студента самостійності та ініціативи. 
У медичному виші дистанційне навчання є дещо невиправданим, оскільки основою медичної освіти $€$ професійне спрямування, що є важливим, враховуючи те, що від самосвідомості і компетентності студента-медика в подальшому буде залежати здоров'я, а можливо, і життя людини. Тому під час практичних занять широко використовують різноманітні муляжі, тренажери, віртуальні симулятори та інші технічні засоби навчання. Особливо важливим $є$ живе спілкування 3 профрільними хворими. Між лікарем і хворим мають встановитися міжособистісні стосунки, адже взаємодія між ними - це не простий обмін інформацією, а частина лікувального процесу. Якщо перефразувати висловлювання нашого відомого співвітчизника В.М. Бехтерєва, якщо хворий після зустрічі 3 лікарем не відчув полегшення, то був не лікар. Адже процес лікування передбачає поєднання як соматичних, так і психологічних впливів на хворого. Розмова 3 пацієнтом, уміння проникати у психологію пацієнта, навички відокремлювати головне від другорядного, диференціювати основні симптоми захворювання, виставляти діагноз та призначати еорективне лікування - це мистецтво, яке здобувається під час навчання у вищому медичному закладі. Для цього необхідною умовою є спілкування 3 досвідченими викладачами, які мотивують, спрямовують і координують навчальний процес та допомагають у спілкуванні з хворими. Спілкування з хворими є дещо утрудненим під час дистанційного навчання. Однак ми повинні вміти протистояти викликам часу. Пандемія коронавірусної інфрекції поставила перед нами завдання: зберегти систему медичної освіти, тим більше що невідомо, як у подальшому буде змінюватись епідеміологічна ситуація в Україні.

В Івано-Франківському національному медичному університеті для дистанційного навчання використовуються хмарні технології - інтернетплатформа Teams. До речі, широко використовуються і мобільні версії цих програм. У «хмарі» розміщені методичні матеріали кафедр, навчальні посібники, атласи, книги вітчизняних та зарубіжних авторів, презентації лекцій, тестові завдання, створені електронні журнали. Викладачі змушені були в короткий термін навчитися працювати 3 дистанційними платорормами. Позитивним моментом дистанційного навчання було те, що викладачі старшого покоління навчилися користуватися комп'ютером та інтернетом. Під час дистанційного навчання викладачі на кафедрі анатомії ІФНМУ розглядають тему заняття за допомогою презентацій та атласу зі схемами. Крім того, студенти проходять звичне тестування (визначення початкового і кінцевого рівня знань). Для складання підсумкового модульного контролю також використовувалися спеціальні презентації для теоретичної частини, презентації для практичних навичок (із препарованими частинами людського тіла) та ситуаційні завдання до цього розділу, вибрані 3 буклету ліцензійного іспиту «Крок 1».

За нашими спостереженнями, ще одним позитивним моментом дистанційного навчання є:

- можливість працювати зі значно більшою аудиторією;

- можливість ширше використовувати інтерактивні методи навчання;

- можливість займатися у зручній для себе обстановці;

- рівні можливості отримання освіти - незалежно від стану здоров'я та матеріальної забезпеченості студента;

- стимулювання студента-медика до самоорганізації, самодисципліни, самостійного оволодіння матеріалом та самостійного прийняття відповідальних рішень, збільшуючи при цьому його інтелектуальний потенціал;

- стимулювання студента-медика вдосконалювати володіння комп'ютерною технікою;

- оновлення ролі викладача, який повинен підвищувати педагогічну активність і кваліфікацію відповідно до інновацій та нововведень.

Однак ми на кафедрі анатомії людини зіткнулися 3 деякими труднощами, які полягають у тому, що до нас на навчання приходять першокурсники. Студенти, в минулому учні, відрізняються один від одного базовими знаннями, здібностями, характером, різною реакцією на зміну середовища. Крім того, навчання в університеті має свої особливості, такі як більший рівень вимог до знань, самостійна підготовка та самостійна робота. Тому майже всім першокурсникам потрібний перехідний період. А викладачам необхідно враховувати нюанси перехідного періоду та якомога більше допомагати в адаптації у виші.

Іншою негативною рисою дистанційного навчання ми вважаємо відсутність живого спілкування між викладачем і студентом. Це також не сприяє соціалізації студентів, оскільки вони не мають змоги спілкуватися один з одним.

Також дистанційне навчання називають «дорослим», тобто 3 високим рівнем освітньої самомотивації. Студенти повинні проявити себе досить свідомими, цілеспрямованими та наполегливими. І основною проблемою в Україні $€$ недоступність інтернету, особливо у невеликих містечках, а також шкідлива дія монітору.

Висновки. Незважаючи на незначні негативні моменти, ми думаємо, що дистанційне навчання у медичних вишах себе виправдало і, можливо, буде розвиватись як одна із фрорм освітнього процесу в поєднанні 3 очним навчанням (змішаний навчальний процес).

Століття назад американський педагог і фрілоcoф Джон Дьюї написав: «Якщо ми вчимо сьогоднішніх студентів так, як ми вчили вчорашніх, ми позбавляємо їх завтрашнього дня». Це і досі залишається актуальним. 
БІБЛІОГРАФІЧНИЙ СПИСОК:

1. Berezhna S., Prokopenko I. Higher Education Institutions in Ukraine during the Coronavirus, or COVID-19, Outbreak: New Challenges vs New Opportunities // Revista Romaneasca pentru Educatie Multidimensionala. 2020. Vol. 12, Is. 1 Sup. 2. P. 130-135.

2. Пьянников М.М. К вопросу об истории развития дистанционного обучения. Ученые записки Забайкальского государственного университета. Серия: Педагогические науки. 2011. С. 119-124.
3. Лукиных Т.Н., Можаева Г.В. Информационные революции и их роль в развитии общества. Гуманитарная инфрорматика. 2005. № 2. С.34-39.

4. Москаль Ю. Світові тенденції розвитку заочної та дистанційної вищої освіти. Психологія і суспільство. 2008. № 3. С. 116-122.

5. Васюк О. Теоретико-методичні аспекти організації дистанційної освіти. Вісник Книжкової палати України. 2011. № 2. С. 30-32. 
ФОРМУВАННЯ ІНФОРМАЦІЙНО-КОМУНІКАТИВНОЇ

КОМПЕТЕНТНОСТІ СТУДЕНТІВ ТЕХНІЧНИХ СПЕЦІАЛЬНОСТЕЙ

НА ЗАНЯТТЯХ 3 АНГЛІЙСЬКОї МОВИ

\section{FORMATION OF INFORMATION AND COMMUNICATIVE COMPETENCE OF STUDENTS OF TECHNICAL SPECIALTIES IN THE ENGLISH LANGUAGE CLASSES}

УДК 378:661.041

DOI https://doi.org/10.32843/2663-

6085/2021/31-1.33

\section{Саєнко Н.С.,}

канд. пед. наук, професор, декан фракультету лінгвістики Національного технічного університету України «Київський політехнічний інститут імені Ігоря Сікорського»

\section{Галацин К.О.,}

канд. пед. наук,

доцент кафедри англійської мови технічного спрямування

Національного технічного університету України «Київський політехнічний інститут імені Ігоря Сікорського»
Актуальність проблеми фрормування інфрормаційно-комунікативної компетентності зумовлена тим, що сучасне інфрормаційне суспільство потребує підготовки фрахівця, здатного до організації різнобічних ділових контактів із використанням різних інсрормачійних технологій. Тому стаття присвячена аналізу теорії та практики фрормування інфоормаційно-комунікативної компетентності майбутніх інженерів машинобудівної сорери у прочесі вивчення англійської мови. мета статті полягає в обірунтуванні теорії та практики формування інфоораційнокомунікативної компетентності майбутніх інженерів на заняттях з англійської мови у закладах вищої технічної освіти. Реалізація мети потребує вирішення таких завдань: 1) визначити сутність інсрормаційної, комунікативної та інфрормаційно-комунікативної компетентності майбутніх інженерів; 2) проаналізувати теорію й практику фоормування інсоормаційно-комунікативної компетентності майбутніх інженерів на заняттях з англійської мови.

У процесі виконання завдань використано методи аналізу, синтезу, узагальнення, систематизації, вивчення нормативних документів.

Інсрормаційно-комунікативну компетентність майбутнього інженера будемо розуміти як інтегральну характеристику особистості, яка полягає у сформованій здатності налагоджувати та здійснювати професійну комунікативну взаємодію з використанням вербальних та невербальних засобів комунікації, інсрормаційно-комунікаційних технологій задля вирішення профресійних завдань у технічній сфрері та задля особистісного і профресійного вдосконалення.

Розглянуто та проаналізовано досвід власної практичної діяльності на заняттях англійської мови з використанням завдань, спрямованих на формування в майбутніх інженерів машинобудівної галузі інформаційно-комунікативної компетентності.

Ключові слова: компетентність, інформаційна компетентність, комунікативні компетентність, майбутні інженери, заняття з англійської мови в закладах вищої технічної освіти, формування компетентностей.

The relevance of the problem of formation information and communicative competence is due to the fact that modern information society requires the training of a specialist capable of organizing versatile business contacts using various information technologies. Therefore, the article is devoted to the analysis of the theory and practice of formation the information and communicative competence of future mechanical engineers in the process of studying English.

The purpose of the article is to substantiate the theory and practice of formation the information and communication competence of future engineers in English language classes at higher technical education institutions. The realization of the goal requires solving the following problems: 1) to determine the essence of the information, communicative and information and communicative competence of future engineers 2) analyse the theory and practice of formation information and communicative competence of future engineers in English language classes. In the process of performing tasks, methods of analysis, synthesis, generalization, systematization, study of normative documents were used.

The information and communication competence of the future engineer will be understood as an integral characteristic of the personality, which consists in the established ability to perform and carry out professional communication using verbal and non-verbal means of communication, information and communication technologies to solve professional tasks in the technical field and for personal and professional improvement.

We considered and analysed the experience of our own practical activities in English language classes on the use of tasks aimed at creating information and communicative competence among future engineers of the mechanical engineering industry.

Key words: competence, information competence, communicative competence, future engineers, English language classes at higher technical educational institution, formation of competencies.
Постановка проблеми у загальному вигляді. Інтеграція української держави до світового співтовариства, орієнтація на загальноєвропейські гуманістичні традиції, підтримка й захист національних цінностей, долучення до полікультурних освітніх, економічних, мовних програм та проєктів вимагають підготовки фрахівців, здатних до ефрективної взаємодії як на рівні міжособистісного спілкування, так і в межах міждержавного співробітництва. У низці законодавчих документів («Національна стратегія розвитку освіти в Україні на 2012-2021 рр., Закони України «Про освіту» (2017), «Про вищу освіту» (2014 р.) тощо) виокремлено нові завдання та критерії фрахової підготовки фрахівців, серед яких пріоритетним $є$ формування у студентів фахових компетентностей, пріоритетною серед яких $є$ саме інформаційно-комунікативна.

У комунікативному процесі як процесі обміну думками визначаються статуси речей і суб'єктів комунікації. Відповідно, постають вимоги до володіння комунікативною компетентністю студентами 
закладів вищої технічної освіти як вагомої передумови їхньої професійної компетентності. Поряд із цим сучасне інформаційне суспільство вимагає від фрахівця XXI сторіччя ґрунтовного володіння іноземною мовою та досконалого оперування інформаційними технологіями. 3 огляду на це, важливим завданням вищої профресійної технічної освіти $€$ пошук ефективних засобів фрормування інформаційно-комунікативної компетентності майбутніх інженерів із метою забезпечення виконання ними професійних обов'язків та своєчасного вирішення різних професійних завдань.

Аналіз останніх досліджень і публікацій. Розвиткові компетентностей присвячено праці Н. Бібік, С. Бондар, І. Єрмакова, І. Зимньої, О. Овчарук, О. Пометун, Дж. Равена, С. Тищенко й інших. Низка досліджень присвячена проблемі фрормування комунікативної компетентності (М. Васильєва, Н. Волкова, І. Комарова, С. Ольховецький, Л. Паламар, Л. Петровська, В. Полторацька, В. Тернопільська та інші). Використанню інфрормаційних технологій в освітньому процесі закладів вищої технічної освіти присвячено наукові доробки О. Алексєєва, В. Бикова, М. Коротуна, С. Семерікова, Д. Требухова та інших. Роль інфрормаційних технологій на заняттях з англійської мови аналізують О. Дакалюк, Л. Ломакіна, Г. Сорокіна, Н. Тимощук та інші.

Інфрормаційно-комунікативну компетентність вивчають учені І. Водько, Т. Гурова, Л. Дзюба-Шпурик, А. Приходько, Г. Федорук та інші у таких аспектах, як: фоормування інформаційно-комунікативної компетентності вчителів фрізичного виховання та спорту (І. Водько), умови фрормування інфрормаційно-комунікативної компетентності викладачів сучасних технологій (Г. Федорук).

Виділення не вирішених раніше частин загальної проблеми. Варто відзначити, що ці інтенсивні різнопланові дослідження значною мірою не вирішують проблему формування інформаційно-комунікативної компетентності студентів закладів вищої технічної освіти, поза увагою науковців залишаються питання її формування на заняттях 3 англійської мови.

Мета статті полягає в обґрунтуванні теорії та практики фрормування інфрормаційно-комунікативної компетентності майбутніх інженерів на заняттях 3 англійської мови в закладах вищої технічної освіти.

Формулювання цілей статті. Реалізація мети потребує вирішення таких завдань: 1) визначити сутність інфрормаційної, комунікативної та інфрормаційно-комунікативної компетентності майбутніх інженерів; 2) проаналізувати теорію і практику форомування інфрормаційно-комунікативної компетентності майбутніх інженерів машинобудівної галузі на заняттях 3 англійської мови.

У процесі виконання завдань використано методи аналізу, синтезу, узагальнення, систематизації, вивчення нормативних документів.
Виклад основного матеріалу дослідження. Інформаційно-комунікативна компетентність фрахівця О. Спіріним розглядається як підтверджена здатність особистості використовувати на практиці інформаційно-комунікаційні технології для задоволення власних потреб і розв'язування суспільно значущих, зокрема професійних, завдань у певній предметній галузі [8]. А. Зав'ялов зазначає, що сорормована інфрормаційно-комунікативна компетентність особистості забезпечує їй можливість орієнтуватися в динамічному соціокультурному просторі різних культур, $з$ одного боку, а з іншого - допомагає збільшувати обсяг інфрормації і знань, поступово будувати певний стиль комунікації, що вирізняється підвищеною соціальною активністю, а також новими принципами взаємодії в інфрормаційному суспільстві [3].

Поняття «інорормаційно-комунікативна компетентність» визначаємо як інтегральне від понять «інформаційна компетентність» і «комунікативна компетентність». У процесі наукового пошуку (М. Васильєва, Н. Волкова, І. Комарова, Л. Паламар та інші) комунікативну компетентність майбутнього інженера розглядаємо як здатність фрахівця встановлювати інтерактивну взаємодію у процесі професійної інженерної діяльності, використовуючи вербальні й невербальні засоби спілкування та створювати міжособистісний простір у процесі активної та ініціативної комунікації з іншими.

У контексті цього ми підтримуємо погляди H. Баловсяк, яка зазначає, що інформаційна компетентність включає три компоненти, такі як: інфрормаційна компонента (здатність ефективної роботи 3 повідомленнями у всіх фрормах їх представлення); комп'ютерна або комп'ютернотехнологічна компонента (здатність роботи з сучасними комп'ютерними засобами та програмним забезпеченням); процесуально-діяльнісна компонента (здатність застосовувати сучасні засоби інфрормаційних та комп'ютерних технологій роботи з інфрормаційними ресурсами та розв'язування різноманітних задач) [1].

3 огляду на окреслене, інформаційно-комунікативну компетентність майбутнього інженера будемо розуміти як інтегральну характеристику особистості, яка полягає у сорормованій здатності налагоджувати та здійснювати професійну комунікативну взаємодію з використанням вербальних та невербальних засобів комунікації, інфрормаційно-комунікаційних технологій задля вирішення профресійних завдань у технічній сорері та задля особистісного й професійного вдосконалення.

Значний потенціал у фрормуванні інфрормаційно-комунікативної компетентності відводимо заняттям 3 англійської мови. У контексті нашого дослідження вагомими є погляди Т. Пахомової, яка визначає англомовну комунікативну компетентність як здатність і готовність студентів 
здійснювати ефрективну комунікацію англійською мовою та включає: мовну (лінгвістичну) компетенцію, яка передбачає систему знань, умінь і навичок здійснювати англомовну комунікацію в типових ситуаціях навчальної, трудової та культурної сорер спілкування; соціокультурну компетенцію, яка включає фронові знання (сукупність відомостей про соціокультурні особливості народу, мова якого вивчається, та про стандарти комунікативної поведінки, прийняті в цій культурній спільноті); професійну компетенцію, яка передбачає знання фахової термінологічної лексики, а також навички роботи з матеріалом [5, с. 60].

Зупинимося на аналізі практики фрормування інфрормаційно-комунікативної компетентності у студентів галузі знань 13 Механічна інженерія, спеціальності 133 Галузеве машинобудування.

Метою вивчення курсу «Практичний курс іншомовного наукового спілкування» $€$ фрормування в майбутніх інженерів професійно орієнтованих іншомовних мовленнєвих компетенцій в аудіюванні, говорінні, читанні, письмі та перекладі/ медіації [2].

Відповідно до Стандарту Вищої освіти, зміст формування інфрормаційно-комунікативної компетентності майбутніх інженерів на заняттях 3 англійської мови має бути спрямований на досягнення таких програмових результатів, як: ПР03 - розуміти та пояснювати англійською мовою екологічно небезпечні та шкідливі фрактори профресійної діяльності та коригувати ії зміст із метою попередження негативного впливу на навколишнє середовище; ПР04 - володіти засобами сучасних інорормаційних та комунікаційних технологій в обсязі, достатньому для навчання та професійної англомовної діяльності; ПР05 - пояснювати англійською мовою свої рішення і підґрунтя їх прийняття фрахівцям і нефахівцям у ясній і однозначній формі; ПР10 пояснювати англійською мовою вплив конструктивних параметрів елементів машинобудівної техніки на її технічні характеристики; ПР13 - описувати англійською мовою будову металів та неметалів та знати методи модифікації їх властивостей; призначати оптимальні матеріали для елементів та систем машинобудівної техніки з урахуванням їхньої структури, фрізичних, механічних, хімічних та експлуатаційних властивостей, а також економічних фракторів; ПР15 - описувати англійською мовою експериментальні методи дослідження структурних, фрізико-механічних і технологічних властивостей матеріалів та конструкцій; ПР16 мати навички розроблення технологічних процесів, в тому числі із застосуванням автоматизованого комп'ютерного проектування виробництва конструктивних елементів та систем машинобудівної техніки; ПР23 - оцінювати англійською мовою економічну ефрективність виробництва елементів та систем машинобудівної техніки [9].
Тому 3 метою фрормування інфрормаційнокомунікативної компетентності та забезпечення сорормованості кінцевих програмових результатів навчання майбутніх інженерів на заняттях 3 англійської мови фрормуємо лінгвістичні здатності через засвоєння широкого діапазону словникового запасу лексики за фрахом; граматичні англомовні знання професійних термінів; мовленнєві вміння 3 аудіювання (вилучати специфрічну інфрормацію з аудіоповідомлень; розуміти складну інфрормацію, таку як оперативні інструкції, специорікації на знайомі продукти, пропозиції послуг тощо; розуміти аудіоповідомлення на теми, які здебільшого зустрічаються в академічному та професійному житті, та визначати погляди й ставлення мовця), уміння англомовного говоріння (виступати 3 непідготовленими англомовними повідомленнями на теми машинобудівної проблематики, складати професійно орієнтовані діалоги, обмінюватися думками та інформацією на складні теми машинобудівної галузі, розуміти монологічне і діалогічне мовлення у рамках різних сорер і професійно орієнтованих ситуацій спілкування), англомовного читання (розуміти складні автентичні тексти з машинобудівної галузі, визначати позиції і погляди в автентичних текстах, пов'язаних зі спеціальністю; розпізнавати широкий діапазон термінології та скорочень з галузі), англомовного перекладу (здатність продукувати на письмі відповідні фрункції та поняття машинобудівної галузі, володіння широким діапазоном галузевої термінології) та англомовного письма (здійснювати підготовку анотацій до автентичних галузевих текстів; формулювати власні резюме, здійснювати підготовку проблемно-тематичних повідомлень, готувати і продукувати ділову та професійну кореспонденцію тощо) [2, с. 122-123].

Варто наголосити, що кожна 3 тем курсу «Практичний курс іншомовного наукового спілкування» містить значний потенціал у формуванні інформаційно-комунікативної компетентності. Наприклад, у процесі вивчення теми «Evaluation. Projects», здійснюючи оцінку реалізації різноманітних проєктів, майбутні інженери, використовуючи такі інформаційні технології, як мультимедійні програми, у своєму режимі та відповідно до своїх потреб через одночасність візуального та слухового сприйняття, синтезу та синхронізації вербалізованих та невербалізованих знань, синхронізації та інтеграції часово-просторових та візуально-просторових джерел навчальної інорормації аналізують та вдосконалюють профресійну англомовну лексику. На наш погляд, використання власно підготовлених англомовних мультимедійних презентацій забезпечує удосконалення монологічного мовлення студентів із машинобудівної галузі. У процесі свого виступу майбутні інженери оперують англомовними професійними термінами 
(mechanical engineering, gearbox, precaution, update, regenerative, combustion chamber та ін.), ілюструючи свою доповідь самостійно розробленими схемами.

Ефективним у фрормуванні інфрормаційно-комунікативної компетентності майбутніх інженерів $€$ використання методів, що мають на меті пошук та використання комплексу тематично організованих on-line автентичних матеріалів. Наприклад, у процесі вивчення теми «Agreements. Proposals» пропонуємо віднайти і здійснити аналіз «Експортна стратегія сектору машинобудування 2020 року» та визначити умови подальшого розвитку авіаційної промисловості в Україні. Або віднайти «Розвиток співпраці у сорері машинобудування», здійснити ії аналіз та провести обговорення основних напрямів відродження національного машинобудування в Україні тощо.

Формуванню інорормаційно-комунікативної компетентності студентів у процесі вивчення курсу «Практичний курс іншомовного наукового спілкування» сприяє й робота із професійно-орієнтованими пошуковими системами Metasearch Search Engine, Yahoo та RefSeek 3 метою пошуку цікавих матеріалів із машинобудівної галузі, а саме серед веб-сторінок (American Society of Mechanical Engineers, Technology Student Association, NCEES та ін.), енциклопедій (енциклопедія Half-Life тощо), журналів і газет (Government courier, The Journal of Engineering in Economic Development тощо).

Висновки. Отже, інформаційно-комунікативна компетентність студентів $€$ важливою складовою частиною їхньої профресійної компетентності. Формування інорормаційно-комунікативної компетентності на заняттях 3 англійської мови передбачає удосконалення в майбутніх інженерів машинобудування здатностей здійснювати пошук, відбір та інтерпретацію професійної інформації з галузі, її аналіз, продукування, поширення та відтворення у процесі англомовного профресійного спілкування. Майбутній інженер зі сфрормованою інфрормаційно-комунікативною компетентністю здатний ефективно використовувати інорормаційні технології, здійснювати пошук, аналіз та продукування різного виду інфрормації; має новий тип мислення.
Проведене дослідження не претендує на вичерпний розгляд проблеми. Подальшого вивчення потребують питання організації самостійної роботи з англійської мови з розвитку інформаційно-комунікативної компетентності майбутніх інженерів.

\section{БІБЛІОГРАФІЧНИЙ СПИСОК:}

1. Баловсяк Н. Структура та зміст інорормаційної компетентності майбутнього спеціаліста. Науковий часопис Національного педагогічного університету імені М.П. Драгоманова. 2006. № 11. URL: http:// enpuir.npu.edu.ua/bitstream/123456789/888/1/30.pdf

2. Галацин К.О., Хом'як А.П. Інтерактивні технології формування комунікативної культури майбутніх фахівців на заняттях з англійської мови : навч. посіб. Луцьк, 2019. 128 с.

3. ЗавьяловА.Н. Формированиеынорормационной компетентности студентов в области компьютерных технологий: автореф. дис. ... канд. пед. наук : 13.00.01 «Общая педагогика, история педагогики и образования»; Тюменский государственный университет. Тюмень, 2005. 17 с.

4. Педагогічна майстерність: підручник / І.А. Зязюн, Л.В. Крамущенко, І.Ф. Кривонос та ін. ; за ред. І. А. Зязюна. Київ, 1997. 349 с.

5. Пахомова Т.О., Сенченко Я.С. Формування англомовної комунікативної компетентності студентів-срілологів в умовах лінгвосоціокультурного підходу. Вісник Дніпропетровського університету імені Альфреда Нобеля. Серія «Педагогіка і психологія». 2013. № 1. С. 59-64.

6. Рапацевич Е.С. Педагогика: Большая современная энциклопедия. Минск, 2005. 720 с.

7. Семотюк О. Сучасний словник іншомовних слів. 2011. 688 с.

8. Спірін О. Інформаційно-комунікаційні та інсрормативні компетентності як компоненти системи профресійно-спеціалізованих компетентностей вчителя інформатики. Інфрормаційні технології і засоби навчання. 2009. № 5(13). 16 c. URL: http:// eprints.zu.edu.ua/3733/2/09somtio.htm

9. Стандарт Вищої освіти України для першого (бакалаврського) рівня вищої освіти галузі знань 13 «Механічна інженерія», спеціальності 133 «Галузеве машинобудування» : Наказ Міністерства освіти і науки України 16.06.2020 р. № 806: URL: https://mon.gov.ua/ storage/app/media/vyshcha/standarty/2020/06/17/133\%20 Haluzeve\%20mashynobuduvannya\%20bakalavr.pdf 
ВИКЛАДАННЯ МЕДИЧНОЇ ТЕРМІНОЛОГІЇ ПІД ЧАС ВИВЧЕННЯ

АНГЛІЙСЬКОЇ МОВИ В УМОВАХ ДИСТАНЦІЙНОГО НАВЧАННЯ ЗА ДОПОМОГОЮ ПЛАТФОРМИ ДЛЯ ПРОВЕДЕННЯ ОНЛАЙН-ЗАНЯТЬ ZОOМ

\section{TEACHING OF MEDICAL TERMINOLOGY DURING THE STUDY OF ENGLISH IN THE CONDITIONS OF DISTANCE LEARNING USING A PLATFORM FOR ONLINE CLASSES ZOOM}

у статті проаналізовано методику викладання спеціальної медичної термінології для студентів вищих навчальних закладів на заняттях з англійської мови в умовах дистаниійного навчання. Освіта завжди має оперативно реагувати на актуальні тенденціі розвитку суспільства, адже тільки тоді вона зможе забезпечити її здобувачам можливість повноцінно жити та функціонувати в сучасному глобалізованому світі. Узагальнено досвід використання онлайн-платорорм під час навчання студентів у вітчизняних вищих навчальних закладах в умовах карантинних обмежень. Простежено шляхи створення нових комунікативних методик викладання фрахової мови на базі інтернет-платформ. При цьому встановлено, що найчастіше викладачі використовують для проведення лекційних та семінарських занять програмний додаток Zоом. 3 огляду на це було досліджено можливості використання платорорми для проведення онлайн-занять Zоом під час вивчення лексичного матеріалу в межах курсу з англійської мови для нефрілологічних спеціальностей медичних ЗВО. Зокрема, проаналізовано основний фуннціонал програми та можливості його використання на заняттях з метою кращого засвоєння студентами медичної термінології іноземною мовою. Визначено есрективні методи та прийоми навчання на уроках іноземної мови під час вивчення спеціальної термінології студентами медичних вищих навчальних закладів. Спрогнозовано, які методи та прийоми можна адаптувати та використовувати під час занять на платформі Zоом. Визначено форми організації навчального процесу, які $\epsilon$ найбільш есрективними під час вивчення медичної термінології студентами під час онлайн-занять. Узагальнено рекомендації для викладачів щодо організації навчального процесу в досліджуваному онлайн-середовищі, підбору методів і форм навчання, дидактичного та роздаткового матеріалу. Окреслено форми проведення онлайн-занять у Zоом, способи організації навчання та можливості платного $і$ безкоштовного використання додатку. З'ясовано, які труднощі можуть виникати під час вивчення спеціальних медичних термінів англійською мовою на дистаниійному навчанні, та запропоновано шляхи оптимізації цього процесу. Також вивчено світовий досвід використання інтернет-платформ для навчання студентів в онлайн-режимі.

Ключові слова: дистанційне навчання, медична термінологія, онлайн-заняття, платформа Zоом, вивчення англійської мови онлайн.

The article analyzes the method of teaching special medical terminology for students of higher educational institutions in English classes in terms of distance learning. The experience of using online platforms during students' education in higher education institutions in the conditions of quarantine restrictions is generalized. And most often teachers use the software application Zoom for lectures and seminars. Education must always respond quickly to current trends in society, because only then will it be able to provide its students with the opportunity to live and function fully in today's globalized world.

The subject of the study is an innovative method of conducting professional vocabulary through the viewing of authentic video segments. The issue of using medical videos as a lexical aspect of repetition learning is covered in this article. The possibilities of using the platform for online Zoom classes during the study of lexical material within the English language course for non-philological specialties of medical universities were explored. In particular, the main functionality of the program and the possibility of its use in the classroom in order to better master medical terminology by students in a foreign language are analyzed. Effective methods and techniques of teaching foreign language lessons during the study of special terminology by students of medical higher educational institutions are determined. It is predicted what methods and techniques can be adapted and used during classes on the Zoom platform. The forms of organization of the educational process that are the most effective in the study of medical terminology by students during online classes are identified. Recommendations for teachers on the organization of the educational process in the studied online environment, selection of methods and forms of teaching, didactic and handouts are summarized. Forms of conducting online classes in Zoom, ways of organizing training and the possibility of paid and free use of the application are outlined. Find out what difficulties may arise when learning special medical terms in English in distance learning and suggest ways to optimize this process. The world experience of using Internet platforms for teaching students online has also been studied. Key words: distance learning, medical terminology, online classes, Zoom platform, learning English online.
Постановка проблеми в загальному вигляді. Найбільшим викликом для світової спільноти останніх років стала пандемія, яка розпочалася 2019 року і так чи інакше вплинула на всі соціальні процеси, що відбуваються в сучасному світі.
Учасники освітнього процесу всіх рівнів за умов часткових або тотальних локдаунів змушені пристосовуватися до нового типу здобуття освіти дистанційного навчання. У досить короткий термін перед викладачами постало завдання організувати 
навчальний процес таким чином, щоб пандемія не вплинула на його якість і, тим паче, не призвела до повної зупинки навчання. Найкращим виходом у цій ситуації стало використання онлайн-платорорм та програмових додатків, які дали змогу організовувати для учнів та студентів повноцінні заняття 3 можливістю віртуальної присутності в режимі живого часу. 3 огляду на це методика викладання у вищій школі має започаткувати та активно розвивати якісно новий напрям наукових розвідок організацію дистанційного навчання та методику його проведення. Вивчення медичної термінології іноземною мовою вимагало підбору ефективних навчальних методик в умовах традиційного навчання, тому цю проблему висвітлювали у своїх наукових розвідках Ю. Блажевич, О. Петрова, Н. Попова та ін. На нашу думку, в теперішніх умовах варто розвивати цю тематику вже в контексті дистанційної форми здобуття освіти.

Мета статті - науково обґрунтувати методику використання платформи для проведення онлайн-занять Zоом під час вивчення спеціальної медичної термінології на заняттях 3 англійської мови; узагальнити рекомендації щодо організації навчального процесу в онлайн-середовищі для студентів закладів вищої освіти, зокрема на заняттях $з$ іноземної мови.

Виклад основного матеріалу. Для студентів немовних спеціальностей вивчення іноземної мови $€$ не менш важливим, ніж засвоєння спеціальних предметів. Англійська мова сьогодні $€$ не лише мовою інтернаціонального спілкування: в умовах пандемії знання англійської - це спосіб швидкого обміну досвідом та науковими відкриттями для лікарів з усіх країн, а також можливість для медиків отримати престижну роботу за кордоном. О. Петрова стверджує, що курс англійської мови професійного спрямування в медичному університеті включає медичну термінологію, оскільки це $є$ базовим для професійної діяльності. Саме навчання медичної термінології може стати позитивним аспектом в оволодінні іншомовним спілкуванням у спеціальності. У контексті вивчення англійської мови студентами-медиками актуальним завданням для них є знання медичних термінів та отримання навичок і вмінь використовувати спеціалізовану медичну лексику для виконання навчальних завдань, спрямованих на подальше професійне спілкування [2, с. 123].

Для студентів закладів вищої освіти в усьому світі використовуються такі популярні онлайнплаторорми: Docebo, Google Classroom, WizIQ, Adobe Captivate, Elucidat та ін. [7]. Аналіз педагогічного досвіду (власного, колег та відповідно до даних, взятих із мережі Інтернет) дає підстави стверджувати, що натепер однією 3 найпопулярніших платорорм для проведення онлайнзанять різних фрорм в Україні $€$ додаток Zoom.
Він надає можливість здійснювати відеоконореренції, онлайн-зустрічі, лекційні, групові та семінарські заняття, практикуми тощо.

Розглянемо більш детально фрункціонал цієї платорорми в контексті вивчення англійської мови студентами медичних вищих навчальних закладів в умовах дистанційного навчання:

1. Створення конореренцій. Для викладачів та студентів платорорма пропонує режими створення, планування, або можливість приєднатися до існуючої конференції. Це дозволяє викладачеві планувати заздалегідь час заняття, при цьому учасники майбутньої конореренції отримують посилання або код доступу, за яким вони можуть відвідати семінарське чи лекційне заняття.

2. Найефективнішим способом вивчення англійської медичної термінології дослідники і практики методики викладання вважають шлях через розуміння структури слова та значень частин слова, оскільки робота з медичною термінологією може бути порівняна з будівництвом споруди. Тому розпочинати знайомство з англійською медичною термінологією належить із базових мовних знань, а саме з нагадування про частини мови (nouns, verbs, pronouns, adverbs, and adjectives), актуальні для вивчення медичної термінології [6]. Для вивчення цього матеріалу можна використовувати міні-лекції з елементами наочності, яку викладач може розмістити на головному екрані за допомогою функціоналів, проаналізованих нижче.

3. Можливість одночасної демонстрації кількох екранів. Під час вивчення лексичного матеріалу на заняттях з іноземної мови візуалізація $€$ одним із найефективніших прийомів засвоєння навчального матеріалу. Готуючись до заняття, викладач зазвичай вибирає потрібні наочні матеріали, які використовує в ході опрацювання теми. Ïх можна організовувати у вигляді зображень, мультимедійних презентацій чи коротких відеороликів. Використання мультимедійних засобів навчання передбачає створення особливого типу мовленнєвих одиниць - полікодових текстів, які поєднують у собі знаки різних семіотичних систем. Мультимедіа - комбінування різних фрорм представлення інфрормації на одному носієві, сучасна комп'ютерна інформаційна технологія, що дозволяє об'єднувати в одній комп'ютерній програмнотехнічній системі текст, звук, відео, графрічне зображення, анімацію та мультиплікацію. Так, для роботи з термінами варто фокусувати увагу на обов'язковості запам'ятовування та повторювання («importance of learning by memorization and repetition» [2, с.124]). Для того щоб покращити запам'ятовування англійських термінів студентами, викладач може, наприклад, застосовувати різні кольори для презентації кожного виду частин слова (red for prefixes, blue for suffixes, green for word roots, and black for combining forms) [2, c. 124]). 
Тоді кожного разу, коли студент бачитиме колір, він асоціюватиме його з певною частиною слова. У сучасній методиці розроблені численні мнемонічні прийоми для вивчення медичної термінологіï. Так, можна ефективно використовувати mind maps, які слугують для візуалізаційної організації інорормації.

Оскільки вивчення термінології так чи інакше передбачає використання наочності, одним із найзручніших фрункціоналів програми Zoom у цьому контексті $€$ можливість відкриття одночасно кількох вікон на головному екрані, а також демонстрація окремих вікон і перемикання між ними під час проведення заняття. Так, іноземні педагоги стверджують, що для кращого засвоєння медичні терміни варто поділяти на частини - структурні одиниці. Ці частини, як правило, становлять собою комбінацію кореневого слова (основа слова), префрікса (перших кількох букв слова) та сусрікса (закінчення слова). Розбиття слів таким чином зменшує об'єм запам'ятовування, що полегшує засвоєння термінів англійською. 3 цією метою викладачеві доцільно використовувати графічні схеми й таблиці, підготовлені заздалегідь. Функція демонстрації екрану дозволяє виводити ці таблиці «у загальне поле» заняття, коментувати та аналізувати їх. При цьому корисним інструментом може стати олівець. Під час демонстрації екрану є можливість коментувати (Co-annotation), тобто можна малювати, виділяти, витирати тощо. Це може робити як викладач, так і студенти (якщо дана фрункцію дозволена викладачем) [5].

4. Під час вивчення іноземної термінології важливим $€$ не тільки засвоєння морфології, граматики й орфографії, а й фронетичне звучання кожного слова. У цьому плані корисною є можливість платорорми Zoom відтворювати відео- та аудіофайли прямо під час заняття. Крім того, студенти можуть по черзі потренувати вимову під керівництвом викладача - для цього досить натиснути на значок «піднята рука», і викладач побачить, який саме зі студентів бажає висловитися, щоб надати йому слово. Окрім того, щоб більше зрозуміти структуру та походження слова, є кілька прийомів запам'ятовування, які викладач може використовувати під час онлайн-навчання за допомогою фрункціоналів Zoom.

Поєднання візуальних образів із новими термінами за допомогою техніки асоціацій. Вивчаючи медичну термінологію, за допомогою зображень чи в презентації викладач може поєднати слово із зображенням, якому воно відповідає. Крім того, можна використовувати не статичні, а рухомі зображення різних фрорматів, таких як Гіфрф. Такі ілюстрації виглядатимуть нестандартно і, відповідно, краще запам'ятовуватимуться. Їх також можна використовувати під час заняття за допомогою фрункції «демонстрація екрану».
Флеш-картки - це перевірений спосіб вивчити нові слова та поняття іноземною мовою. Написання терміна, який потрібно вивчити, з одного боку, та визначення, з іншого боку, може бути корисним прийомом запам'ятовування. Щоб створити цифровий фрормат фрлеш-карток, викладач може використовувати безліч навчальних програм, таких як Ankidroid, StudyDroid, Dictonary.com Flashcards, Chegg Flashcards i StudyBlue [4]. Створення фрлеш-карт може бути однією із фрорм домашнього завдання для студентів. Демонструвати виконане завдання студенти можуть по черзі з використанням функції «піднята рука» - такого собі аналогу відповіді біля дошки перед аудиторією.

5. Одним з обов'язкових етапів вивчення медичної термінології на заняттях з англійської мови $€$ виконання студентами вправ і практичних занять. Якщо під час традиційного навчання викладач міг контролювати цей процес протягом заняття, в умовах дистанційного такої можливості практично немає. Частково здійснювати таку фрорму роботи в Zoom можна за допомогою чатів. Викладач може надіслати студентам для виконання заздалегідь підготовлені практичні завдання, а студенти можуть їх викладати до загального чату або надсилати викладачеві у приватному повідомленні.

Безперечно, вивчення медичних термінів на заняттях з англійської мови у Zoom вимагає ретельної підготовки саме від викладача. Для оптимізації цього процесу ми узагальнили та систематизували практичні рекомендації щодо організації навчального процесу онлайн, зокрема для підготовки занять з вивчення медичної термінології.

Планувати час і фрорму проведення заняття варто заздалегідь. Для цього треба вибрати у Zoom функцію планування конференції і надіслати студентам повідомлення 3 посиланням на кабінет і точним часом проведення заняття. Робити це варто з урахуванням календарно-тематичного планування, узгодивши графрік навчання з іншими викладачами. Крім того, варто врахувати час, потрібний для виконання студентами індивідуальних завдань, які теж варто розіслати заздалегідь.

Варто використовувати шаблони дистанційного навчання, щоб допомогти в організації загального курсу. Для вивчення термінології варто використовувати оригінальні фрорми подання лекційного матеріалу (наприклад, попередньо записане відео, презентації Power Points або конспекти лекцій), дописи в блозі, короткі аудіо- чи відеофрагменти, приклади роботи тощо.

Варто створювати 5-10-хвилинні міні-лекції (менше 500 МБ), що зосереджуються на окремих блоках вивчення лексичного матеріалу (відповідно позначених, щоб студенти могли їх легко знайти для навчальних цілей); ця тривалість відповідає тривалості уваги, обмеженням зв'язку та мінливості часу для перегляду матеріалу студентами. 
Зробити чіткими зв'язки між результатами навчання, темами й методами навчання, щоб допомогти студентам структурувати свою увагу.

Відпрацьовувати корисні звички студентів під час заняття, наприклад, робити перерви під час прослуховування теоретичного матеріалу, щоб підсумувати свої замітки та визначити запитання, які потрібно поставити чи опублікувати.

Варто забезпечити студентам вільність та гнучкість, дозволивши їм виконати підгрупу завдань під час заняття. Варто активізувати діяльність студентів у ході заняття, щоб дозволити застосувати набуті вміння та оцінити своє розуміння. Варто також ураховувати час, необхідний для виконання цих заходів, у плануванні робочого навантаження.

Важливо забезпечити доступність навчального матеріалу, щоб студенти могли переглянути його перед або після заняття, перевірити своє розуміння, коли новий матеріал ґрунтуються на попередніх знаннях.

Треба давати студентам достатньо часу між розміщенням матеріалів та кінцевими термінами для їх виконання.

Можна активно використовувати під час заняття чат, який дозволяє всім студентам взаємодіяти, брати участь у роботі над вивченням нових термінів та бачити роботу одногрупників.

Варто враховувати, що колективна робота може бути надзвичайно складною для студентів в Інтернеті, тому треба чітко визначити рекомендації, як виконувати групову роботу асинхронно, зокрема 3 використанням випереджувальних завдань.

Наостанок варто зазначити, що онлайн-платформа Zoom пропонує для своїх користувачів два способи використання - безкоштовний і платний. Безкоштовне заняття може тривати протягом 40 хвилин, що відповідає тривалості академічної години. Такий варіант є досить зручним для викладача, оскільки він отримує можливість організувати повноцінне заняття зі студентами без додаткових матеріальних витрат.

Висновки. Сучасна освіта розвивається за досить складних обставин, які спричинило поширення пандемії. За таких умов навчання студентів вимагає нових фрорм і методів організації навчання, що дають змогу здійснювати дистанційне навчання онлайн. Вивчення медичної термі- нології студентами на заняттях 3 англійської мови передбачає системну роботу 3 використанням різних видів наочності та виконання практичних завдань. Вирішити ці навчальні задачі можна 3 використанням онлайн-платорорм, зокрема таких, як Zoom. Ця програма містить необхідний набір інструментів, що дають можливість організувати повноцінне заняття з вивчення медичної термінології, таких як: можливість попереднього планування, демонстрація екрану, функція «олівець», відтворення аудіо- та відеофайлів, спілкування в чаті, фрункція «піднята рука» та ін. Безперечно, такі заняття вимагають ґрунтовної підготовки як з боку викладача, так і студентів. Саме тому перспективним є напрям методологічних досліджень, що полягає у створенні системи вправ, матеріалів та готових шаблонів і кейсів для проведення таких занять.

\section{БІБЛІОГРАФІЧНИЙ СПИСОК:}

1. Блажевич Ю. Наскільки важлива англійська в медицині? URL: https://yappi.com.ua/ua/posts/read/ anglijskij-v-medicine-osobennosti-terminologiya-isamostoyatelnoe-izuchenie

2. Петрова О.Б., Попова Н.О. До питання про навчання англійської медичної термінології. Проблеми та перспективи розвитку науки на початку третього тисячоліття у країнах Європи та Азії : матеріали XVI Міжнародної науково-практичної інтернет-конореренції (1-2 серпня 2015 р.). Збірник наукових праць. Переяслав-Хмельницький, 2015. C. $123-125$.

3. 3 Tips for Memorizing Medical Terminology in Your Health Administration Courses. URL: https:// canadianbusinesscollege.com/2019/10/18/3-tipsfor-memorizing-medical-terminology-in-your-healthadministration-courses/

4. 6 Ways to Learn Medical Terminology. URL: https://www.bryantstratton.edu/blog/2015/december/ keys-to-learning-medical-terminology

5. Green Forest. Інструкція для студентів Green Forest по користуванню. URL: Zoom//https:// greenforest.com.ua/ua/journal/read/instrukciya-dlyastudentov-green-forest-po-polzovaniyu-zoom

6. Lynette M. Veach, Marsha M. Holtsberry. Medical Terminology. Pearls of Wisdom. Pearson Education, 2009.

7. Dalton W., Turner B. Best online learning platforms of 2020: LMS and VLE for education. URL: https:// www.techradar.com/best/best-online-learning-platforms 


\section{FORMATION OF ENGLISH COMPETENCE IN DIALOGUE SPEECH OF FUTURE SPECIALISTS IN HOTELS, RESTAURANTS AND CATERING ФОРМУВАННЯ АНГЛОМОВНОÏ КОМПЕТЕНТНОСТІ В ДІАЛОГІЧНОМУ
МОВЛЕННІ МАЙБУТНІХ ФАХІВЦІВ 3 ГОТЕЛЬНО-РЕСТОРАННОЇ СПРАВИ}

The article researched the formation of English competence in dialogue speech of future specialists in hotels, restaurants and catering. English competence in dialogical speech of future specialists in hotels, restaurants and catering is an integrated quality of a personality. English competence in dialogical speech of future specialists in hotels, restaurants and catering includes both professional knowledge and theoretical one concerning theoretical bases of a dialogue; required skills for listening and speaking; an ability to initiate a dialogue, answer to replicas, encourage him/her to continue the conversation considering local linguistic and cultural characteristics of the speaker.

Teaching dialogic speech is based on two approaches, i.e. inductive (bottom-up) and deductive (top-down). We preferred the inductive approach, according to it the teaching process involves acquaintance with separate replicas of dialogic units, and then further mastering the content of dialogue as a whole on the basis of the proposed educational communicative situations, it also includes listening to sample dialogues, i.e. elements of deductive approach.

The content of English language dialogue of future specialists in hotels, restaurants and catering teaching has been defined taking into account the components of the content of teaching a foreign language, in particular: spheres and types of communication; themes and typical situations of foreign language communication and communicative intentions that arise in these situations; linguistic and speech material necessary for professional foreign language communication; relevant knowledge, skills and abilities. In accordance with the mentioned professional area of communication has been defined as the main one; among the types of communication the advantage is given to the official individual dialogue of the dialogical form.

The formation of English competence in dialogic speech of future specialists in hotel and restaurant business according to the inductive approach involves the implementation of the following stages: "turn-taking", making up dialogical units, making up microdialogues, making up dialogues of certain functional types.

In our opinion, the interactive methods, the project method, and the case method are the most effective methods of formation of English competence in dialogue speech of future specialists in hotels, restaurants and catering Key words: English competence in dialogue speech, hotels, restaurants and catering, exercises, future specialists, communicative situations

у статті досліджено особливості фрормування англомовної компетентності в діалогічному мовленні майбутніх спеціалістів з готельно-ресторанної справи, яка передбачає наявність як профресійних знань, так тих, що охоплюють теоретичні основи діалогічного мовлення; формування належних навичок, необхінни як для слухання, так для говоріння; вмінь розпочинати діалог, відповідати на репліки співрозмовника, спонукати його до продовження розмови, беручи до уваги його країнознавчі та лінгвокраїнознавчі особливості.

Навчання діалогічного мовлення ґрунтується на двох підходах: індуктивному («знизу вверх») та дедуктивному («зверху вниз»). Ми надали перевагу індуктивному підходу. Він передбачає ознайомлення з окремими репліками та кліше, а також подальше засвоєння загального змісту діалогу на основі запропонованої навчальної комунікативної ситуації, що не виключає елементів дедуктивного підходу, зокрема прослуховування автентичних діалогів-зразків.

Зміст навчання англомовного діалогічного мовлення майбутніх фрахівців готельно-ресторанної справи вмотивовано з урахуванням складників змісту навчання іноземної мови: сфери та види спілкування; теми та типові ситуації іншомовного спілкування; мовний і мовленнєвий матеріал, потрібний для здійснення профресійного спілкування іноземною мовою; відповідні знання, уміння та навички. Зазначено, що офріційний індивідуальний контакт діалогічної форми превалює серед видів іншомовного спілкування.

Навчання формування англомовної компетентності в діалогічному мовленні майбутніх фрахівців з готельно-ресторанної справи згідно з індуктивним підходом має на меті реалізацію таких етапів, як «реплікування», укладання діалогічних єдностей, укладання мінідіалогів, укладання діалогів певних функчіональних типів, на кожному з яких використовуються відповідні вправи. На нашу думку, ефективними методами фрормування англомовної компетентності в діалогічному мовленні $\epsilon$ інтерактивні методи, метод проєктів, кейс-метод

Ключові слова: англомовна компетент ність у діалогічному мовленні, готельноресторанна справа, вправи, комунікативні ситуації, майбутні фрахівці.
Statement of the problem. Nowadays, the need to communicate in a foreign language has grown significantly. Thus, knowledge of a foreign language for professional purposes is the key to exchange of scientific and technical information. Today, English is a means of international communication, modern linguists also nominate it as the language of intercultural communication considering such areas as politics, international relations, computer science, international (global) logistics and commercial activities. The factors mentioned above have caused a significant interest to foreign languages, now it is majority of Ukrainian higher educational establishments. Thus, the problem of improving existing and finding new effective methods of forming Englishlanguage competence in dialogic speech is both extremely relevant and scientifically important. 
Analysis of recent publications. It should be noted that the question of finding effective approaches and principles of foreign languages teaching has been the research subject of such scientists as N. Bondar, O. Osaulchyk, V. Redko, N. Gavryliuk, L. Dovhan, R. Kravets and others. It should be noted that communicative orientation of foreign language education has got the priority role considering the above-mentioned aspect. Some issues of professional training of future specialists in hotels, restaurants and catering were researched by A. Apukhtin, I. Andrianova, S. Bailyk, A. Bainazarov, A. Bohdanova, M. Vorobiova, P. Gudz, O. Dudina, L. Lukianova, O. Liubitseva, K. Annaraud, D. Baker, A. Freedman, J. Kwon and other scholars.

However, the analysis of psychological and pedagogical literature shows that the peculiarities of the formation of formation of English competence in dialogue speech of future specialists in hotels, restaurants and catering are researched insufficiently by scholars despite the significant research results and numerous scientific investigations.

The purpose of the article. We aim to research the problem of formation of English competence in dialogue speech of future specialists in hotels, restaurants and catering.

The main part of the research. The communicative approach in teaching foreign languages is one of the leading areas of communicative linguistics. D. Phillips notes that this approach is an attempt to avoid formal (or traditional) approaches based on grammar and translation, and move to approaches by which the student will use language as a means of communication [1, p. 154]. It is implemented through a communicative method of teaching foreign languages. Methodists rightly consider it pragmatic, because it partially neglects the fundamentals of knowledge to prepare students in a short time to use a foreign language in everyday life. According to Yashchenko Yu.B., game situations play the main role in communicative learning of a foreign language, they also develop analytical thinking [2].

Modern didactics distinguishes two basic approaches to dialogue speech teaching, i.e. inductive (analytical) and deductive (synthetic). The first approach is often referred to as bottom-up processing [3], it involves reading individual cues for further assimilation and understanding of the content of the dialogue as a whole on the basis of the teacher's proposed communicative situation. This approach is based on the assumption that the gradual acquisition of language units that are part of the structure of dialogue, forms the ability to participate independently in the communication process [4, p. 231].

The deductive approach to dialogue speech teaching is often referred to as the top-down processing, because mastering holistic dialogues of certain functional types (repeated listening, reading, memorizing sample dialogues, etc.) is the first stage according to this approach; the next stage is the mastery of dialogic units, and the mastery of individual cues is the final one.

According to scholars [3-5], the inductive approach is more effective in the process of formation of English competence in dialogue speech of future specialists in hotels, restaurants and catering because it represents the practical nature of mastering the educational material. Its main advantage is that students develop their skills from simple to complex.

Interactive, case and project methods are the most effective methods of formation of English competence in dialogue speech of future specialists in hotels, restaurants and catering. According to V. Redko, interactive teaching is one of the most effective forms of stimulating speech activity [6, p. 168]. The main component of interactive teaching is interactive methods; they make learning activities as productive as possible by increasing the cognitive activity of students in accordance with learning objectives within conversational topics, communicative situations and with appropriate language and speech material selected considering communicative needs [7, p. 226]. Interactive technology can be represented by discussion, game and training methods, their application optimizes the process of formation of English competence in dialogue speech of future specialists in hotels, restaurants and catering.

Taking into account the significant practical application of project technology, we consider it necessary to note its main features and peculiarities of implementation in the process of a foreign language mastering. Ye. Polat notes that it is a way to achieve the didactic goal through the detailed development of the problem, which should end with a real practical result [8, p. 66]. We consider it appropriate to implement group research projects in order to form English competence in dialogue speech of future specialists in hotels, restaurants and catering. O. Bihych, O. Ivanova, O. Yaroshenko insist on special role of the case method in foreign language teaching, they believe that its effectiveness is realized through problem discussion by students, it contributes both to mastering dialogue speech and the critical thinking formation [9-11]. Of course, the effectiveness of formation of English competence in dialogue speech depends on the correct selection of exercises. First, our tasks have been implemented within the conversational topics of the current program. Developing the exercises, we have taken into account the structural components of this competence. We have given a prominent place to the tasks forming both listening and speaking skills. N. Skliarenko notes that the tasks selection should take into account the exercise purpose realization, i.e. practical goal (to develop certain communicative skills), professional goal (to provide relevant professional knowledge), 
and developmental goal (to develop general skills and abilities) [12].

At the first stage it is necessary to form the student's ability to respond to the given remark. It is appropriate here to use pre communicative exercises. Teachers can control student activities fully or partial. Fully controlled communication is an imitation of speech units addressed to the addressee. If communication is partially controlled tasks are performed according to a certain speech pattern, but the student has the opportunity to choose a speech unit according to the communicative situation (multiple choice, filling in gaps, answering questions, correcting mistakes etc.).

The next stage of teaching is the formation of the ability to form dialogical unities, students develop the skills of perception of normal (average) rate of speech with a sufficient number of language clichés. The exercises are characterized by a low level of semantic and linguistic complexity with the application of limited, carefully selected communication material. For example,

Example 1: You and your groupmate are foreign tourists. He wants to stay at the same hotel. Tell him what type of room you have already booked. Make up short exchanges using the following words as in the example: single room, double room, twin room, suite room.

Student 1: I have booked a twin room.

Student 2: I have booked a twin room, too. I I haven't booked a room yet.

Example 2: Solve the following problems as in the example.

- What would happen if you couldn't choose a dessert?

(I / ask / waiter)

1. If I couldn't choose a dessert, I would ask the waiter.

1. What would you do if your business partners couldn't come to the business lunch? (I / postpone the business lunch);

2. What would you do if your salmon was overdone? (I / ask to fix);

3. What would you do if the guests of your hotel had some complaints? (I / apologize and deal with a complaint).

4. What would you do if you break a cup in a cafe? (I / apologize and pay for it).

Example 3: You are employed as a waiter at a local restaurant. The client asks you to recommend him some dishes from the menu. Help him, as in the example.

- Will you recommend me something from the menu?

- Sure. You may order chicken soup, steak and juice.

Training at the next stage involves the formation of skills to conclude micro-dialogues. A significant part of the training materials are authentic audio dialogues. The main features of these exercises are listening and understanding of audio materials for further activities, i.e. making a micro-dialogue in a situation similar to the sample dialogue.

\section{Example 1. Making a reservation.}

Student A: You want to book a hotel room. Telephone Student $B$ and make a reservation with the following details

- reserve a room (with bath) for yourself and two children;

- arrival on 13 March and departure on 15 March;

- you need a cod for a baby (age 15 months);

- you would like to know the room rates;

- your credit card number is 986323174563 9912.

Student B: You work as a receptionist. Answer the phone with the name of the hotel. Take all the necessary details.

\section{Example 2.}

a) Read the offered information about Barcelona hotels.

b) Using this information, make up a questionanswer dialogue for the situation.

Student A: You want to find out about weekend breaks to Barcelona. Write questions to ask the travel agent. Then phone and ask for details about the holiday.

Student B: You are a travel agent. Answer the client's questions.

\section{Example 3.}

Student A: You are a guest at a hotel. Look at the following problems and complain to reception.

- you lose your key and the replacement key is missing;

- the service in the restaurant is very slow and the waiter doesn't speak English well and brought the wrong order;

- there are no instructions on how to operate the $T V$ set and the remote control is not working.

Student B: You are the hotel receptionist. Deal with the guest's complaints.

Conclusions. Dialogue speech teaching is based on two approaches, i.e. inductive (bottom-up processing) and deductive (top-down processing). We have preferred the inductive approach. According to it dialogue speech teaching involves teaching separate expressions of dialogic units and further mastering the content of the dialogue considering the proposed educational communicative situation, it also includes listening to sample dialogues, i.e. elements of deductive approach.

Teaching formation of English competence in dialogue speech of future specialists in hotels, restaurants and catering according to the inductive approach involves the implementation of the following stages: "turn-taking", making up dialogical units, making up microdialogues, making up dialogues of 
certain functional types. In our opinion, the interactive methods, the project method, and the case method are the most effective methods of formation of English competence in dialogue speech of future specialists in hotels, restaurants and catering.

\section{REFERENCES:}

1. Филипс Л., Йоргенсен М.В. Дискурс-анализ: теория и метод ; пер. с англ. Харьков : Гуманит. центр, 2004. 336 c.
2. Ященко Ю.В. Сутнісний зміст фрормування іншомовної комунікативної компетентності у студентів ВН3. Вісник Черкаського національного університету імені Богдана Хмельницького. Серія: Педагогічні науки. 2009. Вип. 149. С. 57-59.

3. Методика навчання іноземних мов і культур: теорія і практика / О.Б. Бігич та ін. / за загальн. ред. С.Ю. Ніколаєвої. Київ : Ленвіт, 2013. 590 с.

4. Щукин А.Н. Методика обучения речевому общению на иностранном языке. Москва : Икар, 2011. $454 \mathrm{c}$. 
ЗАПРОВАДЖЕННЯ ІНФОРМАЦІЙНО-КОМУНІКАЦІЙНИХ ТЕХНОЛОГІЙ У ПРОЦЕС ПРОФЕСІЙНОЇ ПІДГОТОВКИ МОЛОДШИХ СПЕЦІАЛІСТІВ З ПРАВА

INTRODUCTION OF INFORMATION AND COMMUNICATION TECHNOLOGIES IN THE PROCESS OF PROFESSIONAL TRAINING OF JUNIOR LAW SPECIALISTS

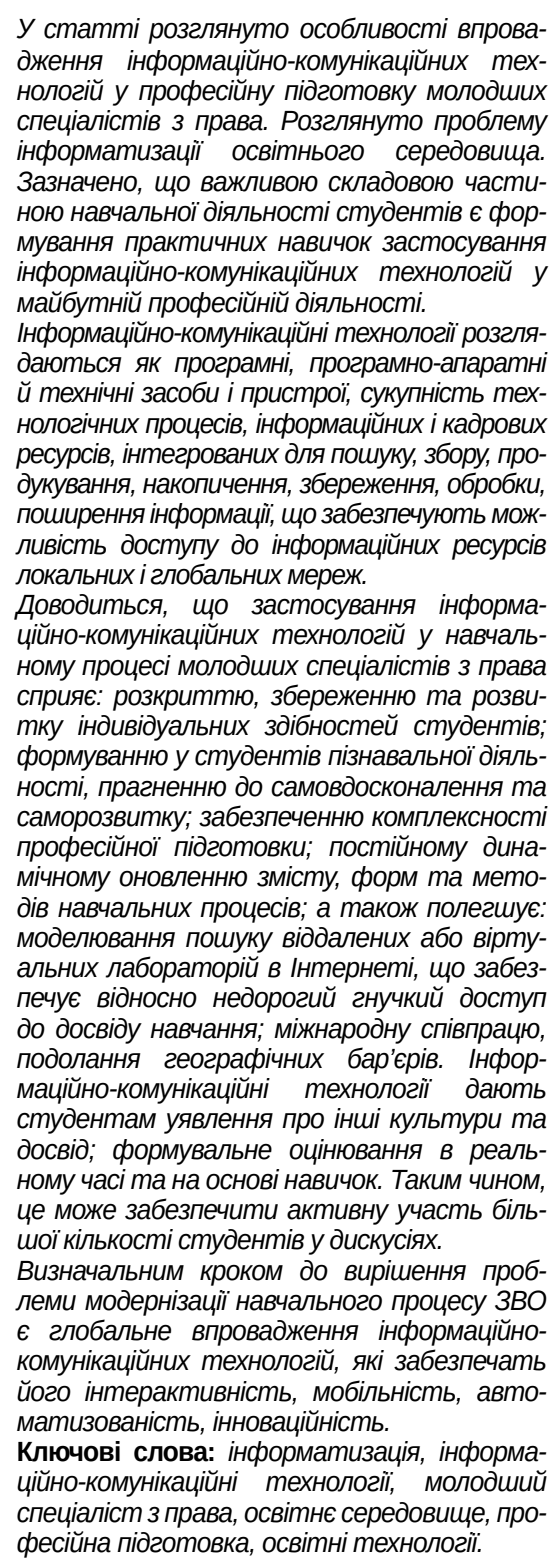

УДК 378.147(045)

DOI https://doi.org/10.32843/2663-

6085/2021/31-1.36

\section{Титок I.B.,}

викладач

Фахового коледжу інженерії

та управління

Національного авіаційного університету
This article considers the features of the introduction of information and communication technologies in the training of junior law professionals. The problem of informatization of the educational environment is considered. It is noted that an important component of students' learning activities is the formation of practical skills in the application of information and communication technologies in future professional activities.

Information and communication technologies are considered as software, software and hardware and technical means and devices, a set of technological processes, information and human resources integrated to search, collect, produce, accumulate, store, process, disseminate information that provide access to information resources local and wide area networks. It is proved that the use of information and communication technologies in the educational process of junior specialists in law contributes to: the disclosure, preservation and development of individual abilities of students; formation of students' cognitive activity, the desire for self-improvement and self-development; ensuring the complexity of professional training; constant dynamic updating of the content, forms and methods of educational processes; and also facilitates: modeling of search as remote or virtual laboratories on the Internet, which provides relatively inexpensive flexible access to the learning experience; international cooperation, overcoming geographical barriers. Information and communication technologies give students an idea of other cultures and experiences; formative assessment in real time and based on skills. Thus, it can ensure the active participation of more students in discussions.

The defining step towards solving the problem of modernization of the educational process of free economic education is the global introduction of information and communication technologies that will ensure its interactivity, mobility, automation, innovation.

Key words: informatization, information and communication technologies, junior specialist in law, educational environment, professional training, educational technologies.
Постановка проблеми в загальному вигляді. Сучасна освіта України переживає суттєві трансформації. Стрімкий розвиток інфрормаційних та телекомунікаційних технологій, вплив яких дедалі більше поширюється на всі сорери соціального життя, відкриває перспективи вдосконалення вищої освіти, обміну науково-навчальною інфрормацією [5].

Інфрорматизація суспільства, в тому числі й усіх форм освітньої діяльності, характеризується модернізацією і глобальним запровадженням сучасних інфрормаційно-комунікаційних техно- логій (далі - IKT). ІКТ активно використовуються для передачі інфрормації і забезпечення взаємодії викладача і студента в сучасних системах відкритої та дистанційної освіти. Особливої актуальності проблема запровадження IКТ в освітній процес набуває сьогодні, коли заклади вищої освіти (3ВО) перейшли на дистанційну фрорму навчання у зв'язку з поширенням пандемії (Covid-19).

Ефективне впровадження інформаційно-комунікаційних технологій, як зазначають Р. Гуревич, М. Кадемія, М. Козяр, «сприяє розвитку мислення, пам'яті, уваги, спостережливості; фрормуванню 
професійно орієнтованих знань, умінь і навичок; розвитку комунікативних здібностей; фрормуванню умінь і навичок приймати оптимальні рішення або пропонувати варіанти їх розв'язку в надзвичайних ситуаціях; розвитку вміння здійснювати експериментально-дослідницьку діяльність; створенню умов для самооцінки, систематизації та узагальнення майбутнім кваліфікованим фрахівцем одержаної інфрормації з метою професійного самовизначення, покращення якості підготовки» [2], що $€$ важливим завданням закладу вищої освіти. Успішність організації дистанційного навчання у 3 ВО 3 використанням новітніх IKT зумовлена, по-перше, інформатизацією як провідним освітнім трендом; по-друге, варто враховувати особистість сучасного студентства - представника «покоління Z», або «цифрового покоління», для якого існування у віртуальному інорормаційному середовищі є абсолютно природним.

Разом із тим спостерігається проблема застосування ІКТ в освітньому процесі, яка безпосередньо пов'язана 3 неготовністю педагогічних працівників використовувати інфрормаційні технології в організації навчального процесу. Сучасний викладач повинен не тільки володіти знаннями у сфері IKT, але й бути фрахівцем щодо їх застосування у своїй професійної діяльності.

Аналіз останніх досліджень і публікацій. Теорія та практика підготовки фрахівців з права досліджувалась низкою науковців, серед яких А. Андрощук, О. Василенко, В. Журавський, П. Касперович, Л. Насілєнко, М. Сидоренко та ін. Проблемою модернізації освіти займалися В. Безпалько, Б. Гершунський, Ю. Дорошенко, І. Зимня, М. Кадемія, Е. Лузік, О. Падалка, С. Сисоєва, А. Хуторський, А. Шматко та ін. Психологічні та педагогічні особливості впровадження інформаційно-комунікаційних технологій у навчальний процес ЗВО досліджували Л. Дітковська, М. Жалдак, А. Кокарєва, Ю. Рамський, О. Пєхота, О. Пометун, О. Спірін, Ю. Триус, Л. Хоменко-Семенова, О. Шестопал.

На жаль, у підготовці молодших спеціалістів 3 права є ще багато невирішених питань і завдань, а в розробках її теоретичних і методичних основ $€$ ще чимало нерозв'язаних проблем, зокрема ефективності застосування ІКТ у професійній підготовці молодших спеціалістів 3 права.

Виділення не вирішених раніше частин загальної проблеми. На сучасному етапі одна 3 дискусійних проблем розвитку ефективного українського суспільства - збереження молодого покоління для розбудови успішної держави, сприяння самовизначенню, прагненню до саморозвитку, мотивуванню до професійної діяльності за фрахом. Виховання зацікавленості, мотивації в здобутті профресії - найважливіші умови навчальної діяльності майбутніх молодих фрахівців.
Студент коледжу вже з перших днів навчання повинен усвідомити, що недостатній рівень інорормаційних умінь і навичок не дозволить йому в подальшій виробничій діяльності займатися творчістю, пов'язаною $з$ раціоналізацією та винахідництвом. Цей недолік проявляється уже під час курсового і дипломного проєктування, викликаючи потребу в поповненні недостатнього рівня знань через самоосвіту, використання інорормаційних комп'ютерних засобів навчання. Процес навчання самореалізується через ланцюжок конкретних проблем, що потребують самостійного вирішення за внутрішньою потребою.

Вихід на інноваційні технології освіти, мета яких - підготувати конкурентоспроможного спеціаліста з необхідним рівнем особистих і професійно значущих якостей, що оптимально задовольнять запити виробництва, відкриває нові горизонти для навчальної діяльності [4].

Тому метою статті $€$ дослідження ефективності впровадження інфрормаційно-комунікаційних технологій у підготовку майбутніх молодших спеціалістів $з$ права.

Виклад основного матеріалу. Інорормаційнокомунікаційні технології (далі - IKT), до яких входять новітні циоррові технології, такі як комп'ютери та Інтернет, радіо та телебачення, $€$ потенційно потужними інструментами, що сприяють змінам та реформам у сучасній освіті України. Ефективне застосування IКT допомагає полегшити доступ до освіти, підвищити якість освіти, допомагаючи перетворити викладання та навчання на цікавий, активний процес, пов'язаний із реальним життям.

Інорормаційно-комунікаційні технології ми розглядаємо як комплекс різноманітних засобів, способів і технологій зі збирання, зберігання, процесу обробки, подання та передачі інорормації.

Під засобами інорормаційно-комунікаційних технологій будемо розуміти програмні, програмноапаратні й технічні засоби і пристрої, сукупність технологічних процесів, інформаційних і кадрових ресурсів, інтегрованих для пошуку, збору, продукування, накопичення, збереження, обробки, поширення інфрормації, що забезпечують можливість доступу до інформаційних ресурсів локальних і глобальних мереж.

Аналіз психологічної, педагогічної, методичної, технічної літератури та дисертаційних досліджень дозволив нам виділити такі напрями інноваційного розвитку педагогічної освіти в умовах впровадження ІКТ у ЗВО України:

- науково-педагогічні підходи до реалізації вимог модернізації освітнього середовища;

- розроблення і використання засобів IKT у навчальному процесі;

- інноваційні технології навчання: створення інформаційного середовища навчального закладу, електронні навчально-методичні комплекси, 


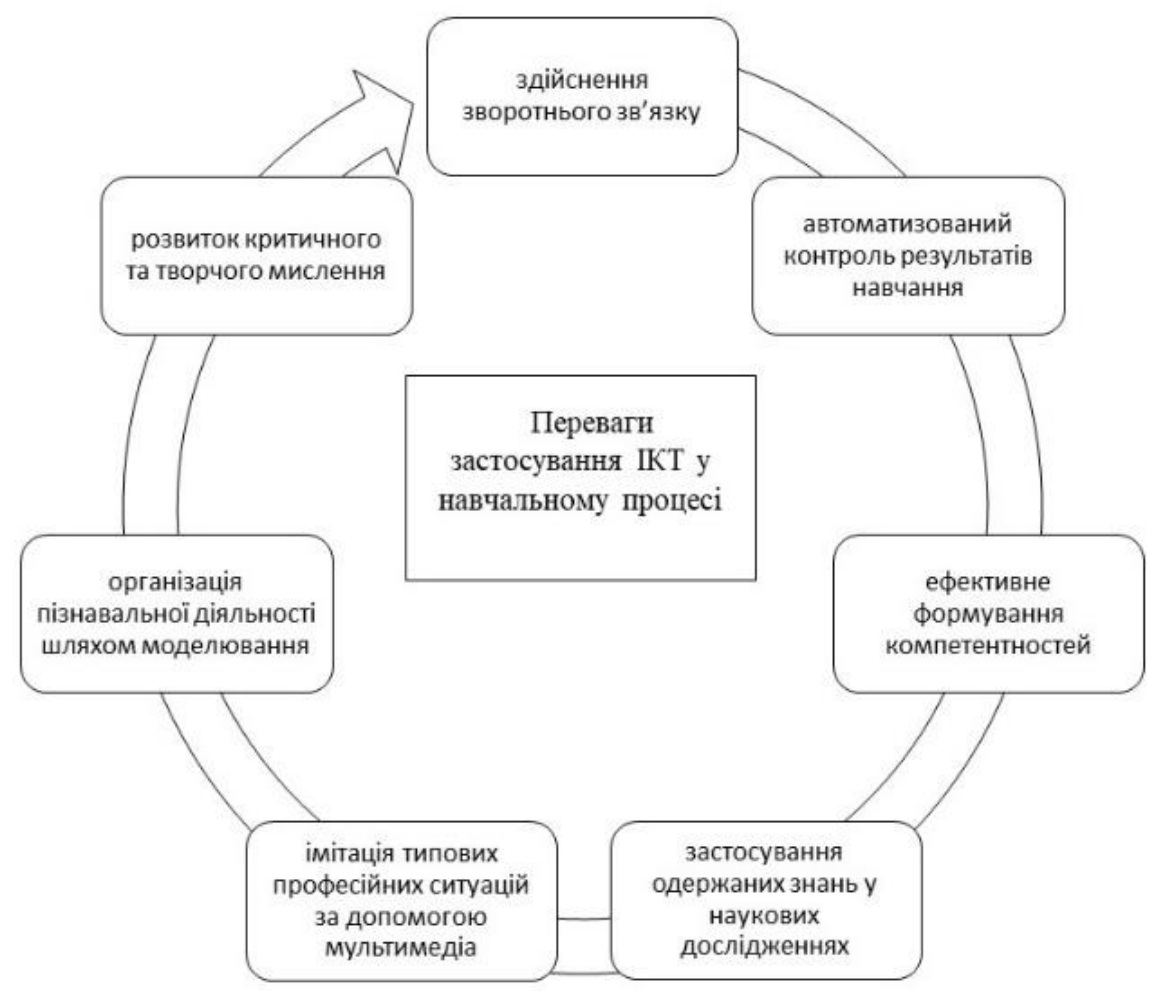

Рис. 1. Переваги застосування IКT у навчальному процесі ЗBО

застосування інтерактивних методик навчання, інновації в системі контролю й оцінки результатів навчання, моделювання, мультимедійні тренінги, дистанційна освіта, віртуальні лабораторії;

- особистісно-орієнтований підхід до організації профресійної освіти;

- компетенції в професійній освіті;

- організація науково-дослідної роботи студентів;

- автоматизація роботи бібліотек;

- інновації в підготовці й підвищенні кваліфрікації викладачів;

- взаємодія між 3ВО [6].

На рисунку 1 зображено переваги застосування IКТ у навчальному процесі.

Під час пандемії COVID-19 спостерігаємо активне впровадження в освітній процес вищої школи різних віртуальних фрорм навчання. Ці процеси не оминули й організацію навчання в коледжі інженерії та управління Національного авіаційного університету. Проведення онлайн-курсів, онлайнтренінгів, онлайн-воркшопів, онлайн-коучингів, хакатонів, вебінарів; використання електронних віртуальних лабораторій, соціальних мереж, створення платорорм спілкування за науковими інтересами, проведення міжнародних онлайн-конкурсів тощо. Цей процес став би неможливим без інорормаційно-комунікаційних технологій. Застосування освітньої платорорми Google Classroom (Google Клас) (Google Classroom - онлайн-клас для ефективного навчання) надає зручний інтерфейс для створення й керування навчальними курсами. Це відкриває нові можливості у викладанні: створювати, перевіряти та оцінювати завдання в режимі реального часу, реалізувати індивідуальний підхід у навчанні, проводити онлайн-обговорення, консультації. У випадку з Google Classroom користувачам потрібно мати обліковий запис Google, а якщо освітня установа організувала свій Єдиний інформаційний простір за допомогою сервicy Google Suite for Education, то такий обліковий запис є у кожного викладача і студента з можливістю використання всіх сервісів Google у корпоративному режимі.

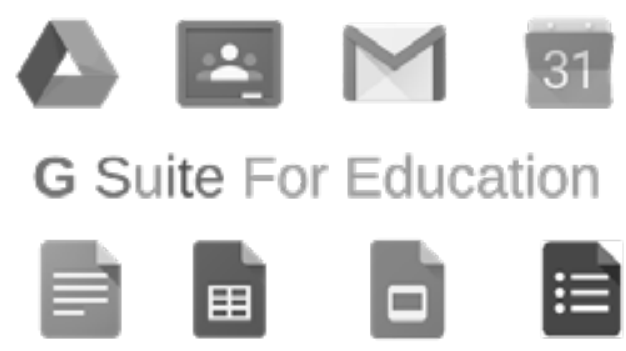

Рис. 2. Google-сервіси G Suite

Серед різноманітних віртуальних освітніх платфрорм сервіс Google Classroom вирізняється передусім простотою у використанні. Він не потребує спеціального навчання для створення курсу, а також надає користувачам зручний інтерфейс для керування навчальним процесом. 
Отже, упровадження IKT у підготовку молодших спеціалістів з права надає важливі переваги викладачеві в організації навчального процесу:

1) Інтерактивність: IKT дозволяють обмінюватися інфрормацією між користувачем та комп'ютером, і саме така взаємодія дозволяє адаптувати використовувані ресурси до вимог і характеристик зазначеного користувача;

2) Взаємозв'язок: це пов'язано зі створенням нових можливостей, починаючи зі зв'язку між студентом і викладачем, між студентом і програмним навчальним середовищем;

3) Миттєвість: ця фрункція стосується здатності інформаційно-комунікаційних технологій передавати інорормацію на великі відстані та дуже швидко;

4) Оцифровка: інфрормація представлена в унікальному універсальному форматі, що дозволяє передавати звуки, тексти, зображення тощо за допомогою тих самих засобів. Візуалізація навчального матеріалу; автоматизація процесів контролю, реєстрації і аналізу результатів навчального процесу, рівнів навчальних досягнень студентів; забезпечення дистанційної системи та індивідуального вивчення окремих фракультативних курсів.

Інфрормаційно-комунікаційні технології не лише дають людям можливість отримати доступ до великого обсягу інфрормації, щоб набути 3 неї знання, але також дозволяють їм це робити через асоціацію $з$ іншими підключеними користувачами до мережі.

5) Інновації: розвиток ІКТ характеризується необхідністю інновацій, особливо щодо освітньої ссрери, що породжує створення нових засобів для поліпшення комунікацій.

Висновки. Застосування IKT у профресійній підготовці молодших спеціалістів з права відповідає принципам особистісного підходу, орієнтованого на студента, де він розглядається як активний учасник навчального процесу. Відчутно, що ІКТ підтримують персоналізоване навчання, активізуючи взаємодію між викладачами та студентами, а отже, викладачі мають можливість впливати на розвиток студентів.

Крім того, як один із найбільш фрундаментальних принципів особистісно-орієнтованого підходу, IKT дозволяють навчатись у будь-який час і в будьякому місці за допомогою веб-діяльності в позааудиторний час, що підтверджує наразі застосування дистанційних платформ. Разом із тим студенти мають можливість у процесі комп'ютеризованого навчання розвивати інформаційну компетентність.

Проте, хоча процес інорорматизації і широкі можливості використання комп'ютерних технологій стрімко розвивається, в системі освіти вищої школи спостерігається і серйозна проблема. Застосування всього потенціалу IKT-ресурсів у щоденному освітньому процесі ЗВО все ще залишається недостатнім.

Потенційні можливості інорормаційно-комунікаційних технологій розкриті не повністю і не в повній мірі затребувані системою освіти. Під час розгляду порушених проблем слід ураховувати такі об'єктивно-суб'єктивні причини, як:

- недостатня розробленість методології впровадження нових інорормаційних технологій в освітній процес;

- низький рівень адаптації комп'ютеризованих освітніх платсорм до курсу спеціальних дисциплін;

- відсутність спеціалізованої системи розвитку IКТ-педагогів;

- низький рівень загальної комп'ютерної підготовки викладацького складу;

- недостатня вивченість психолого-педагогічних аспектів комп'ютерного навчання;

- недостатній рівень підвищення мотивації викладачів до опанування IKT;

- труднощі у фрормуванні критеріїв оцінки інфрорматизації освіти, які виникають за відсутності вимірників і чітких критеріїв ефективності застосування IKT.

\section{БІБЛІОГРАФІЧНИЙ СПИСОК:}

1. Гуревич Г.С. Інноваційні освітні технології як чинник розвитку професійних компетенцій педагогічного персоналу ПТНЗ. Сучасні інформаційні технології та інноваційні методики навчання в підготовці фрахівців: методологія, теорія, досвід, проблеми. 2015. № 42. С. 3-6.

2. Гуревич Р., Кадемія М., Козяр М. Інформаційнокомунікаційні технології в професійній освіті ; за ред. член-кор. НАПН України Р.С. Гуревича. Львів : Вид-во «СПОЛОМ», 2012. 502 с.

3. Журавський В.С. Юридична освіта в Україні: сучасний стан та напрями вдосконалення. Право України. 2004. № 11. С. 3-6.

4. Кобилянський О.В. Використання інтернет-технологій у процесі вивчення безпеки життєдіяльності. Наукові записки. Серія: Педагогічні науки. Кіровоград : РВВ КДПУ ім. В. Винниченка. 2014. Вип. 132. C. 61-65.

5. Козяр М. Інноваційні технології як інструмент студентоцентрованого підходу в практичній підготовці майбутнього інженера. Нова педагогічна думка. 2014. № 1. С. 90-93.

6. Information and Communication Technologies in the Professional Training of Engineers. International Workshop on Conflict Management in Global Information Networks (CMiGIN 2019) / A. Kokarieva et al. Lviv, 29 November. 2019. CEUR-WS.org, online.

7. Насілєнко Л. Професійна підготовка майбутніх юристів на основі компетентнісного підходу (з досвіду роботи Університету сучасних знань). Освіта дорослих : теорія, досвід, перспективи : зб. наук. пр. ; редкол Л.Б. Лук'янова (голова) та ін. ; Ін-т пед.. освіти дорослих НАПН України. Ніжин : Видавець П.П. Лисенко, 2013. Вип. 6. С. 75-81. 


\section{ТЕХНОЛОГІЯ МОВНО-КОНФЛІКТНОГО МОДЕЛЮВАННЯ В ОСВІТНЬОМУ ПРОЦЕСІ}

\section{LANGUAGE-CONFLICTS MODELING TECHNOLOGY IN ADUCATION}

У статті здійснено порівняльний аналіз проблемного навчання та авторської технології мовно-коноліктного моделювання. Визначено методи навчання англомовного монологічного мовлення в закладах вищої освіти крізь призму зазначеної технології. Авторка наголошує на важливості розпізнавання проблем і можливих конфрліктів та пошуку оптимальних шляхів їх вирішення. Актуальність статті не викликає жодних сумнівів, адже події на сході України засвідчили необізнаність суспільства з тактиками та стратегіями врегулювання конфрліктів шляхом мирних переговорів.

Mema cmammi полягає в характеристиці авторської технології мовно-конорліктного моделювання, виявленні взаємозв'язків проблемного навчання і технології мовно-конфоліктного моделювання.

Запропонована авторкою технологія мовно конорліктного моделювання може бути задіяна під час навчання англомовного монологічного мовлення студентів. Цей вид мовлення характеризується підготовле ністю і продуманістю, що важливо під час вирішення конфрліктних ситуацій. Наголошується на важливості фоормування навички передбачення консрліктних ситуацій та розвитку комунікативних умінь, спрямованих на вирішення зазначених ситуачій, що сприятиме зниженню кількості конфрліктів загалом та в межах окремих сфрер профресійної та людської діяльності зокрема

у статті запропоновано схематично розглянути складники алгоритму аналізу конфрлікту. Схематичне представлення дає чітке уявлення про конфрлікт, про етапи роботи над урегулюванням конфолікту. Авторка виокремила методи проблемного навчання та представила їх у взаємодії з технологією мовно-конфліктного моделювання. Знаходимо таке представлення у вигляді таблиці, що є своєрідним синтезом проблемного навчання. Наведено основні тлумачення понять «технологія», «проблемне навчання», «проблема», «навчальна проблема». Обгрунтовано використання методів проблемного навчання в освітньому процесі.

Ключові слова: проблемне навчання, конфрліктологія, конфлікт, метод навчання, технологія навчання.
The article provides a comparative analysis of problem-based learning and the author's technology of language-conflict modeling Methods of teaching English monologue speech in higher education institutions through the prism of this technology are determined.

The author emphasizes on the importance of recognizing problems and possible conflicts and finding optimal ways to solve them. The relevance of the article is beyond doubt, as events in eastern Ukraine have shown society's ignorance of tactics and strategies for resolving conflicts through peace talks.

The purpose of the article is to characterize the author's technology of language-conflict modeling, identify the relationship between problem-based learning and technology of language-conflict modeling.

The technology of language-conflict modeling, that proposed by the author, can be used during the teaching of English spoken production of mono-lingual students. This type of speech is characterized by preparedness and thoughtfulness, which is important for resolving conflict situations.

Also it is said about the importance of developing the ability to anticipate conflict situations and develop communication skills aimed at resolving these situations, which will help reduce the number of conflicts in general and within individual areas of professional and human activity in particular.

Moreover, it is offered to consider schematically components of algorithm of the analysis of the conflict. The schematic representation gives a clear idea of the conflict, the stages of work on conflict resolution.

The author singled out the methods of problembased learning and presented them in interaction with the technology of language-conflict modeling. There is a representation in the form of a table, which is a kind of synthesis of problem-based learning, in the article. The main interpretations of the concepts "technology", "problem-based learning", "problem", "learning problem" are given. The use of problem-based learning methods in the educational process is substantiated.

Key words: problem-based learning, conflictology, conflict, teaching method, learning technology. України «Київський політехнічний інститут імені Ігоря Сікорського»

Постановка проблеми в загальному вигляді. Пропонуємо зосередити увагу на процесі людського пізнання, яке відзначається творчо-активним характером, а пізнавальні здібності індивідів розвиваються завдяки активній самостійній діяльності. Процес пізнання передбачає відкриття нового: нових знань, нових проблем, нових методів та шляхів їх рішення. У зв'язку з цим проблемне навчання представляється у вигляді вирішення нестандартних науково-навчальних завдань нестандартними методами. Ми виокремили проблемне навчання, адже цей вид навчання, як і конфрлікт, містить проблему. Появі проблем (як і консрліктів) передують певні події, обставини або слова. Пропонуємо розглядати консрлікти в межах комунікативної площини, що дозволяє робити мовленнєві моделі конфрліктів, систематизує загальні уявлення про конфрлікт.

Зауважимо, що в запропонованій нами технології мовно-консрліктного моделювання ми виокремили методи проблемного навчання: частково-пошуковий, репродуктивний, дослідницький. Таким чином, аналіз технології мовно-конорліктного моделювання потребує усвідомлення концепції проблемного навчання.

Аналіз останніх досліджень та публікацій. За результатами аналізу теоретичних джерел і 
наукових досліджень можемо зробити висновок, що педагогічна технологія не має однозначного визначення. Безпосередньо проблема технологій навчання розроблялася в наукових працях А. Алексюка (1993), В. Беспалька (1977), А. Вербицького (1993) та ін. Теоретичні засади та практичні рекомендації стосовно навчання технології конфліктного моделювання знаходимо в дослідженнях P. Putman (2012); приклади моделей конфрліктних ситуацій з деталізованою характеристикою основ моделювання - у роботах Н. Praehofer (1999). Появу понять «проблема», «проблемне запитання» та «проблемна ситуація» пов'язують 3 іменем І. Лернера. Тлумаченню проблемної ситуації присвячені роботи А. Матюшкіна (1972), в яких дослідник зазначає, що проблемна ситуація $є$ особливим видом розумової діяльності під час виконання завдань, який стимулює до пошуку нових рішень [3, с. 10-15].

Виділення не вирішених раніше частин загальної проблеми. Проблема технології мовноконфліктного моделювання в навчанні англомовного монологічного мовлення наразі залишається малодослідженою: не визначено передумови становлення технології мовно-конфліктного моделювання та не охарактеризовано взаємозв'язок зазначеної технології з проблемним навчанням; не окреслено педагогічні умови використання вищезгаданої технології в освітньому процесі.

Отже, метою статті $€$ характеристика технології мовно-конфліктного моделювання, виявлення взаємозв'язків проблемного навчання і технології мовно-конорліктного моделювання.

Виклад основного матеріалу. Технологія проблемного навчання ґрунтується на засадах американського фрілософра, психолога і педагога Д. Дьюї, який стверджував, що слід учитися спостерігати за фрактами. Дослідник пропонує аналізувати й порівнювати фракти, послуговуючись індуктивним методом [2, розділ 7]. Запропонована нами технологія мовно-конфлліктного моделювання є результатом педагогічної діяльності, що передбачає багатоманітність та неповторність ситуацій, адже окремо взятий реципієнт сприймає інформацію відповідно до свого уявлення про світ та відповідно до свого життєвого досвіду. Множина фракторів, що впливають на результат, роблять їх законами-тенденціями, законами, які прокладають собі дорогу крізь безліч різноманітних відхилень, неповторних варіантів, а точність - відносна. щоразу необхідний аналіз особливостей навчальної операції та наступний розумовий синтез і зіставлення [3, с. 25].

Отже, керуючись принципами проблемного навчання Д. Дьюї та враховуючи специфіку педагогічної діяльності, ми можемо стверджувати про можливість імплементації технології мовно-конфрліктного моделювання в навчальний процес.
Зауважимо, що першоджерелом проблемного навчання $є$ евристична бесіда (Сократ), де передбачається самостійний пошук відповіді на запропоноване проблемне питання. Ми згодні з тим, що проблемне навчання $€$ одним із типів розвивального навчання, мета якого полягає у виокремленні та поясненні проблем (або конорліктів) [6]. На нашу думку, суть проблемного навчання, як і технології мовно-конорліктного моделювання, зводиться до створення ситуації, яка стимулює до пошуку рішення. Віднайти рішення допомагають психологічні закономірності пошуку нового [4, с. 100]. Зазначена технологія може бути адаптована для навчання студентів 3ВО різних спеціальностей, зокрема: «Адміністративний менеджмент та управління», «Право», «Соціальна робота», «Міжнародні соціальні проєкти» тощо.

У проблемному навчанні виділяють навчальну проблему, проблемні ситуації, задачу і запитання. На відміну від наукової проблеми, навчальна проблема містить суперечливу інформацію. Пропонуємо розглянути спільні та відмінні риси проблемного навчання і технології мовно-комунікативного моделювання (див. табл. 1).

Таблиця 1

Порівняльна характеристика проблемного навчання та технології мовно-конфрліктного моделювання

\begin{tabular}{|c|c|}
\hline Проблемне навчання & $\begin{array}{c}\text { Технологія мовно- } \\
\text { конфліктного моделювання }\end{array}$ \\
\hline Навчальна проблема & конфрлікт \\
\hline самостійний пошук оптимальних шляхів вирішення \\
\hline \multicolumn{2}{|c|}{ створення проблемних/конфрліктних ситуацій } \\
\hline запропоноване & пошук та виявлення \\
проблемне питання & конфрлікту \\
\hline
\end{tabular}

Під час навчання англомовного монологічного мовлення засобами технології мовно-конфрліктного моделювання пропонуємо послуговуватися методами проблемного навчання (див. табл. 2). На вибір методів навчання впливають цілі та зміст навчання. Вибір монологічного мовлення був зумовлений характеристиками зазначеного виду мовлення, адже для нього характерна продуманість висловлювань, підготовка та чітка структура.

Слід звернути увагу також на розвиток професійних компетентностей, адже лише висококваліфрікований фрахівець буде конкурентоспроможним. У нашому розумінні поняття «компетентність» діяльнісна характеристика, що демонструє рівень інтегрованості індивіда в суспільну діяльність і передбачає орієнтацію на світоглядні переконання особистості, ціннісне ставлення до діяльності та її предметів [1, с. 44-47].

Запропоновані нами методи проблемного навчання мають на меті виявити та вирішити проблеми, а також розвивати профресійні компетентності. 
Беручи до уваги спалахи конфліктів у світі загалом та на сході України зокрема, пропонуємо процес навчання монологічного мовлення будувати з урахуванням потреб суспільства, що тяжіють до мирного врегулювання конфліктів шляхом залучення мовних практик. Монологічне мовлення в цьому контексті $€$ своєрідним знаряддям праці, засобом впливу на масову свідомість. Таким чином, задіявши методи проблемного навчання, ми зможемо виявити та проаналізувати шляхи вирішення конфлікту.

Таблиця 2

\section{Методи проблемного навчання}

\begin{tabular}{|c|c|c|}
\hline Метод & Зміст & Застосування \\
\hline $\begin{array}{c}\text { Частково- } \\
\text { пошуковий }\end{array}$ & $\begin{array}{c}\text { Пошукова діяльність } \\
\text { студента ґрунтується } \\
\text { на поясненнях викла- } \\
\text { дача (інструкціях) }\end{array}$ & $\begin{array}{c}\text { Всі етапи } \\
\text { пнавального } \\
\text { процесу }\end{array}$ \\
\hline $\begin{array}{c}\text { Репродук- } \\
\text { тивний }\end{array}$ & Систематизація фрактів & $\begin{array}{c}\text { Осмислення } \\
\text { теоретичних } \\
\text { знань }\end{array}$ \\
\hline $\begin{array}{c}\text { Дослід- } \\
\text { ницький }\end{array}$ & Постановка проблеми & експеримент \\
\hline
\end{tabular}

3'ясуємо науковий статус конфоліктології як складової частини технології мовно-конфліктного моделювання. Для нас важливо чітко розрізняти об'єкт і предмет. Об'єктом конфліктологічного пізнання є людське суспільство і людина з її вчинками та відносинами в суспільстві. Предметом виступає сукупність понять для опису об'єктивної реальності. За сорерою функціонування конфрлікти поділяються на інституціональні, організаційні, міжгрупові, групові та міжособистісні.

Відповідно, розгляд кожного різновиду конфрлікту відбувається крізь призму методологічної бази. 3-поміж методів проблемного навчання та стратегій медіаційних практик ми виокремили методи технології мовно-конфліктного моделювання: інформаційний, валідаційний, метод картографрії конфрлікту та структурний.

Обґрунтуємо використання вищезазначених методів.

Інфрормаційний метод реалізовується завдяки інфрормаційному підходу і затребуваний на стадії аналізу фрактів і виявлення проблем (прогноз розвитку подій у разі ухвалення рішень, наслідки, обставини; фрункціонує монологічне мовлення).
Метод картографої конфрлікту взаємодіє 3 діяльнісним та інформаційним підходами. Ми послуговуємося розробкою методу картографії конорлікту за Х. Корнеліус \& Ш. Фейр (1992), що передбачає аналіз потреб учасників конслікту та проблеми конфлікту. Пропонуємо розглянути на рис. 1 модифріковане нами графічне зображення картографрії конфрлікту.

Обов'язковою умовою процесу медіації та врегулювання конфрліктів є врахування потреб обох сторін конфрлікту.

Валідаційний метод реалізовується через діяльнісний, комунікативний, соціологічний та культурологічний підходи. Валідаційний метод передбачає створення простору довіри, що полегшує процес управління коноліктом. Ми розглядаємо технологію як процес розкриття зв'язків і закономірностей, що забезпечує досягнення запланованого результату [5, с. 100-101].

Цілями технології мовно-конорліктного моделювання під час навчання англомовного монологічного мовлення в межах нашої статті пропонуємо вважати:

1) формування профресійних інтересів;

2) формування цілісного уявлення про конфрлікт і шляхи його вирішення;

3) інтегрування теоретичних знань у практичну площину;

4) розвиток професійної відповідальності;

5) засвоєння професійно орієнтованої лексики тощо.

Пропонуємо розглянути можливі складники аналізу конфрліктів у площині технології мовноконфрліктного моделювання (рис. 2).

Завдання з використанням технології мовноконфліктного моделювання передбачають аналіз конфліктних ситуацій і виконання студентами поетапних дій, які відтворюють або імітують конфрлікт. Пошук нових шляхів вирішення конфрліктів відповідає реальному процесу мислення, що розкриває закономірності між набутими знаннями про конфлікти та новими конфрліктами [4, с. 102]. Студенти проєктують на себе сюжет конфллікту таким чином, щоб мати учасників самого конфрлікту; аналізують та досліджують конфрлікт у конкретній профресійно орієнтованій комунікативній ситуації в рамках заданої програми, чітко

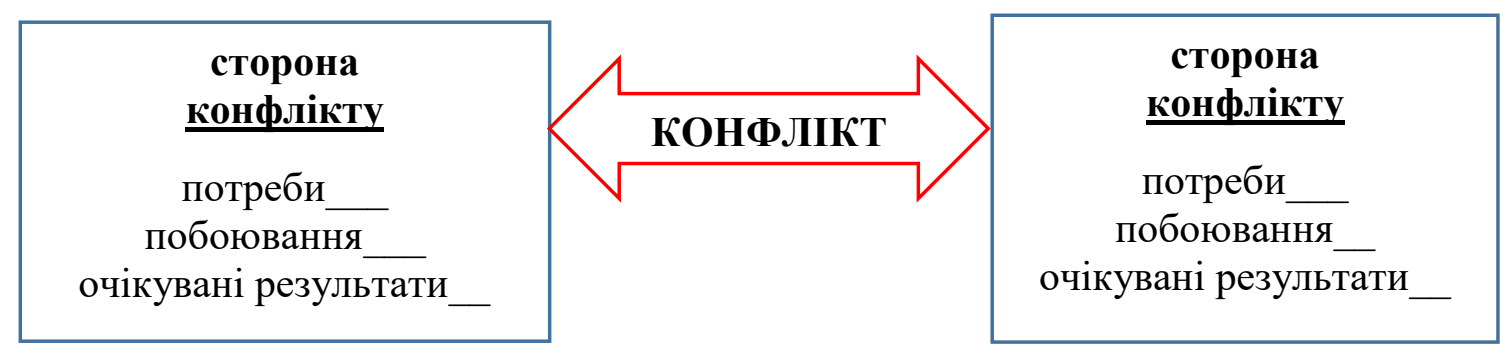

Рис. 1. Картографрія конфрлікту 
MEDIATION 1. Інтереси сторін конфлікту

2 2. Ідентифікація конфлікту

3. Умови вирішення конфлікту

MEDIATION 1. Прогнозування конфлікту

2 2. Етапи регулювання конфлікту

3. Пошук конструктивних рішень

MEDIATION 1. Попередження конфлікту

2. Етапи переговорного процесу

3. Стратегії і тактики

Рис. 2. Складники аналізу конфрлікту

виконують інструкцію. Щодо організації заняття, то студенти можуть виконувати дії в парах або малих групах. Тому таку технологію ми вважаємо кооперативною за суттю і характеристиками.

Висновки. Таким чином, нами було уточнено зміст понять «проблемне навчання», «конфрліктологія», «метод навчання» і «технологія навчання», охарактеризовано взаємозв'язок між проблемним навчанням та технологією мовно-конфліктного моделювання; представлено методи проблемного навчання, наведено приклади складників алгоритму аналізу конфлікту.

\section{БІБЛІОГРАФІЧНИЙ СПИСОК:}

1. Гулай О.І. Компетентнісний підхід як основа нової парадигми освіти. Вісник Національної академії
Державної прикордонної служби України. 2009. № 2. С. $41-51$.

2. Джон Дьюи. Психология и педагогика мышления / перевод с английского Н.М. Никольской ; под редакцией Н.Д. Виноградова. Москва : Издание Т-ва «Мир», 1919. VІ. 202 с.

3. Загвязинский В.И. Педагогическое предвидение. Москва, 1987. 160 с.

4. Матюшкин, А.М. Проблемные ситуации в мышлении и обучении. Москва : Педагогика, 1972. 392 c.

5. Тулякова К.Р. Методика навчання англомовного професійно орієнтованого монологічного мовлення майбутніх фрахівців у сфрері медіації та врегулювання конфрліктів : дис. канд. пед. наук : 13.00.02. Київ, 2020. 260 c.

6. Фіцула M.M. URL: http://westudents.com.ua/ glavy/50058-problemne-navchannya.html 


\section{ІНТЕГРАЛЬНА КОМПЕТЕНТНІСТЬ ЯК СКЛАДНИК ПРОФЕСІЙНОЇ КОМПЕТЕНТНОСТІ В ПЕДАГОГІЧНІЙ ОСВІТІ

\author{
INTEGRAL COMPETENCE AS A COMPONENT \\ OF PROFESSIONAL COMPETENCE IN PEDAGOGICAL EDUCATION
}

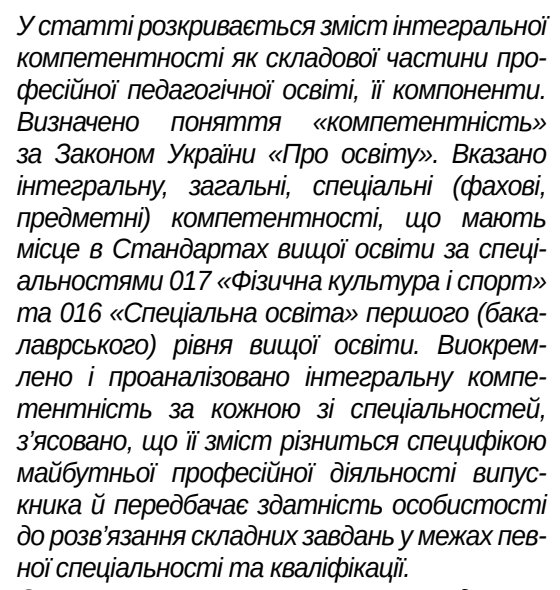

Охарактеризовано низку наукових джерел, що дало можливість з'ясувати структуру інтегральної компетентності, иляхи їі формування. Авторами визначено компоненти, які уможливлюють фрормування інтегральноі компетентності як складника професійної компетентності в педагогічній освіті: мотиваційний, що сприяє формуванню позитивної мотивації до розвитку загальних та спеціальних складників профресійної компетентності, встановлено ієрархію мотивів; когнітивний, що грунтується на інтелектуальній сорері діяльності, володінні сукупністю теоретичного і практичного матеріалу, необхідних для майбутнього фаху, встановлено моделі інтеграції: міждисциплінарну і концептуальну; діяльнісний, який передбачає фрормування практичних умінь під час освітнього процесу та проходження різних видів педагогічної практики, запропоновано застосування методів, як-от моделювання, кейс-метод, що спонукають здобувача освіти до розвитку креативного мислення, пошуку рішень нестандартних ситуацій; комунікативний, в основі якого -удосконалення культури профресійного мовлення, дотримання норм етики та культури спілкування. Зазначено інноваційні методи навчання, що є важливими для реалізації комунікативного компоненту. Вказано на особистісні якості випускника, що становлять, на думку авторів, основу інтегральної компетентності: цілеспрямованість, працелюбство, лідерство, відповідальність, толерантність та інші. Ключові слова: інтегральна компетентність, компоненти, мотиваційний, когнітивний, діяльнісний, комунікативний.
The article reveals the content of integral competence as a component of professional competence in pedagogical education and its other components. The concept of "competence" is defined by the Law of Ukraine "On Education". The integral, general, special (professional, subject) competencies that take place in the Standards of Higher Education in the specialties 017 "Physical Culture and Sports" and 016 "Special Education" of the first (bachelor's) level of higher education are indicated. The integral competence for each of the specialties is singled out and analyzed. It was found out that its content differs in the specifics of the future professional activity of a graduate student and presupposes the ability of the individual to solve complex problems within a certain specialty and qualification.

A number of scientific resources were characterized, which made it possible to clarify the structure of integral competence, the ways of its formation. The authors identify the components that enable the formation of integrated competence as a component of professional competence in pedagogical education: motivational, which contributes to the formation of positive motivation for the development of general and special components of professional competence, a hierarchy of motives was established; cognitive, which is based on the intellectual sphere of activity, possession of a set of theoretical and practical material necessary for the future profession, models of integration were established: interdisciplinary and conceptual; active, which involves the formation of practical skills during the educational process and the passage of various types of pedagogical practice, the usage of certain methods is proposed, such as: modeling, case method, which encourages a student to develop creative thinking, finding solutions to unusual situations; communicative, which is based on the improvement of the culture of speech, the formation of professional business speech, compliance with ethics and culture of communication. Innovative teaching methods that are important for the implementation of the communicative component were indicated. According to the authors, these personal qualities of a graduate student are the basis of integral competence: purposefulness, diligence, leadership, responsibility, tolerance and others. Key words: integral competence, components, motivational, cognitive, active, communicative.
Постановка проблеми в загальному вигляді. Сучасна система освіти працює за новою парадигмою - формування професійної компетентності. Законом України «Про освіту» визначено зміст поняття «компетентність». Це «динамічна комбінація знань, умінь, навичок, способів мислення, поглядів, цінностей, інших особистих якостей, що визначає здатність особи успішно соціалізуватися, провадити професійну та/або подальшу навчальну діяльність» [8]. У Стандартах вищої освіти за рівнями й спеціальностями сорормульовано складники професійної компетентності та їхній зміст. Виокремлюють інтегральну, загальні, спеціальні (фрахові, предметні) компетентності. Проаналізуємо інтегральну компетентність. Зміст іï фрормулюється на основі відповідного рівня Національної рамки кваліфікацій і для першого (бакалаврського) рівня вищої освіти визначається 
як здатність особи вирішувати складні спеціалізовані завдання і практичні проблеми в певній галузі профресійної діяльності або в процесі навчання, що передбачає застосування певних теорій і методів відповідних наук і характеризується комплексністю і невизначеністю умов [7]. Йдеться про компетентність як складову частину базових компетентностей, в яких описуються кваліфікаційні рівні. Вона вказує на здатність фрахівця за певною спеціальністю розв'язувати завдання різного рівня складності.

У Методичних рекомендаціях щодо розроблення стандартів вищої освіти, затверджених Наказом Міністерства освіти і науки України № 600 від 01 червня 2017 року, термін «інтегральна компетентність» трактується так: «узагальнений опис кваліфрікаційного рівня, який виражає основні компетентністні характеристики рівня щодо навчання та/або профресійної діяльності» [6].

Нами проаналізовано Стандарти вищої освіти за спеціальностями, зокрема 017 «Фізична культура і спорт» та 016 «Спеціальна освіта» першого (бакалаврського) рівня вищої освіти. Зміст інтегральної компетентності за кожною зі спеціальностей різниться специфікою майбутньої професійної діяльності випускника. Зокрема, в Стандарті вищої освіти за спеціальністю 017 «Фізична культура і спорт» інтегральна компетентність визначена як «здатність розв'язувати складні спеціалізовані завдання та практичні проблеми у сорері фрізичної культури і спорту або в процесі навчання, що передбачає застосування теорій та методів наук з фрізичного виховання і спорту та характеризується комплексністю та невизначеністю умов» [10]. Стандартом спеціальності 016 «Спеціальна освіта» інтегральну компетентність сорормульовано як «здатність розв'язувати складні спеціалізовані задачі і практичні проблеми спеціальної та інклюзивної освіти в процесі корекційно-педагогічної, діагностико-консультативної, дослідницької та культурно-просвітницької діяльності або в процесі навчання, що передбачає застосування основних теорій і методів дефектології і характеризується комплексністю та невизначеністю умов» [9].

Отже, фрормування інтегральної компетентності передбачає здатність особистості до розв'язання складних завдань у межах певної спеціальності та кваліфрікації.

Аналіз останніх досліджень і публікацій. Шляхи формування інтегральної компетентності, іï структуру вивчала низка науковців (О. Глазунова, В. Корольчук, Т. Волошина, М. Марусинець, О. Хмелевська та ін.).

О. Хмелевська досліджує структуру інтегральної компетентності як мета-кваліфікаційний конструкт, фрункція якого полягає в координації процесів актуалізації та фрормування компетентностей відповідно до мети та завдань варіативно-творчого процесу мистецької освіти [11]. М. Марусинець виокремлює психолого-педагогічну компетентність як компонент інтегральної компетентності викладача закладу вищої освіти, в якому інтегруються педагогічні та психологічні знання й професійні цілі [5].

О. Глазунова, В. Корольчук, Т. Волошина пропонують організаційно-методичні підходи до використання міждисциплінарних проєктів для фрормування і розвитку інтегральної компетентності [2].

Сучасний ринок освітніх послуг вимагає вдосконалення шляхів формування інтегральної компетентності з метою якісного вирішення педагогічних ситуацій, що характеризуються комплексністю та невизначеністю умов. Ця проблема визначає актуальність означеного дослідження.

Мета статті - розкрити компоненти інтегральної компетентності як складника профресійної компетентності в педагогічній освіті.

Виклад основного матеріалу. У процесі дослідження означеної проблеми нами виокремлено та охарактеризовано компоненти, які уможливлюють формування інтегральної компетентності як складника професійної компетентності в педагогічній освіті.

Студіювання наукової літератури та наше спостереження за організацією освітнього процесу дає можливість стверджувати, що компонентами інтегральної компетентності є:

1. Мотиваційний - сприяє фрормуванню позитивної мотивації до розвитку загальних та спеціальних складників профресійної компетентності. 3 цією метою важливо встановити ієрархію мотивів: усвідомлення важливості вибору педагогічної професії; намагання досягти успіху в навчальній діяльності (участь у рейтинговому оцінюванні); прагнення до саморозвитку та самоосвіти. Дотримуємося думки, що «мотивація навчально-пізнавальної діяльності студентів у процесі професійної підготовки також містить: профресійно-педагогічні мотиви (зумовлюють підготовку студентів до викладання в початковій школі); пізнавальні мотиви (передбачають засвоєння нових знань у галузі педагогіки початкової освіти, ознайомлення з науковими проблемами навчально-ігрової діяльності молодших школярів і методиками викладання предметів у початкових класах, розширення спеціальних знань у галузі навчально-ігрових технологій); мотиви самореалізації (уможливлюють реалізацію творчих устремлінь, прагнення активізувати й удосконалювати процес викладання в початковій школі тощо); моральні мотиви (стимулюють прагнення отримати схвалення з боку викладача, виконувати вимоги внутрішнього розпорядку тощо)» [4]. Відсутність у здобувачів освіти мотивації до майбутньої професійної діяльності може негативно вплинути на результати навчання та фрормування компетентностей, інтегральної зокрема. 
2. Когнітивний - ґрунтується на інтелектуальній сорері діяльності, володінні сукупністю теоретичного і практичного матеріалу, необхідних для майбутнього фаху. Однак йдеться не тільки про одержання знань, а й про вміння інтегрувати ïx. Інтеграція як педагогічне явище дає можливість сорормувати цілісне уявлення про предмет вивчення і, як результат, розвиває здатність до вирішення нестандартних ситуацій. Для професійної підготовки педагогічних фрахівців нами зазначено моделі інтеграції: міждисциплінарну із встановленням зв'язків і концептуальну, що передбачає розгляд проблеми в межах кількох дисциплін, споріднених або неспоріднених. Когнітивний компонент є наскрізним для загальних і спеціальних складників професійної компетентності, оскільки забезпечує систему знань із психолого-педагогічних та інших дисциплін. За О. Лахтадир, він включає високий рівень професійної ерудиції; знання психологічних закономірностей та специоріки міжособистісного спілкування, знання про застосування комунікативних стратегій, психологічні знання механізмів міжособистісного оцінювання та міжособистісних взаємодій; творче мислення; знання методів психологічного впливу, правил і прийомів риторики та полеміки, рефлексивного слухання; знання про особистісні якості, які сприяють або заважають спілкуванню; знання про емоції та почуття, які завжди супроводжують спілкування [3].

3. Діяльнісний - має на меті фрормування практичних умінь під час освітнього процесу та проходження різних видів педагогічної практики. Технології навчання в закладах вищої освіти передбачають застосування таких методів, які спонукають здобувача освіти до розвитку креативного мислення, пошуку рішень нестандартних ситуацій. Одним з ефективних методів вважаємо моделювання. Суть його полягає в тому, що здобувач освіти діє в умовах квазіпрофресійного середовища, вчиться вирішувати різноманітні педагогічні ситуації, як-от: проведення на практичних заняттях оррагментів уроків за темами, добірка творчих завдань, дидактичних ігор, Моделювання може завершуватись створенням інтелектуального продукту - проєкту.

Не менш ефективним $€$ впровадження кейсметоду. Він сприяє комплексному фрормуванню компетентностей на основі розв'язання конкретних ситуацій. Кейс-метод передбачає їх аналіз, що пов'язаний із вирішенням професійних завдань. На наш погляд, зміст кейсу повинен будуватися на основі інтеграції знань, оскільки вирішення ситуацій вимагає нестандартних рішень.

Н. Гатеж виділяє креативно-діяльнісний компонент, що охоплює сукупність умінь і навичок студентів щодо нестандартного вирішення педагогічних завдань; проектування власних та грамотне застосування існуючих технологій виховання естетичної культури учнів [1].

4. Комунікативний - передбачає вдосконалення культури мовлення та фрормування профресійного. Здатність до комунікації вимагає володіння нормами мовлення та етикою і культурою спілкування.

На нашу думку, комунікативний компонент, що впливає на формування інтегральної компетентності майбутніх педагогів, характеризується потребою в професійному спілкуванні, володінням термінами, вирішенням педагогічних задач, виконанням соціокультурних ролей, фрормуванням національної свідомості. Для реалізації комунікативного компоненту важливим $€$ застосування інноваційних методів навчання. Ми акцентуємо увагу на тих, що формують профресійне мовлення: «вільний діалог», що побудований у формі спілкування на педагогічну тему, «власна позиція» - обстоювання поглядів у процесі вирішення педагогічних задач та ситуацій; «порівнюю, аналізую» - засвоєння педагогічної термінології в порівнянні 3 українською та іноземною мовами тощо.

Слід зазначити, що інтегральна компетентність як складова частина професійної фрормулює специфріку діяльності за фрахом, виступає «стрижнем» для підготовки здобувачів освіти. В її основу ставимо особистісні якості випускників: цілеспрямованість, працелюбство, лідерство, відповідальність, толерантність та інші. Системне формування означених чеснот сприятиме становленню педагогічної профресійної етики.

Висновки. Таким чином, нами охарактеризовано інтегральну компетентність як складник професійної компетентності в педагогічній освіті, виокремлено їі компоненти: мотиваційний, когнітивний, діяльнісний, комунікативний.

\section{БІБЛІОГРАФІЧНИЙ СПИСОК:}

1. Гатеж Н. Профресійні вміння у структурі креативно-діяльнісного компоненту готовності майбутніх учителів образотворчого мистецтва до виховання естетичної культури учнів. Science and Education a New Dimension. Pedagogy and Psychology. 2018. № VI (65). 155 c. C. 15-18.

2. Глазунова О., Корольчук В., Волошина Т. Міждисциплінарний проєкт як засіб формування інтегральної компетентності майбутніх ІТ-фрахівців. Наукові записки Тернопільського національного педагогічного університету імені Володимира Гнатюка. Сер. Педагогіка. Тернопіль : ТНПУ ім. В. Гнатюка, 2019. № 1. С. 136-147.

3. Лахтадир О.В. Психологічні особливості розвитку комунікативної компетентності майбутніх фрахівців з фрізичної культури і спорту : дис. ... канд. психол. н. : 19.00.07. Київ, 2017. 261 с.

4. Марко М.М. Визначення структурних компонентів готовності майбутніх учителів початкових класів до застосування навчально-ігрових технологій. 
Journal «ScienceRise: Pedagogical Education». 2017. № 7 (15). C. 49-53.

5. Марусинець М. Формування інтегральної психолого-педагогічної компетентності викладача закладу вищої освіти. Освітній простір України. 2018. № 14. С. 81-88.

6. Методичні рекомендації щодо розроблення стандартів вищої освіти. URL: https://mon.gov. ua/storage/app/media/vishcha-osvita/proekty\% 20standartiv \%20vishcha\%20osvita/1648.pdf

7. Про затвердження Національної рамки кваліфрікацій України : Постанова Кабінету міністрів України від 23.11.2011 р. № 1341 (в редакції Постанови Кабінету Міністрів України № 509 від 12.06.2019 р., № 519 від 25.06.2020 р.). URL: https://zakon.rada.gov.ua/laws/ show/1341-2011-\%D0\% BF\#Text

8. Про освіту : Закон України від 05.09.2017 р. № 2145-VIII. Голос України. 2017. 27 верес. (№ 178-179). С. 10-22.

9. Стандарт вищої освіти України першого (бакалаврського) рівня вищої освіти - ступеня бака- лавра - 3 галузі знань 01 Освіта/Педагогіка спеціальності 016 Спеціальна освіта. Затверджено і введено в дію наказом Міністерства освіти і науки України від 16.06.2020 р. № 799. URL: https://mon.gov.ua/ storage/app/media/vyshcha/standarty/2020/06/17/016spetsialna-osvita-bakalavr.pdf

10. Стандарт вищої освіти України: перший (бакалаврський) рівень вищої освіти, галузь знань 01 Освіта/Педагогіка, спеціальність 017 Фізична культура і спорт. Затверджено та введено в дію наказом Міністерства освіти і науки України від 24.04.2019 р. № 567. URL: https://mon.gov.ua/storage/ app/media/vishcha-osvita/zatverdzeni\%20 standarty / 2019/04/25/017-fizichna-kultura-i-sport-bakalavr. pdf

11. Хмелевська І.О. Структура інтегральної компетентності майбутніх викладачів мистецьких дисциплін. Педагогічні науки: теорія, історія, інноваційні технології : науковий журнал ; МОН України, Сумський держ. пед. ун-т ім. А.С. Макаренка ; редкол. : А.А. Сбруєва та ін. Суми : СумдПУ ім. А. С. Макаренка, 2019. № 7 (91). С. 304-316. 


\section{НОВИЙ ВИД НАУКОВИХ ПОСЛУГ}

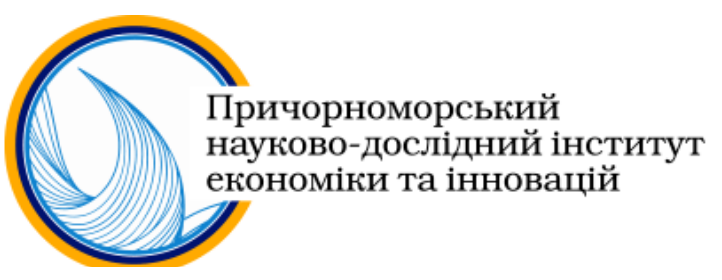

Шановні колеги! Питання академічної доброчесності $€$ надзвичайно актуальними у наш час. Враховуючи великі масиви інформації, що з'являються у всесвітній мережі, жоден вчений не може бути впевненим, що його авторське право захищене. Крім того, поширеною є ситуація, коли декілька вчених в одній галузі науки користуються однаковими джерелами інформації, а в результаті безкоштовні програми пошуку плагіату засвідчують стовідсоткові збіги тексту, що може призвести до безпідставних звинувачень у плагіаті, особливо після перевірки за базою даних авторефератів та дисертацій. Це викликано тим, що порівняння з іншими дисертаціями не вказує на використання спільних першоджерел (статей, монографій, статистичних щорічників, словників тощо), а однозначно визначає тільки збіг тексту, ігноруючи навіть цитати. Важливим є також те, що чинне законодавство однозначно визначає, що перевірку може здійснювати виключно установа за профрілем дослідження, а не поширені в мережі безкоштовні програми. Для уникнення подібних ситуацій ми пропонуємо Вам скористатися науковою послугою оцінки технічної унікальності наукового тексту за допомогою ліцензованого програмного забезпечення, яке гарантує похибку перевірки до 3\%. Переваги такої перевірки порівняно з іншими методами:

- Ви укладаєте угоду про надання послуг;

- Ваш фрайл не розмішується у мережі, тобто інфрормація і авторство залишаються анонімними;

- Ви отримуєте звіт, підготовлений за допомогою ліцензованого програмного забезпечення; порівняльну таблицю однакових фррагментів тексту із зазначенням джерела; офріційний звіт про надану послугу із зазначенням результатів;

- Ви отримуєте вичерпну інформацію про текстові збіги у Вашому дослідженні та дослідженнях інших авторів не тільки українською, але і російською та англійською мовами;

- Ви користуєтесь програмним забезпеченням, яке використовується тільки спеціалізованими науковими та освітніми установами і розроблене виключно для пошуку текстових збігів саме у наукових дослідженнях, а не у публіцистиці, рекламних веб-сайтах тощо;

- Виключна робота з авторами - ніхто, крім автора тексту, не зможе замовити у нас перевірку цього тексту, що убезпечить Вас від перевірок третіми особами;

- Ви отримуєте можливість коректно осрормити посилання на першоджерела;

- Існує можливість перевірки будь-яких наукових досліджень: статей, рефератів, авторефрератів, дисертацій, доповідей, тез, звітів тощо.

\begin{tabular}{|c|c|c|}
\hline \multicolumn{3}{|c|}{ Терміни і вартість перевірки і надання звіту: } \\
\hline Характер наукової роботи & Терміни (робочих днів) & Вартість \\
\hline Докторська дисертація & $5-10$ & 5500 грн \\
\hline Кандидатська дисертація & $3-7$ & 3500 грн \\
\hline Авторесрерат & $1-2$ & 500 грн \\
\hline Стаття & $1-2$ & 500 грн \\
\hline (обсягом до 12 сторінок) & За домовленістю & За домовленістю \\
\hline Інші види робіт &
\end{tabular}

Для того, щоб замовити послугу, Вам необхідно звернутись електронною поштою до Причорноморського науково-дослідного інститут економіки та інновацій, вказавши у темі листа «Оцінка унікальності тексту». У листі вкажіть адресу для листування, додайте файл у форматі MS Word з текстом наукового дослідження. Фахівець відповідного відділу надасть Вам відповідь щодо процедури здійснення експертизи.

Контактна особа:

Партенюха Дар'я - молодший науковий співробітник

Причорноморського науково-дослідного інституту економіки та інновацій.

+38 (048) 709-38-69

+38 (093) 253-57-15

info@iei.od.ua

3 повагою, дирекція Причорноморського науково-дослідного інституту економіки та інновацій. 


\title{
ІННОВАЦІЙНА ПЕДАГОГІКА
}

\author{
Науковий журнал
}

Випуск 31

\section{ToM 1}

Коректура • Н. Ігнатова

Комп'ютерна верстка • Ю. Семенченко

Формат 60x84/8. Гарнітура Arimo.

Папір офрсетний. Цифровий друк. Обл.-вид. арк. 21,12. Ум. друк. арк. 21,16.

Підписано до друку 28.01.2021. Замов. № 0321/80. Наклад 100 прим.

Видавництво і друкарня - Видавничий дім «Гельветика»

65101, м. Одеса, вул. Інглезі, 6/1

Телесрон +38 (048) 70938 69, +38 (095) 93448 28, +38 (097) 7230608

E-mail: mailbox@helvetica.com.ua

Свідоцтво суб'єкта видавничої справи

ДК № 6424 від 04.10.2018 р. 